SAND- -91-0077

SAND91-0077

DE92 000191

TTC 1053

Unlimited Release

June 19, 1991

ACCELEROM_ IER AND STRAIN GAGE EVALUATION*
D. J. Ammerman
M. M. Madsen
W. L. Uncapher
D. R. Stenberg
D. R. Bronowski

Transportation System Development Department 6320 Sandia National Laboratories**

Albuquerque, NM $\mathbf{8 7 1 8 5}$

\begin{abstract}
This document describes the method developed by Sandia National Laboratories (SNL) to evaluate transducers used in the design certification testing of nuclear material shipping packages. This testing project was performed by SNL for the Office of Civilian Radioactive Waste Management (OCRWM). This evaluation is based on the results of tests conducted to measure ruggedness, failure frequency, repeatability, and manufacturers' calibration data under both field and laboratory conditions. The results of these tests are provided and discussed. The transducers were selected for testing by surveying cask contractors and testing facilities. Important insights relating to sperational characteristics of accelerometer types were gained during field testing.
\end{abstract}

\footnotetext{
* This work was performed at Sandia National Laboratories, Albuquerque, New Mexico, and supported by the U.S. Department of Energy under Contract DE-AC04-76DP00789.
}

${ }^{* *}$ A $\therefore$ s. Department of Energy Facility. 
The authors wish to acknowledge several persons who made contributions to the accelerometer and strain gage evaluation project. These are D. M. Gutierrez, C. C. Holland, H. Kovaschetz, W. B. Leisher, R. A. May, J. W. Munford, T. L. Sanders, C. M. Stone, S. L. Toledo, and

G. W. Wellman of Sandia National Laboratories (SNL).

In addition, we wish to thank C. Kouts, W. Lake, S. Hinschberger, N. Burrel1, and M. Fisher of the U.S. Department of Energy for supporting the SNL testing program. Finally, special thanks to R. E. Glass and D. C. Harding of SNL and the staff of Creative Computer Services for their review effort and assistance in preparing this manuscript. 


\section{QUALITY ASSURANCE}

This work was performed under a quality level of QL-3. The applicable level-three requirements of the Sandia National Laboratories' Transportation Systems Development Division Quality Assurance Program Plan were implemented for all of this activity. 
CONTENTS

Page

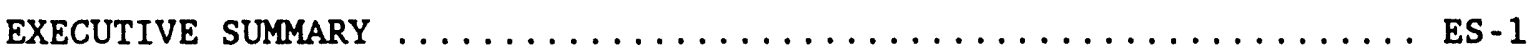

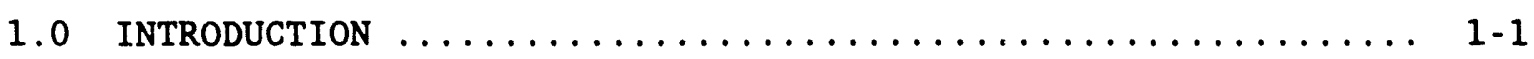

2.0 DESCRIPTION OF THE TEST PROGRAM $\ldots \ldots \ldots \ldots \ldots \ldots \ldots \ldots \ldots \ldots \ldots \ldots \ldots \ldots \ldots$

2.1 Accelerometer Laboratory Testing .............. 2-1

2.1.1 Calibration Testing .................. 2-2

2.1 .2 Shock Impulse Testing $\ldots \ldots \ldots \ldots \ldots \ldots \ldots \ldots \ldots .3$

2.2 Strain Gage Laboratory Testing ................ 2-4

2.3 End-Impact Testing .......................... 2-14

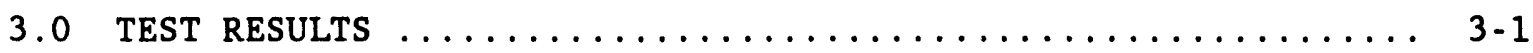

3.1 Accelerometer Calibration Testing ............. 3-1

3.2 Accelerometer Shock Tests .................. 3-1

3.3 Strain Gage Static Tests .................... 3-8

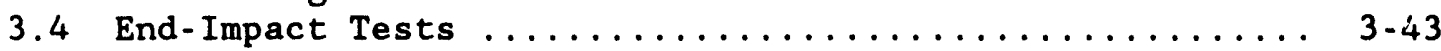

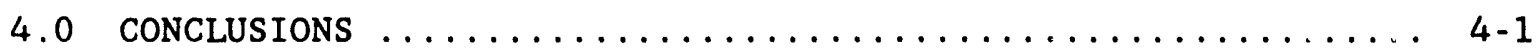

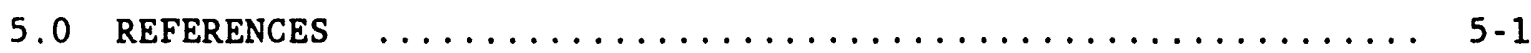

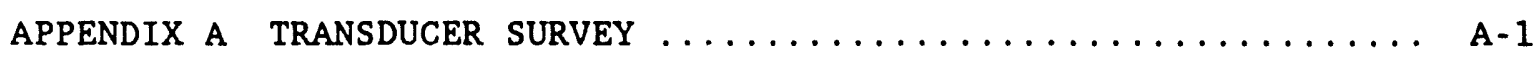

APPENDIX B STATIC TEST DIMENSIONAL INSPECTION DATA $\ldots \ldots \ldots \ldots \ldots$ B-1

APPENDIX $C$ END-IMPACT DIMENSIONAL INSPECTION DATA $\ldots \ldots \ldots \ldots \ldots, c-1$

APPENDIX $D$ STRAIN GAGE MULTIPLOTS $\ldots \ldots \ldots \ldots \ldots \ldots \ldots \ldots \ldots \ldots \ldots \ldots$

APPENDIX E ACCELEROMETER MULTIPLOTS $\ldots \ldots \ldots \ldots \ldots \ldots \ldots \ldots \ldots$ E-1 
2-1 Shock Impulse Test Fixture With the Mounted

Accelerometers .......................... 2-5

2-2 Shock Test Fixture Mounted on a 10,000-g MTS

Vertical Shock Frame ....................... 2-6

2-3 Close-Up View of the Shock Test Fixture Mounted

on a $10,000-\mathrm{g}$ MTS Vertical Shock Frame ............... 2-7

2-4 Idealized Haversine Shock Pulse $\ldots \ldots \ldots \ldots \ldots \ldots \ldots \ldots \ldots \ldots$

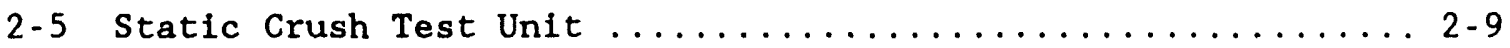

2-6 Locations of the Static Crush Test Dimensional

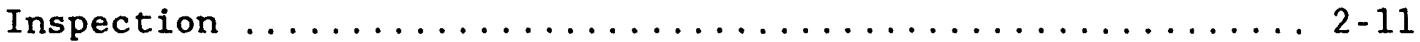

2-7 Calibrated MTS Compression/Tension Test Machine

With a 220,000-1b Capacity, and the Test Setup .......... 2-12

2-8 Static Test Unit Positioned in the MTS Test Machine ....... 2-13

2-9 Impact Test Setup at the 2,500-ft Aerial Cable

Facility at SNL .......................... 2-15

2-10 Close-Up View of the Impact Test Unit .............. 2-16

2-11 View of Strain Gages on Impact Test Units $\ldots \ldots \ldots \ldots \ldots \ldots \ldots$ 2-18

2-12 Close-Up View of Accelerometers on the Impact

Test Unit ................................. 2-19

2-13 Locations of the End-Impact Test Dimensional

Inspection .............................. 2-20

3-1 Representative Plot of a Shock Pulse From the

1,000 -g Shock Impulse Test ..................... 3-18

3-2 Representative Plot of a Shock Pulse From the 5,000-g Shock Impulse Test .................... 3-18

3-3 Representative Plot of a Shock Pulse From the 10,000-g Shock Impulse Test ..................... 3-19

3-4 Distribution of Normalized MFA Accelerations From

Shock Impulse Tests ....................... 3-22

3-5 Typical Elastic Load History From Static Crush Tests ...... 3-26

3-6 Elastic Deflection History From Static Crush Tests ....... 3-26 


\section{LIST OF FIGURES}

(Continued)

Figure

3-7 Typical Elastic Axial Strain Gage Plot From

Static Crush Tests .......................... 3-27

3-8 Elastic Axial Strain Distribution From Static

Crush Tests ............................. 3-30

3-9 Elastic Hoop Strain Distribution From Static

Crush Tests ............................. 3-30

3-10 Plastic Load History From Static Crush Tests ........... 3-31

3-11 Plastic Deflection History From Static Crush Tests ........ 3-31

3-12 Plastic Axial Strain Gage Plot From Static

Crush Tests ............................ 3-32

3-13 Load Versus Extensometer Strain Plot From Static

Crush Tests ............................. 3-32

3-14 Plastic Axial Strain Distribution From Static

Crush Tests ............................ 3-42

3-15 Plastic Hoop Strain Distribution From Static

Crush Tests ............................. 3-42

3-16 Typical Accelerometer Filtered at 10,000 $\mathrm{Hz}$ From

End-Impact Tests .......................... 3-44

3-17 Typical Accelerometer Filtered at 1,000 $\mathrm{Hz}$ From

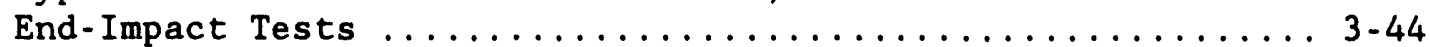

3-18 Typical Strain-Time History for an Axial Gage From

End-Impact Tests.......................... 3-46

3-19 End-Impact Test Distribution of Permanent

Axial Deformations .......................... 3-51

3-20 End-Impact Test Multiplot of Strain Histories for Axial Gages SG 1, SG 6, SG 11, and SG 16 Located at 1 in. From the Impact End .................. 3-52

3-21 End-Impact Test Multiplot of Strain Histories for Axial Gages SG 5, SG 10, SG 15, and SG 20 Located at 6 in. From the Impact End .................. 3-52

3-22 End-Impact Test Multiplot of 10,000-Hz Filtered Time Histories for Accelerometers A1, A2, A3, and A4 ....... 3-54 
(Continued)

\section{Figure}

3-23 End-Impact Test Multiplot of 10,000-Hz Filtered Time Histories for B\&K Accelerometers A5, A6, and A7 ....... 3-54

D-1 End-Impact Test 1 Axial Strain at 1 in. $\ldots \ldots \ldots \ldots \ldots \ldots$ D.2

D-2 End-Impact Test 1 Hesp Strain at 1 in. $\ldots \ldots \ldots \ldots \ldots \ldots \ldots$. 2

D-3 End-Impact Test 1 Axial Strain at 3 in. $\ldots \ldots \ldots \ldots \ldots \ldots$

D-4 End-Impact Test 1 Hoop Strain at 3 in. $\ldots \ldots \ldots \ldots \ldots \ldots \ldots$

D-5 End-Impact Test 1 Axial Strain at 6 in. $\ldots \ldots \ldots \ldots \ldots \ldots$ D-4

D-6 End-Impact Test 2 Axial Strain at 1 in. $\ldots \ldots \ldots \ldots \ldots \ldots$

D-7 End-Impact Test 2 Hoop Strain at 1 in. $\ldots \ldots \ldots \ldots \ldots \ldots \ldots$

D-8 End-Impact Test: 2 Axial Strain at 3 in. $\ldots \ldots \ldots \ldots \ldots \ldots$ D-5

D-9 End-Impact Test 2 Hoop Strain at 3 in. $\ldots \ldots \ldots \ldots \ldots \ldots$ D-6

D-10 End-Impact Test 2 Axial Strain at 6 in. $\ldots \ldots \ldots \ldots \ldots \ldots$

D-11 End-Impact Test 3 Axial Strain at 1 in. ............. D-7

D-12 End-Impact Test 3 Hoop Strain at 1 in. $\ldots \ldots \ldots \ldots \ldots \ldots$

D-13 End-Impact Test 3 Axial Strain at 3 in. $\ldots \ldots \ldots \ldots \ldots \ldots$

D-14 End-Impact Test 3 Hoop Strain at 3 in. $\ldots \ldots \ldots \ldots \ldots \ldots$ D-8

D-15 End-Impact Test 3 Axial Strain at 6 in. ............. D-9

D-16 End-Impact Test 4 Axial Strain at 1 in. $\ldots \ldots \ldots \ldots \ldots \ldots$

D-17 End-Impact Test 4 Hoop Strain at 1 in. ............. D-10

D-18 End-Impact Test 4 Axial Strain at 3 in. ............ D-10

D-19 End-Impact Test 4 Hoop Strain at 3 in. $\ldots \ldots \ldots \ldots \ldots \ldots \ldots$ D-11

D-20 End-Impact Test 4 Axial Strain at 6 in. ............

D-21 End-Impact Test 5 Axial Strain at 1 in. ............ D-12

D-22 End-Impact Test 5 Hoop Strain at 1 in. ..............

D-23 End-Impact Test 5 Axial Strain at 3 in. ............. D-13 
D-24 End-Impact Test 5 hoop Strain at 3 in. ............. D-13

D-25 End-Impact Test 5 Axial Strain at 6 in. ............. D-14

D-26 End-Impact Test 6 Axial Strain at 1 in. ............. D-14

D-27 End-Impact Test 6 Hoop Strain at 1 in. ............. D-15

D-28 End-Impact Test 6 Axial Strain at 3 in. ............. D-15

D-29 End-Impact Test 6 Hoop Strain at 3 in. ............ D-16

D-30 End-Impact Test 6 Axial Strain at 6 in. ............. D-16

D-31 End-Impact Test 7 Axial Strain at 1 in. ............ D-17

D-32 End-Impact Test 7 Hoop Strain at 1 in. ............. D-17

D-33 End-Impact Test 7 Axial Strain at 3 in. ............. D-18

D-34 End-Impact Test 7 Hoop Strain at 3 in. ............. D-18

D-35 End-Impact Test 7 Axial Strain at 6 in. ............ D-19

D-36 End-Impact Test 8 Axial Strain at 1 in. ............. D-19

D-37 End-Impact Test 8 Hoop Strain at 1 in. ............ D-20

D-38 End-Impact Test 8 Axial Strain at 3 in. $\ldots \ldots \ldots \ldots \ldots \ldots$ D-20

D-39 End-Impact Test 8 Hoop Strain at 3 in. ............. D-21

D-40 End-Impact Test 8 Axial Strain at 6 in. $\ldots \ldots \ldots \ldots \ldots \ldots \ldots \ldots$

D-41 End-Impact Test 9 Axial Strain at 1 in. $\ldots \ldots \ldots \ldots \ldots \ldots$ D-22

D-42 End-Impact Test 9 Hoop Strain at 1 in. $\ldots \ldots \ldots \ldots \ldots \ldots \ldots \ldots \ldots \ldots \ldots$

D-43 End-Impact Test 9 Axial Strain at 3 in. ............ D-23

D-44 End-Impact Test 9 Hoop Strain at 3 in. ............ D-23

D-45 End-Impact Test 9 Axial Strain at 6 in. ........... D-24

D-46 End-Impact Test 10 Axial Strain at 1 in. ............. D-24

D-47 End-Impact Test 10 Hoop Strain at 1 in. ............ D-25

D-48 End-Impact Test 10 Axial Strain at 3 in. ........... D-25 


\section{LIST OF FIGURES}

(Continued)

Figure

$\underline{\text { Page }}$

D-49 End-Impact Test 10 Hoop Strain at 3 in. $\ldots \ldots \ldots \ldots \ldots \ldots \ldots$

D-50 End-Impact Test 10 Axial Strain at 6 in. ............ D-26

E-1 End-Impact Test 1 Endevco 7270A-20K Accelerations

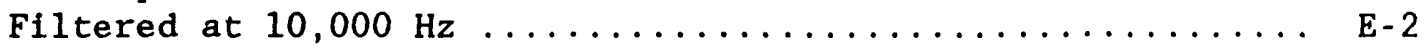

E-2 End-Impact Test 2 Endevco 7270A-20K Accelerations

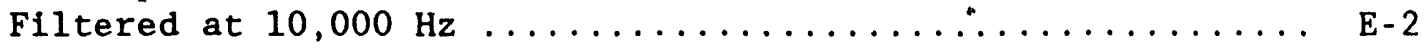

E-3 End-Impact Test 3 Endevco 7270A-20K Accelerations

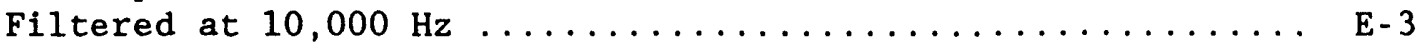

E-4 End-Impact Test 4 Endevco 7270A-20K Accelerations

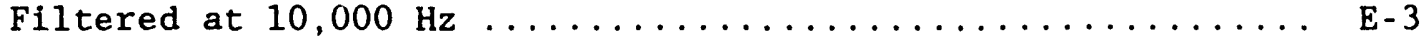

E-5 End-Impact Test 5 Endevco 7270A-20K Accelerations

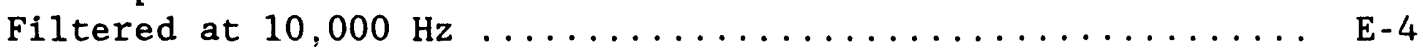

E-6 End-Impact Test 6 Endevco 7270A-20K Accelerations

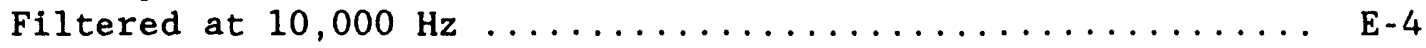

E-7 End-Impact Test 7 Endevco 7270A-20K Accelerations

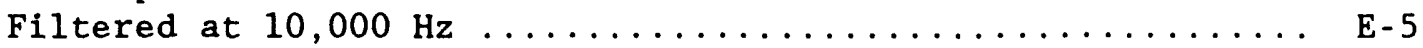

E-8 End-Impact Test 8 Endevco 7270A-20K Accelerations

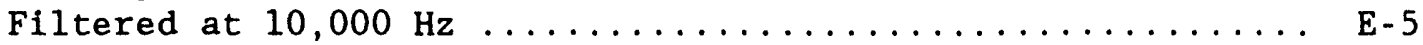

E-9 End-Impact Test 9 Endevco $7270 \mathrm{~A}-20 \mathrm{~K}$ Accelerations
Filtered at $10,000 \mathrm{~Hz} \ldots \ldots \ldots \ldots \ldots \ldots \ldots \ldots \ldots \ldots \ldots \ldots \ldots \ldots \ldots \ldots$

E-10 End-Impact Test 10 Endevco 7270A-20K Accelerations

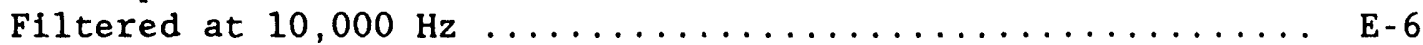

E-11 End-Impact Test 1 B\&K 8309 Accelerations Filtered
at $10,000 \mathrm{~Hz} \ldots \ldots \ldots \ldots \ldots \ldots \ldots \ldots \ldots \ldots \ldots \ldots \ldots \ldots \ldots \ldots \ldots \ldots$

E-12 End-Impact Test 2 B\&K 8309 Accelerations Filtered

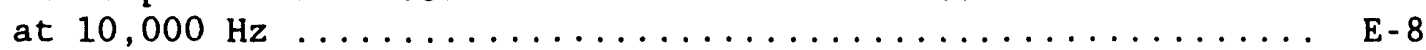

E-13 End-Impact Test 3 B\&K 8309 Accelerations Filtered

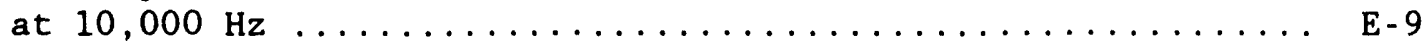

E-14 End-Impact Test 4 B\&K 8309 Accelerations Filtered

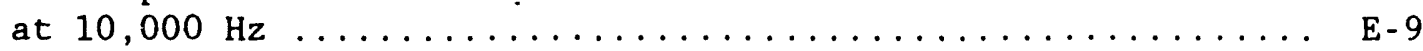

E-15 End-Impact Test 5 B\&K 8309 Acceleritions Filtered

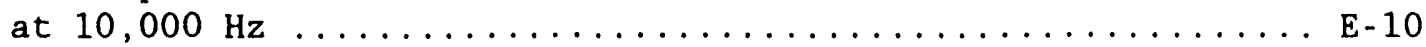




\section{LIST OF FIGURES}

(Concluded)

Figure

Page

E-16 End-Impact Test 6 B\&K 8309 Accelerations Filtered

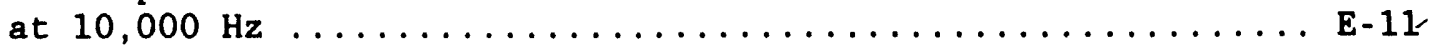

E-17 End-Impact Test 7 B\&K 8309 Accelerations Filtered

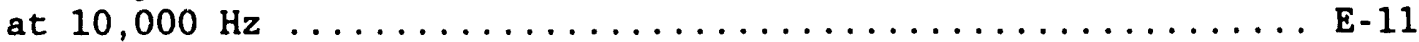

E-18 End-Impact Test 8 B\&K 8309 Accelerations Filtered

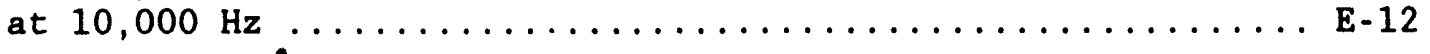

¿-19 End-Impact Test 9 B\&K 8309 Accelerations Filtered

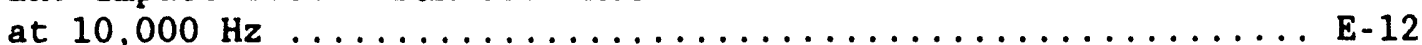


Table

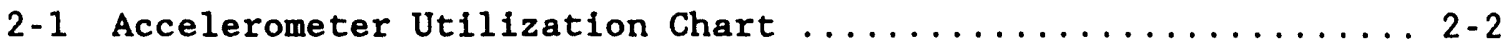

2-2 Location and Direction of Strain Gages for the Static Crush Tests .........................2-10

2-3 Locations, Designations, and Directions of End-Impact

Test Strain Gages and Accelerometers ............... 2-17

3-1 Accelerometer Calibration Data From Shock Impulse Tests ............................ 3-2

3-2 Accelerometer Calibration Data From End-Impact Tests ...... 3-5

3-3 Accelerometer Output Pulse Parameters From Shock Impulse Tests ............................ 3-9

3-4 Normalized Accelerations From Shock Impulse Tests (Normalized With Respect to A9) .................. 3-20

3-5 Shock Impulse Test Velocity Change Determined Froin the Integration of Acceleration .................. 3-23

3-6 Peak Elastic Strain $(\mu \varepsilon)$ at the First and Fourth Peaks From Static Crush Tests ................... 3-28

3-7 Material Yield Stress and Elastic Limit Determined From Static Crush Tests ...................... 3-33

3-8 Plastic Peak and Permanent Strain $(\mu \varepsilon)$ From Static Crush Tests ............................. 3-34

3-9 Measured and Calculated Permanent Strain $(\mu \varepsilon)$ From Static Crush Tests ....................... 3-38

3-10 Accelerometer Data (g) From End-Impact Tests .......... 3-45

3-11 Plastic Peak and Permanent Strain $(\mu \varepsilon)$ From End-Impact Tests ............................ 3-47

3-12 Permanent Measured Versus Calculated Strain $(\mu \varepsilon)$

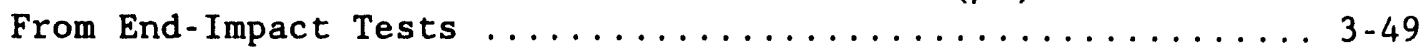

4-1 Standard Deviations for the Normalized Shock Impulse Tests, Static Crush Plastic Tests, and End-Impact Tests................................ 4-2 
Sandia National Laboratories (SNL) has completed an extensive testing project to evaluate transducers used in the design certification testing of nuclear material shipping packages for the Office of Civilian Radioactive Waste Management (OCRWM) Cask Systems Development Program. This testing project compared results of experiments obtained from transducers in laboratory and field tests. A large number of tests were conducted to investigate scatter in test data and the repeatability of results.

Two types of accelerometers and two types of strain gages were evaluated. Accelerometers were evaluated using calibration, shock, and impact testing. Only the calibration testing is directly comparable to factory specifications. Strain gages were evaluated using static loading and impact testing. This range of tests provided wellcharacterized laboratory tests for both the accelerometers and the strain gages and closely modeled the environment the transducers are subjected to in the testing of radioactive material shipping packages.

The results indicated little difference between the measurements obtained by transducers manufactured by different companies. However, results showed that a high confidence should not be placed in a single transducer to give reliable results. Even in well-controlled tests, the results were subject to considerable scatter. This emphasizes the importance of having redundant instrumentaion in test programs. Tests also revealed that the results from any single transducer give only an estimate of the actual results. The standard deviation of the peak accelerations obtaint in the shock impulse tests was 3.48 of the average value. For the static crush plastic tests, the standard deviation of the axial strains was approximately $8 z$ of the average value. For the end-impact tests, the $1,000-\mathrm{Hz}$ filtered peak accelerations had a standard deviation of 158 of their average value, and the $10,000-\mathrm{Hz}$ filtered peak acceleration data had a standard deviation of 218 of the average. The results showed that test data were not, in general, more accurate than \pm 10 of the measured result. It is very likely that the majority of these deviations are due to changes in the quantities being measured, rather than transducer response. Part of the reason for this is that transducers give results only for the location at which they are located on the test specimen, and the local response at this point may not be representative of the quantity being measured at nearby locations. Also, because problems with the instrumentation or connections to or within the data acquisition system can produce questionable measurements, a data acquisition system must be used with diagnostics or other methods capable of isolating problems. Because the goal of this project was to compare transducers, readings where the deviation was suspected of being caused by other sources were not included in the evaluations.

This report can be used as a tool for instrumentation workers to aid in the selection of transducer types and numbers. It also can provide better understanuing of the process by which published data are derived concerning design certification testing of nuclear material shipping packages. 


\subsection{INTRODUCTION}

The Nuclear Waste Policy Act (NWPA) of 1982 (U.S. Congress, 1982) and its amendment in 1987 (the Amendments Act) (U.S. Congress, 1987) mandates the U.S. Department of Energy (DOE) to establish and operate a comprehensive, integrated system for the disposal of spent nuclear fuel and high-level radioactive waste. Under the NWPA, the Office of Civilian Radioactive Waste Management (OCRWM) was established within the DOE to fulfill this responsibility. A key component of the disposal program is the development and operation of a transportation system to move the waste from present locations to disposal facilities. A fleet of casks capable of transporting the waste by truck, rail, or barge is being developed.

Section 5061 of the Amendment Act specifies that each cask must be certified by the U.S. Nuclear Regulatory Commission (NRC). To meet these requirements, OCRWM is undertaking a program to design, test, certify, and fabricate a variety of cask systems. Design verification tests will be performed by the cask contractors to demonstrate design safety and to aid in cask certification by the NRC. During design verification testing of Type $B$ shipping packagings, designers verify analytical calculations with instrumentation data. Many packagings are tested with transducers that measure structural response. Two types of tranducers, accelerometers and strain gages, are considered here. Accelerometers measure acceleration and strain gages measure surface strain at the mounted location.

This document describes the method developed by Sandia Natioral Laboratories (SNL) to evaluate various accelerometers and strain gages. This evaluation is based on the results of tests conducted to measure ruggedness, failure frequency, repeatability, and manufacturers' calibration data under both field and laboratory conditiuns. The results of these tests are provided and discussed. The transducers were selected for testing by surveying cask contractors and testing facilities. Important insights relating to operational characteristics of acceleroneter types were gained during field testing.

Chapter 2.0 of this document describes the calibration and shock impulse testing of the accelerometers and static testing of strain gages under laboratory conditions. Chapter 2.0 also describes the impact testing for accelerometers and strain bages performed under field conditions. Chapter 3.0 describes the test results of accelerometer calibration and shock tests, strain gage static tests, and end-impact tests for both accelerometers and strain gages. Chapter 4.0 discusses the results of the field and laboratory tests, which demonstrate that there is little difference in the performance of the transducers evaluated.

Appendix A lists the survey participants who suggested accelerometers and strain gages for study and includes a copy of the survey form. Dimensional inspection data from the static test are provided in Appendix B, and end-impact dimensional inspection data are provided in Appencix $C$. Strain gage and accelerometer multiplots from end-impact tests are provided in Appendices $D$ and $E$, respectively. 


\subsection{DESCRIPTION OF THE TEST PROGRAM}

The transducers that were evaluated were selected based on a survey of OCRWM cask contractors and various testing laboratories. The survey requested data concerning the types of test transducers in use currently or in the future. The responses to this survey led to the selection of Endevco 7270 series and Bruel and Kjaer (B\&K) 8309 accelerometers, and Micro-Measurements and BLH strain gages. A list of surveyed companies and a sample of the survey questionnaire are provided in Appendix $A$.

This evaluation of selected accelerometers and stain gages was compised of laboratory and end-impact tests. The accelerometers were evaluated using calibration, shock, and impact testing. The strain gages were evaluated using static loading and impact testing. This range of tests provided well-characterized laboratory tests for both the accelerometers and the strain gages. The end-impact tests closely modeled the enviroiment transducers encountered during the testing of radioactive material shipping packages. Multiple tests of each type were performed to determine the repeatability of the test results. Detailed descriptions of the tests performed for this evaluation are provided in the following sections.

\subsection{Accelerometer Laboratory Testing}

Accelerometers convert mechanical energy that is proportional to the input acceleration into electrical energy. Endevco 7270A-20K accelerometers are piezoresistive and B\&K 8309 accelerometers are piezoelectric. The selected piezoresistive accelerometer uses a single, monolithic silicon chip sensing element. This element is a four-arm resistive strain gage assembly that is arranged in a full wheatstone bridge circuit to monitor the resistance change. The sensing element has a mass mounted at the end of a cantilevered beam. When subjected to an acceleration, the mass deflects, bending the beam. This bending causes a strain in the strain gage assembly that changes its resistance. The bridge circuit requires an input voltage and measures the change in output voltage proportional to the change in resistance.

The piezoelectric accelerometer is a self-generating device that produces a change in the electrical charge due to an applied strain by an internal mass on a piezoelectric ceramic. The induced strain changes the electrical charge across the piezoelectric sensing element. This change is proportional to the applied acceleration.

In addition to the test accelerometers, two types of reference accelerometers, Kistler 805 and Endevco 2270M9, were used. The Kistler 805 is calibrated as a primary standard accelerometer and the Endevco 2270 is an accelerometer that Endevco suggests using as a primary standard for comparison calibration of other accelerometers. The tested accelerometers were divided into three sets. In each set, there were four Endevco 7270 accelerometers, three B\&K 8309 accelerometers, and one Endevco 2270 reference accelerometer. Sets 1 and 3 used the same Kistler 805 reference accelerometer, and Set 2 had a different Kistler 805 reference. Table 2-1 shows the set that was used in each test. 


\section{TABLE 2-1. ACCELEROMETER UTILIZATION CHART}

\begin{tabular}{|c|c|c|c|c|c|c|c|c|c|c|c|}
\hline \multirow{2}{*}{$\begin{array}{c}\text { SET } \\
\text { NUMBER }\end{array}$} & \multirow{2}{*}{$\begin{array}{c}\text { SHOCK } \\
\text { IMPULSE } \\
\text { SERIES }\end{array}$} & \multicolumn{10}{|c|}{ END-IMPACT TEST NUMBER } \\
\hline & & 1 & 2 & 3 & 4 & 5 & 6 & 7 & 8 & 9 & 10 \\
\hline 1 & $\mathbf{x}$ & $\mathbf{x}$ & & & $\mathbf{x}$ & & & $\mathbf{x}$ & & & \\
\hline 2 & $\mathbf{x}$ & & $\mathbf{x}$ & & & $\mathbf{x}$ & & & $\mathbf{x}$ & & $\mathbf{x}$ \\
\hline 3 & $\mathbf{x}$ & & & $\mathbf{x}$ & & & $\mathbf{x}$ & & & $\mathbf{x}$ & \\
\hline
\end{tabular}

\subsubsection{Calibration Testing}

Calibration testing of the accelerometers was performed in two controlled laboratory environments. Three important characteristics of accelerometers--sensitivity, amplitude linearity and frequency response--were calibrated by the manufacturer. Data acquisition systems require amplitude linearity and also require the sensitivity to relate acceleration to electrical output (Walter, 1978). Performance over the required range of frequencies was verified by frequency response calibration. The accelerometers that were evaluated by SNL were procured with manufacturer calibration certificates.

In addition, each of the accelerometers was subjected to a series of calibrations at the SNL calibration laboratory. The SNL calibration laboratory provides calibrations traceable to DOE's primary standards. These calibrations were performed in conjunction with the factory calibrations to provide a baseline to compare the post-test calibrations.

Three types of calibrations were performed on the Endevco 7270 accelerometers at SNL: shock, centrifuge, and frequency. The frequency calibration was performed at ambient temperature and at $-20^{\circ} \mathrm{F}$. Cold temperature calibration was performed to determine the response of the accelerometers in cold environments. The Code of Federal Regulations (10 CFR 71) requires evaluation of Type B nuclear material packages at this temperature (NRC, 1989). The B\&K 8309 accelerometers were calibrated using shock and frequency techniques only; the nature of piezoelectric accelerometers precluded their use in measuring a steady acceleration field, as generated in the centrifuge calibration technique.

The shock calibration technique used was the drop-ball method. In this comparative calibration, the accelerometer was shocked five times at varying amplitude levels. A reference accelerometer calibrated by the 
SNL Primary Standards Laboratory was mounted on the same fixture as the accelerometer to be calibrated. The reference accelerometer's output was used to determine the acceleration level experienced by the accelerometer to be calibrated, and the sensitivity was determined by dividing its output by the acceleration determined by the reference accelerometer. Sandia's calibration laboratory has determined that deviations in the sensitivity within 88 of the value obtained by the frequency calibration are acceptable. If the deviation is larger than this, the acceleromete: was rejected.

Centrifuge calibration was used to determine amplitude linearity. The output of the accelerometer at specified acceleration levels divided by the input acceleration produced the accelerometer sensitivity. The acceleration level was determined from the rotation rate of the centrifuge and the distance between the position of the mounted accelerometer and the axis of rotation. Readings were taken at $1,000 \mathrm{~g}$ increments, from $-5,000$ to $+5,000 \mathrm{~g}$. The accelerometer output was plotted against the applied acceleration level and a least-squares straight-line fit was determined. The accelerometer sensitivity is the slope of this line. Amplitude linearity is expressed as a percent deviation from the straight-line fit. Sandia's calibration laboratory has determined that deviations of less than \pm 38 of accelerometer range provide acceptable amplitude linearity.

The frequency response of an accelerometer was determined by the deviation in sensitivity with respect to frequency. Accelerometers that were tested were considered by Sandia's calibration laboratory to have flat frequency response when the variation in sensitivity versus frequency deviated no greater than 58 from the base sensitivity (at $100 \mathrm{~Hz}$ ) over their frequency range. If the accelerometer data fell within this frequency band, the accelerometer was considered to have an acceptable linear response in the frequency dorain. The frequency response of the accelerometers were determined by shaker calibration. The accelerometer was subjected to a constant acceleration level over a broad range of frequencies, from 50 to $10,000 \mathrm{~Hz}$, for this calibration. The transducer sensitivity was determined from the ratio of the accelerometer output at the specified frequency to the acceleration level. In this type of calibration, the acceleration level was constant at approximately $30 \mathrm{~g}$ rhile the frequency was changed. The accelerometer sensitivity was referenced to the output at $100 \mathrm{~Hz}$.

This calibration process was performed again for each set of test evaluation accelerometers after their shock test series and after each of the end-impact tests in which they were used. The primary standard accelerometers were re-calibrated after the shock tests.

\subsubsection{Shock Impulse Testing}

Cask impact testing produces a shock input to accelerometers and the accelerometers, in turn, produce an electrical output representative of the input. Therefore, shock testing on each accelerometer was performed under controlled conditions. The tests consisted of a series of shocks to each of the three sets of accelerometers. Four Endevco 7270 accelerometers, three B\&K 8309 accelerometers, and two reference accelerometers 
calibrated as primary standards were mounted on a common test fixture. This fixture was a 5.5-in.-square by 1.0-in.-thick plate of 7075-T651 aluminum. Figure 2-1 shows a photograph of the test fixture and the location of the accelerometers. The fixture was mounted on a $10,000-\mathrm{g}$ vertical shock frame manufactured by Minnesota Testing Systems (MTS) (Figures 2-2 and 2-3). The shock frame provided a haversine pulse, with a pulse width ranging from 0.5 to $2.5 \mathrm{~ms}$, depending on the acceleration level. An idealized haversine shock pulse is shown in Figure 2-4. The fixture was shocked three times at each of three levels: $1,000,5,000$, and $10,000 \mathrm{~g}$. These acceleration levels were chosen to utilize the accelerometers in ranges that envelope the response experienced in typical cask impact testing. The characteristics of the shock pulse were controlled by selecting the impact velocity and the stiffness of the impacting surface. The output of the accelerometers was recorded using digital storage oscilloscopes, one channel for each accelerometer. This procedure was repeated for each of the remaining two sets.

\subsection{Strain Gage Laboratory Testing}

In general, the response of the strain gages can be affected by installation practices. Typically, because strain gages are permanently installed, they are not calibrated on large structures. Instead, reliance is placed on established manufacturer's specifications and installation techniques. The manufacturer publishes properties of the strain gages based on lot sampling and proven lot tclerances. In typical cask testing, the strain gages are wired in a quarter-bridge configuration, where the strain gage is the only active element. [Strain gage circuits are described in detail by Window (1983) and Dally (1978).] After installation, the resistance across the strain gage and the resistance between the strain gage and the test specimen are measured to verify the electrical circuit. The person who installs the gage verifies that the gage is properly bonded to the test article, based on his or her judgment and experience.

Static tests were first performed at SNL on the strain gages to evaluate their performance during low-loading rates. These tests provided a verification of the acceptability of the installation procedures. A series of ten tests were conducted on ten individual aluminum cylinders fabricated from aluminum 6061-0 tubing. The cylinders were 24 in. in length, with inner and outer diameters of 3.58 and $5.42 \mathrm{in}$, respectively. The biaxial Micro-Measurement CEA-13-125UT-350 and BLH FAET12D-35-S13EG gages were installed to measure strains in both the axial and hoop direction. Strain gages of each type were installed at 45degree intervals around the outer circumference at positions located 6 , 12, and $18 \mathrm{in.}$ from the bottom, as shown in Figure 2-5. Each specimen had 12 biaxial Micro-Measurement gages and 12 biaxial BLH gages, but only ten of the BLH gages in the hoop direction were monitored because of data acquisition channel availability. The gage designation, location, and direction are listed in Table 2-2. Before testing, each specimen was sent to the SNL inspection laboratory, where detailed measurements of radius and length were taken at the locations shown in Figure 2-6. This provided baseline measurement information for comparison with the subsequent dimensional inspection. 


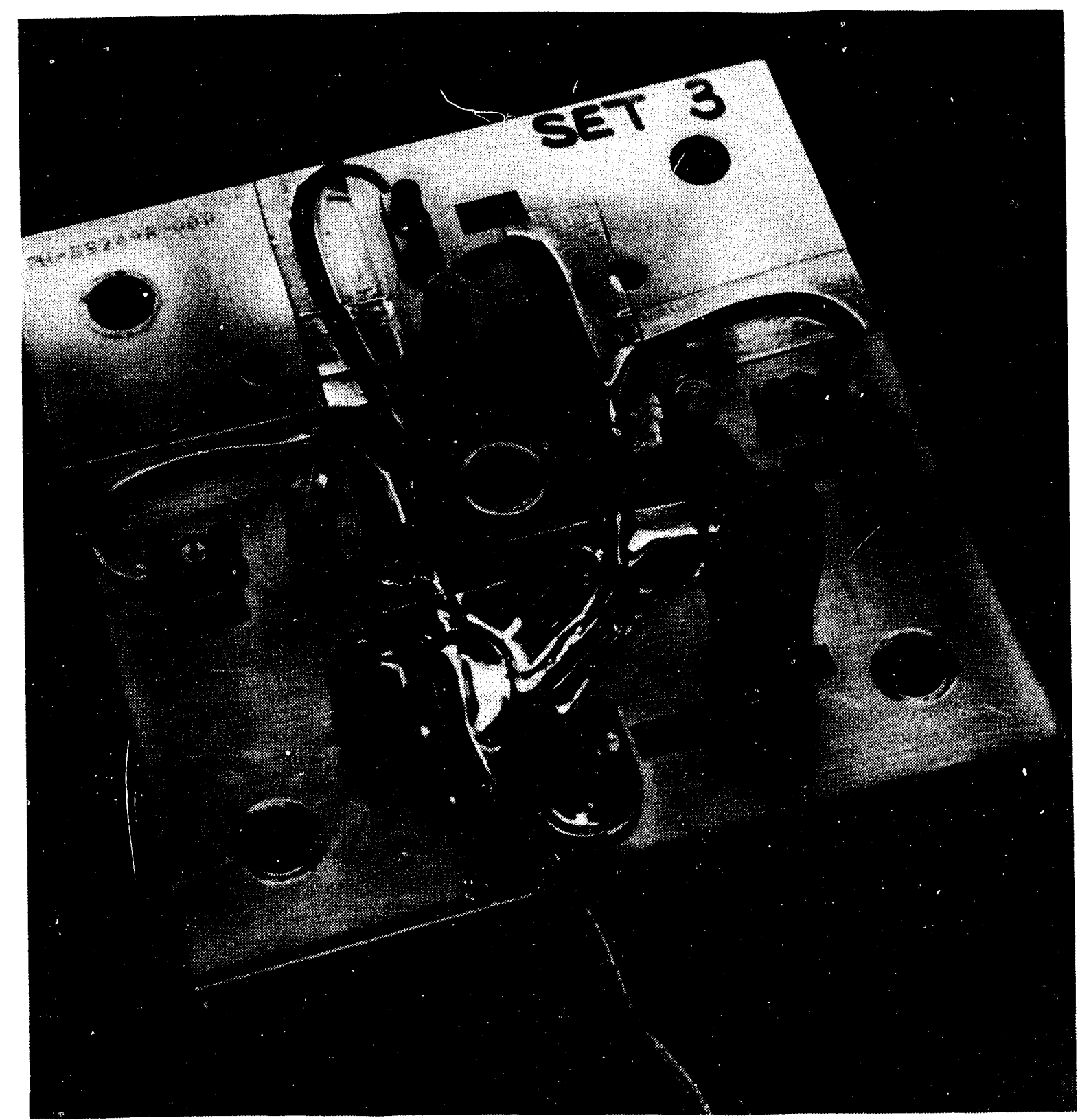

Figure 2-1. Shock Impulse Test Fixture With the Mounted Accelerometers 


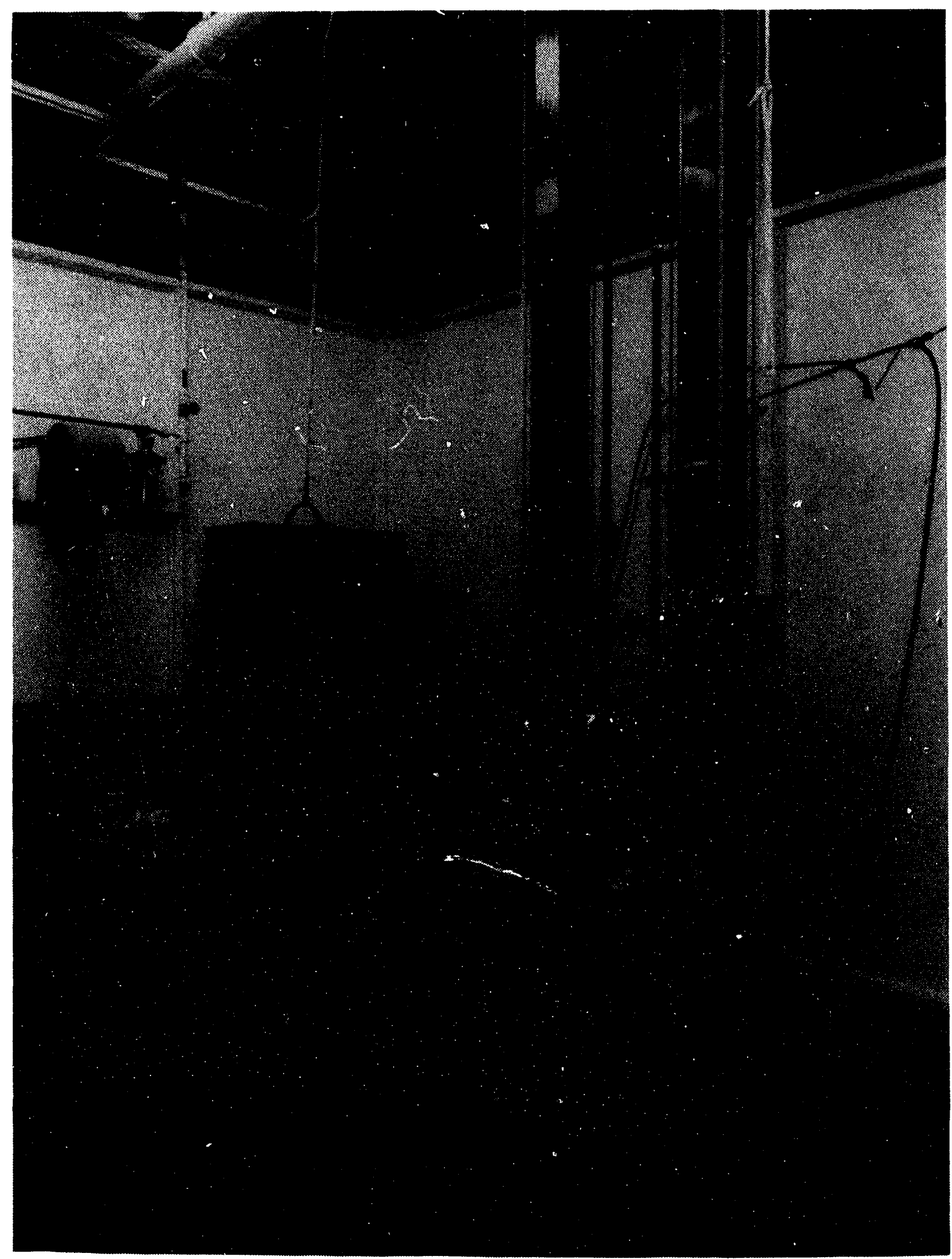

Figure 2-2. Shock Test Fixture Mounted on a 10,000-g MTS Vertical Shock Frame 


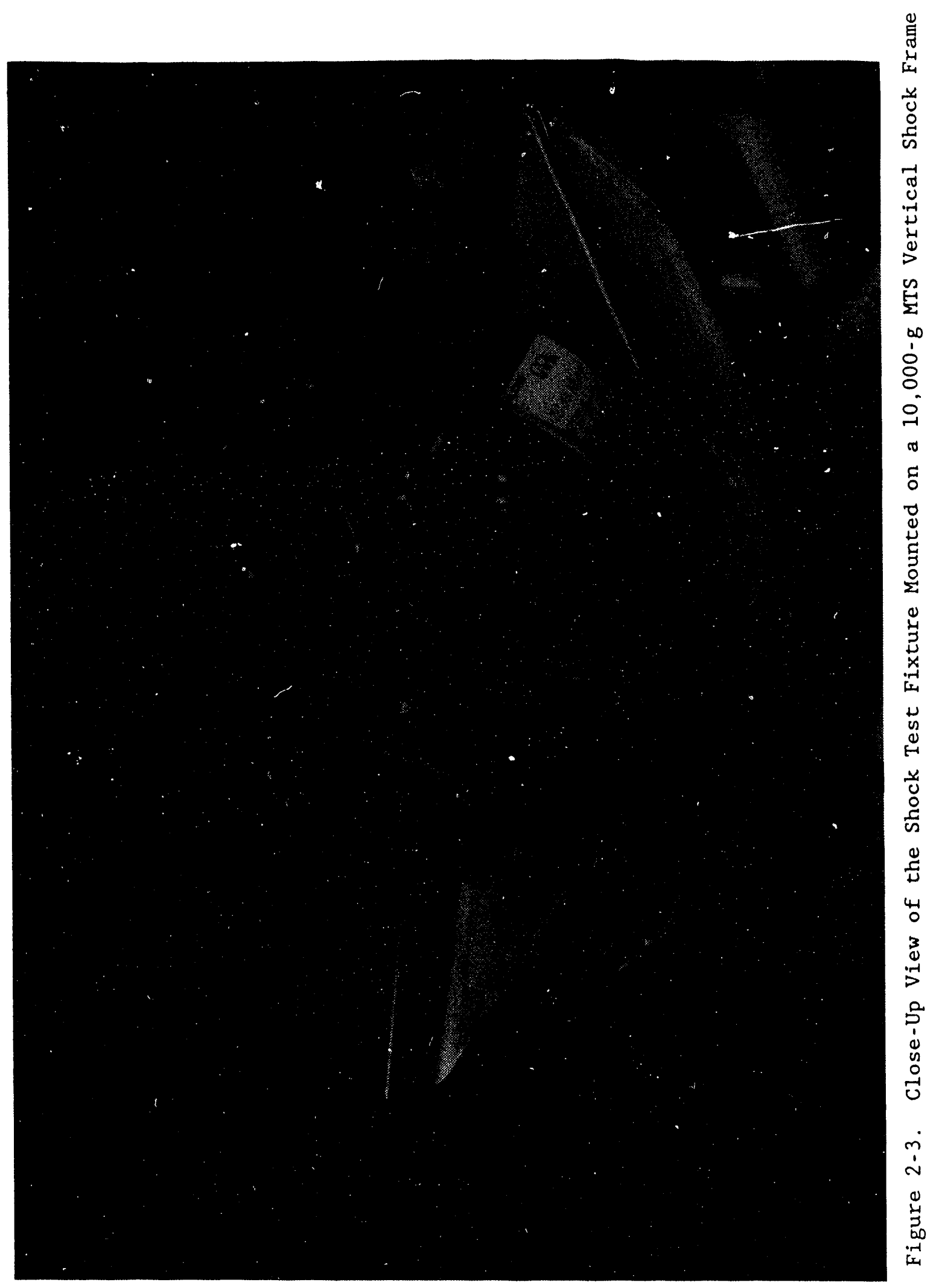




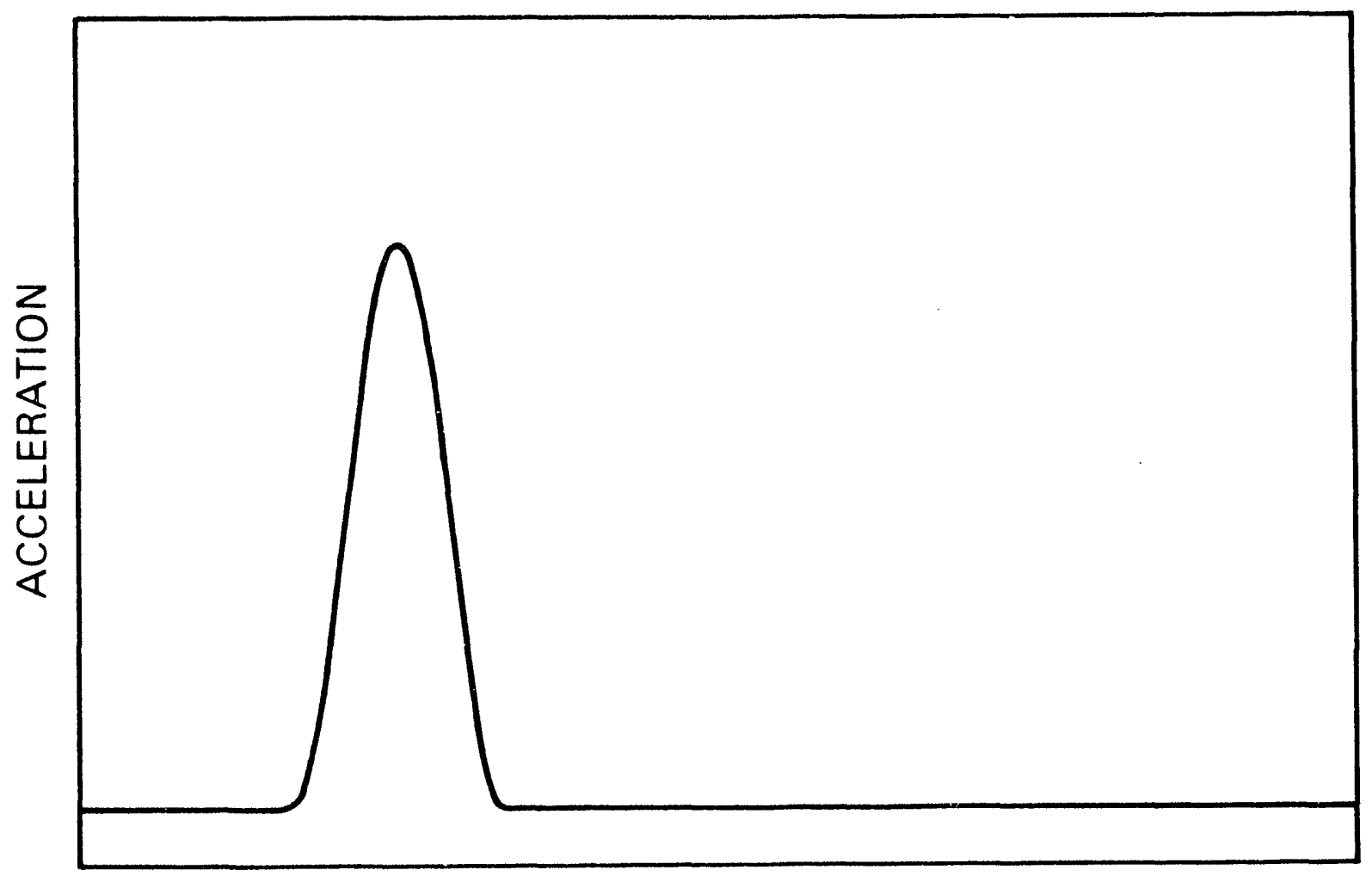

TIME

Figure 2-4. Idealized Haversine Shock Pulse

The axial compression test was conducted using a calibrated MTS compression/tension test machine with a 220,000-1b capacity.

Figures 2-7 and 2-8 show the machine and test setup. The static crush test of each unit consisted of two parts. During the first portion of the test, a load control test was performed. The load was cycled four times to 40,000 $\mathrm{lb}$, which is approximately 708 of the elastic limit of the material. The purpose of the load control test was to determine the hysteretic behavior of the strain gages. The loading rate for these tests was $8,000 \mathrm{lb} / \mathrm{s}$, which corresponds to a strain rate of $6.15 \times 10^{-5}$ in./in./s. After the load control test, the test machine was operated in a displacement control mode and the specimen was loaded through the elastic range, extending to approximately 28 strain. The displacement rate for this portion of the test was $0.0125 \mathrm{in.} / \mathrm{s}$, which corresponds to a strain rate of $5.21 \times 10^{-4} \mathrm{in./in./s.} \mathrm{Strain,} \mathrm{load,} \mathrm{and} \mathrm{displacement}$ data were recorded during each test using digital transient recorders. After the tests were completed, each specimen was returned to the inspection laboratory and all of the measurements were repeated to determine the magnitude of the permanent deformation. 


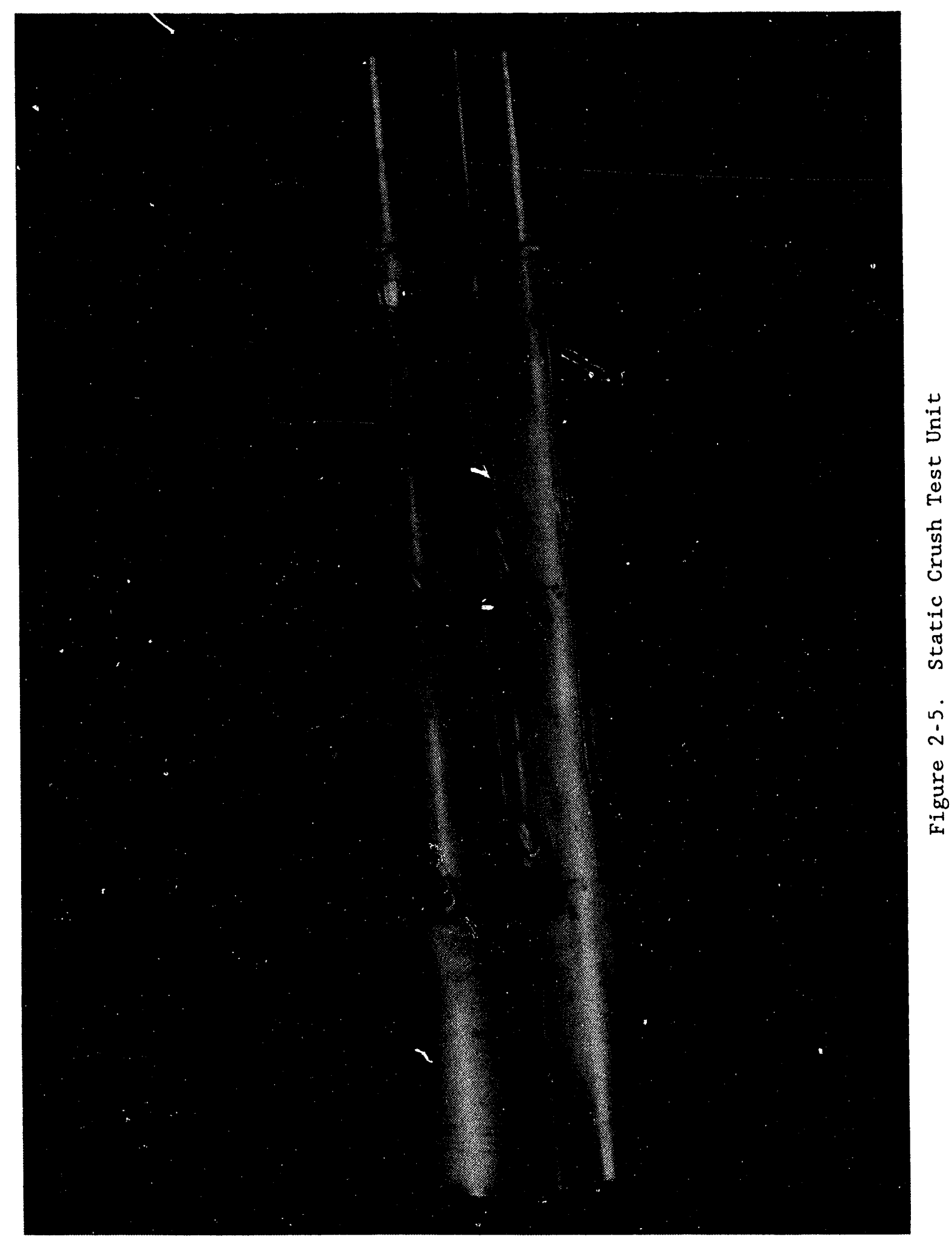




\begin{tabular}{|c|c|c|c|c|}
\hline \multicolumn{5}{|c|}{$\begin{array}{l}\text { TABLE 2-2. LOCATION AND DIRECTION OF STRAIN GAGES } \\
\text { FOR THE STATIC CRUSH TESTS }\end{array}$} \\
\hline $\begin{array}{c}\text { GAGE } \\
\text { DESIGNATION }\end{array}$ & $\begin{array}{c}\text { TYPE/CATALOG } \\
\text { NUMBER }\end{array}$ & $\frac{L C}{\text { DEGREE }}$ & In. & DIRECTION \\
\hline $\begin{array}{l}\text { SG1 } \\
\text { SG2 } \\
\text { SG3 } \\
\text { SG4 } \\
\text { SG5 } \\
\text { SG6 } \\
\text { SG7 } \\
\text { SG8 } \\
\text { SG9 } \\
\text { SG10 } \\
\text { SG11 } \\
\text { SG12 } \\
\text { SG13 } \\
\text { SG14 } \\
\text { SG15 } \\
\text { SG16 } \\
\text { SG17 } \\
\text { SG18 } \\
\text { SG19 } \\
\text { SG20 } \\
\text { SG21 } \\
\text { SG22 } \\
\text { SG23 } \\
\text { SG24 } \\
\text { SG25 } \\
\text { SG26 } \\
\text { SG27 } \\
\text { SG28 } \\
\text { SG29 } \\
\text { SG30 } \\
\text { SG31 } \\
\text { SG32 } \\
\text { SG33 } \\
\text { SG34 } \\
\text { SG35 } \\
\text { SG36 } \\
\text { SG37 } \\
\text { SG38 } \\
\text { SG39 } \\
\text { SG40 } \\
\text { SG41 } \\
\text { SG42 } \\
\text { SG43 } \\
\text { SG44 } \\
\text { SG45 } \\
\text { SG46 } \\
\text { SG47 } \\
\text { SG48 }\end{array}$ & $\begin{array}{l}\text { CEA-13-125UT-350 } \\
\text { CEA-13-125UT-350 } \\
\text { CEA-13-125UT-350 } \\
\text { CEA-13-125UT-350 } \\
\text { CEA-13-125UT-350 } \\
\text { CEA-13-125UT-350 } \\
\text { FAET-12D-35-S13EG } \\
\text { FAET-12D-35-S13EG } \\
\text { FAET-12D-35-S13EG } \\
\text { FAET-12D-35-S13EG } \\
\text { FAET-12D-35-S13EG } \\
\text { FAET-12D-35-S13EG } \\
\text { CEA-13-125UT-350 } \\
\text { CEA-13-125UT-350 } \\
\text { CEA-13-125UT-350 } \\
\text { CEA-13-125UT-350 } \\
\text { CEA-13-125UT-350 } \\
\text { CEA-13-125UT-350 } \\
\text { FAET-12D-35-S13EG } \\
\text { FAET-12D-35-S13EG } \\
\text { FAET-12D-35-S13EG } \\
\text { FAET-12D-35-S13EG } \\
\text { FAET-12D-35-S13EG } \\
\text { FAET-12D-35-S13EG } \\
\text { CEA-13-125UT-350 } \\
\text { CEA-13-125UT-350 } \\
\text { CEA-13-125UT-350 } \\
\text { CEA-13-125UT-350 } \\
\text { CEA-13-125UT-350 } \\
\text { CEA-13-125UT-350 } \\
\text { FAET-12D-35-S13E } \\
\text { FAET-12D-35-S13EG } \\
\text { FAET-12D-35-S13EG } \\
\text { FAET-12D-35-S13EG } \\
\text { FAET-12D-35-S13EG } \\
\text { FAET-12D-35-S13EG } \\
\text { CEA-13-125UT-350 } \\
\text { CEA-13-125UT-350 } \\
\text { CEA-13-125UT-350 } \\
\text { CEA-13-125UT-350 } \\
\text { CEA-13-125UT-350 } \\
\text { CEA-13-125UT-350 } \\
\text { FAET-12D-35-S13EG } \\
\text { FAET-12D-35-S13EG } \\
\text { FAET-12D-35-S13EG } \\
\text { FAET-12D-35-S13EG } \\
\text { FAET-12D-35-S13EG } \\
\text { FAET-12D-35-S13EG }\end{array}$ & $\begin{array}{r}0 \\
0 \\
0 \\
0 \\
0 \\
0 \\
45 \\
45 \\
45 \\
45 \\
45 \\
45 \\
90 \\
90 \\
90 \\
90 \\
90 \\
90 \\
135 \\
135 \\
135 \\
135 \\
135 \\
135 \\
180 \\
180 \\
180 \\
180 \\
180 \\
180 \\
225 \\
225 \\
225 \\
225 \\
225 \\
225 \\
270 \\
270 \\
270 \\
270 \\
270 \\
270 \\
315 \\
315 \\
315 \\
315 \\
315 \\
315\end{array}$ & $\begin{array}{r}6.0 \\
6.0 \\
12.0 \\
12.0 \\
18.0 \\
18.0 \\
6.0 \\
6.0 \\
12.0 \\
12.0 \\
18.0 \\
18.0 \\
6.0 \\
6.0 \\
12.0 \\
12.0 \\
18.0 \\
18.0 \\
6.0 \\
6.0 \\
12.0 \\
12.0 \\
18.0 \\
18.0 \\
6.0 \\
6.0 \\
12.0 \\
12.0 \\
18.0 \\
18.0 \\
6.0 \\
6.0 \\
12.0 \\
12.0 \\
18.0 \\
18.0 \\
6.0 \\
6.0 \\
12.0 \\
12.0 \\
18.0 \\
18.0 \\
6.0 \\
6.0 \\
12.0 \\
12.0 \\
18.0 \\
18.0\end{array}$ & $\begin{array}{l}\text { Axlal } \\
\text { Hoop } \\
\text { Axlal } \\
\text { Hoop } \\
\text { Axlal } \\
\text { Hoop } \\
\text { Axlal } \\
\text { Hoop } \\
\text { Axlal } \\
\text { Hoop } \\
\text { Axlal } \\
\text { Hoop } \\
\text { Axlal } \\
\text { Hoop } \\
\text { Axlal } \\
\text { Hoop } \\
\text { Axlal } \\
\text { Hoop } \\
\text { Axial } \\
\text { Hoop } \\
\text { Axlal } \\
\text { Hoop } \\
\text { Axlal } \\
\text { Hoop } \\
\text { Axial } \\
\text { Hoop } \\
\text { Axial } \\
\text { Hoop } \\
\text { Axial } \\
\text { Hoop } \\
\text { Axlal } \\
\text { Hoop } \\
\text { Axlal } \\
\text { Hoop } \\
\text { Axlal } \\
\text { Hoop } \\
\text { Axlal } \\
\text { Hoop } \\
\text { Axial } \\
\text { Hoop } \\
\text { Axlal } \\
\text { Hoop } \\
\text { Axial } \\
\text { Hoop } \\
\text { Axial } \\
\text { Hoop } \\
\text { Axlal } \\
\text { Hoop }\end{array}$ \\
\hline
\end{tabular}



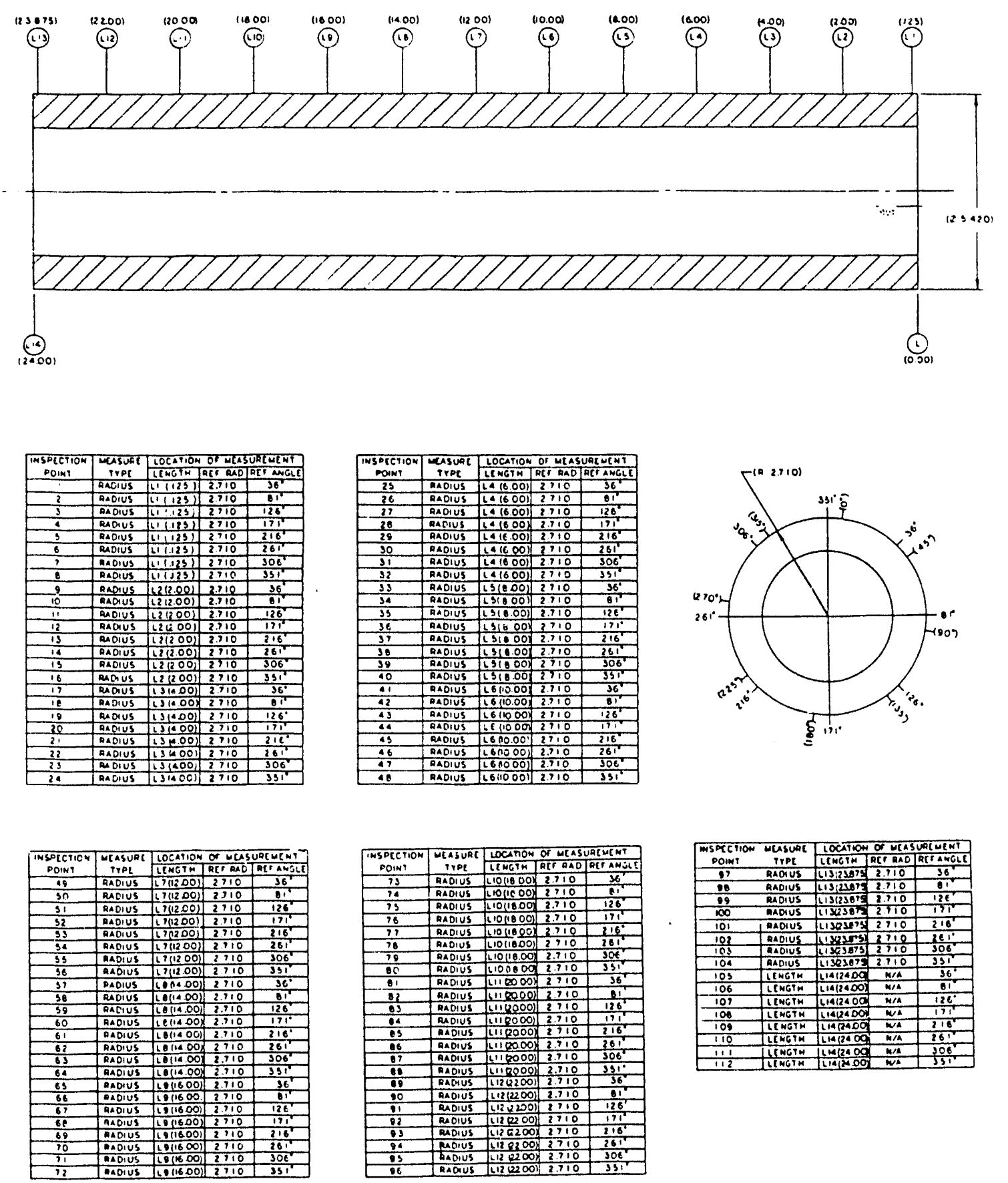

Figure 2-6. Locations of the Static Crush Test Dimensional Inspection 


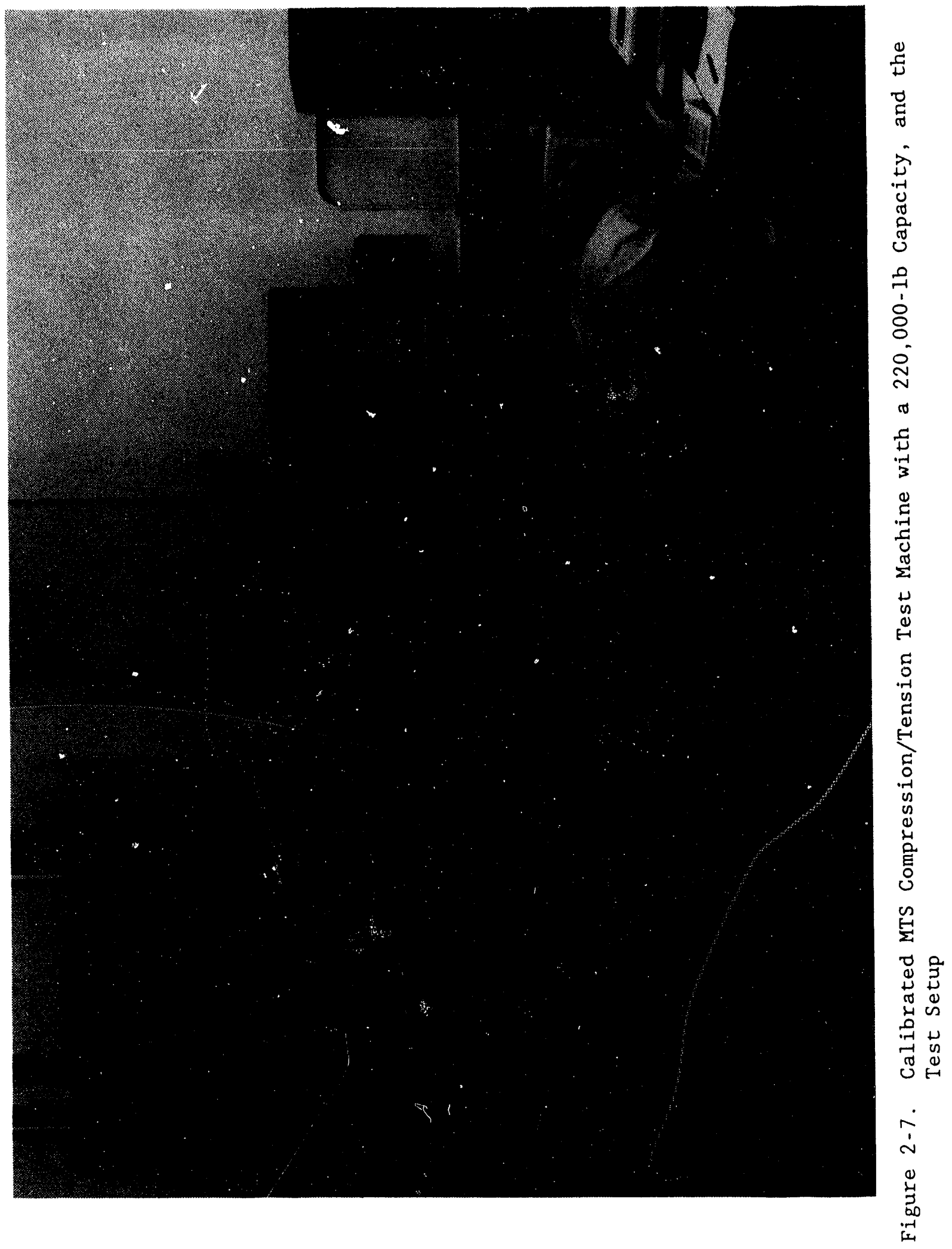




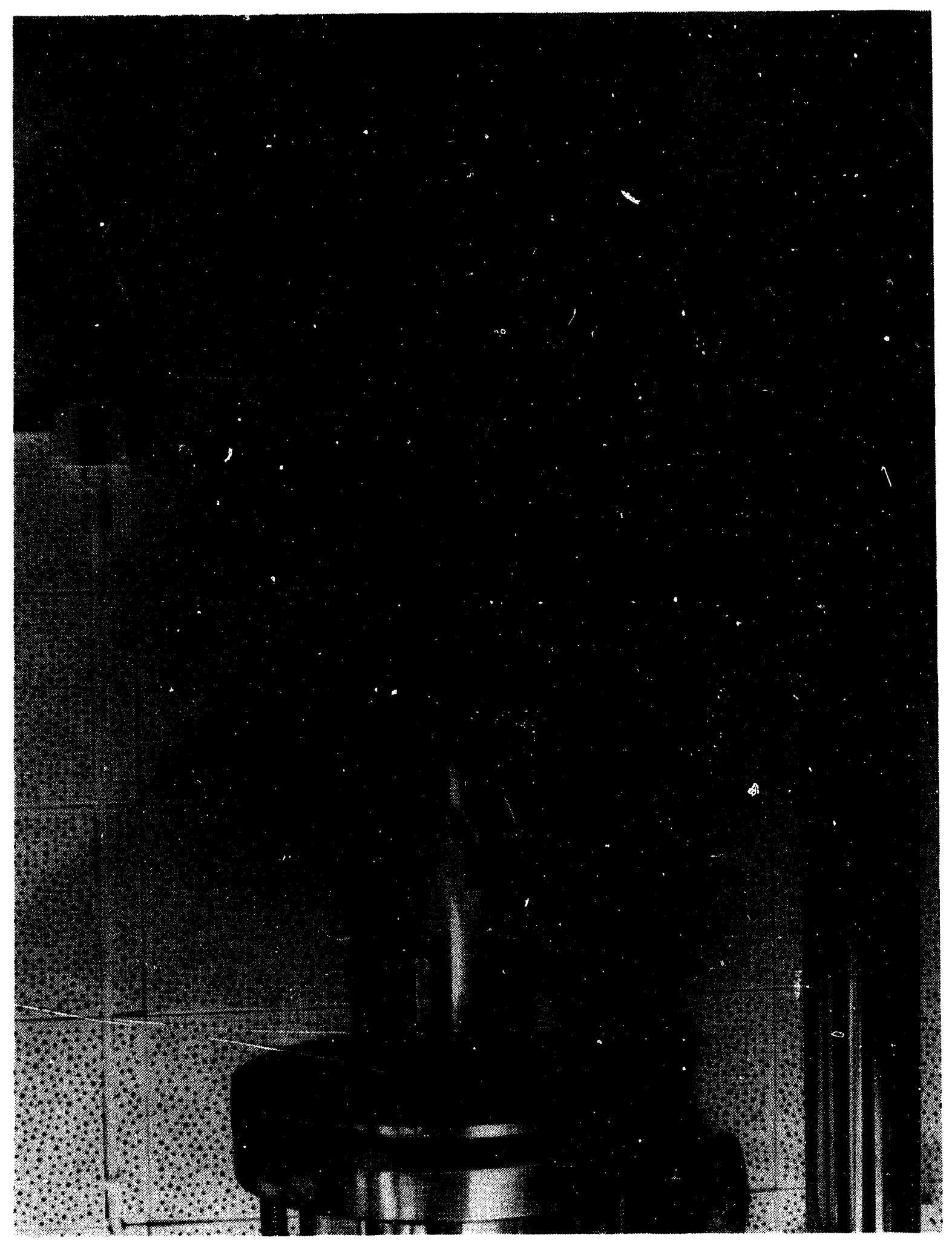

Figure 2-8. Static Test Unit Positioned in the MTS Test Machine 


\subsection{End-Impact Testing}

The tests described above were well-defined, and therefore useful in characterizing the response of the transducers. However, they did not subject the transducers to environments that are representative of cask testing. To evaluate the transducers in an environment similar to cask testing, a set of impact tests was conducted. Both accelerometers and strain gages were installed on a test unit to evaluate their behavior during impact testing. The structural code benchmark unit selected as the test unit is described in "Structural Code Benchmarking: Impact Response Resulting from the Regulatory Nine-Meter Lrop" (Glass, 1989). This test unit was selected to provide an economical experiment that would produce varying strain levels and acceleraticns with rapid amplitude changes.

The test cylinders were fabricated from aluminum 6061-0 tubing. They were $45 \mathrm{in}$. In length, with inner and outer diameters of 3.58 and 5.42 in., respectively. This was the same material and diameters used for the static crush tests. As shown in Figure 2-9 and 2-10, the tests consisted of a serles of ten guided drops of ten individual test units onto an unyielding target located at the 2,500-ft aerial cable facility in the Coyote Test Field at SNL (Uncapher, 1983). The lowest point on the guided units was positioned $32 \mathrm{ft}$, $4 \mathrm{in}$. above the target, so the impact velocity was $44 \mathrm{ft} / \mathrm{s}$. The additional height above the regulatory $30-\mathrm{ft}$ test was required to compensate for guide wire friction.

The test units were instrumented with four Micro-Measurement biaxial CEA-13-125UT-350 strain gages, two Micro-Measurement uniaxial CEA-13125-UW-350 strain gages, four biaxial BLH FAET-12D-35-S13EG strain gages, anc two uniaxial BLH FAE-12S-35-S13EG strain gages. These gages were located at 90 -degree intervals around the olster circumference of the cylinder and at positions that were 1,3 , and 6 in. from the impacting end to measure axial and hoop strain. The accelerometers were installed on the top surface of the test unit. The locations, designations, and directions of the accelerometers and strain gages ars listed in Table 2-3. The locations of the acculerometers and strain gage:; are shown in Figures $2-11$ and 2-12. The accelerometers were divided into three sets, each set containing four Erdevco 7270 accelerometers and three B\&K 8309 accelerometers. Table 2-1 shows the set used in each of the ten drop tests. Each set of accelerometers was alibrated before the first test, between successive tests, and after the final test. Before testing, detalled radius and length measurements of each specimen at the locations shown in Figure 2-13 were taken at the SNI. Inspection Laboratory.

Accelerations and strains were recorded using an analog tape machine. Photometric coverage of the impact test was provided by three cameras operating at 2,000 frames/s and three cameras operating at 400 frames/s. 


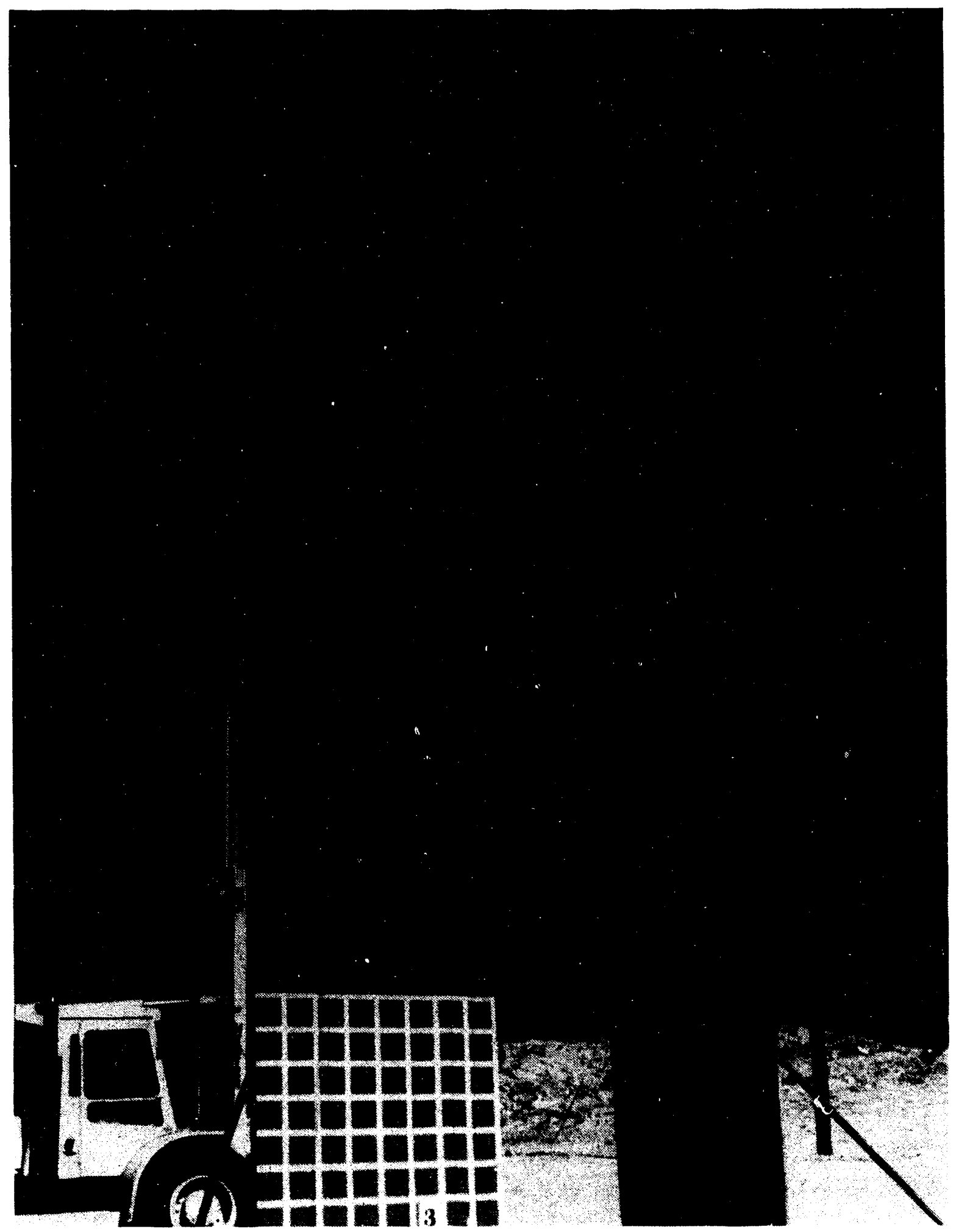

Figure 2-9. Impact Test Setup at the 2,500-ft Aerial Cable Facilicy at SNL 


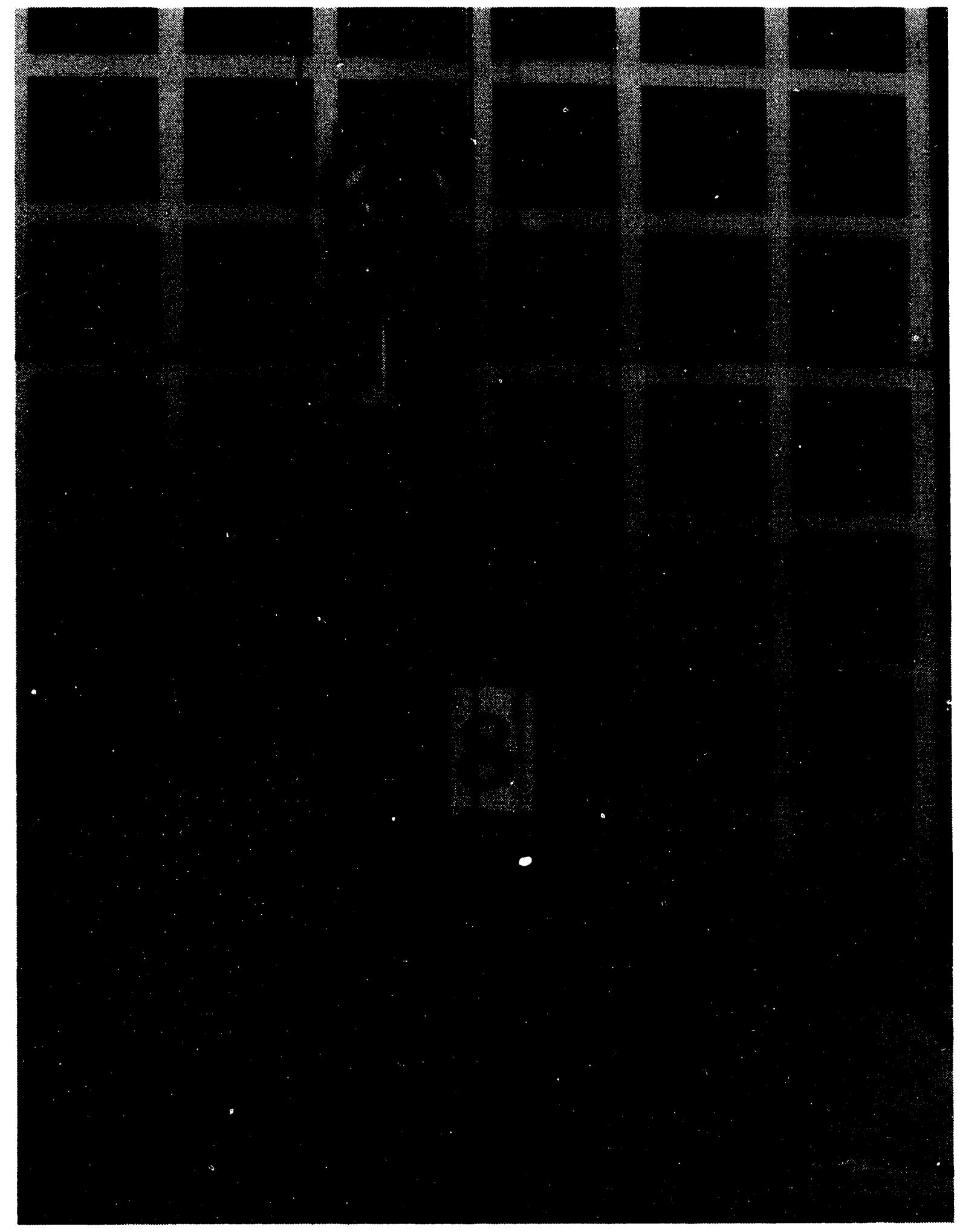

Figure 2-10. Close-Up View of the Impact Test Unit 


\begin{tabular}{|c|c|c|c|c|}
\hline \multicolumn{5}{|c|}{$\begin{array}{l}\text { TABLE 2-3. LOCATIONS, DESIGNATIONS, AND DIRECTIONS } \\
\text { OF END-IMPACT TEST STRAIN GAGES } \\
\text { AND ACCELEROMETERS }\end{array}$} \\
\hline $\begin{array}{c}\text { GAGE } \\
\text { DESIGNATION } \\
\end{array}$ & $\begin{array}{c}\text { TYPE/CATALOG } \\
\text { NUMBER }\end{array}$ & $\frac{\text { LO }}{\text { DEGREE }}$ & In. & DIRECTION \\
\hline $\begin{array}{l}\text { SG1 } \\
\text { SG2 } \\
\text { SG3 } \\
\text { SG4 } \\
\text { SG5 } \\
\text { SG6 } \\
\text { SG7 } \\
\text { SG8 } \\
\text { SG9 } \\
\text { SG10 } \\
\text { SG11 } \\
\text { SG12 } \\
\text { SG13 } \\
\text { SG14 } \\
\text { SG15 } \\
\text { SG16 } \\
\text { SG17 } \\
\text { SG18 } \\
\text { SG19 } \\
\text { SG20 }\end{array}$ & $\begin{array}{l}\text { CEA-13-125UT-350 } \\
\text { CEA-13-125UT-350 } \\
\text { CEA-13-125UT-350 } \\
\text { CEA-13-125UT-350 } \\
\text { CEA-13-125UW-350 } \\
\text { FAET-12D-35-S13EG } \\
\text { FAET-12D-35-S13EG } \\
\text { FAET-12D-35-S13EG } \\
\text { FAET-12D-35-S13EG } \\
\text { FAE-12S-35-S13EG } \\
\text { CEA-13-125UT-350 } \\
\text { CEA-13-125UT-350 } \\
\text { CEA-13-125UT-350 } \\
\text { CEA-13-125UT-350 } \\
\text { CEA-13-125UW-350 } \\
\text { FAET-12D-35-S13EG } \\
\text { FAET-12D-35-S13EG } \\
\text { FAET-12D-35-S13EG } \\
\text { FAET-12D-35-S13EG } \\
\text { FAE-12S-35-S13EG }\end{array}$ & $\begin{array}{r}0 \\
0 \\
0 \\
0 \\
0 \\
90 \\
90 \\
90 \\
90 \\
90 \\
180 \\
180 \\
180 \\
180 \\
180 \\
270 \\
270 \\
270 \\
270 \\
270\end{array}$ & $\begin{array}{l}1.0 \\
1.0 \\
3.0 \\
3.0 \\
6.0 \\
1.0 \\
1.0 \\
3.0 \\
3.0 \\
6.0 \\
1.0 \\
1.0 \\
3.0 \\
3.0 \\
6.0 \\
1.0 \\
1.0 \\
3.0 \\
3.0 \\
6.0\end{array}$ & $\begin{array}{l}\text { AXIAL } \\
\text { HOOP } \\
\text { AXIAL } \\
\text { HOOP } \\
\text { AXIAL } \\
\text { AXIAL } \\
\text { HOOP } \\
\text { AXIAL } \\
\text { HOOP } \\
\text { AXIAL } \\
\text { AXIAL } \\
\text { HOOP } \\
\text { AXIAL } \\
\text { HOOP } \\
\text { AXIAL } \\
\text { AXIAL } \\
\text { HOOP } \\
\text { AXIAL } \\
\text { HOOP } \\
\text { AXIAL }\end{array}$ \\
\hline $\begin{array}{l}\text { ACCELEROMETER } \\
\text { DESIGNATION } \\
\end{array}$ & $\begin{array}{c}\text { TYPE/CATALOG } \\
\text { NUMBER }\end{array}$ & $\frac{\text { LO }}{\text { DEGREE }}$ & In. & DIRECTION \\
\hline $\begin{array}{l}A 1 \\
A 2 \\
A 3 \\
A 4 \\
A 5 \\
A 6 \\
A 7\end{array}$ & $\begin{array}{l}7270 A-20 K \\
7270 A-20 K \\
7270 A-20 K \\
7270 A-20 K \\
8309 \\
8309 \\
8309\end{array}$ & $\begin{array}{r}0 \\
90 \\
180 \\
270 \\
45 \\
157 \\
292\end{array}$ & $\begin{array}{l}45.0 \\
45.0 \\
45.0 \\
45.0 \\
45.0 \\
45.0 \\
45.0\end{array}$ & $\begin{array}{l}\text { AXIAL } \\
\text { AXIAL } \\
\text { AXIAL } \\
\text { AXIAL } \\
\text { AXIAL } \\
\text { AXIAL } \\
\text { AXIAL }\end{array}$ \\
\hline
\end{tabular}




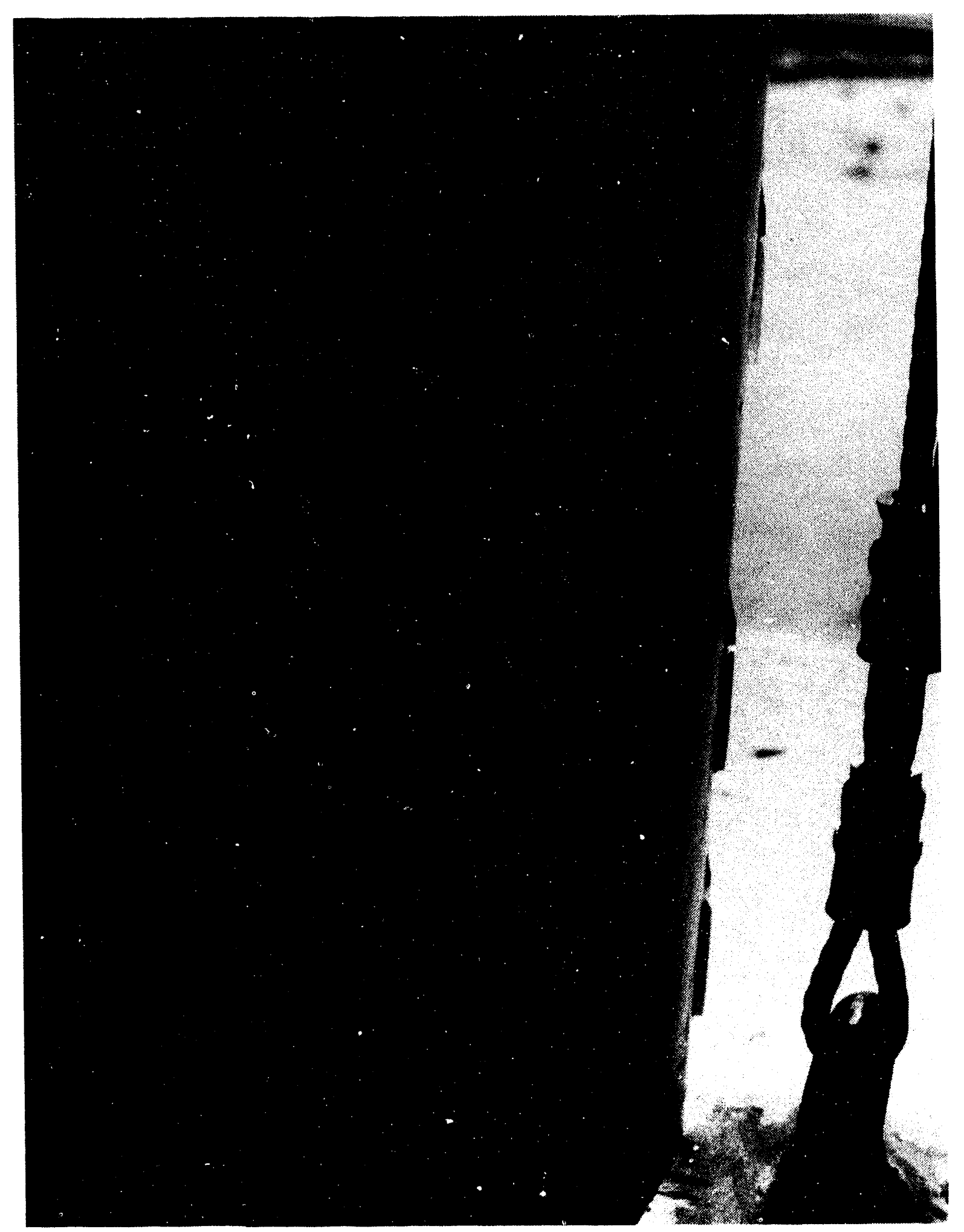

Figure 2-11. View of Strain Gages on Impact Test Units 


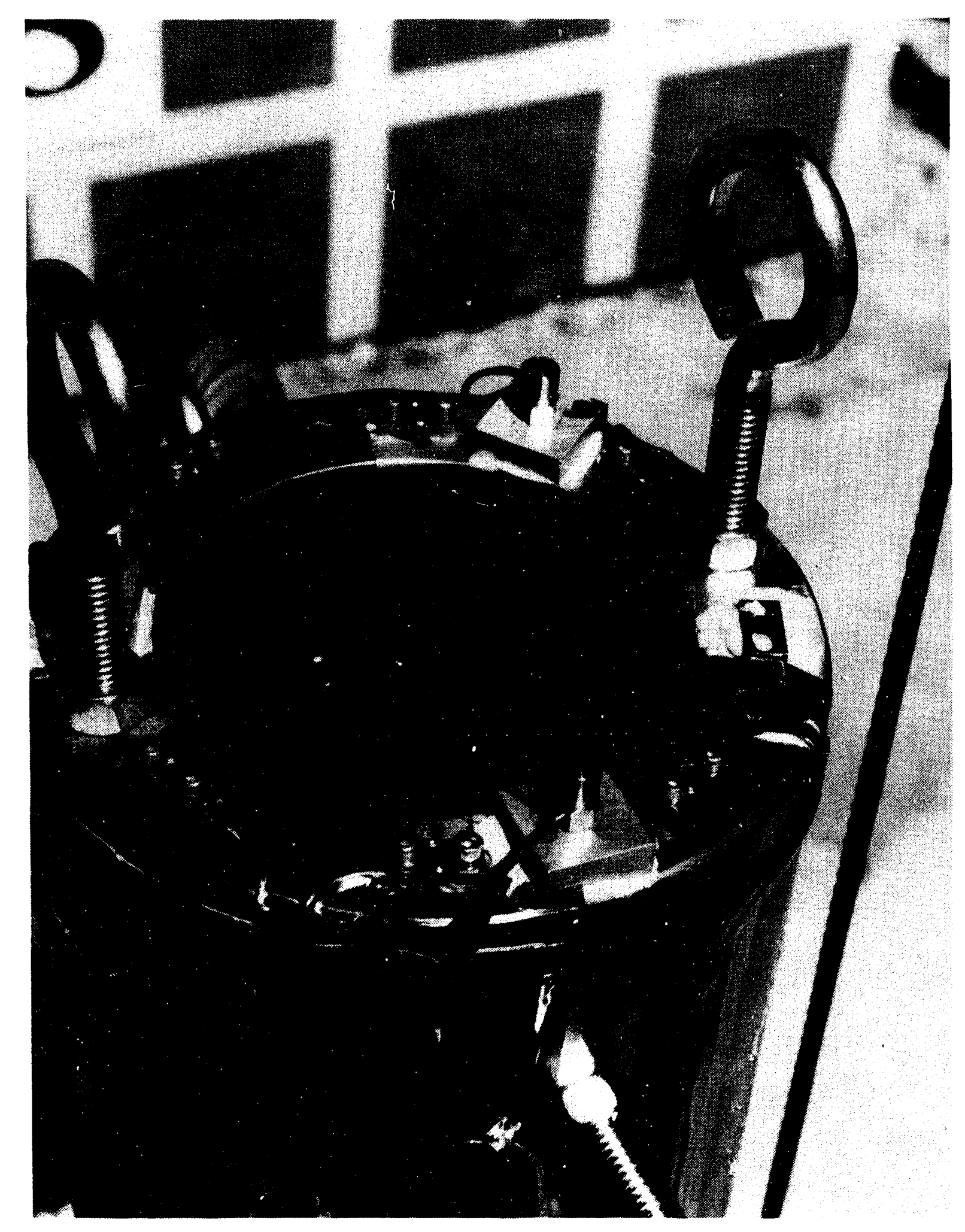

Figure 2-12. Close-Up View of Accelerometers on the Impact Test Unit 


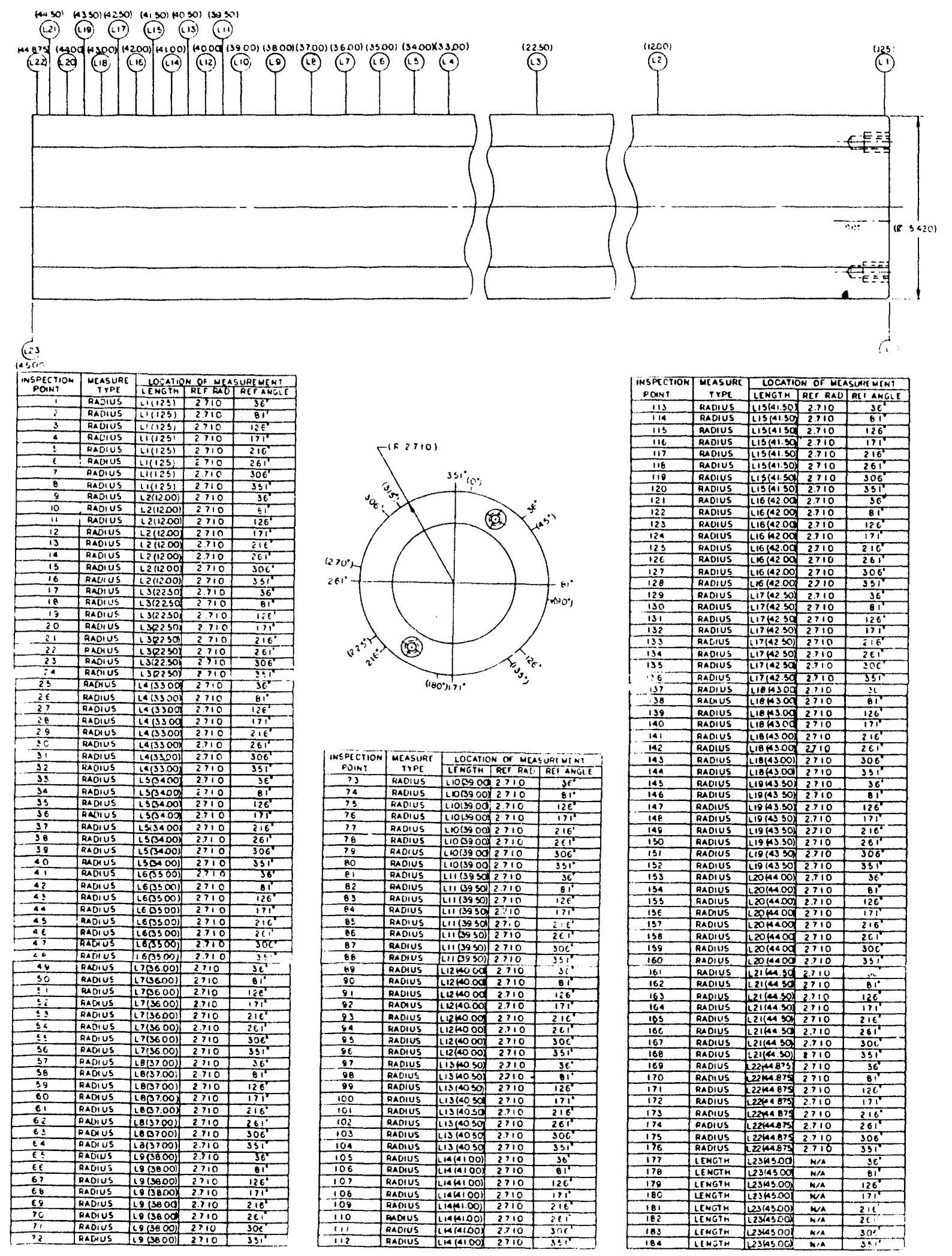

Figure 2-13. Locations of the End-Impact Test Dimensional Inspection 


\subsection{TEST RESULTS}

\subsection{Accelerometer Calibration Testing}

Table 3-1 lists the results of the calibration tests performed on the three sets of accelerometers used in the shock impulse tests. Table 3-1 includes the results of the manufacturer shock and frequency calibrations as well as SNL pre-test and post-test calibrations. The SNL pre-test and post-test calibrations included centrifuge, shock, and frequency at ambient temperature $\left(70^{\circ} \mathrm{F}\right)$ and $-20^{\circ} \mathrm{F}$. Table $3-2$ ists the results of the SNL calibrations after each of the end-impact tests, and the pre-test calibrations for each set used in the end-impact testing. These are the same as the post-test calibrations from the shock impulse testing. Similar types of calibrations, such as pre-test and post-test shock, were compared to detect any changes in the transducer sensitivity. Large deviations (greater than 108) may indicate functional problems. Tables $3-1$ and 3-2 show the results of these calibrations.

Accelerometer A2 in Set 2 was replaced after the shock impulse tests and A3 in Set 3 was replaced before Test 6 because they failed the SNL calibrations. Test results indicated that the SNL shock calibration resulted in a lower sensitivity for the piezoresistive accelerometers. The frequency calibration at $-20^{\circ} \mathrm{F}$ also reflected a different sensitivity due to the change in temperature. These changes were within the manufacturer's specification for sensitivity change versus temperature. The standard deviation of the sensitivities determined from all calibrations performed on any specific accelerometer was less than 38 of the average sensitivity. This is consistent with manufacturer and SNL centrifuge and frequency calibrations. For the piezoresistive accelerometers, the standard deviation of the sensitivities was within 18. Therefore, there was good agreement between the various calibration techniques.

\subsection{Accelerometer Shock Tests}

Accelerometer shock pulses were recorded at sample rates of 200,000 samples/s for Sets 1 and 3 and at 500,000 samples/s for Set 2. Due to the short shock pulse width, the difference in the sample rates of the two sets did not affect the data. These pulses were adjusted to a baseline of zero and were digitally filtered at cutoff frequencies of $10,000 \mathrm{~Hz}$ for Sets 1 and 3 and $25,000 \mathrm{~Hz}$ for Set 2 . The digital filter approximated a low-pass, constant-phase response with a 48 -dB/octave rolloff. This procedure is referred to as fairing the data. The following pulse parameters were determined from the faired data:

- the maximum faired amplitude (MFA) of the signal;

- the rise time (TR) of the pulse, defined as the time between 108' of MFA and 908 of MFA on the leading edge;

- the time to peak (TP), defined as the time between 108 of MFA on the leading edge and MFA; 


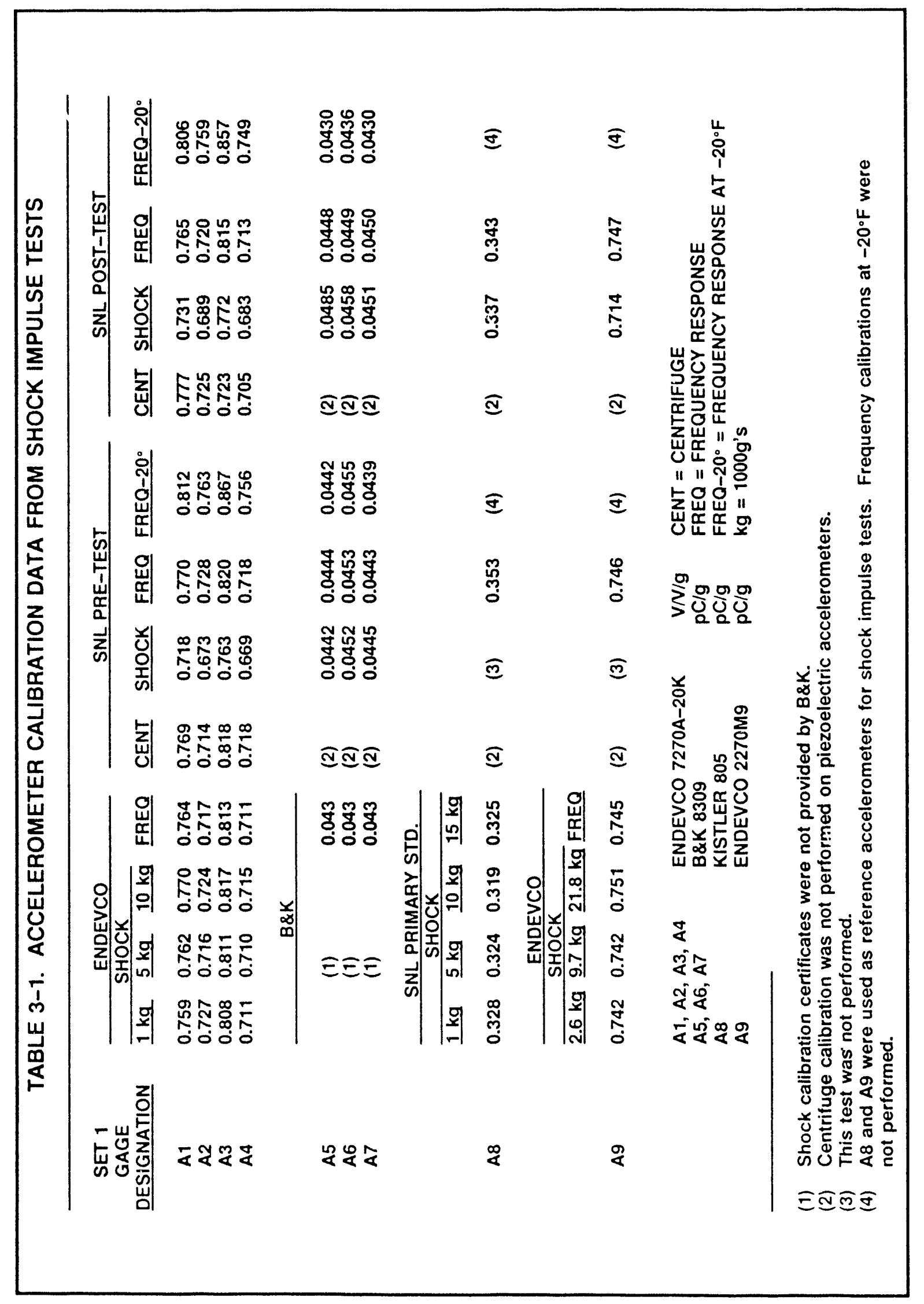




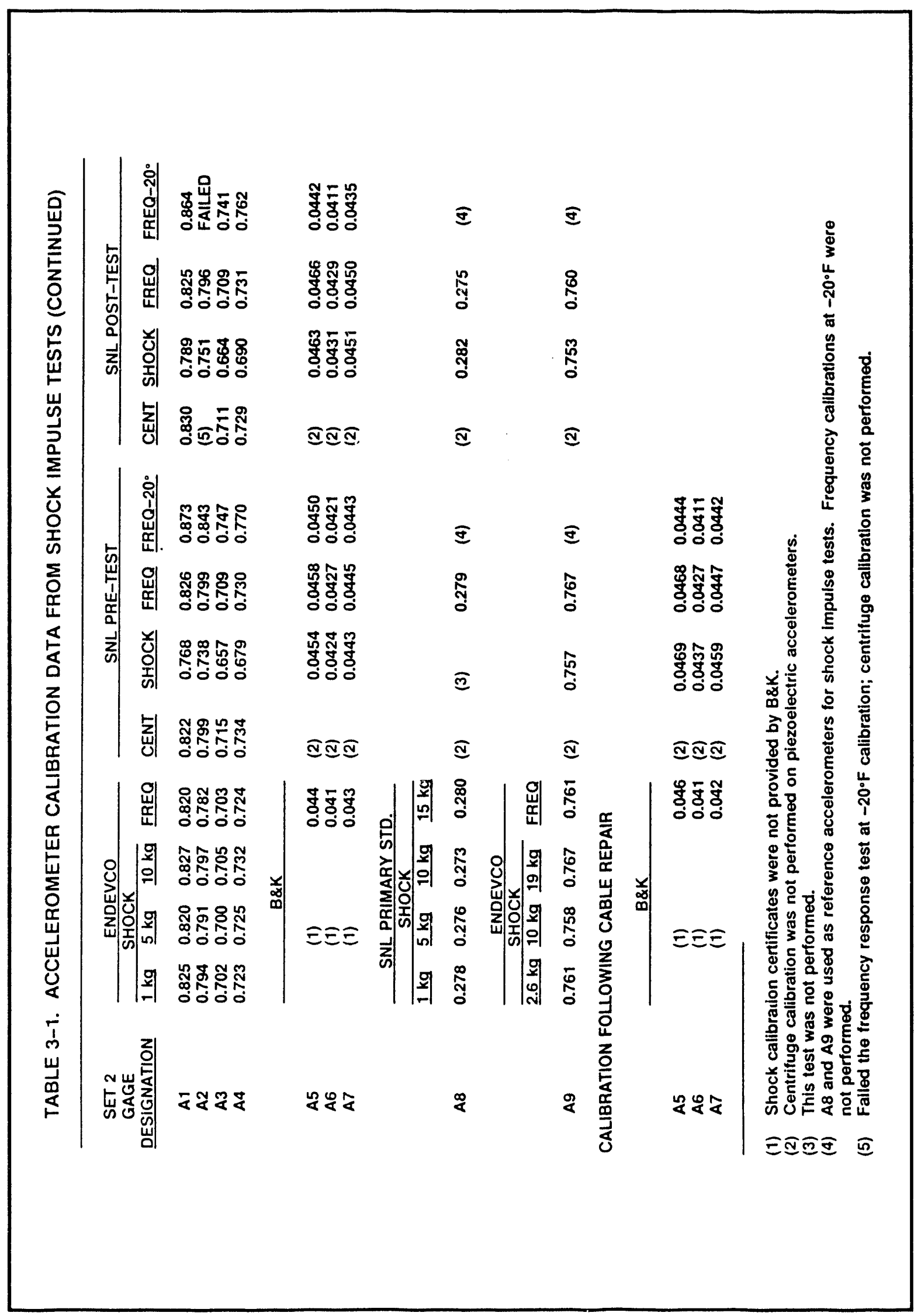




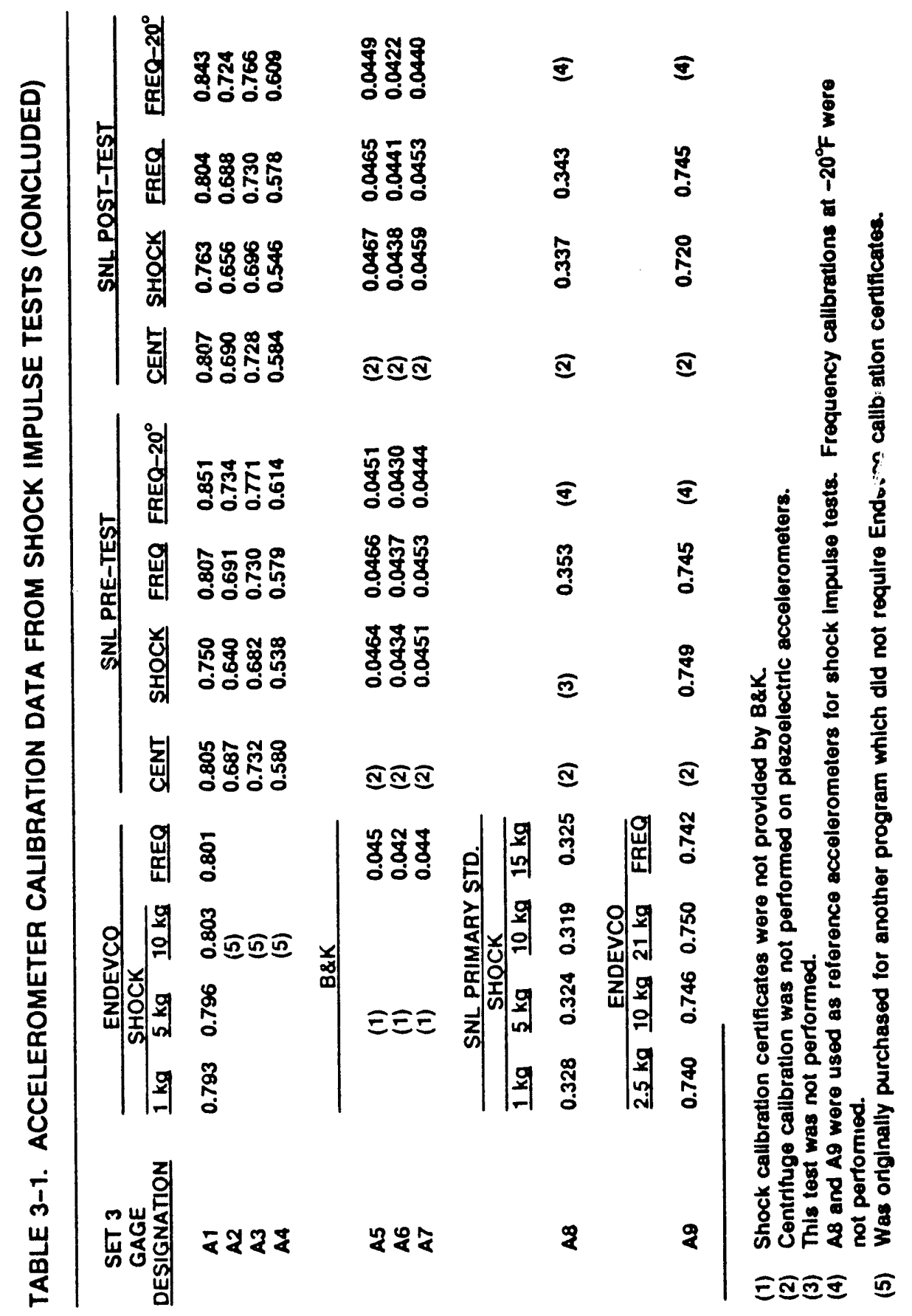




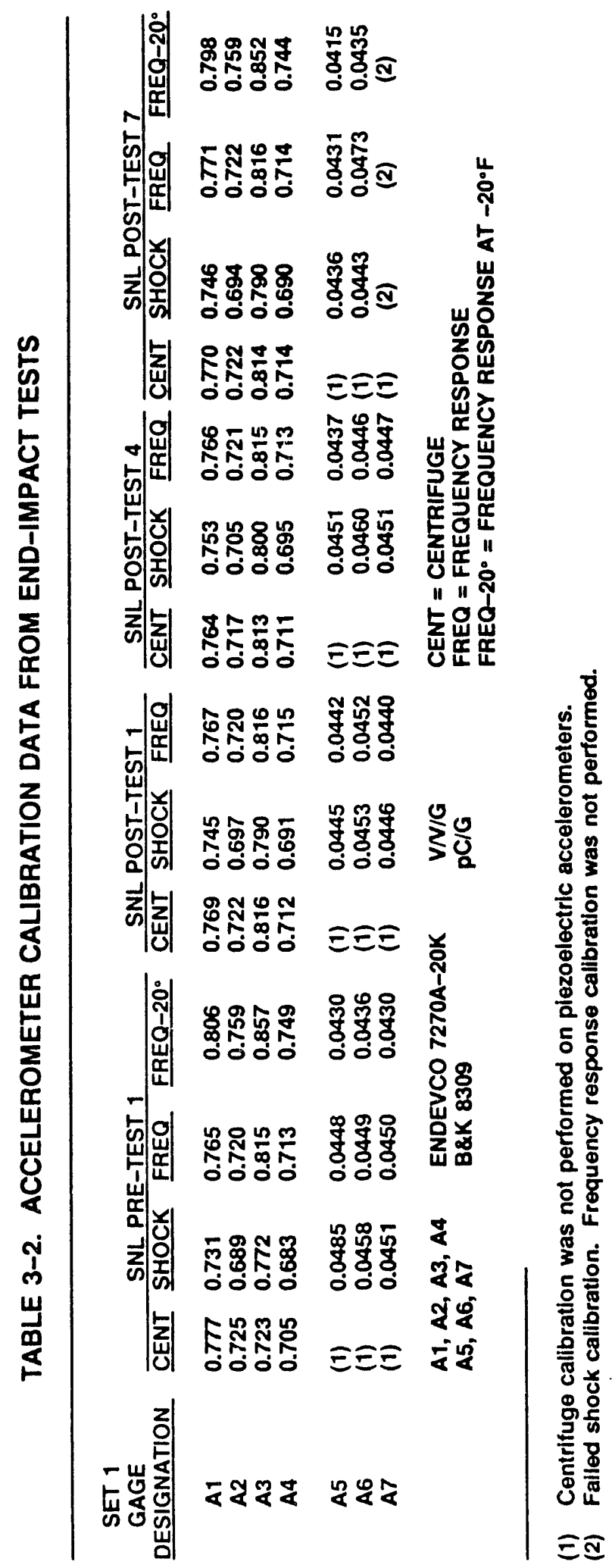




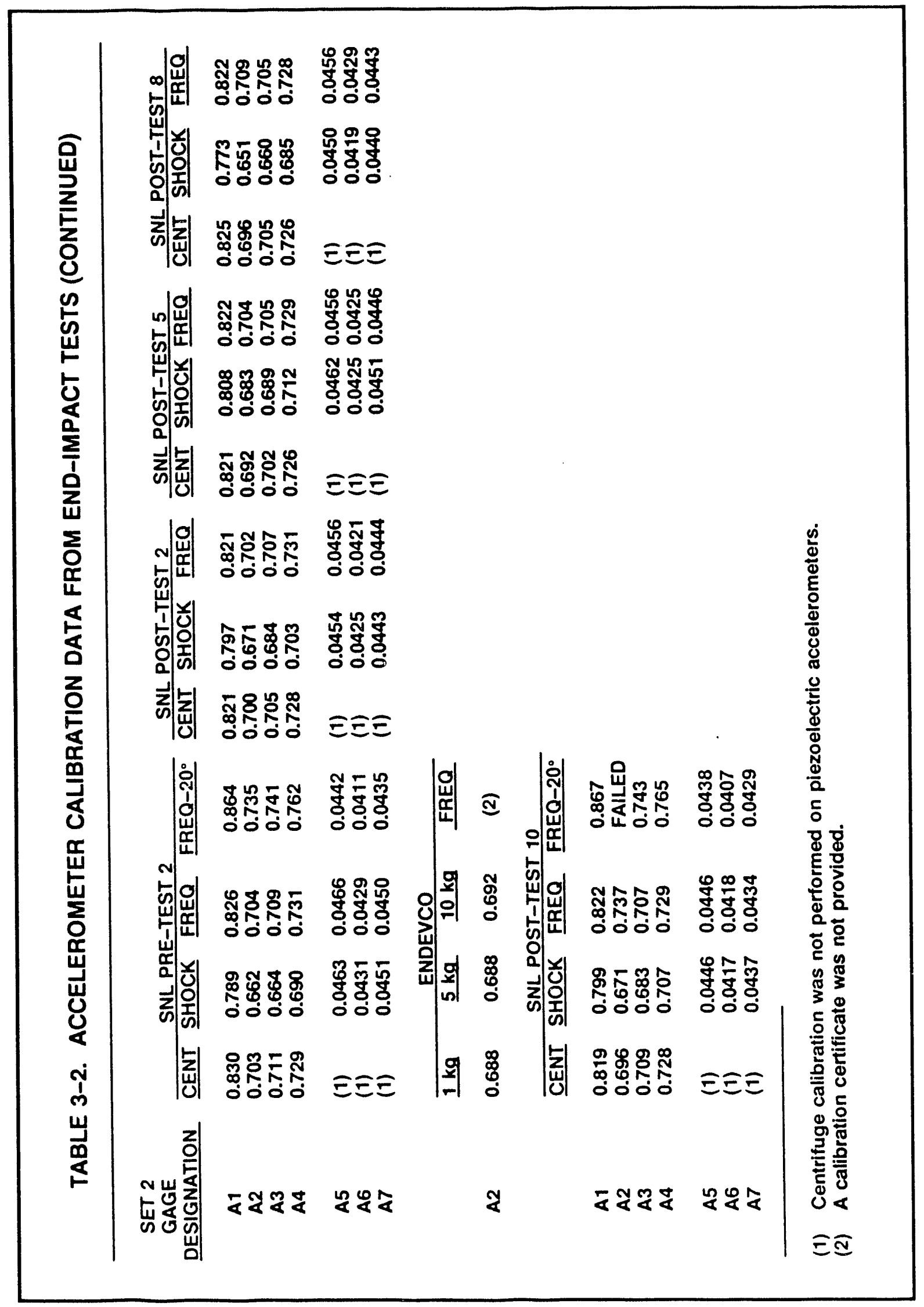




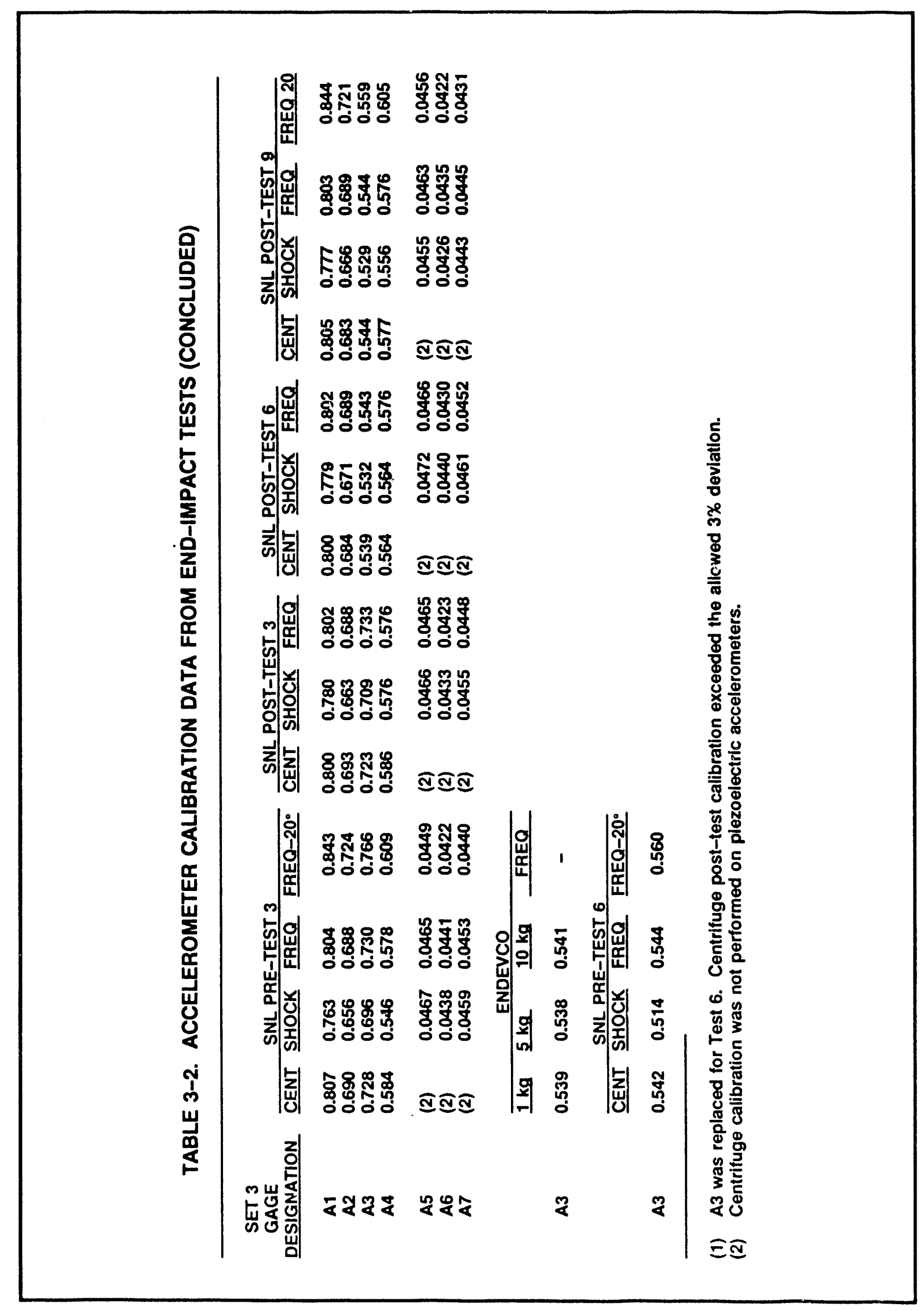


- the total time (TT) of the shock pulse, defined as the time between 108 of MFA on the leading edge and 108 of MFA on the trailing edge; and

- the fall time (TF) of the pulse, defined as the time between 908 of MFA and 108 of MFA on the trailing edge.

These valises were determined by scanning the filtered digital data to determine the peak value, or MFA, and the time of this value. The data were then processed to find the points corresponding to 10 and 908 of this value on both sides of the peak. Table 3-3 gives a compilation of the pulse parameters from all the tests. Amplitude, TR, TP, TT, and TF data are grouped to compare similar amplitude ranges. In Set 1 for Tests 1,2 , and 3 conducted at $1,000 \mathrm{~g}$, the amplitude of $\mathrm{A} 2$ was consi ently higher than the amplitudes of the other transducers. For Tests 4,5, and 6 conducted at $5,000 \mathrm{~g}$, the amplitude of A2 was similar to amplitudes of the other transducers. A consistently higher amplitude was recorded for Tests 7,8, and 9. Figures 3-1, 3-2, and $3-3$ shor: representative plots of a shock pulse from the $1,000-, 5,000-$, and 10,000 -g tests, respectively. The 5,000- and $10,000-\mathrm{g}$ plots have oscillations following the major pulse that may be due to test fixture vibration. The highest amplitude pulse produced the sharpest rise time.

The shock impulse tests were conducted on a frame that provided the initial velocity by releasing an elastomeric spring. The pulse duration was adjusted by varying the number and thickness of felt pads placed on the impact surface. This procedure led to tests that were not exactly reproducible. For this reason, a better comparison between results was made with normalized data. To do this, the accelerations from each test were normalized with respect to the reference acceleromete1; $A 9$.

Tabi: $3-4$ gives the normalized peak accelerations from each test, and the averages and standard deviations. Figure 3-4 shows the distribution of these results. As shown, the data were quite consistent with a standard deviation of 38 .

In addition to determining the pulse parameters for each shock input, the shock pulse was digitally integrated to determine the change in velocity. This integration indicated how well the accelerometer's signal returned to zero or oscillated near zero. Table 3-5 gives the values for change in velocity at the end of the pulse and at $12 \mathrm{~ms}$ after the end of the pulse ( $5 \mathrm{~ms}$ after the pulse for set 2). The comparison in $T$ able $3-5$ shows lasge deviations in the piezoelectric accelerometers, indicating a slower return to zero.

\subsection{Strain Gage Static Tests}

A typical load history from the elastic portion of the static tests is shown in Figure: 5. The test unit was loaded four times to 40,000 1b. Figure 3-6 shows the corresponding deflections ior the four cycles. (The deflection measurement is the change in position of the loading head of the MTS machine and, therefore, includes the flexibility of the machine). Figure 3-7 shows a typical strain gage result for this test. The strain gage did not appear to exhlvit hystcrosis in its measurement. For this test all of the strain gages had similar hehavior. Table $3-6$ 


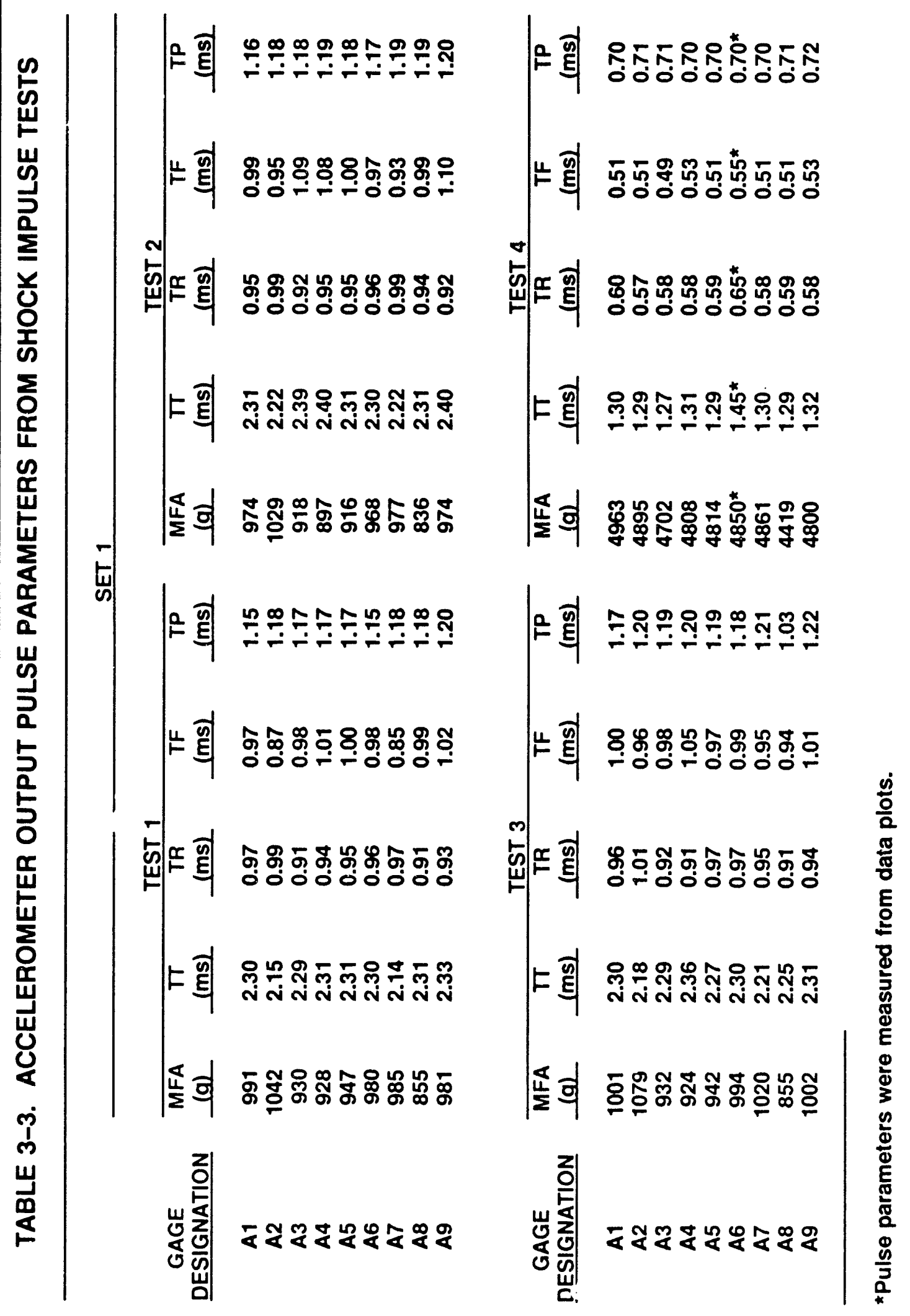




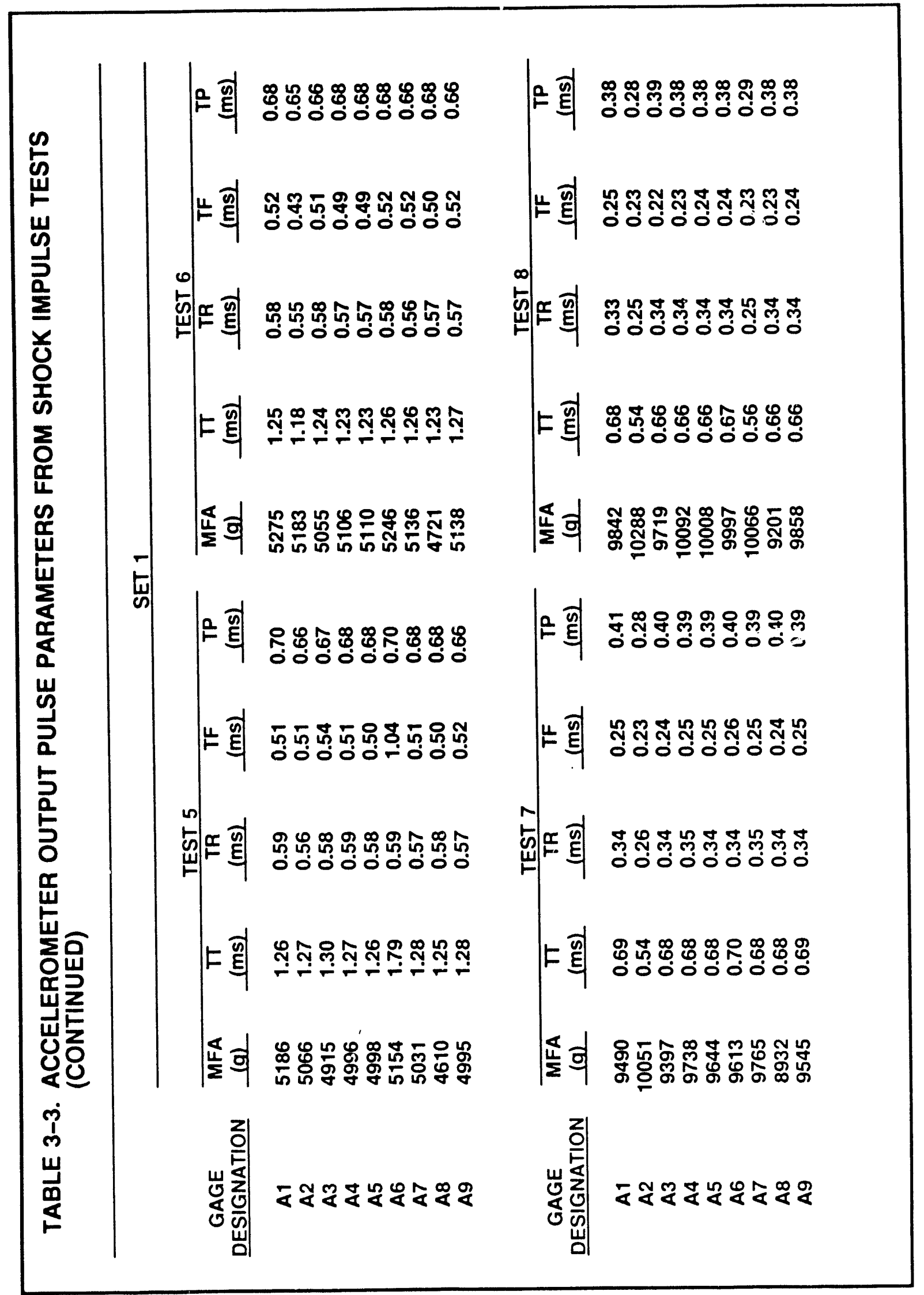




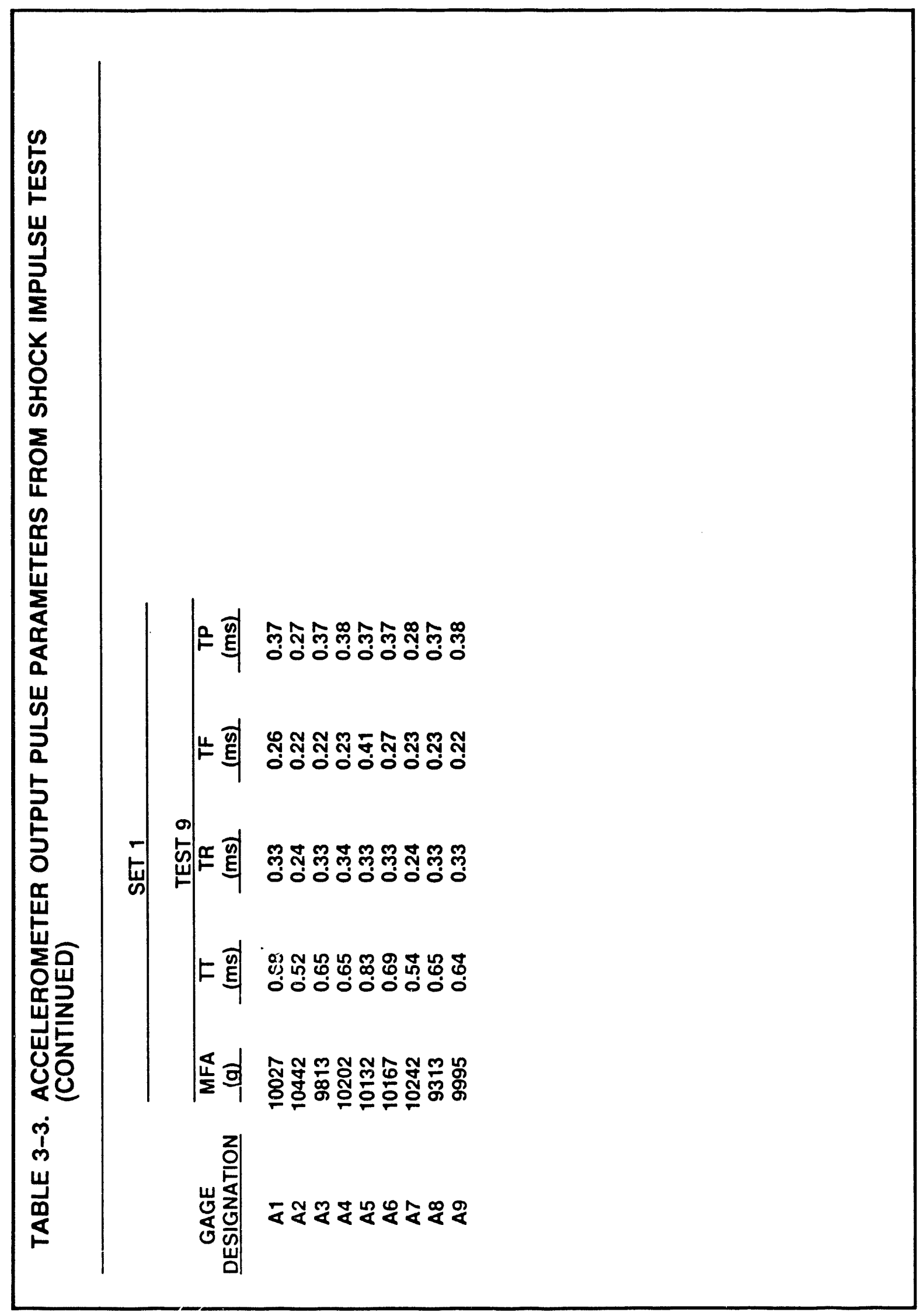




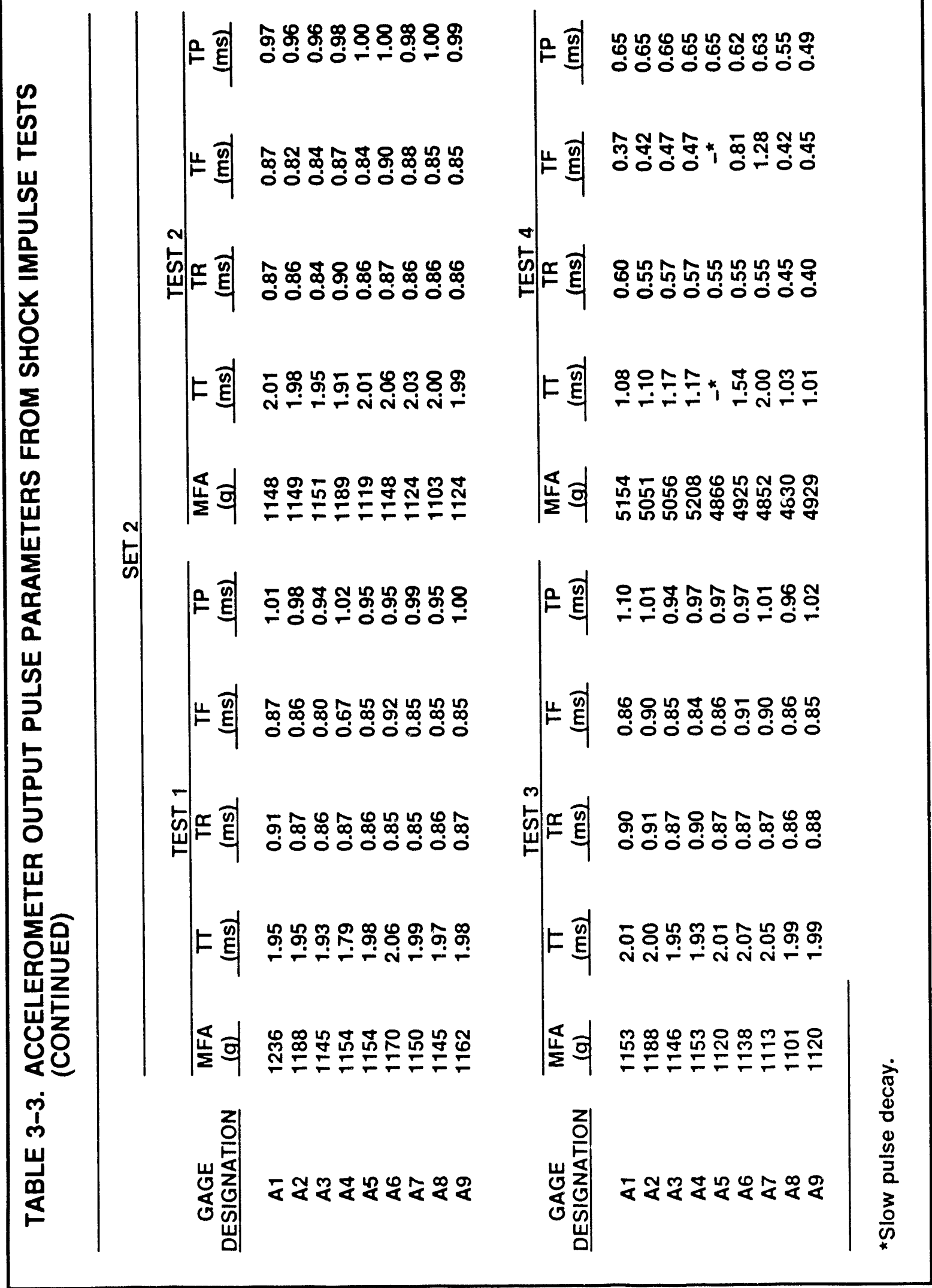




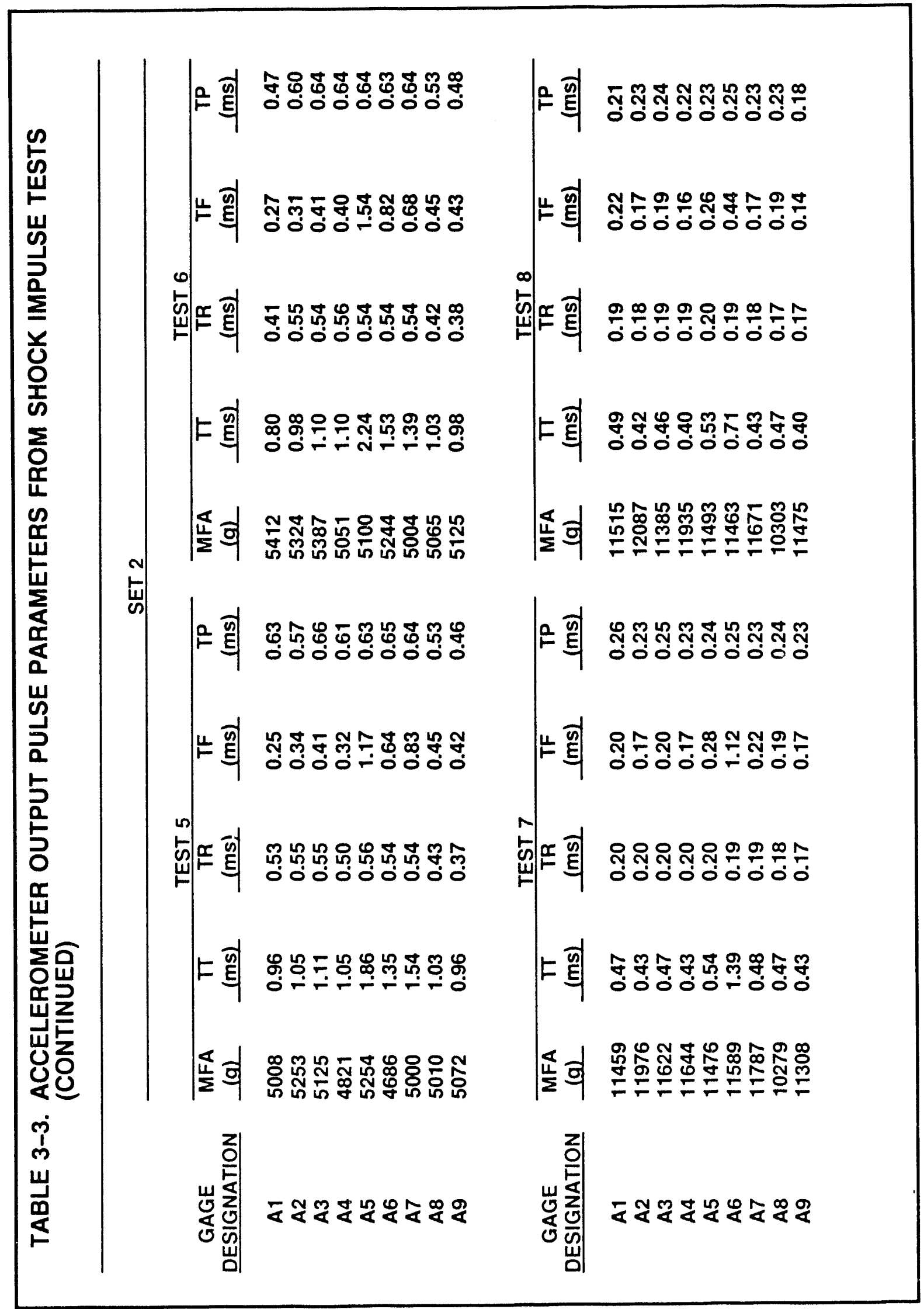




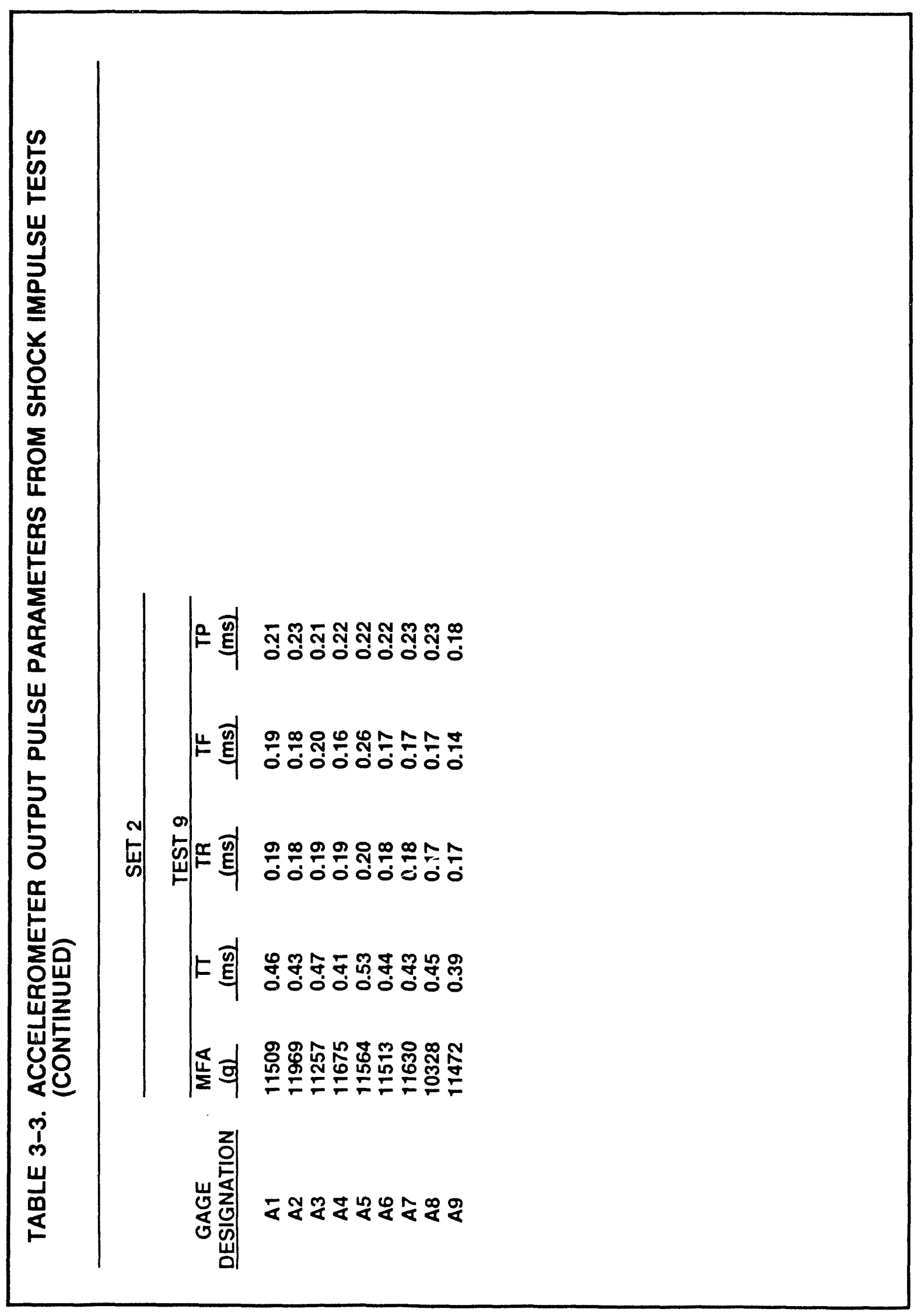




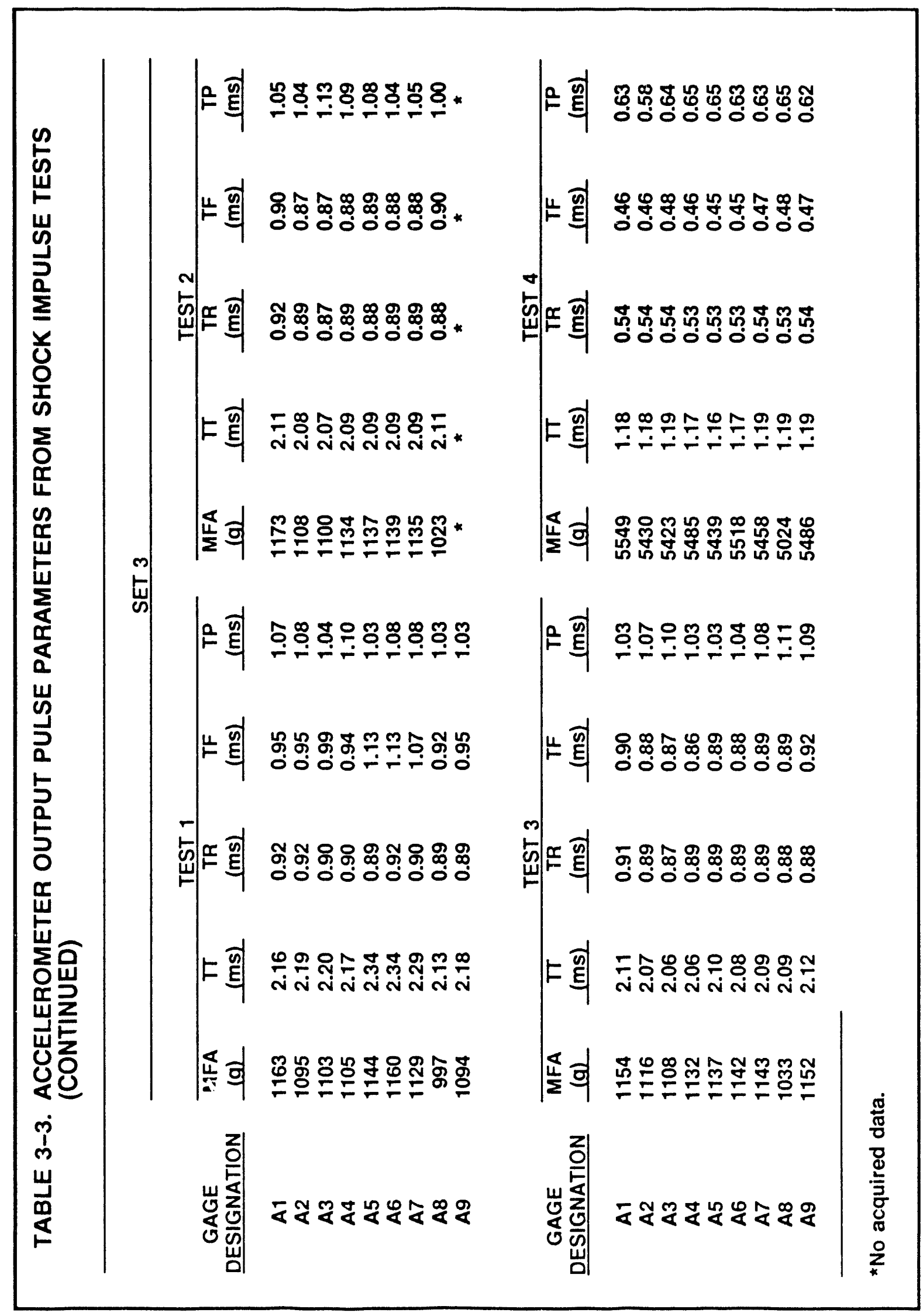




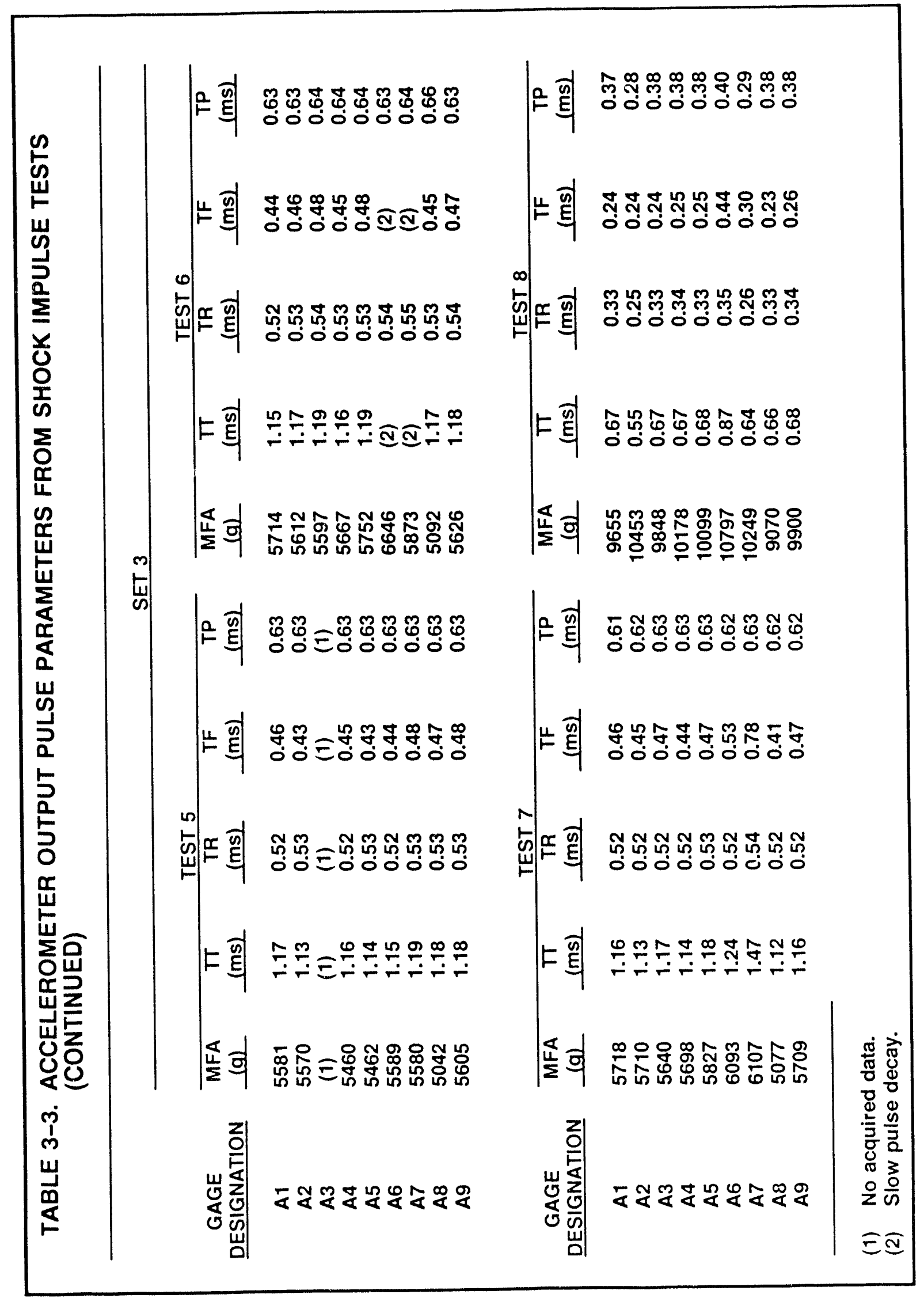




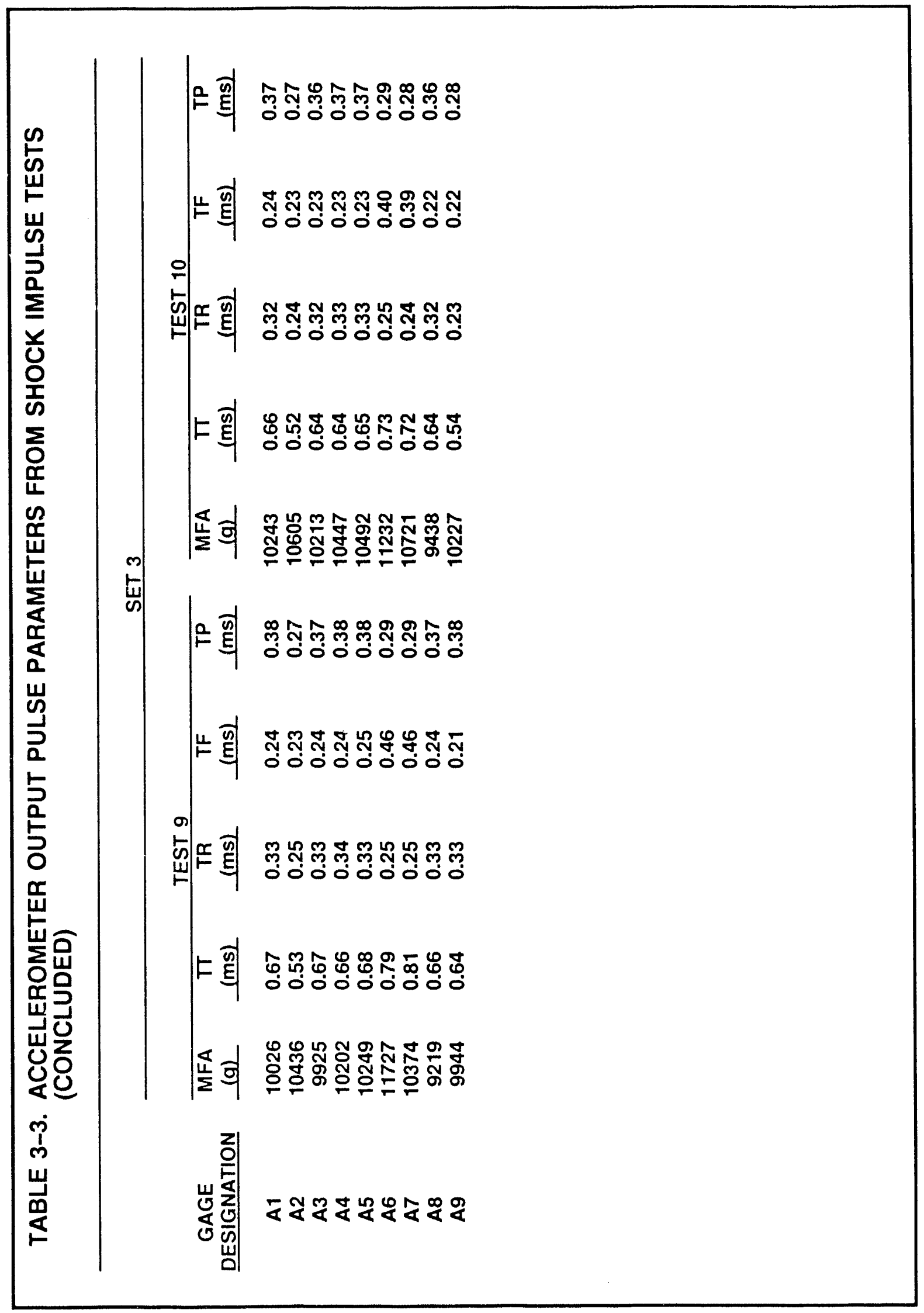




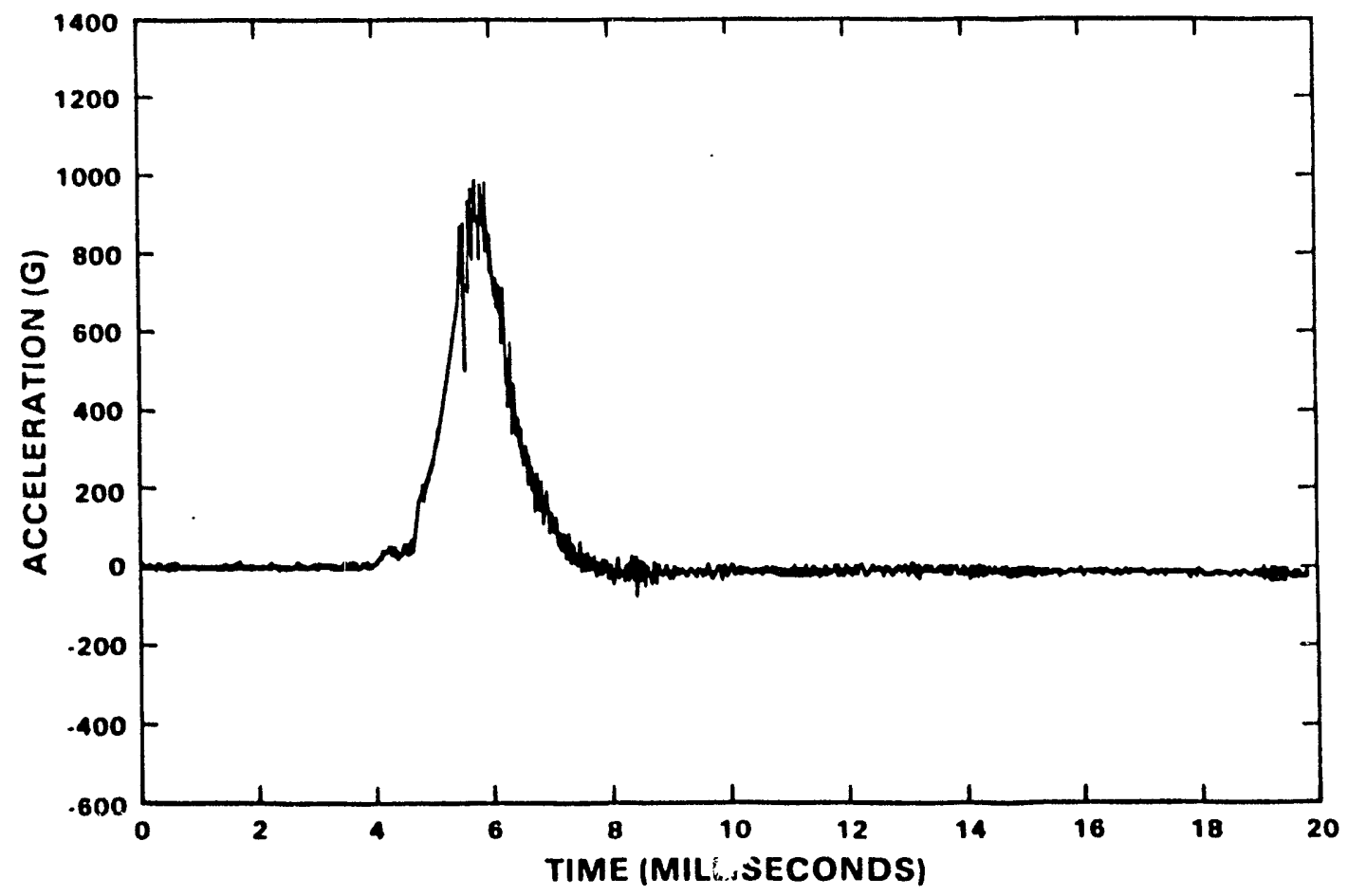

Figure 3-1. Representative Plot of a Shock Pulse From the 1,000-g Shock Impulse Test

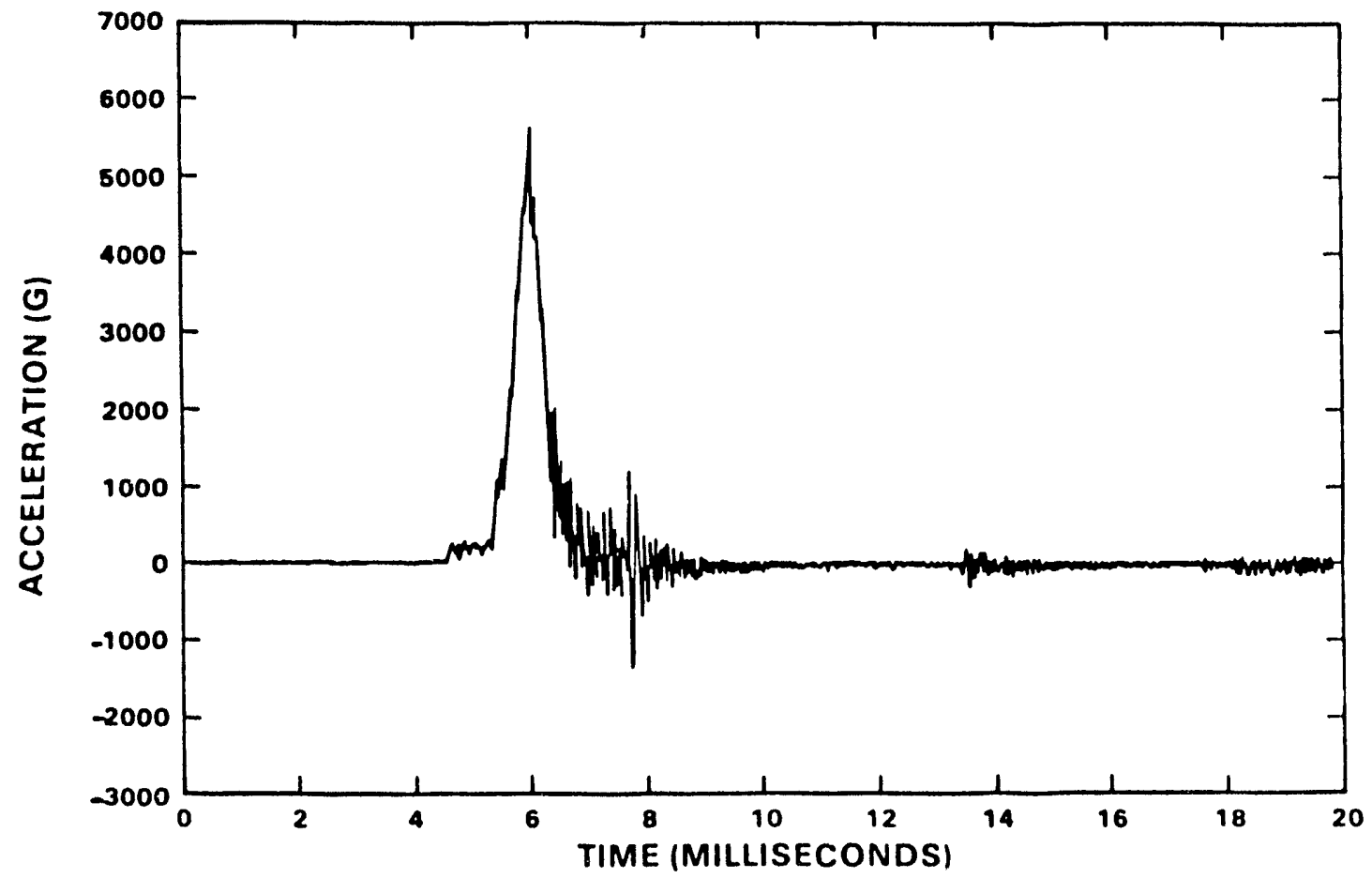

Figure 3-2. Representative Plot of a Shock Pulse From the 5,000-g Shock Impulse Test 


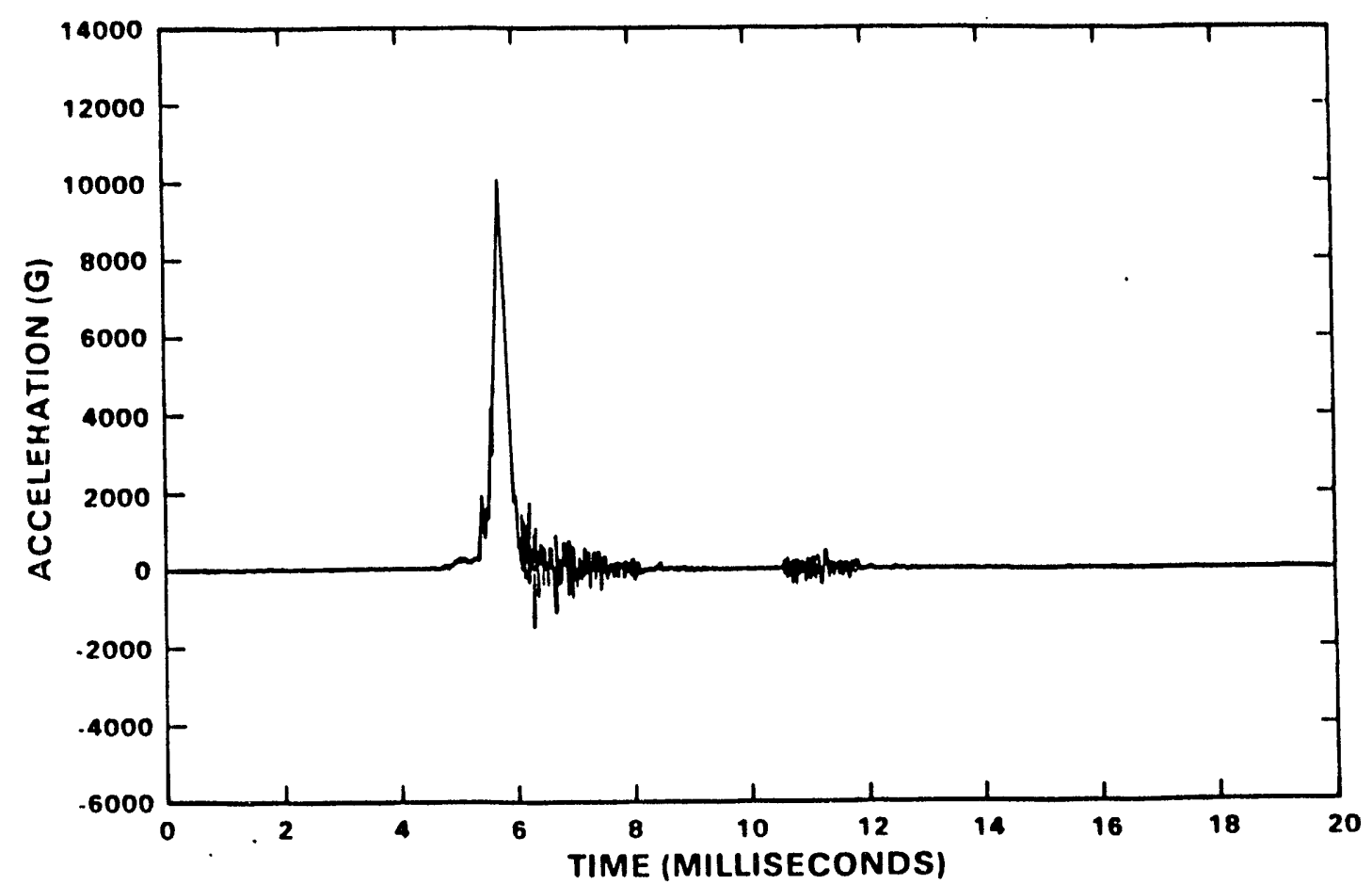

Figure 3-3. Representative Plot of a Shock Pulse From the 10,000-g Shock Impulse Test

lists the maximum strain for each gage at the first and fourth load peaks. The average peak strain for the axial gages in the first cycle was 310 microstrains $(\mu \varepsilon)$, with a standard deviation of 33 , and the average peak strain on the fourth cycle was $302 \mu \varepsilon$, with a standard deviation of 29. These numbers compared with a theoretical value of 308 for the 40,000-1b load and a modulus of elasticity of $10^{7}$ psi.

Figure 3-8 shows a plot of the distribution of these strains for the first and fourth cycles from all of the axial gages ( 240 points from each cycle). In the hoop direction, the average of the peak strains for the first cycle was $102 \mu \varepsilon$, with a standard deviation of 13 , and the average for the fourth cycle was $99 \mu \varepsilon$, with a standard deviation of 8 . Figure 3-9 shows a plot of the distribution of these strains for the first and fourth cycles. The distribution centers between 95 and $105 \mu \varepsilon$.

The results of the elastic portion of the test showed that even in this well-characterized test there was some scatter in the data. The standard deviation of the strain gages was approximately 10 of of the average value. Generally for strains as low as those recorded in this test, a large portion of the scatter can result from the data acquisition system. A strain of $300 \mu \varepsilon$ corresponds to a voltage signal of only $1.5 \mathrm{mV}$; frequently, noise may be as large as $1 \mathrm{mV}$. The largest level of noise in this test series was $0.95 \mathrm{mV}$, but most channels had less than $0.2 \mathrm{mV}$ of peak-to-peak noise. If it is known that the maximum 


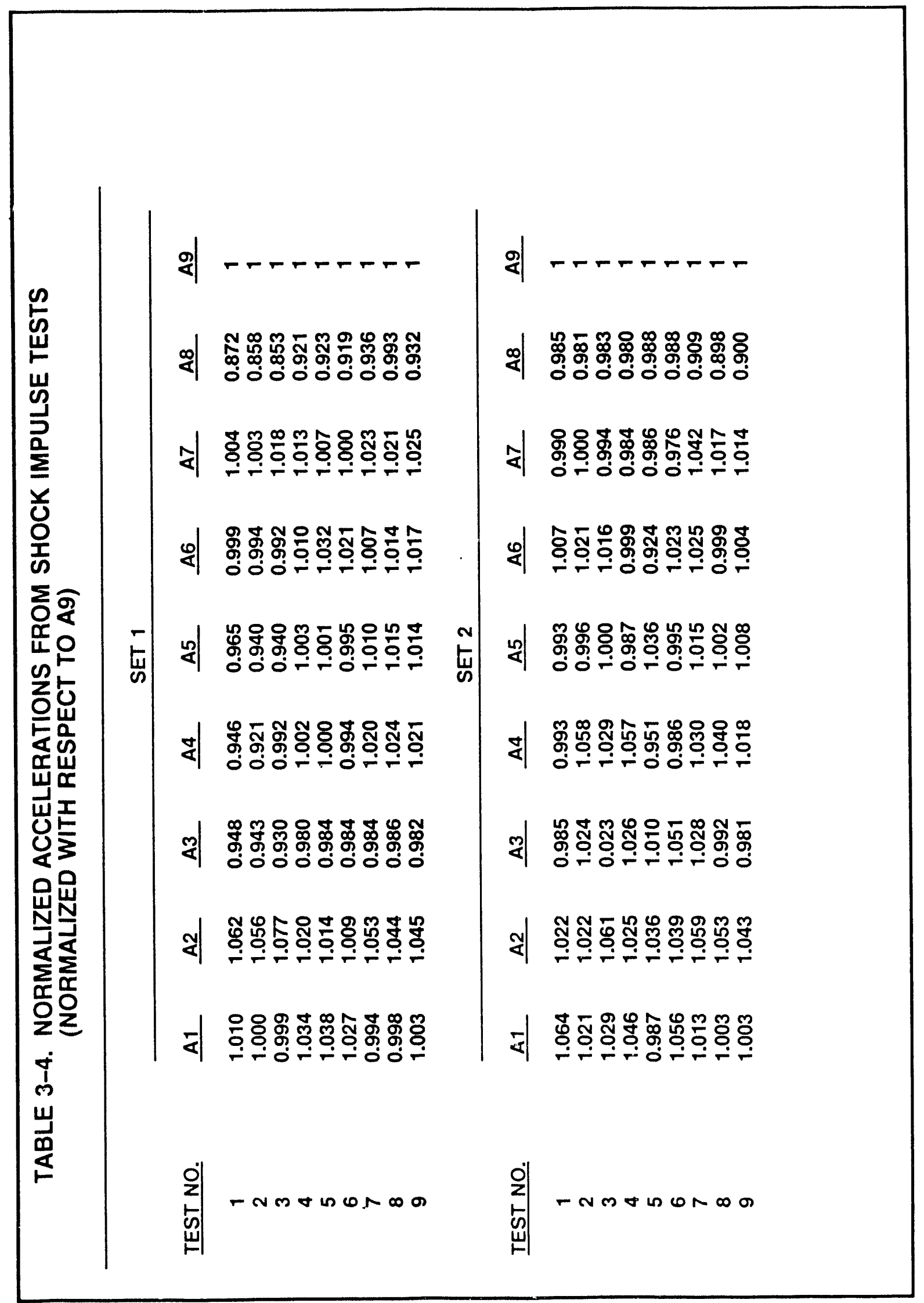




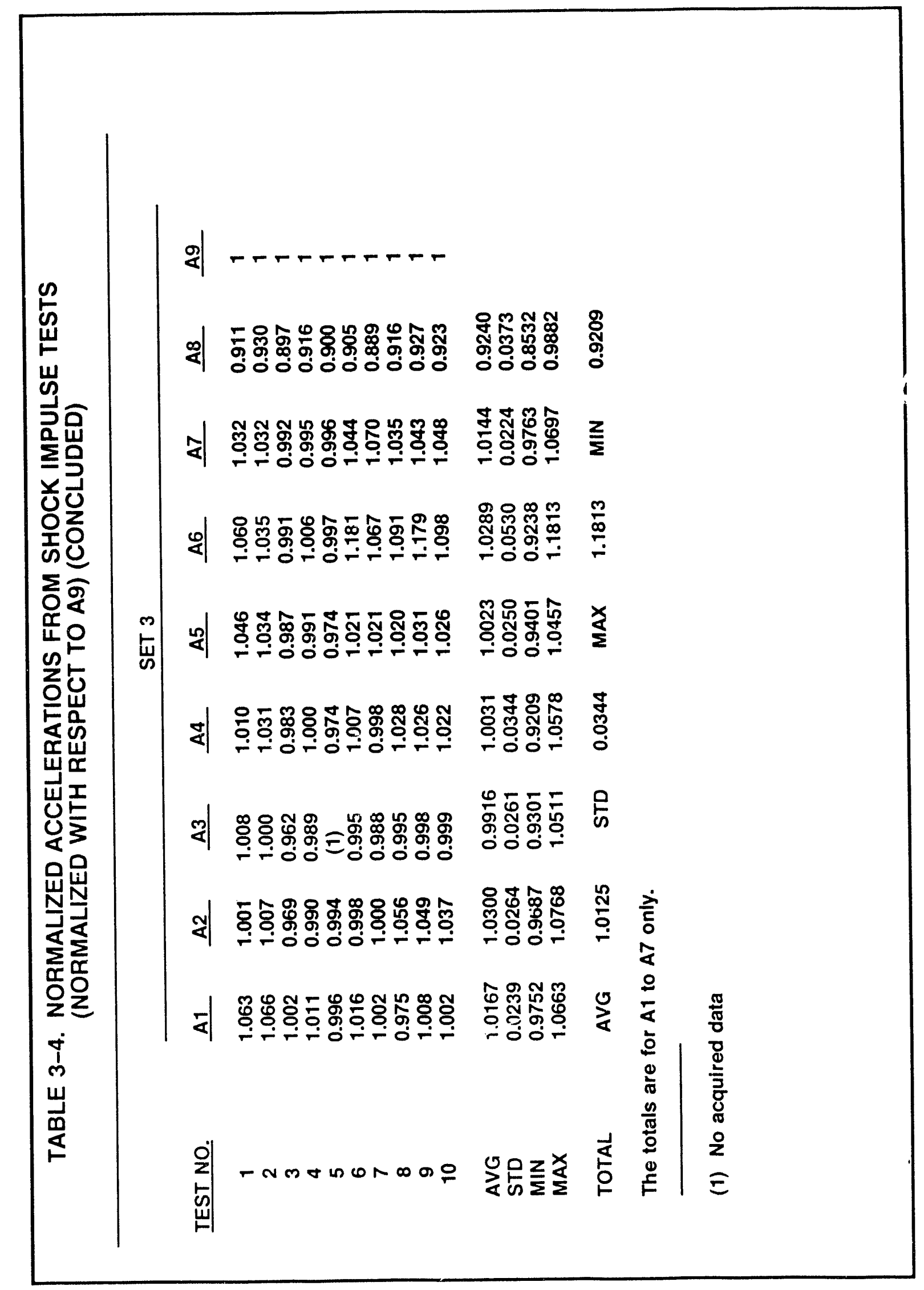




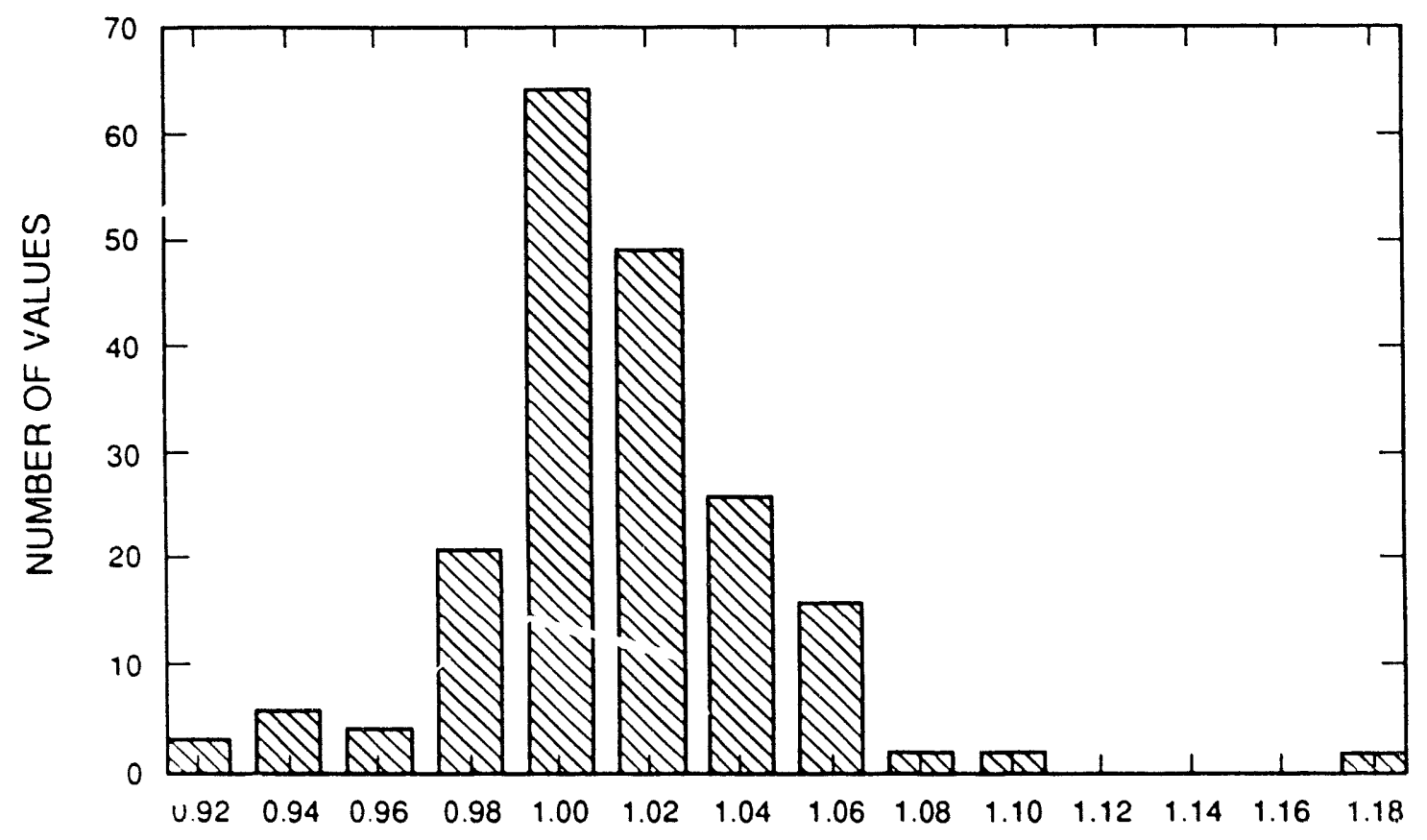

NORMALIZED MFA ACCELERATION

Figure 3-4. Distribution of Normalized MFA Accelerations From Shock Ir. ulse Tests

strains are of such low magnitude, this problem can be alleviated by selecting strain gages with higher output, i.e., semiconductor type gages. However, this type of gage may be larger, more expensive, and more difficult to install.

A typical load history for the inelastic portion of the static tests is shown in Figure 3-10. Following the iritial rise, a nearly linear loading was applied up to $140,000 \mathrm{lb}$. Figure $3-11$ shows the corresponding deflection was approximately 0.5 in. A typical strain gage response is shown in Figure 3-12. The serrations in the strain response were likely caused by dynamic strain-aging of the test specimen, also known as the Portevin-LeChatelier effect (Dieter, 1976). In this portion of the testing, the flexibility of the test machine was not as significant as in the elastic range because once the specimen yialded, the stiffuess of the machine was much higher than the stiffness of the specimen. Since these specimens were loaded past the yield point, the data from these tests could be used to determine the yield strength of the material. For materials that do not exhibit a sharp yield point, such as aluminum, the reported yield strength is determined from a 0.002 -strain offset. For each of the test specimens, an external extensometer with a 2 -in. gage length was attached near the midpoint. The output of this extensometer, i.e., strain, was plotted versus load on an X-Y recorder during each test, except for Test 1 . An example of these plots is shown in Figure 3-13. The effect of dynamic strain-aging 


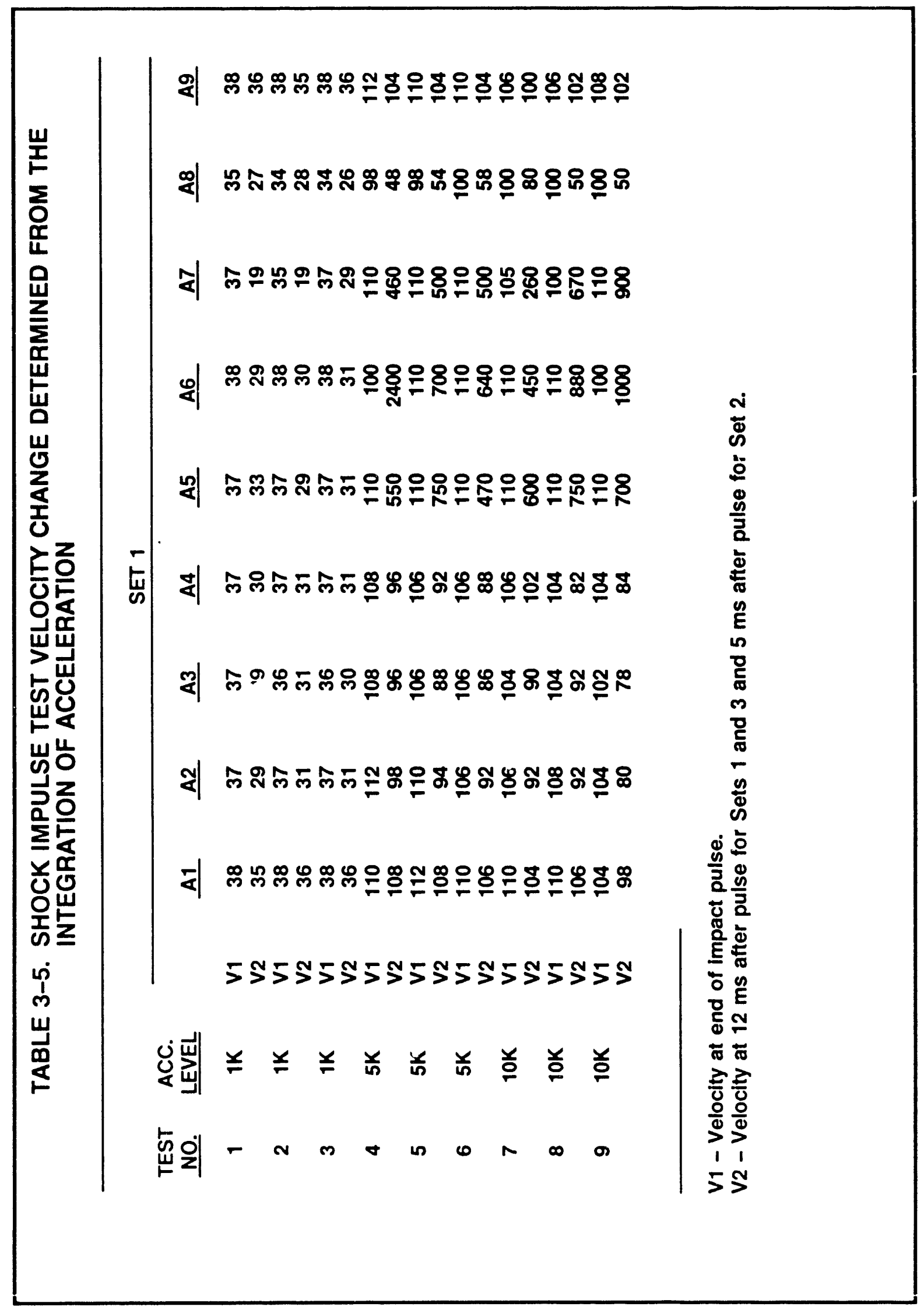




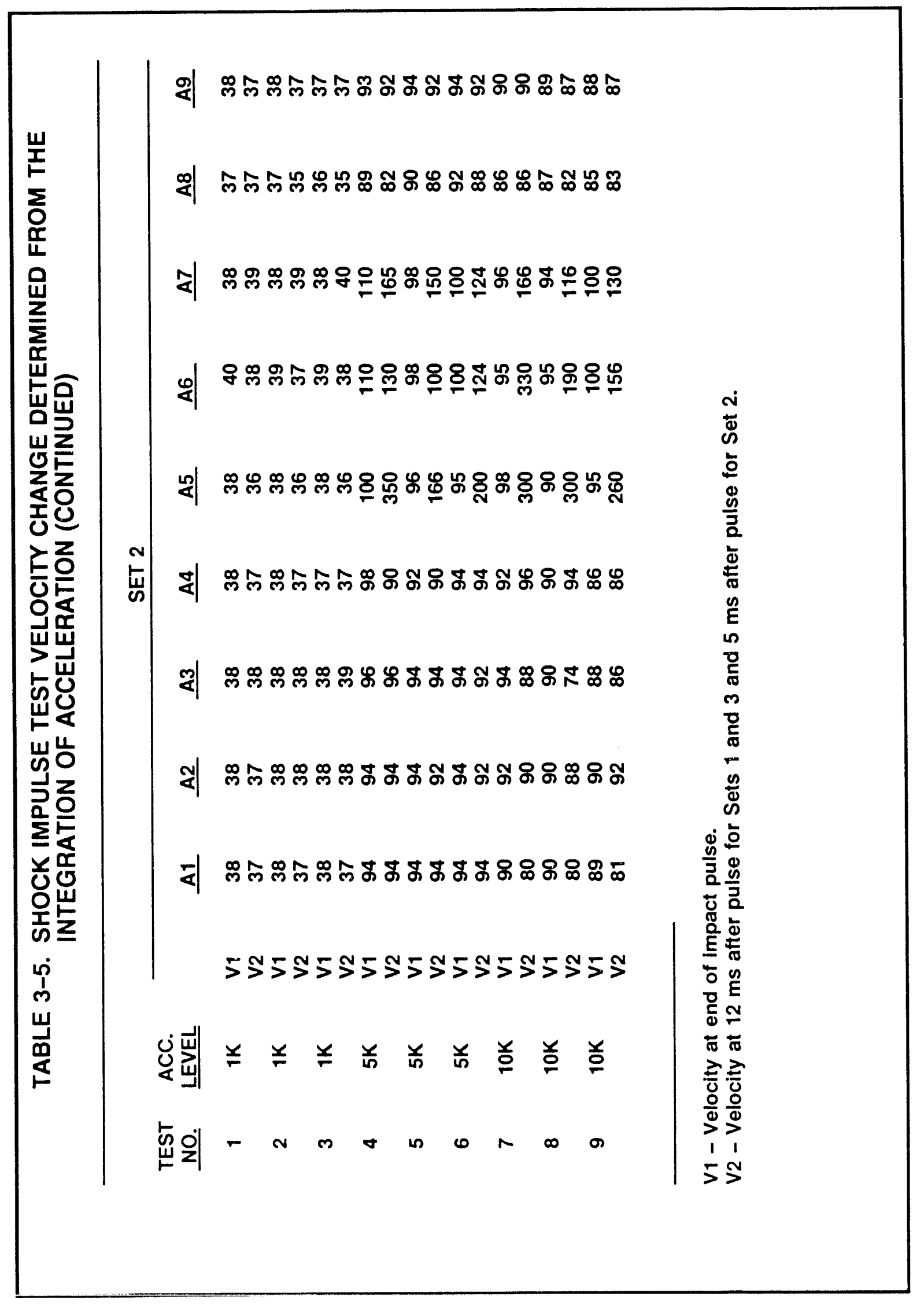




\begin{tabular}{|c|c|c|c|c|}
\hline 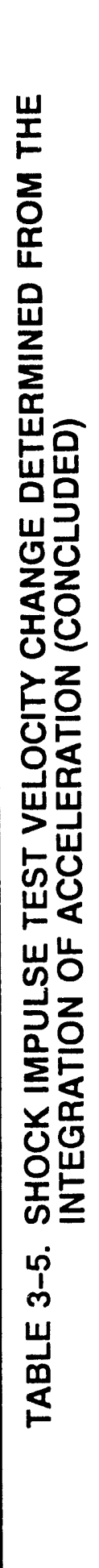 & $\stackrel{m}{5}$ & 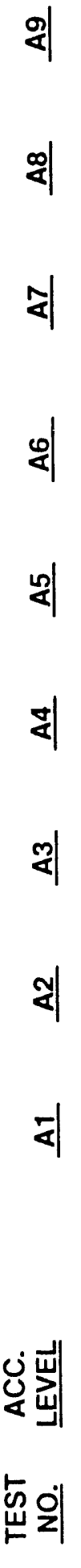 & 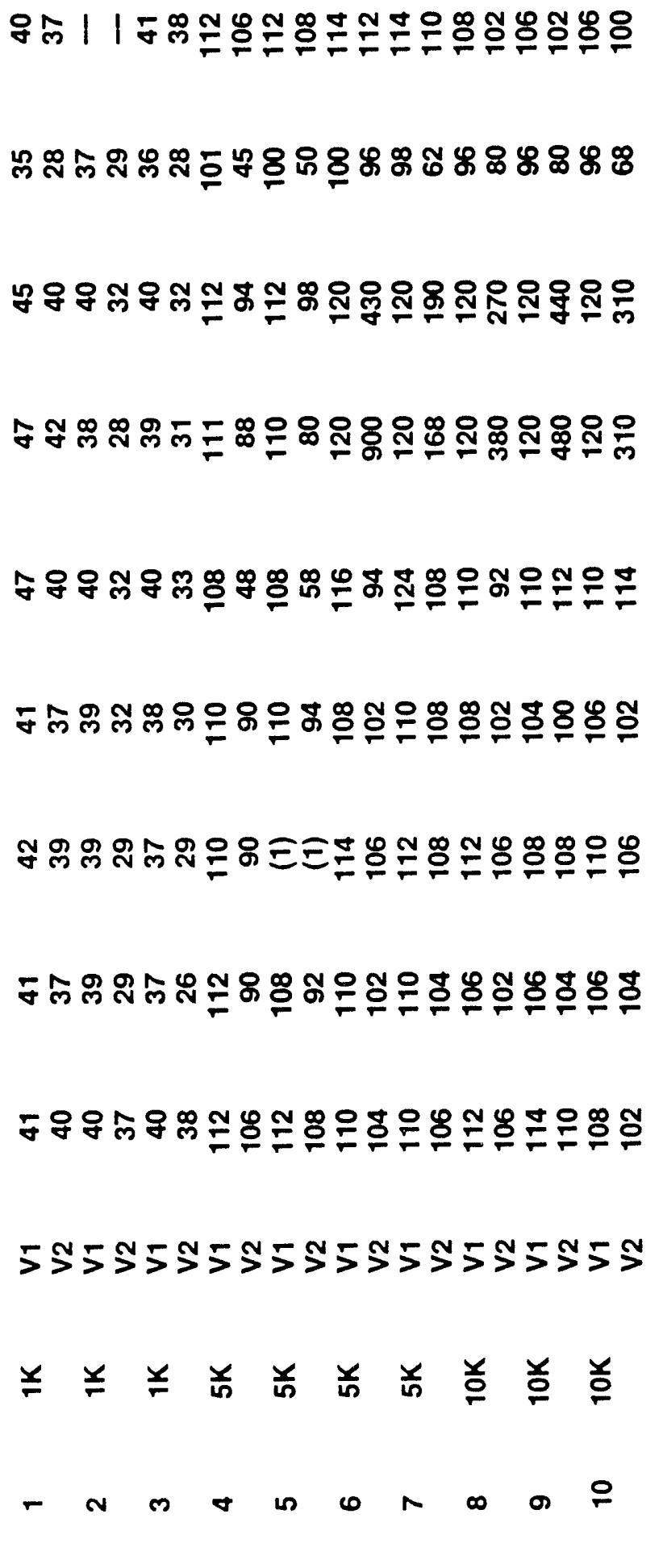 & 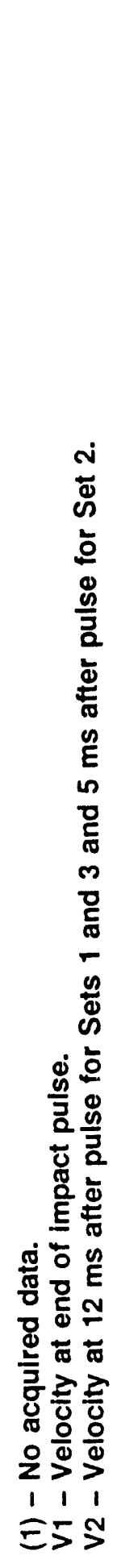 \\
\hline
\end{tabular}




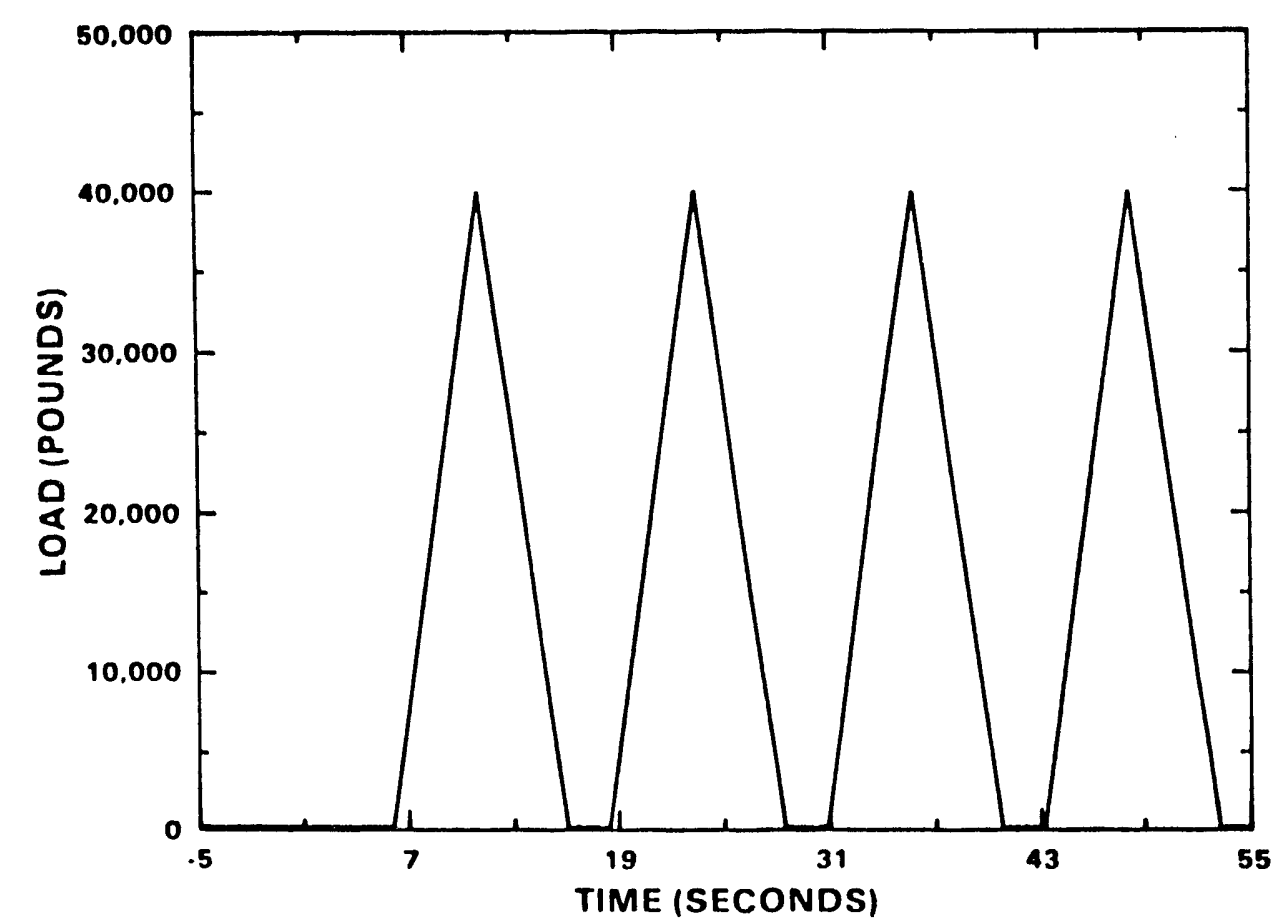

Figure 3-5. Typical Elastic Load History From Static Crush Tests

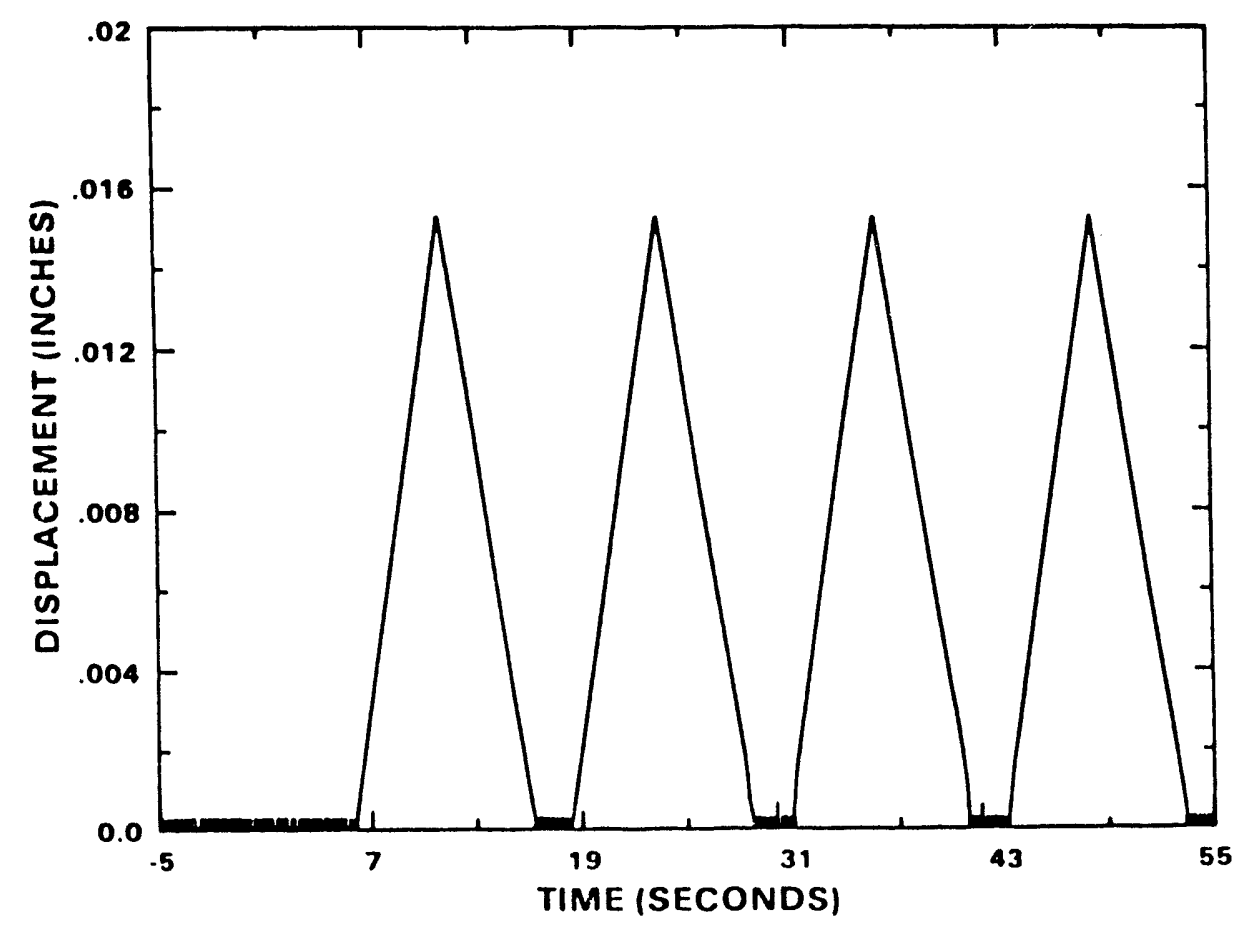

Figure 3-6. Elastic Deflection History From Static Crush Tests 


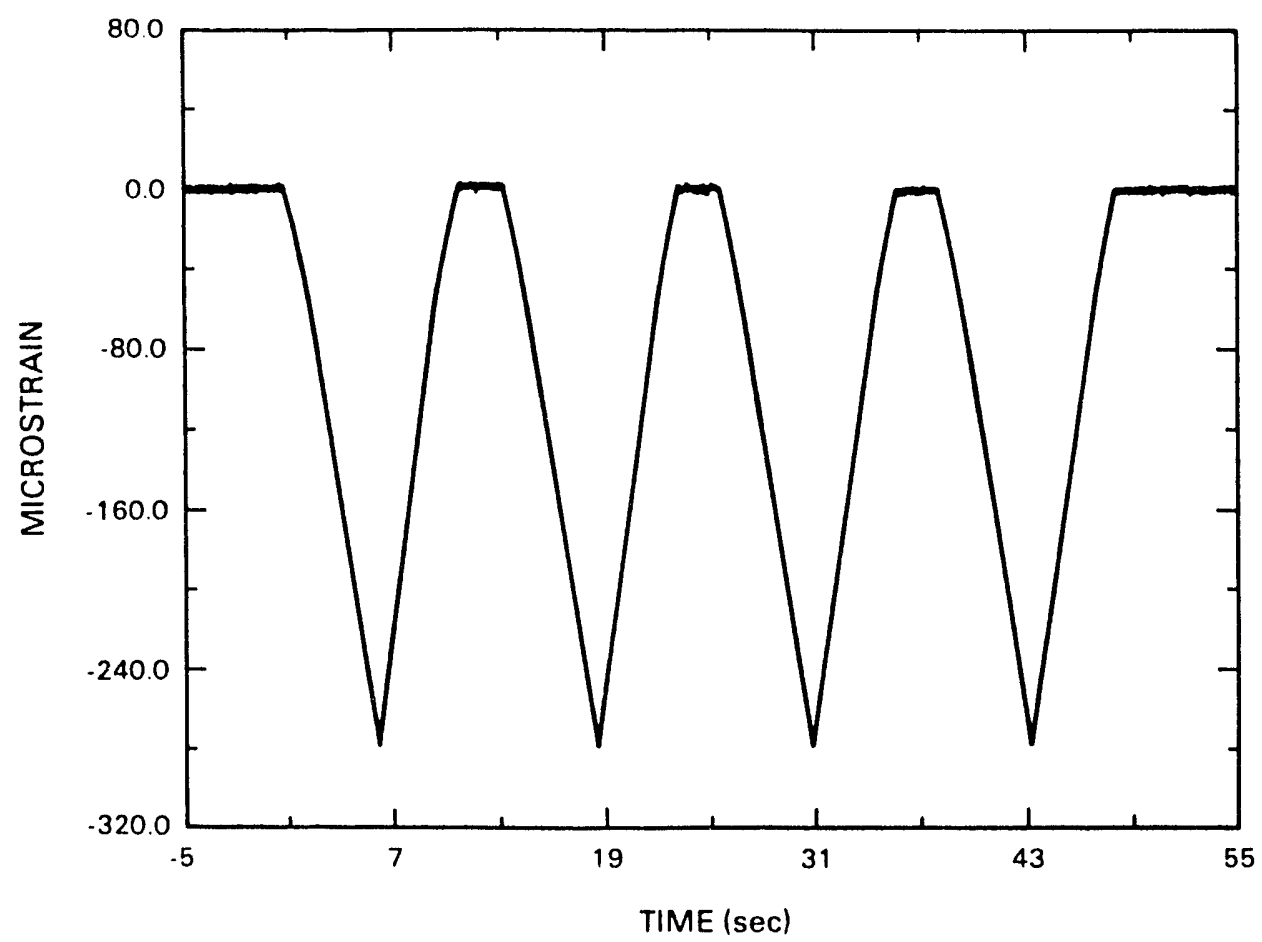

Figure 3-7. Typical Elastic Axial Strain Gage Plot From Static Crush Tests

can also be seen in Figure 3-13. These plots were used to determine the 0.002 -strain offset yield point, as well as the elastic limit, or limit of proportionality, of the material. Table 3-7 lists the yield strength and elastic limit obtained from each test. The yields ranged from 5,300 to $6,400 \mathrm{psi}$ and the elastic limits ranged from 3,700 to 4,750 psi.

In general, an important use of strain gages in test programs is to determine the peak and permanent strains at the gage location.

Table 3-8 lists the peak and permanent strains recorded for each gage in the inelastic portion of the static crush test. The method used for checking the permanent strain was to measure the resistance of the gage before and after the test. The difference in resistance is proportional to the permanent strain; the constant of proportionality is the gage factor times the initial resistance. These measurements were made for each gage, and the calculated permanent strain was then compared with the measured value. The results of this comparison are shown in Table 3-9. This method located recorded strain gage errors that may have resulted from the cabling or data acquisition system. If the calculated strain from the change in resistance did not correspond with the measured permanent strain, the error was likely in the cabling or data acquisition system and not in the strain gage itself. 


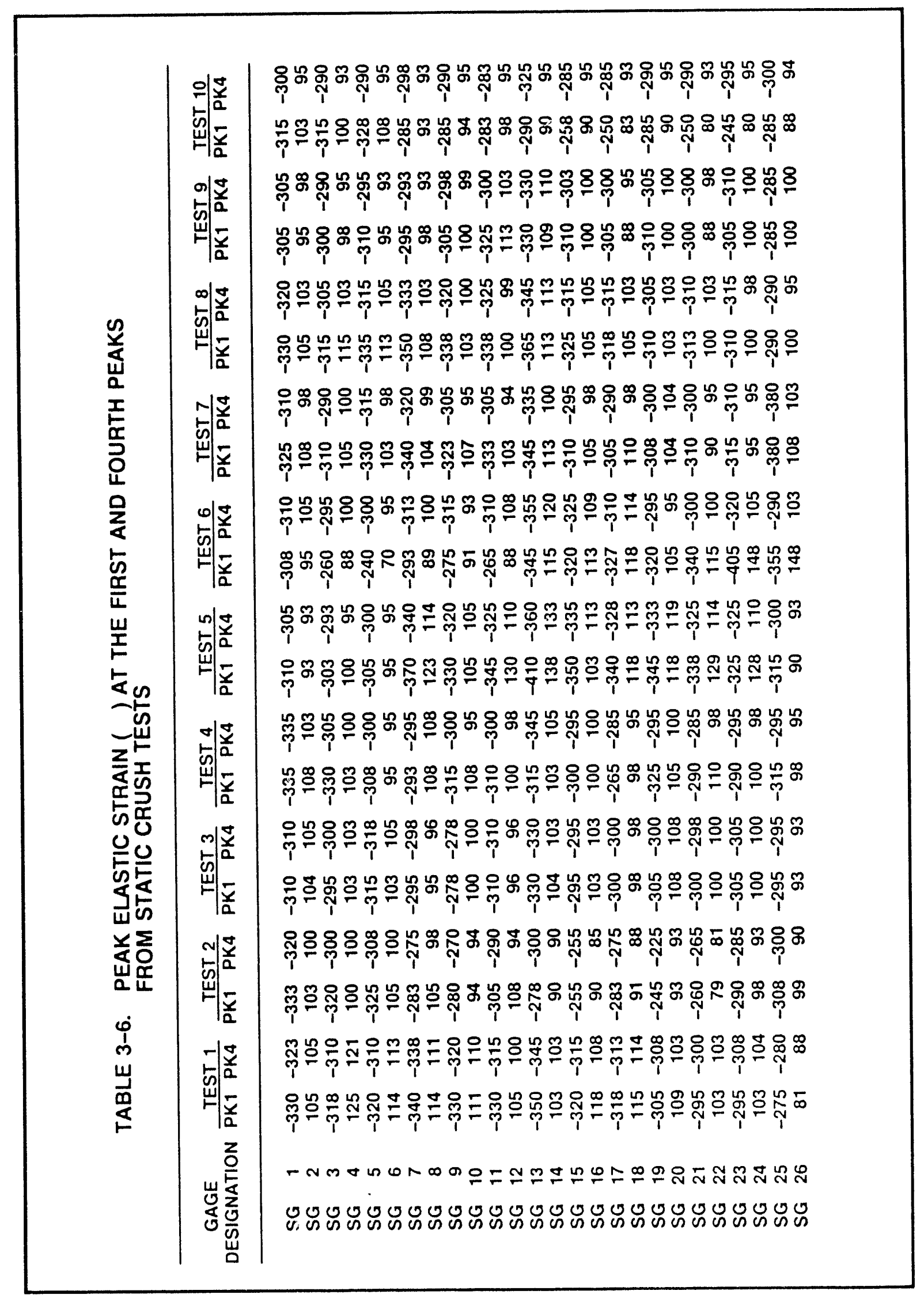




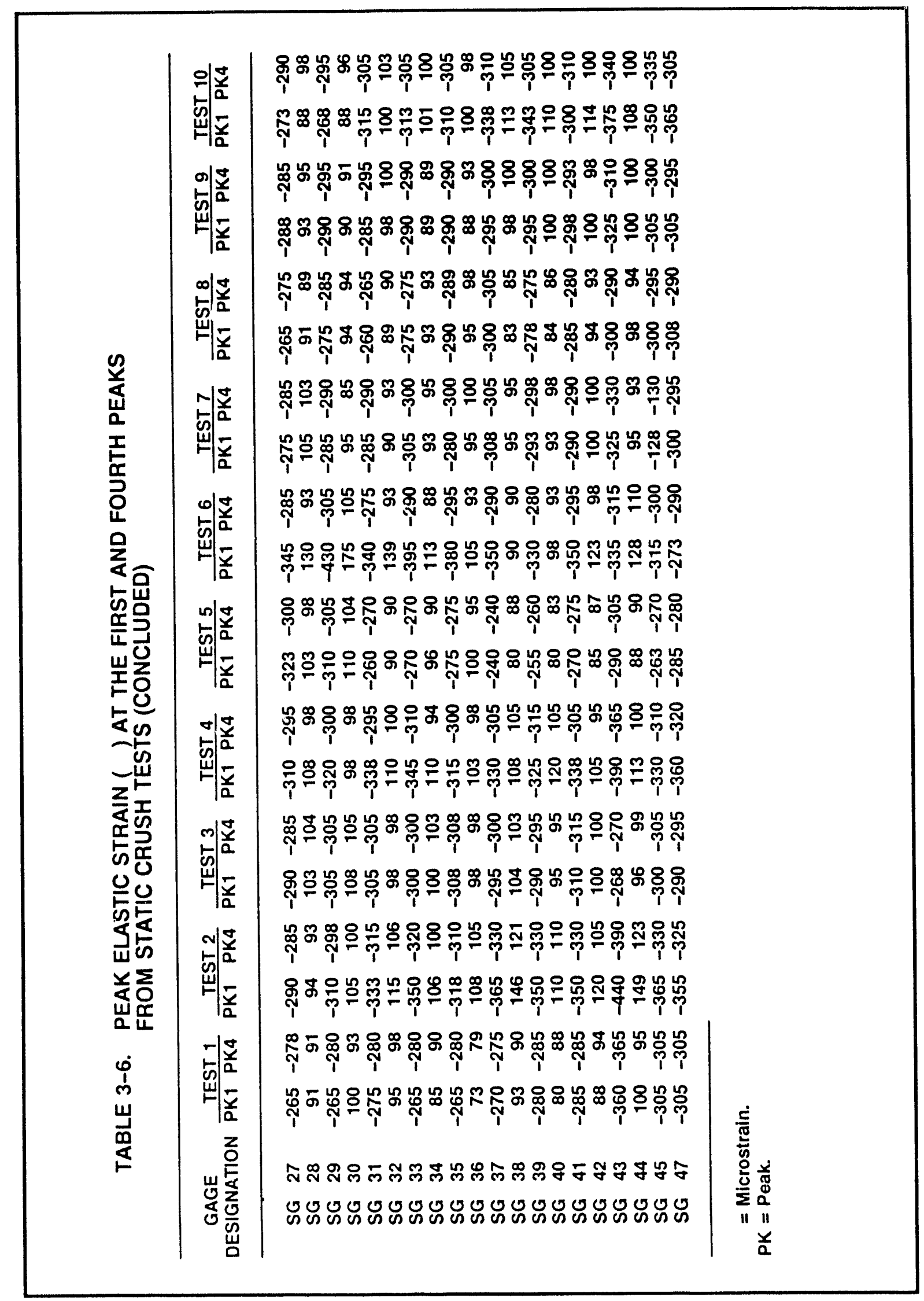




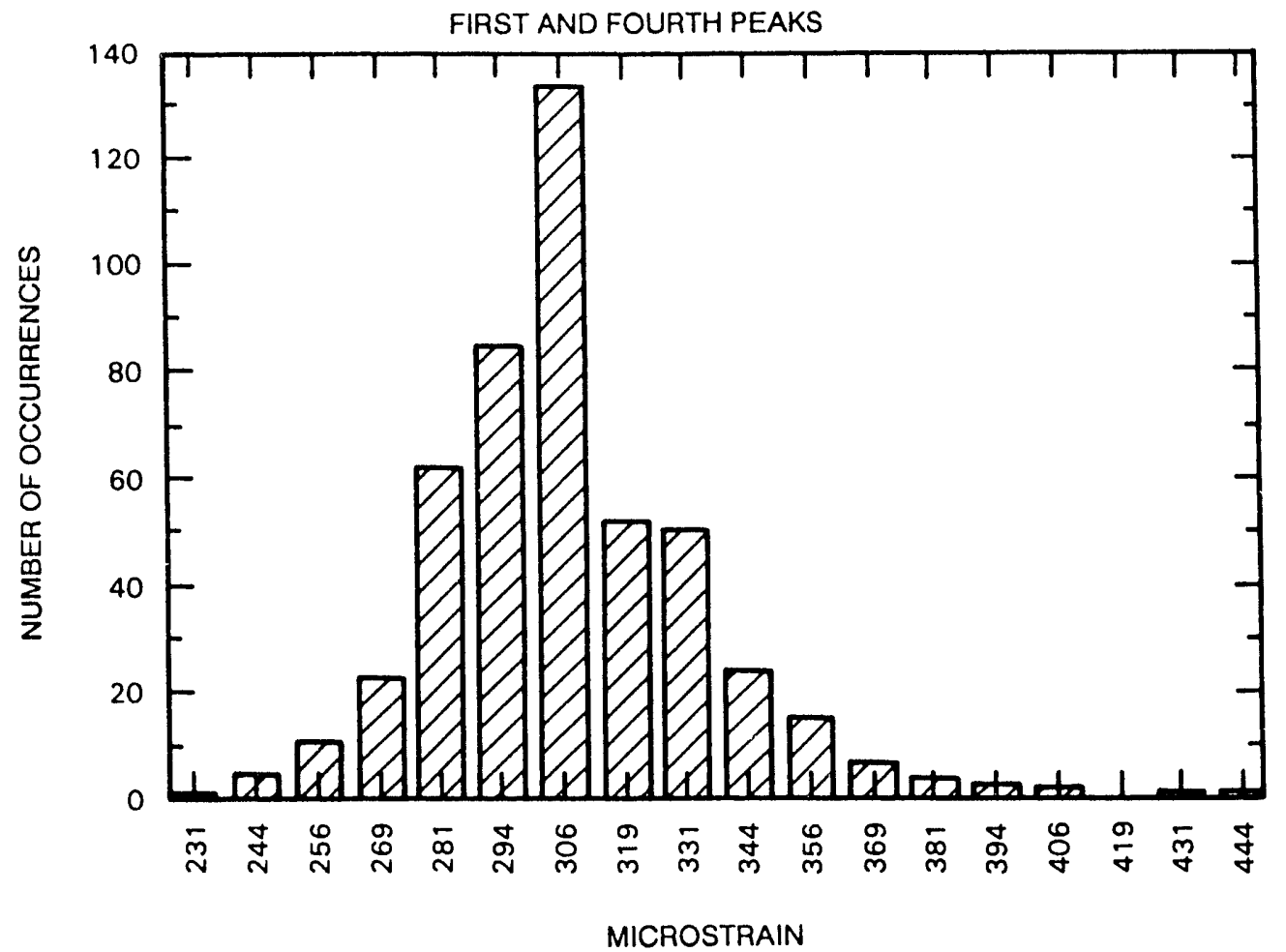

Figure 3-8. Elastic Axial Strain Distribution From Static Crush Tests

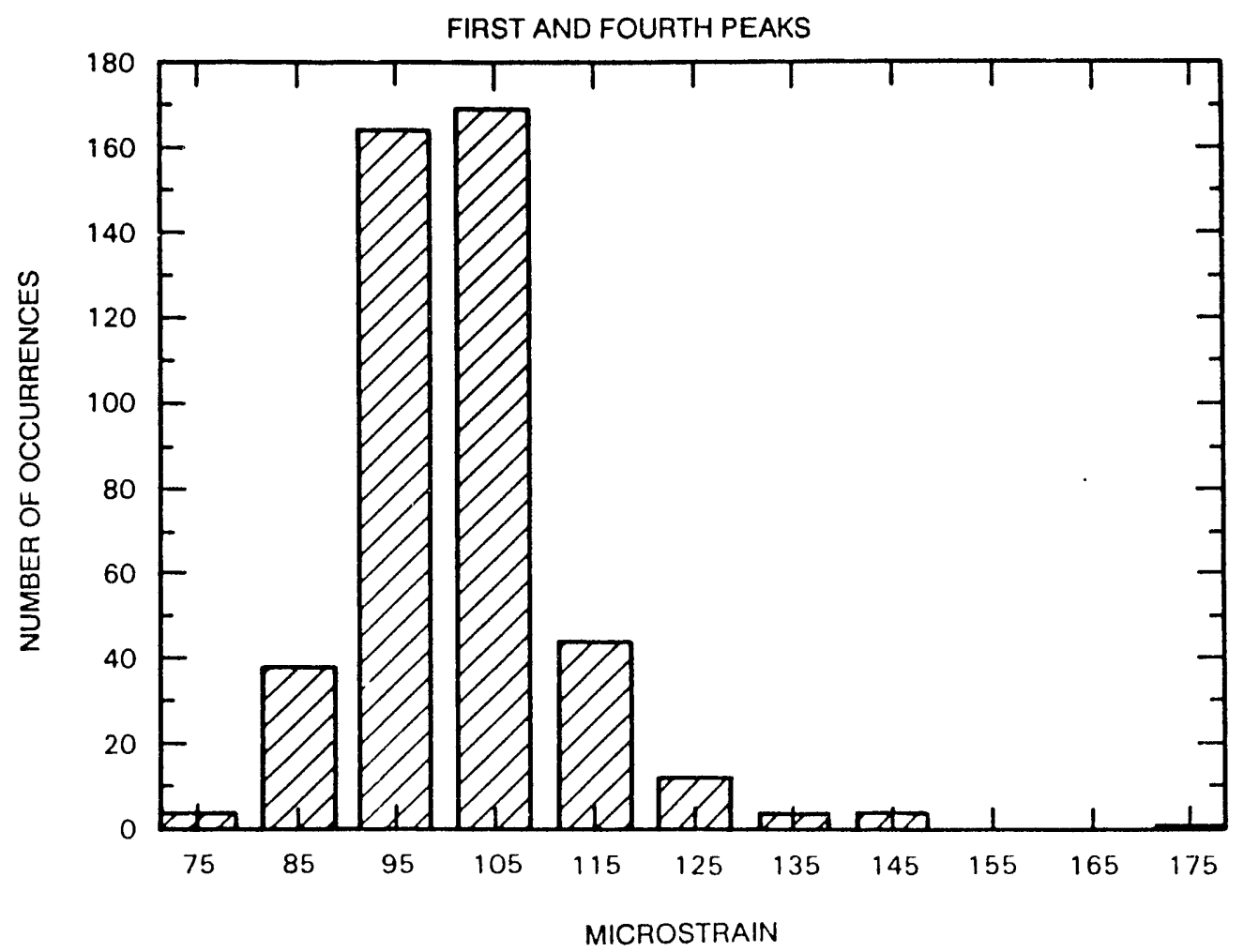

Figure 3-9. Elastic Hoop Strain Distribution From Static Crush Tests 


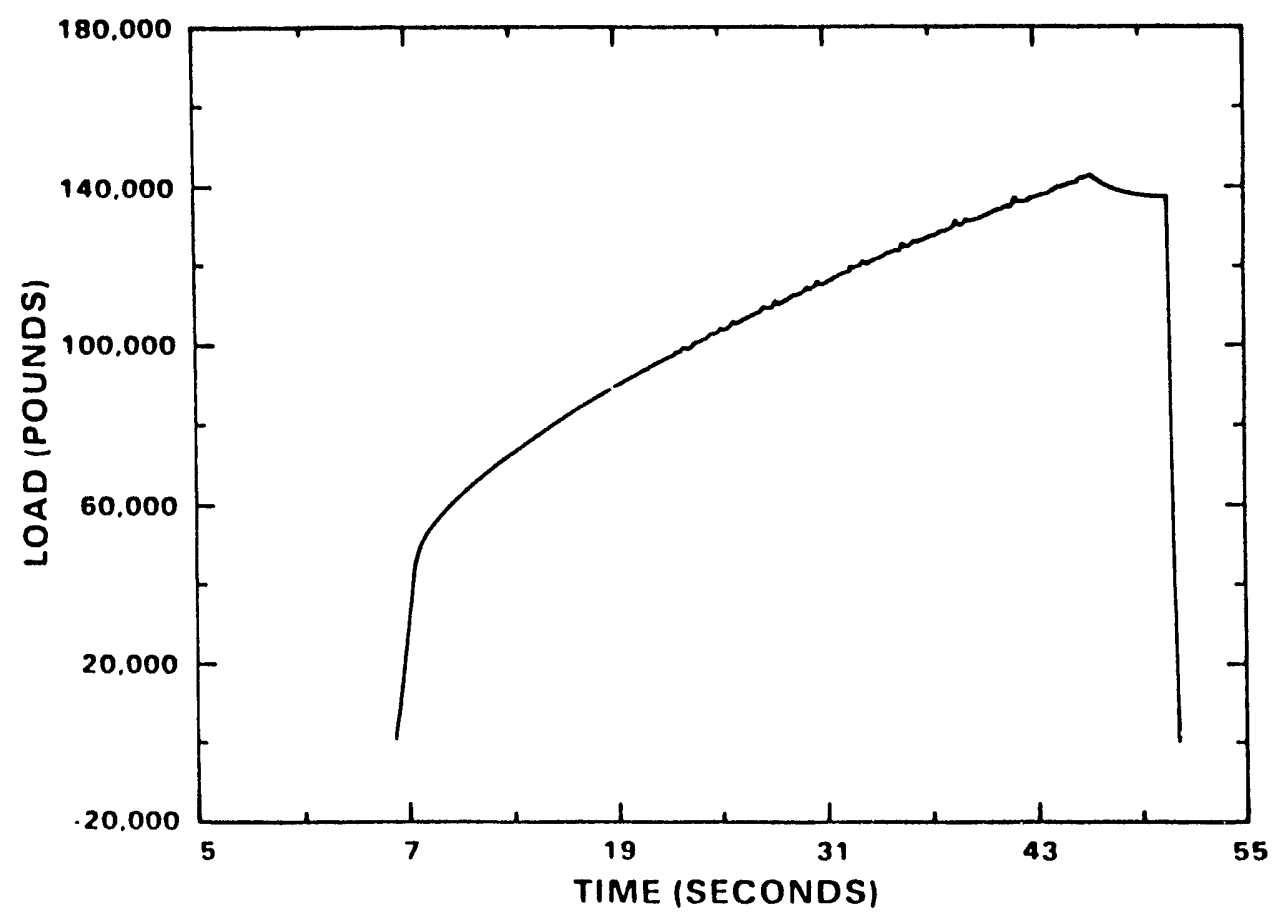

Figure 3-10. Plastic Load History From Static Crush Tests

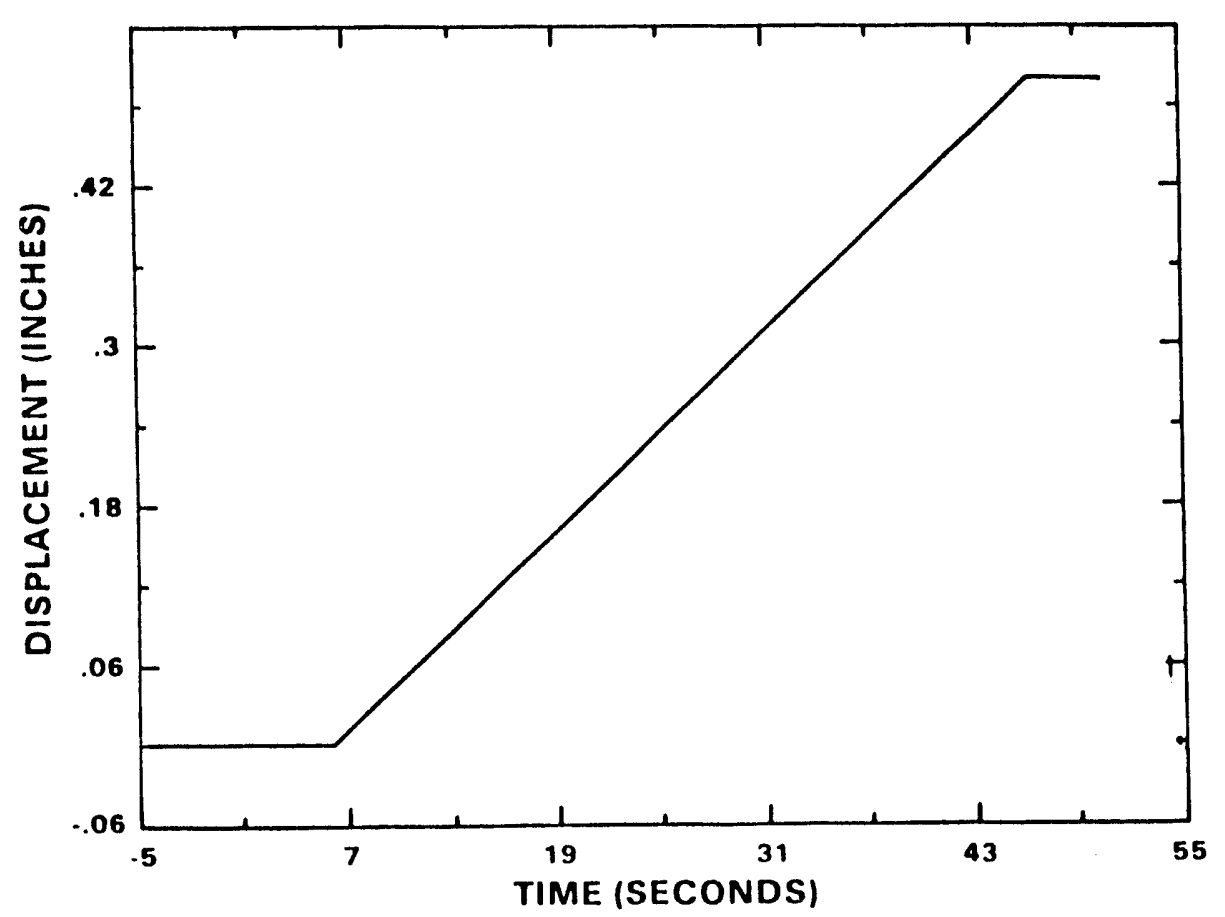

Figure 3-11. Plastic Deflection History From Static Crush Tests 


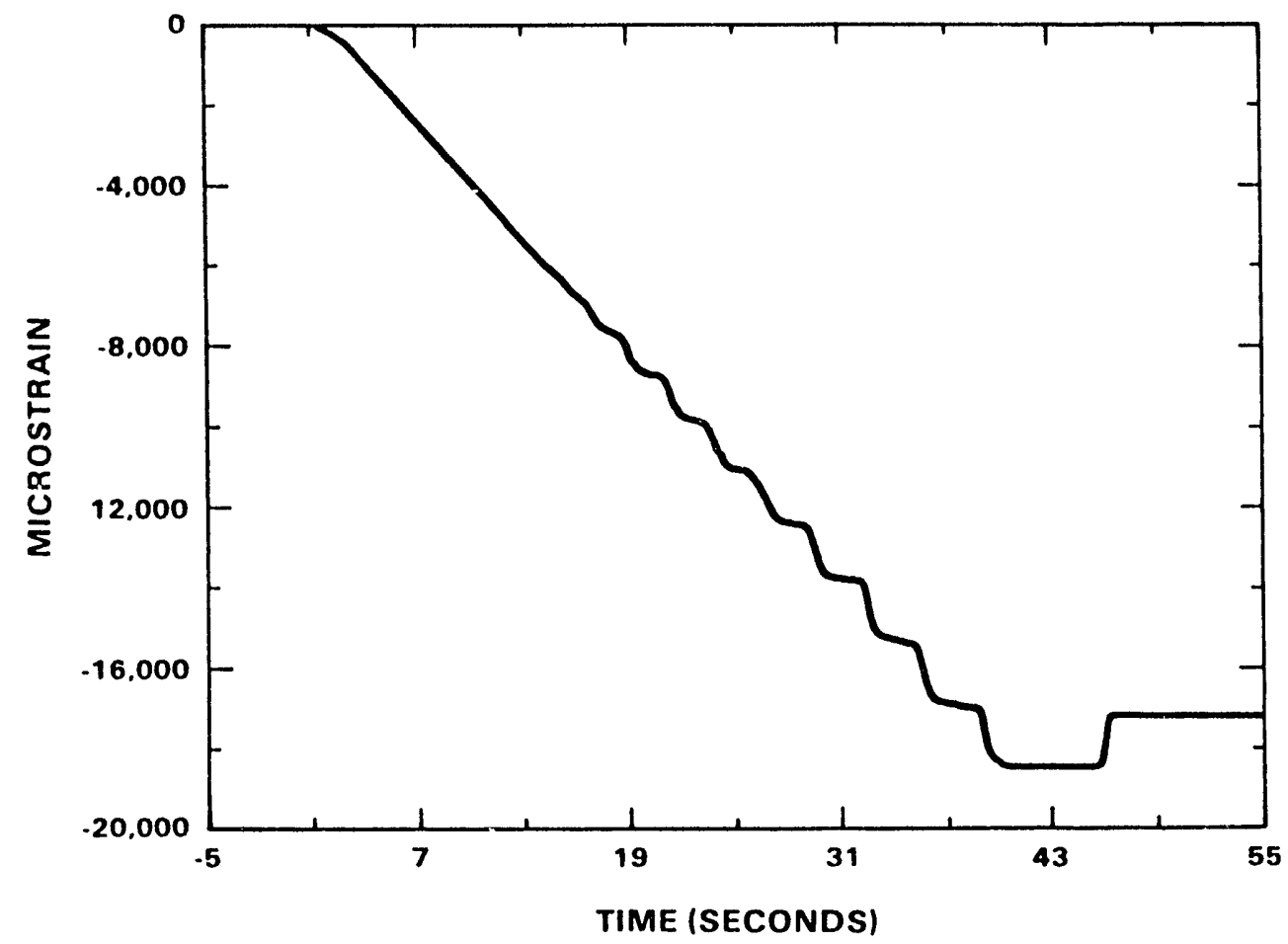

Figure 3-12. Plastic Axial Strain Gage Plot From Static Crush Tests

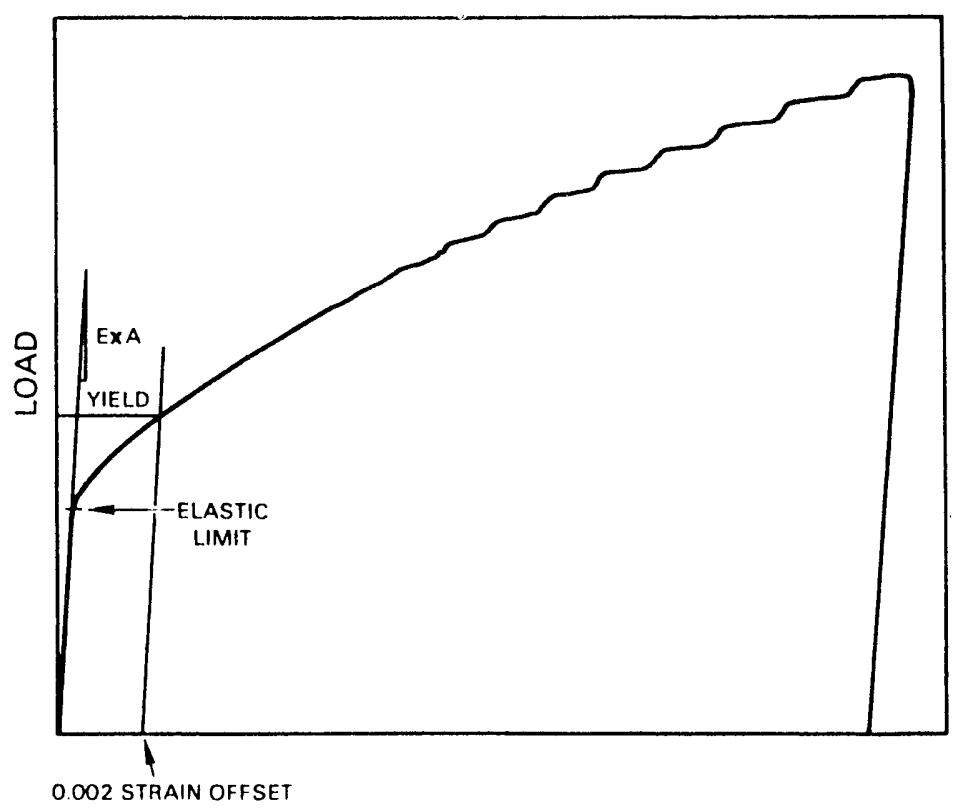

STRAIN FROM EXTENSOMETER

Figure 3-13. Load Versus Extensometer Strain Plot From Static Crush Tests 


\section{TABLE 3-7. MATERIAL YIELD STRESS AND ELASTIC LIMIT DETERMINED FROM STATIC CRUSH TESTS}

TEST NUMBER

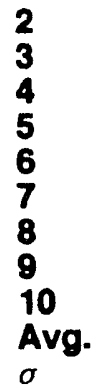

\section{YIELD STRESS}

(psi)

$\mathbf{5 7 6 8}$
$\mathbf{5 3 1 1}$
$\mathbf{5 6 3 3}$
$\mathbf{5 9 5 4}$
$\mathbf{5 4 6 4}$
$\mathbf{6 1 0 6}$
$\mathbf{6 2 0 8}$
$\mathbf{6 2 5 9}$
$\mathbf{6 3 9 4}$
$\mathbf{5 9 0 0}$
$\mathbf{3 7 7}$

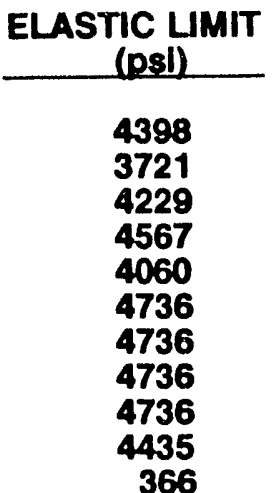

Figure 3-14 shows the distribution of the permanent axial strains from all of the reduced strain gage data. The average value was $17,358 \mu \varepsilon$, with a standard deviation of 1,377. These values did not include the results from six gages determined to be highly suspect. Five of these gages had measured permanent axial strains that differed from the value determined by the change in resistance by more than $5,000 \mu \varepsilon$. The sixth gage measured a permanent strain approximately $10,000 \mu \varepsilon$ lower than the average. The average value determined from the change of resistance was $17,339 \mu \varepsilon$, with a standard deviation of 1,364 . The average value from the extensometer was $18,512 \mu \varepsilon$, with a standard deviation of 528. The average value determined from dimensional inspection was $18,411 \mu \varepsilon$, with a standard deviation of 178 . A11 of the dimensional inspection data are given in Appendix $B$. The distribution of the permanent hoop strains from the reduced data is shown in Figure 3-15. The average value was $7,892 \mu \varepsilon$, with a standard deviation of $2,451 \mu \varepsilon$. This large standard deviation was due to variations in the tests. This is shown by the dimensional inspection which indicated large variations in permanent deformations that corresponded to these strains. The average value from the dimensional inspection data was $8,540 \mu \varepsilon$, with a standard deviation of 1,509 .

The average measured strains in both the axial and hoop directions were smaller than the values determined by the dimensional inspections. For the axial direction, the average value of the Micro-Measurement gages from the reduced data was $17,103 \mu \varepsilon$, with a standard deviation of 1,198 , and the calculated permanent strain average was $17,186 \mu \varepsilon$, with a standard deviation of 1,147. The average value of the BLH gages was $17,613 \mu \varepsilon$, with a standard deviation of 1,500 , and the average calculated permanent strain was $17,494 \mu \varepsilon$, with a standard deviation of 1,537. If the true permanent strain was $18,411 \mu \varepsilon$, then the BLH gages gave a closer result, but with more scatter. Both sets were within one standard deviation ( $7 \%$ ) of the result determined from dimensional inspection. One BLH gage in this test series appeared to give faulty 


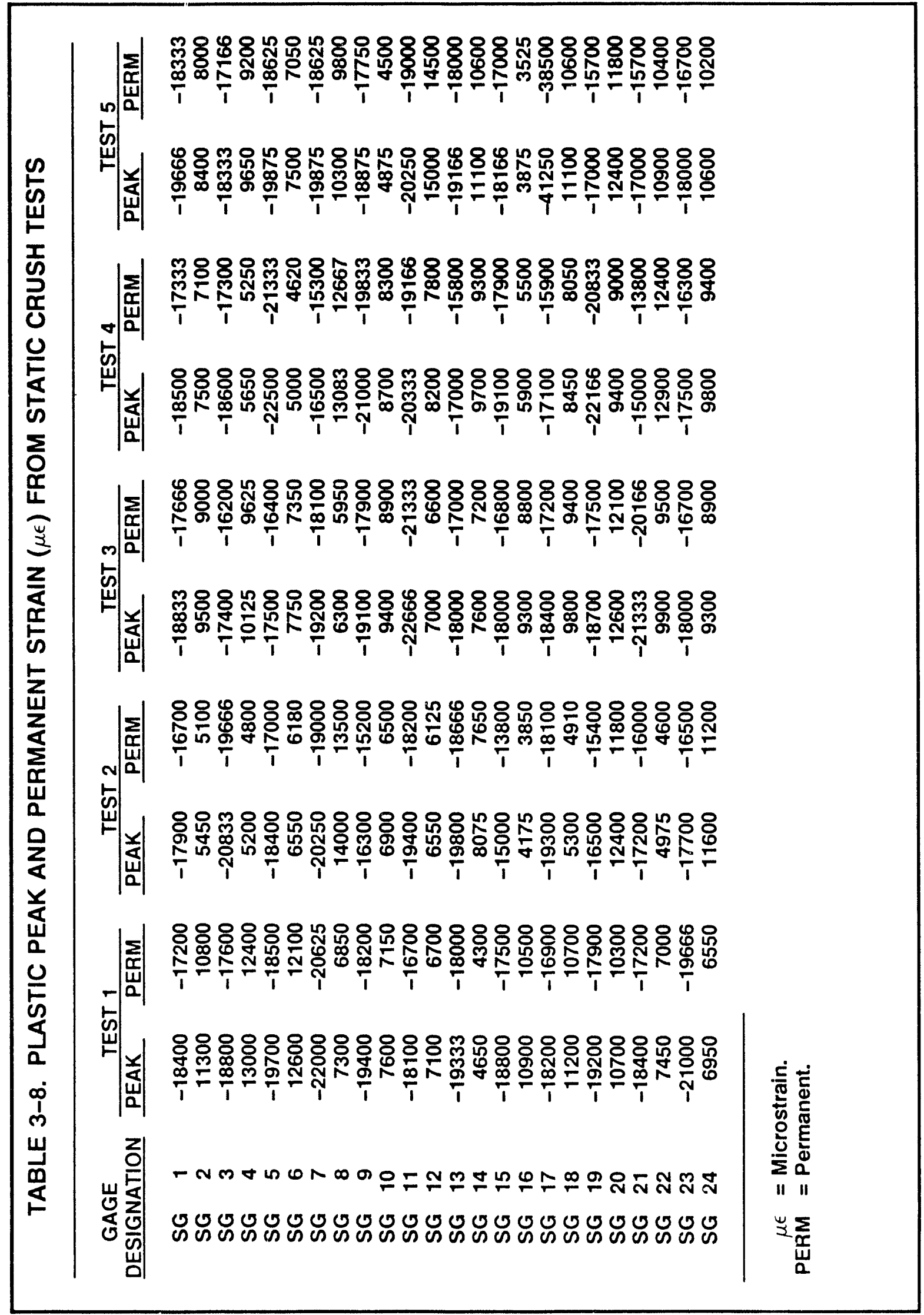




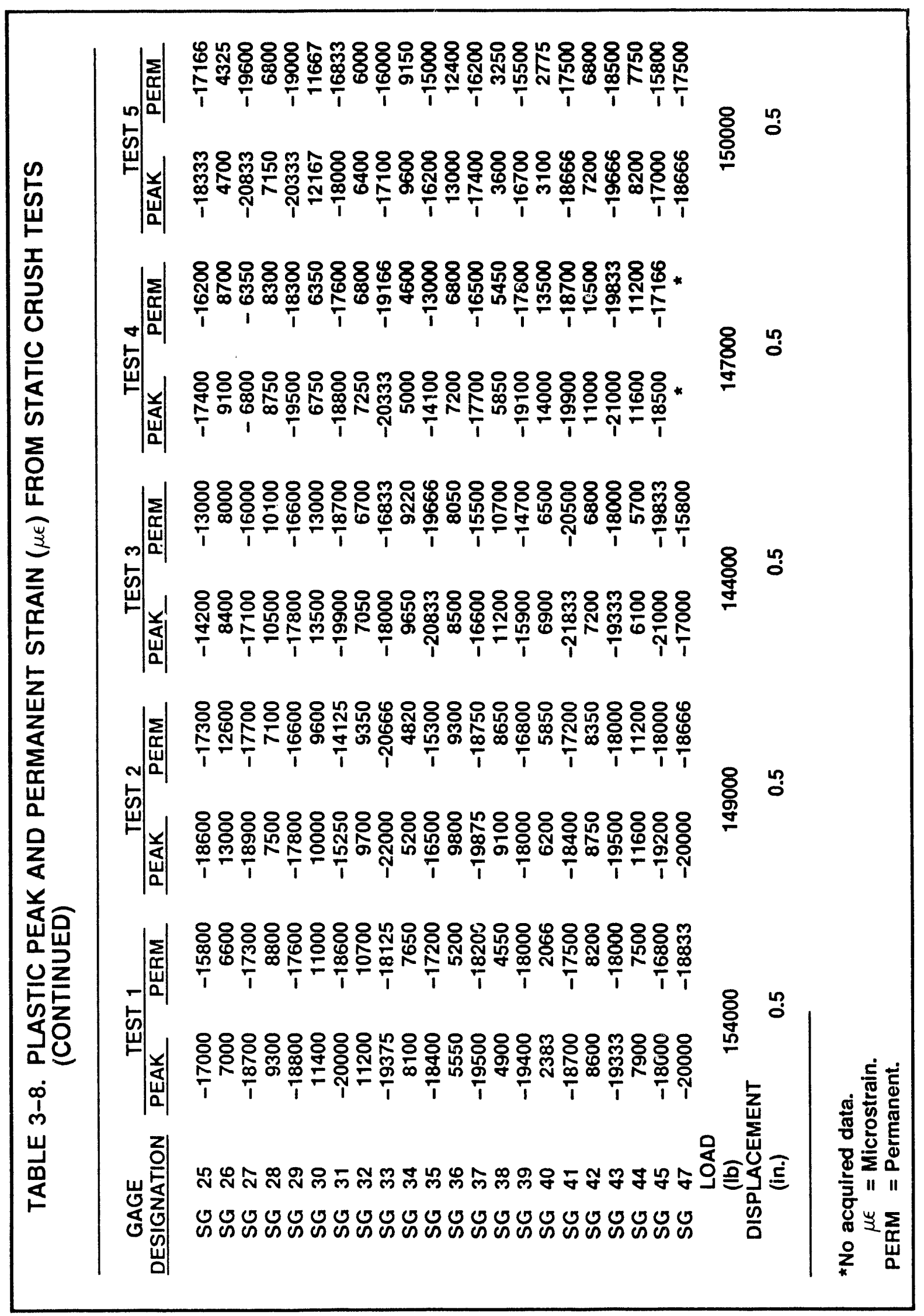




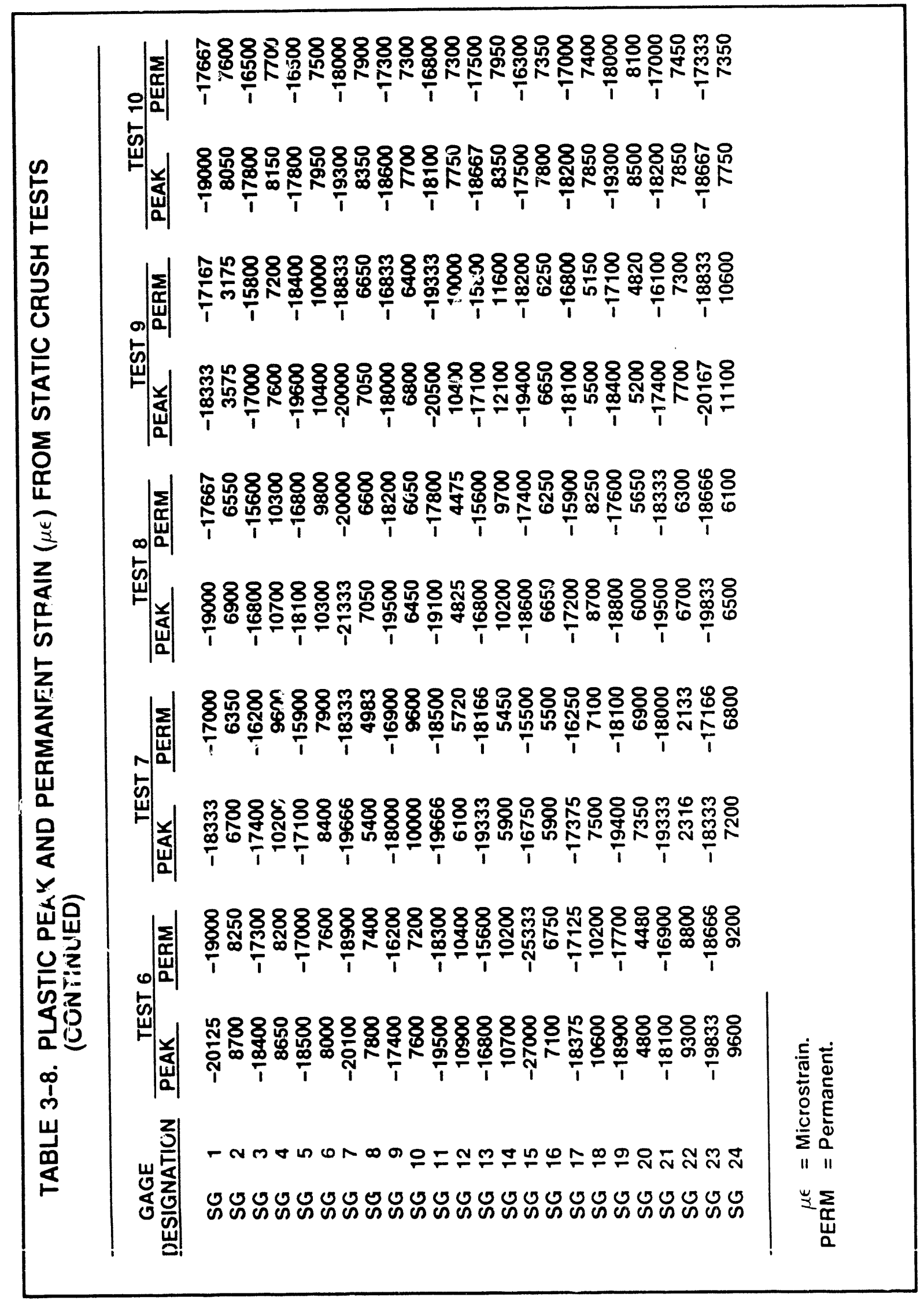




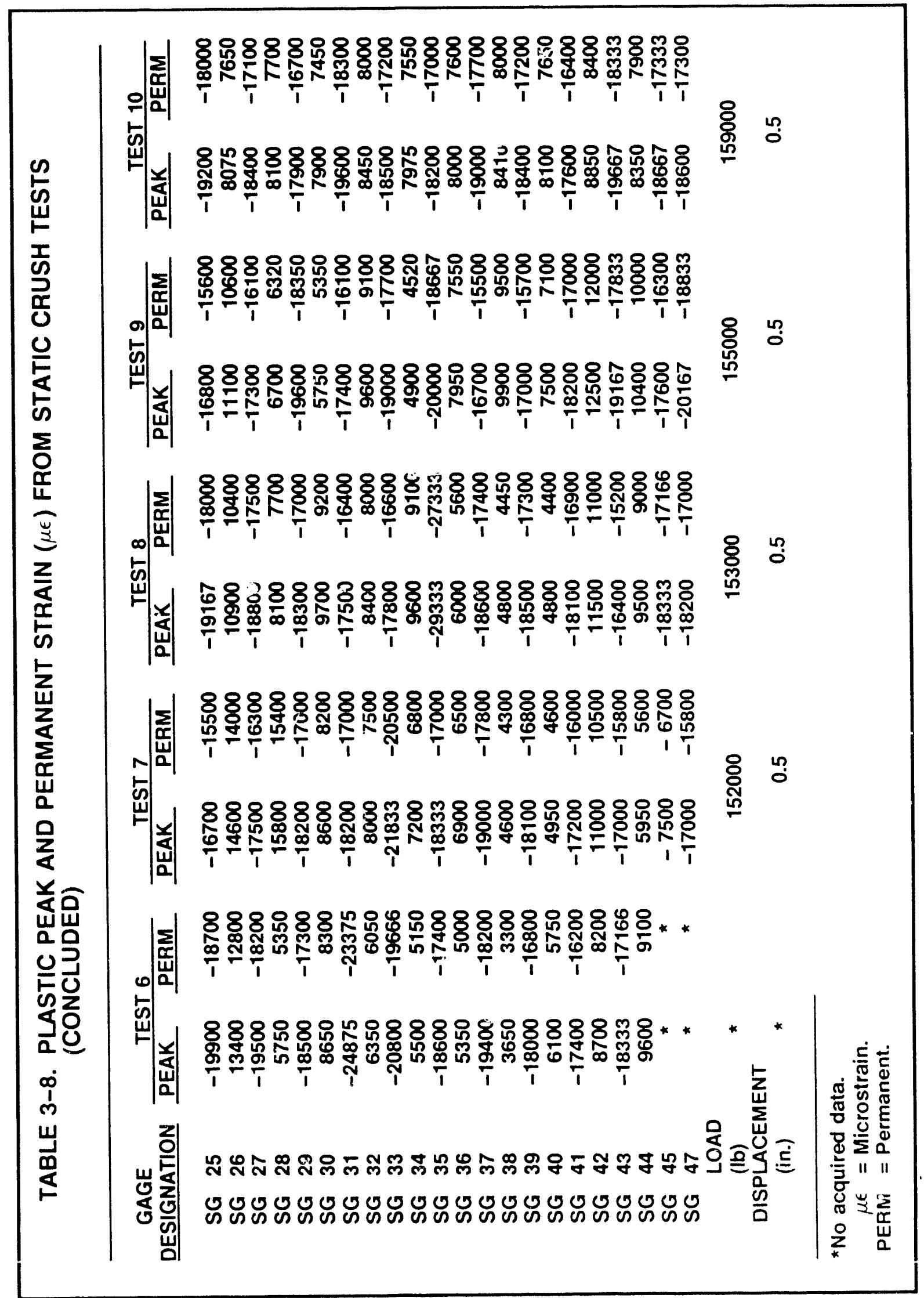




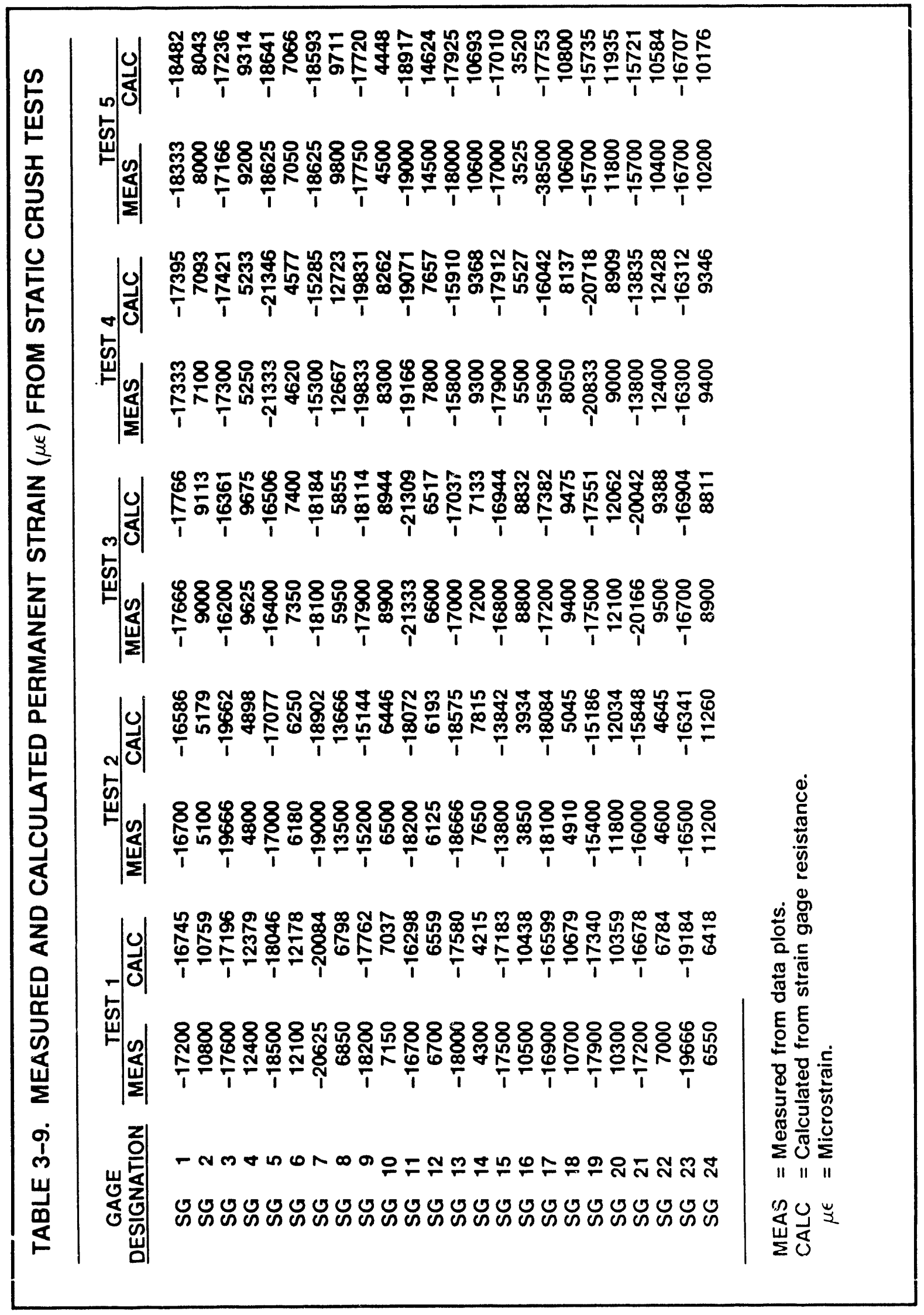




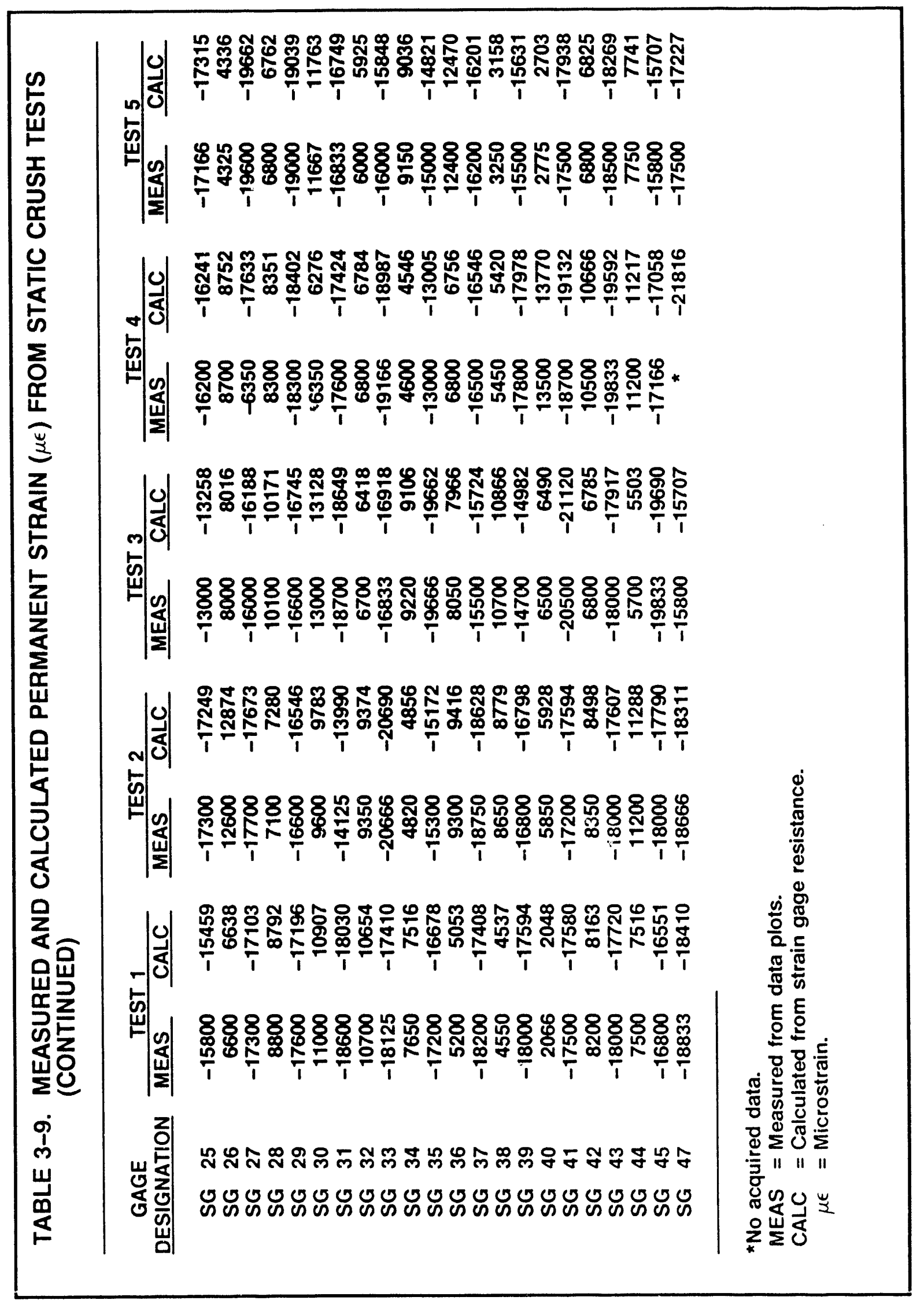




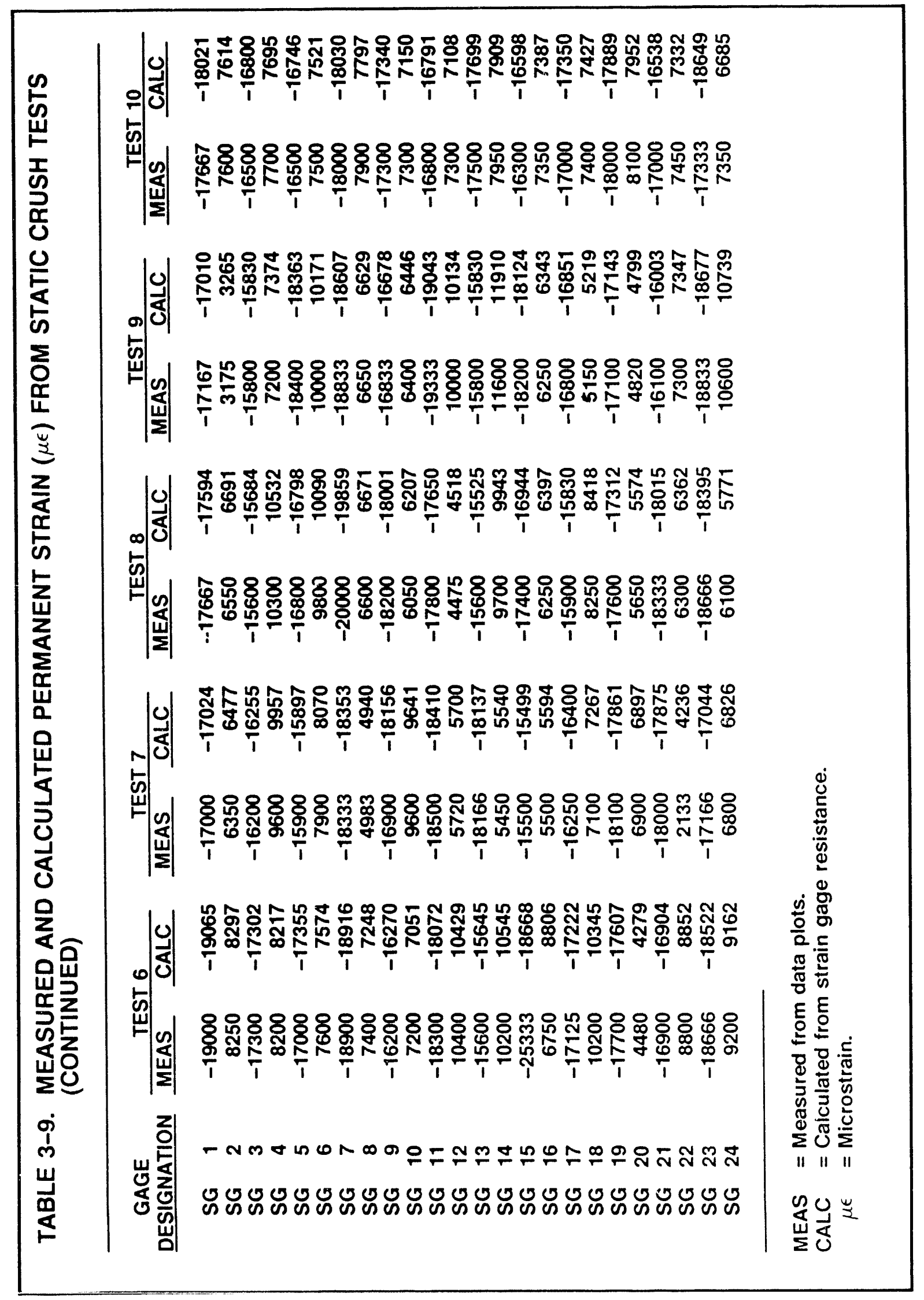




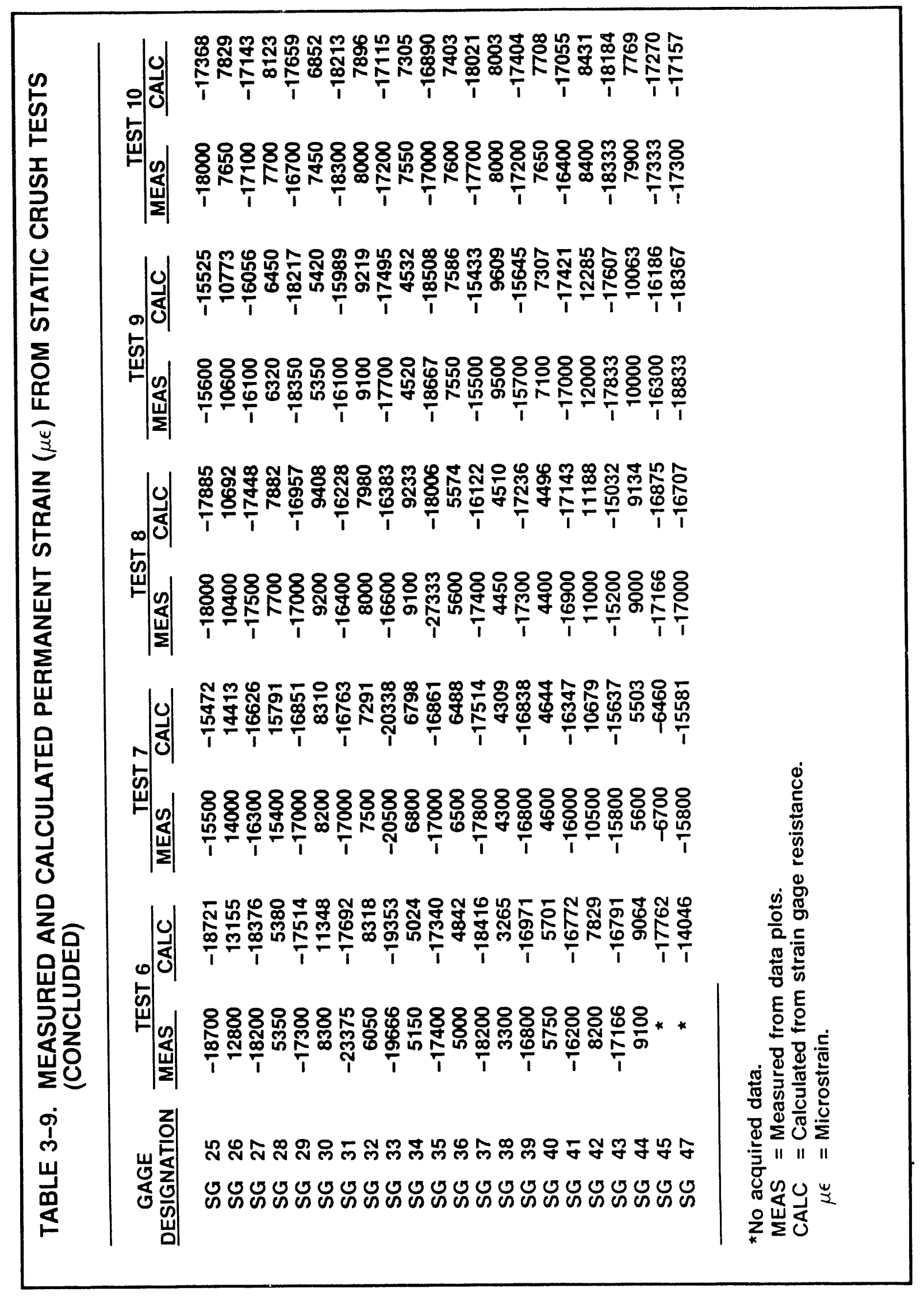




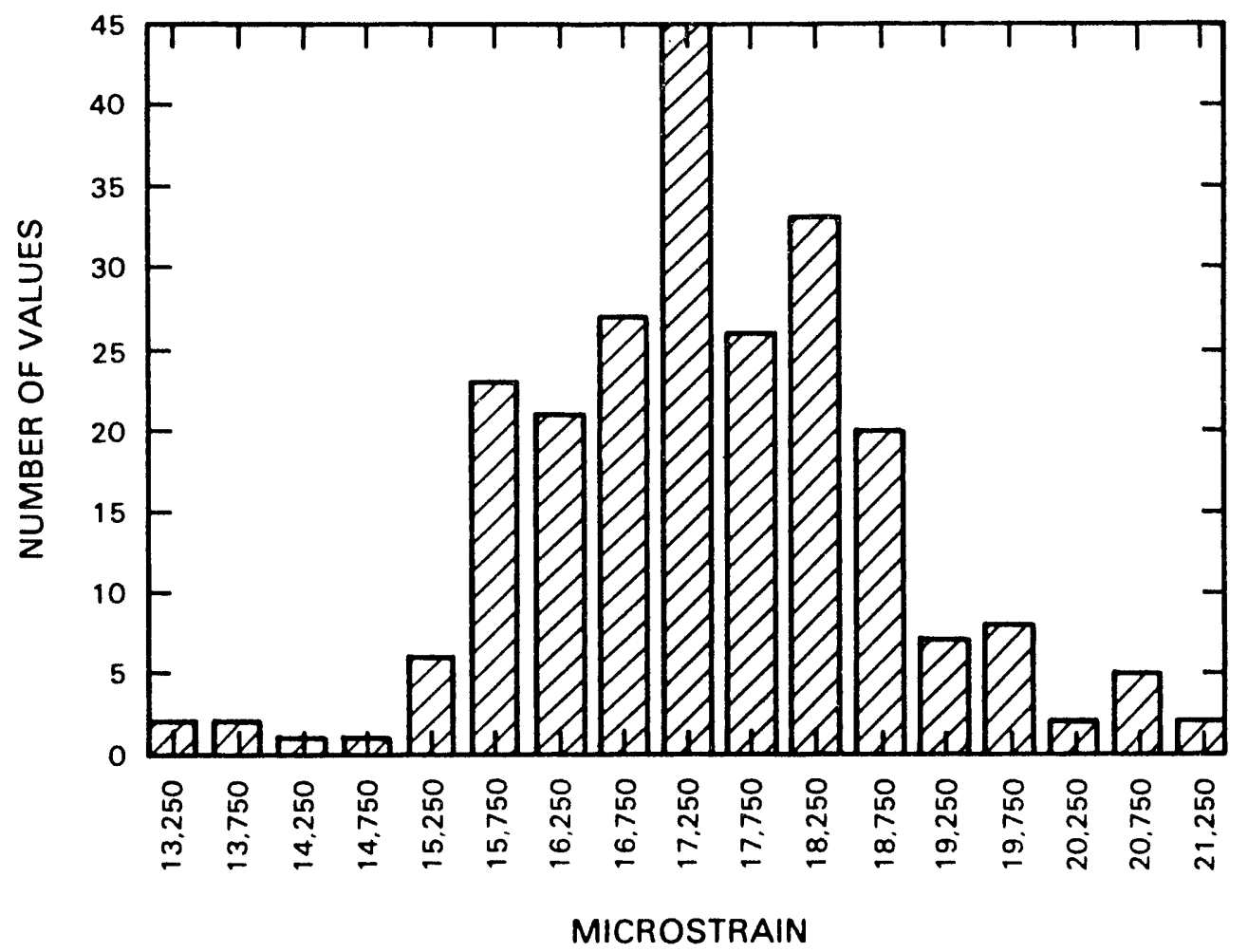

Figure 3-14. Plastic Axial Strain Distribution From Static Crush Tests

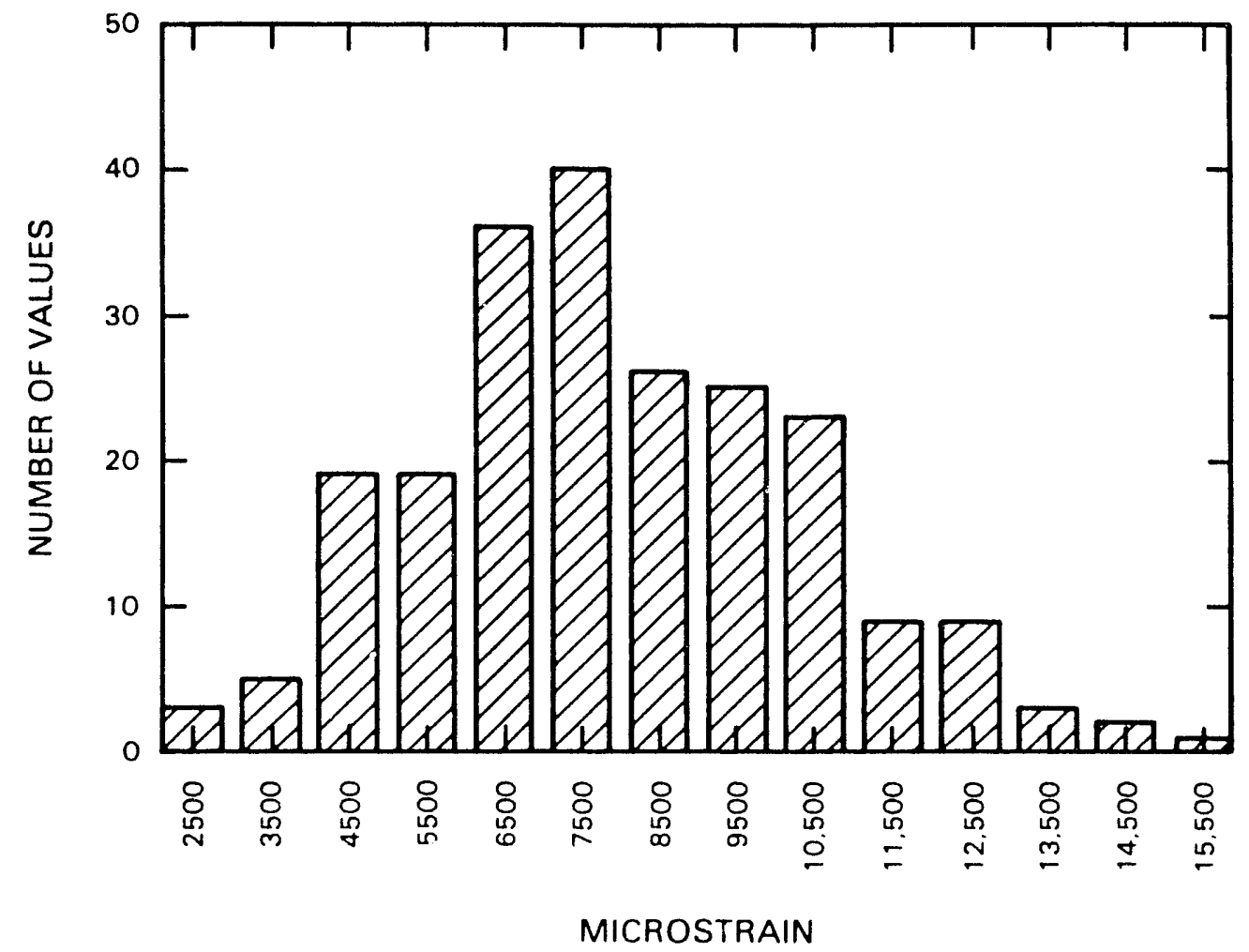

Figure 3-15. Plastic Hoop Strain Distribution From Static Crush Tests 
readings either because the gage was defective or because the bond between the gage and the specimen was incomplete.

In general, the BLH gages showed a higher instance of required reinstallation due to questionable bonding. A total of 21 BLH gages were replaced on the ten test specimens.

\subsection{End-Impact Tests}

The two types of instrumentation results from the end-impact tests were acceleration-time histories and strain-time histories. Figure 3-16 shows a typical plot of filtered accelerometer data with a cutoff frequency of $10,000 \mathrm{~Hz}$. The filter used for this data was a digital Butterworth filter (Stearns, 1988). Figure 3-17 shows a plot of this same data filtered at $1,000 \mathrm{~Hz}$, which was below the lowest natural frequency (approximately 2,400 $\mathrm{Hz}$ ) of the test specimen and thus represented the rigid-body acceleration. Table 3-10 gives the values for peak accelerations from the $10,000-\mathrm{Hz}$ plot and the $1,000-\mathrm{Hz}$ plot for each accelerometer for all ten tests. Variations in amplitude between the $10,000-\mathrm{Hz}$ filtered data and the $1,000-\mathrm{Hz}$ filtered data were the result of removing the vibratory response of the test article from the higher filtered frequency. Table $3-2$ gives the calibration information for the accelerometers.

A typical strain-time history for an axial strain gage located at 1 in. from the bottom of the specimen is shown in Figure 3-18. A permanent strain offset due to plastic deformation was measured. Table 3-11 gives the values of peak and permanent strain for all of the gages for the ten tests, and Table 3-12 compares the permanent strain values obtained from the data to those calculated by the change in resistance of the strain gage. For strain gages 1 and 2, the large difference between measured and calculated permanent strains for some of the tests was because the measured strains only included primary impact and the calculated strains included the effect of secondary impact, which produced additional permanent deformation in some of the test articles.

For these tests it was more difficult to make comparisons between transducers on the same test specimen because the specimen's impact on the unyielding target was not perfectly flat. This caused the strains and accelerations on the initial impacting side to be higher than those on the side away from initial impact. This behavior was also seen in the dimensional inspection permanent axial deformations. Figure 3-19 illustrates the average distribution of permanent axial strains at 1 in. from the impacting end, the permanent deformations, the peak $10,000-\mathrm{Hz}$ accelerations, and the peak $1,000-\mathrm{Hz}$ accelerations around the test specimen. Figure 3-19 shows that the maximum accelerations corresponded to the maximum strains and maximum permanent deformations. For most of the tests, the initial impact occurred at approximately 150 degrees, which was near accelerometer $A 6$ and between strain gages 6 and 11 at 1 in., strain gages 8 and 13 at 3 in., and strain gages 10 and 15 at 6 in. (See the dimensional inspection data in Appendix C.) For the accelerations the effect of the angled impact was less pronounced for the $1,000-\mathrm{Hz}$ filtered data because these data were more representative of the rigid body motion of the test article. For the strain gages the 


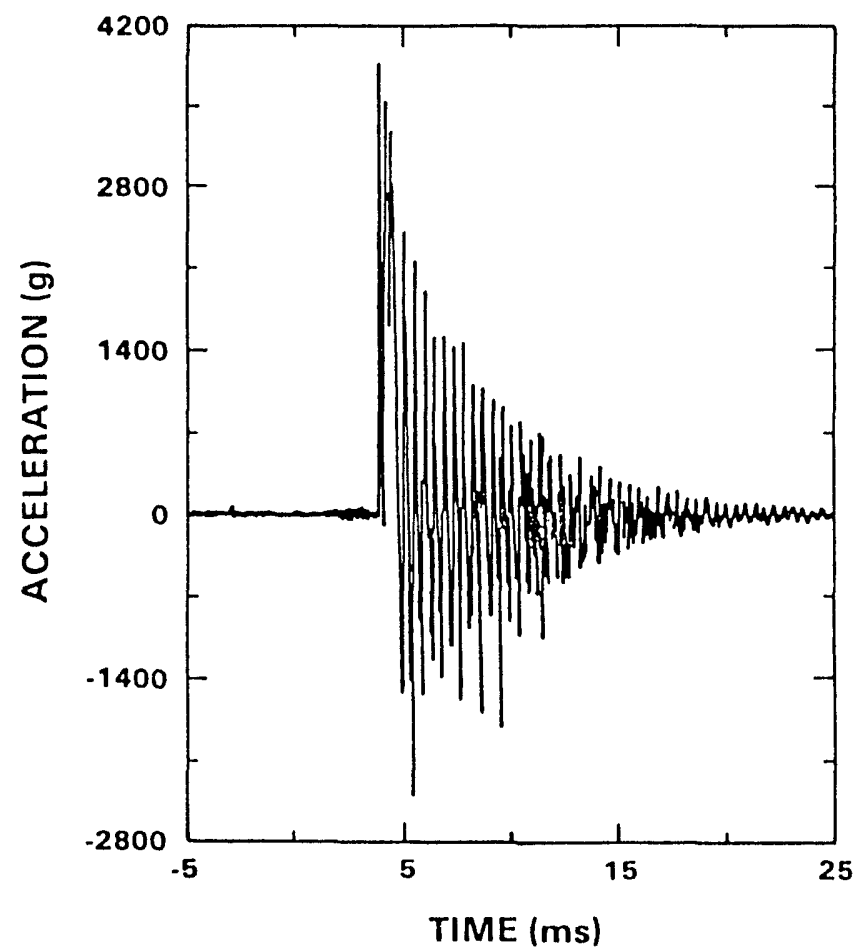

Figure 3-16. Typical Accelerometer Filtered at 10,000 $\mathrm{Hz}$ From EndImpact Tests

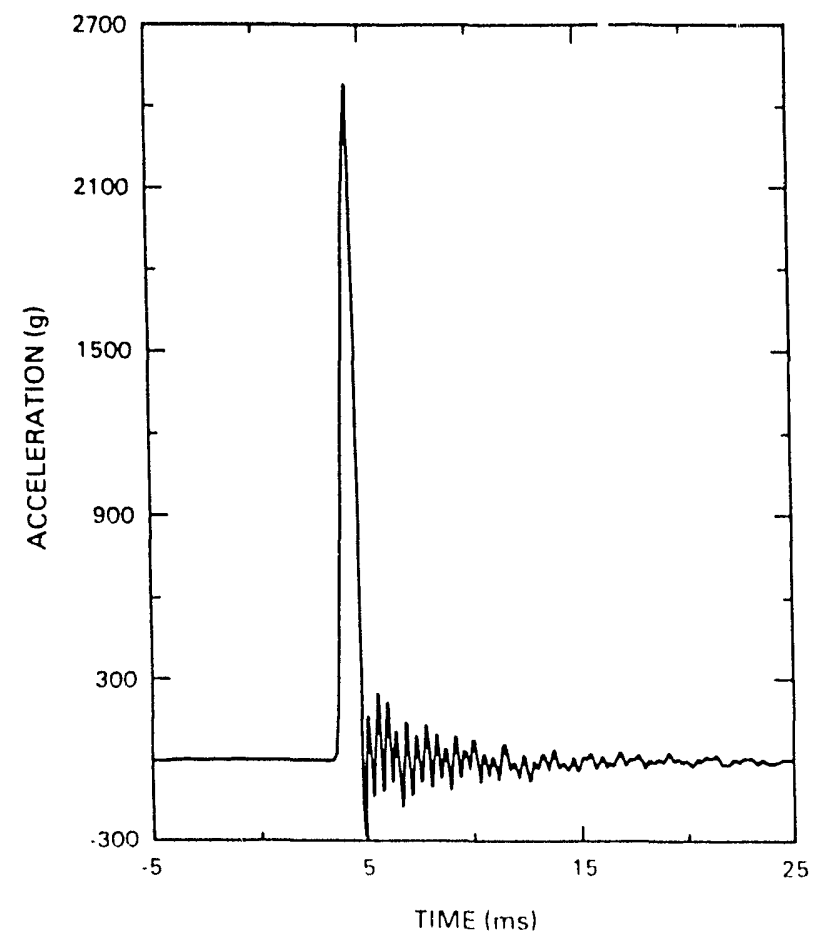

Figure 3-17. Typical Accelerometer Filtered at 1,000 Hz From End-Impact Tests 


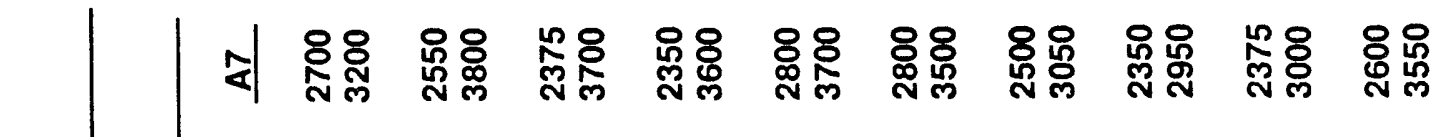

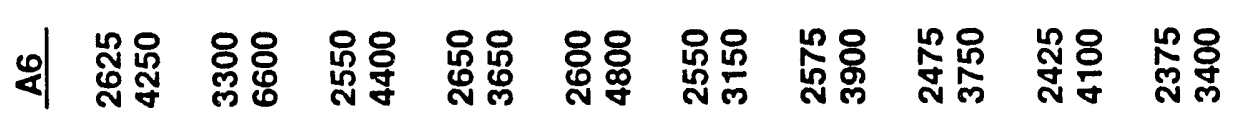

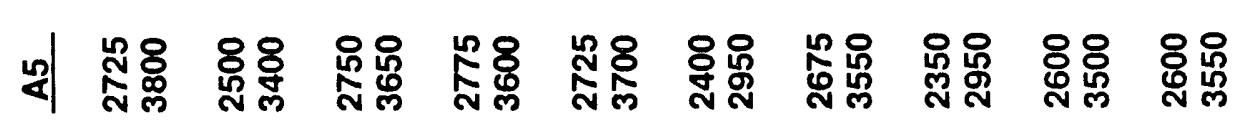

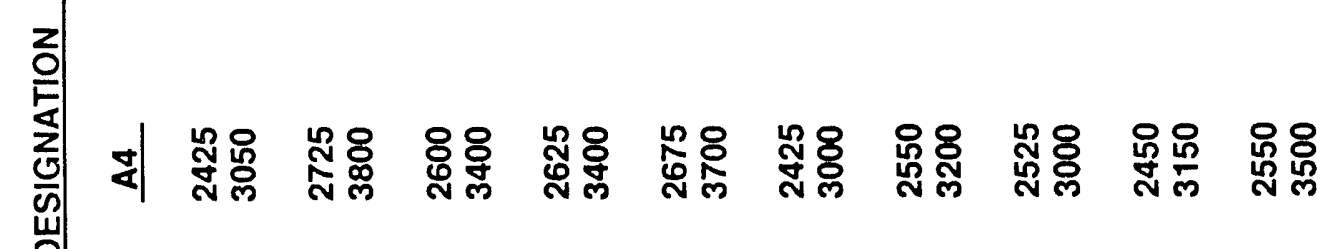

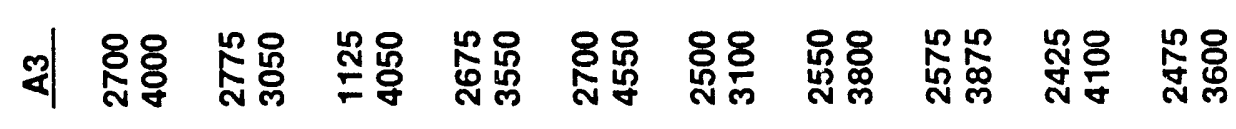

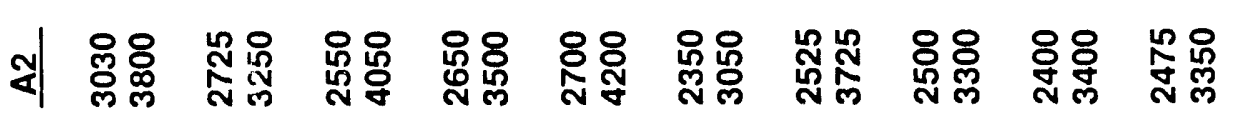

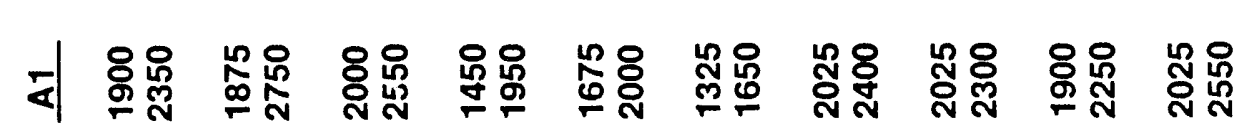

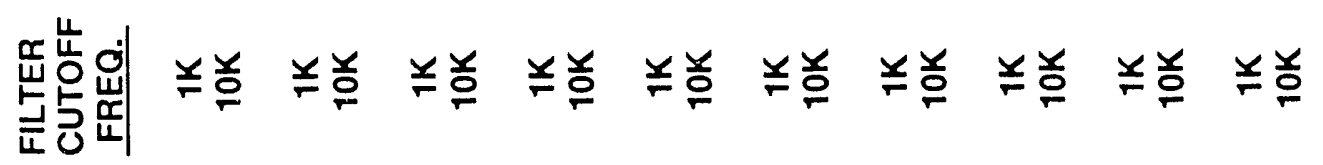

$$
\begin{aligned}
& \text { 武一 }
\end{aligned}
$$

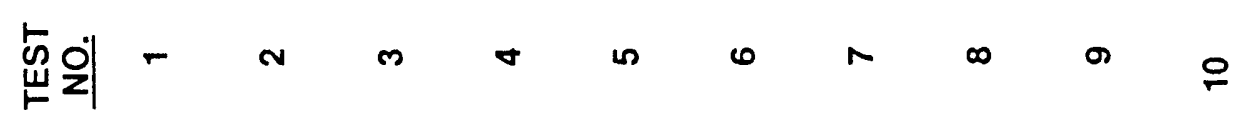




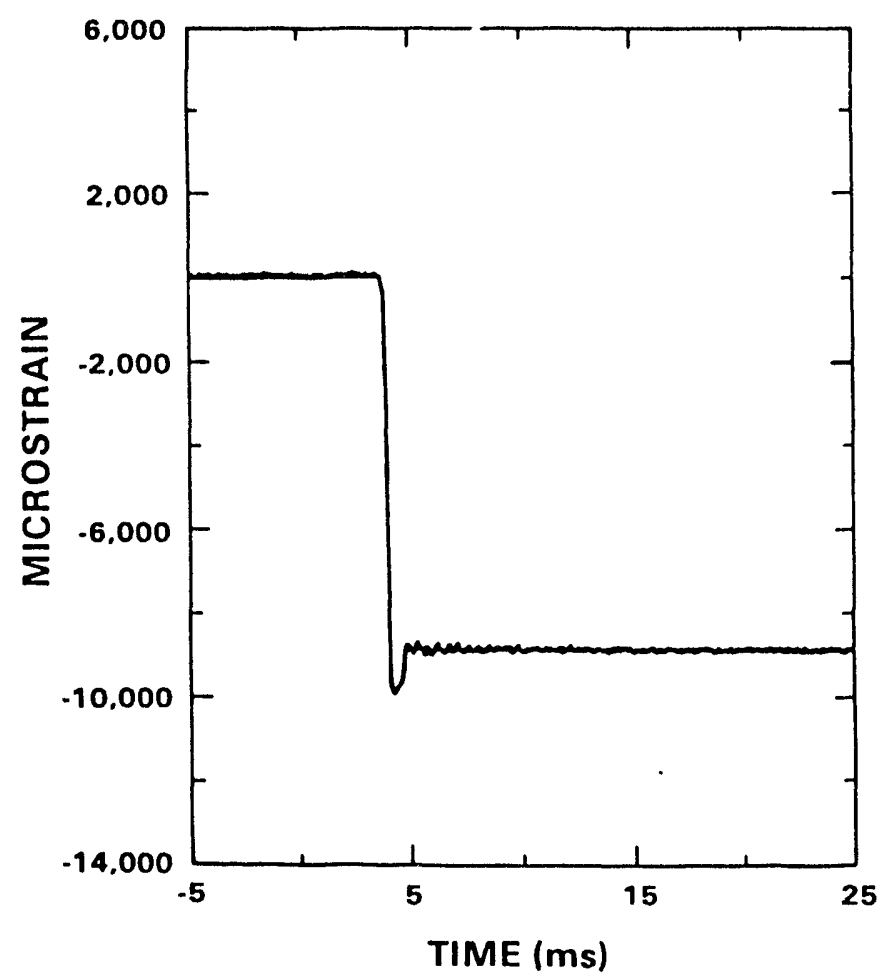

Figure 3-18. Typical Strain-Time History for an Axial Gage From EndImpact Tests. The axial gage was located 1 in. from the impact end.

effect of the off-angle impact was less pronounced for the gages higher on the specimen. This is predicted by the Saint-Venant principle that states, "For bodies extended in two or three dimensions, such as disks, spheres, or the semi-infinite solid, the stress or strain due to loading on a small part of the body may be expected to diminish with distance due to 'geometrical divergence', whether or not the resultant is zero" (Timoshenko, 1970).

This result can also be observed by comparing the magnitude of the permanent strains from the strain gages at different locations. A larger range was present in the strains at 1 in. from the impact end than at 6 in. from the end. Figure 3-20 shows a representative multiplot of the strain histories for axial gages located at 1 in. from the impact end. Figure 3-21 shows a similar plot for the gages at 6 in. from the end for Test 1 . Maximum strains were measured at locations nearest to the impact. Multiplots for all tests are included in Appendix D. 


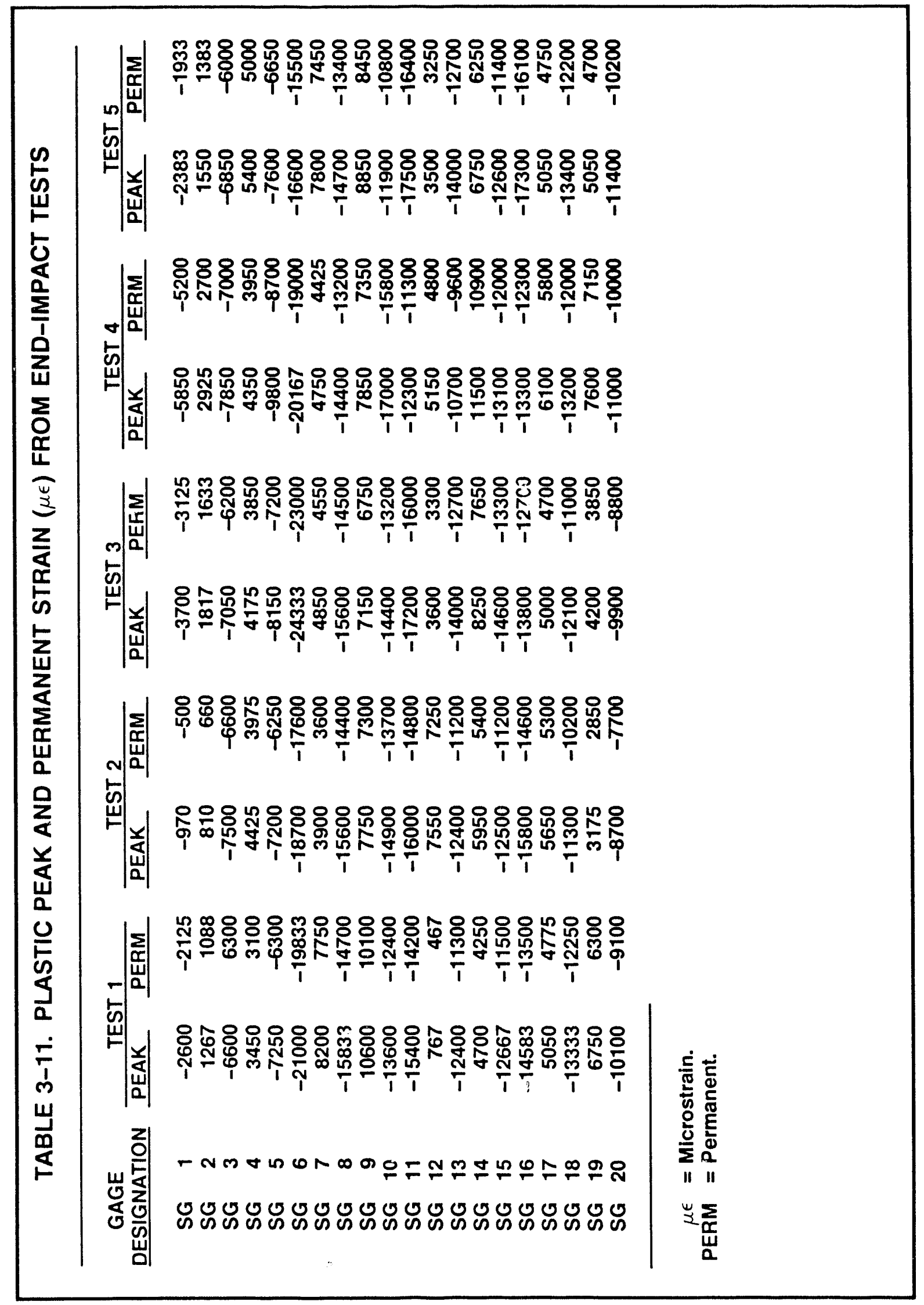




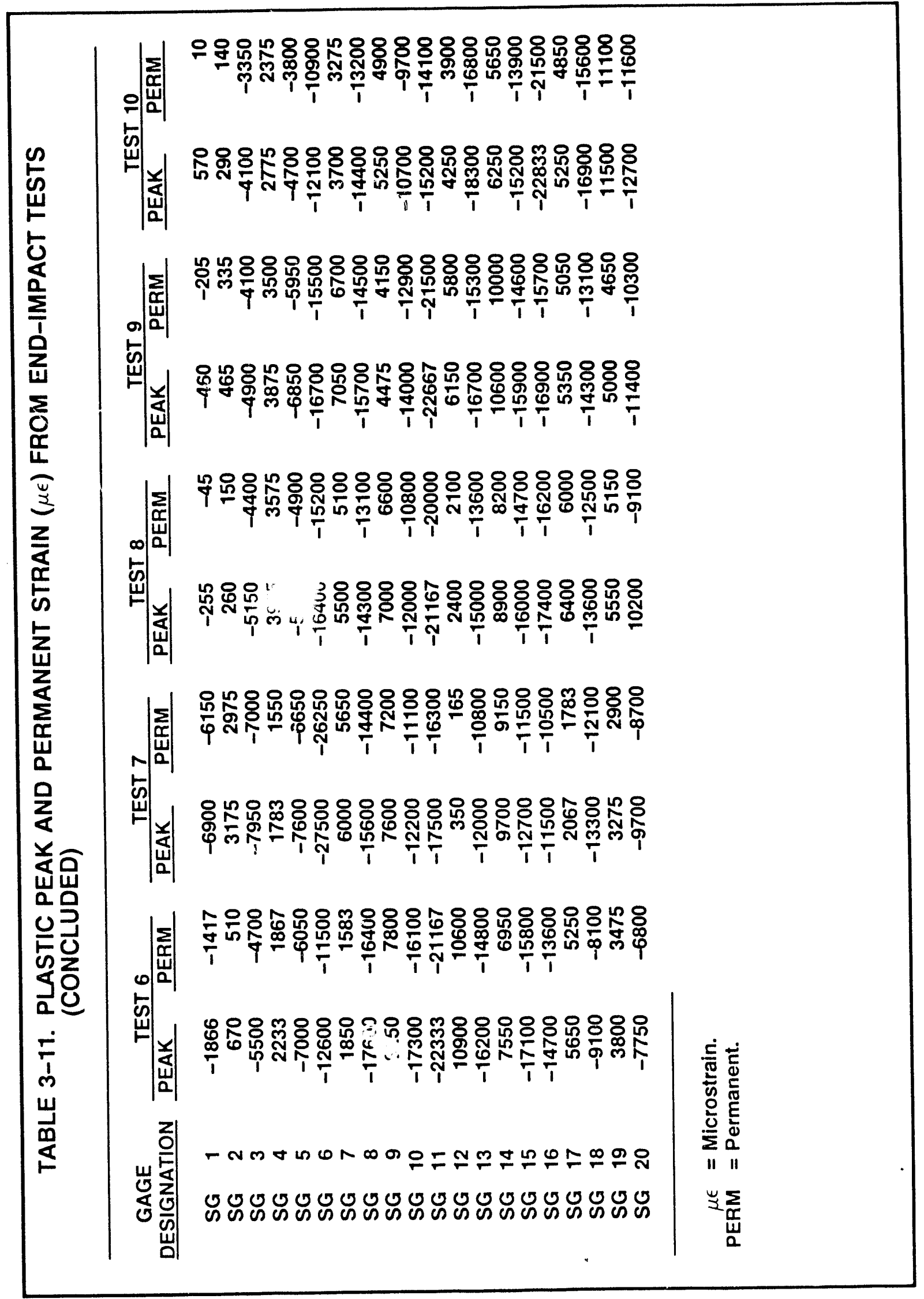




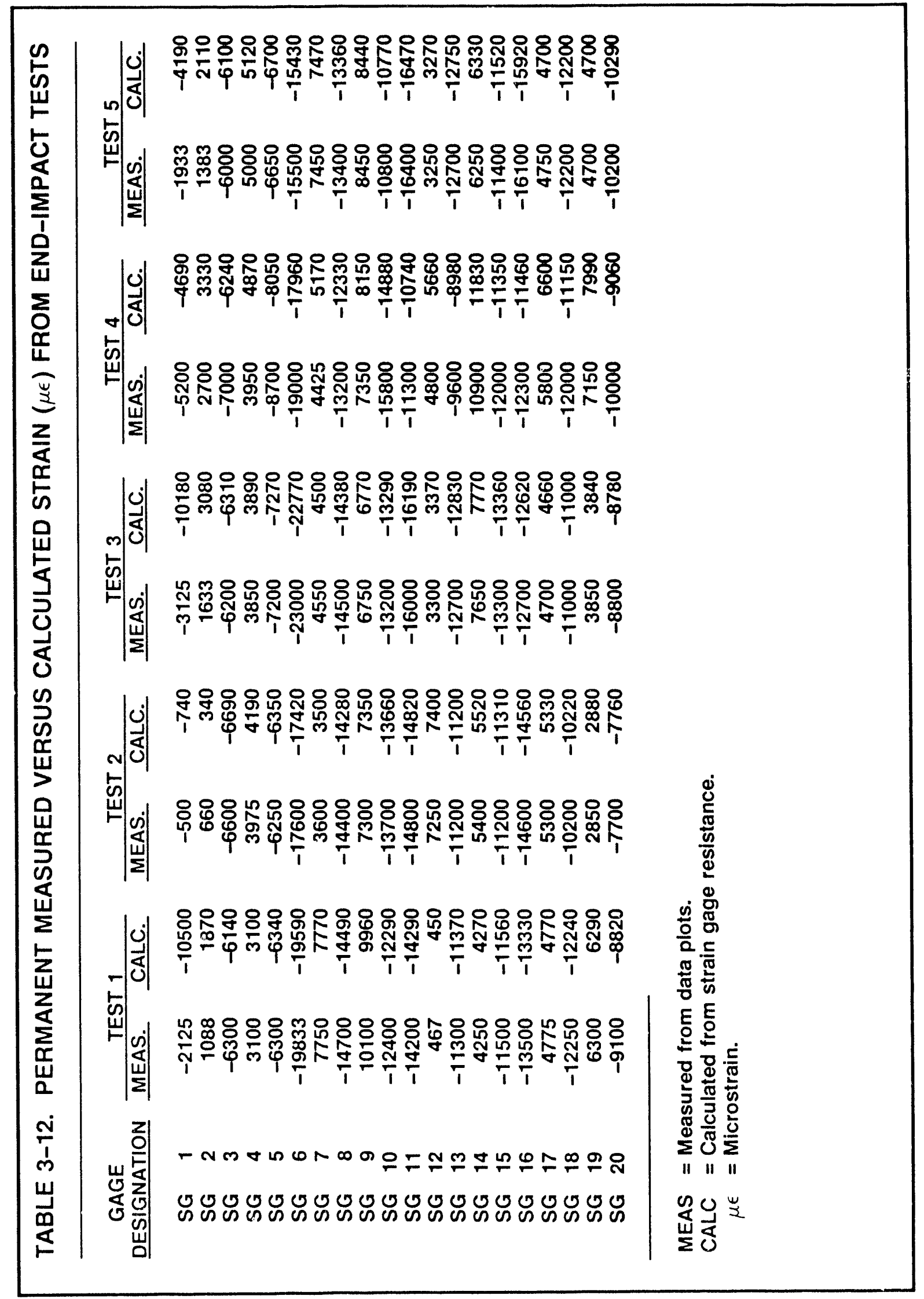




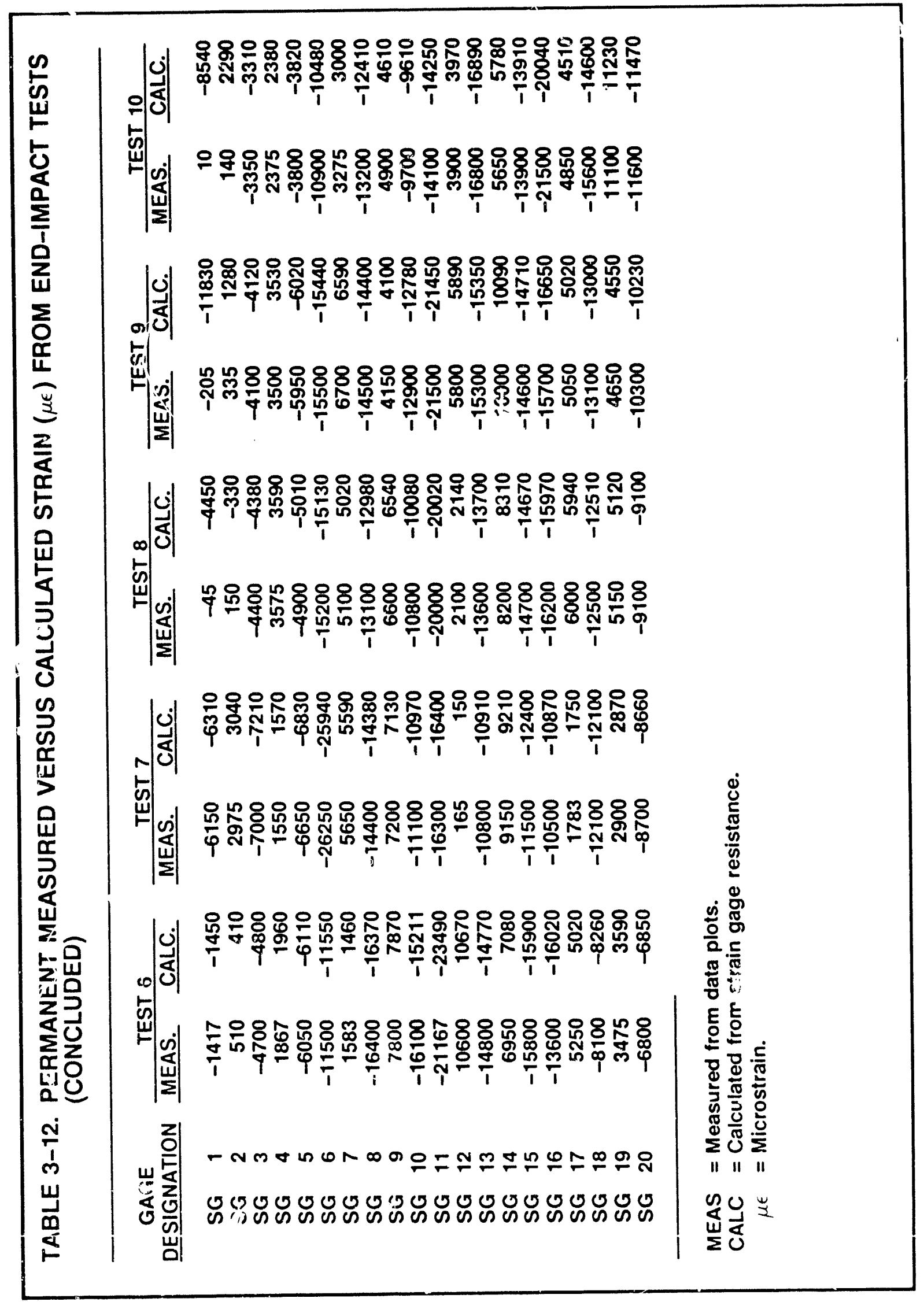



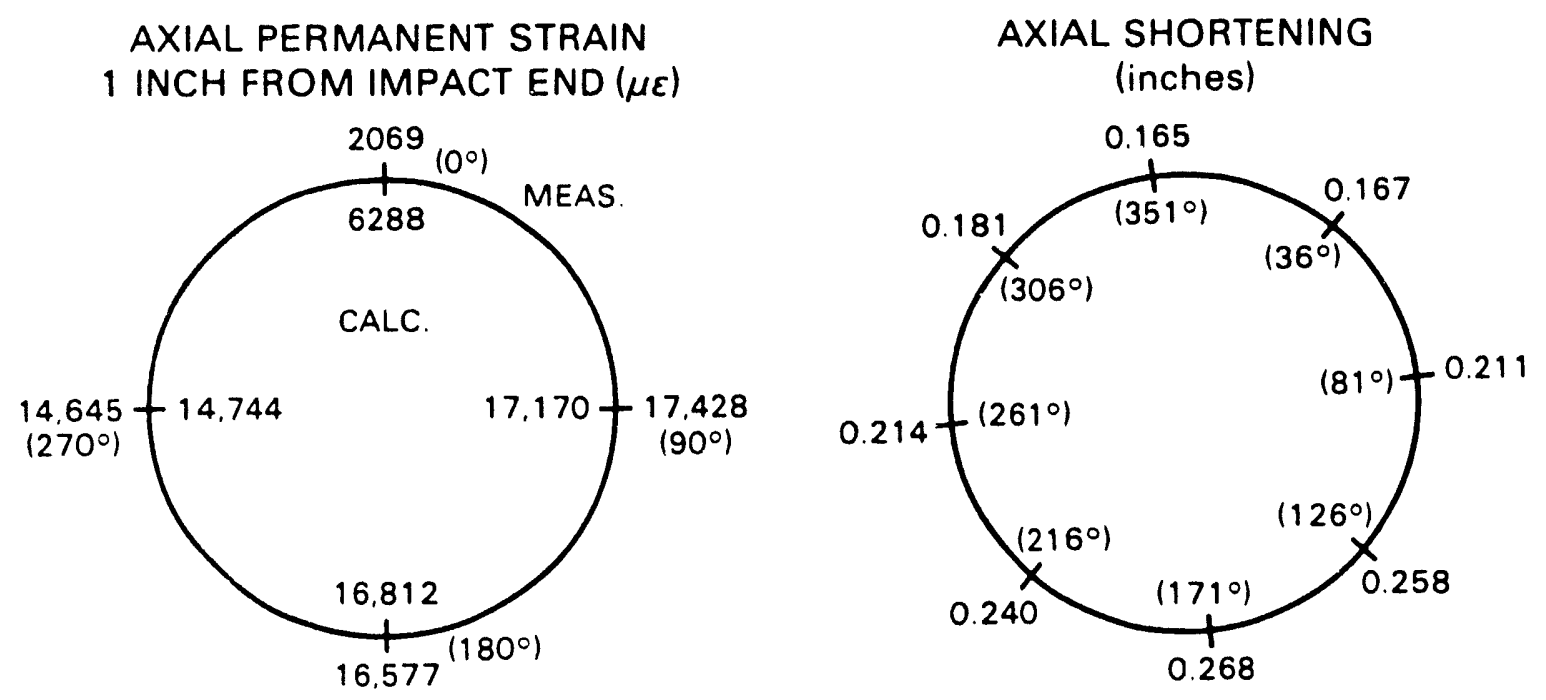

PEAK $10,000 \mathrm{~Hz}$ ACCELERATIONS (g)

PEAK $1000 \mathrm{~Hz}$ ACCELERATIONS (g)
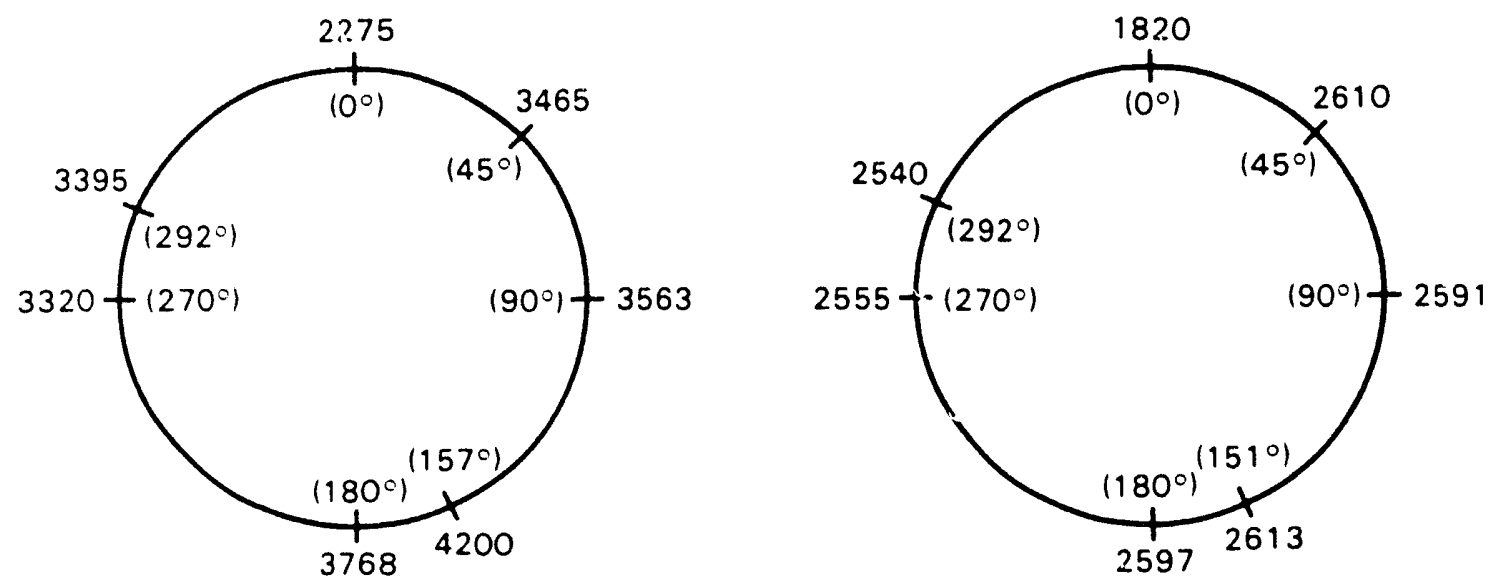

Fizure 3-19. End-Impact Test Distribution of Permanent Axial Deformations 


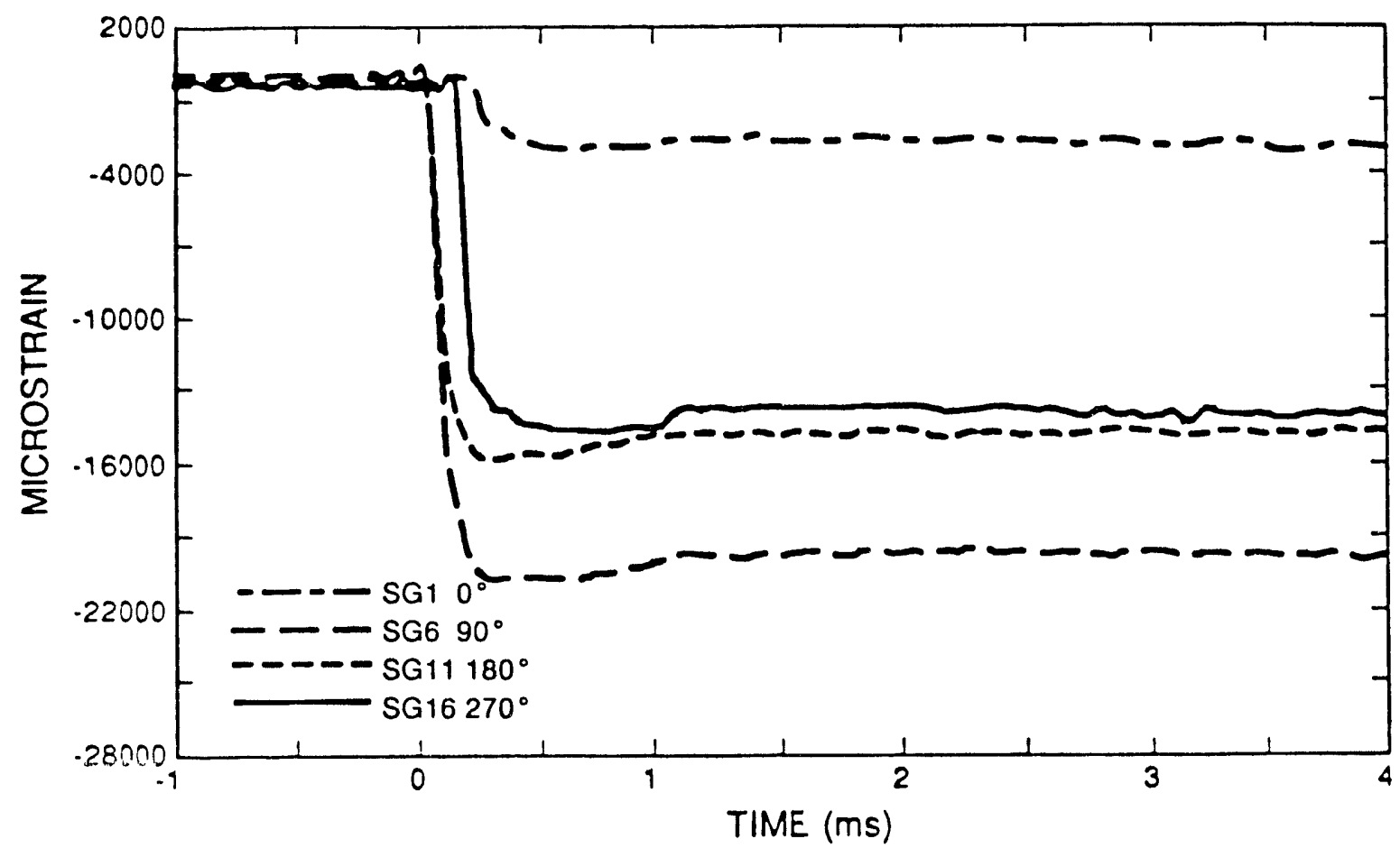

Figure 3-20. End-Impact Test Mutiplot $r_{L}^{\prime}$ Strain Histories for Axial Gages SG 1, SG 6, SG 11, and SG 16 Located at 1 in. From the Impact End

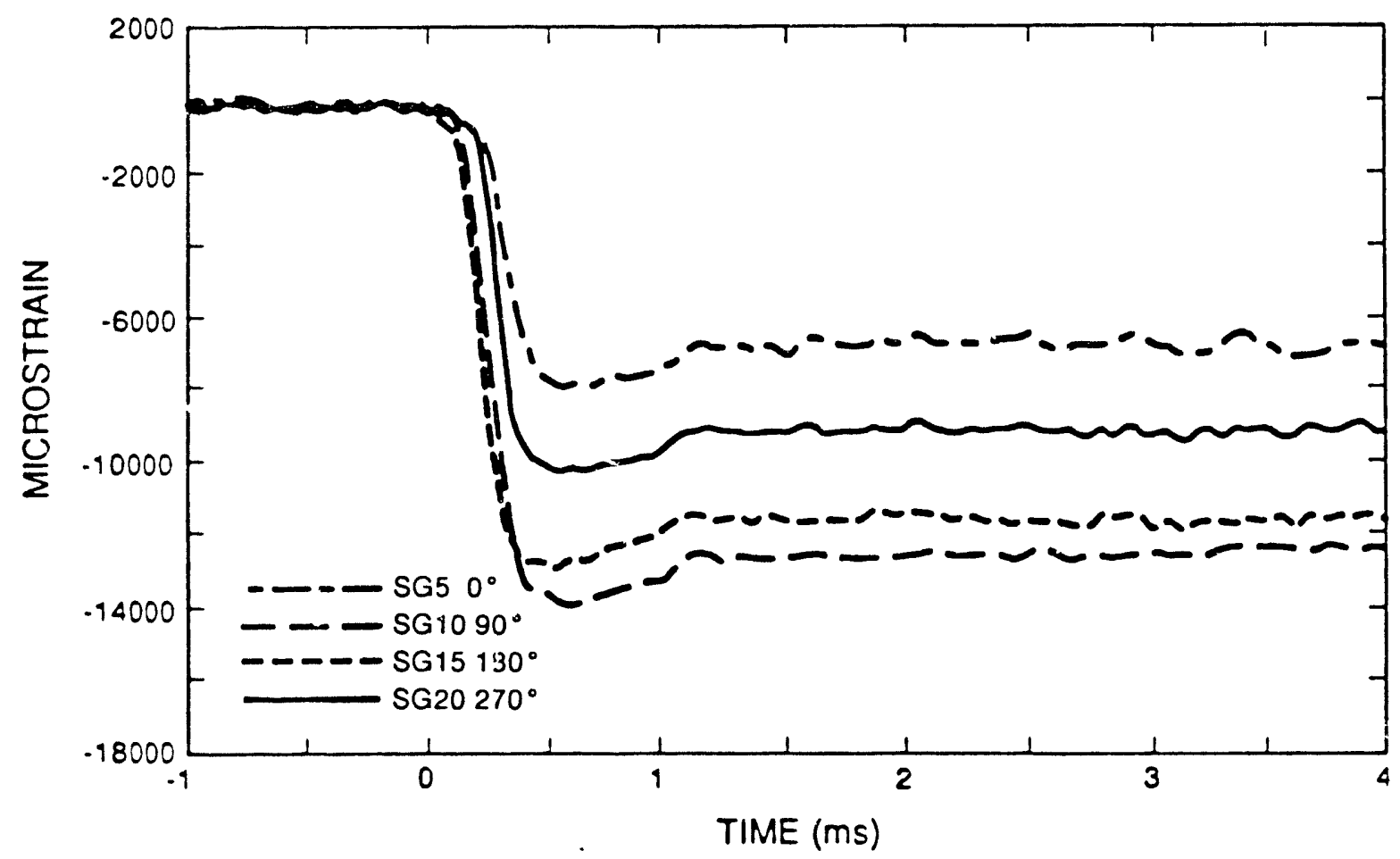

Figure 3-21. End-Impact Test Multiplot of Strain Histories for Axial Gages SG 5, SG 10, SG 15, and SG 20 Located at 6 in. From the Impact End 
Except for the slight change in magnitude from the off-axis impact, the output of the Endevco accelerometers for each test was very consistent. Figure 3-22 shows a multiplot of the $10,000-\mathrm{Hz}$ filtered time histories for these four accelerometers from Test 8 . All of the signals were in very close agreement. For all of the tests the magnitude of the signal for accelerometer $A 1$, which was not always the same transducer, was lower than expected. This result was likely due to a problem not associated with the accelerometer, such as cabling or data acquisition. Figure 3-23 shows a multiprot of the time histories for the $B \& K$ accelerometers for Test 8. Comparison of Figures 3-22 and 3-23 shows that the transducers had very similar output other than the sign difference caused by an invorsion of the signal for the piezoelectric accelerometers in the charge amplifiers. In general, both types of accelerometers gave good results during the initial impact pulse. However, the B\&Ks had more nonrepresentative large amplitude signals later in the time history, such as the pulse shown for accelerometer $A 6$ at approximately $2 \mathrm{~ms}$ in Figure 3-23. Multiplots of the accelerometer outputs filtered at $10,000 \mathrm{~Hz}$ for all the tests are included in Appendix E.

An important purpose of the drop test was to determine the ruggedness of the accelerometers. During the drop test sequence, only three accelerometers failed: A7 from Set 1 failed shock calibration following Test 7, A2 from Set 2 failed frequency calibration at $-20^{\circ} \mathrm{F}$ following Test 10, and A3 from Set 3 failed centrifuge calibration following Test 3. Also, A2 from Set 2 failed frequency calibration at $-20^{\circ} \mathrm{F}$ following the shock impulse tests. This was a different accelerometer than the one that failed after Test 10. The loading history for a typical piezoresistive accelerometer that survived to the end of the test series was the following:

- manufacturer shock calibration at $1,000,5,000$, and $10,000 \mathrm{~g}$;

- manufacturer frequency calibration;

- SNL calibration, consisting of centrifuge calibration, shock calibration using five shock pulses, frequency calibration at ambient temperature, and frequency calibration at $-20^{\circ} \mathrm{F}$;

- three 1,000-g shock impulse tests;

- three 5,000-g shock impulse tests;

- three 10,000-g shock impulse tests; and

- three sequences of a drop test and SNL calibration without the $-20^{\circ} \mathrm{F}$ frequency calibration.

The total history of a typical peizoresistive accelerometer that survived to the end of the tast series was 40 shocks above $1000 \mathrm{~g}$, eight frequency calibrations, and five centrifuge calibrations. The loading history for the piezoelectric accelerometers was similar, except that line centrifuge calibiations were not performed. 


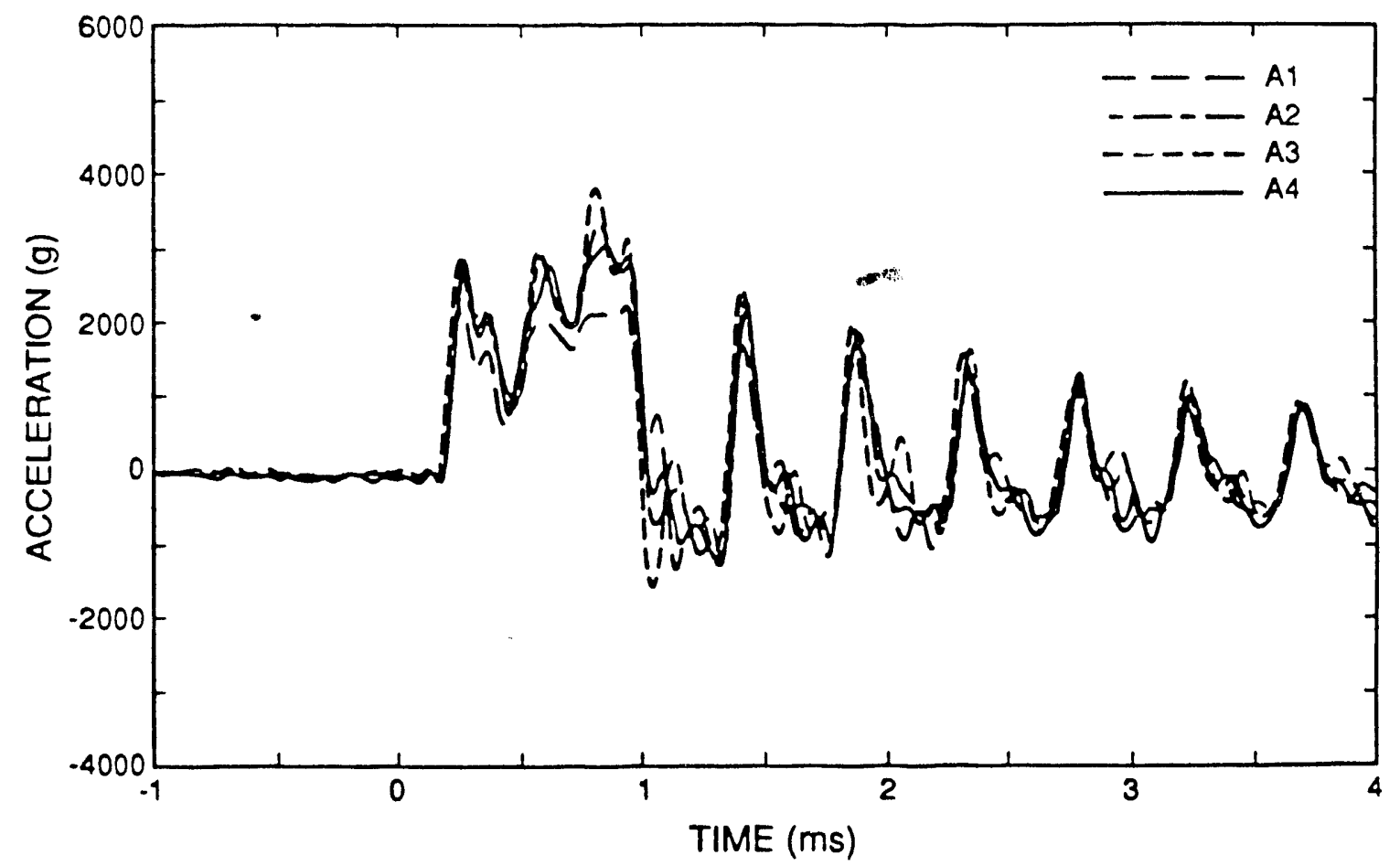

Figure 3-22. End-Impact Test Multiplot of 10,000-Hz Filtered Time Histories for Accelerometers A1, A2, A3, and A4

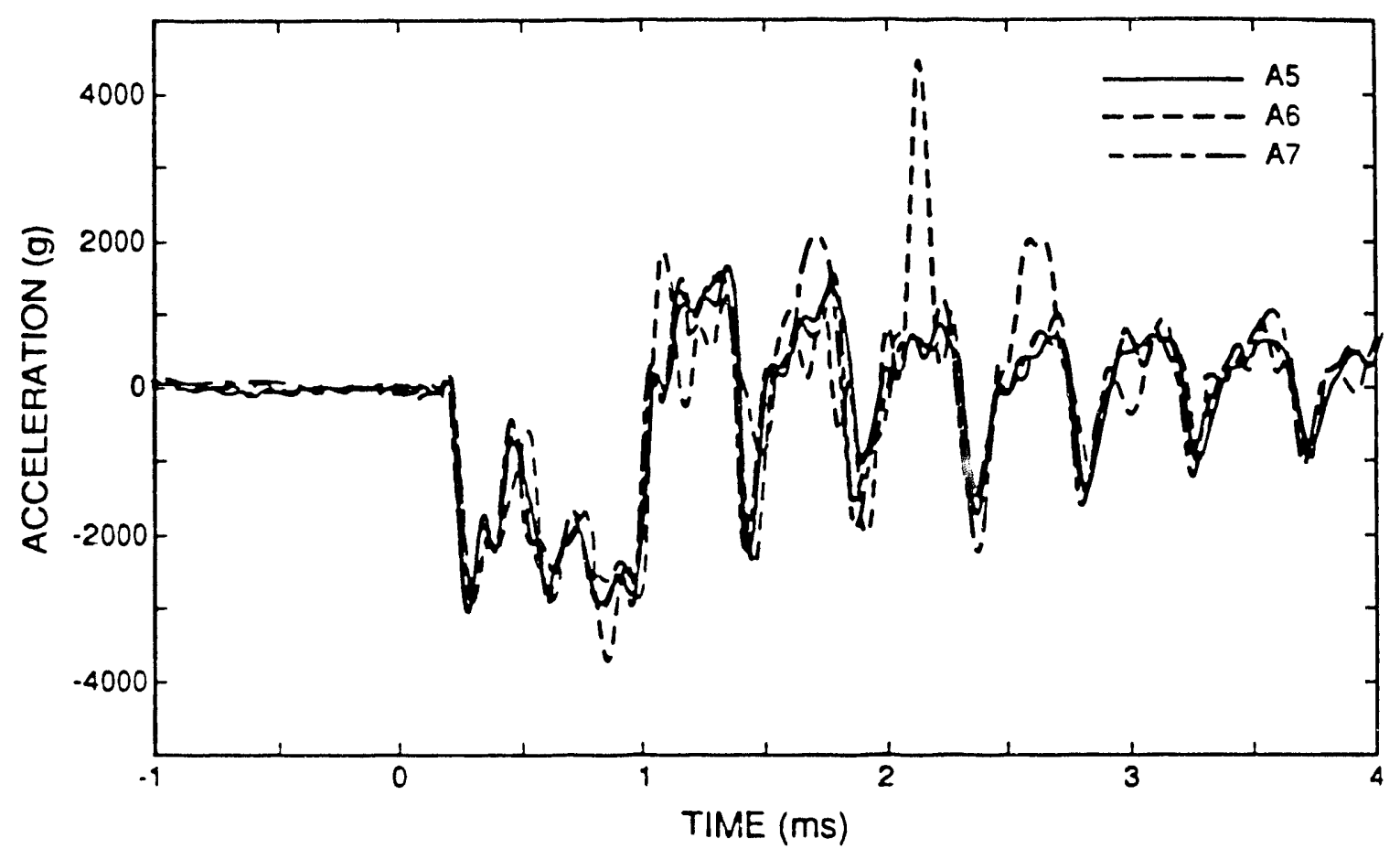

Figure 3-23. End-Impact Test Multiplot of 10,000-Hz Filtered Time Histories for $B \& K$ Accelerometers $A 5, A 6$, and $A 7$ 


\subsection{CONCLUSIONS}

The results if this test program showed no major difference in the measurements obtained by transducers manufactured by different companies. One ininor difference was the slower pulse decay for the $B \& K$ 8309 accelerometers, which did not significantly affect the initial filtered or unfiltered peak accelerations in the end-impact tests. The area where this difference was most pronounced was in integrating the accelerations to obtain change in velocity. In general, the method of integrating accelerations to obtain change in velocity is frequently performed to validate accelerometer data. The slower pulse decay can also affect tests where multiple shocks are separated by only a few milliseconds, such as in slapdown cask tests or during secondary impact of the cask. Another minor difference in transducers was that the lead wires for the $B \& K$ accelerometers required more care in handling than those of the Endevco accelerometers.

The strain gage data indicates that the BLH strain gages measured higher average strain, which was closer to the value determined from dimensional inspection. Also, the BLH strain gages measured larger deviation between readings than the Micro-Measurement gages. It is uncertain if the difference was due to differences in the gages or the result of the testing. The BLH gages had a higher instance of required reapplication than the Micro-Measurement gages when following the instructions provided by the manufacturer.

The purpose of this project was to compare the results from different types of transducers. For the comparison to be significant, a large number of tests with several transducers were conducted. This allowed for the examination of scatter in test data, which is seldom available in test programs. Several conclusions may be drawn from the data. The most important of these is that a high confidence should not be placed in a single transducer to give reliable results. This emphasizes the importance of having redundant instrumentation in test programs. In addition, problems with the instrumentation or connections to or within the data acquisition system can make the results questionable. Errors within the data acquisition system can be reduced or identified if the system has methods capable of isolating problems, such as diagnostics. Another important conclusion drawn from these studies is that the choice of a transducer must be appropriate for the application, e.g., acceleration range or strain range.

The standard deviation of the peak accelerations for the normalized shock impulse tests was 3.48 of the average value. For the static crush plastic tests, the standard deviation of the axial strains was approximately $8 \%$ of the average value. For the end-impact tests, the $1,000-\mathrm{Hz}$ filtered peak accelerations had a standard deviation of 158 of their average value, and the $10,000-\mathrm{Hz}$ filtered peak acceleration data had a standard deviation of 218 of the average. Table 4-1 summarizes these results. The results showed that test data were not, in general, more accurate than \pm 10 of the measured result. It is very likely that the majority of these deviations are due to changes in the quantities 
being measured, rather than transducer response. This is because the transducers only measure the response at the location where they are attached, which may not be the same as the response at a nearby location.

\section{TABLE 4-1. STANDARD DEVIATIONS FOR THE NORMALIZED SHOCK IMPULSE TESTS, STATIC CRUSH PLASTIC TESTS, AND END-IMPACT TESTS}

\begin{tabular}{|c|c|c|c|c|}
\hline Test Sequence & Measure & Mean & $\sigma$ & $\%$ \\
\hline Shock Impulse & $\begin{array}{l}\text { Normalized MFA } \\
\text { Acceleration }\end{array}$ & 1.01 & 0.034 & 3.40 \\
\hline Static Crush & $\begin{array}{l}\text { Permanent Axial } \\
\text { Deformation }\end{array}$ & $17,354 \mu \varepsilon$ & $1,379 \mu \varepsilon$ & 7.95 \\
\hline End Impact & $\begin{array}{l}\text { Peak 1,000 Hz } \\
\text { Filtered } \\
\text { Acceleration }\end{array}$ & $2,454 \mathrm{~g}$ & $360 \mathrm{~g}$ & 14.7 \\
\hline End Impact & $\begin{array}{l}\text { Peak } 10,000 \mathrm{~Hz} \\
\text { Filtered } \\
\text { Acceleration }\end{array}$ & $3,426 \mathrm{~g}$ & $716 \mathrm{~g}$ & 20.9 \\
\hline
\end{tabular}




\subsection{REFERENCES}

Dally, J. W., and W. F. Riley, Experimental Stress Analysis, 2d. ed., New York: McGraw-Hill, 1978.

Dieter, G. E., Mechanical Metallurgy, 2d. ed., New York: McGraw-Hill, 1976, pp. 208-210.

Glass, R. E., "Structural Code Benchmarking Data Report," SAND88-3362, Sandia National Laboratories, Albuquerque, NM, 1989.

NRC (U.S. Nuclear Regulatory Commission), "Packaging and Transportation of Radioactive Material," in the U.S. Code of Federal Regulations, Title 10, Part 71, 1989.

Stearns, S. D., and R. A. David, Signal Processing Algorithms, New Jersey: Prentice-Hall, 1988 .

Timoshenko, S. P., and J. N. Goodier, Theory of Elasticity, 3d ed., New York: McGraw-Hill, 1970.

U.S. Congress, Nuclear Waste Policy Act of 1982, Public Law 97-425, 1982 .

U.S. Congress, Nuclear Waste Policy Amendments Act of 1987, Public Law $100-203,1987$.

Uncapher, W. L., "Packaging Test Capabilities of the SNL Aerial Cable Facility," in Proceedings of the Seventh International Symposium on Packaging and Transportation of Radioactive Materials, May 15-20, New Orleans, LA, 1983.

Walter, P. L., "Limitations and Corrections in Measuring Dynamic Characteristics of Structural Systems," SAND78-1015, Sandia National Laboratories, Albuquerque, NM, 1978.

Window, A. L., and G. S. Holister, Strain Gauge Technology, United Kingdom: Applied Science Publishers, Ltd., 1983. 
APPENDIX A

TRANSDUCER SURVEY

A - 1 
SURVEY PARTICIPANTS

GENERAL ATOMICS

NUCLEAR ASSURANCE CORPORATION

WESTINGHOUSE

BABCOCK AND WILCOX

NUCLEAR PACKAGING

WYLIE LABORATORIES

FRANKLIN RESEARCH CENTER

OAK RIDGE NATIONAL LABORATORIES

SANDIA NATIONAL LABORATORIES 
In order to conduct a comprehensive evaluation, several private industry test companies and national laboratories have been surveyed to provide transducer recommendations. The chart at the bottom of this page lists transducers currently included in the evaluation. Would you please circle the $Y$ at the right of any transducer you plan to use. If you plan to use transducers not included on the list, please supply manufacturer and model numbers on the blank lines. Thank you.

Transducer Type

Strain Gage

Strain Gage

Accelerometer

Accelerometer
Manufacturer

BLH Electronics

Measurements Group, Micro Measurements Div.

Bruel \& Kjaer

Evdavco

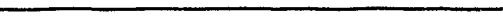

Mode1

FAE/FAET $350 \mathrm{Ohm}$

CEA UW/UT 350 Ohm

$\underline{\text { Yes }}$

$\mathrm{Y}$

Y

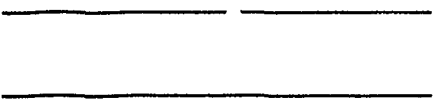

8309 series

7270A series 
APPENDIX B

STATIC TEST DIMENSIONAL INSPECTION DATA

B - 1 


\begin{tabular}{|c|c|c|c|}
\hline \multicolumn{4}{|c|}{$\begin{array}{c}\text { CYLINDER } \\
\text { DIMENSIONAL INSPECTION DATA }\end{array}$} \\
\hline \multicolumn{4}{|c|}{ STATIC CRUSH, TEST 1} \\
\hline $\begin{array}{l}\text { MEASUREMENT } \\
\text { DESIGNATION }\end{array}$ & PRE-TEST & POST-TEST & $\begin{array}{c}\text { MEASUREMENT } \\
\text { CHANGE } \\
\end{array}$ \\
\hline $\begin{array}{l}\text { L1-36 } \\
\text { L1-81 } \\
\text { L1-126 } \\
\text { L1-171 } \\
\text { L1-216 } \\
\text { L1-261 } \\
\text { L1-306 } \\
\text { L1-351 } \\
\text { L2-36 } \\
\text { L2-81 } \\
\text { L2-126 } \\
\text { L2-171 } \\
\text { L2-216 } \\
\text { L2-261 } \\
\text { L2-306 } \\
\text { L2-351 } \\
\text { L3-36 } \\
\text { L3-81 } \\
\text { L3-126 } \\
\text { L3-171 } \\
\text { L3-216 } \\
\text { L3 }-261 \\
\text { L3-306 } \\
\text { L3-351 } \\
\text { L4-36 } \\
\text { L4-81 } \\
\text { L4-126 } \\
\text { L4-171 } \\
\text { L4-216 } \\
\text { L4-261 } \\
\text { L4-306 } \\
\text { L4-351 } \\
\text { L5-36 } \\
\text { L5-81 } \\
\text { L5-126 } \\
\text { L5-171 } \\
\text { L5-216 } \\
\text { L5-261 } \\
\text { L5-306 } \\
\text { L5-351 } \\
\text { L6-36 } \\
\text { L6-81 } \\
\text { L6-126 } \\
\text { L6-171 }\end{array}$ & $\begin{array}{l}2.709 \\
2.710 \\
2.710 \\
2.711 \\
2.711 \\
2.711 \\
2.710 \\
2.710 \\
2.709 \\
2.710 \\
2.710 \\
2.711 \\
2.711 \\
2.710 \\
2.710 \\
2.710 \\
2.709 \\
2.710 \\
2.710 \\
2.711 \\
2.711 \\
2.710 \\
2.710 \\
2.710 \\
2.710 \\
2.710 \\
2.710 \\
2.711 \\
2.710 \\
2.709 \\
2.710 \\
2.710 \\
2.710 \\
2.710 \\
2.710 \\
2.711 \\
2.710 \\
2.710 \\
2.710 \\
2.710 \\
2.710 \\
2.710 \\
2.710 \\
2.710\end{array}$ & $\begin{array}{l}2.729 \\
2.727 \\
2.724 \\
2.726 \\
2.730 \\
2.731 \\
2.727 \\
2.727 \\
2.734 \\
2.733 \\
2.731 \\
2.734 \\
2.736 \\
2.738 \\
2.736 \\
2.735 \\
2.733 \\
2.732 \\
2.731 \\
2.733 \\
2.736 \\
2.738 \\
2.736 \\
2.735 \\
2.732 \\
2.731 \\
2.731 \\
2.733 \\
2.735 \\
2.736 \\
2.736 \\
2.735 \\
2.732 \\
2.730 \\
2.731 \\
2.733 \\
2.735 \\
2.736 \\
2.735 \\
2.734 \\
2.733 \\
2.730 \\
2.731 \\
2.733\end{array}$ & $\begin{array}{l}0.020 \\
0.017 \\
0.014 \\
0.015 \\
0.019 \\
0.020 \\
0.017 \\
0.017 \\
0.025 \\
0.023 \\
0.021 \\
0.023 \\
0.025 \\
0.028 \\
0.026 \\
0.025 \\
0.024 \\
0.022 \\
0.021 \\
0.022 \\
0.025 \\
0.028 \\
0.026 \\
0.025 \\
0.022 \\
0.021 \\
0.021 \\
0.022 \\
0.025 \\
0.027 \\
0.026 \\
0.025 \\
0.022 \\
0.020 \\
0.021 \\
0.022 \\
0.025 \\
0.026 \\
0.025 \\
0.024 \\
0.023 \\
0.020 \\
0.021 \\
0.023\end{array}$ \\
\hline
\end{tabular}




\begin{tabular}{|c|c|c|c|}
\hline \multicolumn{4}{|c|}{$\begin{array}{c}\text { CYLINDER } \\
\text { DIMENSIONAL INSPECTION DATA }\end{array}$} \\
\hline \multicolumn{4}{|c|}{ STATIC CRUSH, TEST 1} \\
\hline $\begin{array}{l}\text { MEASUREMENT } \\
\text { DESIGNATION } \\
\end{array}$ & PRE-TEST & POST-TEST & $\begin{array}{c}\text { MEASUREMENT } \\
\text { CHANGE } \\
\end{array}$ \\
\hline $\begin{array}{l}\text { L6-216 } \\
\text { L6-261 } \\
\text { L6-306 } \\
\text { L6-351 } \\
\text { L7-36 } \\
\text { L7-81 } \\
\text { L7-126 } \\
\text { L7-171 } \\
\text { L7-216 } \\
\text { L7-261 } \\
\text { L7-305 } \\
\text { L7-351 } \\
\text { L8-36 } \\
\text { L8-81 } \\
\text { L8-126 } \\
\text { L8-171 } \\
\text { L8-216 } \\
\text { L8-261 } \\
\text { L8-306 } \\
\text { L8-351 } \\
\text { L9-36 } \\
\text { L9-81 } \\
\text { L9-126 } \\
\text { L9-171 } \\
\text { L9-216 } \\
\text { L9-261 } \\
\text { L9-306 } \\
\text { L9-351 } \\
\text { L10-36 } \\
\text { L10-81 } \\
\text { L10-126 } \\
\text { L10-171 } \\
\text { L10-216 } \\
\text { L10-261 } \\
\text { L10-306 } \\
\text { L10-351 } \\
\text { L11-36 } \\
\text { L11-81 } \\
\text { L11-126 } \\
\text { L11-171 } \\
\text { L11-216 } \\
\text { L11-261 } \\
\text { L11-306 } \\
\text { L11-351 }\end{array}$ & $\begin{array}{l}2.710 \\
2.710 \\
2.710 \\
2.710 \\
2.710 \\
2.710 \\
2.710 \\
2.711 \\
2.710 \\
2.710 \\
2.710 \\
2.710 \\
2.710 \\
2.710 \\
2.710 \\
2.711 \\
2.710 \\
2.710 \\
2.710 \\
2.710 \\
2.710 \\
2.710 \\
2.710 \\
2.711 \\
2.710 \\
2.709 \\
2.710 \\
2.710 \\
2.710 \\
2.710 \\
2.710 \\
2.710 \\
2.710 \\
2.710 \\
2.710 \\
2.710 \\
2.710 \\
2.710 \\
2.710 \\
2.711 \\
2.709 \\
2.709 \\
2.710 \\
2.710\end{array}$ & $\begin{array}{l}2.735 \\
2.735 \\
2.735 \\
2.733 \\
2.732 \\
2.729 \\
2.732 \\
2.734 \\
2.735 \\
2.735 \\
2.734 \\
2.733 \\
2.732 \\
2.731 \\
2.732 \\
2.734 \\
2.735 \\
2.735 \\
2.735 \\
2.733 \\
2.733 \\
2.731 \\
2.732 \\
2.734 \\
2.735 \\
2.735 \\
2.735 \\
2.733 \\
2.733 \\
2.733 \\
2.733 \\
2.734 \\
2.734 \\
2.734 \\
2.735 \\
2.733 \\
2.734 \\
2.734 \\
2.733 \\
2.734 \\
2.733 \\
2.735 \\
2.735 \\
2.734\end{array}$ & $\begin{array}{l}0.025 \\
0.025 \\
0.025 \\
0.023 \\
0.022 \\
0.019 \\
0.022 \\
0.023 \\
0.025 \\
0.025 \\
0.024 \\
0.023 \\
0.022 \\
0.021 \\
0.022 \\
0.023 \\
0.025 \\
0.025 \\
0.025 \\
0.023 \\
0.023 \\
0.021 \\
0.022 \\
0.023 \\
0.025 \\
0.026 \\
0.025 \\
0.023 \\
0.023 \\
0.023 \\
0.023 \\
0.024 \\
0.024 \\
0.024 \\
0.025 \\
0.023 \\
0.024 \\
0.024 \\
0.023 \\
0.023 \\
0.024 \\
0.026 \\
0.025 \\
0.024\end{array}$ \\
\hline
\end{tabular}




\section{CYLINDER \\ DIMENSIONAL INSPECTION DATA}

\section{STATIC CRUSH, TEST 1}

MEASUREMENT DESIGNATION

\begin{tabular}{c} 
PRE-TEST \\
\hline 2.710 \\
2.710 \\
2.710 \\
2.710 \\
2.709 \\
2.709 \\
2.710 \\
2.710 \\
2.710 \\
2.710 \\
2.710 \\
2.710 \\
2.709 \\
2.709 \\
2.709 \\
2.710 \\
24.010 \\
24.010 \\
24.012 \\
24.014 \\
24.015 \\
24.015 \\
24.013 \\
24.013
\end{tabular}

\begin{tabular}{c} 
POST-TEST \\
\hline 2.732 \\
2.733 \\
2.732 \\
2.733 \\
2.731 \\
2.735 \\
2.735 \\
2.734 \\
2.724 \\
2.723 \\
2.723 \\
2.726 \\
2.723 \\
2.725 \\
2.728 \\
2.726 \\
23.569 \\
23.567 \\
23.567 \\
23.567 \\
23.568 \\
23.569 \\
23.570 \\
23.570
\end{tabular}

MEASUREMENT CHANGE

L12-36
L12-81
L12-126
L12-171
L12-216
L12-261
L12-306
L12-35
L13-36
L13-81
L13-126
L13-171
L13-216
L13-261
L13-306
L13-351
L14-36
L14-81
L14-126
L14-171
L14-216
L14-261
L14-306
L14-351

L12-36

L12-126

L12-171

L12-261

L12-351

L13-36

13-12

13-171

$13-261$

L13-306

L14-36

L14-81

L14-171

L14-261

L14-351

\begin{tabular}{c} 
CHANGE \\
\hline 0.022 \\
0.023 \\
0.022 \\
0.023 \\
0.022 \\
0.026 \\
0.025 \\
0.024 \\
0.014 \\
0.013 \\
0.013 \\
0.016 \\
0.014 \\
0.016 \\
0.019 \\
0.016 \\
-0.441 \\
-0.443 \\
-0.445 \\
-0.447 \\
-0.447 \\
-0.446 \\
-0.443 \\
-0.443
\end{tabular}




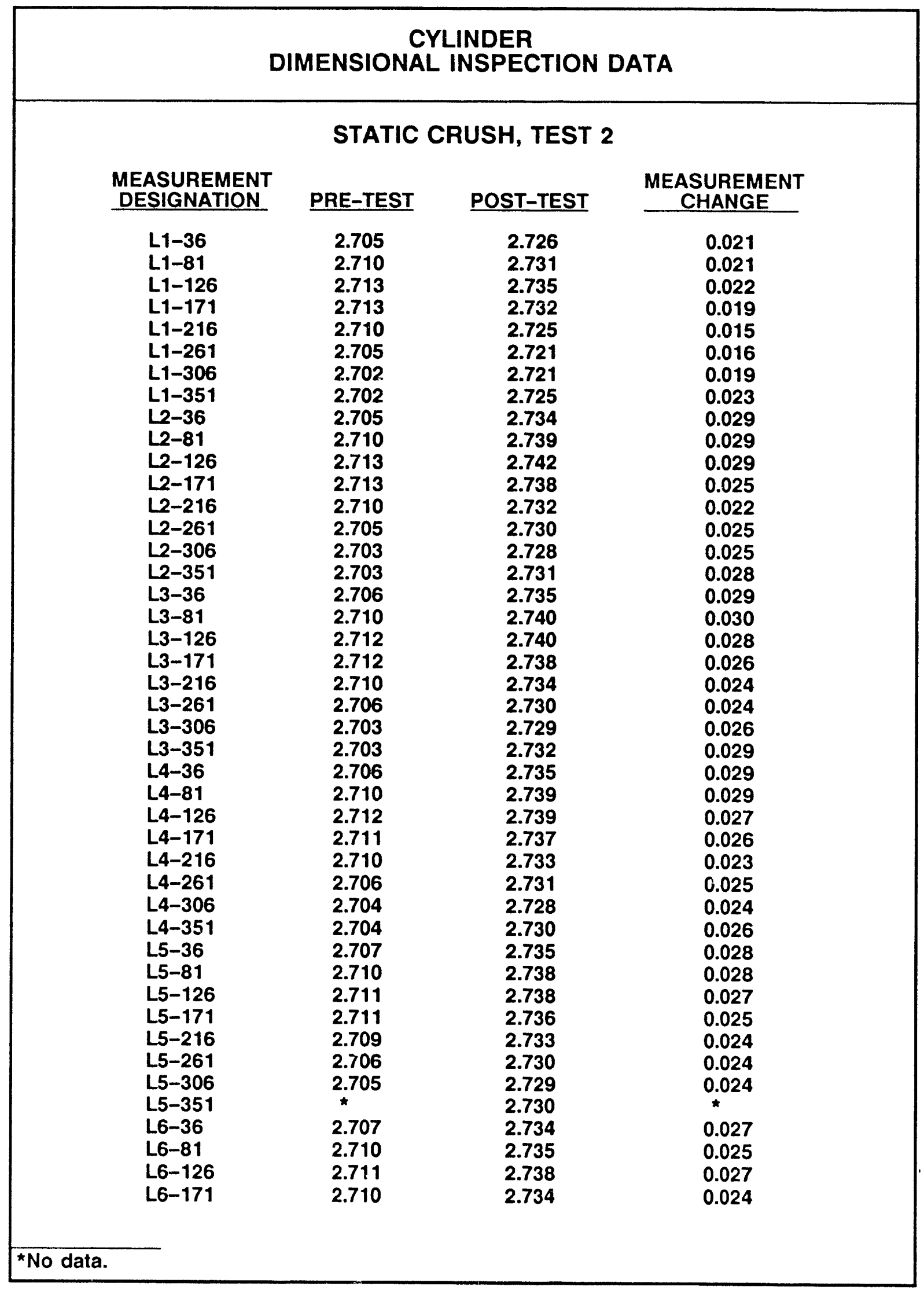




\section{CYLINDER \\ DIMENSIONAL INSPECTION DATA}

\section{STATIC CRUSH, TEST 2}

MEASUREMENT DESIGNATION

L6-216
L6-261
L6-306
L6-351
L7-36
L7-81
L7-126
L7-171
L7-216
L7-261
L7-306
L7-351
L8-36
L8-81
L8-126
L8-171
L8-216
L8-261
L8-306
L8-351
L9-36
L9-81
L9-126
L9-171
L9-216
L9-261
L9-306
L9-351
L10-36
L10-81
L10-126
L10-171
L10-216
L10-261
L10-306
L10-351
L11-36
L11-81
L11-126
L11-1171
L11-216
L11-261
L111-306
L11-351

PRE-TEST

2.709

2.706

2.705

2.706

2.707

2.709

2.710

2.710

2.709

2.707

2.706

2.706

2.708

2.709

2.710

2.710

2.709

2.707

2.706

2.707

2.708

2.709

2.709

2.709

2.709

2.708

2.707

2.707

2.709

2.709

2.709

2.709

2.708

2.708

2.708

2.708

2.709

2.709

2.708

2.708

2.708

2.708

2.708

2.709

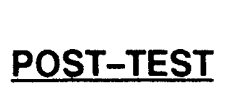

2.731

2.730

2.729

2.730

2.733

2.735

2.737

2.734

2.731

2.729

2.729

2.731

2.733

2.734

2.735

2.734

2.731

2.729

2.728

2.731

2.732

2.733

2.735

2.733

2.731

2.729

2.730

2.731

2.733

2.734

2.734

2.733

2.731

2.731

2.731

2.731

2.734

2.735

2.734

2.733

2.732

2.732

2.732

2.732
MEASUREMENT CHANGE

0.022

0.024

0.024

0.024

0.026

0.026

0.027

0.024

0.022

0.022

0.023

0.025

0.025

0.025

0.025

0.024

0.022

0.022

0.022

0.024

0.024

0.024

0.026

0.024

0.022

0.021

0.023

0.024

0.024

0.025

0.025

0.024

0.023

0.023

0.023

0.023

0.025

0.026

0.026

0.025

0.024

0.024

0.024

0.023 


\section{CYLINDER \\ DIMENSIONAL INSPECTION DATA}

STATIC CRUSH, TEST 2

MEASUREMENT DESIGNATION

L12-36

L12-81

L12-126

L12-171

L12-216

L12-261

L12-306

L12-351

L13-36

L13-81

L13-126

L13-171

L13-216

L13-261

L13-306

L13-351

L14-36

L14-81

L14-126

L14-171

L14-216

L14-261

L14-306

L14-351

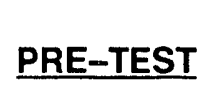

2.709

2.709

2.708

2.708

2.708

2.709

2.709

2.709

2.709

2.708

2.708

2.707

2.708

2.709

2.709

2.709

24.014

24.015

24.015

24.014

24.014

24.013

24.013

24.014

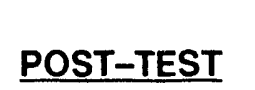

2.734

2.734

2.732

2.730

2.731

2.732

2.732

2.732

2.725

2.727

2.728

2.723

2.723

2.725

2.725

2.724

23.573

23.573

23.573

23.573

23.573

23.573

23.572

23.572
MEASUREMENT

CHANGE

0.025

0.025

0.024

0.022

0.023

0.023

0.023

0.023

0.016

0.019

0.020

0.016

0.015

0.016

0.016

0.015

$-0.441$

$-0.442$

$-0.442$

$-0.441$

$-0.441$

$-0.440$

$-0.441$

$-0.442$ 


\section{DIMENSIONAL INSPECTION DATA}

\section{STATIC CRUSH, TEST 3}

\begin{tabular}{|c|c|c|c|}
\hline $\begin{array}{l}\text { MEASUREMENT } \\
\text { DESIGNATION }\end{array}$ & PRE-TEST & POST-TEST & $\begin{array}{c}\text { MEASUREMENT } \\
\text { CHANGE } \\
\end{array}$ \\
\hline 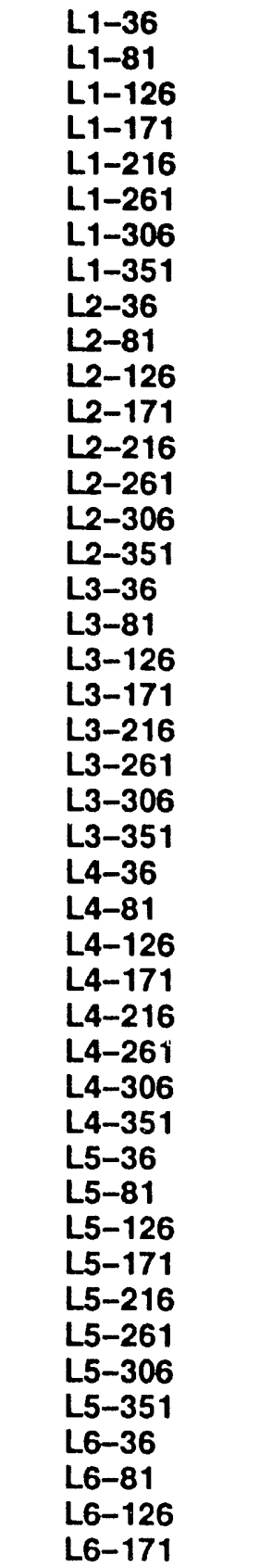 & $\begin{array}{l}2.716 \\
2.715 \\
2.709 \\
2.703 \\
2.701 \\
2.703 \\
2.709 \\
2.714 \\
2.715 \\
2.714 \\
2.709 \\
2.703 \\
2.701 \\
2.703 \\
2.709 \\
2.713 \\
2.714 \\
2.714 \\
2.709 \\
2.704 \\
2.703 \\
2.704 \\
2.709 \\
2.713 \\
2.713 \\
2.713 \\
2.709 \\
2.705 \\
2.704 \\
2.705 \\
2.709 \\
2.712 \\
2.713 \\
2.713 \\
2.709 \\
2.706 \\
2.705 \\
2.705 \\
2.709 \\
2.712 \\
2.712 \\
2.712 \\
2.709 \\
2.707\end{array}$ & $\begin{array}{l}2.730 \\
2.725 \\
2.724 \\
2.723 \\
2.722 \\
2.728 \\
2.738 \\
2.738 \\
2.736 \\
2.730 \\
2.729 \\
2.728 \\
2.729 \\
2.735 \\
2.743 \\
2.743 \\
2.736 \\
2.732 \\
2.729 \\
2.729 \\
2.734 \\
2.738 \\
2.743 \\
2.742 \\
2.736 \\
2.731 \\
2.729 \\
2.730 \\
2.734 \\
2.738 \\
2.742 \\
2.740 \\
2.736 \\
2.732 \\
2.729 \\
2.730 \\
2.735 \\
2.739 \\
2.742 \\
2.740 \\
2.736 \\
2.732 \\
2.730 \\
2.732\end{array}$ & $\begin{array}{l}0.014 \\
0.010 \\
0.015 \\
0.020 \\
0.021 \\
0.025 \\
0.029 \\
0.024 \\
0.021 \\
0.016 \\
0.020 \\
0.025 \\
0.028 \\
0.032 \\
0.034 \\
0.030 \\
0.022 \\
0.018 \\
0.020 \\
0.025 \\
0.031 \\
0.034 \\
0.034 \\
0.029 \\
0.023 \\
0.018 \\
0.020 \\
0.025 \\
0.030 \\
0.033 \\
0.033 \\
0.028 \\
0.023 \\
0.019 \\
0.020 \\
0.024 \\
0.030 \\
0.034 \\
0.033 \\
0.028 \\
0.024 \\
0.020 \\
0.021 \\
0.025\end{array}$ \\
\hline
\end{tabular}




\begin{tabular}{|c|c|c|c|}
\hline \multicolumn{4}{|c|}{$\begin{array}{c}\text { CYLINDER } \\
\text { DIMENSIONAL INSPECTION DATA }\end{array}$} \\
\hline \multicolumn{4}{|c|}{ STATIC CRUSH, TEST 3} \\
\hline $\begin{array}{l}\text { MEASUREMENT } \\
\text { DESIGNATION }\end{array}$ & PRE-TEST & POST-TEST & $\begin{array}{l}\text { MEASUREMENT } \\
\text { CHANGE } \\
\end{array}$ \\
\hline $\begin{array}{l}\text { L6-216 } \\
\text { L6-261 } \\
\text { L6-306 } \\
\text { L6-351 } \\
\text { L7-36 } \\
\text { L7-81 } \\
\text { L7-126 } \\
\text { L7-171 } \\
\text { L7-216 } \\
\text { L7-261 } \\
\text { L7-306 } \\
\text { L7-351 } \\
\text { L8-36 } \\
\text { L8-81 } \\
\text { L8-126 } \\
\text { L8-171 } \\
\text { L8-216 } \\
\text { L8-261 } \\
\text { L8-306 } \\
\text { L8-351 } \\
\text { L9-36 } \\
\text { L9-81 } \\
\text { L9-126 } \\
\text { L9-171 } \\
\text { L9-216 } \\
\text { L9-261 } \\
\text { L9-306 } \\
\text { L9-351 } \\
\text { L10-36 } \\
\text { L10-81 } \\
\text { L10-126 } \\
\text { L10-171 } \\
\text { L10-216 } \\
\text { L10-261 } \\
\text { L10-306 } \\
\text { L10-351 } \\
L 11-36 \\
\text { L11-81 } \\
\text { L11-126 } \\
\text { L11-171 } \\
\text { L11-216 } \\
L 11-261 \\
\text { L11-306 } \\
\text { L11-351 }\end{array}$ & $\begin{array}{l}2.706 \\
2.707 \\
2.709 \\
2.711 \\
2.712 \\
2.711 \\
2.709 \\
2.707 \\
2.707 \\
2.708 \\
2.709 \\
2.711 \\
2.711 \\
2.711 \\
2.709 \\
2.708 \\
2.708 \\
2.709 \\
2.710 \\
2.711 \\
2.711 \\
2.710 \\
2.709 \\
2.708 \\
2.708 \\
2.709 \\
2.710 \\
2.710 \\
2.710 \\
2.710 \\
2.710 \\
2.709 \\
2.709 \\
2.710 \\
2.710 \\
2.710 \\
2.710 \\
2.709 \\
2.710 \\
2.710 \\
2.709 \\
2.711 \\
2.711 \\
2.709\end{array}$ & $\begin{array}{l}2.736 \\
2.740 \\
2.742 \\
2.739 \\
2.736 \\
2.734 \\
2.733 \\
2.732 \\
2.736 \\
2.740 \\
2.742 \\
2.738 \\
2.736 \\
2.736 \\
2.735 \\
2.734 \\
2.736 \\
2.740 \\
2.740 \\
2.738 \\
2.737 \\
2.738 \\
2.735 \\
2.735 \\
2.736 \\
2.738 \\
2.739 \\
2.738 \\
2.738 \\
2.738 \\
2.737 \\
2.735 \\
2.736 \\
2.737 \\
2.736 \\
2.738 \\
2.739 \\
2.738 \\
2.737 \\
2.736 \\
2.737 \\
2.737 \\
2.738 \\
2.738\end{array}$ & $\begin{array}{l}0.030 \\
0.033 \\
0.033 \\
0.028 \\
0.024 \\
0.023 \\
0.024 \\
0.025 \\
0.029 \\
0.032 \\
0.033 \\
0.027 \\
0.025 \\
0.025 \\
0.026 \\
0.026 \\
0.028 \\
0.031 \\
0.030 \\
0.027 \\
0.026 \\
0.028 \\
0.026 \\
0.027 \\
0.028 \\
0.029 \\
0.029 \\
0.028 \\
0.028 \\
0.028 \\
0.027 \\
0.026 \\
0.027 \\
0.027 \\
0.026 \\
0.028 \\
0.029 \\
0.029 \\
0.027 \\
0.026 \\
0.028 \\
0.026 \\
0.027 \\
0.029\end{array}$ \\
\hline
\end{tabular}




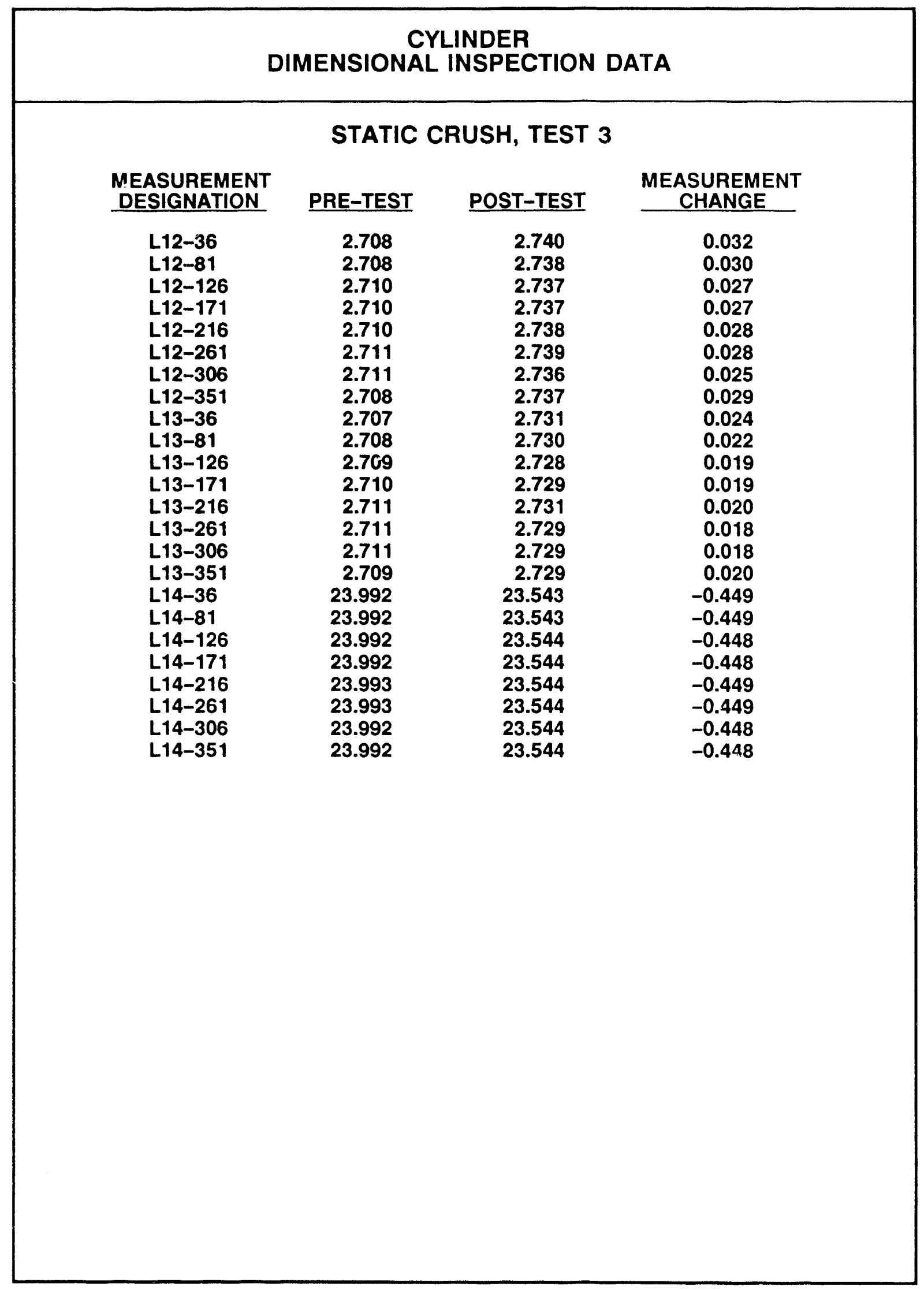




\begin{tabular}{|c|c|c|c|}
\hline \multicolumn{4}{|c|}{$\begin{array}{c}\text { CYLINDER } \\
\text { DIMENSIONAL INSPECTION DATA }\end{array}$} \\
\hline \multicolumn{4}{|c|}{ STATIC CRUSH, TEST 4} \\
\hline $\begin{array}{l}\text { MEASURE'MENT } \\
\text { DESIGNATION }\end{array}$ & PRE-TEST & POST-TEST & $\begin{array}{c}\text { MEASUREMENT } \\
\text { CHAIVGE } \\
\end{array}$ \\
\hline $\begin{array}{l}\text { L1-36 } \\
\text { L1-81 } \\
\text { L1-126 } \\
\text { L1-171 } \\
\text { L1-216 } \\
\text { L1-261 } \\
\text { L1-306 } \\
\text { L1-351 } \\
\text { L2-36 } \\
\text { L2-81 } \\
\text { L2-126 } \\
\text { L2-171 } \\
\text { L2-216 } \\
\text { L2-261 } \\
\text { L2-306 } \\
\text { L2-351 } \\
\text { L3-36 } \\
\text { L3-81 } \\
\text { L3-126 } \\
\text { L3-171 } \\
\text { L3-216 } \\
\text { L3-261 } \\
\text { L3-306 } \\
\text { L3-351 } \\
\text { L4-36 } \\
\text { L4-81 } \\
\text { L4-126 } \\
\text { L4-171 } \\
\text { L4-216 } \\
\text { L4-261 } \\
\text { L4-306 } \\
\text { L4-351 } \\
\text { L5-36 } \\
\text { L5-81 } \\
\text { L5-126 } \\
\text { L5-171 } \\
\text { L5-216 } \\
\text { L5-261 } \\
\text { L5-306 } \\
\text { L5-351 } \\
\text { L6-36 } \\
\text { L6-81 } \\
\text { L6-126 } \\
\text { L6-171 }\end{array}$ & $\begin{array}{l}2.710 \\
2.715 \\
2.718 \\
2.715 \\
2.708 \\
2.702 \\
2.702 \\
2.704 \\
2.709 \\
2.715 \\
2.717 \\
2.714 \\
2.708 \\
2.702 \\
2.703 \\
2.704 \\
2.709 \\
2.714 \\
2.716 \\
2.714 \\
2.708 \\
2.703 \\
2.703 \\
2.705 \\
2.709 \\
2.713 \\
2.716 \\
2.714 \\
2.708 \\
2.704 \\
2.704 \\
2.706 \\
2.709 \\
2.712 \\
2.715 \\
2.713 \\
2.708 \\
2.705 \\
2.705 \\
2.706 \\
2.709 \\
2.712 \\
2.714 \\
2.712\end{array}$ & $\begin{array}{l}2.729 \\
2.734 \\
2.739 \\
2.735 \\
2.726 \\
2.720 \\
2.722 \\
2.726 \\
2.736 \\
2.740 \\
2.743 \\
2.740 \\
2.733 \\
2.727 \\
2.727 \\
2.731 \\
2.736 \\
2.740 \\
2.743 \\
2.739 \\
2.734 \\
2.723 \\
2.728 \\
2.731 \\
2.733 \\
2.738 \\
2.740 \\
2.738 \\
2.735 \\
2.728 \\
2.728 \\
2.730 \\
2.733 \\
2.737 \\
2.739 \\
2.738 \\
2.735 \\
2.729 \\
2.729 \\
2.732 \\
2.733 \\
2.736 \\
2.738 \\
2.738\end{array}$ & $\begin{array}{l}0.019 \\
0.019 \\
0.021 \\
0.020 \\
0.018 \\
0.018 \\
0.020 \\
0.022 \\
0.027 \\
0.025 \\
0.026 \\
0.026 \\
0.025 \\
0.025 \\
0.024 \\
0.027 \\
0.027 \\
0.026 \\
0.027 \\
0.025 \\
0.026 \\
0.025 \\
0.025 \\
0.026 \\
0.024 \\
0.025 \\
0.024 \\
0.024 \\
0.027 \\
0.024 \\
0.024 \\
0.024 \\
0.024 \\
0.025 \\
0.024 \\
0.025 \\
0.027 \\
0.024 \\
0.024 \\
0.026 \\
0.024 \\
0.024 \\
0.024 \\
0.026\end{array}$ \\
\hline
\end{tabular}




\section{CYLINDER}

DIMENSIONAL INSPECTION DATA

\section{STATIC CRUSH, TEST 4}

MEASUREMENT DESIGNATION
L6-216
L6-261
L6-306
L6-351
L7-36
L7-81
L7-126
L7-171
L7-216
L7-261
L7-306
L7-351
L8-36
L8-81
L8-126
L8-171
L8-216
L8-261
L8-306
L8-351
L9-36
L9-81
L9-126
L9-171
L9-216
L9-261
L9-306
L9-351
L10-36
L10-81
L10-126
L10-171
L10-216
L10-261
L10-306
L10-351
L11-36
L11-81
L11-126
L11-171
L11-216
L11-261
L11-306
L11-351

\section{PRE-TEST}

2.709

2.705

2.706

2.706

2.708

2.711

2.713

2.711

2.709

2.706

2.705

2.707

2.709

2.711

2.712

2.711

2.709

2.707

2.706

2.708

2.709

2.710

2.711

2.710

2.709

2.707

2.707

2.708

2.709

2.710

2.711

2.710

2.709

2.708

2.708

2.709

2.709

2.709

2.710

2.709

2.709

2.708

2.709

2.709
POST-TEST

2.736

2.729

2.729

2.733

2.732

2.734

2.737

2.738

2.736

2.730

2.729

2.733

2.731

2.734

2.736

2.737

2.734

2.730

2.729

2.731

2.732

2.734

2.734

2.737

2.735

2.731

2.730

2.733

2.732

2.734

2.734

2.735

2.736

2.732

2.732

2.733

2.734

2.734

2.735

2.734

2.734

2.733

2.733

2.734
MEASUREMENT

CHANGE

0.027

0.024

0.023

0.027

0.024

0.023

0.024

0.027

0.027

0.024

0.024

0.026

0.022

0.023

0.024

0.026

0.025

0.023

0.023

0.023

0.023

0.024

0.023

0.027

0.026

0.024

0.023

0.025

0.023

0.024

0.023

0.025

0.027

0.024

0.024

0.024

0.025

0.025

0.025

0.025

0.025

0.025

0.024

0.025 


\section{CYLINDER \\ DIMENSIONAL INSPECTION DATA}

\section{STATIC CRUSH, TEST 4}

\section{MEASUREMENT DESIGNATION}

L12-36

L12-81

L12-126

L12-171

L12-216

L12-261

L12-306

L12-351

L13-36

L13-81

L13-126

L13-171

L13-216

L13-261

L13-306

L13-351

L14-36

L14-81

L14-126

L14-171

L14-216

L14-261

L14-306

L14-351

\begin{tabular}{c} 
PRE-TES \\
\hline 2.709 \\
2.709 \\
2.709 \\
2.709 \\
2.709 \\
2.709 \\
2.709 \\
2.709 \\
2.709 \\
2.709 \\
2.709 \\
2.709 \\
2.709 \\
2.709 \\
2.709 \\
2.709 \\
24.007 \\
24.007 \\
24.008 \\
24.007 \\
24.006 \\
24.007 \\
24.008 \\
24.008
\end{tabular}

POST-TEST

2.733

2.733

2.733

2.733

2.734

2.731

2.733

2.734

2.723

2.723

2.723

2.723

2.722

2.723

2.723

2.723

23.563

23.563

23.563

23.564

23.565

23.565

23.565

23.564

MEASUREMENT

CHANGE

0.024

0.024

0.024

0.024

0.025

0.022

0.024

0.025

0.014

0.014

0.014

0.014

0.013

0.014

0.014

0.014

$-0.444$

$-0.444$

$-0.445$

$-0.443$

$-0.441$

$-0.442$

$-0.443$

$-0.444$ 


\begin{tabular}{|c|c|c|c|}
\hline \multicolumn{4}{|c|}{$\begin{array}{c}\text { CYLINDER } \\
\text { DIMENSIONAL INSPECTION DATA }\end{array}$} \\
\hline \multicolumn{4}{|c|}{ STATIC CRUSH, TEST 5} \\
\hline $\begin{array}{l}\text { MEASUREMENT } \\
\text { DESIGNATION }\end{array}$ & PRE-TEST & POST-TEST & $\begin{array}{c}\text { MEASUREMENT } \\
\text { CHANGE } \\
\end{array}$ \\
\hline 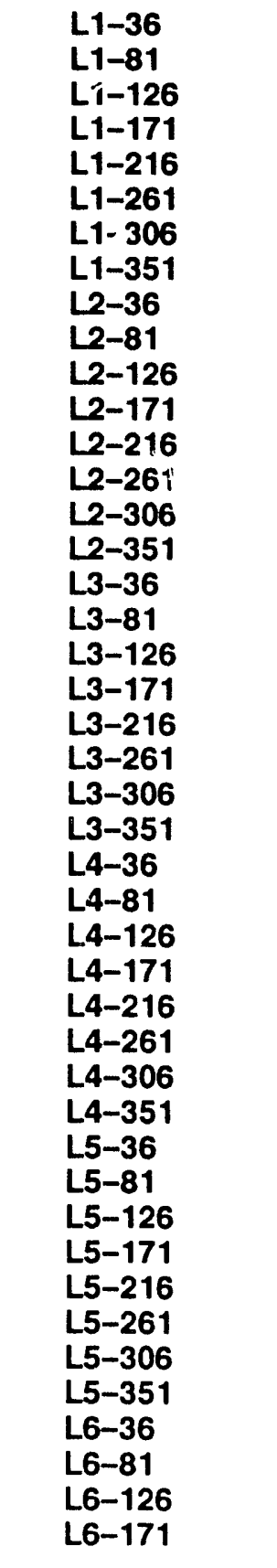 & $\begin{array}{l}2.714 \\
2.702 \\
2.694 \\
2.694 \\
2.702 \\
2.714 \\
2.723 \\
2.722 \\
2.714 \\
2.703 \\
2.696 \\
2.696 \\
2.703 \\
2.713 \\
2.722 \\
2.721 \\
2.714 \\
2.704 \\
2.698 \\
2.698 \\
2.703 \\
2.713 \\
2.720 \\
2.719 \\
2.713 \\
2.705 \\
2.700 \\
2.700 \\
2.705 \\
2.712 \\
2.719 \\
2.718 \\
2.712 \\
2.706 \\
2.701 \\
2.701 \\
2.706 \\
2.712 \\
2.719 \\
2.717 \\
2.711 \\
2.707 \\
2.703 \\
2.701\end{array}$ & $\begin{array}{l}2.730 \\
2.715 \\
2.709 \\
2.710 \\
2.719 \\
2.730 \\
2.740 \\
2.740 \\
2.736 \\
2.723 \\
2.716 \\
2.717 \\
2.728 \\
2.738 \\
2.746 \\
2.745 \\
2.736 \\
2.724 \\
2.718 \\
2.720 \\
2.729 \\
2.739 \\
2.745 \\
2.745 \\
2.735 \\
2.725 \\
2.720 \\
2.721 \\
2.730 \\
2.739 \\
2.743 \\
2.743 \\
2.734 \\
2.725 \\
2.721 \\
2.723 \\
2.729 \\
2.737 \\
2.743 \\
2.742 \\
2.734 \\
2.727 \\
2.723 \\
2.724\end{array}$ & $\begin{array}{l}0.016 \\
0.013 \\
0.015 \\
0.016 \\
0.017 \\
0.016 \\
0.017 \\
0.018 \\
0.022 \\
0.020 \\
0.020 \\
0.021 \\
0.025 \\
0.025 \\
0.024 \\
0.024 \\
0.022 \\
0.020 \\
0.020 \\
0.022 \\
0.026 \\
0.026 \\
0.025 \\
0.026 \\
0.022 \\
0.020 \\
0.020 \\
0.021 \\
0.025 \\
0.027 \\
0.024 \\
0.025 \\
0.022 \\
0.019 \\
0.020 \\
0.022 \\
0.023 \\
0.025 \\
0.024 \\
0.025 \\
0.023 \\
0.020 \\
0.020 \\
0.023\end{array}$ \\
\hline
\end{tabular}




\begin{tabular}{|c|c|c|c|}
\hline \multicolumn{4}{|c|}{$\begin{array}{c}\text { CYLINDER } \\
\text { DIMENSIONAL INSPECTION DATA }\end{array}$} \\
\hline \multicolumn{4}{|c|}{ STATIC CRUSH, TEST 5} \\
\hline $\begin{array}{l}\text { MEASUREMENT } \\
\text { DESIGNATION }\end{array}$ & PRE-TEST & POST-TEST & $\begin{array}{c}\text { MEASUREMENT } \\
\text { CHANGE } \\
\end{array}$ \\
\hline $\begin{array}{l}\text { L6-216 } \\
\text { L6-261 } \\
\text { L6-306 } \\
\text { L6-351 } \\
\text { L7-36 } \\
\text { L7-81 } \\
\text { L7-126 } \\
\text { L7-171 } \\
\text { L7-216 } \\
\text { L7-261 } \\
\text { L7-306 } \\
\text { L7-351 } \\
\text { L8-36 } \\
\text { L8-81 } \\
\text { L8-126 } \\
\text { L8-171 } \\
\text { L8-216 } \\
\text { L8-261 } \\
\text { L8-306 } \\
\text { L8-351 } \\
\text { L9-36 } \\
\text { L9-81 } \\
\text { L9-126 } \\
\text { L9-171 } \\
\text { L9-216 } \\
\text { L9-261 } \\
\text { L9-306 } \\
\text { L9-351 } \\
\text { L10-36 } \\
\text { L10-81 } \\
\text { L10-126 } \\
\text { L10-171 } \\
\text { L10-216 } \\
\text { L10-261 } \\
\text { L10-306 } \\
\text { L10-351 } \\
\text { L11-36 } \\
\text { L11-81 } \\
\text { L11-126 } \\
\text { L11-171 } \\
\text { L11-216 } \\
\text { L11-261 } \\
\text { L11-306 } \\
\text { L11-351 }\end{array}$ & $\begin{array}{l}2.707 \\
2.711 \\
2.716 \\
2.715 \\
2.711 \\
2.708 \\
2.705 \\
2.704 \\
2.707 \\
2.710 \\
2.714 \\
2.713 \\
2.711 \\
2.709 \\
2.706 \\
2.706 \\
2.708 \\
2.710 \\
2.711 \\
2.712 \\
2.710 \\
2.708 \\
2.708 \\
2.708 \\
2.709 \\
2.709 \\
2.711 \\
2.711 \\
2.709 \\
2.709 \\
2.710 \\
2.710 \\
2.709 \\
2.708 \\
2.709 \\
2.709 \\
2.708 \\
2.710 \\
2.710 \\
2.710 \\
2.710 \\
2.709 \\
2.708 \\
2.708\end{array}$ & $\begin{array}{l}2.729 \\
2.736 \\
2.742 \\
2.740 \\
2.733 \\
2.728 \\
2.726 \\
2.726 \\
2.729 \\
2.736 \\
2.740 \\
2.739 \\
2.734 \\
2.730 \\
2.727 \\
2.728 \\
2.730 \\
2.737 \\
2.739 \\
2.739 \\
2.735 \\
2.732 \\
2.730 \\
2.730 \\
2.732 \\
2.736 \\
2.739 \\
2.738 \\
2.735 \\
2.732 \\
2.731 \\
2.732 \\
2.733 \\
2.735 \\
2.737 \\
2.737 \\
2.736 \\
2.733 \\
2.733 \\
2.733 \\
2.733 \\
2.735 \\
2.736 \\
2.736\end{array}$ & $\begin{array}{l}0.022 \\
0.025 \\
0.026 \\
0.025 \\
0.022 \\
0.020 \\
0.021 \\
0.022 \\
0.022 \\
0.026 \\
0.026 \\
0.026 \\
0.023 \\
0.021 \\
0.021 \\
0.022 \\
0.022 \\
0.027 \\
0.028 \\
0.027 \\
0.025 \\
0.024 \\
0.022 \\
0.022 \\
0.023 \\
0.027 \\
0.028 \\
0.027 \\
0.026 \\
0.023 \\
0.021 \\
0.022 \\
0.024 \\
0.027 \\
0.028 \\
0.028 \\
0.028 \\
0.023 \\
0.023 \\
0.023 \\
0.023 \\
0.026 \\
0.028 \\
0.028\end{array}$ \\
\hline
\end{tabular}




\section{CYLINDER}

DIMENSIONAL INSPECTION DATA

\section{STATIC CRUSH, TEST 5}

\begin{tabular}{ccc}
$\begin{array}{ccc}\text { MEASUREMENT } \\
\text { DESIGNATION }\end{array}$ & & \\
\cline { 1 - 1 } PRE-TES & \\
L12-36 & & 2.708 \\
L12-81 & & 2.710 \\
L12-126 & & 2.712 \\
L12-171 & & 2.711 \\
L12-215 & & 2.711 \\
L12-261 & & 2.708 \\
L12-306 & & 2.707 \\
L12-351 & & 2.706 \\
L13-36 & & 2.707 \\
L13-81 & & 2.710 \\
L13-126 & & 2.714 \\
L13-1171 & & 2.712 \\
L13-216 & & 2.712 \\
L13-261 & & 2.708 \\
L13-306 & & 2.705 \\
L13-351 & 2.704 \\
L14-36 & 24.005 \\
L14-81 & 24.006 \\
L14-126 & 24.010 \\
L14-171 & 24.012 \\
L14-216 & 24.011 \\
L14-261 & 24.010 \\
L14-306 & 24.007 \\
L14-351 & 24.005
\end{tabular}

\begin{tabular}{c} 
POST-TEST \\
\hline 2.734 \\
2.734 \\
2.734 \\
2.735 \\
2.733 \\
2.735 \\
2.735 \\
2.735 \\
2.725 \\
2.725 \\
2.725 \\
2.725 \\
2.725 \\
2.725 \\
2.725 \\
2.725 \\
23.563 \\
23.565 \\
23.568 \\
23.569 \\
23.569 \\
23.567 \\
23.565 \\
23.564
\end{tabular}

MEASUREMENT CHANGE

0.026

0.024

0.022

0.024

0.022

0.027

0.028

0.029

0.018

0.015

0.011

0.013

0.013

0.017

0.020

0.021

$-0.442$

$-0.441$

$-0.442$

$-0.443$

$-0.442$

$-0.443$

$-0.442$

$-0.441$ 


\begin{tabular}{|c|c|c|c|}
\hline \multicolumn{4}{|c|}{$\begin{array}{c}\text { CYLINDER } \\
\text { DIMENSIONAL INSPECTION DATA }\end{array}$} \\
\hline \multicolumn{4}{|c|}{ STATIC CRUSH, TEST 6} \\
\hline $\begin{array}{l}\text { MEASUREMENT } \\
\text { DESIGNATION } \\
\end{array}$ & PRE-TEST & POST-TEST & $\begin{array}{c}\text { MEASUREMENT } \\
\text { CHANGE } \\
\end{array}$ \\
\hline 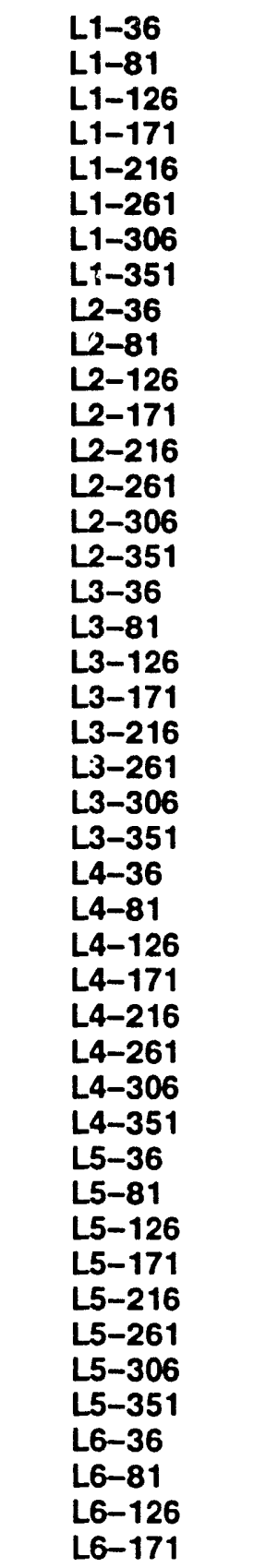 & $\begin{array}{l}2.707 \\
2.707 \\
2.708 \\
2.708 \\
2.710 \\
2.710 \\
2.709 \\
2.708 \\
2.707 \\
2.707 \\
2.708 \\
2.709 \\
2.710 \\
2.710 \\
2.709 \\
2.708 \\
2.707 \\
2.707 \\
2.708 \\
2.709 \\
2.710 \\
2.710 \\
2.709 \\
2.708 \\
2.707 \\
2.707 \\
2.708 \\
2.710 \\
2.710 \\
2.710 \\
2.709 \\
2.708 \\
2.708 \\
2.708 \\
2.708 \\
2.710 \\
2.710 \\
2.710 \\
2.709 \\
2.709 \\
2.708 \\
2.708 \\
2.709 \\
2.710\end{array}$ & $\begin{array}{l}2.716 \\
2.720 \\
2.728 \\
2.738 \\
2.737 \\
2.732 \\
2.729 \\
2.720 \\
2.725 \\
2.728 \\
2.734 \\
2.742 \\
2.744 \\
2.741 \\
2.735 \\
2.729 \\
2.727 \\
2.730 \\
2.734 \\
2.740 \\
2.743 \\
2.740 \\
2.736 \\
2.729 \\
2.727 \\
2.730 \\
2.734 \\
2.739 \\
2.741 \\
2.740 \\
2.735 \\
2.730 \\
2.729 \\
2.730 \\
2.734 \\
2.738 \\
2.740 \\
2.740 \\
2.735 \\
2.731 \\
2.730 \\
2.730 \\
2.733 \\
2.736\end{array}$ & $\begin{array}{l}0.009 \\
0.013 \\
0.020 \\
0.030 \\
0.027 \\
0.022 \\
0.020 \\
0.012 \\
0.018 \\
0.021 \\
0.026 \\
0.033 \\
0.034 \\
0.031 \\
0.026 \\
0.021 \\
0.020 \\
0.023 \\
0.026 \\
0.031 \\
0.033 \\
0.030 \\
0.027 \\
0.021 \\
0.020 \\
0.023 \\
0.026 \\
0.029 \\
0.031 \\
0.030 \\
0.026 \\
0.022 \\
0.021 \\
0.022 \\
0.026 \\
0.028 \\
0.030 \\
0.030 \\
0.026 \\
0.022 \\
0.022 \\
0.022 \\
0.024 \\
0.026\end{array}$ \\
\hline
\end{tabular}




\section{DIMENSIONAL INSPECTION DATA}

\section{STATIC CRUSH, TEST 6}

MEASUREMENT DESIGNATION

L6-216
L6-261
L6-306
L6-351
L7-36
L7-81
L7-126
L7-171
L7-216
L7-261
L7-306
L7-351
L8-36
L8-81
L8-126
L8-171
L8-216
L8-261
L8-306
L8-351
L9-36
L9-81
L9-126
L9-171
L9-216
L9-261
L9-306
L9-351
L10-36
L10-81
L10-126
L10-171
L10-216
L10-261
L10-306
L10-351
L11-36
L11-81
L11-126
L11-171
L11-216
L11-261
L11-306
L11-351

\section{PRE-TEST}

2.710

2.710

2.709

2.709

2.708

2.708

2.709

2.710

2.710

2.710

2.709

2.709

2.708

2.708

2.709

2.710

2.710

2.709

2.709

2.709

2.709

2.709

2.709

2.710

2.710

2.710

2.709

2.709

2.709

2.709

2.710

2.710

2.709

2.709

2.709

2.709

2.709

2.709

2.710

2.710

2.709

2.709

2.709

2.709

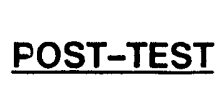

2.739

2.739

2.735

2.732

2.731

2.731

2.732

2.734

2.737

2.737

2.736

2.733

2.731

2.731

2.733

2.734

2.736

2.737

2.735

2.734

2.733

2.732

2.732

2.734

2.735

2.736

2.735

2.735

2.735

2.734

2.734

2.735

2.735

2.736

2.736

2.736

2.736

2.736

2.734

2.735

2.738

2.737

2.737

2.736
MEASUREMENT

CHANGE

0.029

0.029

0.026

0.023

0.023

0.023

0.023

0.024

0.027

0.027

0.027

0.024

0.023

0.023

0.024

0.024

0.026

0.028

0.026

0.025

0.024

0.023

0.023

0.024

0.025

0.026

0.026

0.026

0.026

0.025

0.024

0.025

0.026

0.027

0.027

0.027

0.027

0.027

0.024

0.025

0.029

0.028

0.028

0.027 


\section{DIMENSIONAL INSPECTION DATA}

\section{STATIC CRUSH, TEST 6}

MEASUREMENT DESIGNATION

L12-36
L12-81
L12-126
L12-171
L12-216
L12-261
L12-306
L12-351
L13-36
L13-81
L13-126
L13-171
L13-216
L13-261
L13-306
L13-351
L14-36
L14-81
L14-126
L14-171
L14-216
L14-261
L14-306
L14-351

PRE-TEST POST-TEST

2.710

2.709

2.710

2.710

2.709

2.709

2.709

2.709

2.710

2.710

2.710

2.710

2.709

2.709

2.709

2.709

23.989

23.990

23.990

23.990

23.990

23.989

23.989

23.990
2.735

2.734

2.733

2.735

2.734

2.736

2.733

2.735

2.725

2.723

2.723

2.725

2.725

2.723

2.723

2.725

23.547

23.548

23.548

23.546

23.544

23.543

23.543

23.545
MEASUREMENT

CHANGE

0.025

0.025

0.023

0.025

0.025

0.027

0.024

0.026

0.015

0.013

0.013

0.015

0.016

0.014

0.014

0.016

$-0.442$

$-0.442$

$-0.442$

$-0.444$

$-0.446$

$-0.446$

$-0.446$

$-0.445$ 


\begin{tabular}{|c|c|c|c|}
\hline \multicolumn{4}{|c|}{$\begin{array}{c}\text { CYLINDER } \\
\text { DIMENSIONAL INSPECTION DATA }\end{array}$} \\
\hline \multicolumn{4}{|c|}{ STATIC CRUSH, TEST 7} \\
\hline $\begin{array}{l}\text { MEASUREMENT } \\
\text { DESIGNATION }\end{array}$ & PRE-TEST & POST-TEST & $\begin{array}{c}\text { MEASUREMENT } \\
\text { CHANGE }\end{array}$ \\
\hline $\begin{array}{l}\text { L1-36 } \\
\text { L1-81 } \\
\text { L1-126 } \\
\text { L1-171 } \\
\text { L1-216 } \\
\text { L1-261 } \\
\text { L1-306 } \\
\text { L1-351 } \\
\text { L2-36 } \\
\text { L2-81 } \\
\text { L2-126 } \\
\text { L2-171 } \\
\text { L2-216 } \\
\text { L2-261 } \\
\text { L2-306 } \\
\text { L2-351 } \\
\text { L3-36 } \\
\text { L3-81 } \\
\text { L3-126 } \\
\text { L3-171 } \\
\text { L3-216 } \\
\text { L3-261 } \\
\text { L3-306 } \\
\text { L3-351 } \\
\text { L4-36 } \\
\text { L4-81 } \\
\text { L4-126 } \\
\text { L4-171 } \\
\text { L4-216 } \\
\text { L4-261 } \\
\text { L4-306 } \\
\text { L4-351 } \\
\text { L5-36 } \\
\text { L5-81 } \\
\text { L5-126 } \\
\text { L5-171 } \\
\text { L5-216 } \\
\text { L5-261 } \\
\text { L5-306 } \\
\text { L5-351 } \\
\text { L6-36 } \\
\text { L6-81 } \\
\text { L6-126 } \\
\text { L6-171 }\end{array}$ & $\begin{array}{l}2.707 \\
2.704 \\
2.704 \\
2.705 \\
2.708 \\
2.711 \\
2.712 \\
2.711 \\
2.707 \\
2.704 \\
2.704 \\
2.705 \\
2.708 \\
2.711 \\
2.711 \\
2.710 \\
2.707 \\
2.705 \\
2.705 \\
2.706 \\
2.708 \\
2.710 \\
2.710 \\
2.710 \\
2.707 \\
2.705 \\
2.705 \\
2.706 \\
2.708 \\
2.710 \\
2.710 \\
2.709 \\
2.707 \\
2.706 \\
2.706 \\
2.706 \\
2.708 \\
2.709 \\
2.709 \\
2.709 \\
2.707 \\
2.706 \\
2.706 \\
2.707\end{array}$ & $\begin{array}{l}2.729 \\
2.725 \\
2.721 \\
2.719 \\
2.717 \\
2.719 \\
2.726 \\
2.731 \\
2.735 \\
2.732 \\
2.729 \\
2.729 \\
2.725 \\
2.726 \\
2.731 \\
2.736 \\
2.734 \\
2.733 \\
2.730 \\
2.729 \\
2.726 \\
2.727 \\
2.731 \\
2.735 \\
2.734 \\
2.734 \\
2.732 \\
2.729 \\
2.727 \\
2.727 \\
2.731 \\
2.733 \\
2.734 \\
2.734 \\
2.733 \\
2.729 \\
2.727 \\
2.729 \\
2.731 \\
2.733 \\
2.731 \\
2.734 \\
2.733 \\
2.730\end{array}$ & $\begin{array}{l}0.022 \\
0.021 \\
0.017 \\
0.014 \\
0.009 \\
0.008 \\
0.014 \\
0.020 \\
0.028 \\
0.028 \\
0.025 \\
0.024 \\
0.017 \\
0.015 \\
0.020 \\
0.026 \\
0.027 \\
0.028 \\
0.025 \\
0.023 \\
0.018 \\
0.017 \\
0.021 \\
0.025 \\
0.027 \\
0.029 \\
0.027 \\
0.023 \\
0.019 \\
0.017 \\
0.021 \\
0.024 \\
0.027 \\
0.028 \\
0.027 \\
0.023 \\
0.019 \\
0.020 \\
0.022 \\
0.024 \\
0.024 \\
0.028 \\
0.027 \\
0.023\end{array}$ \\
\hline
\end{tabular}




\begin{tabular}{|c|c|c|c|}
\hline \multicolumn{4}{|c|}{$\begin{array}{c}\text { CYLINDER } \\
\text { DIMENSIONAL INSPECTION DATA }\end{array}$} \\
\hline \multicolumn{4}{|c|}{ STATIC CRUSH, TEST 7} \\
\hline $\begin{array}{l}\text { MEASUREMENT } \\
\text { DESIGNATION }\end{array}$ & PRE-TEST & POST-TEST & $\begin{array}{l}\text { MEASUREMENT } \\
\text { CHANGE } \\
\end{array}$ \\
\hline $\begin{array}{l}\text { L6-216 } \\
L 6-261 \\
L 6-306 \\
L 6-351 \\
L 7-36 \\
L 7-81 \\
L 7-126 \\
L 7-171 \\
L 7-216 \\
L 7-261 \\
L 7-306 \\
L 7-351 \\
L 8-36 \\
L 8-81 \\
L 8-126 \\
L 8-171 \\
L 8-216 \\
L 8-261 \\
L 8-306 \\
L 8-351 \\
L 9-36 \\
L 9-81 \\
L 9-126 \\
L 9-171 \\
L 9-216 \\
L 9-261 \\
L 9-306 \\
L 9-351 \\
L 10-36 \\
L 10-81 \\
L 10-126 \\
L 10-171 \\
L 10-216 \\
L 10-261 \\
L 10-306 \\
L 10-351 \\
L 11-36 \\
L 11-81 \\
L 11-126 \\
L 11-171 \\
L 11-216 \\
L 11-261 \\
L 11-306 \\
L 11-351 \\
\text { L }\end{array}$ & $\begin{array}{l}2.708 \\
2.709 \\
2.709 \\
2.708 \\
2.707 \\
2.707 \\
2.707 \\
2.707 \\
2.708 \\
2.708 \\
2.708 \\
2.708 \\
2.707 \\
2.707 \\
2.707 \\
2.707 \\
2.708 \\
2.708 \\
2.707 \\
2.708 \\
2.707 \\
2.708 \\
2.707 \\
2.708 \\
2.708 \\
2.708 \\
2.707 \\
2.707 \\
2.707 \\
2.708 \\
2.708 \\
2.708 \\
2.707 \\
2.707 \\
2.707 \\
2.707 \\
2.707 \\
2.708 \\
2.708 \\
2.708 \\
2.707 \\
2.707 \\
2.706 \\
2.706\end{array}$ & $\begin{array}{l}2.729 \\
2.730 \\
2.731 \\
2.733 \\
2.731 \\
2.734 \\
2.732 \\
2.730 \\
2.729 \\
2.730 \\
2.731 \\
2.731 \\
2.731 \\
2.732 \\
2.731 \\
2.729 \\
2.730 \\
2.731 \\
2.731 \\
2.731 \\
2.730 \\
2.731 \\
2.730 \\
2.729 \\
2.730 \\
2.731 \\
2.731 \\
2.730 \\
2.729 \\
2.730 \\
2.729 \\
2.729 \\
2.729 \\
2.731 \\
2.731 \\
2.729 \\
2.730 \\
2.730 \\
2.730 \\
2.730 \\
2.731 \\
2.731 \\
2.731 \\
2.730\end{array}$ & $\begin{array}{l}0.021 \\
0.021 \\
0.022 \\
0.025 \\
0.024 \\
0.027 \\
0.025 \\
0.023 \\
0.021 \\
0.022 \\
0.023 \\
0.023 \\
0.024 \\
0.025 \\
0.024 \\
0.022 \\
0.022 \\
0.023 \\
0.024 \\
0.023 \\
0.023 \\
0.023 \\
0.023 \\
0.021 \\
0.022 \\
0.023 \\
0.024 \\
0.023 \\
0.022 \\
0.022 \\
0.021 \\
0.021 \\
0.022 \\
0.024 \\
0.024 \\
0.022 \\
0.023 \\
0.022 \\
0.022 \\
0.022 \\
0.024 \\
0.024 \\
0.025 \\
0.024\end{array}$ \\
\hline
\end{tabular}




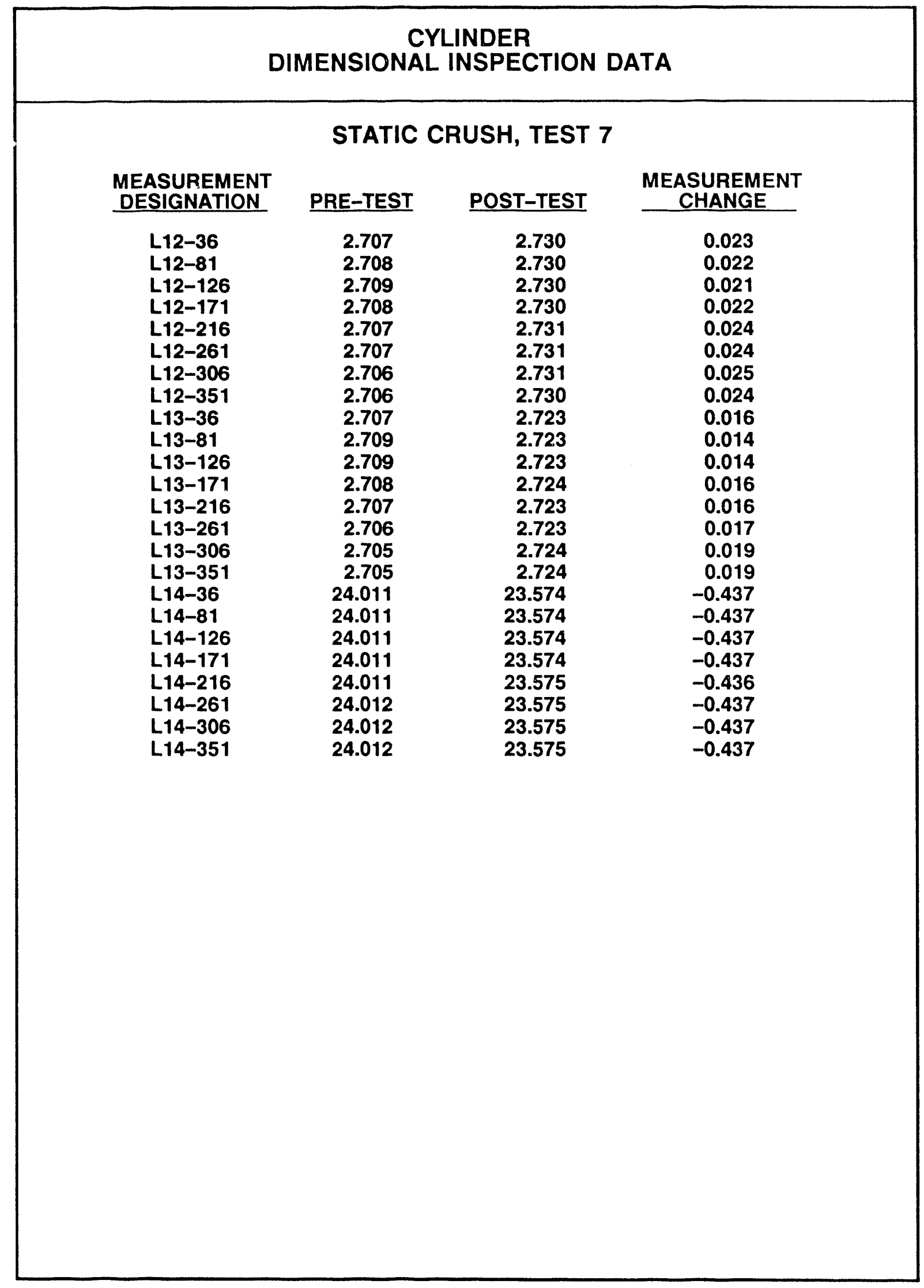




\begin{tabular}{|c|c|c|c|}
\hline \multicolumn{4}{|c|}{$\begin{array}{c}\text { CYLINDER } \\
\text { DIMENSIONAL INSPECTION DATA }\end{array}$} \\
\hline \multicolumn{4}{|c|}{ STATIC CRUSH, TEST 8} \\
\hline $\begin{array}{l}\text { MEASUREMENT } \\
\text { DESIGNATION }\end{array}$ & PRE-TEST & POST-TEST & $\begin{array}{l}\text { MEASUREMENT } \\
\text { CHANGE } \\
\end{array}$ \\
\hline $\begin{array}{l}\text { L1-36 } \\
\text { L1-81 } \\
\text { L1-126 } \\
\text { L1-171 } \\
\text { L1-216 } \\
\text { L1-261 } \\
\text { L1-306 } \\
\text { L1-351 } \\
\text { L2-36 } \\
\text { L2-81 } \\
\text { L2-126 } \\
\text { L2-171 } \\
\text { L2-216 } \\
\text { L2-261 } \\
\text { L2-306 } \\
\text { L2-351 } \\
\text { L3-36 } \\
\text { L3-81 } \\
\text { L3-126 } \\
\text { L3-171 } \\
\text { L3-216 } \\
\text { L3-261 } \\
\text { L3-306 } \\
\text { L3-351 } \\
\text { L4-36 } \\
\text { L4-81 } \\
\text { L4-126 } \\
\text { L4-171 } \\
\text { L4-216 } \\
\text { L4-261 } \\
\text { L4-306 } \\
\text { L4-351 } \\
\text { L5-36 } \\
\text { L5-81 } \\
\text { L5-126 } \\
L 5-171 \\
\text { L5-216 } \\
\text { L5-261 } \\
\text { L5-306 } \\
\text { L5-351 } \\
\text { L6-36 } \\
\text { L6-81 } \\
\text { L6-126 } \\
\text { L6-171 }\end{array}$ & 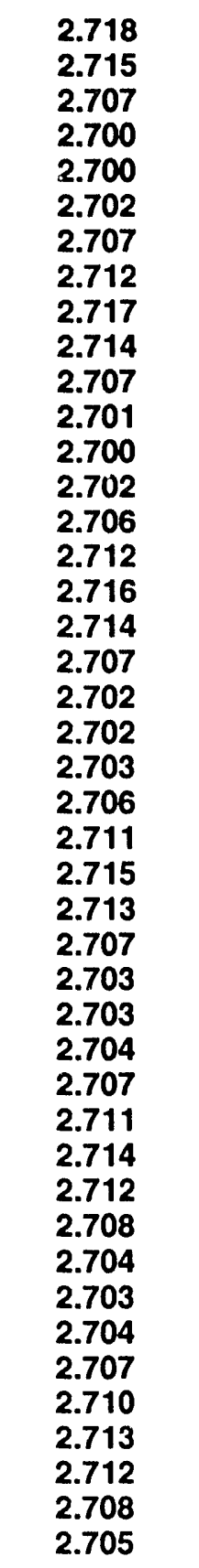 & $\begin{array}{l}2.728 \\
2.728 \\
2.722 \\
2.716 \\
2.718 \\
2.723 \\
2.727 \\
2.727 \\
2.735 \\
2.733 \\
2.727 \\
2.725 \\
2.725 \\
2.729 \\
2.733 \\
2.735 \\
2.736 \\
2.733 \\
2.728 \\
2.727 \\
2.728 \\
2.731 \\
2.733 \\
2.736 \\
2.735 \\
2.732 \\
2.728 \\
2.728 \\
2.730 \\
2.731 \\
2.733 \\
2.736 \\
2.735 \\
2.733 \\
2.729 \\
2.729 \\
2.732 \\
2.733 \\
2.733 \\
2.735 \\
2.734 \\
2.732 \\
2.729 \\
2.729 \\
\end{array}$ & $\begin{array}{l}0.010 \\
0.013 \\
0.015 \\
0.016 \\
0.018 \\
0.021 \\
0.020 \\
0.015 \\
0.018 \\
0.019 \\
0.020 \\
0.024 \\
0.025 \\
0.027 \\
0.027 \\
0.023 \\
0.020 \\
0.019 \\
0.021 \\
0.025 \\
0.026 \\
0.028 \\
0.027 \\
0.025 \\
0.020 \\
0.019 \\
0.021 \\
0.025 \\
0.027 \\
0.027 \\
0.026 \\
0.025 \\
0.021 \\
0.021 \\
0.021 \\
0.025 \\
0.029 \\
0.029 \\
0.026 \\
0.025 \\
0.021 \\
0.020 \\
0.021 \\
0.024\end{array}$ \\
\hline
\end{tabular}




\section{CYLINDER}

DIMENSIONAL INSPECTION DATA

\section{STATIC CRUSH, TEST 8}

MEASUREMENT DESIGNATION

L6-216
L6-261
L6-306
L6-351
L7-36
L7-81
L7-126
L7-171
L7-216
L7-261
L7-306
L7-351
L8-36
L8-81
L8-126
L8-171
L8-216
L8-261
L8-306
L8-351
L9-36
L9-81
L9-126
L9-171
L9-216
L9-261
L9-306
L9-351
L10-36
L10-81
L10-126
L10-171
L10-216
L10-261
L10-306
L10-351
L11-36
L11-81
L11-126
L11-171
L11-216
L11-261
L11-306
L11-351

\section{PRE-TEST}

2.705

2.705

2.707

2.710

2.713

2.711

2.708

2.706

2.706

2.706

2.707

2.710

2.712

2.711

2.709

2.707

2.706

2.707

2.708

2.710

2.711

2.710

2.709

2.708

2.708

2.707

2.708

2.709

2.710

2.710

2.709

2.709

2.709

2.708

2.709

2.709

2.710

2.709

2.709

2.710

2.709

2.709

2.709

2.709

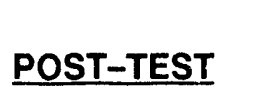

2.732

2.733

2.733

2.734

2.732

2.732

2.729

2.729

2.732

2.733

2.732

2.732

2.730

2.730

2.729

2.729

2.732

2.733

2.731

2.730

2.730

2.730

2.729

2.730

2.732

2.732

2.731

2.730

2.730

2.730

2.730

2.732

2.732

2.732

2.731

2.730

2.730

2.731

2.732

2.733

2.733

2.732

2.732

2.731
MEASUREMENT CHANGE

0.027

0.028

0.026

0.024

0.019

0.021

0.021

0.023

0.026

0.027

0.025

0.022

0.018

0.019

0.020

0.022

0.026

0.026

0.023

0.020

0.019

0.020

0.020

0.022

0.024

0.025

0.023

0.021

0.020

0.020

0.021

0.023

0.023

0.024

0.022

0.021

0.020

0.022

0.023

0.023

0.024

0.023

0.023

0.022 


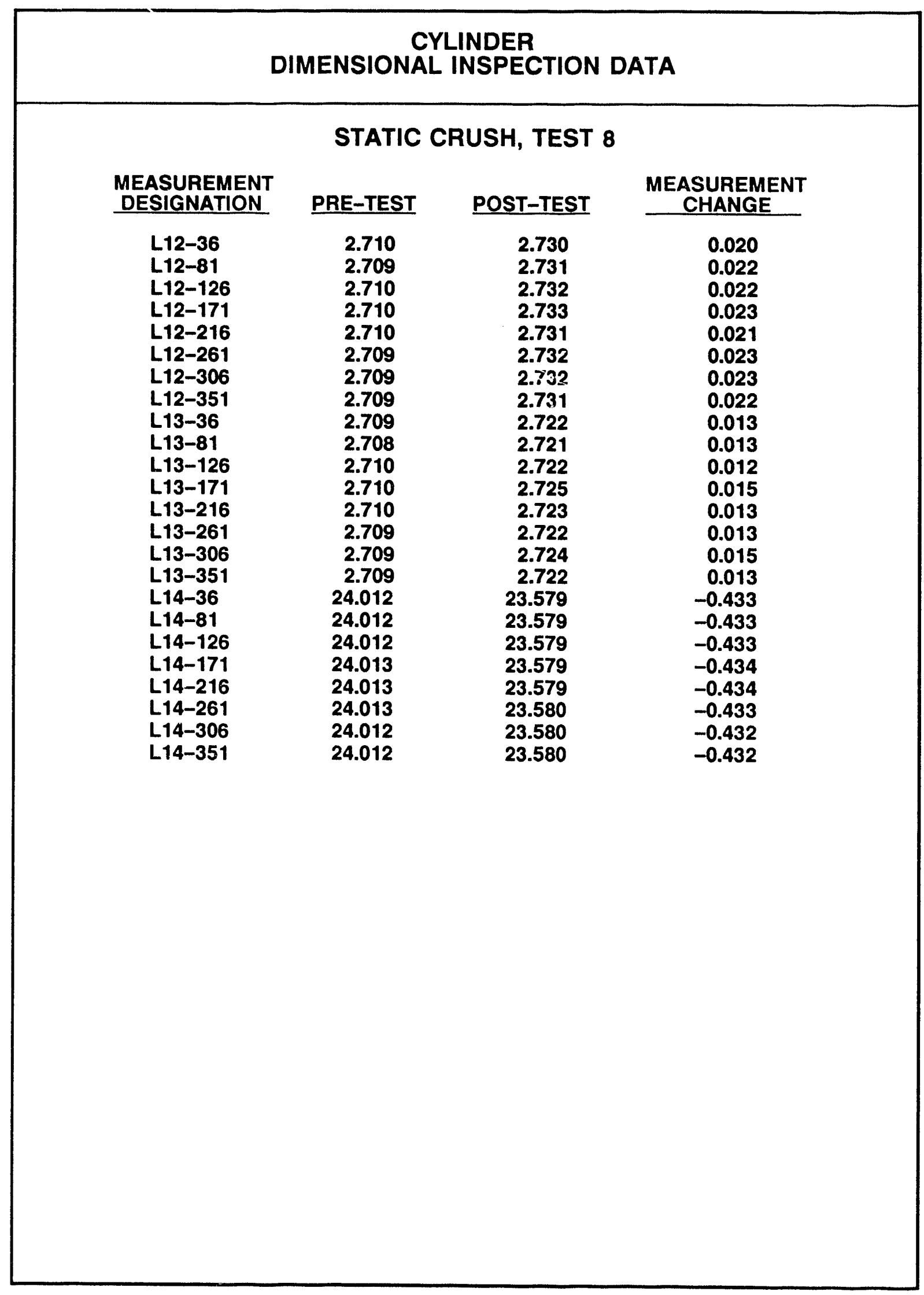




\begin{tabular}{|c|c|c|c|}
\hline \multicolumn{4}{|c|}{$\begin{array}{c}\text { CYLINDER } \\
\text { DIMENSIONAL INSPECTION DATA }\end{array}$} \\
\hline \multicolumn{4}{|c|}{ STATIC CRUSH, TEST 9} \\
\hline $\begin{array}{l}\text { MEASUREMENT } \\
\text { DESIGNATION }\end{array}$ & PRE-TEST & POST-TEST & $\begin{array}{c}\text { MEASUREMENT } \\
\text { CHANGE } \\
\end{array}$ \\
\hline $\begin{array}{l}\text { L1-36 } \\
\text { L1-81 } \\
\text { L1-126 } \\
\text { L1-171 } \\
\text { L1-216 } \\
\text { L1-261 } \\
\text { L1-306 } \\
\text { L1-351 } \\
\text { L2-36 } \\
\text { L2-81 } \\
\text { L2-126 } \\
\text { L2-171 } \\
\text { L2-216 } \\
\text { L2-261 } \\
\text { L2-306 } \\
\text { L2-351 } \\
\text { L3-36 } \\
\text { L3-81 } \\
\text { L3-126 } \\
\text { L3-171 } \\
\text { L3-216 } \\
\text { L3-261 } \\
\text { L3-306 } \\
\text { L3-351 } \\
\text { L4-36 } \\
\text { L4-81 } \\
\text { L4-126 } \\
\text { L4-171 } \\
\text { L4-216 } \\
\text { L4-261 } \\
\text { L4-306 } \\
L 4-351 \\
L 5-36 \\
L 5-81 \\
L 5-126 \\
L 5-171 \\
L 5-216 \\
L 5-261 \\
L 5-306 \\
L 5-351 \\
\text { L6-36 } \\
\text { L6-81 } \\
\text { L6-126 } \\
\text { L6-171 }\end{array}$ & $\begin{array}{l}2.702 \\
2.704 \\
2.708 \\
2.711 \\
2.712 \\
2.710 \\
2.707 \\
2.703 \\
2.703 \\
2.705 \\
2.708 \\
2.711 \\
2.712 \\
2.710 \\
2.707 \\
2.703 \\
2.704 \\
2.706 \\
2.709 \\
2.711 \\
2.712 \\
2.710 \\
2.707 \\
2.704 \\
2.704 \\
2.706 \\
2.709 \\
2.711 \\
2.711 \\
2.710 \\
2.708 \\
2.705 \\
2.705 \\
2.706 \\
2.709 \\
2.710 \\
2.711 \\
2.710 \\
2.708 \\
2.705 \\
2.705 \\
2.707 \\
2.709 \\
2.710\end{array}$ & $\begin{array}{l}2.721 \\
2.725 \\
2.729 \\
2.729 \\
2.727 \\
2.721 \\
2.720 \\
2.720 \\
2.731 \\
2.734 \\
2.737 \\
2.737 \\
2.734 \\
2.730 \\
2.728 \\
2.728 \\
2.731 \\
2.734 \\
2.737 \\
2.738 \\
2.734 \\
2.731 \\
2.729 \\
2.729 \\
2.730 \\
2.733 \\
2.736 \\
2.737 \\
2.733 \\
2.732 \\
2.728 \\
2.729 \\
2.730 \\
2.732 \\
2.735 \\
2.735 \\
2.734 \\
2.732 \\
2.730 \\
2.730 \\
2.731 \\
2.733 \\
2.735 \\
2.735\end{array}$ & $\begin{array}{l}0.019 \\
0.021 \\
0.021 \\
0.018 \\
0.015 \\
0.011 \\
0.013 \\
0.017 \\
0.028 \\
0.029 \\
0.029 \\
0.026 \\
0.022 \\
0.020 \\
0.021 \\
0.025 \\
0.027 \\
0.028 \\
0.028 \\
0.027 \\
0.022 \\
0.021 \\
0.022 \\
0.025 \\
0.026 \\
0.027 \\
0.027 \\
0.026 \\
0.022 \\
0.022 \\
0.020 \\
0.024 \\
0.025 \\
0.026 \\
0.026 \\
0.025 \\
0.023 \\
0.022 \\
0.022 \\
0.025 \\
0.026 \\
0.026 \\
0.026 \\
0.025\end{array}$ \\
\hline
\end{tabular}




\begin{tabular}{|c|c|c|c|}
\hline \multicolumn{4}{|c|}{$\begin{array}{c}\text { CYLINDER } \\
\text { DIMENSIONAL INSPECTION DATA }\end{array}$} \\
\hline \multicolumn{4}{|c|}{ STATIC CRUSH, TEST 9} \\
\hline $\begin{array}{l}\text { MEASUREMENT } \\
\text { DESIGNATION }\end{array}$ & PRE-TEST & POST-TEST & $\begin{array}{c}\text { MEASUREMENT } \\
\text { CHANGE } \\
\end{array}$ \\
\hline $\begin{array}{l}\text { L6-216 } \\
\text { L6-261 } \\
L 6-306 \\
L 6-351 \\
L 7-36 \\
L 7-81 \\
L 7-126 \\
L 7-171 \\
L 7-216 \\
L 7-261 \\
L 7-306 \\
L 7-351 \\
L 8-36 \\
L 8-81 \\
L 8-126 \\
L 8-171 \\
L 8-216 \\
L 8-261 \\
L 8-306 \\
L 8-351 \\
L 9-36 \\
L 9-81 \\
L 9-126 \\
L 9-171 \\
L 9-216 \\
L 9-261 \\
L 9-306 \\
L 9-351 \\
L 10-36 \\
L 10-81 \\
L 10-126 \\
L 10-171 \\
L 10-216 \\
L 10-261 \\
L 10-306 \\
L 10-351 \\
L 11-36 \\
L 11-81 \\
L 11-126 \\
L 11-171 \\
L 11-216 \\
L 11-261 \\
L 11-306 \\
L 11-351 \\
\text { L }\end{array}$ & $\begin{array}{l}2.711 \\
2.710 \\
2.708 \\
2.706 \\
2.706 \\
2.707 \\
2.709 \\
2.710 \\
2.710 \\
2.709 \\
2.708 \\
2.706 \\
2.707 \\
2.708 \\
2.709 \\
2.710 \\
2.710 \\
2.709 \\
2.708 \\
2.706 \\
2.707 \\
2.708 \\
2.709 \\
2.709 \\
2.710 \\
2.709 \\
2.709 \\
2.707 \\
2.708 \\
2.709 \\
2.709 \\
2.709 \\
2.709 \\
2.709 \\
2.710 \\
2.708 \\
2.708 \\
2.709 \\
2.709 \\
2.709 \\
2.709 \\
2.709 \\
2.710 \\
2.708\end{array}$ & $\begin{array}{l}2.733 \\
2.732 \\
2.731 \\
2.731 \\
2.732 \\
2.732 \\
2.733 \\
2.733 \\
2.732 \\
2.732 \\
2.733 \\
2.733 \\
2.732 \\
2.732 \\
2.733 \\
2.733 \\
2.732 \\
2.732 \\
2.733 \\
2.733 \\
2.733 \\
2.732 \\
2.734 \\
2.733 \\
2.732 \\
2.734 \\
2.735 \\
2.734 \\
2.733 \\
2.733 \\
2.734 \\
2.734 \\
2.733 \\
2.734 \\
2.735 \\
2.735 \\
2.735 \\
2.734 \\
2.734 \\
2.735 \\
2.735 \\
2.734 \\
2.735 \\
2.735\end{array}$ & $\begin{array}{l}0.022 \\
0.022 \\
0.023 \\
0.025 \\
0.026 \\
0.025 \\
0.024 \\
0.023 \\
0.022 \\
0.023 \\
0.025 \\
0.027 \\
0.025 \\
0.024 \\
0.024 \\
0.023 \\
0.022 \\
0.023 \\
0.025 \\
0.027 \\
0.026 \\
0.024 \\
0.025 \\
0.024 \\
0.022 \\
0.025 \\
0.026 \\
0.027 \\
0.025 \\
0.024 \\
0.025 \\
0.025 \\
0.024 \\
0.025 \\
0.025 \\
0.027 \\
0.027 \\
0.025 \\
0.025 \\
0.026 \\
0.026 \\
0.025 \\
0.025 \\
0.027\end{array}$ \\
\hline
\end{tabular}




\section{CYLINDER}

DIMENSIONAL INSPECTION DATA

\section{STATIC CRUSH, TEST 9}

MEASUREMENT DESIGNATION

$\begin{array}{lr}\text { L12-36 } & 2.709 \\ \text { L12-81 } & 2.709 \\ \text { L12-126 } & 2.709 \\ \text { L12-171 } & 2.709 \\ \text { L12-216 } & 2.709 \\ \text { L12-261 } & 2.709 \\ \text { L12-306 } & 2.710 \\ \text { L12-351 } & 2.709 \\ \text { L13-36 } & 2.709 \\ \text { L13-81 } & 2.710 \\ \text { L13-126 } & 2.710 \\ \text { L13-171 } & 2.709 \\ \text { L13-216 } & 2.709 \\ \text { L13-261 } & 2.709 \\ \text { L13-306 } & 2.710 \\ \text { L13-351 } & 2.709 \\ \text { L14-36 } & 24.013 \\ \text { L14-81 } & 24.014 \\ \text { L14-126 } & 24.014 \\ \text { L14-171 } & 24.013 \\ \text { L14-216 } & 24.013 \\ \text { L14-261 } & 24.013 \\ \text { L14-306 } & 24.013 \\ \text { L14-351 } & 24.013\end{array}$

POST-TEST

2.735

2.734

2.733

2.734

2.736

2.735

2.733

2.735

2.728

2.725

2.723

2.727

2.730

2.725

2.725

2.729

23.573

23.573

23.573

23.573

23.572

23.572

23.572

23.572
MEASUREMENT

CHANGE

0.026

0.025

0.024

0.025

0.027

0.026

0.023

0.026

0.019

0.015

0.013

0.018

0.021

0.016

0.015

0.020

$-0.440$

$-0.441$

$-0.441$

$-0.440$

$-0.441$

$-0.441$

$-0.441$

$-0.441$ 


\begin{tabular}{|c|c|c|c|}
\hline \multicolumn{4}{|c|}{$\begin{array}{c}\text { CYLINDER } \\
\text { DIMENSIONAL INSPECTION DATA }\end{array}$} \\
\hline \multicolumn{4}{|c|}{ STATIC CRUSH, TEST 10} \\
\hline $\begin{array}{l}\text { MEASUREMENT } \\
\text { DESIGNATION }\end{array}$ & PRE-TEST & POST-TEST & $\begin{array}{c}\text { MEASUREMENT } \\
\text { CHANGE } \\
\end{array}$ \\
\hline $\begin{array}{l}\text { L1-36 } \\
\text { L1-81 } \\
\text { L1-126 } \\
\text { L1-171 } \\
\text { L1-216 } \\
\text { L1-261 } \\
\text { L1-306 } \\
\text { L1-351 } \\
\text { L2-36 } \\
\text { L2-81 } \\
\text { L2-126 } \\
\text { L2-171 } \\
\text { L2-216 } \\
\text { L2-261 } \\
\text { L2-306 } \\
\text { L2-351 } \\
\text { L3-36 } \\
\text { L3-81 } \\
\text { L3-126 } \\
\text { L3-171 } \\
\text { L3-216 } \\
\text { L3-261 } \\
\text { L3-306 } \\
\text { L3-351 } \\
\text { L4-36 } \\
\text { L4-81 } \\
\text { L4-126 } \\
\text { L4-171 } \\
\text { L4-216 } \\
\text { L4-261 } \\
\text { L4-306 } \\
\text { L4-351 } \\
\text { L5-36 } \\
\text { L5-81 } \\
\text { L5-126 } \\
\text { L5-171 } \\
\text { L5-216 } \\
\text { L5-261 } \\
\text { L5-306 } \\
\text { L5-351 } \\
\text { L6-36 } \\
\text { L6-81 } \\
\text { L6-126 } \\
\text { L6-171 }\end{array}$ & $\begin{array}{l}2.707 \\
2.705 \\
2.706 \\
2.707 \\
2.711 \\
2.714 \\
2.714 \\
2.711 \\
2.708 \\
2.705 \\
2.706 \\
2.707 \\
2.711 \\
2.714 \\
2.714 \\
2.711 \\
2.708 \\
2.706 \\
2.706 \\
2.707 \\
2.711 \\
2.713 \\
2.713 \\
2.711 \\
2.709 \\
2.708 \\
2.708 \\
2.708 \\
2.711 \\
2.713 \\
2.713 \\
2.711 \\
2.709 \\
2.708 \\
2.708 \\
2.708 \\
2.710 \\
2.712 \\
2.713 \\
2.710 \\
2.709 \\
2.709 \\
2.708 \\
2.708\end{array}$ & $\begin{array}{l}2.721 \\
2.718 \\
2.720 \\
2.727 \\
2.730 \\
2.731 \\
2.731 \\
2.728 \\
2.731 \\
2.727 \\
2.729 \\
2.733 \\
2.738 \\
2.739 \\
2.740 \\
2.737 \\
2.732 \\
2.729 \\
2.730 \\
2.733 \\
2.737 \\
2.739 \\
2.740 \\
2.737 \\
2.733 \\
2.730 \\
2.730 \\
2.730 \\
2.734 \\
2.736 \\
2.738 \\
2.737 \\
2.734 \\
2.731 \\
2.730 \\
2.730 \\
2.732 \\
2.735 \\
2.737 \\
2.737 \\
2.735 \\
2.732 \\
2.730 \\
2.730\end{array}$ & $\begin{array}{l}0.014 \\
0.013 \\
0.014 \\
0.020 \\
0.019 \\
0.017 \\
0.017 \\
0.017 \\
0.023 \\
0.022 \\
0.023 \\
0.026 \\
0.027 \\
0.025 \\
0.026 \\
0.026 \\
0.024 \\
0.023 \\
0.024 \\
0.026 \\
0.026 \\
0.026 \\
0.027 \\
0.026 \\
0.024 \\
0.022 \\
0.022 \\
0.022 \\
0.023 \\
0.023 \\
0.025 \\
0.026 \\
0.025 \\
0.023 \\
0.022 \\
0.022 \\
0.022 \\
0.023 \\
0.024 \\
0.027 \\
0.026 \\
0.023 \\
0.022 \\
0.022\end{array}$ \\
\hline
\end{tabular}




\begin{tabular}{|c|c|c|c|}
\hline \multicolumn{4}{|c|}{$\begin{array}{c}\text { CYLINDER } \\
\text { DIMENSIONAL INSPECTION DATA }\end{array}$} \\
\hline \multicolumn{4}{|c|}{ STATIC CRUSH, TEST 10} \\
\hline $\begin{array}{l}\text { MEASUREMENT } \\
\text { DESIGNATION }\end{array}$ & PRE-TEST & POST-TEST & $\begin{array}{c}\text { MEASUREMENT } \\
\text { CHANGE } \\
\end{array}$ \\
\hline 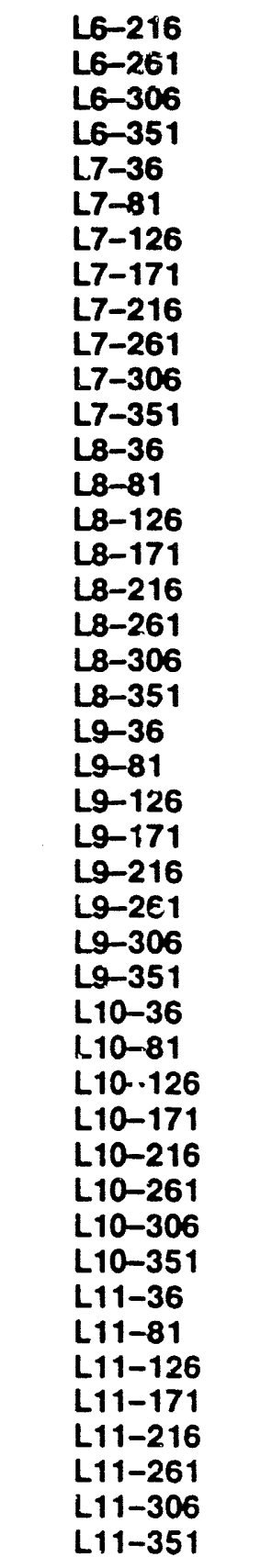 & $\begin{array}{l}2.710 \\
2.712 \\
2.712 \\
2.710 \\
2.709 \\
2.710 \\
2.708 \\
2.709 \\
2.710 \\
2.712 \\
2.712 \\
2.710 \\
2.709 \\
2.710 \\
2.709 \\
2.709 \\
2.710 \\
2.711 \\
2.711 \\
2.710 \\
2.710 \\
2.710 \\
2.710 \\
2.709 \\
2.710 \\
2.710 \\
2.711 \\
2.710 \\
2.710 \\
2.710 \\
2.709 \\
2.710 \\
2.710 \\
2.710 \\
2.710 \\
2.710 \\
2.710 \\
2.710 \\
2.710 \\
2.710 \\
2.710 \\
2.710 \\
2.710 \\
2.710\end{array}$ & $\begin{array}{l}2.732 \\
2.733 \\
2.736 \\
2.736 \\
2.735 \\
2.732 \\
2.730 \\
2.730 \\
2.732 \\
2.733 \\
2.735 \\
2.736 \\
2.735 \\
2.732 \\
2.730 \\
2.730 \\
2.732 \\
2.733 \\
2.735 \\
2.736 \\
2.734 \\
2.731 \\
2.730 \\
2.731 \\
2.733 \\
2.732 \\
2.734 \\
2.735 \\
2.733 \\
2.731 \\
2.730 \\
2.731 \\
2.733 \\
2.733 \\
2.733 \\
2.733 \\
2.733 \\
2.732 \\
2.731 \\
2.732 \\
2.734 \\
2.733 \\
2.733 \\
2.733\end{array}$ & $\begin{array}{l}0.022 \\
0.021 \\
0.024 \\
0.026 \\
0.026 \\
0.022 \\
0.022 \\
0.021 \\
0.022 \\
0.021 \\
0.023 \\
0.026 \\
0.026 \\
0.022 \\
0.021 \\
0.021 \\
0.022 \\
0.022 \\
0.024 \\
0.026 \\
0.024 \\
0.021 \\
0.020 \\
0.022 \\
0.023 \\
0.022 \\
0.023 \\
0.025 \\
0.023 \\
0.021 \\
0.021 \\
0.021 \\
0.023 \\
0.023 \\
0.023 \\
0.023 \\
0.023 \\
0.022 \\
0.021 \\
0.022 \\
0.024 \\
0.023 \\
0.023 \\
0.023\end{array}$ \\
\hline
\end{tabular}




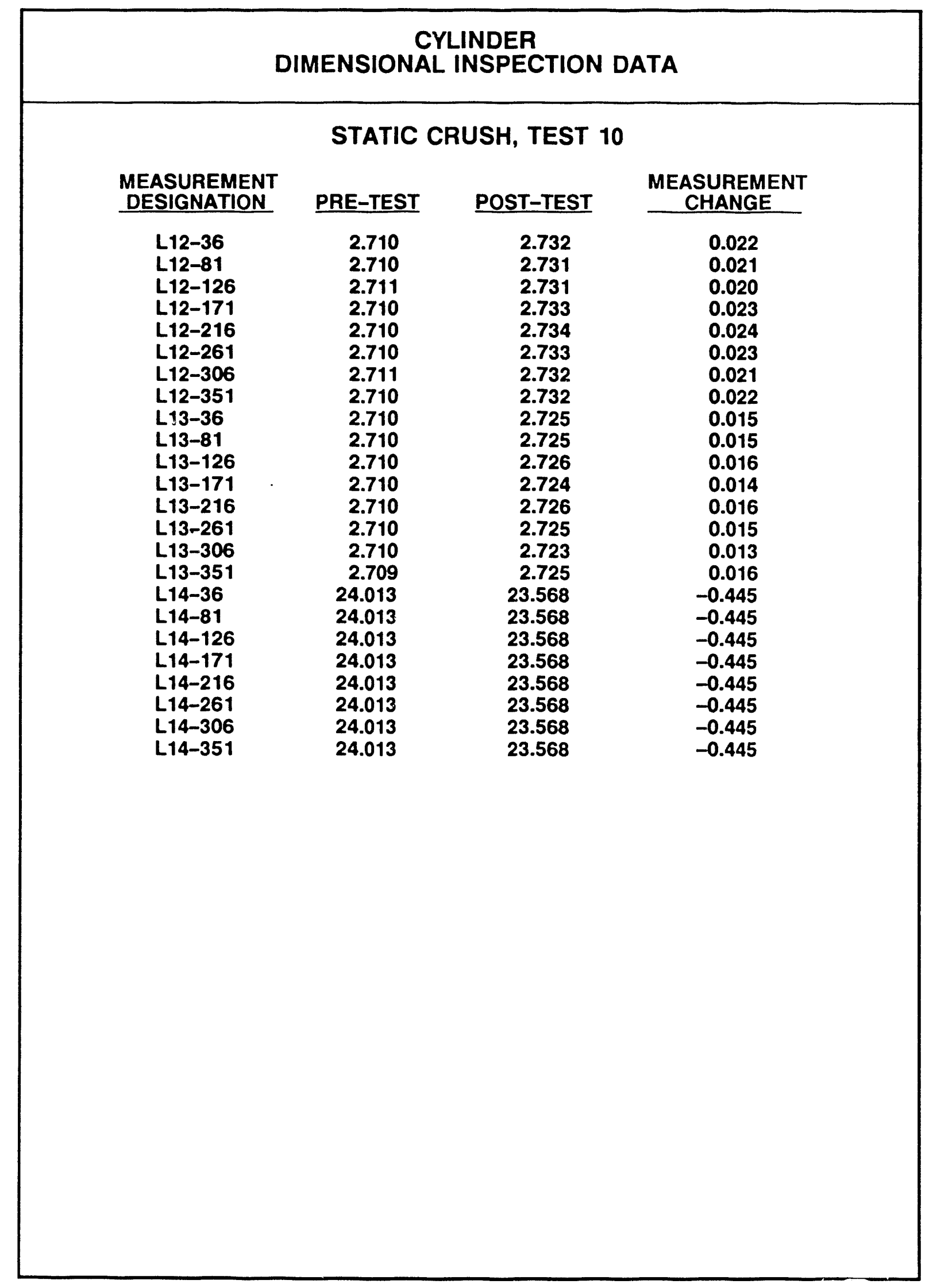




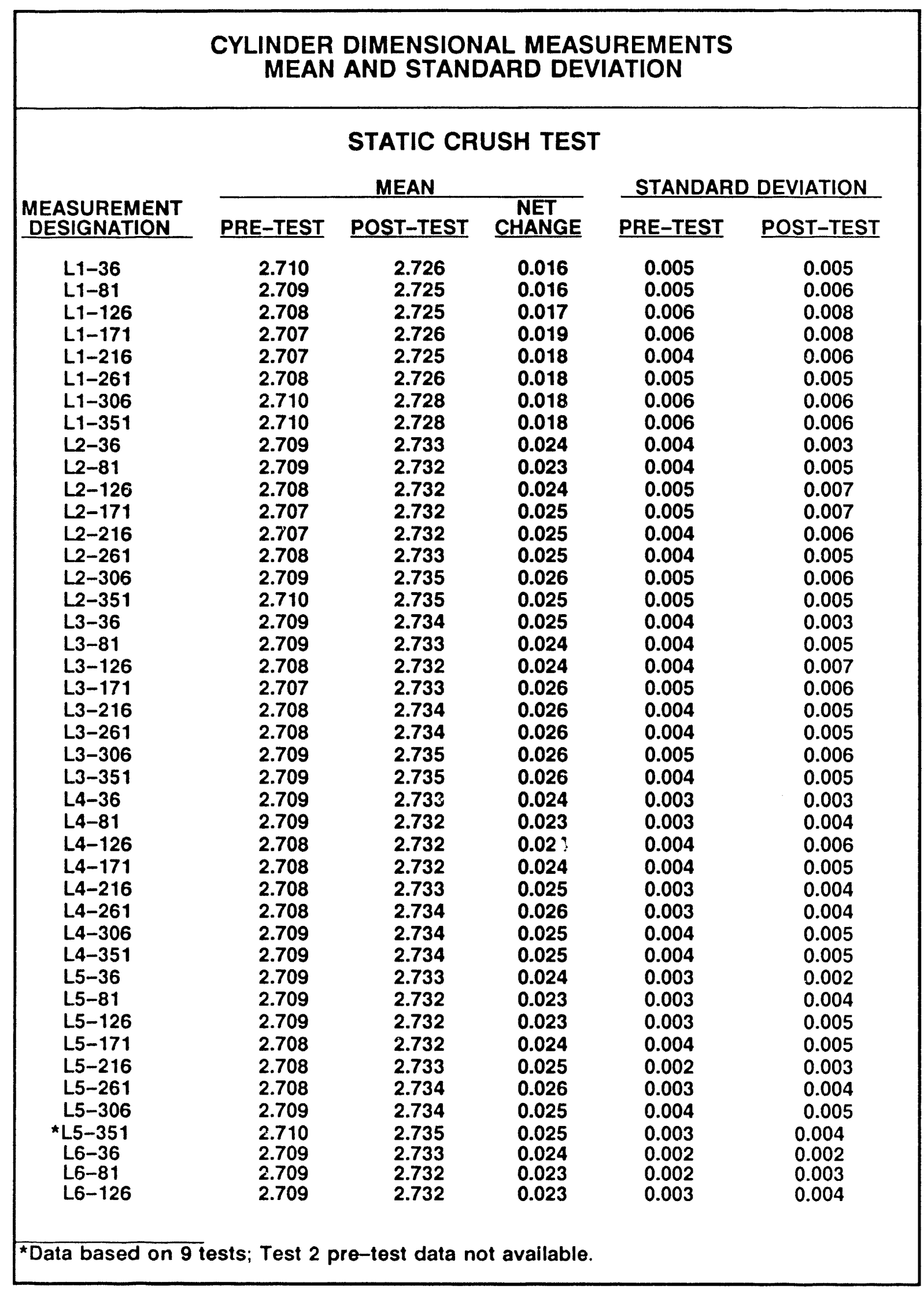




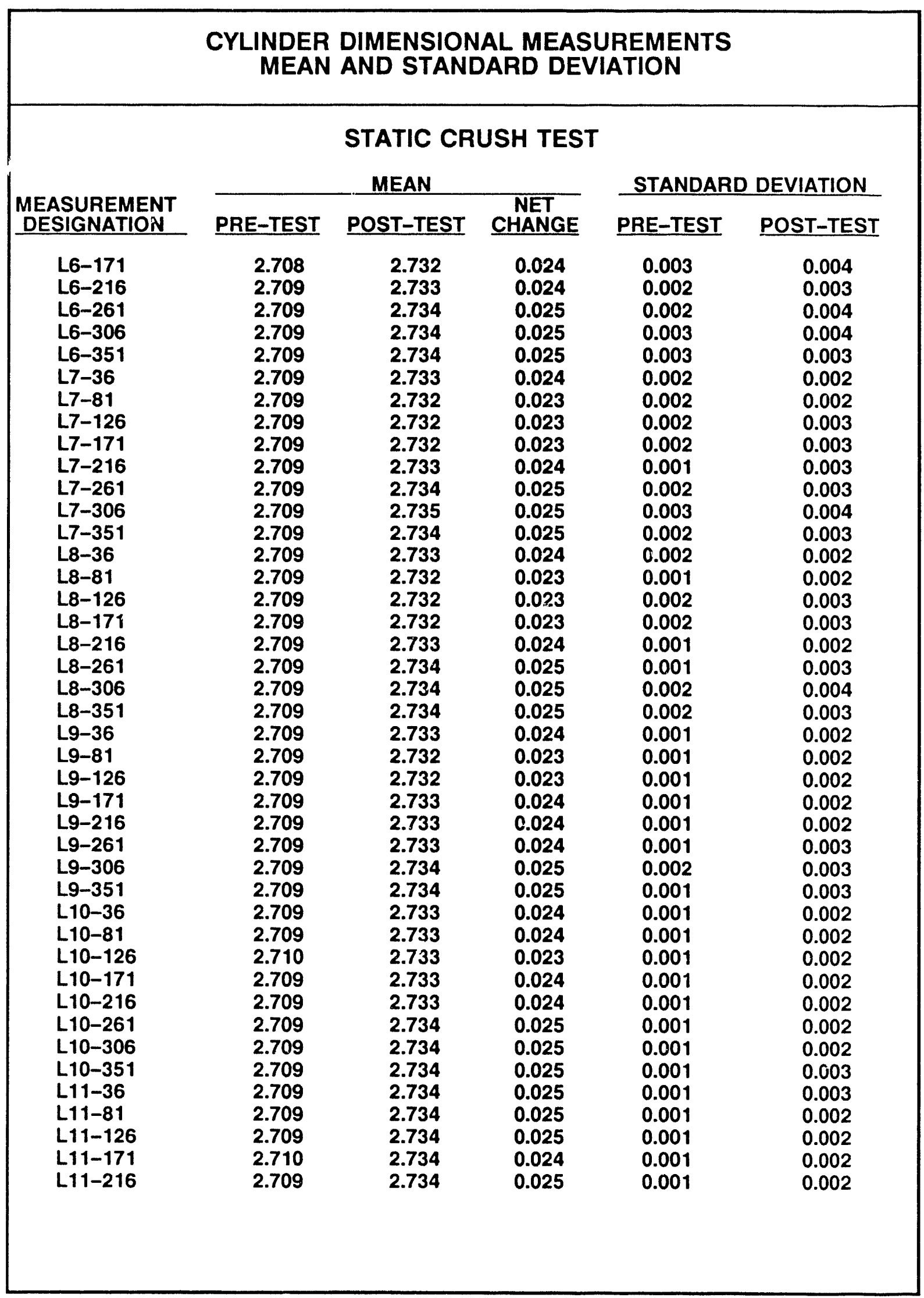




\begin{tabular}{|c|c|c|c|c|c|}
\hline \multicolumn{6}{|c|}{$\begin{array}{l}\text { CYLINDER DIMENSIONAL MEASUREMENTS } \\
\text { MEAN AND STANDARD DEVIATION }\end{array}$} \\
\hline \multirow{2}{*}{$\begin{array}{l}\text { MEASUREMENT } \\
\text { DESIGNATION } \\
\end{array}$} & \multicolumn{3}{|c|}{$\begin{array}{l}\text { STATIC CRUSH TEST } \\
\text { MEAN }\end{array}$} & \multicolumn{2}{|c|}{ STANDARD DEVIATION } \\
\hline & PRE-TEST & POST-TEST & CHANGE & PRE-TEST & POST-TEST \\
\hline $\begin{array}{l}\text { L11-261 } \\
\text { L11-306 } \\
\text { L11-351 } \\
\text { L12-36 } \\
\text { L12-81 } \\
\text { L12-126 } \\
\text { L12-171 } \\
\text { L12-216 } \\
\text { L12-261 } \\
\text { L12-306 } \\
\text { L12-351 } \\
\text { L13-36 } \\
\text { L13-81 } \\
\text { L13-126 } \\
\text { L13-171 } \\
\text { L13-216 } \\
\text { L13-261 } \\
\text { L13-306 } \\
\text { L13-351 } \\
\text { L14-36 } \\
\text { L14-81 } \\
\text { L14-126 } \\
\text { L14-171 } \\
\text { L14-216 } \\
\text { L14-261 } \\
\text { L14-306 } \\
\text { L14-351 }\end{array}$ & $\begin{array}{r}2.709 \\
2.709 \\
2.709 \\
2.709 \\
2.709 \\
2.710 \\
2.710 \\
2.709 \\
2.709 \\
2.709 \\
2.709 \\
2.709 \\
2.709 \\
2.710 \\
2.710 \\
2.709 \\
2.709 \\
2.709 \\
2.708 \\
24.007 \\
24.007 \\
24.008 \\
24.008 \\
24.008 \\
24.008 \\
24.007 \\
24.007\end{array}$ & $\begin{array}{r}2.734 \\
2.734 \\
2.734 \\
2.734 \\
2.733 \\
2.733 \\
2.733 \\
2.733 \\
2.734 \\
2.733 \\
2.734 \\
2.725 \\
2.725 \\
2.724 \\
2.725 \\
2.725 \\
2.725 \\
2.725 \\
2.725 \\
23.565 \\
23.565 \\
23.566 \\
23.566 \\
23.566 \\
23.566 \\
23.565 \\
23.565\end{array}$ & $\begin{array}{l}0.025 \\
0.025 \\
0.025 \\
0.025 \\
0.024 \\
0.023 \\
0.023 \\
0.024 \\
0.025 \\
0.024 \\
0.025 \\
0.016 \\
0.016 \\
0.014 \\
0.015 \\
0.016 \\
0.016 \\
0.016 \\
0.017 \\
-0.442 \\
-0.442 \\
-0.442 \\
-0.442 \\
-0.442 \\
-0.442 \\
-0.442 \\
-0.442\end{array}$ & $\begin{array}{l}0.001 \\
0.001 \\
0.001 \\
0.001 \\
0.001 \\
0.001 \\
0.001 \\
0.001 \\
0.001 \\
0.002 \\
0.001 \\
0.001 \\
0.001 \\
0.002 \\
0.001 \\
0.001 \\
0.001 \\
0.002 \\
0.002 \\
0.009 \\
0.008 \\
0.009 \\
0.009 \\
0.009 \\
0.009 \\
0.009 \\
0.009\end{array}$ & $\begin{array}{l}0.002 \\
0.002 \\
0.002 \\
0.003 \\
0.002 \\
0.002 \\
0.002 \\
0.002 \\
0.002 \\
0.002 \\
0.002 \\
0.003 \\
0.002 \\
0.002 \\
0.002 \\
0.003 \\
0.002 \\
0.002 \\
0.002 \\
0.011 \\
0.011 \\
0.011 \\
0.011 \\
0.011 \\
0.012 \\
0.012 \\
0.011\end{array}$ \\
\hline
\end{tabular}


APPENDIX C

END IMPACT DIMENSIONAL INSPECTION DATA

C- 1 


\begin{tabular}{|c|c|c|c|}
\hline \multicolumn{4}{|c|}{$\begin{array}{c}\text { CYLINDER } \\
\text { DIMENSIONAL INSPECTION DATA }\end{array}$} \\
\hline \multicolumn{4}{|c|}{ END IMPACT, TEST 1} \\
\hline $\begin{array}{l}\text { MEASUREMENT } \\
\text { DESIGNATION } \\
\end{array}$ & PRE-TEST & POST-TEST & $\begin{array}{c}\text { MEASUREMENT } \\
\text { CHANGE } \\
\end{array}$ \\
\hline $\begin{array}{l}\text { L1-36 } \\
\text { L1-81 } \\
\text { L1-126 } \\
\text { L1-171 } \\
\text { L1-216 } \\
\text { L1-261 } \\
\text { L1-306 } \\
\text { L1-351 } \\
\text { L2-36 } \\
\text { L2-81 } \\
\text { L2-126 } \\
\text { L2-171 } \\
\text { L2-216 } \\
\text { L2-261 } \\
\text { L2-306 } \\
\text { L2-351 } \\
\text { L3 }-36 \\
\text { L3-81 } \\
\text { L3-126 } \\
\text { L3-171 } \\
\text { L3-216 } \\
\text { L3-261 } \\
\text { L3-306 } \\
\text { L3-351 } \\
\text { L4-36 } \\
\text { L4-81 } \\
\text { L4-126 } \\
\text { L4-171 } \\
\text { L4-216 } \\
\text { L4-261 } \\
\text { L4-306 } \\
\text { L4-351 } \\
\text { L5-36 } \\
\text { L5-81 } \\
\text { L5-126 } \\
\text { L5-171 } \\
\text { L5-216 } \\
\text { L5-261 } \\
\text { L5-306 } \\
\text { L5-351 } \\
\text { L6-36 } \\
\text { L6-81 } \\
\text { L6-126 }\end{array}$ & $\begin{array}{l}2.705 \\
2.705 \\
2.701 \\
2.698 \\
2.701 \\
2.703 \\
2.703 \\
2.704 \\
2.707 \\
2.706 \\
2.703 \\
2.701 \\
2.703 \\
2.706 \\
2.706 \\
2.707 \\
2.708 \\
2.707 \\
2.705 \\
2.703 \\
2.706 \\
2.707 \\
2.708 \\
2.708 \\
2.709 \\
2.708 \\
2.707 \\
2.706 \\
2.707 \\
2.708 \\
2.709 \\
2.709 \\
2.709 \\
2.708 \\
2.707 \\
2.707 \\
2.707 \\
2.708 \\
2.709 \\
2.709 \\
2.709 \\
2.708 \\
2.707\end{array}$ & $\begin{array}{l}2.709 \\
2.709 \\
2.709 \\
2.709 \\
2.709 \\
2.708 \\
2.707 \\
2.707 \\
2.709 \\
2.710 \\
2.711 \\
2.709 \\
2.707 \\
2.705 \\
2.703 \\
2.704 \\
2.715 \\
2.715 \\
2.711 \\
2.708 \\
2.706 \\
2.707 \\
2.707 \\
2.712 \\
2.732 \\
2.715 \\
2.695 \\
2.690 \\
2.700 \\
2.718 \\
2.724 \\
2.739 \\
2.732 \\
2.715 \\
2.695 \\
2.689 \\
2.699 \\
2.718 \\
2.724 \\
2.740 \\
2.732 \\
2.715 \\
2.695\end{array}$ & $\begin{array}{r}0.004 \\
0.004 \\
0.008 \\
0.011 \\
0.008 \\
0.005 \\
0.004 \\
0.003 \\
0.002 \\
0.004 \\
0.008 \\
0.008 \\
0.004 \\
-0.001 \\
-0.003 \\
-0.003 \\
0.007 \\
0.008 \\
0.006 \\
0.005 \\
0.000 \\
0.000 \\
-0.001 \\
0.004 \\
0.023 \\
0.007 \\
-0.012 \\
-0.016 \\
-0.007 \\
0.010 \\
0.015 \\
0.030 \\
0.023 \\
0.007 \\
-0.012 \\
-0.018 \\
-0.008 \\
0.010 \\
0.015 \\
0.031 \\
0.023 \\
0.007 \\
-0.012\end{array}$ \\
\hline
\end{tabular}




\begin{tabular}{|c|c|c|c|}
\hline \multicolumn{4}{|c|}{$\begin{array}{c}\text { CYLINDER } \\
\text { DIMENSIONAL INSPECTION DATA }\end{array}$} \\
\hline \multicolumn{4}{|c|}{ END IMPACT, TEST 1} \\
\hline $\begin{array}{l}\text { MEASUREMENT } \\
\text { DESIGNATION }\end{array}$ & PRE-TEST & POST-TEST & $\begin{array}{c}\text { MEASUREMENT } \\
\text { CHANGE } \\
\end{array}$ \\
\hline $\begin{array}{l}\text { L6-171 } \\
\text { L6-216 } \\
\text { L6-261 } \\
\text { L6-306 } \\
\text { L6-351 } \\
\text { L7-36 } \\
\text { L7-81 } \\
\text { L7-126 } \\
\text { L7-171 } \\
\text { L7-216 } \\
\text { L7-261 } \\
\text { L7-306 } \\
\text { L7-351 } \\
\text { L8-36 } \\
\text { L8-81 } \\
\text { L8-126 } \\
\text { L8-171 } \\
\text { L8-216 } \\
\text { L8-261 } \\
\text { L8-306 } \\
\text { L8-351 } \\
\text { L9-36 } \\
\text { L9-81 } \\
\text { L9-126 } \\
\text { L9-171 } \\
\text { L9-216 } \\
\text { L9-261 } \\
\text { L9-306 } \\
\text { L9-351 } \\
L 10-36 \\
\text { L10-81 } \\
\text { L10-126 } \\
\text { L10-171 } \\
\text { L10-216 } \\
\text { L10-261 } \\
\text { L10-306 } \\
\text { L10-351 } \\
\text { L11-36 } \\
\text { L11-81 } \\
\text { L11-126 } \\
\text { L11-171 } \\
\text { L11-216 } \\
\text { L11-261 }\end{array}$ & $\begin{array}{l}2.707 \\
2.707 \\
2.709 \\
2.709 \\
2.709 \\
2.709 \\
2.708 \\
2.708 \\
2.708 \\
2.708 \\
2.709 \\
2.709 \\
2.709 \\
2.709 \\
2.709 \\
2.708 \\
2.708 \\
2.708 \\
2.709 \\
2.709 \\
2.709 \\
2.709 \\
2.709 \\
2.708 \\
2.708 \\
2.708 \\
2.709 \\
2.709 \\
2.709 \\
2.709 \\
2.709 \\
2.709 \\
2.708 \\
2.709 \\
2.709 \\
2.710 \\
2.709 \\
2.709 \\
2.709 \\
2.709 \\
2.709 \\
2.709 \\
2.709\end{array}$ & $\begin{array}{l}2.689 \\
2.699 \\
2.718 \\
2.737 \\
2.742 \\
2.733 \\
2.716 \\
2.694 \\
2.691 \\
2.699 \\
2.718 \\
2.735 \\
2.740 \\
2.734 \\
2.716 \\
2.696 \\
2.692 \\
2.700 \\
2.716 \\
2.734 \\
2.740 \\
2.733 \\
2.717 \\
2.700 \\
2.696 \\
2.701 \\
2.713 \\
2.732 \\
2.738 \\
2.732 \\
2.718 \\
2.701 \\
2.700 \\
2.703 \\
2.710 \\
2.730 \\
2.736 \\
2.731 \\
2.719 \\
2.705 \\
2.702 \\
2.704 \\
2.709\end{array}$ & $\begin{array}{r}-0.018 \\
-0.008 \\
0.009 \\
0.028 \\
0.033 \\
0.024 \\
0.008 \\
-0.014 \\
-0.017 \\
-0.009 \\
0.009 \\
0.026 \\
0.031 \\
0.025 \\
0.007 \\
-0.012 \\
-0.016 \\
-0.008 \\
0.007 \\
0.025 \\
0.031 \\
0.024 \\
0.008 \\
-0.008 \\
-0.012 \\
-0.007 \\
0.004 \\
0.023 \\
0.029 \\
0.023 \\
0.009 \\
-0.008 \\
-0.008 \\
-0.006 \\
0.001 \\
0.020 \\
0.027 \\
0.022 \\
0.010 \\
-0.004 \\
-0.007 \\
-0.005 \\
0.000\end{array}$ \\
\hline
\end{tabular}




\begin{tabular}{|c|c|c|c|}
\hline \multicolumn{4}{|c|}{$\begin{array}{c}\text { CYLINDER } \\
\text { DIMENSIONAL INSPECTION DATA }\end{array}$} \\
\hline \multicolumn{4}{|c|}{ END IMPACT, TEST 1} \\
\hline $\begin{array}{l}\text { MEASUREMENT } \\
\text { DESIGNATION }\end{array}$ & PRE-TEST & POST-TEST & $\begin{array}{c}\text { MEASUREMENT } \\
\text { CHANGE } \\
\end{array}$ \\
\hline $\begin{array}{l}\text { L11-306 } \\
\text { L11-351 } \\
\text { L12-36 } \\
\text { L12-81 } \\
\text { L12-126 } \\
\text { L12-171 } \\
\text { L12-216 } \\
\text { L12-261 } \\
\text { L12-306 } \\
\text { L12-351 } \\
\text { L13-36 } \\
\text { L13-81 } \\
\text { L13-126 } \\
\text { L13-171 } \\
\text { L13-216 } \\
\text { L13-261 } \\
\text { L13-306 } \\
\text { L13-351 } \\
\text { L14-36 } \\
\text { L14-81 } \\
\text { L14-126 } \\
\text { L14-171 } \\
\text { L14-216 } \\
\text { L14-261 } \\
\text { L14-306 } \\
\text { L14-351 } \\
\text { L15-36 } \\
\text { L15-81 } \\
\text { L15-126 } \\
\text { L15-171 } \\
\text { L15-216 } \\
\text { L15-261 } \\
\text { L15-306 } \\
\text { L15-351 } \\
\text { L16-36 } \\
\text { L16-81 } \\
\text { L16-126 } \\
\text { L16-171 } \\
\text { L16-216 } \\
\text { L16-261 } \\
\text { L16-306 } \\
\text { L16-351 } \\
\text { L17-36 }\end{array}$ & $\begin{array}{l}2.710 \\
2.710 \\
2.709 \\
2.709 \\
2.709 \\
2.709 \\
2.709 \\
2.709 \\
2.710 \\
2.710 \\
2.709 \\
2.709 \\
2.709 \\
2.709 \\
2.709 \\
2.710 \\
2.710 \\
2.710 \\
2.709 \\
2.709 \\
2.709 \\
2.709 \\
2.709 \\
2.710 \\
2.710 \\
2.709 \\
2.709 \\
2.709 \\
2.710 \\
2.709 \\
2.709 \\
2.710 \\
2.710 \\
2.709 \\
2.709 \\
2.709 \\
2.710 \\
2.709 \\
2.710 \\
2.710 \\
2.710 \\
2.709 \\
2.709\end{array}$ & $\begin{array}{l}2.727 \\
2.733 \\
2.730 \\
2.721 \\
2.707 \\
2.705 \\
2.705 \\
2.708 \\
2.725 \\
2.731 \\
2.730 \\
2.720 \\
2.710 \\
2.707 \\
2.706 \\
2.708 \\
2.723 \\
2.730 \\
2.729 \\
2.721 \\
2.712 \\
2.709 \\
2.707 \\
2.707 \\
2.720 \\
2.727 \\
2.728 \\
2.722 \\
2.715 \\
2.711 \\
2.709 \\
2.706 \\
2.718 \\
2.724 \\
2.726 \\
2.724 \\
2.717 \\
2.713 \\
2.710 \\
2.703 \\
2.715 \\
2.721 \\
2.726\end{array}$ & $\begin{array}{r}0.017 \\
0.023 \\
0.021 \\
0.012 \\
-0.002 \\
-0.004 \\
-0.004 \\
-0.001 \\
0.015 \\
0.021 \\
0.021 \\
0.011 \\
0.001 \\
-0.002 \\
-0.003 \\
-0.002 \\
0.013 \\
0.020 \\
0.020 \\
0.012 \\
0.003 \\
0.000 \\
-0.002 \\
-0.003 \\
0.010 \\
0.018 \\
0.019 \\
0.013 \\
0.005 \\
0.002 \\
0.000 \\
-0.004 \\
0.008 \\
0.015 \\
0.017 \\
0.015 \\
0.007 \\
0.004 \\
0.000 \\
-0.007 \\
0.005 \\
0.012 \\
0.017\end{array}$ \\
\hline
\end{tabular}




\section{CYLIiVDER}

END IMPACT, TEST 1

MEASUREMENT

DESIGNATION

L17-81

L17-126

L17-171

L17-216

L17-261

L17-306

L17-351

L18-36

L18-81

L18-126

L18-171

L18-216

L18-261

L18-306

L18-351

L19-36

L19-81

L19-126

L19-171

L19-216

L19-261

L19-306

L19-351

L20-36

L20-81

L20-12.6

L20-171

L20-216

L20-261

L20-306

L20-351

L21-36

L21-81

L21-126

L21-171

L21-216

L21-261

L21-306

L21-351

L22-36

L22-81

L22-126

L22-171

PRE-TEST

2.709

2.710

2.710

2.710

2.710

2.710

2.709

2.709

2.709

2.710

2.710

2.710

2.710

2.710

2.709

2.709

2.710

2.710

2.710

2.710

2.710

2.710

2.710

2.709

2.710

2.710

2.710

2.710

2.710

2.710

2.710

2.709

2.710

2.710

2.710

2.710

2.710

2.710

2.710

2.709

2.710

2.710

2.710
POST-TEST

2.726

2.720

2.716

2.710

2.704

2.712

2.715

2.723

2.727

2.722

2.719

2.710

2.703

2.710

2.712

2.722

2.727

2.724

2.720

2.709

2.702

2.706

2.710

2.721

2.726

2.725

2.721

2.707

2.700

2.703

2.707

2.719

2.726

2.725

2.721

2.706

2.699

2.701

2.706

2.718

2.723

2.723

2.720
MEASUREMENT

CHANGE

0.017

0.010

0.006

0.000

$-0.006$

0.002

0.006

0.014

0.018

0.012

0.009

0.000

$-0.007$

0.000

0.003

0.013

0.017

0.014

0.010

$-0.001$

$-0.008$

$-0.004$

0.000

0.012

0.016

0.015

0.011

$-0.003$

$-0.010$

$-0.007$

$-0.003$

0.010

0.016

0.015

0.011

$-0.004$

$-0.011$

$-0.009$

$-0.004$

0.009

0.013

0.013

0.010 


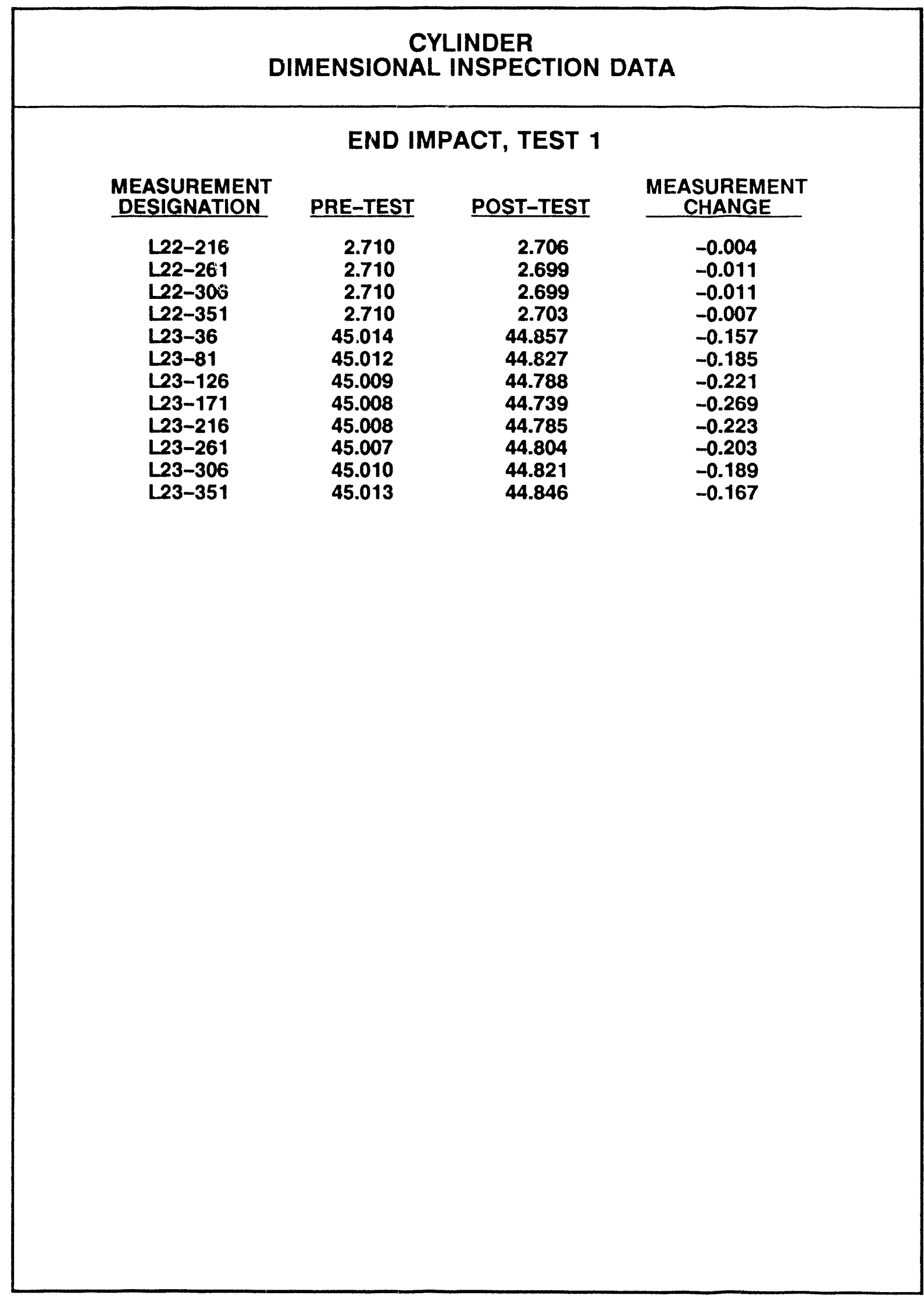




\begin{tabular}{|c|c|c|c|}
\hline \multicolumn{4}{|c|}{$\begin{array}{c}\text { CYLINDER } \\
\text { DIMENSIONAL INSPECTION DATA }\end{array}$} \\
\hline \multicolumn{4}{|c|}{ END IMPACT, TEST 2} \\
\hline $\begin{array}{l}\text { MEASUREMENT } \\
\text { DESIGNATION }\end{array}$ & PRE-TEST & POST-TEST & $\begin{array}{c}\text { MEASUREMENT } \\
\text { CHANGE } \\
\end{array}$ \\
\hline $\begin{array}{l}\text { L1-36 } \\
\text { L1-81 } \\
\text { L1-126 } \\
\text { L1-171 } \\
\text { L1-216 } \\
\text { L1-261 } \\
\text { L1-306 } \\
\text { L1-351 } \\
\text { L2-36 } \\
\text { L2-81 } \\
\text { L2-126 } \\
\text { L2-171 } \\
\text { L2-216 } \\
\text { L2-261 } \\
\text { L2-306 } \\
\text { L2-351 } \\
\text { L3-36 } \\
\text { L3-81 } \\
\text { L3-126 } \\
\text { L3-171 } \\
\text { L3-216 } \\
\text { L3-261 } \\
\text { L3-306 } \\
\text { L3-351 } \\
\text { L4-36 } \\
\text { L4-81 } \\
\text { L4-126 } \\
\text { L4-171 } \\
\text { L4-216 } \\
\text { L4-261 } \\
\text { L4-306 } \\
\text { L4-351 } \\
\text { L5-36 } \\
\text { L5-81 } \\
\text { L5-126 } \\
\text { L5-171 } \\
\text { L5-216 } \\
\text { L5-261 } \\
\text { L5-306 } \\
\text { L5-351 } \\
\text { L6-36 } \\
\text { L6-81 } \\
\text { L6-126 }\end{array}$ & $\begin{array}{l}2.704 \\
2.705 \\
2.701 \\
2.700 \\
2.707 \\
2.710 \\
2.707 \\
2.705 \\
2.706 \\
2.706 \\
2.704 \\
2.703 \\
2.708 \\
2.710 \\
2.709 \\
2.707 \\
2.708 \\
2.707 \\
2.707 \\
2.705 \\
2.709 \\
2.710 \\
2.710 \\
2.708 \\
2.710 \\
2.709 \\
2.708 \\
2.707 \\
2.710 \\
2.709 \\
2.710 \\
2.709 \\
2.710 \\
2.709 \\
2.708 \\
2.708 \\
2.710 \\
2.709 \\
2.710 \\
2.709 \\
2.710 \\
2.709 \\
2.708\end{array}$ & $\begin{array}{l}2.709 \\
2.710 \\
2.710 \\
2.710 \\
2.709 \\
2.709 \\
2.709 \\
2.709 \\
2.709 \\
2.705 \\
2.704 \\
2.705 \\
2.709 \\
2.699 \\
2.696 \\
2.711 \\
2.711 \\
2.709 \\
2.710 \\
2.711 \\
2.714 \\
2.692 \\
2.683 \\
2.715 \\
2.709 \\
2.723 \\
2.737 \\
2.742 \\
2.731 \\
2.679 \\
2.651 \\
2.695 \\
2.708 \\
2.725 \\
2.739 \\
2.743 \\
2.731 \\
2.674 \\
2.649 \\
2.694 \\
2.707 \\
2.725 \\
2.740\end{array}$ & $\begin{array}{r}0.005 \\
0.005 \\
0.009 \\
0.010 \\
0.002 \\
-0.001 \\
0.002 \\
0.004 \\
0.003 \\
-0.001 \\
0.000 \\
0.002 \\
0.001 \\
-0.011 \\
-0.013 \\
0.004 \\
0.003 \\
0.002 \\
0.003 \\
0.006 \\
0.005 \\
-0.018 \\
-0.027 \\
0.007 \\
-0.001 \\
0.014 \\
0.029 \\
0.035 \\
0.021 \\
-0.030 \\
-0.059 \\
-0.014 \\
-0.002 \\
0.016 \\
0.031 \\
0.035 \\
0.021 \\
-0.035 \\
-0.061 \\
-0.015 \\
-0.003 \\
0.016 \\
0.032\end{array}$ \\
\hline
\end{tabular}




\begin{tabular}{|c|c|c|c|}
\hline \multicolumn{4}{|c|}{$\begin{array}{c}\text { CYLINDER } \\
\text { DIMENSIONAL INSPECTION DATA }\end{array}$} \\
\hline \multicolumn{4}{|c|}{ END IMPACT, TEST 2} \\
\hline $\begin{array}{l}\text { MEASUREMENT } \\
\text { DESIGNATION }\end{array}$ & PRE-TEST & POST-TEST & $\begin{array}{c}\text { MEASUREMENT } \\
\text { CHANGE } \\
\end{array}$ \\
\hline 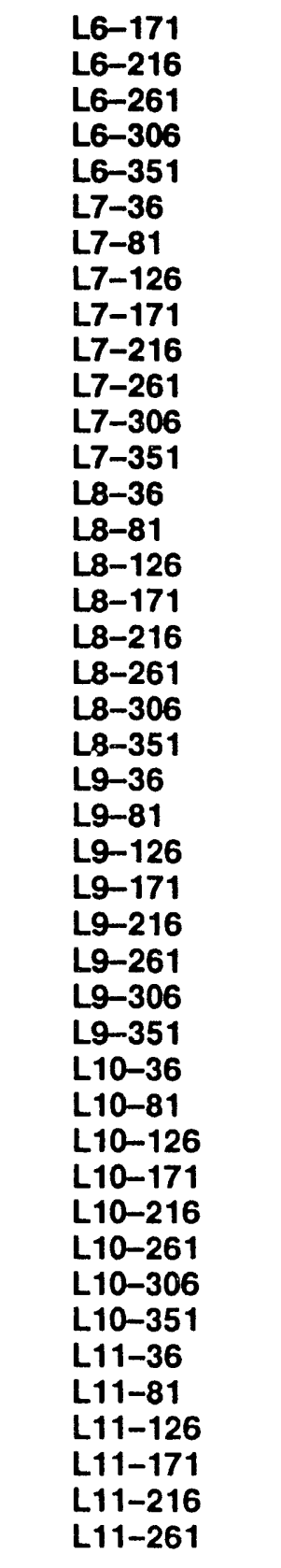 & $\begin{array}{l}2.708 \\
2.710 \\
2.709 \\
2.710 \\
2.709 \\
2.710 \\
2.709 \\
2.709 \\
2.709 \\
2.710 \\
2.709 \\
2.710 \\
2.709 \\
2.710 \\
2.709 \\
2.709 \\
2.709 \\
2.710 \\
2.709 \\
2.710 \\
2.709 \\
2.710 \\
2.709 \\
2.709 \\
2.709 \\
2.710 \\
2.709 \\
2.710 \\
2.709 \\
2.710 \\
2.710 \\
2.710 \\
2.710 \\
2.710 \\
2.709 \\
2.710 \\
2.709 \\
2.710 \\
2.710 \\
2.710 \\
2.710 \\
2.710 \\
2.709\end{array}$ & $\begin{array}{l}2.745 \\
2.732 \\
2.677 \\
2.644 \\
2.694 \\
2.707 \\
2.724 \\
2.740 \\
2.745 \\
2.733 \\
2.676 \\
2.745 \\
2.695 \\
2.708 \\
2.723 \\
2.738 \\
2.746 \\
2.732 \\
2.675 \\
2.646 \\
2.698 \\
2.709 \\
2.720 \\
2.736 \\
2.744 \\
2.731 \\
2.675 \\
2.647 \\
2.701 \\
2.710 \\
2.719 \\
2.734 \\
2.741 \\
2.731 \\
2.675 \\
2.649 \\
2.705 \\
2.712 \\
2.718 \\
2.732 \\
2.740 \\
2.730 \\
2.675\end{array}$ & $\begin{array}{r}0.037 \\
0.022 \\
-0.032 \\
-0.066 \\
-0.015 \\
-0.003 \\
0.015 \\
0.031 \\
0.036 \\
0.023 \\
-0.033 \\
0.035 \\
-0.014 \\
-0.002 \\
0.014 \\
0.029 \\
0.037 \\
0.022 \\
-0.034 \\
-0.064 \\
-0.011 \\
-0.001 \\
0.011 \\
0.027 \\
0.035 \\
0.021 \\
-0.034 \\
-0.063 \\
-0.008 \\
0.000 \\
0.009 \\
0.024 \\
0.031 \\
0.021 \\
-0.034 \\
-0.061 \\
-0.004 \\
0.002 \\
0.008 \\
0.022 \\
0.030 \\
0.020 \\
-0.034\end{array}$ \\
\hline
\end{tabular}




\section{CYLINDER \\ DIMENSIONAL INSPECTION DATA}

END IMPACT, TEST 2

MEASUREMENT DESIGNATION

\section{PRE-TEST}

2.710

2.710

2.710

2.710

2.710

2.710

2.710

2.709

2.710

2.710

2.710

2.710

2.710

2.710

2.710

2.709

2.710

2.710

2.710

2.710

2.710

2.710

2.710

2.709

2.710

2.710

2.710

2.710

2.710

2.710

2.710

2.709

2.710

2.710

2.710

2.710

2.710

2.710

2.710

2.709

2.710

2.710

2.710
POST-TEST

2.649

2.707

2.713

2.716

2.731

2.739

2.729

2.677

2.651

2.710

2.715

2.716

2.730

2.737

2.729

2.677

2.652

2.712

2.716

2.716

2.728

2.736

2.727

2.678

2.654

2.714

2.718

2.715

2.724

2.733

2.726

2.680

2.657

2.716

2.719

2.714

2.722

2.727

2.725

2.680

2.658

2.719

2.720
MEASUREMENT CHANGE

$-0.061$

$-0.003$

0.003

0.006

0.021

0.029

0.019

$-0.032$

$-0.059$

0.000

0.005

0.006

0.020

0.027

0.019

$-0.032$

$-0.058$

0.002

0.006

0.006

0.018

0.026

0.017

$-0.031$

$-0.056$

0.004

0.008

0.005

0.014

0.023

0.016

$-0.029$

$-0.053$

0.006

0.009

0.004

0.012

0.017

0.015

$-0.029$

$-0.052$

0.009

0.010 


\begin{tabular}{|c|c|c|c|}
\hline \multicolumn{4}{|c|}{$\begin{array}{c}\text { CYLINDER } \\
\text { DIMENSIUNAL INSPECTION DATA }\end{array}$} \\
\hline \multicolumn{4}{|c|}{ END IMPACT, TEST 2} \\
\hline $\begin{array}{l}\text { MEASUREMENT } \\
\text { DESIGNATION }\end{array}$ & PRE-TEST & POST-TEST & $\begin{array}{c}\text { MEASUREMENT } \\
\text { CHANGE }\end{array}$ \\
\hline $\begin{array}{l}\text { L17-81 } \\
\text { L17-126 } \\
\text { L17-171 } \\
\text { L17-216 } \\
\text { L17-261 } \\
L: 7-306 \\
\text { L17-351 } \\
\text { L18-36 } \\
\text { L18-81 } \\
\text { L18-126 } \\
\text { L18-171 } \\
\text { L18-216 } \\
\text { L18-261 } \\
\text { L18-306 } \\
\text { L18-351 } \\
\text { L19-36 } \\
\text { L19-81 } \\
\text { L19-126 } \\
\text { L19-171 } \\
\text { L19-216 } \\
\text { L19-261 } \\
\text { L19-306 } \\
L 19-351 \\
L 20-36 \\
L 20-81 \\
L 20-126 \\
L 20-171 \\
L 20-216 \\
L 20-261 \\
L 20-306 \\
L 20-35 i \\
L 21-36 \\
L 21-81 \\
L 21-126 \\
L 21-171 \\
L 21-216 \\
L 21-261 \\
: 21-306 \\
L 21-351 \\
L 22-36 \\
L 22-81 \\
L 22-126 \\
L 22-171\end{array}$ & $\begin{array}{l}2.710 \\
2.710 \\
2.710 \\
2.710 \\
2.709 \\
2.710 \\
2.710 \\
2.710 \\
2.710 \\
2.710 \\
2.710 \\
2.710 \\
2.708 \\
2.710 \\
2.710 \\
2.710 \\
2.710 \\
2.710 \\
2.710 \\
2.710 \\
2.708 \\
2.710 \\
2.710 \\
2.710 \\
2.710 \\
2.710 \\
2.710 \\
2.710 \\
2.709 \\
2.710 \\
2.710 \\
2.710 \\
2.710 \\
2.710 \\
2.710 \\
2.710 \\
2.709 \\
2.710 \\
2.710 \\
2.710 \\
2.710 \\
2.710 \\
2.710\end{array}$ & $\begin{array}{l}2.712 \\
2.719 \\
2.724 \\
2.723 \\
2.682 \\
2.659 \\
2.721 \\
2.720 \\
2.711 \\
2.715 \\
2.722 \\
2.721 \\
2.681 \\
2.660 \\
2.722 \\
2.720 \\
2.711 \\
2.712 \\
2.719 \\
2.720 \\
2.680 \\
2.660 \\
2.721 \\
2.719 \\
2.709 \\
2.707 \\
2.714 \\
2.718 \\
2.677 \\
2.660 \\
2.724 \\
2.716 \\
2.711 \\
2.704 \\
2.711 \\
2.717 \\
2.677 \\
2.662 \\
2.724 \\
2.717 \\
2.710 \\
2.703 \\
2.709\end{array}$ & $\begin{array}{r}0.002 \\
0.009 \\
0.014 \\
0.013 \\
-0.027 \\
-0.051 \\
0.011 \\
0.010 \\
0.001 \\
0.005 \\
0.012 \\
0.011 \\
-0.027 \\
-0.050 \\
0.012 \\
0.010 \\
0.001 \\
0.002 \\
0.009 \\
0.010 \\
-0.028 \\
-0.050 \\
0.011 \\
0.009 \\
-0.001 \\
-0.003 \\
0.004 \\
0.06 \\
-0.032 \\
-0.050 \\
0.014 \\
0.006 \\
0.001 \\
-0.006 \\
0.001 \\
0.007 \\
-0.032 \\
-0.048 \\
0.014 \\
0.007 \\
0.000 \\
-0.007 \\
-0.001\end{array}$ \\
\hline
\end{tabular}




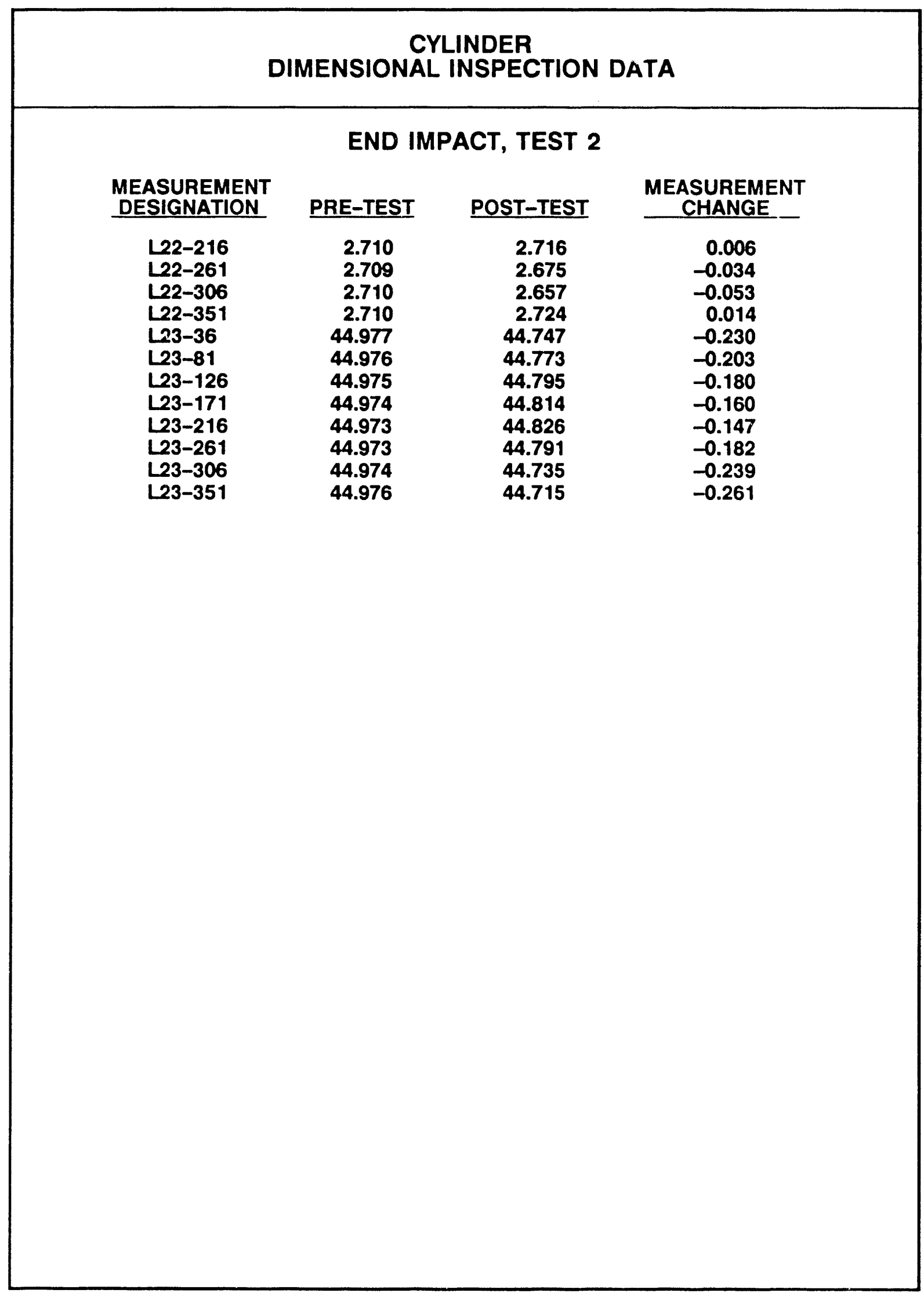




\section{DIMENSIONAL INSPECTION DATA}

\section{END IMPACT, TEST 3}

MEASUREMENT DESIGNATION
L.'-36
L1-81
L1-126
L1-171
L1-216
L1-261
L1-306
L1-351
L2-36
L2-81
L2-126
L2-171
L2-216
L2-261
L2-306
L2-351
L3-36
L3-81
L3-126
L3-171
L3-216
L3-261
L3-306
L3-351
L4-36
L4-81
L4-126
L4-171
L4-216
L4-261
L4-306
L4-351
L5-36
L5-81
L5-126
L5-171
L5-216
L5-261
L5-306
L5-351
L6-36
L6-81
L6-126

\section{PRE-TEST}

2.698

2.703

2.711

2.710

2.703

2.699

2.699

2.699

2.704

2.706

2.711

2.710

2.704

2.701

2.701

2.703

2.705

2.708

2.711

2.709

2.7135

2.703

2.704

2.704

2.707

2.709

2.710

2.709

2.707

2.706

2.706

2.708

2.708

2.709

2.710

2.709

2.707

2.706

2.707

2.708

2.708

2.709

2.710

\section{POST-TEST}

2.709

2.709

2.709

2.708

2.708

2.708

2.709

2.709

2.707

2.706

2.707

2.708

2.710

2.710

2.710

2.708

2.710

2.705

2.704

2.706

2.712

2.717

2.719

2.716

2.725

2.700

2.686

2.689

2.709

2.731

2.748

2.744

2.724

2.700

2.685

2.688

2.708

2.732

2.750

2.746

2.725

2.700

2.685
MEASUREMENT CHANGE

\subsection{1}

0.006

$-0.002$

$-0.002$

0.005

0.009

0.010

0.010

0.003

0.000

$-0.004$

$-0.002$

0.006

0.009

0.009

0.005

0.005

$-0.003$

$-0.007$

$-0.003$

0.007

0.014

0.015

0.012

0.018

$-0.009$

$-0.024$

$-0.020$

0.002

0.025

0.042

0.036

0.016

$-0.009$

$-0.025$

$-0.021$

0.001

0.026

0.043

0.038

0.017

$-0.009$

$-0.025$ 


\begin{tabular}{|c|c|c|c|}
\hline \multicolumn{4}{|c|}{$\begin{array}{c}\text { CYLINDER } \\
\text { DIMENSIONAL INSPECTION DATA }\end{array}$} \\
\hline \multicolumn{4}{|c|}{ END IMPACT, TEST 3} \\
\hline $\begin{array}{l}\text { MEASUREMENT } \\
\text { DESIGNATION } \\
\end{array}$ & PRE-TEST & POST-TEST & $\begin{array}{c}\text { MEASUREMENT } \\
\text { CHANGE } \\
\end{array}$ \\
\hline 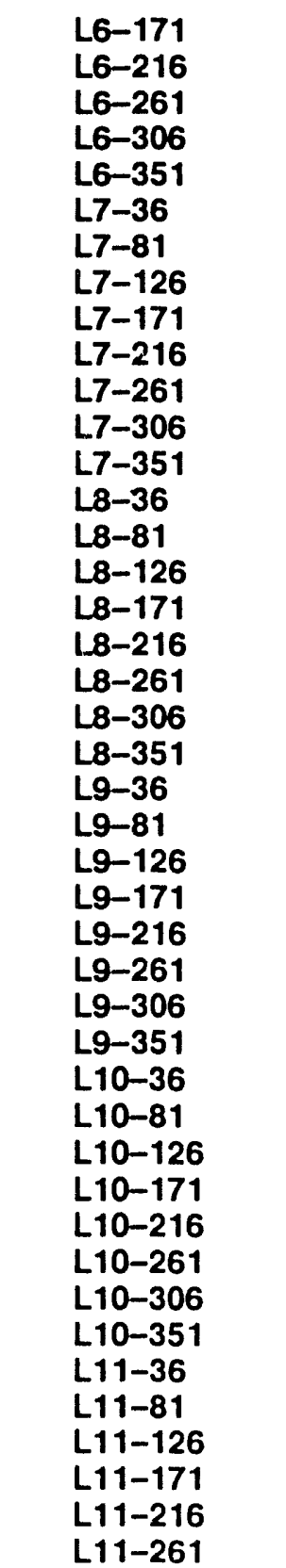 & $\begin{array}{l}2.709 \\
2.708 \\
2.707 \\
2.707 \\
2.708 \\
2.709 \\
2.709 \\
2.710 \\
2.709 \\
2.708 \\
2.707 \\
2.707 \\
2.708 \\
2.709 \\
2.709 \\
2.710 \\
2.709 \\
2.708 \\
2.708 \\
2.707 \\
2.709 \\
2.709 \\
2.709 \\
2.710 \\
2.709 \\
2.708 \\
2.708 \\
2.707 \\
2.709 \\
2.709 \\
2.709 \\
2.710 \\
2.709 \\
2.709 \\
2.708 \\
2.708 \\
2.709 \\
2.710 \\
2.709 \\
2.710 \\
2.709 \\
2.709 \\
2.708\end{array}$ & $\begin{array}{l}2.688 \\
2.708 \\
2.734 \\
2.751 \\
2.747 \\
2.726 \\
2.699 \\
2.686 \\
2.690 \\
2.709 \\
2.734 \\
2.752 \\
2.748 \\
2.725 \\
2.698 \\
2.687 \\
2.692 \\
2.710 \\
2.734 \\
2.750 \\
2.748 \\
2.724 \\
2.698 \\
2.688 \\
2.695 \\
2.712 \\
2.732 \\
2.751 \\
2.747 \\
2.721 \\
2.698 \\
2.692 \\
2.699 \\
2.714 \\
2.730 \\
2.747 \\
2.746 \\
2.720 \\
2.698 \\
2.692 \\
2.701 \\
2.715 \\
2.730\end{array}$ & $\begin{array}{r}-0.021 \\
0.000 \\
0.027 \\
0.044 \\
0.039 \\
0.017 \\
-0.010 \\
-0.024 \\
-0.019 \\
0.001 \\
0.027 \\
0.045 \\
0.040 \\
0.016 \\
-0.011 \\
-0.023 \\
-0.017 \\
0.002 \\
0.026 \\
0.043 \\
0.039 \\
0.015 \\
-0.011 \\
-0.022 \\
-0.014 \\
0.004 \\
0.024 \\
0.044 \\
0.038 \\
0.012 \\
-0.011 \\
-0.018 \\
-0.010 \\
0.005 \\
0.022 \\
0.039 \\
0.037 \\
0.010 \\
-0.011 \\
-0.018 \\
-0.008 \\
0.006 \\
0.022\end{array}$ \\
\hline
\end{tabular}




\section{CYLINDER \\ DIMENSIONAL INSPECTION DATA}

END IMPACT, TEST 3

MEASUREMENT DESIGNATION

L11-306

L11-351

L12-36

L12-81

L12-126

L12-171

L12-216

L12-261

L12-306

L12-351

L13-36

L13-81

L13-126

L13-171

L13-216

L13-261

L13-306

L13-351

L14-36

L14-81

L14-126

L14-171

L14-216

L14-261

L14-306

L14-351

L15-36

L15-81

L15-126

L15-171

L15-216

L15-261

L15-306

L15-351

L16-36

L16-81

L16-126

L16-171

L16-216

L16-261

L16-306

L16-351

L17-36

\section{PRE-TEST}

2.708

2.709

2.710

2.709

2.710

2.709

2.709

2.709

2.708

2.710

2.710

2.709

2.710

2.709

2.709

2.709

2.708

2.710

2.710

2.709

2.710

2.709

2.709

2.709

2.709

2.710

2.710

2.709

2.710

2.709

2.709

2.709

2.709

2.710

2.710

2.710

2.710

2.709

2.709

2.709

2.709

2.710

2.710
POST-TEST

2.745

2.743

2.719

2.699

2.694

2.704

2.717

2.729

2.744

2.742

2.718

2.700

2.696

2.706

2.718

2.728

2.742

2.739

2.716

2.701

2.699

2.708

2.720

2.728

2.740

2.738

2.714

2.701

2.702

2.708

2.722

2.727

2.737

2.737

2.712

2.704

2.703

2.714

2.724

2.728

2.736

2.731

2.711
MEASUREMENT CHANGE

0.037

0.034

0.009

$-0.010$

$-0.016$

$-0.005$

0.008

0.020

0.036

0.032

0.008

$-0.009$

$-0.014$

$-0.003$

0.009

0.019

0.034

0.029

0.006

$-0.008$

$-0.011$

$-0.001$

0.011

0.019

0.031

0.028

0.004

$-0.008$

$-0.008$

$-0.001$

0.013

0.018

0.028

0.027

0.002

$-0.006$

$-0.007$

0.005

0.015

0.019

0.027

0.021

0.001 


\begin{tabular}{|c|c|c|c|}
\hline \multicolumn{4}{|c|}{$\begin{array}{c}\text { CYLINDER } \\
\text { DIMENSIONAL INSPECTION DATA }\end{array}$} \\
\hline \multicolumn{4}{|c|}{ END IMPACT, TEST 3} \\
\hline $\begin{array}{l}\text { MEASUREMENT } \\
\text { DESIGNATION }\end{array}$ & PRE-TEST & POST-TEST & $\begin{array}{c}\text { MEASUREMENT } \\
\text { CHANGE } \\
\end{array}$ \\
\hline $\begin{array}{l}\text { L17-81 } \\
\text { L17-126 } \\
\text { L17-171 } \\
\text { L17-216 } \\
\text { L17-261 } \\
\text { L17-306 } \\
\text { L17-351 } \\
\text { L18-36 } \\
\text { L18-81 } \\
\text { L18-126 } \\
\text { L18-171 } \\
\text { L18-216 } \\
\text { L18-261 } \\
\text { L18-306 } \\
\text { L18-351 } \\
\text { L19-36 } \\
\text { L19-81 } \\
\text { L19-126 } \\
\text { L19-171 } \\
\text { L19-216 } \\
\text { L19-261 } \\
\text { L19-306 } \\
\text { L19-351 } \\
\text { L20-36 } \\
\text { L20-81 } \\
\text { L20-126 } \\
\text { L20-171 } \\
\text { L20-216 } \\
\text { L20-261 } \\
\text { L20-306 } \\
\text { L20-351 } \\
\text { L21-36 } \\
\text { L21-81 } \\
\text { L21-126 } \\
\text { L21-171 } \\
\text { L21-216 } \\
\text { L21-261 } \\
\text { L21-306 } \\
\text { L21-351 } \\
\text { L22-36 } \\
\text { L22-81 } \\
\text { L22-126 } \\
\text { L22-171 }\end{array}$ & $\begin{array}{l}2.710 \\
2.710 \\
2.709 \\
2.709 \\
2.709 \\
2.709 \\
2.710 \\
2.710 \\
2.710 \\
2.710 \\
2.709 \\
2.709 \\
2.709 \\
2.709 \\
2.711 \\
2.710 \\
2.710 \\
2.710 \\
2.709 \\
2.709 \\
2.710 \\
2.709 \\
2.711 \\
2.711 \\
2.710 \\
2.710 \\
2.709 \\
2.709 \\
2.710 \\
2.709 \\
2.711 \\
2.711 \\
2.710 \\
2.710 \\
2.709 \\
2.710 \\
2.710 \\
2.709 \\
2.711 \\
2.711 \\
2.710 \\
2.710 \\
2.709\end{array}$ & $\begin{array}{l}2.704 \\
2.704 \\
2.715 \\
2.725 \\
2.728 \\
2.733 \\
2.730 \\
2.709 \\
2.705 \\
2.706 \\
2.716 \\
2.726 \\
2.728 \\
2.730 \\
2.727 \\
2.707 \\
2.705 \\
2.707 \\
2.716 \\
2.726 \\
2.728 \\
2.729 \\
2.725 \\
2.706 \\
2.705 \\
2.709 \\
2.717 \\
2.725 \\
2.726 \\
2.725 \\
2.719 \\
2.704 \\
2.704 \\
2.710 \\
2.717 \\
2.724 \\
2.726 \\
2.722 \\
2.718 \\
2.706 \\
2.704 \\
2.708 \\
2.715\end{array}$ & $\begin{array}{r}-0.006 \\
-0.006 \\
0.006 \\
0.016 \\
0.019 \\
0.024 \\
0.020 \\
-0.001 \\
-0.005 \\
-0.004 \\
0.007 \\
0.017 \\
0.019 \\
0.021 \\
0.016 \\
-0.003 \\
-0.005 \\
-0.003 \\
0.007 \\
0.017 \\
0.018 \\
0.020 \\
0.014 \\
-0.005 \\
-0.005 \\
-0.001 \\
0.008 \\
0.016 \\
0.016 \\
0.016 \\
0.008 \\
-0.007 \\
-0.006 \\
0.000 \\
0.008 \\
0.014 \\
0.016 \\
0.013 \\
0.007 \\
-0.005 \\
-0.006 \\
-0.002 \\
0.006\end{array}$ \\
\hline
\end{tabular}




\section{CYLINDER \\ DIMENSIONAL INSPECTION DATA}

\section{END IMPACT, TEST 3}

MEASUREMENT DESIGNATION

L22-216

L22-261

L22-306

L22-351

L23-36

L23-81

L23-126

L23-171

L23-216

L23-261

L23-306

L23-351
PRE-TEST POST-TEST

2.710

2.710

2.709

2.711

45.009

45.008

45.006

45.004

45.005

45.005

45.007

45.009
2.724

2.730

2.718

2.714

44.831

44.771

44.733

44.764

44.777

44.797

44.847

44.840

\section{MEASUREMENT}

CHANGE

\subsection{4}

0.020

0.009

0.003

$-0.178$

$-0.237$

$-0.273$

$-0.240$

$-0.228$

$-0.208$

$-0.160$

$-0.169$ 


\section{CYLINDER \\ DIMENSIONAL INSPECTION DATA}

END IMPACT, TEST 4

MEASUREMENT DESIGNATION

\author{
PRE-TEST
}

2.705

2.697

2.694

2.702

2.710

2.717

2.718

2.713

2.708

2.700

2.698

2.704

2.711

2.716

2.717

2.714

2.709

2.704

2.701

2.706

2.711

2.715

2.714

2.714

2.710

2.708

2.706

2.709

2.711

2.714

2.714

2.713

2.710

2.708

2.707

2.709

2.711

2.714

2.714

2.713

2.710

2.709

2.707
POST-TEST

2.709

2.708

2.708

2.708

2.708

2.709

2.709

2.709

2.713

2.713

2.713

2.707

2.702

2.701

2.704

2.709

2.721

2.721

2.715

2.706

2.699

2.701

2.710

2.720

2.742

2.725

2.707

2.691

2.692

2.708

2.731

2.744

2.744

2.725

2.706

2.690

2.691

2.709

2.733

2.745

2.745

2.726

2.706
MEASUREMENT

CHANGE

\subsection{4}

0.011

0.014

0.006

$-0.002$

$-0.05=$

$-0.009$

$-0.004$

0.005

0.013

0.015

0.003

$-0.009$

$-0.015$

$-0.013$

$-0.005$

0.012

0.017

0.014

0.000

$-0.012$

$-0.014$

$-0.004$

0.006

0.032

0.017

0.001

$-0.018$

$-0.019$

$-0.006$

0.017

0.031

0.034

0.017

$-0.001$

$-0.019$

$-0.020$

$-0.005$

0.019

0.032

0.035

0.017

$-0.001$ 


\begin{tabular}{|c|c|c|c|}
\hline \multicolumn{4}{|c|}{$\begin{array}{c}\text { CYLINDER } \\
\text { DIMENSIONAL. INSPECTION DATA }\end{array}$} \\
\hline \multicolumn{4}{|c|}{ END IMPACT, TEST 4} \\
\hline $\begin{array}{l}\text { MEASUREMENT } \\
\text { DESIGNATION }\end{array}$ & PRE-TEST & POST-TEST & $\begin{array}{l}\text { MEASUREMENT } \\
\text { CHANGE } \\
\end{array}$ \\
\hline 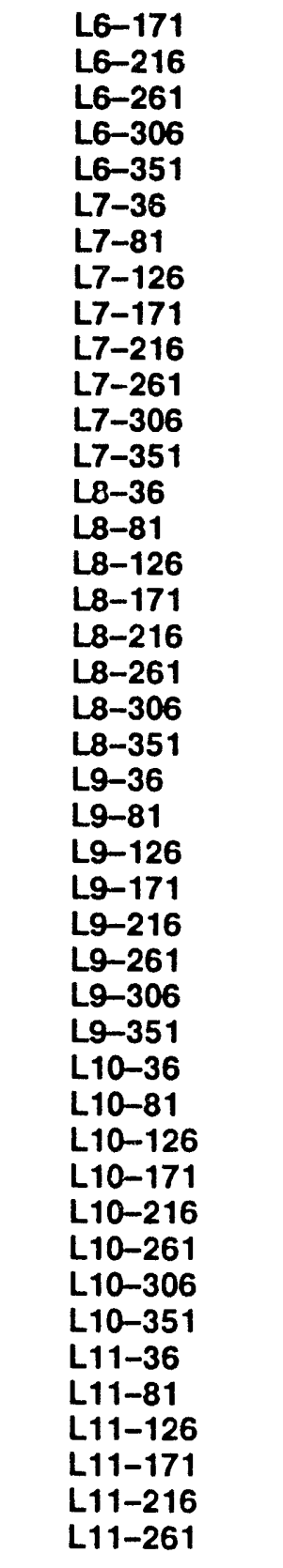 & $\begin{array}{l}2.710 \\
2.711 \\
2.712 \\
2.714 \\
2.713 \\
2.711 \\
2.709 \\
2.708 \\
2.710 \\
2.711 \\
2.712 \\
2.714 \\
2.713 \\
2.711 \\
2.709 \\
2.708 \\
2.710 \\
2.711 \\
2.712 \\
2.713 \\
2.713 \\
2.711 \\
2.710 \\
2.709 \\
2.710 \\
2.711 \\
2.712 \\
2.713 \\
2.712 \\
2.711 \\
2.710 \\
2.709 \\
2.710 \\
2.712 \\
2.712 \\
2.713 \\
2.712 \\
2.711 \\
2.711 \\
2.709 \\
2.710 \\
2.712 \\
2.712 \\
\end{array}$ & $\begin{array}{l}2.691 \\
2.691 \\
2.709 \\
2.733 \\
2.747 \\
2.745 \\
2.726 \\
2.706 \\
2.691 \\
2.691 \\
2.708 \\
2.731 \\
2.748 \\
2.746 \\
2.726 \\
2.707 \\
2.692 \\
2.692 \\
2.707 \\
2.732 \\
2.748 \\
2.746 \\
2.727 \\
2.708 \\
2.695 \\
2.692 \\
2.706 \\
2.730 \\
2.746 \\
2.746 \\
2.727 \\
2.712 \\
2.697 \\
2.693 \\
2.703 \\
2.728 \\
2.745 \\
2.745 \\
2.727 \\
2.712 \\
2.698 \\
2.694 \\
2.702\end{array}$ & $\begin{array}{r}-0.019 \\
-0.020 \\
-0.003 \\
0.019 \\
0.034 \\
0.034 \\
0.017 \\
-0.002 \\
-0.019 \\
-0.020 \\
-0.004 \\
0.017 \\
0.035 \\
0.035 \\
0.017 \\
-0.001 \\
-0.018 \\
-0.019 \\
-0.005 \\
0.019 \\
0.035 \\
0.035 \\
0.017 \\
-0.001 \\
-0.015 \\
-0.019 \\
-0.006 \\
0.017 \\
0.034 \\
0.035 \\
0.017 \\
0.003 \\
-0.013 \\
-0.019 \\
-0.009 \\
0.015 \\
0.033 \\
0.034 \\
0.016 \\
0.003 \\
-0.012 \\
-0.018 \\
-0.010\end{array}$ \\
\hline
\end{tabular}


CYLINDER

DIMENSIONAL INSPECTION DATA

\section{END IMPACT, TEST 4}

MEASUREMENT DESIGNATION
L11-306
L11-351
L12-36
L12-81
L12-126
L12-171
L12-216
L12-261
L12-306
L12-351
L13-36
L13-81
L13-126
L13-171
L13-216
L13-261
L13-306
L13-351
L14-36
L14-81
L14-126
L14-171
L14-216
L14-261
L14-306
L14-351
L15-36
L15-81
L15-126
L15-171
L15-216
L15-261
L15-306
L15-351
L16-36
L16-81
L16-126
L16-171
L16-216
L16-261
L16-306
L16-351
L17-36

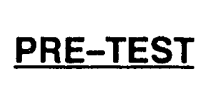

2.713

2.712

2.711

2.711

2.710

2.710

2.712

2.711

2.712

2.712

2.711

2.711

2.710

2.711

2.712

2.711

2.712

2.712

2.711

2.711

2.710

2.711

2.712

2.711

2.712

2.712

2.711

2.711

2.711

2.711

2.712

2.711

2.712

2.712

2.711

2.711

2.711

2.711

2.712

2.711

2.712

2.712

2.711

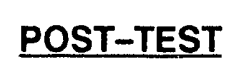

2.726

2.744

2.745

2.729

2.713

2.700

2.695

2.701

2.725

2.744

2.744

2.730

2.715

2.703

2.696

2.701

2.721

2.742

2.744

2.731

2.718

2.703

2.697

2.700

2.721

2.741

2.743

2.732

2.719

2.705

2.698

2.700

2.718

2.740

2.742

2.730

2.719

2.707

2.697

2.699

2.718

2.736

2.741
MEASUREMENT CHANGE

\subsection{3}

0.032

0.034

0.018

0.003

$-0.010$

$-0.017$

$-0.010$

0.013

0.032

0.033

0.019

0.005

$-0.008$

$-0.016$

$-0.010$

0.009

0.030

0.033

0.020

0.008

$-0.008$

$-0.015$

$-0.011$

0.009

0.029

0.032

0.021

0.008

$-0.006$

$-0.014$

$-0.011$

0.006

0.028

0.031

0.019

0.008

$-0.004$

$-0.015$

$-0.012$

0.006

0.024

0.030 


\begin{tabular}{|c|c|c|c|}
\hline \multicolumn{4}{|c|}{$\begin{array}{c}\text { CYLINDER } \\
\text { DIMENSIONAL INSPECTION DATA }\end{array}$} \\
\hline \multicolumn{4}{|c|}{ END IMPACT, TEST 4} \\
\hline $\begin{array}{l}\text { MEASUREMENT } \\
\text { DESIGNATION }\end{array}$ & PRE-TEST & POST-TEST & $\begin{array}{c}\text { MEASUREMENT } \\
\text { CHANGE } \\
\end{array}$ \\
\hline $\begin{array}{l}\text { L17-81 } \\
\text { L17-126 } \\
\text { L17-171 } \\
\text { L17-216 } \\
\text { L17-261 } \\
\text { L17-306 } \\
\text { L17-351 } \\
\text { L18-36 } \\
\text { L18-81 } \\
\text { L18-126 } \\
\text { L18-171 } \\
\text { L18-216 } \\
\text { L18-261 } \\
\text { L18-306 } \\
\text { L18-351 } \\
\text { L19-36 } \\
\text { L19-81 } \\
\text { L19-126 } \\
\text { L19-171 } \\
\text { L19-216 } \\
\text { L19-261 } \\
\text { L19-306 } \\
\text { L19-351 } \\
L 20-36 \\
L 20-81 \\
L 20-126 \\
L 20-171 \\
L 20-216 \\
L 20-261 \\
L 20-306 \\
L 20-351 \\
L 21-36 \\
L 21-81 \\
L 21-126 \\
L 21-171 \\
L 21-216 \\
L 21-261 \\
L 21-306 \\
L 21-351 \\
L 22-36 \\
L 22-81 \\
L 22-126 \\
L 22-171\end{array}$ & $\begin{array}{l}2.711 \\
2.711 \\
2.711 \\
2.712 \\
2.711 \\
2.712 \\
2.712 \\
2.711 \\
2.711 \\
2.711 \\
2.711 \\
2.712 \\
2.711 \\
2.711 \\
2.712 \\
2.711 \\
2.711 \\
2.711 \\
2.712 \\
2.712 \\
2.711 \\
2.711 \\
2.712 \\
2.711 \\
2.711 \\
2.711 \\
2.712 \\
2.712 \\
2.711 \\
2.711 \\
2.711 \\
2.711 \\
2.711 \\
2.711 \\
2.712 \\
2.712 \\
2.710 \\
2.711 \\
2.711 \\
2.711 \\
2.711 \\
2.711 \\
2.712\end{array}$ & $\begin{array}{l}2.731 \\
2.720 \\
2.707 \\
2.697 \\
2.699 \\
2.715 \\
2.735 \\
2.739 \\
2.731 \\
2.720 \\
2.708 \\
2.696 \\
2.698 \\
2.714 \\
2.734 \\
2.737 \\
2.730 \\
2.720 \\
2.708 \\
2.695 \\
2.697 \\
2.711 \\
2.731 \\
2.734 \\
2.730 \\
2.721 \\
2.707 \\
2.692 \\
2.694 \\
2.709 \\
2.725 \\
2.733 \\
2.731 \\
2.722 \\
2.707 \\
2.691 \\
2.693 \\
2.708 \\
2.725 \\
2.733 \\
2.727 \\
2.721 \\
2.705\end{array}$ & $\begin{array}{r}0.020 \\
0.009 \\
-0.004 \\
-0.015 \\
-0.012 \\
0.003 \\
0.023 \\
0.028 \\
0.020 \\
0.009 \\
-0.003 \\
-0.016 \\
-0.013 \\
0.003 \\
0.022 \\
0.026 \\
0.019 \\
0.009 \\
-0.004 \\
-0.017 \\
-0.014 \\
0.000 \\
0.019 \\
0.023 \\
0.019 \\
0.010 \\
-0.005 \\
-0.020 \\
-0.017 \\
-0.002 \\
0.014 \\
0.022 \\
0.020 \\
0.011 \\
-0.005 \\
-0.021 \\
-0.017 \\
-0.003 \\
0.014 \\
0.022 \\
0.016 \\
0.010 \\
-0.007\end{array}$ \\
\hline
\end{tabular}




\section{CYLINDER \\ DIMENSIONAL INSPECTION DATA}

END IMPACT, TEST 4

MEASUREMENT DESIGNATION

L22-216

L22-261

L22-306

L22-351

L23-36

L23-81

L23-126

L23-171

L23-216

L23-261

L23-306

L23-351

\section{PRE-TEST}

2.712

2.710

2.711

2.711

45.010

45.007

45.004

45.003

45.004

45.009

45.010

45.011

\begin{tabular}{c} 
POST-TEST \\
\hline 2.690 \\
2.690 \\
2.704 \\
2.725 \\
44.814 \\
44.754 \\
44.724 \\
44.740 \\
44.764 \\
44.783 \\
44.798 \\
44.809
\end{tabular}

MEASUREMENT

CHANGE

$-0.022$

$-0.020$

$-0.007$

0.014

$-0.196$

$-0.253$

$-0.280$

$-0.263$

$-0.240$

$-0.226$

$-0.212$

$-0.202$ 


\section{CYLINDER \\ DIMENSIONAL INSPECTION DATA}

\section{END IMPACT, TEST 5}

\section{MEASUREMENT DESIGNATION}

L1-36

L1-81

L1-126

L1-171

L1-216

L1-261

L1-306

L1-351

L2-36

L2-81

L2-126

L2-171

ᄂ2-216

L2-261

L2-306

L2-351

L3-36

L3-81

L3-126

L3-171

L3-216

L3-261

L3-306

L3-351

L4-36

L4-81

L4-126

L4-171

L4-216

L4-261

L4-306

L4-351

L5-36

L5-81

L5-126

L5-171

L5-216

L5-261

L5-306

L5-351

L6-36

L6-81

\section{PRE-TEST}

2.708

2.710

2.709

2.704

2.701

2.704

2.708

2.708

2.708

2.710

2.710

2.707

2.704

2.705

2.708

2.708

2.708

2.710

2.711

2.707

2.706

2.707

2.708

2.708

2.708

2.710

2.711

2.708

2.709

2.709

2.709

2.708

2.708

2.710

2.711

2.709

2.709

2.709

2.709

2.708

2.708

2.710

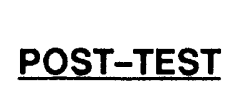

2.707

2.707

2.708

2.708

2.709

2.709

2.708

2.707

2.708

2.705

2.704

2.703

2.705

2.708

2.709

2.709

2.718

2.707

2.698

2.696

2.703

2.711

2.718

2.720

2.740

2.711

2.681

2.672

2.689

2.717

2.741

2.753

2.743

2.712

2.680

2.671

2.686

2.717

2.743

2.786

2.743

2.712
MEASUREMENT CHANGE

$-0.001$

$-0.003$

$-0.001$

0.004

0.008

0.005

0.000

$-0.001$

0.000

$-0.005$

$-0.006$

$-0.004$

0.001

0.003

0.001

0.001

0.010

$-0.003$

$-0.013$

$-0.011$

$-0.003$

0.004

0.010

0.012

0.032

0.001

$-0.030$

$-0.036$

$-0.020$

0.008

0.032

0.045

0.035

0.002

$-0.031$

$-0.038$

$-0.023$

0.008

0.034

0.078

0.035

0.002 


\begin{tabular}{|c|c|c|c|}
\hline \multicolumn{4}{|c|}{$\begin{array}{c}\text { CYLINDER } \\
\text { DIMENSIONAL INSPECTION DATA }\end{array}$} \\
\hline \multicolumn{4}{|c|}{ END IMPACT, TEST 5} \\
\hline $\begin{array}{l}\text { MEASUREMENT } \\
\text { DESIGNATION } \\
\end{array}$ & PRE-TEST & POST-TEST & $\begin{array}{c}\text { MEASUREMENT } \\
\text { CHANGE } \\
\end{array}$ \\
\hline $\begin{array}{l}\text { L6-126 } \\
\text { L6-171 } \\
\text { L6-216 } \\
\text { L6-261 } \\
\text { L6-306 } \\
\text { L6-351 } \\
\text { L7-36 } \\
\text { L7-81 } \\
\text { L7-126 } \\
\text { L7-171 } \\
\text { L7-216 } \\
\text { L7-261 } \\
\text { L7-306 } \\
\text { L7-351 } \\
\text { L8-36 } \\
\text { L8-81 } \\
\text { L8-126 } \\
\text { L8-171 } \\
\text { L8-216 } \\
\text { L8-261 } \\
\text { L8-306 } \\
\text { L8-351 } \\
\text { L9-36 } \\
\text { L9-81 } \\
\text { L9-126 } \\
\text { L9-171 } \\
\text { L9-216 } \\
\text { L9-261 } \\
\text { L9-306 } \\
\text { L9-351 } \\
\text { L10-36 } \\
\text { L10-81 } \\
\text { L10-126 } \\
\text { L10-171 } \\
\text { L10-216 } \\
\text { L10-261 } \\
\text { L10-306 } \\
\text { L10-351 } \\
\text { L11-36 } \\
\text { L11-81 } \\
\text { L11-126 } \\
\text { L11-171 } \\
\text { L11-216 }\end{array}$ & $\begin{array}{l}2.711 \\
2.709 \\
2.709 \\
2.709 \\
2.709 \\
2.708 \\
2.709 \\
2.710 \\
2.711 \\
2.709 \\
2.709 \\
2.709 \\
2.710 \\
2.708 \\
2.709 \\
2.710 \\
2.711 \\
2.709 \\
2.710 \\
2.710 \\
2.710 \\
2.708 \\
2.709 \\
2.710 \\
2.711 \\
2.709 \\
2.710 \\
2.710 \\
2.710 \\
2.708 \\
2.709 \\
2.710 \\
2.711 \\
2.709 \\
2.710 \\
2.710 \\
2.710 \\
2.709 \\
2.709 \\
2.710 \\
2.710 \\
2.709 \\
2.710\end{array}$ & $\begin{array}{l}2.680 \\
2.670 \\
2.685 \\
2.717 \\
2.745 \\
2.757 \\
2.745 \\
2.712 \\
2.680 \\
2.670 \\
2.686 \\
2.717 \\
2.743 \\
2.758 \\
2.745 \\
2.711 \\
2.680 \\
2.670 \\
2.687 \\
2.715 \\
2.743 \\
2.758 \\
2.745 \\
2.711 \\
2.681 \\
2.674 \\
2.689 \\
2.715 \\
2.741 \\
2.759 \\
2.744 \\
2.711 \\
2.682 \\
2.677 \\
2.691 \\
2.712 \\
2.739 \\
2.755 \\
2.743 \\
2.711 \\
2.683 \\
2.679 \\
2.692\end{array}$ & $\begin{array}{r}-0.031 \\
-0.039 \\
-0.024 \\
0.008 \\
0.036 \\
0.049 \\
0.036 \\
0.002 \\
-0.031 \\
-0.039 \\
-0.023 \\
0.008 \\
0.033 \\
0.050 \\
0.036 \\
0.001 \\
-0.031 \\
-0.039 \\
-0.023 \\
0.005 \\
0.033 \\
0.050 \\
0.036 \\
0.001 \\
-0.030 \\
-0.035 \\
-0.021 \\
0.005 \\
0.031 \\
0.051 \\
0.035 \\
0.001 \\
-0.029 \\
-0.032 \\
-0.019 \\
0.002 \\
0.029 \\
0.046 \\
0.034 \\
0.001 \\
-0.027 \\
-0.030 \\
-0.018\end{array}$ \\
\hline
\end{tabular}




\begin{tabular}{|c|c|c|c|}
\hline \multicolumn{4}{|c|}{$\begin{array}{c}\text { CYLINDER } \\
\text { DIMENSIONAL INSPECTION DATA }\end{array}$} \\
\hline \multicolumn{4}{|c|}{ END IMPACT, TEST 5} \\
\hline $\begin{array}{l}\text { MEASUREMENT } \\
\text { DESIGNATION }\end{array}$ & PRE-TEST & POST-TEST & $\begin{array}{l}\text { MEASUREMENT } \\
\text { CHANGE } \\
\end{array}$ \\
\hline 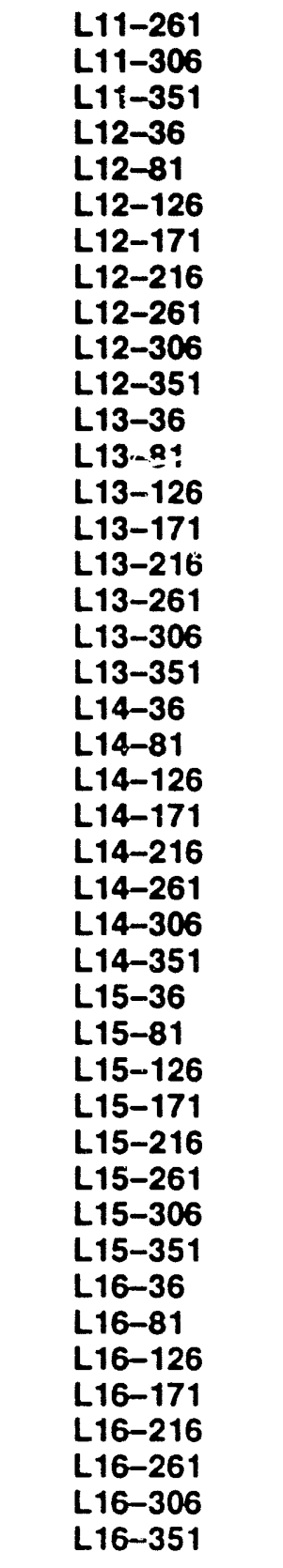 & $\begin{array}{l}2.710 \\
2.710 \\
2.709 \\
2.709 \\
2.710 \\
2.710 \\
2.709 \\
2.710 \\
2.710 \\
2.710 \\
2.709 \\
2.709 \\
2.710 \\
2.710 \\
2.710 \\
2.710 \\
2.710 \\
2.710 \\
2.709 \\
2.709 \\
2.710 \\
2.710 \\
2.710 \\
2.710 \\
2.710 \\
2.710 \\
2.709 \\
2.709 \\
2.710 \\
2.710 \\
2.710 \\
2.710 \\
2.710 \\
2.710 \\
2.709 \\
2.709 \\
2.710 \\
2.710 \\
2.710 \\
2.710 \\
2.710 \\
2.710 \\
2.709\end{array}$ & $\begin{array}{l}2.712 \\
2.737 \\
2.755 \\
2.742 \\
2.711 \\
2.685 \\
2.681 \\
2.694 \\
2.712 \\
2.736 \\
2.755 \\
2.740 \\
2.711 \\
2.687 \\
2.683 \\
2.696 \\
2.712 \\
2.734 \\
2.752 \\
2.740 \\
2.712 \\
2.689 \\
2.686 \\
2.698 \\
2.713 \\
2.732 \\
2.752 \\
2.738 \\
2.712 \\
2.691 \\
2.686 \\
2.700 \\
2.713 \\
2.730 \\
2.752 \\
2.735 \\
2.711 \\
2.693 \\
2.689 \\
2.701 \\
2.713 \\
2.730 \\
2.745\end{array}$ & $\begin{array}{r}0.002 \\
0.027 \\
0.046 \\
0.033 \\
0.001 \\
-0.025 \\
-0.028 \\
-0.016 \\
0.002 \\
0.026 \\
0.046 \\
0.031 \\
0.001 \\
-0.023 \\
-0.027 \\
-0.014 \\
0.002 \\
0.024 \\
0.043 \\
0.031 \\
0.002 \\
-0.021 \\
-0.024 \\
-0.012 \\
0.003 \\
0.022 \\
0.043 \\
0.029 \\
0.002 \\
-0.019 \\
-0.024 \\
-0.010 \\
0.003 \\
0.020 \\
0.043 \\
0.026 \\
0.001 \\
-0.017 \\
-0.021 \\
-0.009 \\
0.003 \\
0.020 \\
0.036\end{array}$ \\
\hline
\end{tabular}




\section{CYLINDER \\ DIMENSIONAL INSPECTION DATA}

\section{END IMPACT, TEST 5}

\section{MEASUREMENT DESIGNATION}

PRE-TEST

2.709

2.710

2.710

2.710

2.710

2.710

2.710

2.709

2.709

2.710

2.710

2.710

2.710

2.711

2.710

2.709

2.709

2.710

2.710

2.710

2.710

2.711

2.710

2.709

2.709

2.710

2.710

2.710

2.710

2.711

2.710

2.709

2.709

2.710

2.710

2.710

2.710

2.711

2.710

2.709

2.709

2.710

2.710
POST-TEST

2.733

2.714

2.694

2.689

2.701

2.713

2.728

2.742

2.732

2.715

2.696

2.690

2.701

2.713

2.726

2.740

2.729

2.715

2.696

2.690

2.700

2.712

2.723

2.740

2.729

2.715

2.696

2.694

2.698

2.712

2.722

2.739

2.726

2.715

2.696

2.694

2.696

2.712

2.722

2.734

2.725

2.711

2.696
MEASUREMENT CHANGE

0.024

0.004

$-0.016$

$-0.021$

$-0.009$

0.003

0.018

0.033

0.023

0.005

$-0.014$

$-0.020$

$-0.009$

0.002

0.016

0.031

0.020

0.005

$-0.014$

$-0.020$

$-0.010$

0.001

0.013

0.031

0.020

0.005

$-0.014$

$-0.016$

$-0.012$

0.001

0.012

0.030

0.017

0.005

$-0.014$

$-0.016$

$-0.014$

0.001

0.012

0.025

0.016

0.001

$-0.014$ 


\section{CYLINDER \\ DIMENSIONAL INSPECTION DATA}

END IMPACT, TEST 5

MEASUREMENT DESIGNATION

L22-171

L22-216

L22-261

L22-306

L22-351

L23-36

L23-81

L23-126

L23-171

L23-216

L23-261

L23-306

L23-351
PRE-TEST

2.710

2.710

2.711

2.710

2.709

45.008

45.008

45.008

45.009

45.009

45.010

45.010

45.009
MEASUREMENT

POST-TEST

2.694

2.697

2.710

2.721

2.734

44.833

44.794

44.747

44.747

44.779

44.795

44.819

44.838
CHANGE

$-0.016$

$-0.013$

$-0.001$

0.011

0.025

$-0.175$

$-0.214$

$-0.261$

$-0.262$

$-0.230$

$-0.215$

$-0.191$

$-0.171$ 


\begin{tabular}{|c|c|c|c|}
\hline \multicolumn{4}{|c|}{$\begin{array}{c}\text { CYLINDER } \\
\text { DIMENSIONAL INSPECTION DATA }\end{array}$} \\
\hline \multicolumn{4}{|c|}{ END IMPACT, TEST 6} \\
\hline $\begin{array}{l}\text { MEASUREMENT } \\
\text { DESIGNATION }\end{array}$ & PRE-TEST & POST-TEST & $\begin{array}{l}\text { MEASUREMENT } \\
\text { CHANGE } \\
\end{array}$ \\
\hline 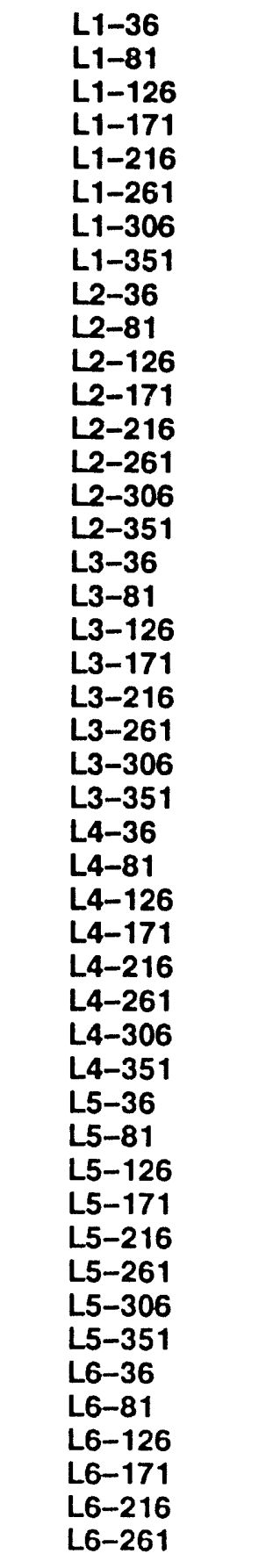 & $\begin{array}{l}2.706 \\
2.708 \\
2.708 \\
2.706 \\
2.703 \\
2.699 \\
2.700 \\
2.703 \\
2.708 \\
2.710 \\
2.710 \\
2.708 \\
2.705 \\
2.702 \\
2.703 \\
2.705 \\
2.709 \\
2.711 \\
2.710 \\
2.709 \\
2.706 \\
2.704 \\
2.705 \\
2.707 \\
2.710 \\
2.711 \\
2.710 \\
2.710 \\
2.708 \\
2.707 \\
2.709 \\
2.709 \\
2.710 \\
2.711 \\
2.710 \\
2.710 \\
2.708 \\
2.708 \\
2.709 \\
2.709 \\
2.711 \\
2.711 \\
2.711 \\
2.710 \\
2.708 \\
2.708\end{array}$ & $\begin{array}{l}2.707 \\
2.707 \\
2.708 \\
2.708 \\
2.708 \\
2.709 \\
2.708 \\
2.707 \\
2.707 \\
2.709 \\
2.709 \\
2.707 \\
2.704 \\
2.704 \\
2.702 \\
2.702 \\
2.715 \\
2.709 \\
2.706 \\
2.703 \\
2.704 \\
2.710 \\
2.713 \\
2.715 \\
2.727 \\
2.694 \\
2.671 \\
2.670 \\
2.698 \\
2.733 \\
2.756 \\
2.753 \\
2.727 \\
2.694 \\
2.670 \\
2.668 \\
2.696 \\
2.735 \\
2.758 \\
2.757 \\
2.729 \\
2.693 \\
2.669 \\
2.668 \\
2.698 \\
2.734\end{array}$ & $\begin{array}{r}0.001 \\
-0.001 \\
0.000 \\
0.002 \\
0.005 \\
0.010 \\
0.008 \\
0.004 \\
-0.001 \\
-0.001 \\
-0.001 \\
-0.001 \\
-0.001 \\
0.002 \\
-0.001 \\
-0.003 \\
0.006 \\
-0.002 \\
-0.004 \\
-0.006 \\
-0.002 \\
0.006 \\
0.008 \\
0.008 \\
0.017 \\
-0.017 \\
-0.039 \\
-0.040 \\
-0.010 \\
0.026 \\
0.047 \\
0.044 \\
0.017 \\
-0.017 \\
-0.040 \\
-0.042 \\
-0.012 \\
0.027 \\
0.049 \\
0.048 \\
0.018 \\
-0.018 \\
-0.042 \\
-0.042 \\
-0.010 \\
0.026\end{array}$ \\
\hline
\end{tabular}




\section{CYLINDER \\ DIMENSIONAL INSPECTION DATA}

\section{END IMPACT, TEST 6}

\section{MEASUREMENT DESIGNATION}

L6-306

L6-351

L7-36

L7-81

L7-126

L7-171

L7-216

L7-261

L7-306

L7-351

L.8-36

L8-81

L8-126

L8-171

L8-216

L8-261

L8-306

L8-351

L9-36

L9-81

L9-126

L9-171

L9-216

L9-261

L9-306

L9-351

L10-36

L10-81

L10-126

L10-171

L10-216

L10-261

L10-306

L10-351

L11-36

L11-81

L11-126

L11-171

L11-216

L11-261

\section{PRE-TEST}

2.709

2.709

2.711

2.712

2.711

2.710

2.709

2.708

2.709

2.710

2.711

2.712

2.711

2.710

2.709

2.709

2.709

2.710

2.711

2.712

2.711

2.710

2.709

2.709

2.709

2.710

2.711

2.712

2.711

2.710

2.709

2.709

2.710

2.711

2.711

2.712

2.711

2.710

2.709

2.710

\section{POST-TEST}

2.760

2.756

2.729

2.694

2.669

2.670

2.696

2.734

2.761

2.757

2.728

2.694

2.671

2.671

2.697

2.733

2.759

2.756

2.727

2.695

2.674

2.675

2.698

2.731

2.757

2.753

2.727

2.698

2.678

2.680

2.700

2.728

2.753

2.751

2.725

2.700

2.681

2.681

2.703

2.728
MEASUREMENT

CHANGE

0.051

0.047

0.018

$-0.018$

$-0.042$

$-0.040$

$-0.013$

0.026

0.052

0.047

0.017

$-0.018$

$-0.040$

$-0.039$

$-0.012$

0.024

0.050

0.046

0.016

$-0.017$

$-0.037$

$-0.035$

$-0.011$

0.022

0.048

0.043

0.016

$-0.014$

$-0.033$

$-0.030$

$-0.009$

0.019

0.043

0.040

0.014

$-0.012$

$-0.030$

$-0.029$

$-0.006$

0.018 


\section{CYLINDER \\ DIMENSIONAL INSPECTION DATA}

END IMPACT, TEST 6

MEASUREMENT DESIGNATION

\section{PRE-TEST}

2.710

2.711

2.711

2.712

2.711

2.711

2.710

2.710

2.710

2.711

2.711

2.712

2.711

2.711

2.710

2.710

2.710

2.711

2.711

2.712

2.711

2.711

2.710

2.710

2.711

2.711

2.712

2.712

2.711

2.711

2.710

2.710

2.711

2.711

2.712

2.712

2.711

2.711

2.710

2.710

2.711

2.711

2.712
POST-TEST

2.750

2.746

2.724

2.702

2.684

2.685

2.705

2.727

2.748

2.746

2.724

2.702

2.688

2.688

2.706

2.725

2.744

2.743

2.723

2.707

2.691

¿689

2.706

2.723

2.741

2.741

2.722

2.708

2.694

2.695

2.708

2.722

2.738

2.741

2.722

2.711

2.699

2.697

2.709

2.718

2.734

2.733

2.720
MEASUREMENT

CHANGE

0.040

0.035

0.013

$-0.010$

$-0.027$

$-0.026$

$-0.005$

0.017

0.038

0.035

0.013

$-0.010$

$-0.023$

$-0.023$

$-0.004$

0.015

0.034

0.032

0.012

$-0.005$

$-0.020$

$-0.022$

$-0.004$

0.013

0.030

0.030

0.010

$-0.004$

$-0.017$

$-0.016$

$-0.002$

0.012

0.027

0.030

0.010

$-0.001$

$-0.012$

$-0.014$

$-0.001$

0.008

0.023

0.022

0.008 


\begin{tabular}{|c|c|c|c|}
\hline \multicolumn{4}{|c|}{$\begin{array}{c}\text { CYLINDER } \\
\text { DIMENSIONAL INSPECTION DATA }\end{array}$} \\
\hline \multicolumn{4}{|c|}{ END IMPACT, TEST 6} \\
\hline $\begin{array}{l}\text { MEASUREMENT } \\
\text { DESIGNATION }\end{array}$ & PRE-TEST & POST-TEST & $\begin{array}{c}\text { MEASUREMENT } \\
\text { CHANGE } \\
\end{array}$ \\
\hline 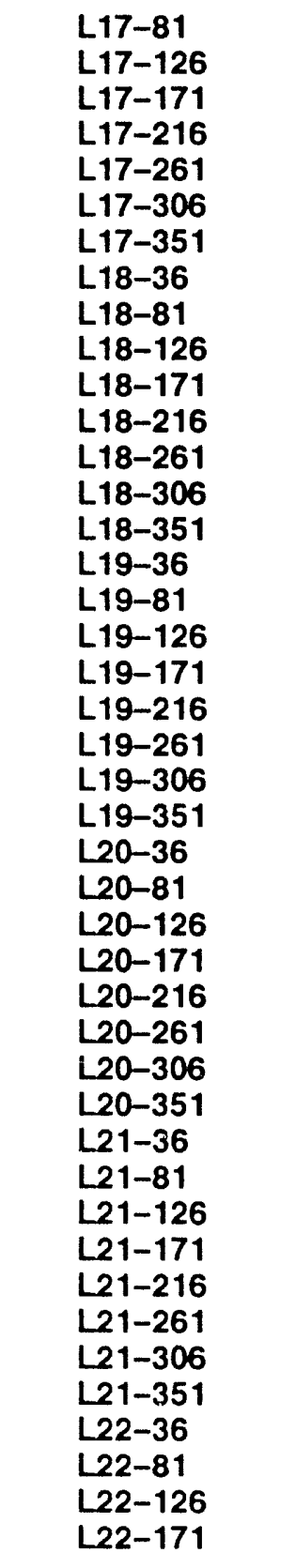 & $\begin{array}{l}2.712 \\
2.711 \\
2.711 \\
2.710 \\
2.710 \\
2.711 \\
2.711 \\
2.712 \\
2.712 \\
2.711 \\
2.711 \\
2.710 \\
2.710 \\
2.711 \\
2.711 \\
2.712 \\
2.712 \\
2.711 \\
2.711 \\
2.710 \\
2.710 \\
2.711 \\
2.712 \\
2.712 \\
2.712 \\
2.711 \\
2.711 \\
2.710 \\
2.710 \\
2.711 \\
2.712 \\
2.712 \\
2.712 \\
2.711 \\
2.711 \\
2.711 \\
2.711 \\
2.711 \\
2.712 \\
2.712 \\
2.712 \\
2.711 \\
2.711\end{array}$ & $\begin{array}{l}2.712 \\
2.701 \\
2.699 \\
2.710 \\
2.718 \\
2.728 \\
2.731 \\
2.719 \\
2.713 \\
2.701 \\
2.701 \\
2.710 \\
2.713 \\
2.726 \\
2.727 \\
2.717 \\
2.714 \\
2.702 \\
2.701 \\
2.707 \\
2.710 \\
2.720 \\
2.720 \\
2.715 \\
2.709 \\
2.704 \\
2.702 \\
2.706 \\
2.712 \\
2.716 \\
2.713 \\
2.714 \\
2.709 \\
2.705 \\
2.703 \\
2.705 \\
2.708 \\
2.713 \\
2.710 \\
2.711 \\
2.709 \\
2.708 \\
2.704\end{array}$ & $\begin{array}{r}0.000 \\
-0.010 \\
-0.012 \\
0.000 \\
0.008 \\
0.017 \\
0.020 \\
0.007 \\
0.001 \\
-0.010 \\
-0.010 \\
0.000 \\
0.003 \\
0.015 \\
0.016 \\
0.005 \\
0.002 \\
-0.009 \\
-0.010 \\
-0.003 \\
0.000 \\
0.009 \\
0.008 \\
0.003 \\
-0.003 \\
-0.007 \\
-0.009 \\
-0.004 \\
0.002 \\
0.005 \\
0.001 \\
0.002 \\
-0.003 \\
-0.006 \\
-0.008 \\
-0.006 \\
-0.003 \\
0.002 \\
-0.002 \\
-0.001 \\
-0.003 \\
-0.003 \\
-0.007\end{array}$ \\
\hline
\end{tabular}




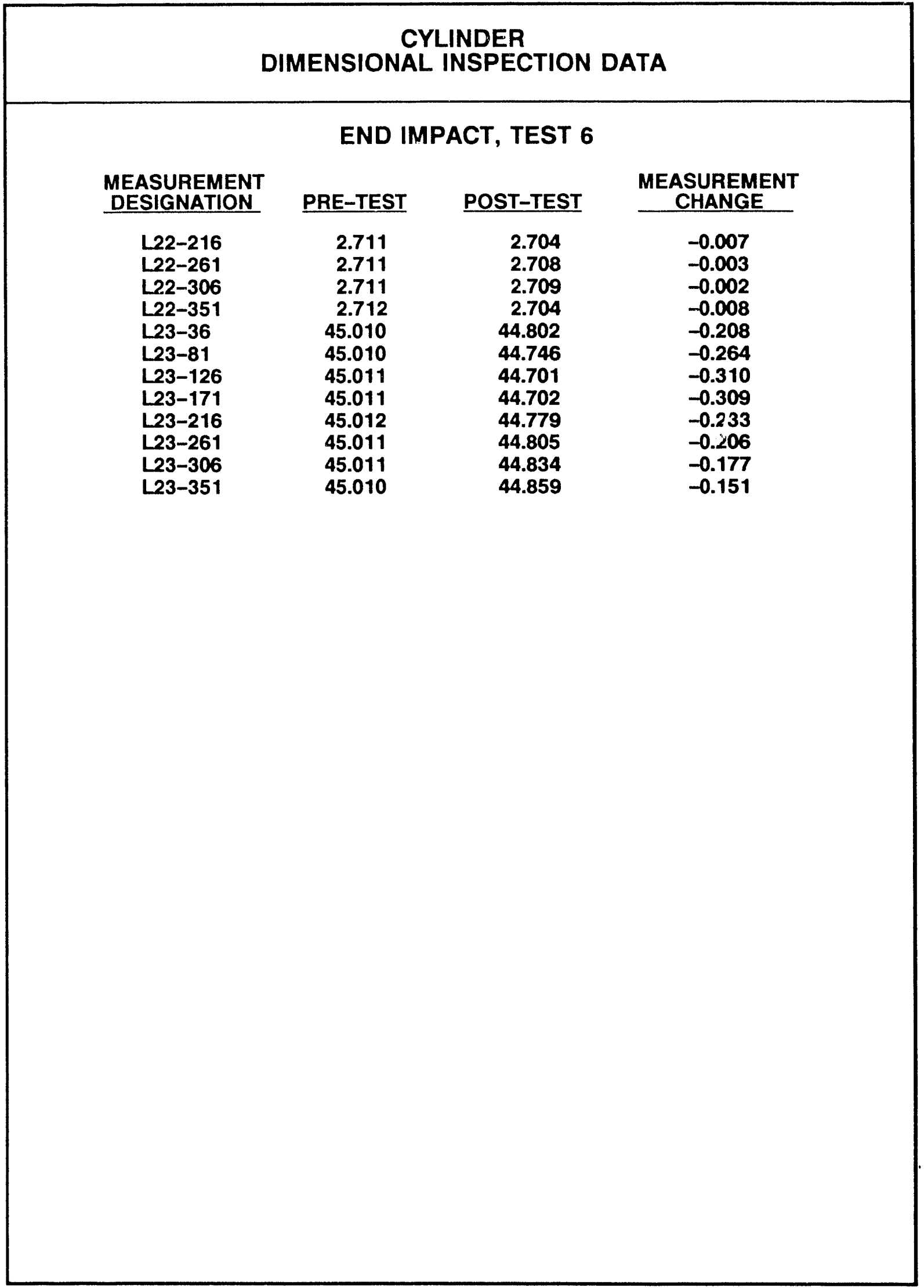




\begin{tabular}{|c|c|c|c|}
\hline \multicolumn{4}{|c|}{$\begin{array}{c}\text { CYLINDER } \\
\text { DIMENSIONAL INSPECTION DATA }\end{array}$} \\
\hline \multicolumn{4}{|c|}{ END IMPACT, TEST 7} \\
\hline $\begin{array}{l}\text { MEASUREMENT } \\
\text { DESIGNATION }\end{array}$ & PRE-TEST & POST-TEST & $\begin{array}{l}\text { MEASUREMENT } \\
\text { CHANGE } \\
\end{array}$ \\
\hline $\begin{array}{l}\text { L1-36 } \\
\text { L1-81 } \\
\text { L1-126 } \\
\text { L1-171 } \\
\text { L1-216 } \\
\text { L1-261 } \\
\text { L1-306 } \\
\text { L1-351 } \\
\text { L2-36 } \\
\text { L2-81 } \\
\text { L2-126 } \\
\text { L2-171 } \\
\text { L2-216 } \\
\text { L2-261 } \\
\text { L2-306 } \\
\text { L2-351 } \\
\text { L3-36 } \\
\text { L3-81 } \\
\text { L3-126 } \\
\text { L3-171 } \\
\text { L3-216 } \\
\text { L3-261 } \\
\text { L3-306 } \\
\text { L3-351 } \\
\text { L4-36 } \\
\text { L4-81 } \\
\text { L4-126 } \\
\text { L4-171 } \\
\text { L4-216 } \\
\text { L4-261 } \\
\text { L4-306 } \\
\text { L4-351 } \\
\text { L5-36 } \\
\text { L5-81 } \\
L 5-126 \\
L 5-171 \\
L 5-216 \\
L 5-261 \\
L 5-306 \\
L 5-351 \\
L 6-36 \\
L 6-81 \\
\text { L6-126 }\end{array}$ & $\begin{array}{l}2.699 \\
2.698 \\
2.697 \\
2.696 \\
2.700 \\
2.701 \\
2.700 \\
2.699 \\
2.703 \\
2.702 \\
2.701 \\
2.701 \\
2.702 \\
2.703 \\
2.703 \\
2.703 \\
2.705 \\
2.705 \\
2.704 \\
2.703 \\
2.705 \\
2.705 \\
2.705 \\
2.704 \\
2.707 \\
2.707 \\
2.706 \\
2.705 \\
2.706 \\
2.707 \\
2.707 \\
2.706 \\
2.707 \\
2.707 \\
2.706 \\
2.705 \\
2.707 \\
2.707 \\
2.707 \\
2.706 \\
2.707 \\
2.707 \\
2.706\end{array}$ & $\begin{array}{l}2.709 \\
2.710 \\
2.710 \\
2.710 \\
2.711 \\
2.711 \\
2.710 \\
2.710 \\
2.713 \\
2.717 \\
2.716 \\
2.716 \\
2.712 \\
2.710 \\
2.709 \\
2.710 \\
2.722 \\
2.722 \\
2.720 \\
2.717 \\
2.714 \\
2.715 \\
2.717 \\
2.720 \\
2.740 \\
2.723 \\
2.706 \\
2.703 \\
2.714 \\
2.731 \\
2.744 \\
2.746 \\
2.740 \\
2.723 \\
2.706 \\
2.701 \\
2.711 \\
2.731 \\
2.746 \\
2.749 \\
2.740 \\
2.723 \\
2.706\end{array}$ & $\begin{array}{r}0.010 \\
0.012 \\
0.013 \\
0.014 \\
0.011 \\
0.010 \\
0.010 \\
0.011 \\
0.010 \\
0.015 \\
0.015 \\
0.015 \\
0.010 \\
0.007 \\
0.006 \\
0.007 \\
0.017 \\
0.017 \\
0.016 \\
0.014 \\
0.009 \\
0.010 \\
0.012 \\
0.016 \\
0.033 \\
0.016 \\
0.000 \\
-0.002 \\
0.008 \\
0.024 \\
0.037 \\
0.040 \\
0.033 \\
0.016 \\
0.000 \\
-0.004 \\
0.004 \\
0.024 \\
0.039 \\
0.043 \\
0.033 \\
0.016 \\
0.000\end{array}$ \\
\hline
\end{tabular}




\begin{tabular}{|c|c|c|c|}
\hline \multicolumn{4}{|c|}{$\begin{array}{c}\text { CYLINDER } \\
\text { DIMENSIONAL INSPECTION DATA }\end{array}$} \\
\hline \multicolumn{4}{|c|}{ END IMPACT, TEST 7} \\
\hline $\begin{array}{l}\text { MEASUREMENT } \\
\text { DESIGNATION }\end{array}$ & PRE-TEST & POST-TEST & $\begin{array}{c}\text { MEASUREMENT } \\
\text { CHANGE } \\
\end{array}$ \\
\hline $\begin{array}{l}\text { L6-171 } \\
\text { L6-216 } \\
\text { L6-261 } \\
\text { L6-306 } \\
\text { L6-351 } \\
\text { L7-36 } \\
\text { L7-81 } \\
\text { L7-126 } \\
\text { L7-171 } \\
\text { L7-216 } \\
\text { L7-261 } \\
\text { L7-306 } \\
\text { L7-351 } \\
\text { L8-36 } \\
\text { L8-81 } \\
\text { L8-126 } \\
\text { L8-171 } \\
\text { L8-216 } \\
\text { L8-261 } \\
\text { L8-306 } \\
\text { L8-351 } \\
\text { L9-36 } \\
\text { L9-81 } \\
\text { L9-126 } \\
\text { L9-171 } \\
\text { L9-216 } \\
\text { L9-261 } \\
\text { L9-306 } \\
\text { L9-351 } \\
\text { L10-36 } \\
\text { L10-81 } \\
\text { L10-126 } \\
\text { L10-171 } \\
\text { L10-216 } \\
\text { L10-261 } \\
\text { L10-306 } \\
\text { L10-351 } \\
\text { L11-36 } \\
\text { L11-81 } \\
\text { L11-126 } \\
\text { L11-171 } \\
\text { L11-216 } \\
\text { L11-261 }\end{array}$ & $\begin{array}{l}2.706 \\
2.707 \\
2.707 \\
2.707 \\
2.706 \\
2.707 \\
2.707 \\
2.706 \\
2.706 \\
2.707 \\
2.707 \\
2.707 \\
2.707 \\
2.707 \\
2.707 \\
2.707 \\
2.706 \\
2.707 \\
2.707 \\
2.707 \\
2.707 \\
2.707 \\
2.707 \\
2.707 \\
2.707 \\
2.707 \\
2.708 \\
2.707 \\
2.707 \\
2.708 \\
2.707 \\
2.707 \\
2.707 \\
2.708 \\
2.708 \\
2.708 \\
2.707 \\
2.708 \\
2.707 \\
2.707 \\
2.707 \\
2.708 \\
2.708\end{array}$ & $\begin{array}{l}2.701 \\
2.711 \\
2.732 \\
2.748 \\
2.750 \\
2.741 \\
2.723 \\
2.706 \\
2.702 \\
2.712 \\
2.732 \\
2.748 \\
2.751 \\
2.741 \\
2.724 \\
2.708 \\
2.704 \\
2.713 \\
2.731 \\
2.748 \\
2.751 \\
2.741 \\
2.724 \\
2.709 \\
2.706 \\
2.714 \\
2.730 \\
2.747 \\
2.751 \\
2.740 \\
2.724 \\
2.711 \\
2.710 \\
2.716 \\
2.730 \\
2.745 \\
2.749 \\
2.739 \\
2.725 \\
2.713 \\
2.711 \\
2.718 \\
2.727\end{array}$ & 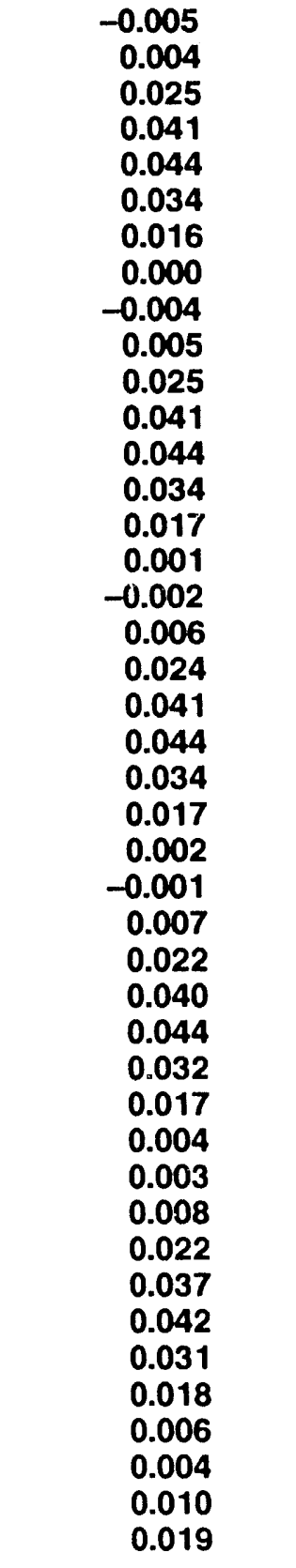 \\
\hline
\end{tabular}




\begin{tabular}{|c|c|c|c|}
\hline \multicolumn{4}{|c|}{$\begin{array}{c}\text { CYLINDER } \\
\text { DIMENSIONÁL INSPECTION DATA }\end{array}$} \\
\hline \multicolumn{4}{|c|}{ END IMPACT, TEST 7} \\
\hline $\begin{array}{l}\text { MEASUREMENT } \\
\text { DESIGNATION }\end{array}$ & PRE-TEST & POST-TEST & $\begin{array}{c}\text { MEASUREMENT } \\
\text { CHANGE } \\
\end{array}$ \\
\hline $\begin{array}{l}\text { L11-306 } \\
\text { L11-351 } \\
\text { L12-36 } \\
\text { L12-81 } \\
\text { L12-126 } \\
\text { L12-171 } \\
\text { L12-216 } \\
\text { L12-261 } \\
\text { L12-306 } \\
\text { L12-351 } \\
\text { L13-36 } \\
\text { L13-81 } \\
\text { L13-126 } \\
\text { L13-171 } \\
\text { L13-216 } \\
\text { L13-261 } \\
\text { L13-306 } \\
\text { L13-351 } \\
\text { L14-36 } \\
\text { L14-81 } \\
\text { L14-126 } \\
\text { L14-171 } \\
\text { L14-216 } \\
\text { L14-261 } \\
\text { L14-306 } \\
\text { L14-351 } \\
\text { L15-36 } \\
\text { L15-81 } \\
\text { L15-126 } \\
\text { L15-171 } \\
\text { L15-216 } \\
\text { L15-261 } \\
\text { L15-306 } \\
\text { L15-351 } \\
\text { L16-36 } \\
\text { L16-81 } \\
\text { L16-126 } \\
\text { L16-171 } \\
\text { L16-216 } \\
\text { L16-261 } \\
\text { L16-306 } \\
\text { L16-351 } \\
\text { L17-36 }\end{array}$ & $\begin{array}{l}2.708 \\
2.707 \\
2.708 \\
2.707 \\
2.707 \\
2.707 \\
2.708 \\
2.708 \\
2.708 \\
2.708 \\
2.708 \\
2.708 \\
2.708 \\
2.707 \\
2.708 \\
2.708 \\
2.708 \\
2.708 \\
2.708 \\
2.708 \\
2.708 \\
2.707 \\
2.708 \\
2.708 \\
2.708 \\
2.708 \\
2.708 \\
2.708 \\
2.708 \\
2.707 \\
2.708 \\
2.708 \\
2.708 \\
2.708 \\
2.708 \\
2.708 \\
2.708 \\
2.707 \\
2.708 \\
2.708 \\
2.708 \\
2.708 \\
2.708\end{array}$ & $\begin{array}{l}2.743 \\
2.749 \\
2.738 \\
2.726 \\
2.716 \\
2.715 \\
2.718 \\
2.726 \\
2.744 \\
2.748 \\
2.737 \\
2.728 \\
2.718 \\
2.717 \\
2.719 \\
2.726 \\
2.740 \\
2.745 \\
2.736 \\
2.728 \\
2.720 \\
2.719 \\
2.722 \\
2.726 \\
2.739 \\
2.745 \\
2.735 \\
2.731 \\
2.722 \\
2.721 \\
2.723 \\
2.725 \\
2.737 \\
2.745 \\
2.735 \\
2.732 \\
2.724 \\
2.722 \\
2.723 \\
2.724 \\
2.736 \\
2.738 \\
2.734\end{array}$ & $\begin{array}{l}0.035 \\
0.042 \\
0.030 \\
0.019 \\
0.009 \\
0.008 \\
0.010 \\
0.018 \\
0.036 \\
0.040 \\
0.029 \\
0.020 \\
0.010 \\
0.010 \\
0.011 \\
0.018 \\
0.032 \\
0.037 \\
0.028 \\
0.020 \\
0.012 \\
0.012 \\
0.014 \\
0.018 \\
0.031 \\
0.037 \\
0.027 \\
0.023 \\
0.014 \\
0.014 \\
0.015 \\
0.017 \\
0.029 \\
0.037 \\
0.027 \\
0.024 \\
0.016 \\
0.015 \\
0.015 \\
0.016 \\
0.028 \\
0.030 \\
0.026\end{array}$ \\
\hline
\end{tabular}




\begin{tabular}{|c|c|c|c|}
\hline \multicolumn{4}{|c|}{$\begin{array}{c}\text { CYLINDER } \\
\text { DIMENSIONAL INSPECTION DATA }\end{array}$} \\
\hline \multicolumn{4}{|c|}{ END IMPACT, TEST 7} \\
\hline $\begin{array}{l}\text { MEASUREMENT } \\
\text { DESIGNATION }\end{array}$ & PRE-TEST & POST-TEST & $\begin{array}{l}\text { MEASUREMENT } \\
\text { CHANGE } \\
\end{array}$ \\
\hline $\begin{array}{l}\text { L17-81 } \\
\text { L17-126 } \\
\text { L17-171 } \\
\text { L17-216 } \\
\text { L17-261 } \\
\text { L17-306 } \\
\text { L17-351 } \\
\text { L18-36 } \\
\text { L18-81 } \\
\text { L18-126 } \\
\text { L18-171 } \\
\text { L18-216 } \\
\text { L18-261 } \\
\text { L18-306 } \\
\text { L18-351 } \\
\text { L19-36 } \\
\text { L19-81 } \\
\text { L19-126 } \\
\text { L19-171 } \\
\text { L19-216 } \\
\text { L19-261 } \\
\text { L19-306 } \\
\text { L19-351 } \\
\text { L20-36 } \\
\text { L20-81 } \\
\text { L20-126 } \\
\text { L20-171 } \\
\text { L20-216 } \\
\text { L20-261 } \\
\text { L20-306 } \\
\text { L20-351 } \\
\text { L21-36 } \\
\text { L21-81 } \\
\text { L21-126 } \\
\text { L21-171 } \\
\text { L21-216 } \\
\text { L21-261 } \\
\text { L21-306 } \\
\text { L21-351 } \\
\text { L22-36 } \\
\text { L22-81 } \\
\text { L22-126 } \\
\text { L22-171 }\end{array}$ & $\begin{array}{l}2.708 \\
2.708 \\
2.708 \\
2.708 \\
2.708 \\
2.708 \\
2.708 \\
2.708 \\
2.708 \\
2.708 \\
2.708 \\
2.708 \\
2.708 \\
2.708 \\
2.708 \\
2.708 \\
2.708 \\
2.708 \\
2.708 \\
2.708 \\
2.708 \\
2.708 \\
2.708 \\
2.708 \\
2.708 \\
2.708 \\
2.708 \\
2.708 \\
2.708 \\
2.709 \\
2.709 \\
2.708 \\
2.709 \\
2.708 \\
2.708 \\
2.708 \\
2.709 \\
2.709 \\
2.709 \\
2.708 \\
2.709 \\
2.708 \\
2.708\end{array}$ & $\begin{array}{l}2.732 \\
2.725 \\
2.722 \\
2.724 \\
2.724 \\
2.733 \\
2.737 \\
2.732 \\
2.731 \\
2.726 \\
2.723 \\
2.724 \\
2.724 \\
2.732 \\
2.735 \\
2.730 \\
2.731 \\
2.726 \\
2.723 \\
2.723 \\
2.723 \\
2.730 \\
2.732 \\
2.729 \\
2.730 \\
2.727 \\
2.724 \\
2.723 \\
2.723 \\
2.727 \\
2.727 \\
2.727 \\
2.730 \\
2.729 \\
2.725 \\
2.722 \\
2.720 \\
2.723 \\
2.725 \\
2.724 \\
2.729 \\
2.729 \\
2.726\end{array}$ & $\begin{array}{l}0.024 \\
0.017 \\
0.014 \\
0.016 \\
0.016 \\
0.025 \\
0.029 \\
0.024 \\
0.023 \\
0.018 \\
0.015 \\
0.016 \\
0.016 \\
0.024 \\
0.027 \\
0.022 \\
0.023 \\
0.018 \\
0.015 \\
0.015 \\
0.015 \\
0.022 \\
0.024 \\
0.021 \\
0.022 \\
0.019 \\
0.016 \\
0.015 \\
0.015 \\
0.018 \\
0.018 \\
0.019 \\
0.021 \\
0.021 \\
0.017 \\
0.014 \\
0.011 \\
0.014 \\
0.016 \\
0.016 \\
0.020 \\
0.021 \\
0.018\end{array}$ \\
\hline
\end{tabular}




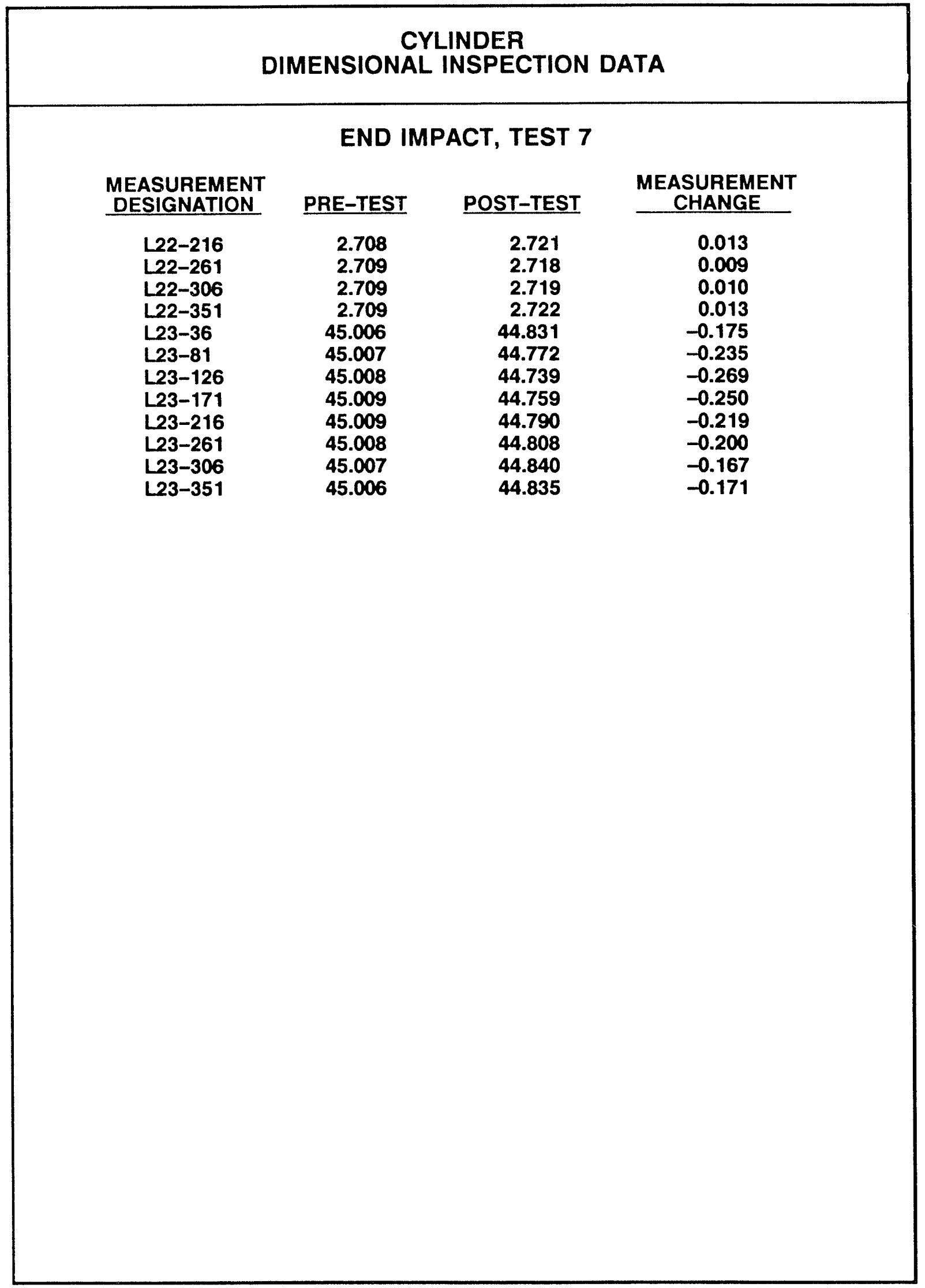




\begin{tabular}{|c|c|c|c|}
\hline \multicolumn{4}{|c|}{$\begin{array}{c}\text { CYLINDER } \\
\text { DIMENSIONAL INSPECTION DATA }\end{array}$} \\
\hline \multicolumn{4}{|c|}{ END IMPACT, TEST 8} \\
\hline $\begin{array}{l}\text { MEASUREMENT } \\
\text { DESIGNATION }\end{array}$ & PRE-TEST & POST-TEST & $\begin{array}{l}\text { MEASUREMENT } \\
\text { CHANGE } \\
\end{array}$ \\
\hline 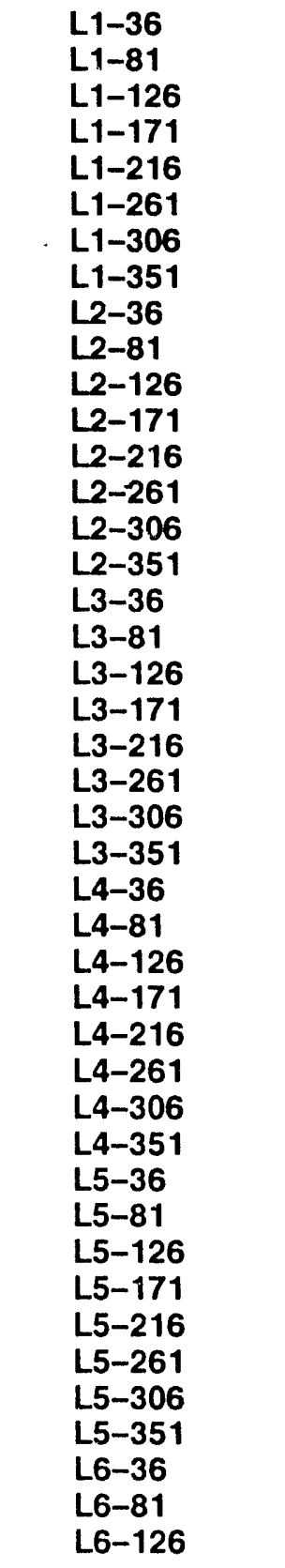 & $\begin{array}{l}2.704 \\
2.701 \\
2.704 \\
2.706 \\
2.705 \\
2.703 \\
2.701 \\
2.703 \\
2.706 \\
2.703 \\
2.705 \\
2.707 \\
2.707 \\
2.706 \\
2.706 \\
2.706 \\
2.707 \\
2.706 \\
2.707 \\
2.708 \\
2.708 \\
2.708 \\
2.707 \\
2.708 \\
2.708 \\
2.709 \\
2.709 \\
2.710 \\
2.710 \\
2.709 \\
2.708 \\
2.709 \\
2.710 \\
2.709 \\
2.709 \\
2.710 \\
2.710 \\
2.709 \\
2.708 \\
2.709 \\
2.709 \\
2.709 \\
2.709\end{array}$ & $\begin{array}{l}2.709 \\
2.709 \\
2.709 \\
2.709 \\
2.709 \\
2.709 \\
2.709 \\
2.709 \\
2.704 \\
2.705 \\
2.707 \\
2.710 \\
2.711 \\
2.709 \\
2.708 \\
2.706 \\
2.709 \\
2.707 \\
2.705 \\
2.708 \\
2.711 \\
2.714 \\
2.715 \\
2.713 \\
2.735 \\
2.709 \\
2.686 \\
2.679 \\
2.695 \\
2.721 \\
2.743 \\
2.748 \\
2.735 \\
2.709 \\
2.686 \\
2.678 \\
2.691 \\
2.721 \\
2.745 \\
2.750 \\
2.736 \\
2.709 \\
2.686\end{array}$ & $\begin{array}{r}0.005 \\
0.008 \\
0.005 \\
0.003 \\
0.004 \\
0.006 \\
0.008 \\
0.006 \\
-0.002 \\
0.002 \\
0.002 \\
0.003 \\
0.004 \\
0.003 \\
0.002 \\
0.000 \\
0.002 \\
0.001 \\
-0.002 \\
0.000 \\
0.003 \\
0.006 \\
0.008 \\
0.005 \\
0.027 \\
0.000 \\
-0.023 \\
-0.031 \\
-0.015 \\
0.012 \\
0.035 \\
0.039 \\
0.025 \\
0.000 \\
-0.023 \\
-0.032 \\
-0.019 \\
0.012 \\
0.037 \\
0.041 \\
0.027 \\
0.000 \\
-0.023\end{array}$ \\
\hline
\end{tabular}




\section{DIMENSIONAL INSPECTION DATA}

\section{END INPPACT, TEST 8}

MEASUREMENT DESIGNATION

L6-171
$L 6-216$
$L 6-261$
$L 6-306$
$L 6-351$
$L 7-36$
$L 7-81$
$L 7-126$
$L 7-171$
$L 7-216$
$L 7-261$
$L 7-306$
$L 7-351$
$L 8-36$
$L 8-81$
$L 8-126$
$L 8-171$
$L 8-216$
$L 8-261$
L8-306
L8 351
$L 9-36$
$L 9-81$
$L 9-126$
$L 9-171$
$L 9-216$
$L 9-261$
$L 9-306$
$L 9-351$
$L 10-36$
$L 10-81$
$L 10-126$
$L 10-171$
$L 10-216$
$L 10-261$
$L 10-306$
$L .10-351$
$L 11-36$
$L 11-81$
$L 11-126$
$L 11-171$
$L 11-216$
$L 11-261$

\section{PRE-TEST}

2.710

2.710

2.710

2.709

2.709

2.709

2.710

2.710

2.710

2.710

2.710

2.709

2.709

2.710

2.710

2.710

2.710

2.710

2.710

2.709

2.709

2.710

2.710

2.710

2.710

2.710

2.710

2.709

2.709

2.710

2.710

2.710

2.711

2.710

2.710

2.709

2.709

2.710

2.710

2.711

2.711

2.710

2.711

\section{POST-TEST}

2.677

2.691

$\therefore .721$

2.743

2.752

2.737

2.709

2.686

2.678

2.692

2.720

2.745

2.753

2.737

2.709

2.687

2.680

2.693

2.719

2.744

2.752

2.735

2.709

2.690

2.684

2.695

2.717

2.741

2.750

2.733

2.709

2.693

2.690

2.698

2.716

2.738

2.748

2.731

2.709

2.695

2.693

2.701

2.715
MEASUREMENT CHANGE

$-0.033$

$-0.019$

0.011

0.034

0.043

0.028

$-0.001$

$-0.024$

$-0.032$

$-0.018$

0.010

0.036

0.044

0.027

$-0.001$

$-0.023$

$-0.030$

$-0.017$

0.009

0.035

0.043

0.025

$-0.001$

$-0.020$

$-0.026$

$-0.015$

0.007

0.032

0.041

0.023

$-0.001$

$-0.017$

$-0.021$

$-0.012$

0.006

0.029

0.039

0.021

$-0.001$

$-0.016$

$-0.018$

$-0.009$

0.004 


\section{CYLINDER \\ DIMENSIONAL INSPECTIOH: DATA}

\section{END IMPACT, TEST 8}

MEASUREMENT

DESIGNATION

L11-306

L11-351

L12-36

L12-81

L12-126

L12-171

L12-216

L12-261

L12-306

L12-351

L13-36

L13-81

L13-126

L13-171

L13-216

L13-261

L13-306

L13-351

L14-36

L14-81

L14-126

L14-171

L14-216

L14-261

L14-306

L14-351

L15-36

L15-81

L15-126

L15-171

L15-216

L15-261

L15-306

L15-351

L16-36

L16-81

L16-126

L16-171

L16-216

L16-261

L16-306

L16-351

L17-36

\begin{tabular}{c} 
PRE-TEST \\
\hline 2.709 \\
2.709 \\
2.710 \\
2.710 \\
2.711 \\
2.711 \\
2.710 \\
2.711 \\
2.709 \\
2.709 \\
2.710 \\
2.710 \\
2.711 \\
2.711 \\
2.711 \\
2.711 \\
2.705 \\
2.709 \\
2.710 \\
2.710 \\
2.711 \\
2.711 \\
2.711 \\
2.711 \\
2.710 \\
2.709 \\
2.710 \\
2.710 \\
2.711 \\
2.711 \\
2.711 \\
2.711 \\
2.710 \\
2.709 \\
2.710 \\
2.710 \\
2.711 \\
2.711 \\
2.711 \\
2.711 \\
2.710 \\
2.709 \\
2.710 \\
\end{tabular}

POST-TEST

2.736

2.745

2.730

2.710

2.698

2.696

2.703

2.714

2.734

2.744

2.729

2.712

2.702

2.700

2.706

2.713

2.731

2.740

2.725

2.713

2.704

2.703

2.709

2.713

2.728

2.738

2.723

2.714

2.708

2.708

2.711

2.712

2.725

2.736

2.721

2.715

2.712

2.712

2.714

2.712

2.722

2.728

2.719
MEASUREMENT

CHANGE

$$
0.027
$$

0.036

0.020

0.000

$-0.013$

$-0.015$

$-0.007$

0.003

0.025

0.035

0.019

0.002

$-0.009$

$-0.011$

$-0.005$

0.002

0.022

0.031

0.015

0.003

$-0.007$

$-0.008$

$-0.002$

0.002

0.018

0.029

0.013

0.004

$-0.003$

$-0.003$

0.000

0.001

0.015

0.027

0.011

0.005

0.001

0.001

0.003

0.001

0.012

0.019

0.009 


\section{CYLINDER \\ DIMENSIONAL INSPECTION DATA}

\section{END IMPACT, TEST 8}

MEASUREMENT DESIGNATION

L17-81
L17-126
L17-171
L17-216
L17-261
L17-306
L17-351
L18-36
L18-81
L18-126
L18-171
L18-216
L18-261
L18-306
L18-351
L19-36
L19-81
L19-126
L19-171
L19-216
L19-261
L19-306
L19-351
L20-36
L20-81
L20-126
L20-171
L20-216
L20-261
L20-306
L20-351
L21-36
L21-81
L21-126
L21-171
L21-216
L21-261
L21-306
L21-351
L22-36
L22-81
L22-126
L22-171

L17-81

L17-171

L17-216

$\lfloor 17-261$

L17-351

L18-36

L18-81

L18-216

L18-261

L18-306

L19-36

L19-81

L19-126

L19-171

L19-261

L19-306

ᄂ19-351

L20-81

L20-126

20-171

L20-261

L20-306

$-351$

L21-81

L21-126

L21-216

L21-261

$1-306$

L22-36

L22-126

L22-171

\section{PRE-TEST}

2.711

2.711

2.711

2.711

2.711

2.710

2.709

2.710

2.711

2.711

2.711

2.711

2.711

2.710

2.709

2.710

2.711

2.711

2.711

2.711

2.711

2.710

2.709

2.711

2.711

2.711

2.711

2.711

2.711

2.710

2.709

2.711

2.711

2.711

2.711

2.711

2.711

2.710

2.709

2.711

2.711

2.711

2.711
POST-TEST

2.716

2.714

2.713

2.715

2.712

2.718

2.726

2.716

2.718

2.716

2.714

2.715

2.712

2.715

2.722

2.713

2.718

2.717

2.715

2.714

2.710

2.712

2.716

2.710

2.715

2.718

2.719

2.712

2.710

2.708

2.711

2.706

2.715

2.718

2.720

2.712

2.709

2.705

2.709

2.705

2.714

2.718

2.720
MEASUREMENT

CHANGE

0.005

0.003

0.002

0.004

0.001

0.008

0.017

0.006

0.007

0.005

0.003

0.004

0.001

0.005

0.013

0.003

0.007

0.006

0.004

0.003

$-0.001$

0.002

0.007

$-0.001$

0.004

0.007

0.008

0.001

$-0.001$

$-0.002$

0.002

$-0.005$

0.004

0.007

0.009

0.001

$-0.002$

$-0.005$

0.000

$-0.006$

0.003

0.007

0.009 


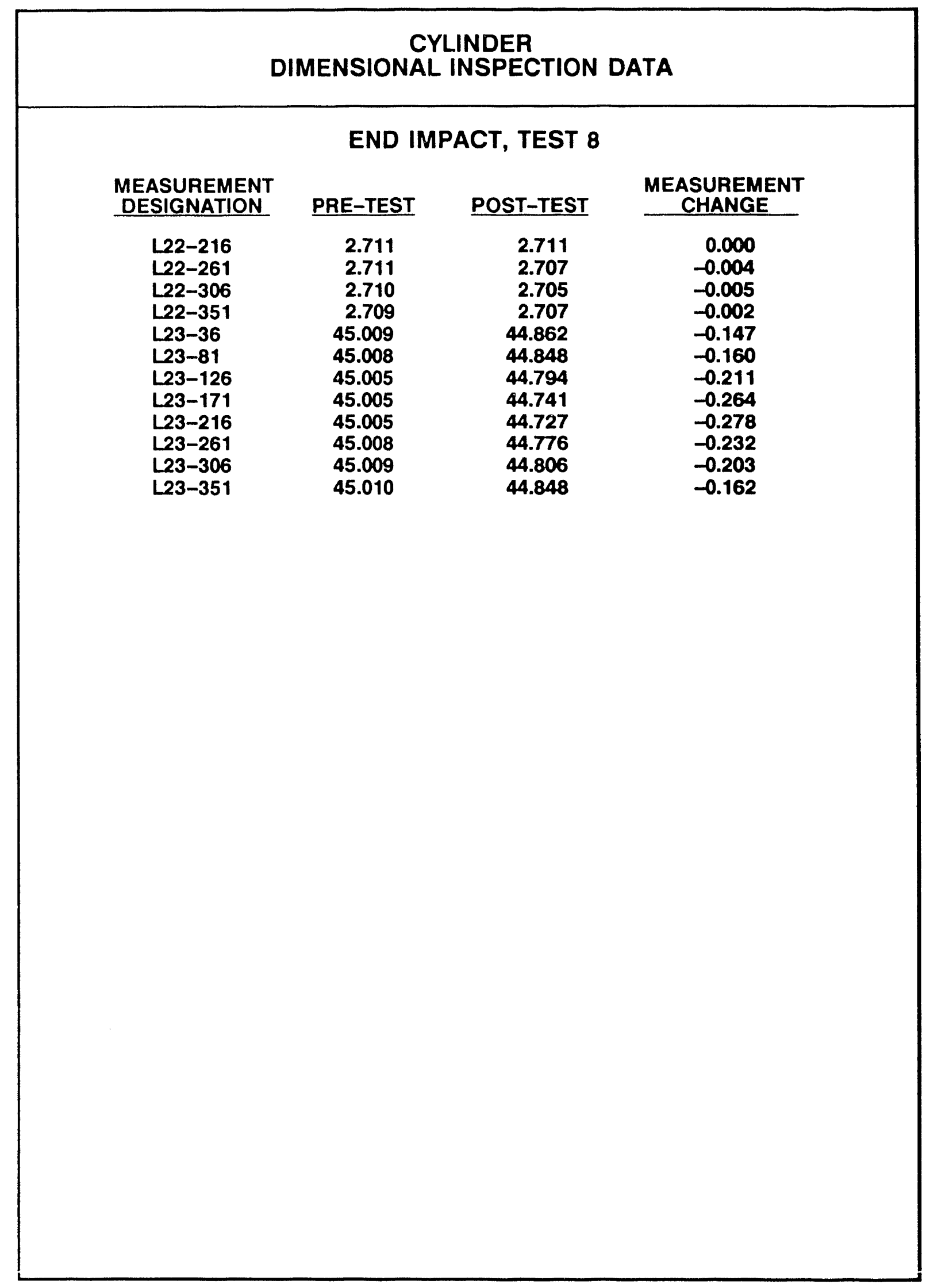




\begin{tabular}{|c|c|c|c|}
\hline \multicolumn{4}{|c|}{$\begin{array}{c}\text { CYLINDER } \\
\text { DIMENSIONAL INSPECTION DATA }\end{array}$} \\
\hline \multicolumn{4}{|c|}{ END IMPACT, TEST 9} \\
\hline $\begin{array}{l}\text { MEASUREMENT } \\
\text { DESIGNATION } \\
\end{array}$ & PRE-TEST & POST-TEST & $\begin{array}{c}\text { MEASUREMENT } \\
\text { CHANGE } \\
\end{array}$ \\
\hline 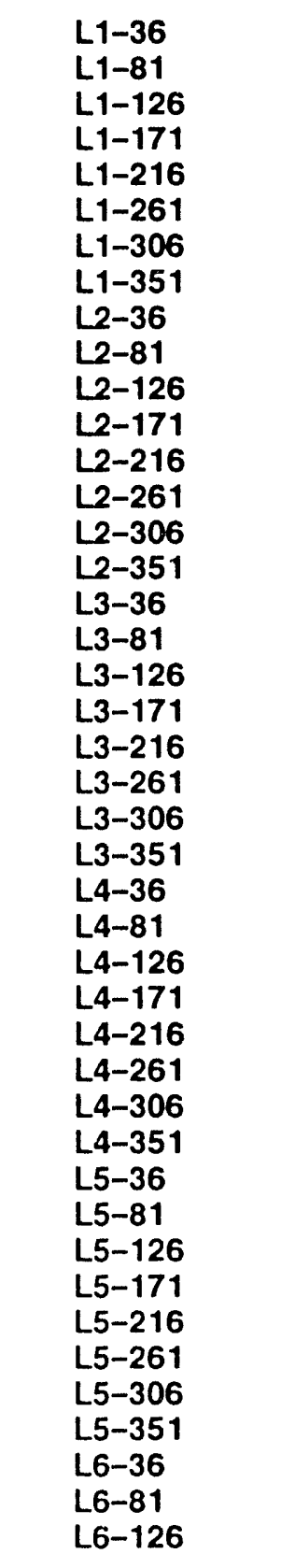 & $\begin{array}{l}2.703 \\
2.706 \\
2.703 \\
2.704 \\
2.702 \\
2.694 \\
2.687 \\
2.692 \\
2.705 \\
2.707 \\
2.705 \\
2.705 \\
2.704 \\
2.700 \\
2.694 \\
2.697 \\
2.707 \\
2.708 \\
2.706 \\
2.706 \\
2.706 \\
2.703 \\
2.700 \\
2.702 \\
2.708 \\
2.708 \\
2.707 \\
2.707 \\
2.708 \\
2.707 \\
2.706 \\
2.706 \\
2.708 \\
2.708 \\
2.707 \\
2.708 \\
2.708 \\
2.707 \\
2.706 \\
2.707 \\
2.708 \\
2.708 \\
2.707\end{array}$ & $\begin{array}{l}2.708 \\
2.708 \\
2.708 \\
2.708 \\
2.708 \\
2.708 \\
2.708 \\
2.708 \\
2.703 \\
2.705 \\
2.709 \\
2.712 \\
2.711 \\
2.708 \\
2.704 \\
2.702 \\
2.706 \\
2.707 \\
2.710 \\
2.713 \\
2.713 \\
2.710 \\
2.707 \\
2.705 \\
2.728 \\
2.713 \\
2.697 \\
2.691 \\
2.699 \\
2.714 \\
2.728 \\
2.734 \\
2.728 \\
2.714 \\
2.697 \\
2.690 \\
2.697 \\
2.714 \\
2.729 \\
2.735 \\
2.729 \\
2.714 \\
2.697\end{array}$ & $\begin{array}{r}0.005 \\
0.002 \\
0.005 \\
0.004 \\
0.006 \\
0.014 \\
0.021 \\
0.016 \\
-0.002 \\
-0.002 \\
0.004 \\
0.007 \\
0.007 \\
0.008 \\
0.010 \\
0.005 \\
-0.001 \\
-0.001 \\
0.004 \\
0.007 \\
0.007 \\
0.007 \\
0.007 \\
0.003 \\
0.020 \\
0.005 \\
-0.010 \\
-0.016 \\
-0.009 \\
0.007 \\
0.022 \\
0.028 \\
0.020 \\
0.006 \\
-0.010 \\
-0.018 \\
-0.011 \\
0.007 \\
0.023 \\
0.028 \\
0.021 \\
0.006 \\
-0.010\end{array}$ \\
\hline
\end{tabular}




\begin{tabular}{|c|c|c|c|}
\hline \multicolumn{4}{|c|}{$\begin{array}{c}\text { CYLINDER } \\
\text { DIMENSIONAL INSPECTION DATA }\end{array}$} \\
\hline \multicolumn{4}{|c|}{ END IMPACT, TEST 9} \\
\hline $\begin{array}{l}\text { MEASUREMENT } \\
\text { DESIGNATION }\end{array}$ & PRE-TEST & POST-TEST & $\begin{array}{c}\text { MEASUREMENT } \\
\text { CHANGE } \\
\end{array}$ \\
\hline $\begin{array}{l}\text { L6-171 } \\
\text { L6-216 } \\
\text { L6-261 } \\
\text { L6-306 } \\
\text { L6-351 } \\
\text { L7-36 } \\
\text { L7-81 } \\
\text { L7-126 } \\
\text { L7-171 } \\
\text { L7-216 } \\
\text { L7-261 } \\
\text { L7-306 } \\
\text { L7-351 } \\
\text { L8-36 } \\
\text { L8-81 } \\
\text { L8-126 } \\
\text { L8-171 } \\
\text { L8-216 } \\
\text { L8-261 } \\
\text { L8-306 } \\
\text { L8-351 } \\
\text { L9-36 } \\
\text { L9-81 } \\
\text { L9-126 } \\
\text { L9-171 } \\
\text { L9-216 } \\
\text { L9-261 } \\
\text { L9-306 } \\
\text { L9-351 } \\
\text { L10-36 } \\
\text { L10-81 } \\
\text { L10-126 } \\
\text { L10-171 } \\
\text { L10-216 } \\
\text { L10-261 } \\
\text { L10-306 } \\
\text { L10-351 } \\
\text { L11-36 } \\
\text { L11-81 } \\
\text { L 11-126 } \\
\text { L11-171 } \\
\text { L11-216 } \\
\text { L11-261 }\end{array}$ & $\begin{array}{l}2.708 \\
2.708 \\
2.708 \\
2.706 \\
2.707 \\
2.708 \\
2.708 \\
2.708 \\
2.708 \\
2.708 \\
2.708 \\
2.706 \\
2.708 \\
2.709 \\
2.708 \\
2.708 \\
2.709 \\
2.709 \\
2.709 \\
2.707 \\
2.708 \\
2.709 \\
2.708 \\
2.708 \\
2.709 \\
2.709 \\
2.709 \\
2.708 \\
2.708 \\
2.709 \\
2.708 \\
2.708 \\
2.709 \\
2.709 \\
2.709 \\
2.708 \\
2.708 \\
2.709 \\
2.708 \\
2.708 \\
2.709 \\
2.709 \\
2.710\end{array}$ & $\begin{array}{l}2.690 \\
2.697 \\
2.714 \\
2.729 \\
2.736 \\
2.730 \\
2.714 \\
2.698 \\
2.692 \\
2.699 \\
2.713 \\
2.729 \\
2.737 \\
2.729 \\
2.713 \\
2.699 \\
2.695 \\
2.701 \\
2.713 \\
2.728 \\
2.736 \\
2.728 \\
2.711 \\
2.701 \\
2.699 \\
2.704 \\
2.711 \\
2.725 \\
2.735 \\
2.725 \\
2.711 \\
2.703 \\
2.705 \\
2.709 \\
2.711 \\
2.722 \\
2.731 \\
2.722 \\
2.710 \\
2.705 \\
2.707 \\
2.710 \\
2.710\end{array}$ & $\begin{array}{r}-0.018 \\
-0.011 \\
0.006 \\
0.023 \\
0.029 \\
0.022 \\
0.006 \\
-0.010 \\
-0.016 \\
-0.009 \\
0.005 \\
0.023 \\
0.029 \\
0.020 \\
0.005 \\
-0.009 \\
-0.014 \\
-0.008 \\
0.004 \\
0.021 \\
0.028 \\
0.019 \\
0.003 \\
-0.007 \\
-0.010 \\
-0.005 \\
0.002 \\
0.017 \\
0.027 \\
0.016 \\
0.003 \\
0.003 \\
-0.005 \\
-0.004 \\
0.000 \\
0.002 \\
0.014 \\
0.023 \\
0.013 \\
0.002 \\
-0.003 \\
-0.002 \\
0.001 \\
0.000\end{array}$ \\
\hline
\end{tabular}




\begin{tabular}{|c|c|c|c|}
\hline \multicolumn{4}{|c|}{$\begin{array}{c}\text { CYLINDER } \\
\text { DIMENSIONAL INSPECTION DATA }\end{array}$} \\
\hline \multicolumn{4}{|c|}{ END IMPACT, TEST 9} \\
\hline $\begin{array}{l}\text { MEASUREMENT } \\
\text { DESIGNATION } \\
\end{array}$ & PRE-TEST & POST-TEST & $\begin{array}{c}\text { MEASUREMENT } \\
\text { CHANGE } \\
\end{array}$ \\
\hline $\begin{array}{l}\text { L11-306 } \\
\text { L11-351 } \\
\text { L12-36 } \\
\text { L12-81 } \\
\text { L12-126 } \\
\text { L12-171 } \\
\text { L12-216 } \\
\text { L12-261 } \\
\text { L12-306 } \\
\text { L12-351 } \\
\text { L13-36 } \\
\text { L13-81 } \\
\text { L13-126 } \\
\text { L13-171 } \\
\text { L13-216 } \\
\text { L13-261 } \\
\text { L13-306 } \\
\text { L13-351 } \\
\text { L14-36 } \\
\text { L14-81 } \\
\text { L14-126 } \\
\text { L14-171 } \\
\text { L14-216 } \\
\text { L14-261 } \\
\text { L14-306 } \\
\text { L14-351 } \\
\text { L15-36 } \\
\text { L15-81 } \\
\text { L15-126 } \\
\text { L15-171 } \\
\text { L15-216 } \\
\text { L15-261 } \\
\text { L15-306 } \\
\text { L15-351 } \\
\text { L16-36 } \\
\text { L16-81 } \\
\text { L16-126 } \\
\text { L16-171 } \\
\text { L16-216 } \\
\text { L16-261 } \\
\text { L16-3066 } \\
\text { L16-351 } \\
\text { L17-36 }\end{array}$ & $\begin{array}{l}2.708 \\
2.709 \\
2.709 \\
2.708 \\
2.708 \\
2.709 \\
2.709 \\
2.710 \\
2.708 \\
2.709 \\
2.709 \\
2.708 \\
2.708 \\
2.709 \\
2.709 \\
2.710 \\
2.709 \\
2.709 \\
2.709 \\
2.708 \\
2.708 \\
2.709 \\
2.709 \\
2.710 \\
2.709 \\
2.709 \\
2.709 \\
2.708 \\
2.708 \\
2.709 \\
2.709 \\
2.710 \\
2.709 \\
2.710 \\
2.709 \\
2.708 \\
2.708 \\
2.709 \\
2.710 \\
2.710 \\
2.709 \\
2.710 \\
2.709\end{array}$ & $\begin{array}{l}2.720 \\
2.730 \\
2.721 \\
2.710 \\
2.708 \\
2.710 \\
2.713 \\
2.711 \\
2.717 \\
2.728 \\
2.718 \\
2.711 \\
2.710 \\
2.714 \\
2.716 \\
2.712 \\
2.715 \\
2.725 \\
2.717 \\
2.712 \\
2.713 \\
2.716 \\
2.720 \\
2.712 \\
2.713 \\
2.723 \\
2.714 \\
2.712 \\
2.716 \\
2.719 \\
2.723 \\
2.713 \\
2.711 \\
2.718 \\
2.711 \\
2.713 \\
2.718 \\
2.723 \\
2.723 \\
2.714 \\
2.710 \\
2.713 \\
2.709\end{array}$ & $\begin{array}{l}0.012 \\
0.021 \\
0.012 \\
0.002 \\
0.000 \\
0.001 \\
0.004 \\
0.001 \\
0.009 \\
0.019 \\
0.009 \\
0.003 \\
0.002 \\
0.005 \\
0.007 \\
0.002 \\
0.006 \\
0.016 \\
0.008 \\
0.004 \\
0.005 \\
0.007 \\
0.011 \\
0.002 \\
0.004 \\
0.014 \\
0.005 \\
0.004 \\
0.008 \\
0.010 \\
0.014 \\
0.003 \\
0.002 \\
0.008 \\
0.002 \\
0.005 \\
0.010 \\
0.014 \\
0.013 \\
0.004 \\
0.001 \\
0.003 \\
0.000\end{array}$ \\
\hline
\end{tabular}




\begin{tabular}{|c|c|c|c|}
\hline \multicolumn{4}{|c|}{$\begin{array}{c}\text { CYLINDER } \\
\text { DIMENSIONAL INSPECTION DATA }\end{array}$} \\
\hline \multicolumn{4}{|c|}{ END IMPACT, TEST 9} \\
\hline $\begin{array}{l}\text { MEASUREMENT } \\
\text { DESIGNATION }\end{array}$ & PRE-TEST & POST-TEST & $\begin{array}{c}\text { MEASUREMENT } \\
\text { CHANGE } \\
\end{array}$ \\
\hline $\begin{array}{l}\text { L17-81 } \\
\text { L17-126 } \\
\text { L17-171 } \\
\text { L17-216 } \\
\text { L17-261 } \\
\text { L17-306 } \\
\text { L17-351 } \\
\text { L18-36 } \\
\text { L18-81 } \\
\text { L18-126 } \\
\text { L18-171 } \\
\text { L18-216 } \\
\text { L18-261 } \\
\text { L18-306 } \\
\text { L18-351 } \\
\text { L19-36 } \\
\text { L19-81 } \\
\text { L19-126 } \\
\text { L19-171 } \\
\text { L19-216 } \\
\text { L19-261 } \\
\text { L19-306 } \\
\text { L19-351 } \\
\text { L20-36 } \\
\text { L20-81 } \\
\text { L20-12 } \\
\text { L20-171 } \\
\text { L20-216 } \\
\text { L20-261 } \\
\text { L20-306 } \\
\text { L20-351 } \\
\text { L21-36 } \\
\text { L21-81 } \\
\text { L21-126 } \\
\text { L21-171 } \\
\text { L21-216 } \\
\text { L21-261 } \\
\text { L21-306 } \\
\text { L21-351 } \\
\text { L22-36 } \\
\text { L22-81 } \\
\text { L22-126 } \\
\text { L22-171 }\end{array}$ & $\begin{array}{l}2.708 \\
2.708 \\
2.709 \\
2.710 \\
2.710 \\
2.710 \\
2.710 \\
2.709 \\
2.708 \\
2.708 \\
2.709 \\
2.710 \\
2.711 \\
2.710 \\
2.710 \\
2.709 \\
2.708 \\
2.708 \\
2.709 \\
2.710 \\
2.711 \\
2.710 \\
2.710 \\
2.709 \\
2.708 \\
2.708 \\
2.709 \\
2.710 \\
2.711 \\
2.710 \\
2.710 \\
2.710 \\
2.708 \\
2.708 \\
2.709 \\
2.709 \\
2.711 \\
2.710 \\
2.710 \\
2.710 \\
2.708 \\
2.708 \\
2.709\end{array}$ & $\begin{array}{l}2.713 \\
2.721 \\
2.725 \\
2.724 \\
2.714 \\
2.706 \\
2.710 \\
2.706 \\
2.713 \\
2.723 \\
2.726 \\
2.725 \\
2.715 \\
2.704 \\
2.708 \\
2.702 \\
2.713 \\
2.724 \\
2.729 \\
2.724 \\
2.714 \\
2.700 \\
2.703 \\
2.699 \\
2.711 \\
2.724 \\
2.733 \\
2.723 \\
2.713 \\
2.698 \\
2.706 \\
2.696 \\
2.710 \\
2.726 \\
2.732 \\
2.723 \\
2.712 \\
2.695 \\
2.699 \\
2.699 \\
2.708 \\
2.724 \\
2.731\end{array}$ & $\begin{array}{r}0.005 \\
0.013 \\
0.016 \\
0.014 \\
0.004 \\
-0.004 \\
0.000 \\
-0.003 \\
0.005 \\
0.015 \\
0.017 \\
0.015 \\
0.004 \\
-0.006 \\
-0.002 \\
-0.007 \\
0.005 \\
0.016 \\
0.020 \\
0.014 \\
0.003 \\
-0.010 \\
-0.007 \\
-0.010 \\
0.003 \\
0.016 \\
0.024 \\
0.013 \\
0.002 \\
-0.012 \\
-0.004 \\
-0.014 \\
0.002 \\
0.018 \\
0.023 \\
0.014 \\
0.001 \\
-0.015 \\
-0.011 \\
-0.011 \\
0.000 \\
0.016 \\
0.022\end{array}$ \\
\hline
\end{tabular}




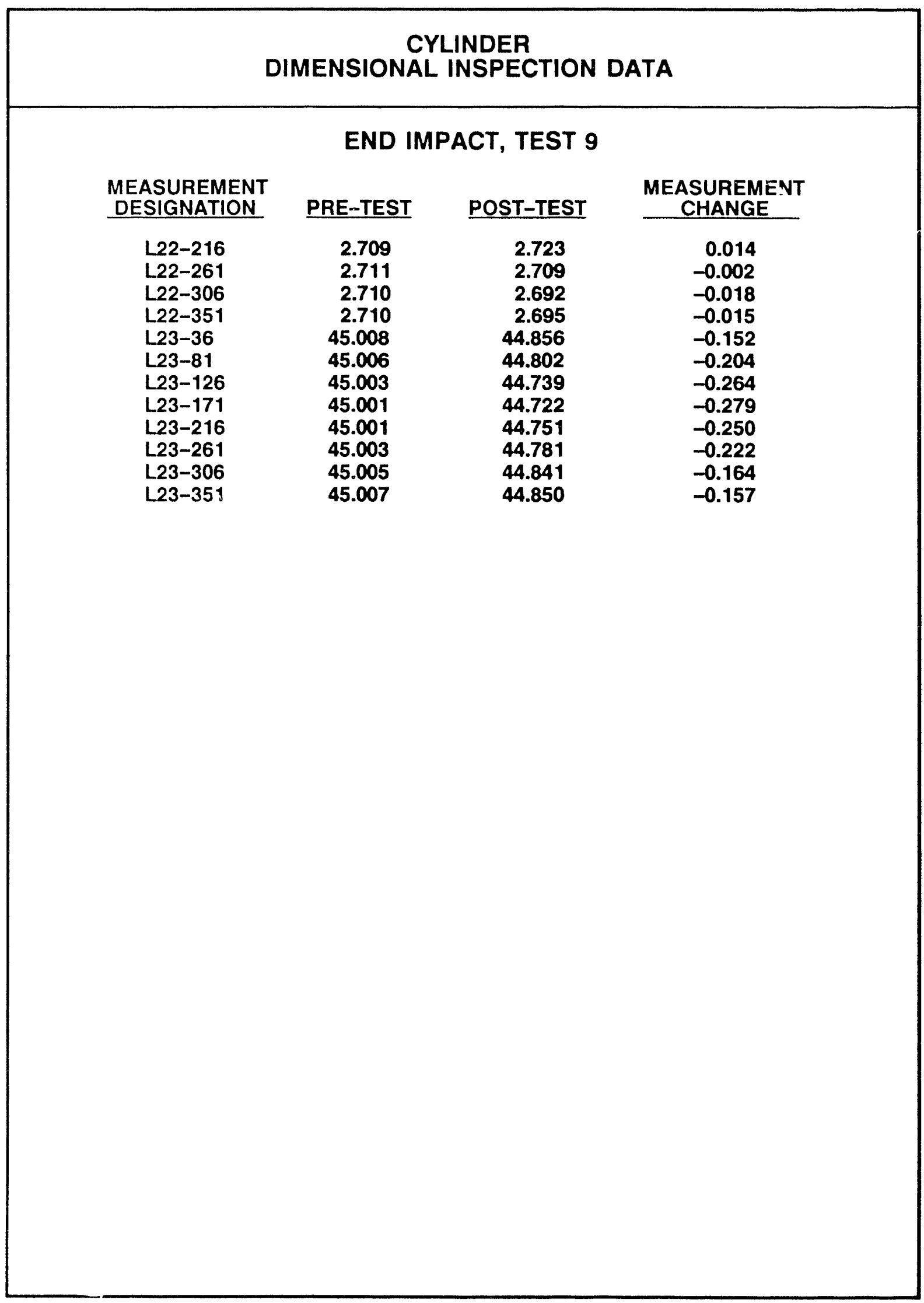




\begin{tabular}{|c|c|c|c|}
\hline \multicolumn{4}{|c|}{$\begin{array}{c}\text { CYLINDER } \\
\text { DIMENSIONAL INSPECTION DATA }\end{array}$} \\
\hline \multicolumn{4}{|c|}{ END IMPACT, TEST 10} \\
\hline $\begin{array}{l}\text { MEASUREMENT } \\
\text { DESIGNATION }\end{array}$ & PRE-TEST & POST-TEST & $\begin{array}{c}\text { MEASUREMENT } \\
\text { CHANGE } \\
\end{array}$ \\
\hline $\begin{array}{l}\text { L1-36 } \\
\text { L1-81 } \\
\text { L1-126 } \\
\text { L1-171 } \\
\text { L1-216 } \\
\text { L1-261 } \\
\text { L1-306 } \\
\text { L1-351 } \\
\text { L2-36 } \\
\text { L2-81 } \\
\text { L2-126 } \\
\text { L2-171 } \\
\text { L2-216 } \\
\text { L2-261 } \\
\text { L2-306 } \\
\text { L2-351 } \\
\text { L3-36 } \\
\text { L3-81 } \\
\text { L3-126 } \\
\text { L3-171 } \\
\text { L3-216 } \\
\text { L3-261 } \\
\text { L3-306 } \\
\text { L3-351 } \\
\text { L4-36 } \\
\text { L4-81 } \\
\text { L4-126 } \\
\text { L4-171 } \\
\text { L4-216 } \\
\text { L4-261 } \\
\text { L4-306 } \\
\text { L4-351 } \\
\text { L5-36 } \\
\text { L5-81 } \\
\text { L5-126 } \\
\text { L5 -171 } \\
\text { L5-216 } \\
\text { L5-261 } \\
\text { L5-306 } \\
\text { L5-351 } \\
\text { L6-36 } \\
\text { L6-81 } \\
\text { L6-126 }\end{array}$ & $\begin{array}{l}2.701 \\
2.703 \\
2.705 \\
2.705 \\
2.707 \\
2.708 \\
2.707 \\
2.703 \\
2.705 \\
2.706 \\
2.706 \\
2.706 \\
2.707 \\
2.709 \\
2.709 \\
2.706 \\
2.707 \\
2.707 \\
2.708 \\
2.707 \\
2.708 \\
2.710 \\
2.710 \\
2.708 \\
2.709 \\
2.709 \\
2.709 \\
2.709 \\
2.709 \\
2.710 \\
2.711 \\
2.710 \\
2.709 \\
2.709 \\
2.709 \\
2.709 \\
2.709 \\
2.711 \\
2.711 \\
2.710 \\
2.710 \\
2.709 \\
2.709\end{array}$ & $\begin{array}{l}2.708 \\
2.707 \\
2.708 \\
2.708 \\
2.708 \\
2.709 \\
2.709 \\
2.709 \\
2.698 \\
2.696 \\
2.704 \\
2.716 \\
2.722 \\
2.720 \\
2.712 \\
2.702 \\
2.692 \\
2.692 \\
2.702 \\
2.720 \\
2.730 \\
2.730 \\
2.719 \\
2.706 \\
2.724 \\
2.692 \\
2.688 \\
2.694 \\
2.713 \\
2.731 \\
2.744 \\
2.741 \\
2.725 \\
2.692 \\
2.688 \\
2.693 \\
2.710 \\
2.732 \\
2.746 \\
2.743 \\
2.724 \\
2.692 \\
2.688\end{array}$ & $\begin{array}{r}0.007 \\
0.004 \\
0.003 \\
0.003 \\
0.001 \\
0.001 \\
0.002 \\
0.006 \\
-0.007 \\
-0.010 \\
-0.002 \\
0.010 \\
0.015 \\
0.011 \\
0.003 \\
-0.004 \\
-0.015 \\
-0.015 \\
-0.006 \\
0.013 \\
0.022 \\
0.020 \\
0.009 \\
-0.002 \\
0.015 \\
-0.017 \\
-0.021 \\
-0.015 \\
0.004 \\
0.021 \\
0.033 \\
0.031 \\
0.016 \\
-0.017 \\
-0.021 \\
-0.016 \\
0.001 \\
0.021 \\
0.035 \\
0.033 \\
0.014 \\
-0.017 \\
-0.021\end{array}$ \\
\hline
\end{tabular}




\begin{tabular}{|c|c|c|c|}
\hline \multicolumn{4}{|c|}{$\begin{array}{c}\text { CYLINDER } \\
\text { DIMENSIONAL INSPECTION DATA }\end{array}$} \\
\hline \multicolumn{4}{|c|}{ END IMPACT, TEST 10} \\
\hline $\begin{array}{l}\text { MEASUREMENT } \\
\text { DESIGNATION }\end{array}$ & PRE-TEST & POST-TEST & $\begin{array}{c}\text { MEASUREMENT } \\
\text { CHANGE } \\
\end{array}$ \\
\hline $\begin{array}{l}\text { L6-171 } \\
\text { L6-216 } \\
\text { L6-261 } \\
\text { L6-306 } \\
\text { L6-351 } \\
\text { L7-36 } \\
\text { L7-81 } \\
\text { L7-126 } \\
\text { L7-171 } \\
\text { L7- } 16 \\
\text { L7- } 61 \\
\text { L7-306 } \\
\text { L7-351 } \\
\text { L8-36 } \\
\text { L8-81 } \\
\text { L8-126 } \\
\text { L8-171 } \\
\text { L8-216 } \\
\text { L8-261 } \\
\text { L8-306 } \\
\text { L8-351 } \\
\text { L9-36 } \\
\text { L9-81 } \\
\text { L9-126 } \\
\text { L9-171 } \\
\text { L9-216 } \\
\text { L9-261 } \\
\text { L9-306 } \\
\text { L9-351 } \\
\text { L10-36 } \\
\text { L10-81 } \\
\text { L10-126 } \\
\text { L10-171 } \\
\text { L10-216 } \\
\text { L10-261 } \\
\text { L10-306 } \\
\text { L10-351 } \\
\text { L11-36 } \\
\text { L } 11-81 \\
\text { L11-126 } \\
\text { L11-171 } \\
\text { L11-216 } \\
\text { L11-261 }\end{array}$ & $\begin{array}{l}2.709 \\
2.709 \\
2.711 \\
2.711 \\
2.710 \\
2.710 \\
2.710 \\
2.709 \\
2.709 \\
2.709 \\
2.711 \\
2.711 \\
2.710 \\
2.710 \\
2.710 \\
2.709 \\
2.709 \\
2.710 \\
2.711 \\
2.711 \\
2.711 \\
2.710 \\
2.710 \\
2.710 \\
2.710 \\
2.710 \\
2.711 \\
2.711 \\
2.711 \\
2.711 \\
2.710 \\
2.710 \\
2.710 \\
2.710 \\
2.711 \\
2.711 \\
2.711 \\
2.711 \\
2.711 \\
2.710 \\
2.710 \\
2.710 \\
2.711\end{array}$ & $\begin{array}{l}2.693 \\
2.712 \\
2.732 \\
2.746 \\
2.743 \\
2.724 \\
2.691 \\
2.687 \\
2.696 \\
2.714 \\
2.733 \\
2.745 \\
2.743 \\
2.722 \\
2.690 \\
2.688 \\
2.699 \\
2.719 \\
2.734 \\
2.744 \\
2.742 \\
2.719 \\
2.691 \\
2.689 \\
2.704 \\
2.724 \\
2.736 \\
2.742 \\
2.740 \\
2.712 \\
2.689 \\
2.694 \\
2.713 \\
2.732 \\
2.738 \\
2.739 \\
2.733 \\
2.711 \\
2.688 \\
2.694 \\
2.718 \\
2.735 \\
2.738\end{array}$ & $\begin{array}{r}-0.016 \\
0.003 \\
0.021 \\
0.035 \\
0.033 \\
0.014 \\
-0.019 \\
-0.022 \\
-0.013 \\
0.005 \\
0.022 \\
0.034 \\
0.033 \\
0.012 \\
-0.020 \\
-0.021 \\
-0.010 \\
0.009 \\
0.023 \\
0.033 \\
0.031 \\
0.009 \\
-0.019 \\
-0.021 \\
-0.006 \\
0.014 \\
0.025 \\
0.031 \\
0.029 \\
0.001 \\
-0.021 \\
-0.016 \\
0.003 \\
0.022 \\
0.027 \\
0.028 \\
0.022 \\
0.000 \\
-0.023 \\
-0.016 \\
0.008 \\
0.025 \\
0.027\end{array}$ \\
\hline
\end{tabular}




\begin{tabular}{|c|c|c|c|}
\hline \multicolumn{4}{|c|}{$\begin{array}{c}\text { CYLINDER } \\
\text { DIMENSIONAL INSPECTION DATA }\end{array}$} \\
\hline \multicolumn{4}{|c|}{ END IMPACT, TEST 10} \\
\hline $\begin{array}{l}\text { MEASUREMENT } \\
\text { DESIGNATION }\end{array}$ & PRE-TEST & POST-TEST & $\begin{array}{c}\text { MEASUREMENT } \\
\text { CHANGE } \\
\end{array}$ \\
\hline $\begin{array}{l}\text { L11-306 } \\
\text { L11-351 } \\
\text { L12-36 } \\
\text { L12-81 } \\
\text { L12-126 } \\
\text { L12-171 } \\
\text { L12-216 } \\
\text { L12-261 } \\
\text { L12-306 } \\
\text { L12-351 } \\
\text { L13-36 } \\
\text { L13-81 } \\
\text { L13-126 } \\
\text { L13-171 } \\
\text { L13-216 } \\
\text { L13-261 } \\
\text { L13-306 } \\
\text { L13-351 } \\
\text { L14-36 } \\
\text { L14-81 } \\
\text { L14-126 } \\
\text { L14-171 } \\
\text { L14-216 } \\
\text { L14-261 } \\
\text { L14-306 } \\
\text { L14-351 } \\
\text { L15-36 } \\
\text { L15-81 } \\
\text { L15-126 } \\
\text { L15-171 } \\
\text { L15-216 } \\
\text { L15-261 } \\
\text { L15-306 } \\
\text { L15-351 } \\
\text { L16-36 } \\
\text { L16-81 } \\
\text { L16-126 } \\
\text { L16-171 } \\
\text { L16-216 } \\
\text { L16-261 } \\
\text { L16-306 } \\
\text { L16-351 } \\
\text { L17-36 }\end{array}$ & $\begin{array}{l}2.711 \\
2.711 \\
2.711 \\
2.711 \\
2.710 \\
2.710 \\
2.710 \\
2.711 \\
2.711 \\
2.711 \\
2.711 \\
2.711 \\
2.710 \\
2.710 \\
2.710 \\
2.711 \\
2.711 \\
2.711 \\
2.711 \\
2.711 \\
2.710 \\
2.710 \\
2.710 \\
2.711 \\
2.711 \\
2.711 \\
2.711 \\
2.711 \\
2.710 \\
2.710 \\
2.710 \\
2.711 \\
2.711 \\
2.711 \\
2.711 \\
2.711 \\
2.710 \\
2.710 \\
2.710 \\
2.711 \\
2.711 \\
2.711 \\
2.711\end{array}$ & $\begin{array}{l}2.737 \\
2.732 \\
2.708 \\
2.686 \\
2.697 \\
2.723 \\
2.740 \\
2.739 \\
2.735 \\
2.728 \\
2.705 \\
2.686 \\
2.700 \\
2.725 \\
2.745 \\
2.741 \\
2.733 \\
2.725 \\
2.700 \\
2.686 \\
2.702 \\
2.732 \\
2.750 \\
2.744 \\
2.731 \\
2.721 \\
2.696 \\
2.685 \\
2.706 \\
2.736 \\
2.755 \\
2.746 \\
2.729 \\
2.715 \\
2.688 \\
2.683 \\
2.759 \\
2.741 \\
2.760 \\
2.747 \\
2.727 \\
2.710 \\
2.682\end{array}$ & $\begin{array}{r}0.026 \\
0.021 \\
-0.03 \\
-0.025 \\
-0.013 \\
0.013 \\
0.030 \\
0.028 \\
0.024 \\
0.017 \\
-0.006 \\
-0.025 \\
-0.010 \\
0.015 \\
0.035 \\
0.030 \\
0.022 \\
0.014 \\
-0.011 \\
-0.025 \\
-0.008 \\
0.022 \\
0.040\end{array}$ \\
\hline
\end{tabular}




\section{DIMENSIONAL INSPECTION DATA}

\section{END IMPACT, TEST 10} \begin{tabular}{l} 
MEASUREMENT \\
DESIGNATION \\
\hline
\end{tabular}

L17-81

L17-126

L17-171

L17-216

L17-261

L17-306

L17-.351

L18-36

L18-81

L18-126

L18-171

L18-216

L18-261

L18-306

L18-351

L19-36

L19-81

L19-126

L19-171

L19-216

L19-261

L19-306

L19-351

L20-36

L20-81

L20-126

L20-171

L20-216

L20-261

L20-306

L20-351

L21-36

L21-81

L21-126

L21-171

L21-216

L21-261

L21-306

L21-351

L22-36

L22-81

L22-126

L22-171

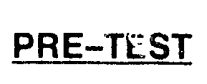

2.711

2.711

2.711

2.711

2.711

2.711

2.711

2.711

2.711

2.711

2.711

2.711

2.711

2.711

2.711

2.711

2.711

2.711

2.711

2.711

2.711

2.711

2.711

2.711

2.711

2.711

2.711

2.711

2.711

2.711

2.711

2.711

2.711

2.711

2.711

2.711

2. 1

2.711

2.711

2.711

2.711

2.711

2.711

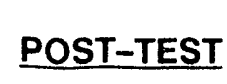

2.683

2.711

2.745

2.763

2.751

2.725

2.706

2.676

2.681

2.714

2.750

2.766

2.752

2.724

2.700

2.671

2.681

2.715

2.756

2.767

2.753

2.722

2.695

2.666

2.674

2.715

2.758

2.770

2.753

2.719

2.687

2.658

2.672

2.715

2.758

2.771

2.752

2.715

2.684

2.654

2.670

2.711

2.757
MEASUREMENT

CHANGE

$-0.028$

0.000

0.034

0.052

0.040

0.014

$-0.005$

$-0.035$

$-0.030$

0.003

0.039

0.055

0.041

0.013

$-0.011$

$-0.040$

$-0.030$

0.004

0.045

0.056

0.042

0.011

$-0.016$

$-0.045$

$-0.037$

0.004

0.047

0.059

0.042

0.008

$-0.024$

$-0.053$

$-0.039$

0.004

0.047

0.060

0.041

0.004

$-0.027$

$-0.057$

$-0.041$

0.000

0.046 
CYLINDER

DIMENSIONAL INSPECTION DATA

\section{END IMPACT, TEST 10}

MEASUREMENT DESIGNATION

L22-216
L22-261
L22-306
L22-351
L23-36
L23-81
L23-126
L23-171
L23-216
L23-261
L23-306
L23-351

\section{PRE-TEST}

2.711

2.711

2.711

2.711

45.012

45.009

45.007

45.006

45.007

45.008

45.009

45.011
POST-TEST

\subsection{0}

2.750

2.713

2.677

44.881

44.830

44.753

44.717

44.737

44.783

44.844

44.876
MEASUREMENT CHANGE

$$
\begin{array}{r}
0.059 \\
0.039 \\
0.002 \\
-0.034 \\
-0.131 \\
-0.179 \\
-0.254 \\
-0.289 \\
-0.270 \\
-0.225 \\
-0.165 \\
-0.135
\end{array}
$$




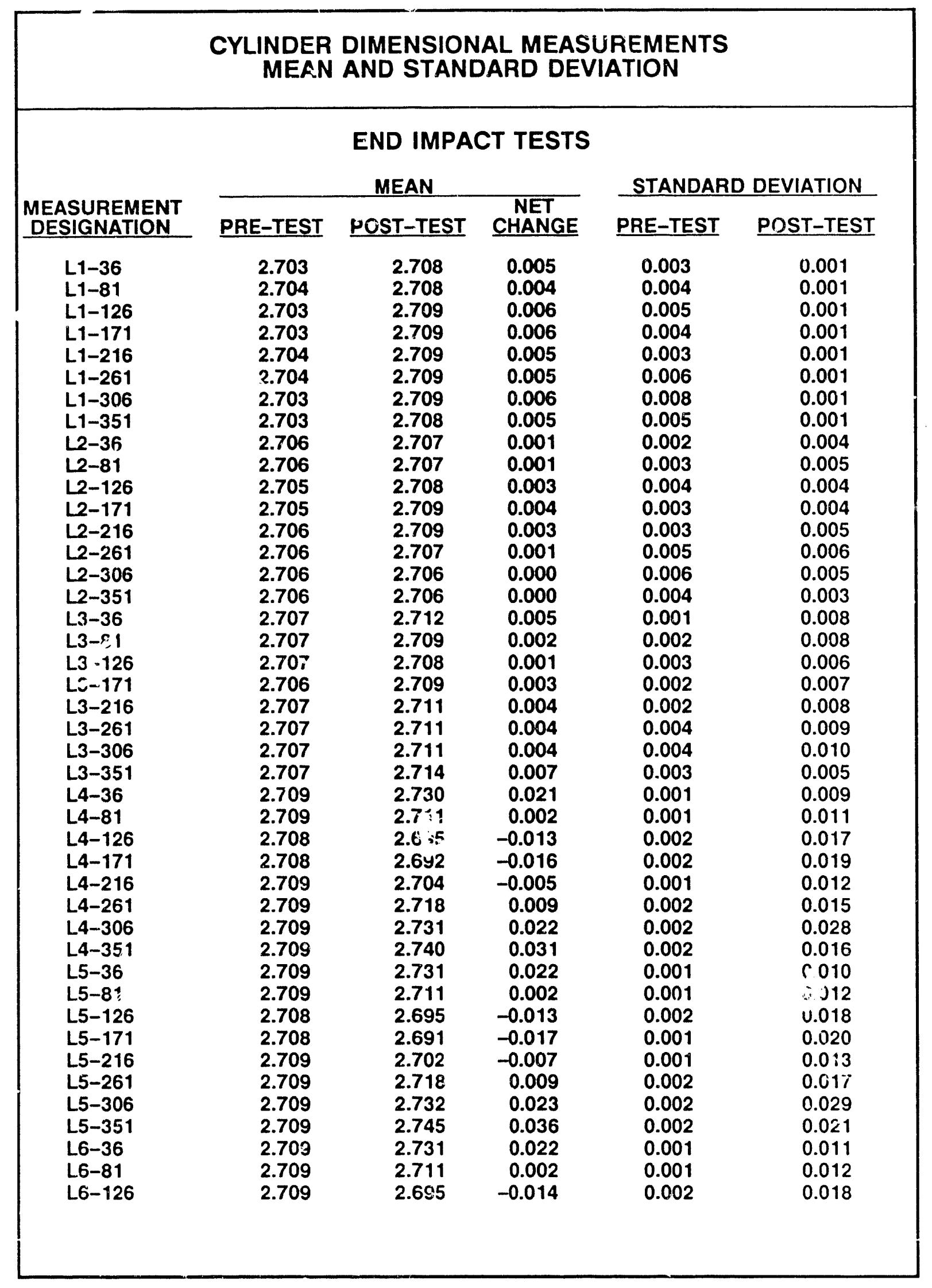




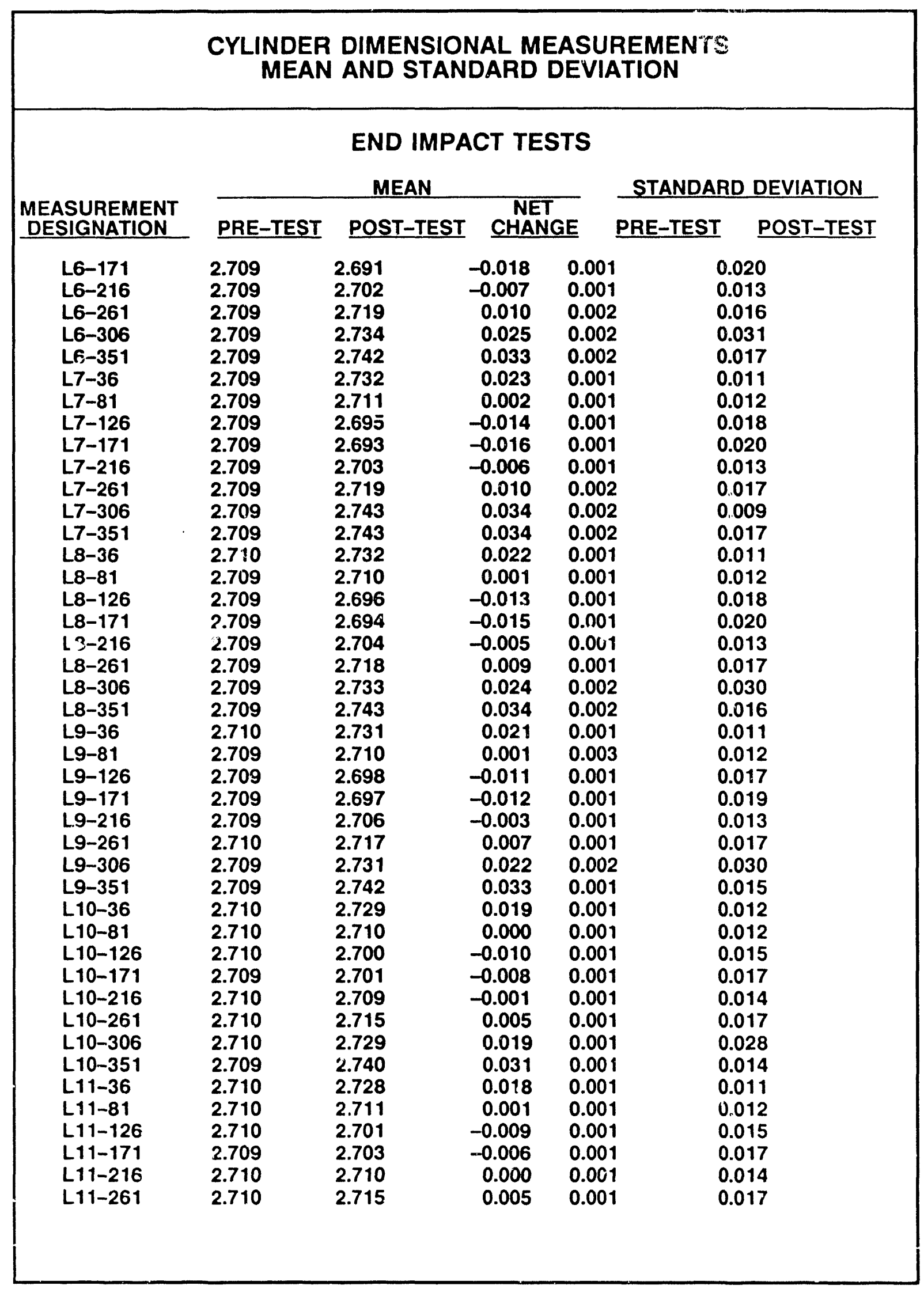




\begin{tabular}{|c|c|c|c|c|c|}
\hline \multicolumn{6}{|c|}{$\begin{array}{l}\text { CYLINDER DIMENSIONAL MEASUREMENTS } \\
\text { MEAN AND STANDARD DEVIATION }\end{array}$} \\
\hline \multirow[b]{3}{*}{$\begin{array}{l}\text { MEASUREMENT } \\
\text { DESIGNATION } \\
\end{array}$} & \multirow{2}{*}{\multicolumn{3}{|c|}{$\begin{array}{l}\text { END IMPACT TESTS } \\
\text { MEAN }\end{array}$}} & \multirow{2}{*}{\multicolumn{2}{|c|}{ STANDARD DEVIATION }} \\
\hline & & & & & \\
\hline & PRE-TEST & POST-TEST & $\begin{array}{c}\text { NET } \\
\text { CHANGE }\end{array}$ & PRE-TEST & POST-TEST \\
\hline 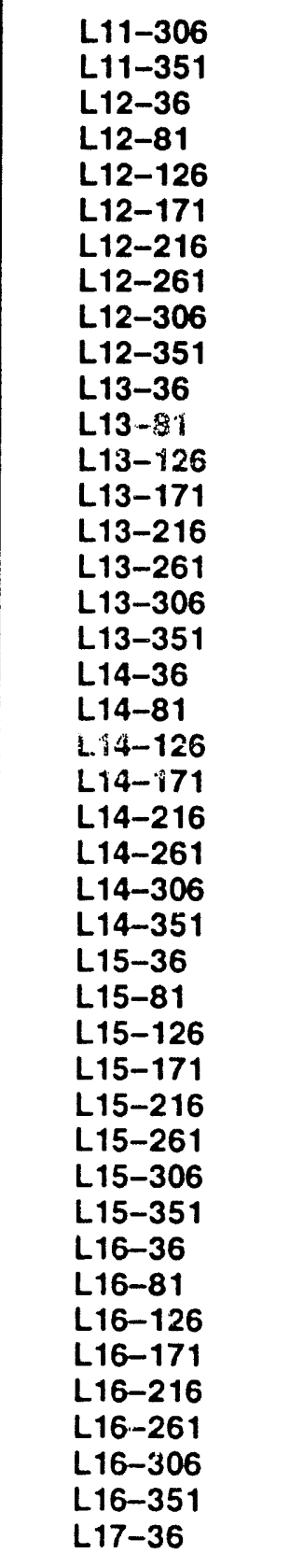 & $\begin{array}{l}2.710 \\
2.710 \\
2.710 \\
2.710 \\
2.710 \\
2.710 \\
2.710 \\
2.710 \\
2.710 \\
2.710 \\
2.710 \\
2.710 \\
2.710 \\
2.710 \\
2.710 \\
2.710 \\
2.710 \\
2.710 \\
2.710 \\
2.710 \\
2.710 \\
2.710 \\
2.710 \\
2.710 \\
2.710 \\
2.710 \\
2.710 \\
2.710 \\
2.710 \\
2.710 \\
2.710 \\
2.710 \\
2.710 \\
2.710 \\
2.710 \\
2.710 \\
2.710 \\
2.710 \\
2.710 \\
2.710 \\
2.710 \\
2.710 \\
2.710\end{array}$ & $\begin{array}{l}2.727 \\
2.738 \\
2.727 \\
2.711 \\
2.703 \\
2.706 \\
2.712 \\
2.714 \\
2.726 \\
2.738 \\
2.726 \\
2.712 \\
2.706 \\
2.708 \\
2.714 \\
2.714 \\
2.724 \\
2.735 \\
2.725 \\
2.713 \\
2.708 \\
2.710 \\
2.716 \\
2.714 \\
2.722 \\
2.734 \\
2.723 \\
2.713 \\
2.710 \\
2.712 \\
2.718 \\
2.714 \\
2.720 \\
2.732 \\
2.721 \\
2.714 \\
2.712 \\
2.715 \\
2.719 \\
2.714 \\
2.719 \\
2.727 \\
2.720\end{array}$ & $\begin{array}{r}0.017 \\
0.028 \\
0.017 \\
0.001 \\
-0.007 \\
-0.004 \\
0.002 \\
0.004 \\
0.016 \\
0.028 \\
0.016 \\
0.002 \\
-0.004 \\
-0.002 \\
0.004 \\
0.004 \\
0.014 \\
0.025 \\
0.015 \\
0.003 \\
-0.002 \\
0.000 \\
0.006 \\
0.004 \\
0.012 \\
0.24 \\
0.013 \\
0.003 \\
0.000 \\
0.002 \\
0.008 \\
0.004 \\
0.010 \\
0.022 \\
0.011 \\
0.004 \\
0.002 \\
0.005 \\
0.009 \\
0.004 \\
0.009 \\
0.017 \\
0.010\end{array}$ & $\begin{array}{l}0.001 \\
0.001 \\
0.001 \\
0.001 \\
0.001 \\
0.000 \\
0.001 \\
0.001 \\
0.001 \\
0.001 \\
0.001 \\
0.001 \\
0.001 \\
0.001 \\
0.001 \\
0.001 \\
0.001 \\
0.001 \\
0.001 \\
0.001 \\
0.001 \\
0.001 \\
0.001 \\
0.001 \\
0.001 \\
0.001 \\
0.001 \\
0.001 \\
0.001 \\
0.001 \\
0.001 \\
0.001 \\
0.001 \\
0.001 \\
0.001 \\
0.001 \\
0.001 \\
0.001 \\
0.001 \\
0.001 \\
0.001 \\
0.001 \\
0.001\end{array}$ & $\begin{array}{l}0.027 \\
0.013 \\
0.012 \\
0.012 \\
0.014 \\
0.016 \\
0.014 \\
0.017 \\
0.027 \\
0.013 \\
0.012 \\
0.013 \\
0.013 \\
0.015 \\
0.014 \\
0.017 \\
0.025 \\
0.011 \\
0.013 \\
0.012 \\
0.012 \\
0.015 \\
0.015 \\
0.017 \\
0.024 \\
0.011 \\
0.013 \\
0.013 \\
0.011 \\
0.015 \\
0.016 \\
0.017 \\
0.023 \\
0.012 \\
0.015 \\
0.013 \\
0.010 \\
0.014 \\
0.017 \\
0.017 \\
0.022 \\
0.011 \\
0.016\end{array}$ \\
\hline
\end{tabular}




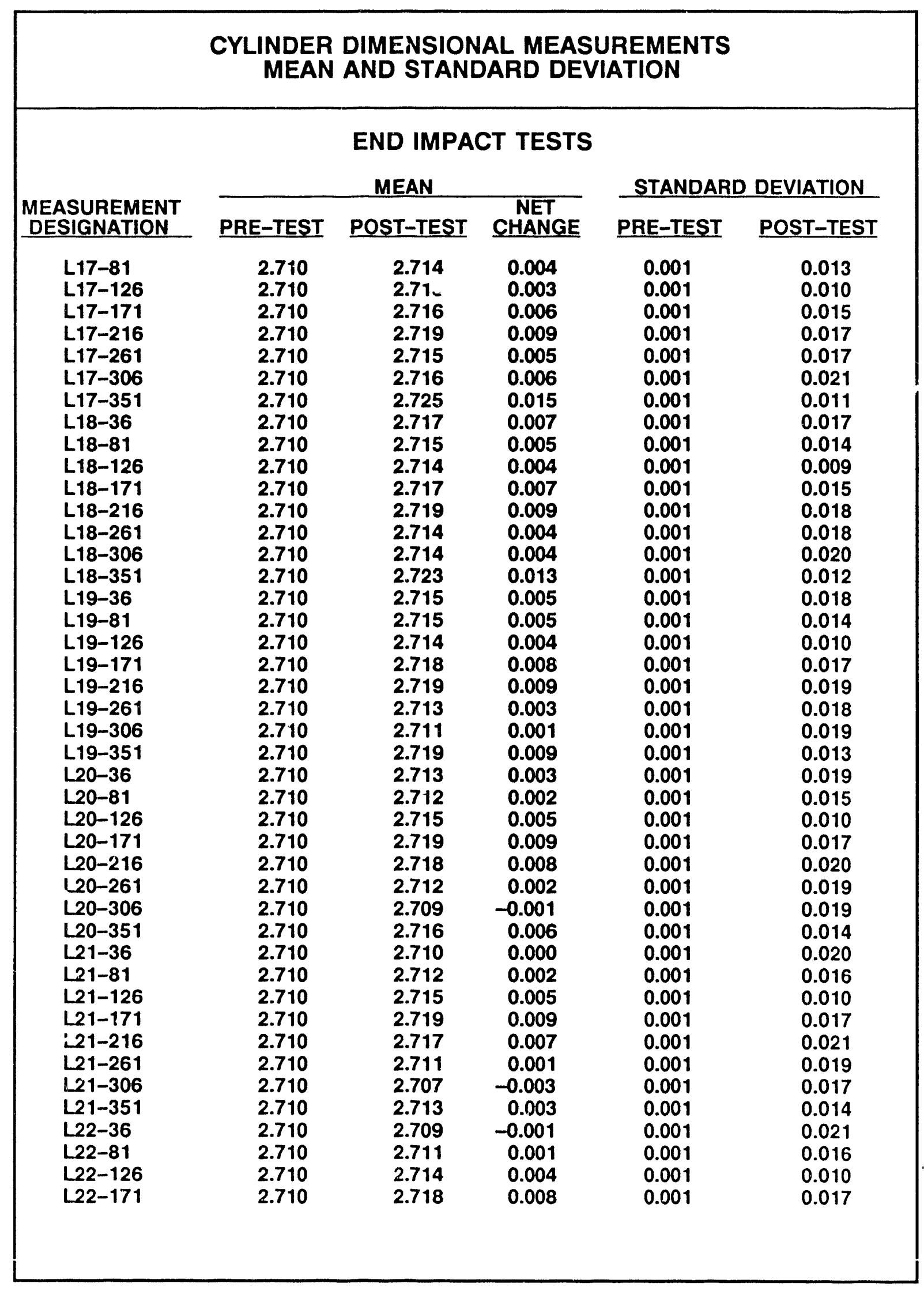




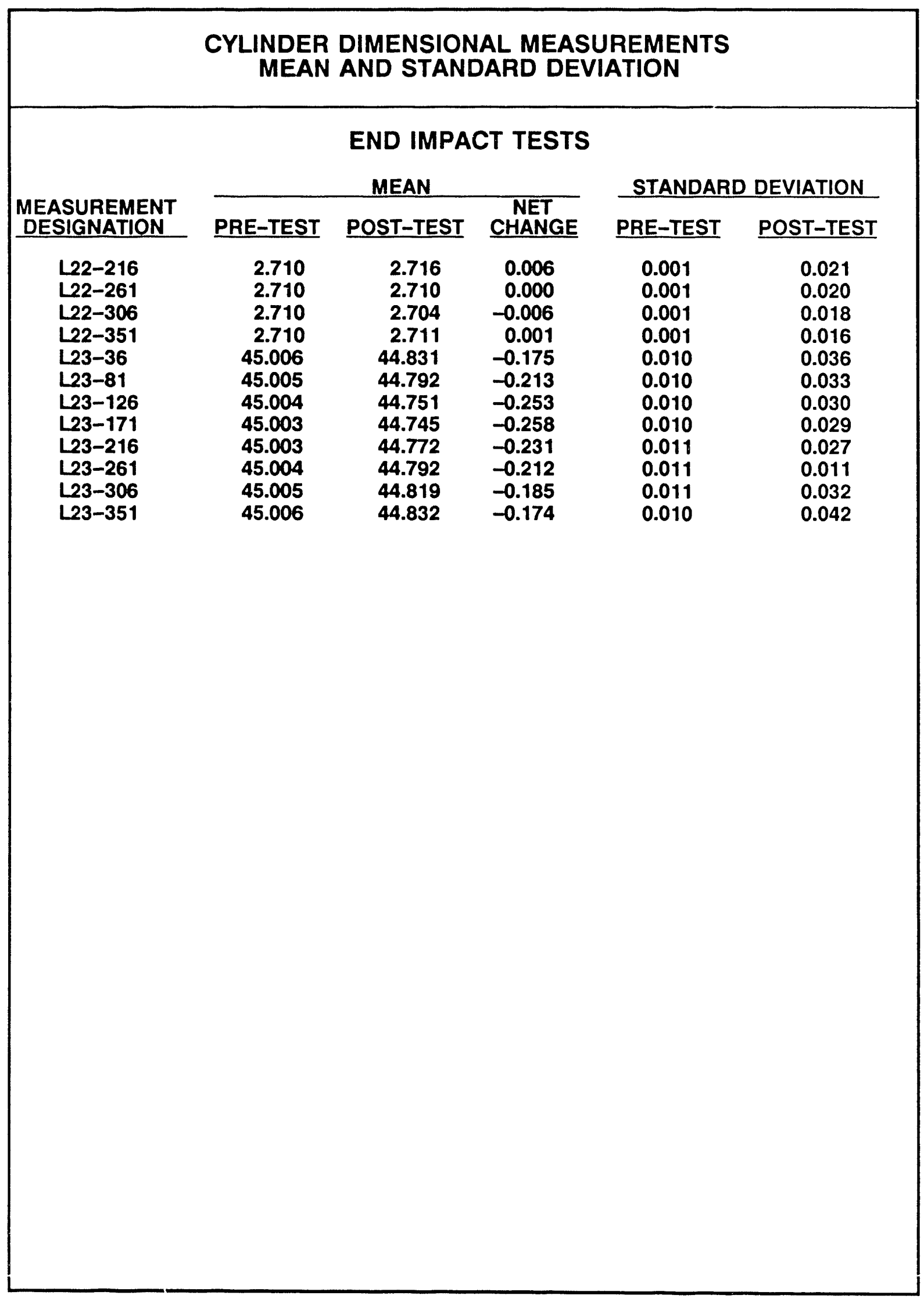


APPENDIX D

STRAIN GAGE MULTIPLOTS

D - 1 


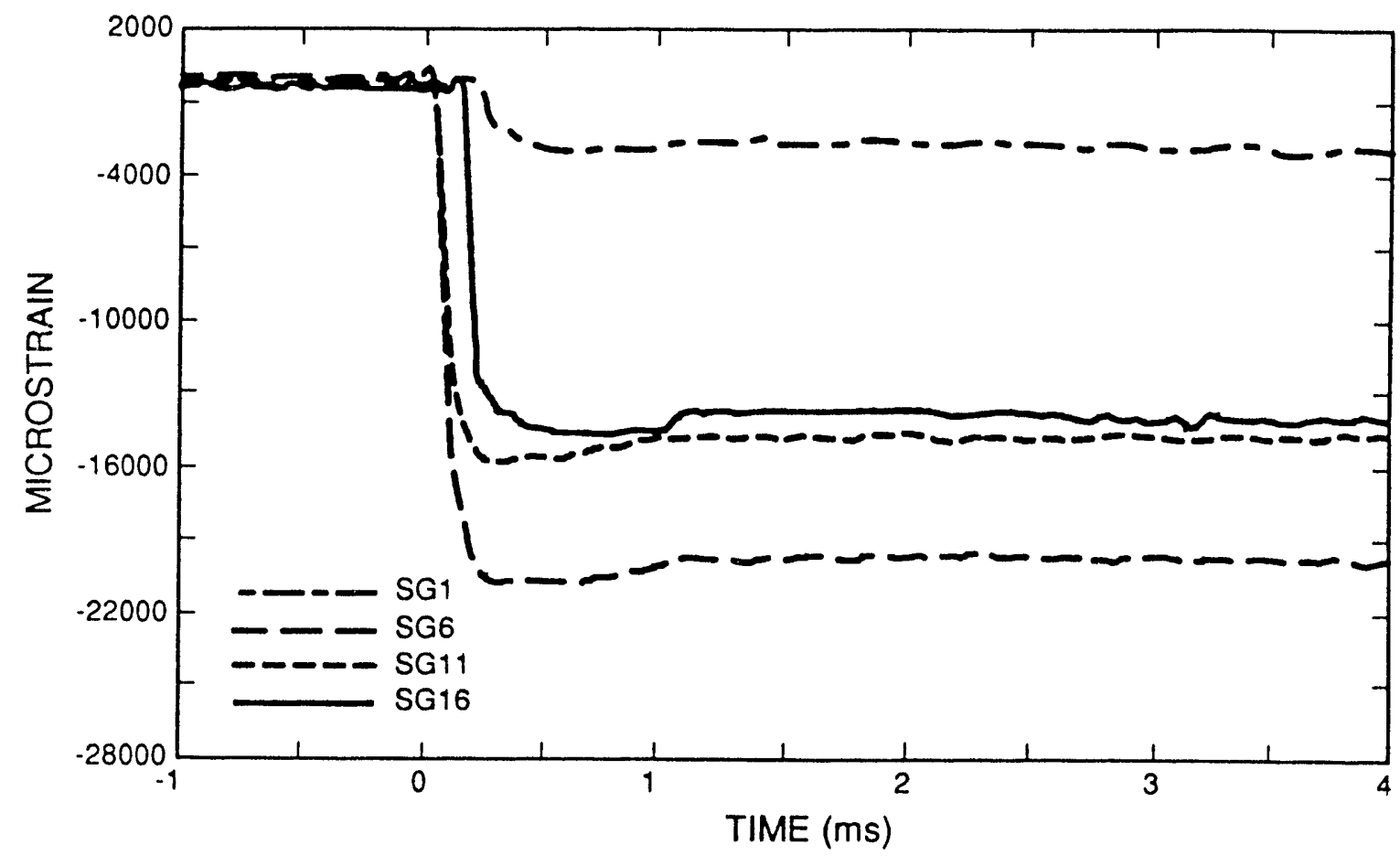

Figure D-1. End-Impact Test 1 Axial Strain at 1 in.

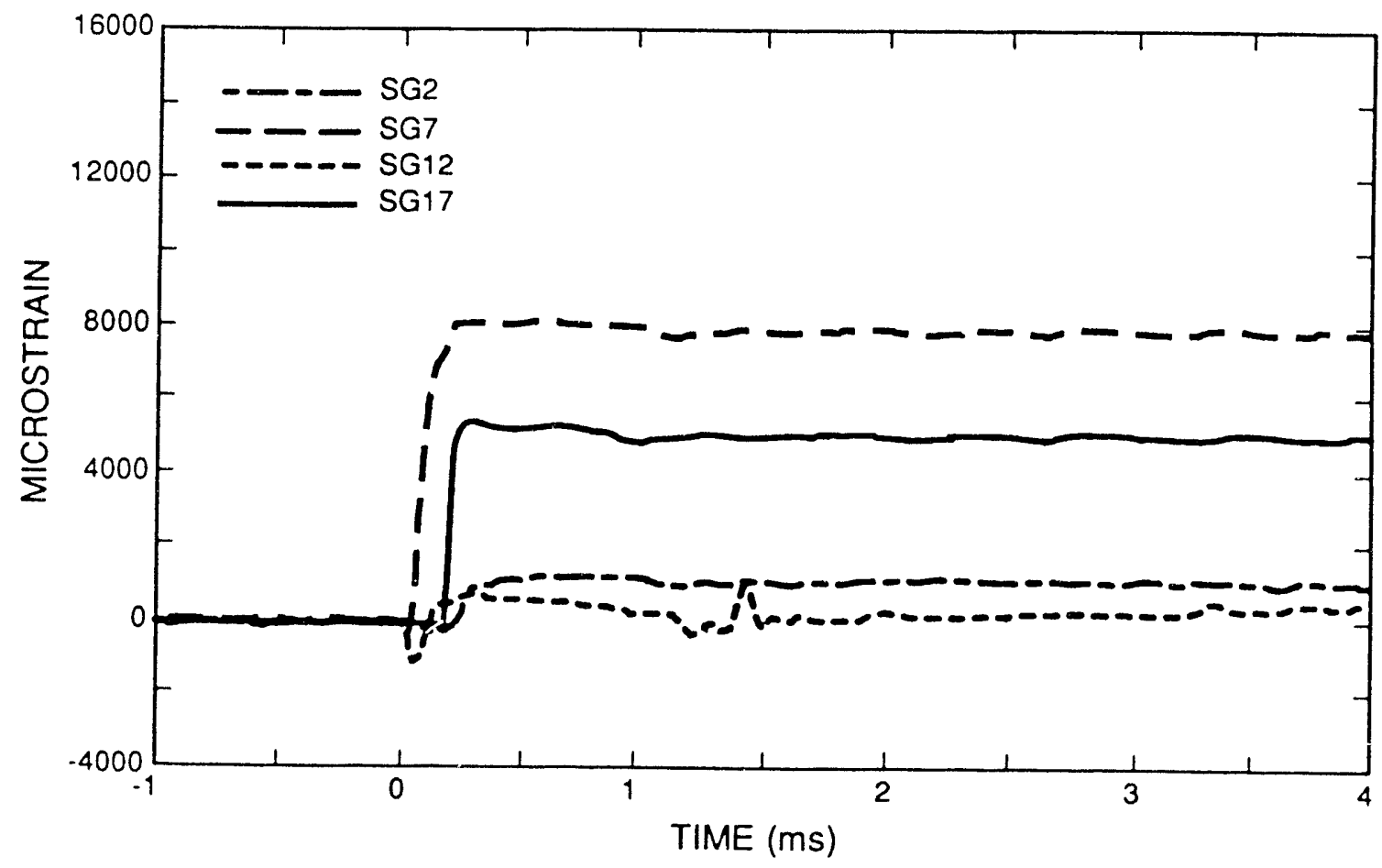

Figure D-2. End-Impact Test 1 Hoop Strain at 1 in. 


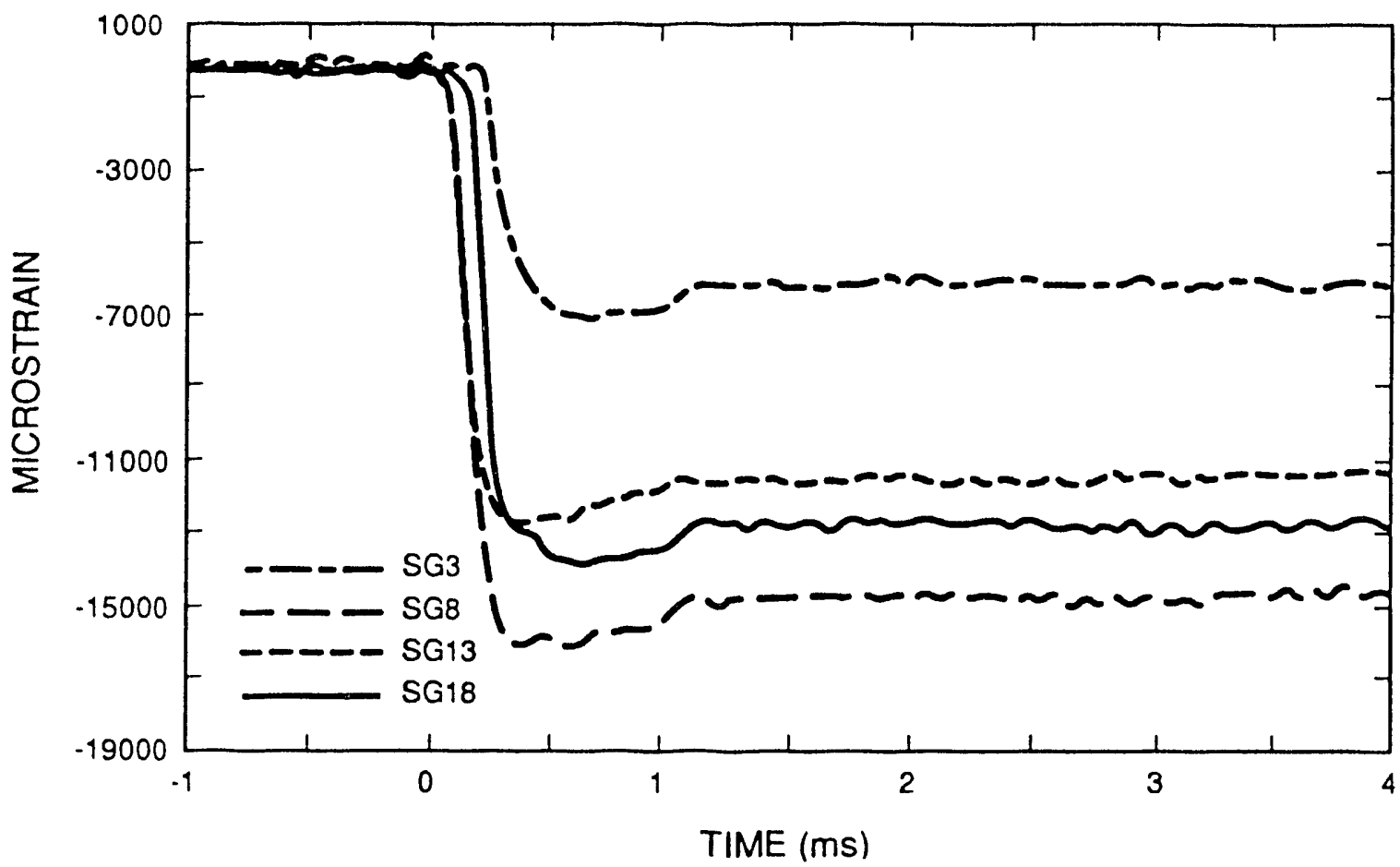

Figure D-3. End-Impact Test 1 Axial Strain at 3 in.

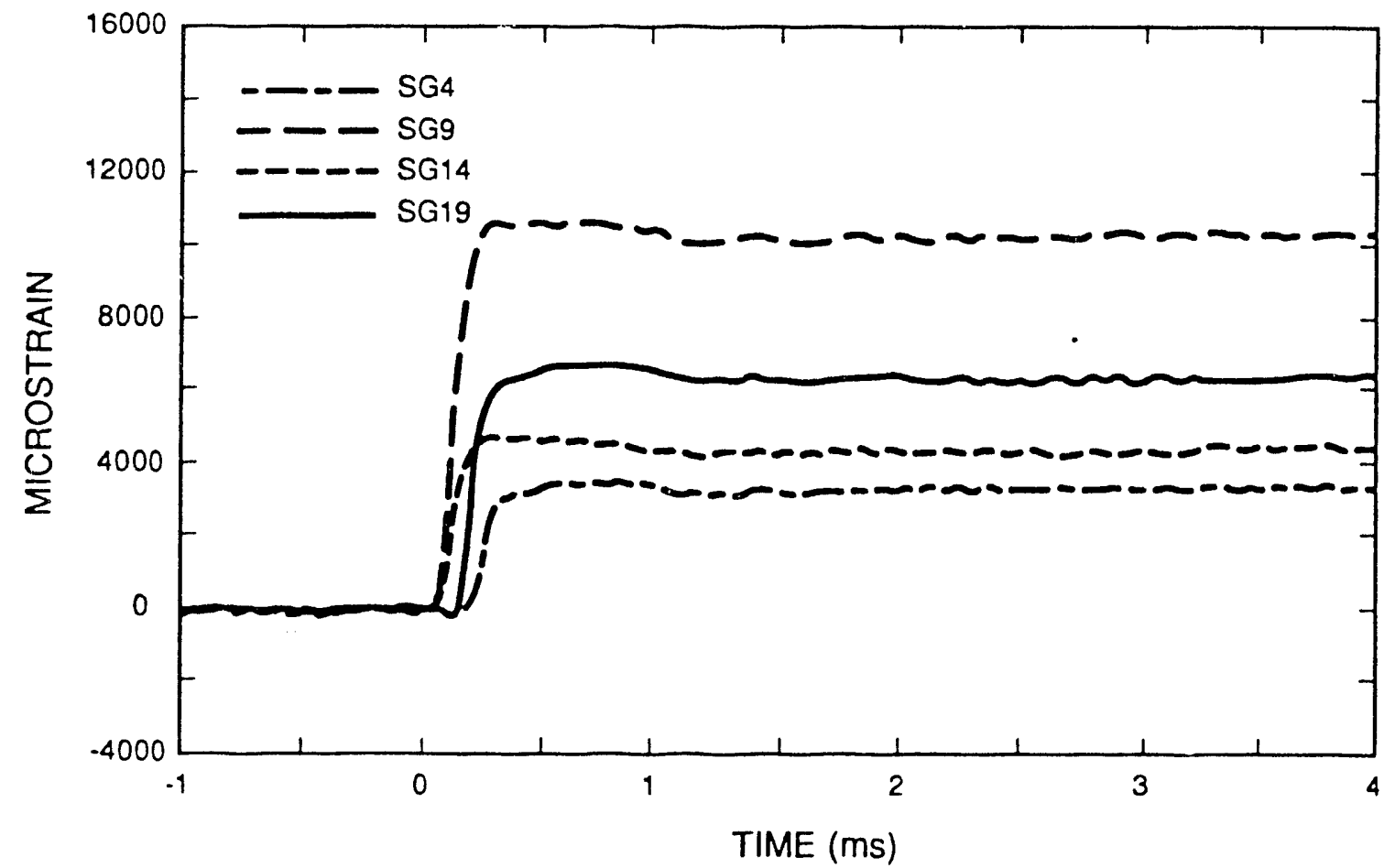

Figure D-4. End-Impact Test 1 Hoop Strain at 3 in. 


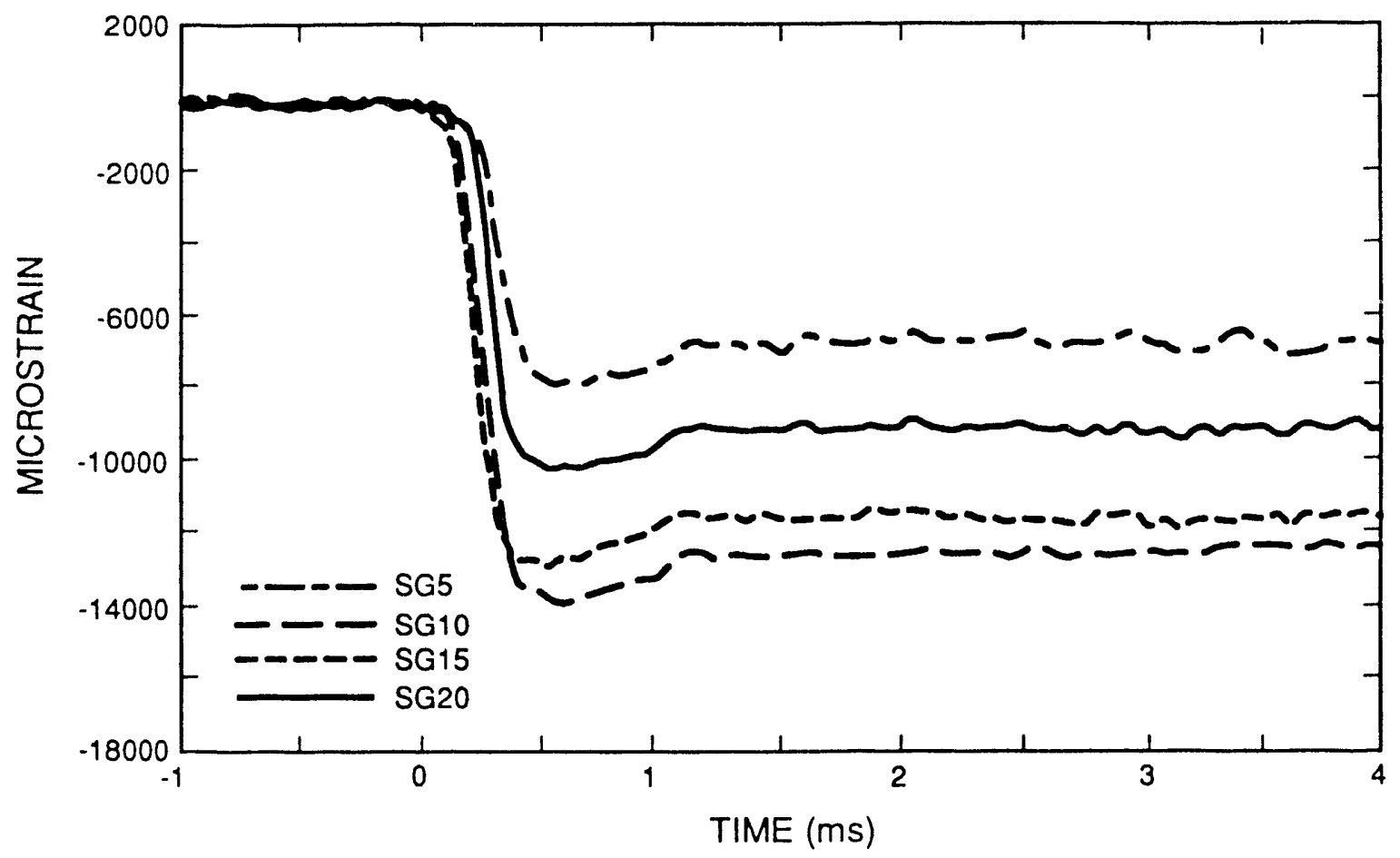

Figure D-5. End-Impact Test 1 Axial Strain at 6 in.

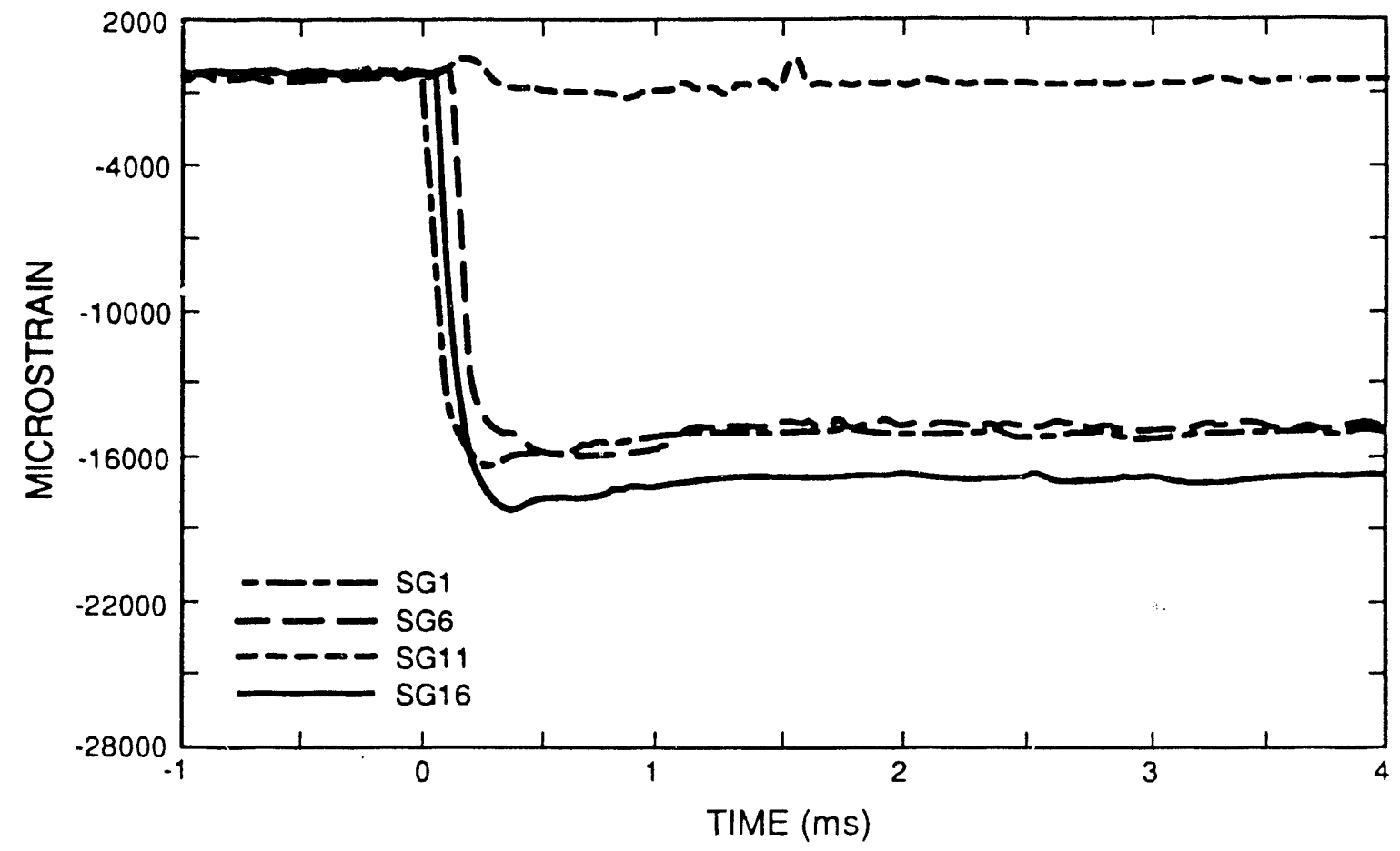

Figure D-6. End-Impact Test 2 Axial Strain at 1 in. 


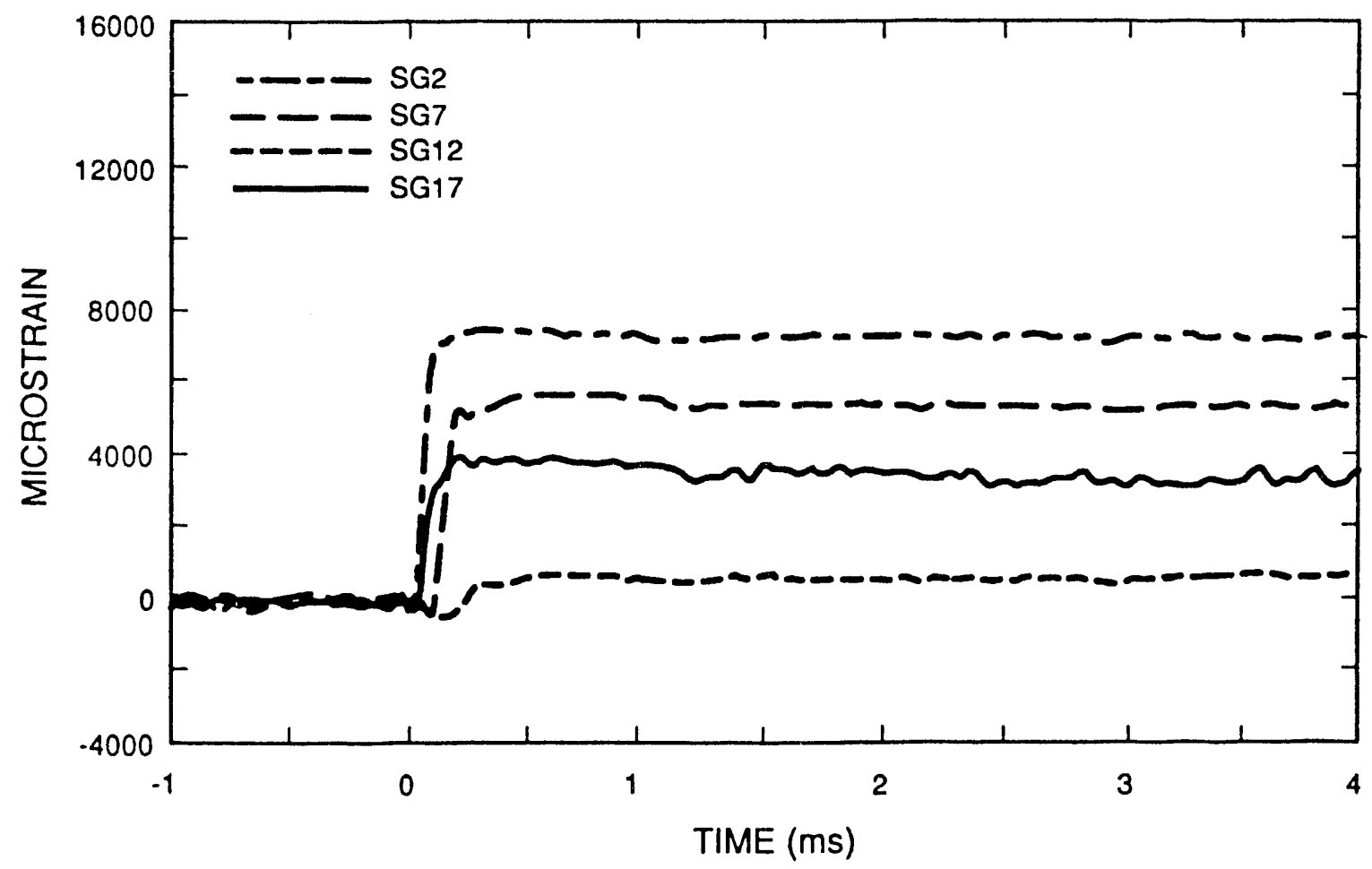

Figure D-7. End-Impact Test 2 Hoop Strain at 1 in.

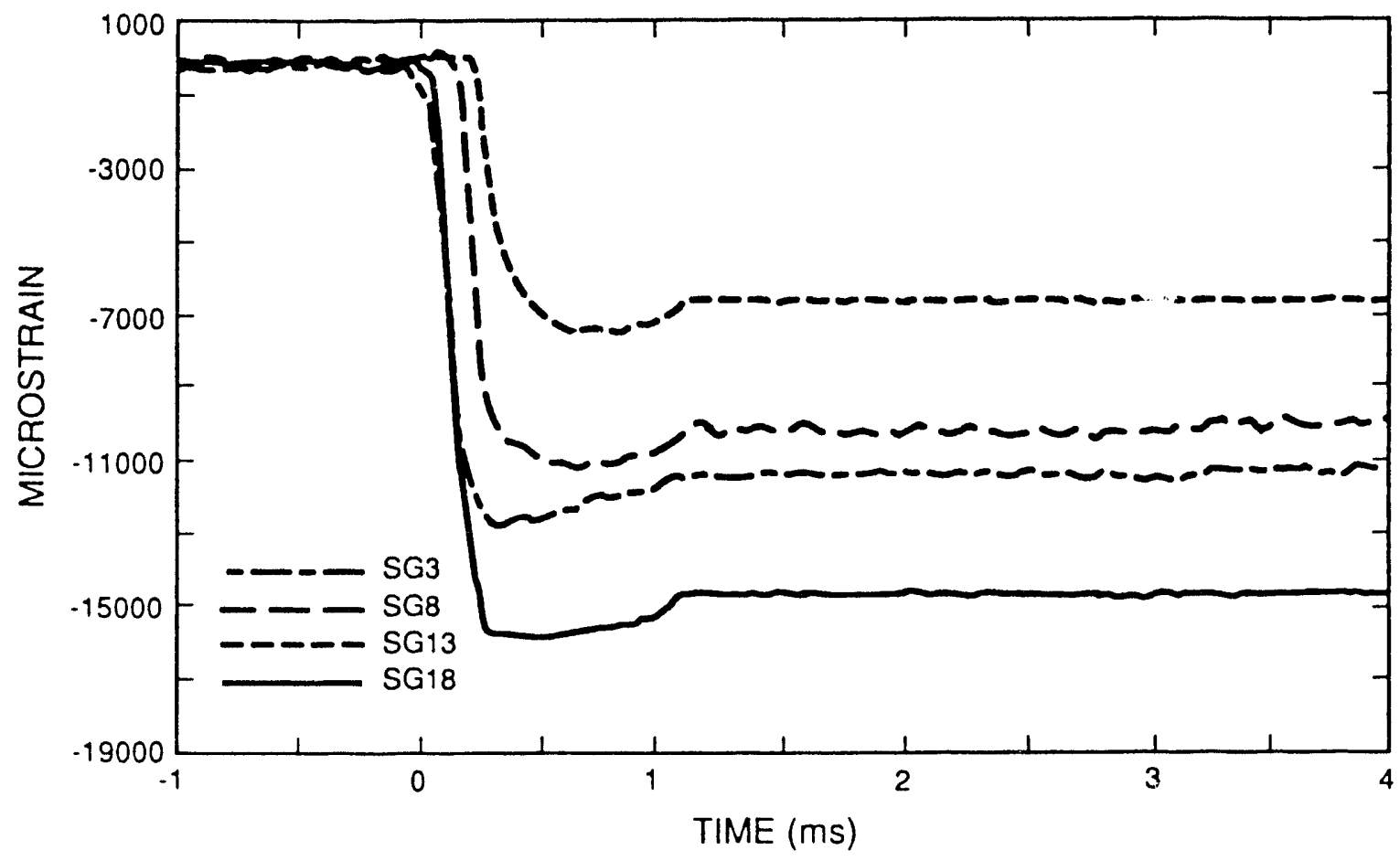

Figure D-8. End-Impact Test 2 Axial Strain at 3 in. 


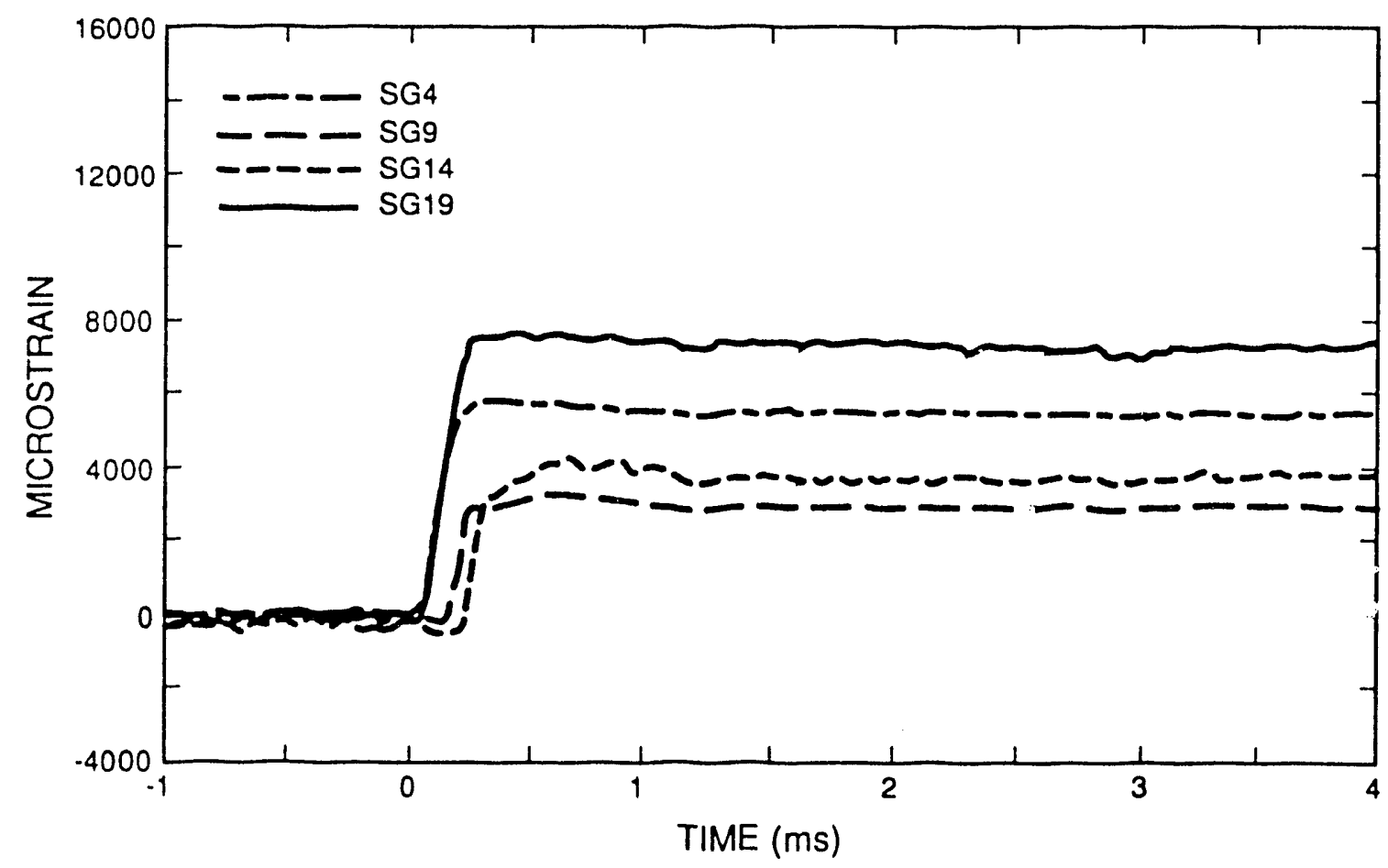

Figure D-9. End-Impact Test 2 Hoop Strain at 3 in.

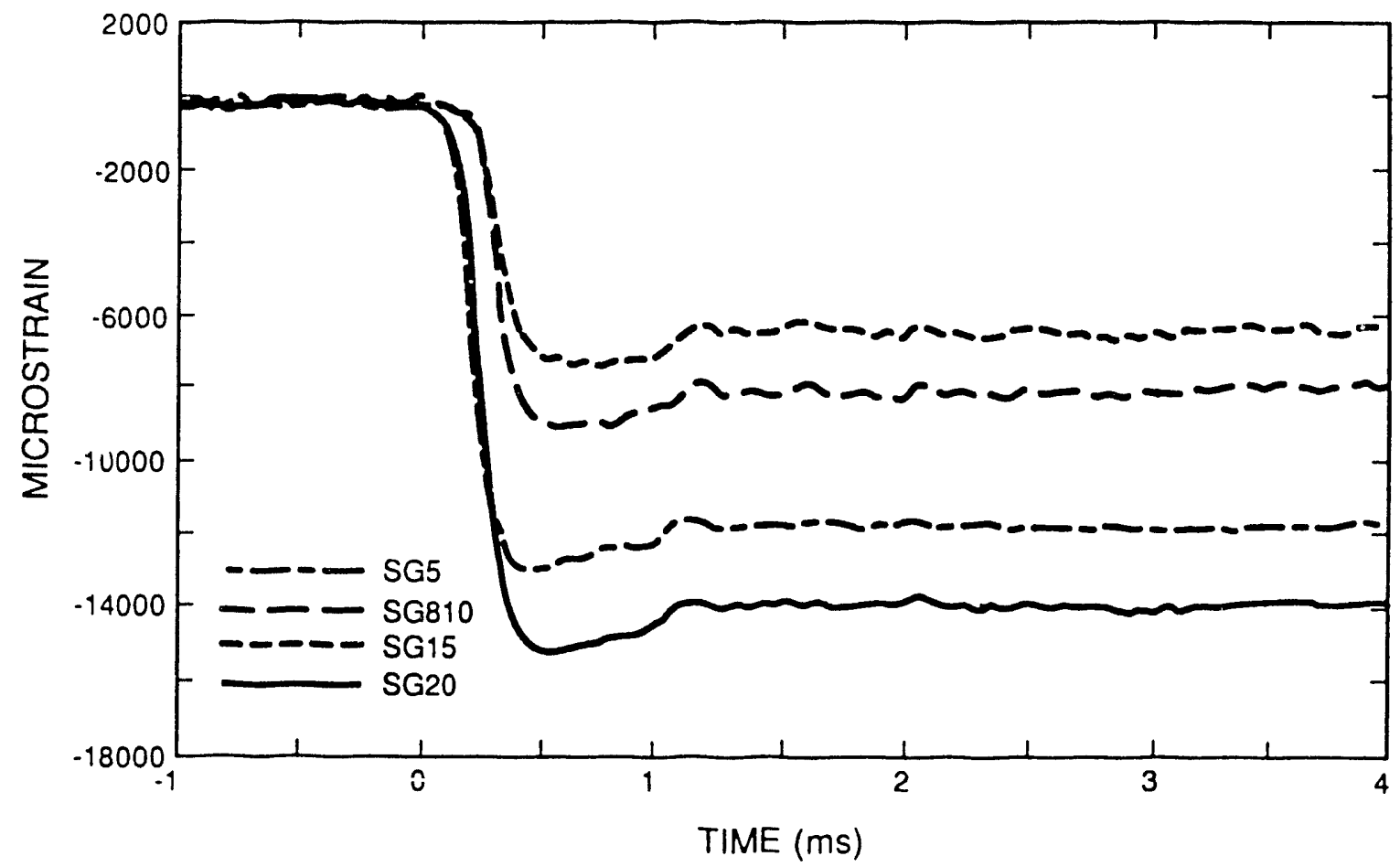

Figure D-10. End-Impact Test 2 Axial Strain at 6 in. 


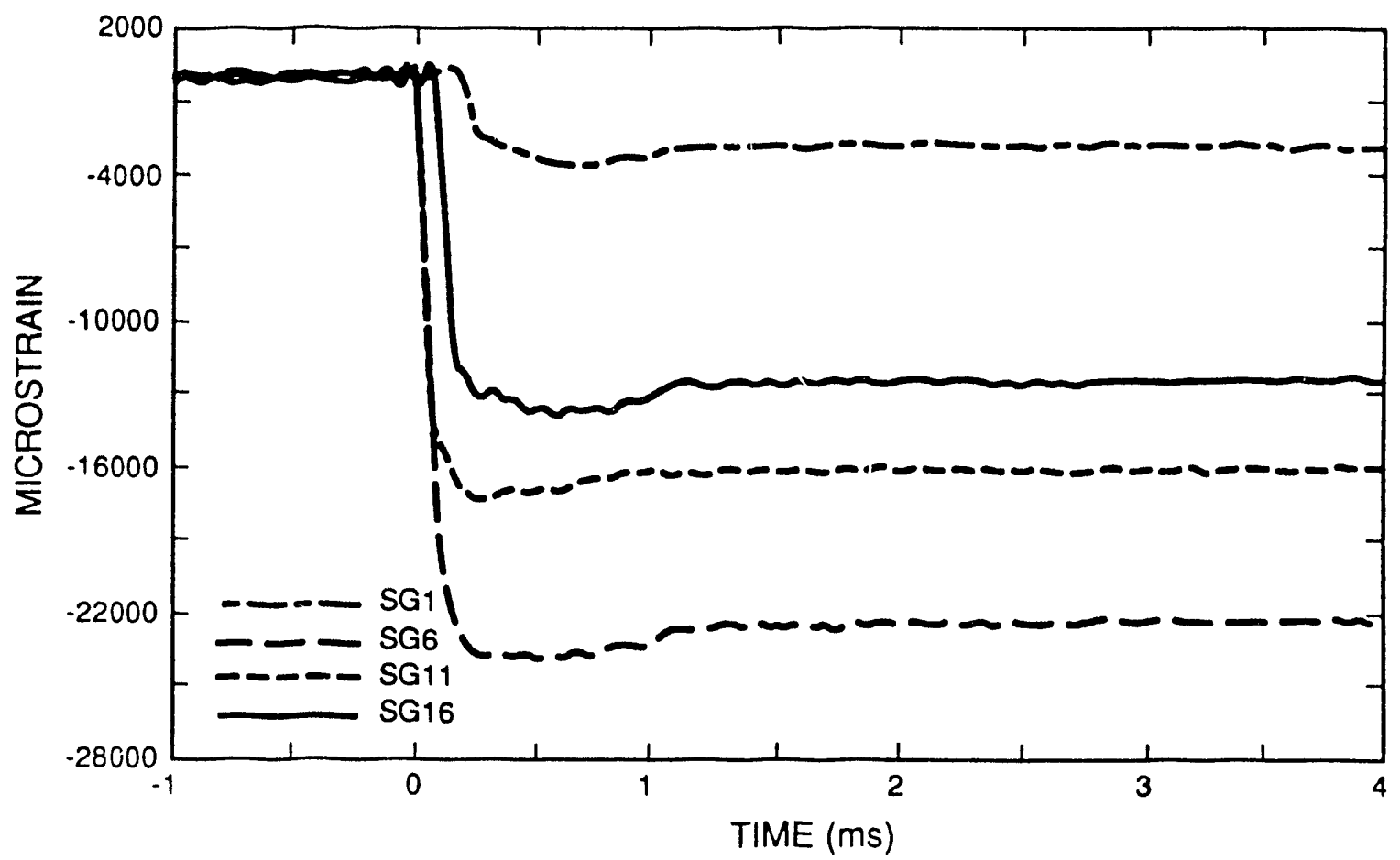

Figure D-11. End-Impact Test 3 Axial Strain at 1 in.

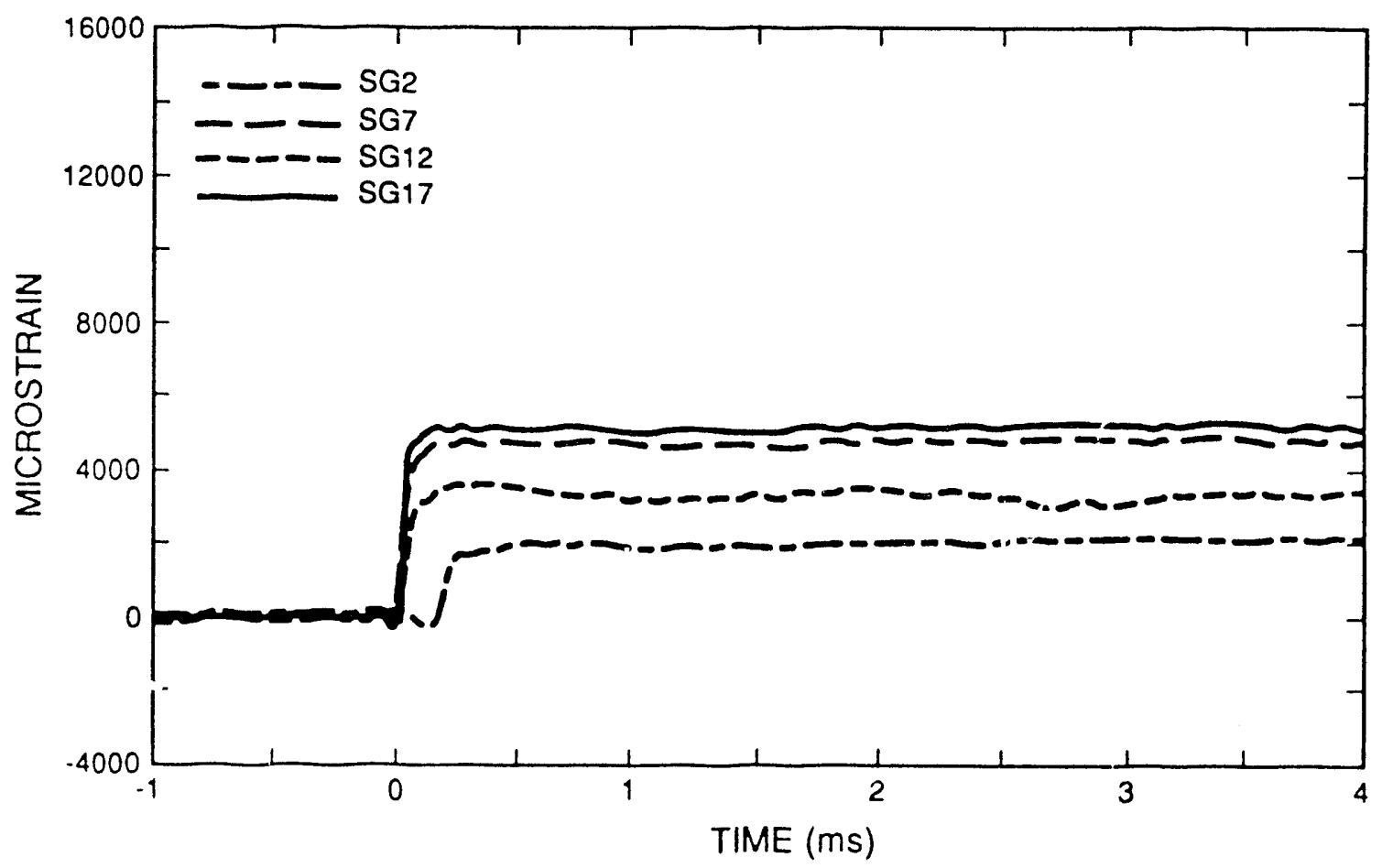

Figure D-12. End-Impact Test 3 Hoop Strain at 1 in. 


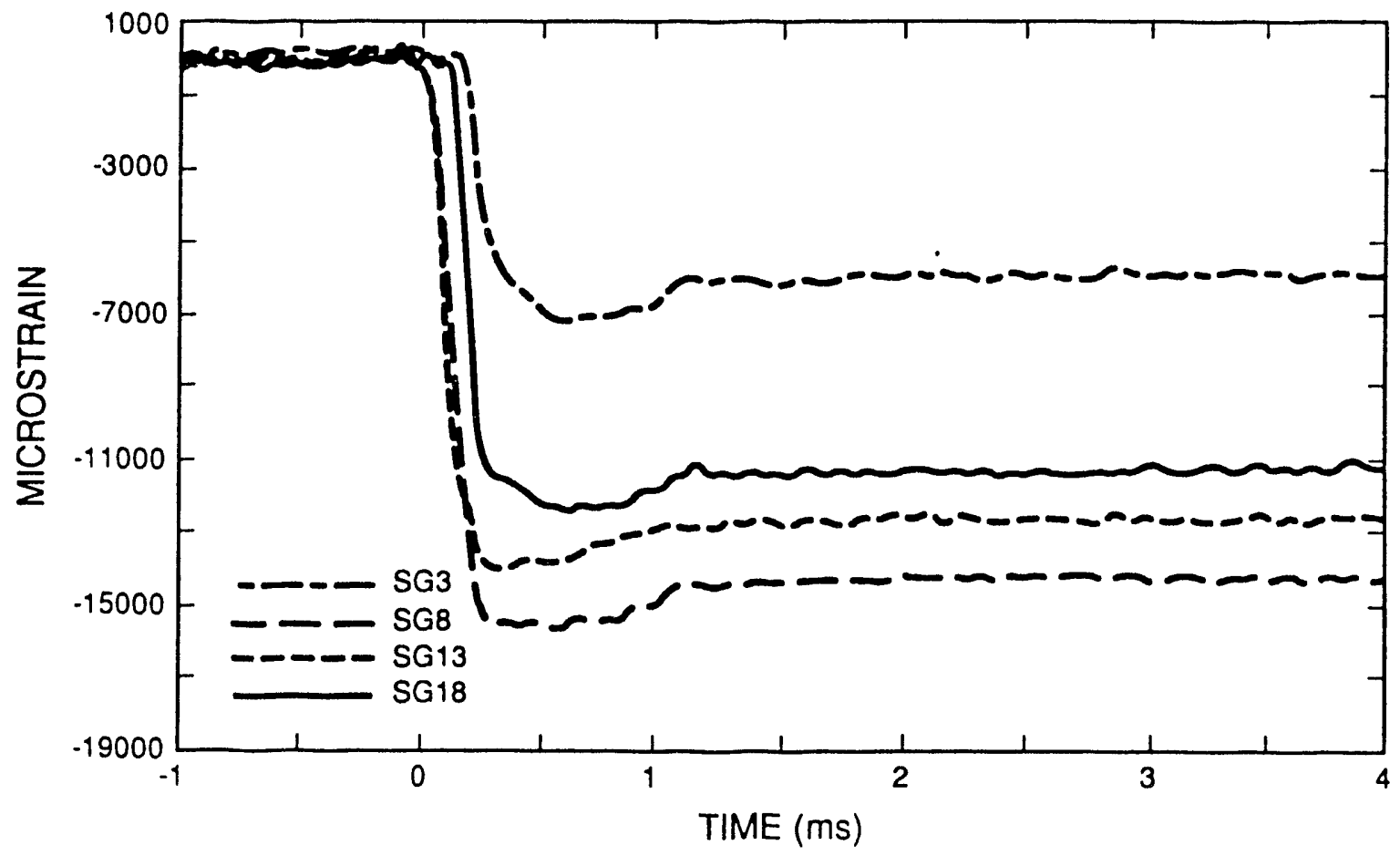

Figure D-13. End-Impact Test 3 Axial Strain at 3 in.

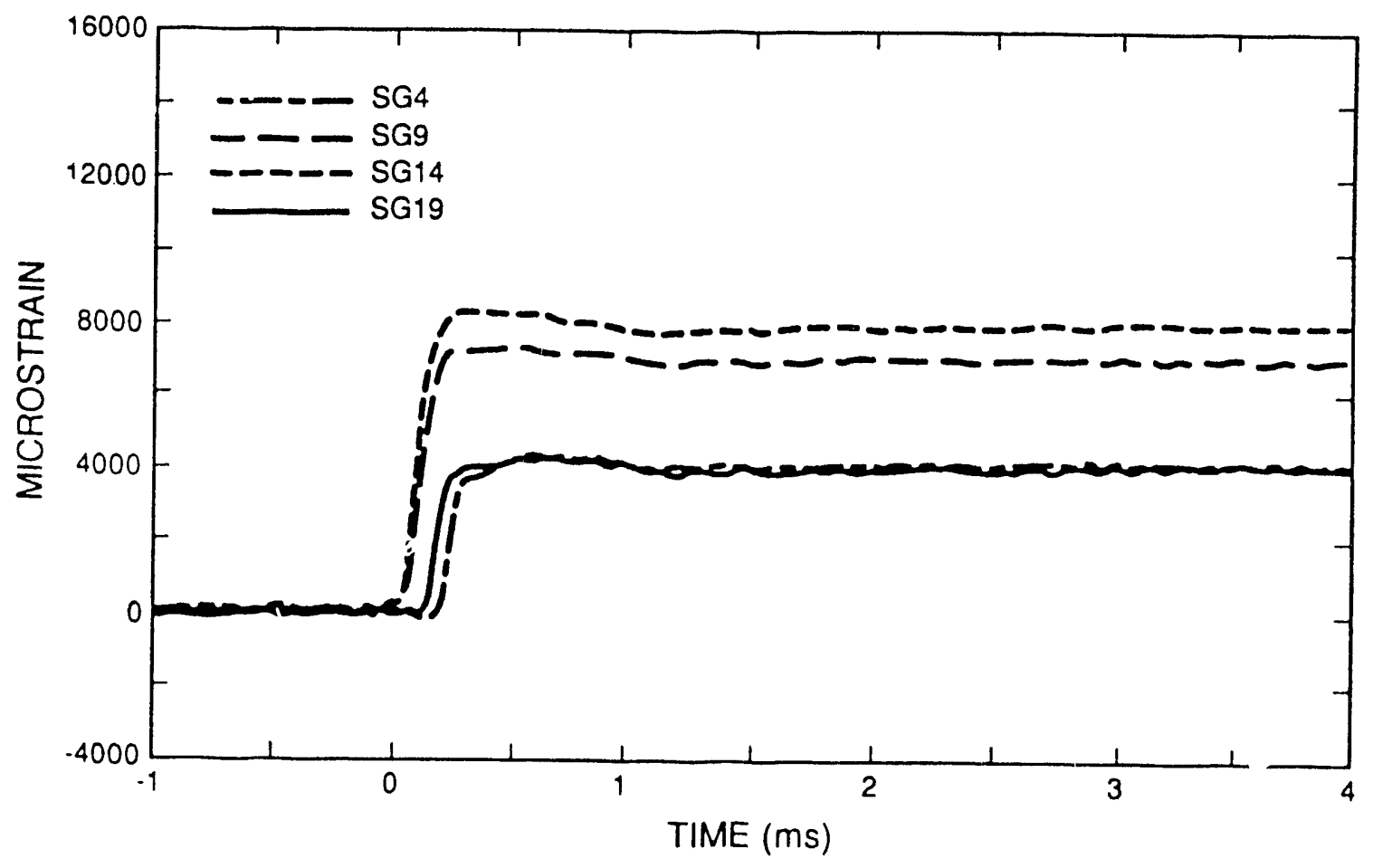

Figure D-14. End-Impact Test 3 Hoop Strain at 3 in. 


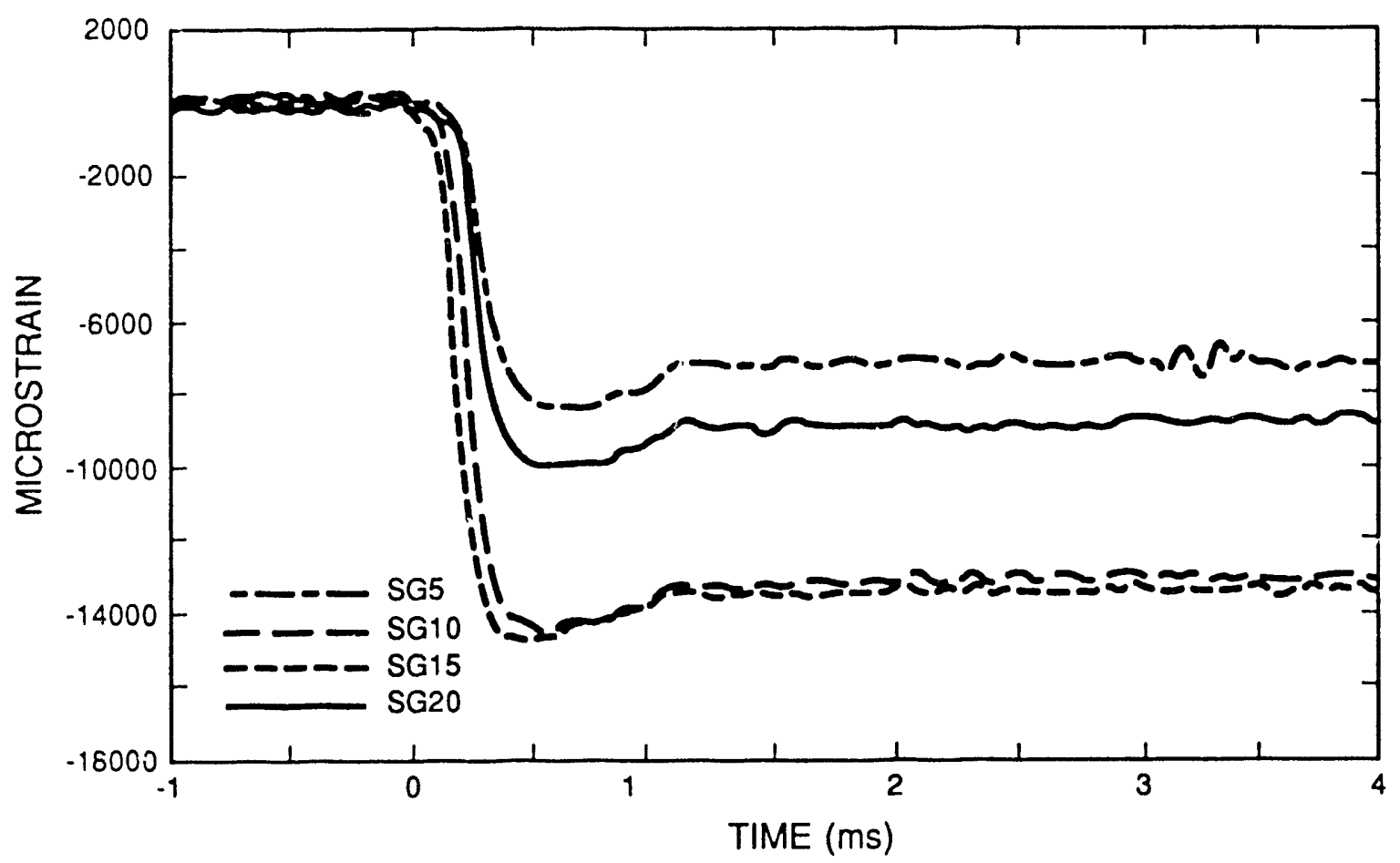

Figure D-15. End-Impact Test 3 Axial Strain at 6 in.

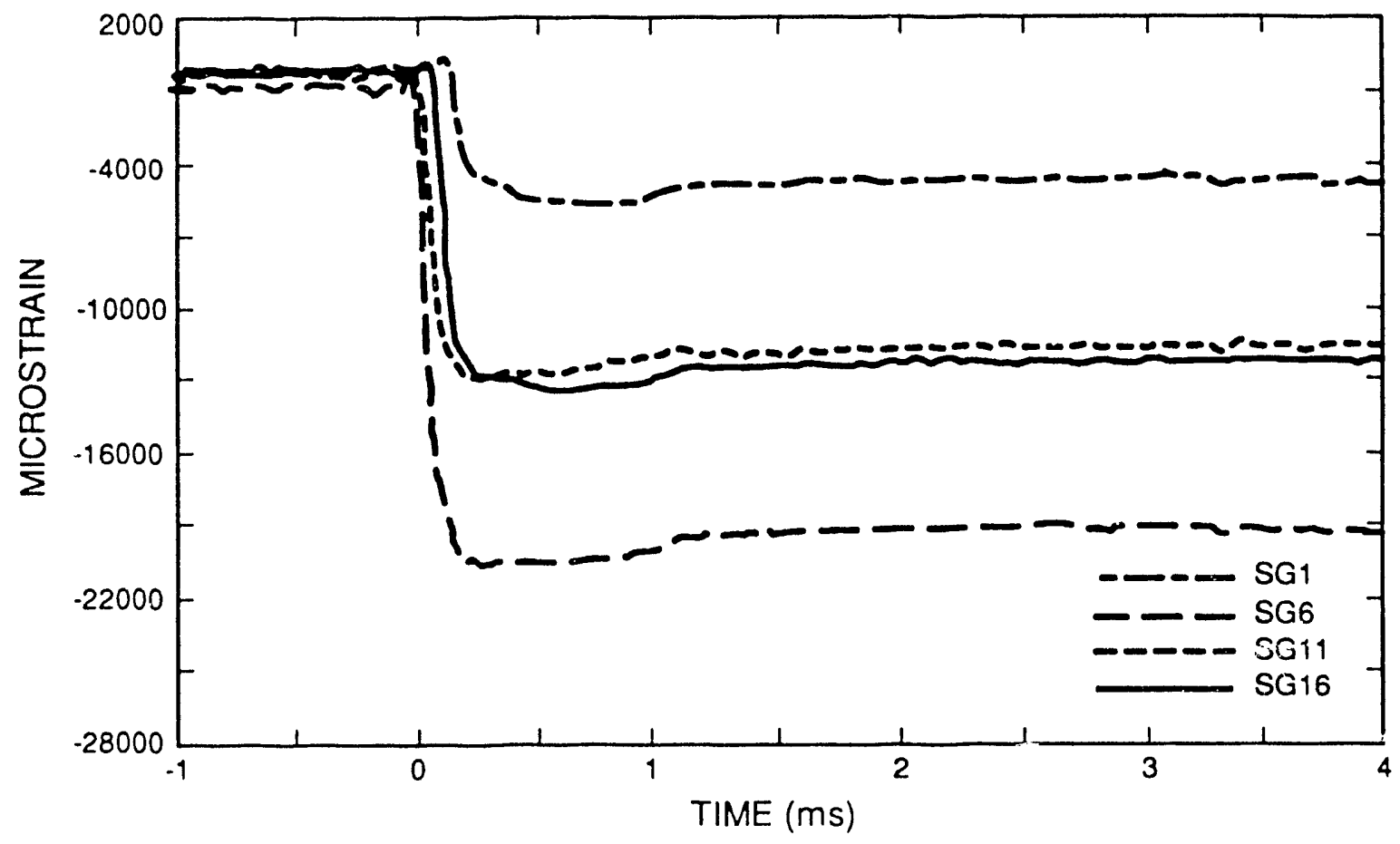

Figure D-16. End-Impact Test 4 Axial Strain at 1 in. 


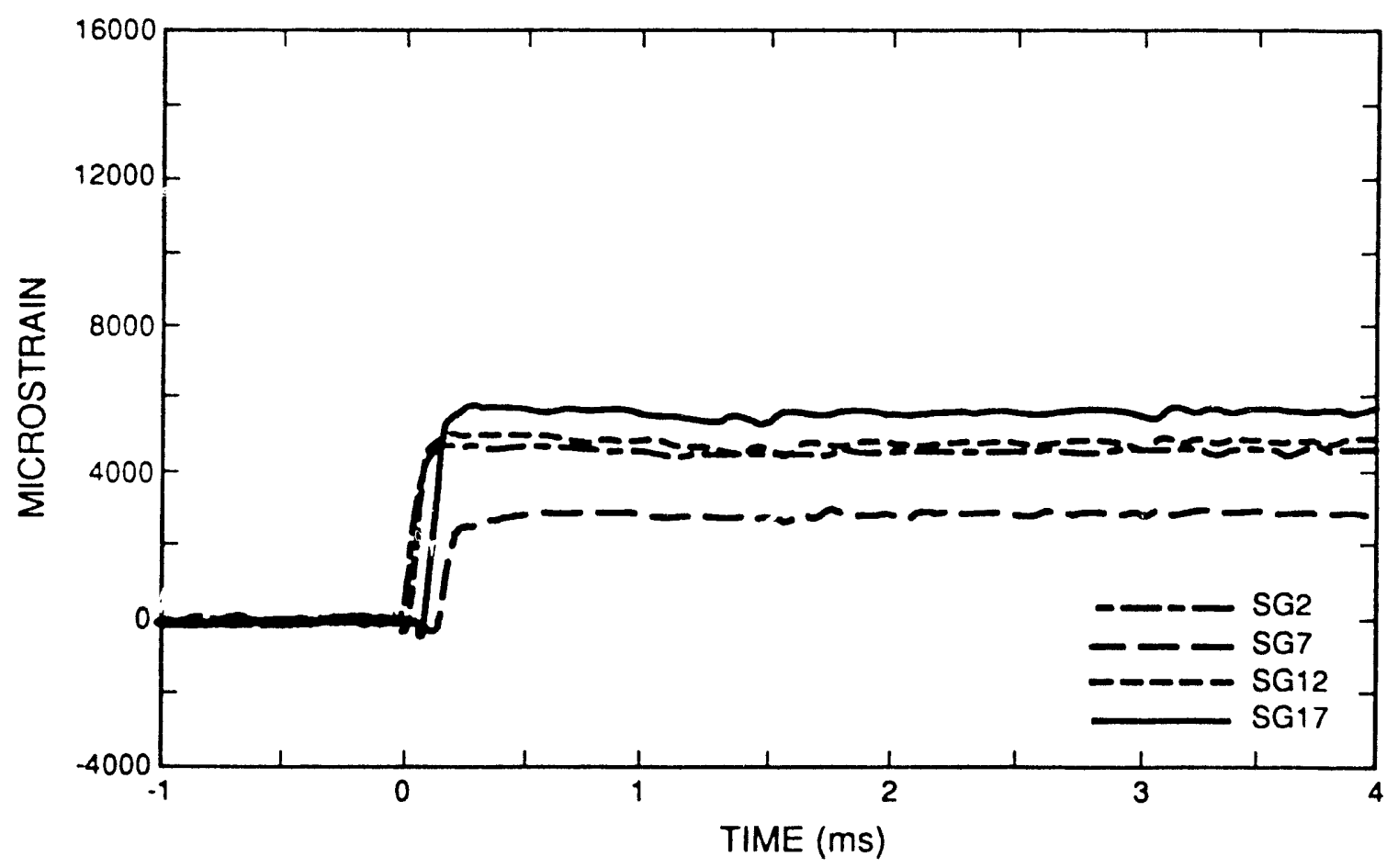

Figure D-17. End-Impact Test 4 Hoop Strain at 1 in.

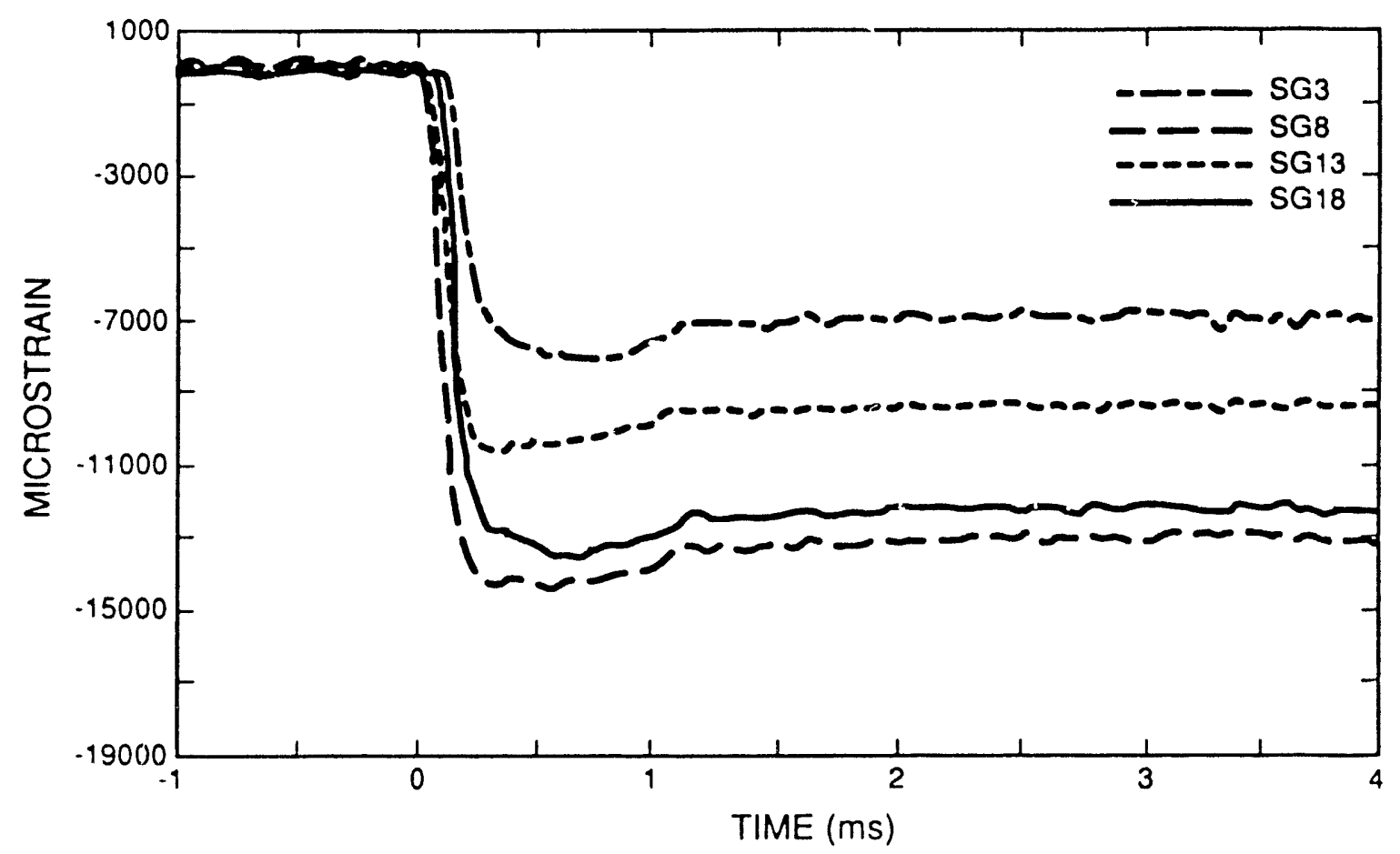

Figure D-18. End-Impact Test 4 Axial Strain at 3 in. 


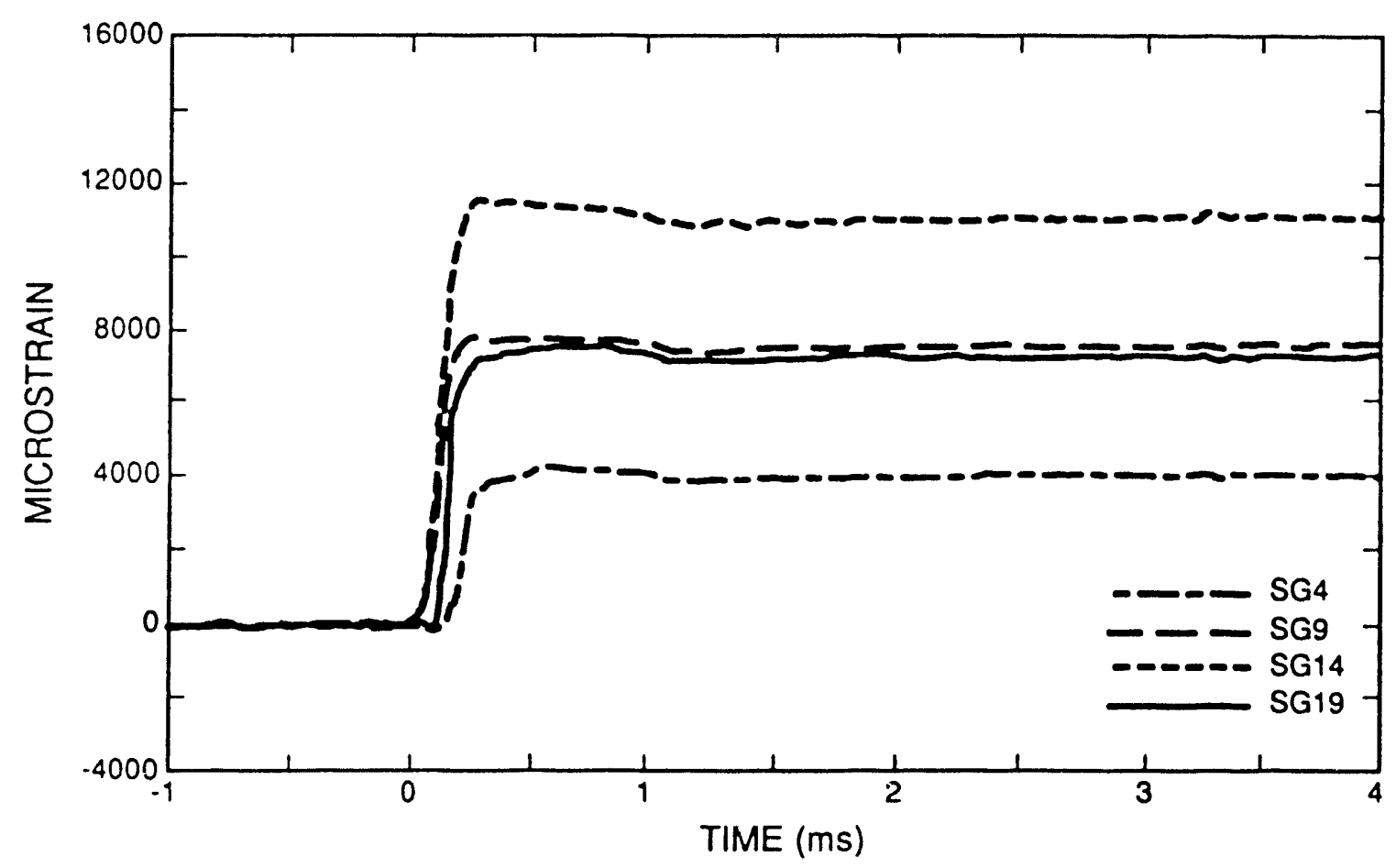

Figure D-19. End-Impact Test 4 Hoop Strain at 3 in.

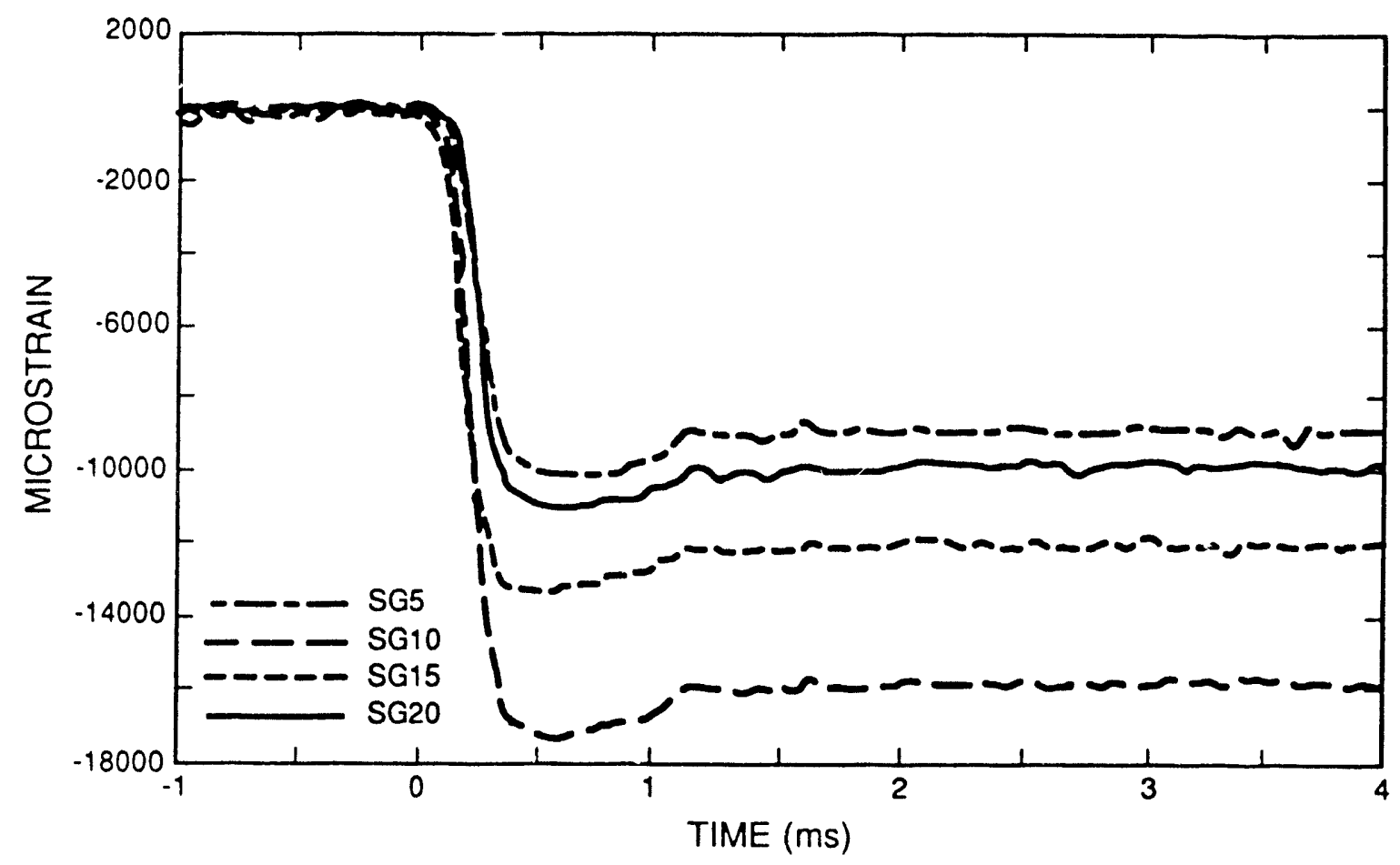

Figure D-20. End-Impact Test 4 Axial Strain at 6 in. 


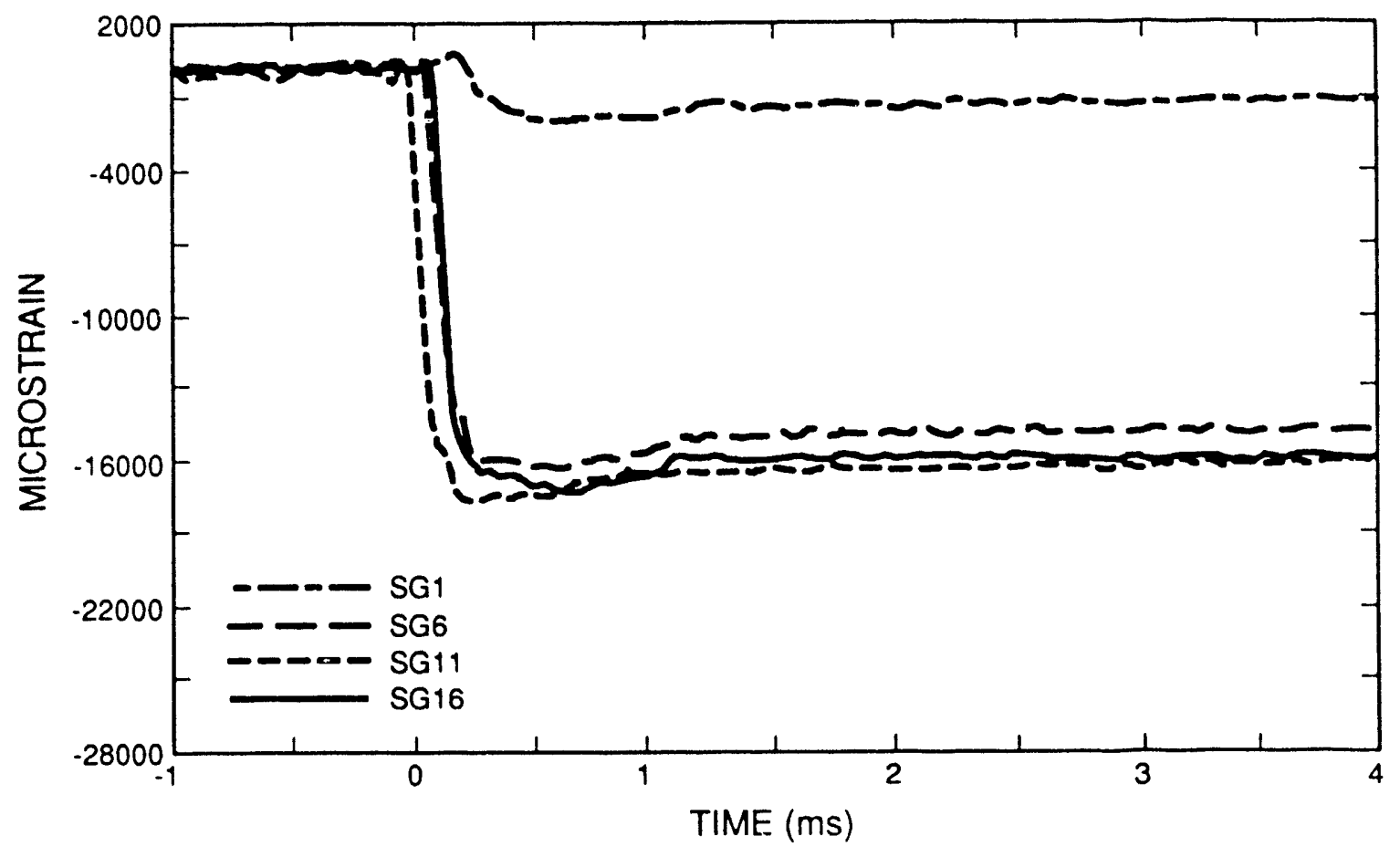

Figure D-21. End-Impact Test 5 Axial Strain at 1 in.

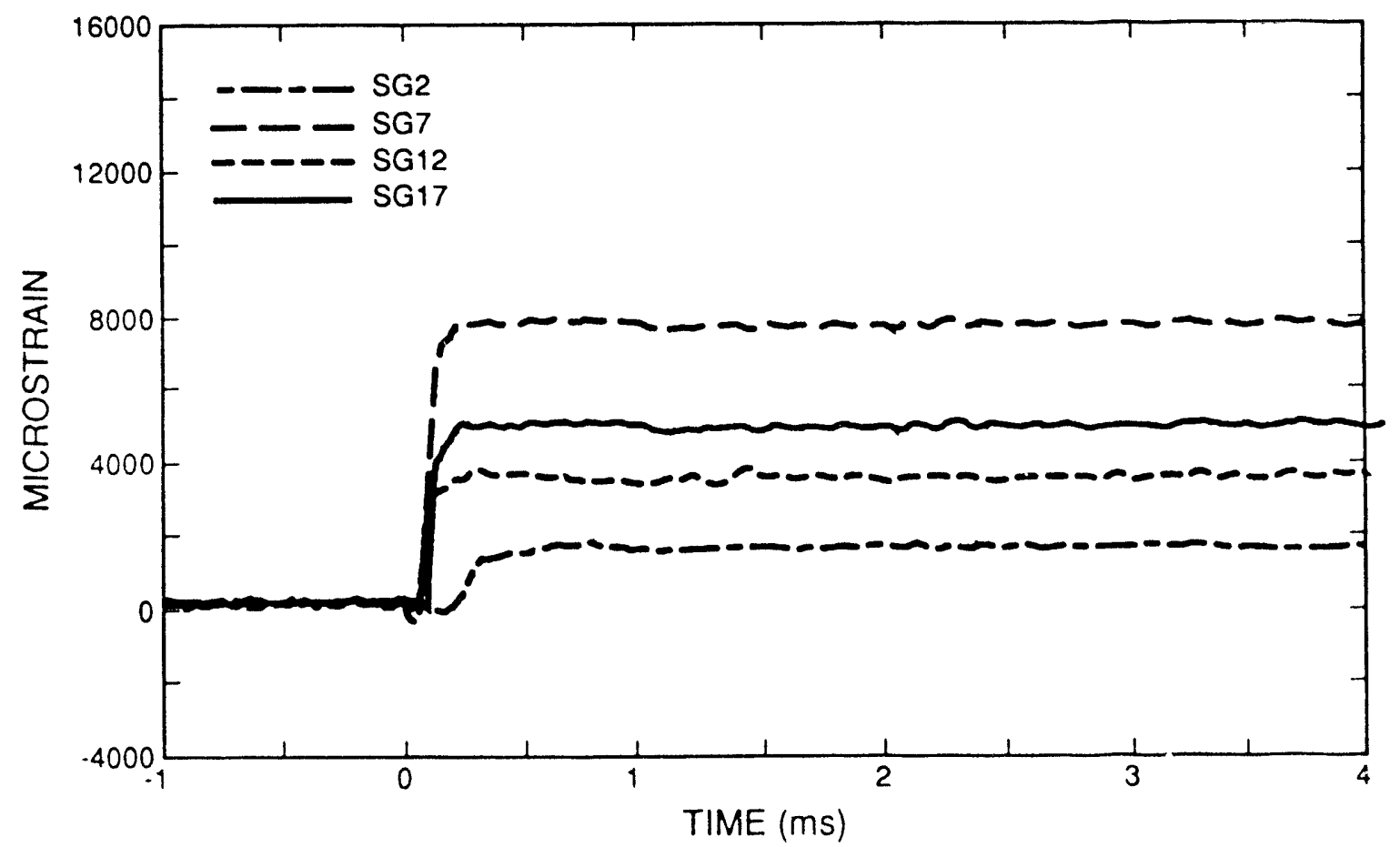

Figure D-22. End-Impact Test 5 Hoop Strain at 1 in. 


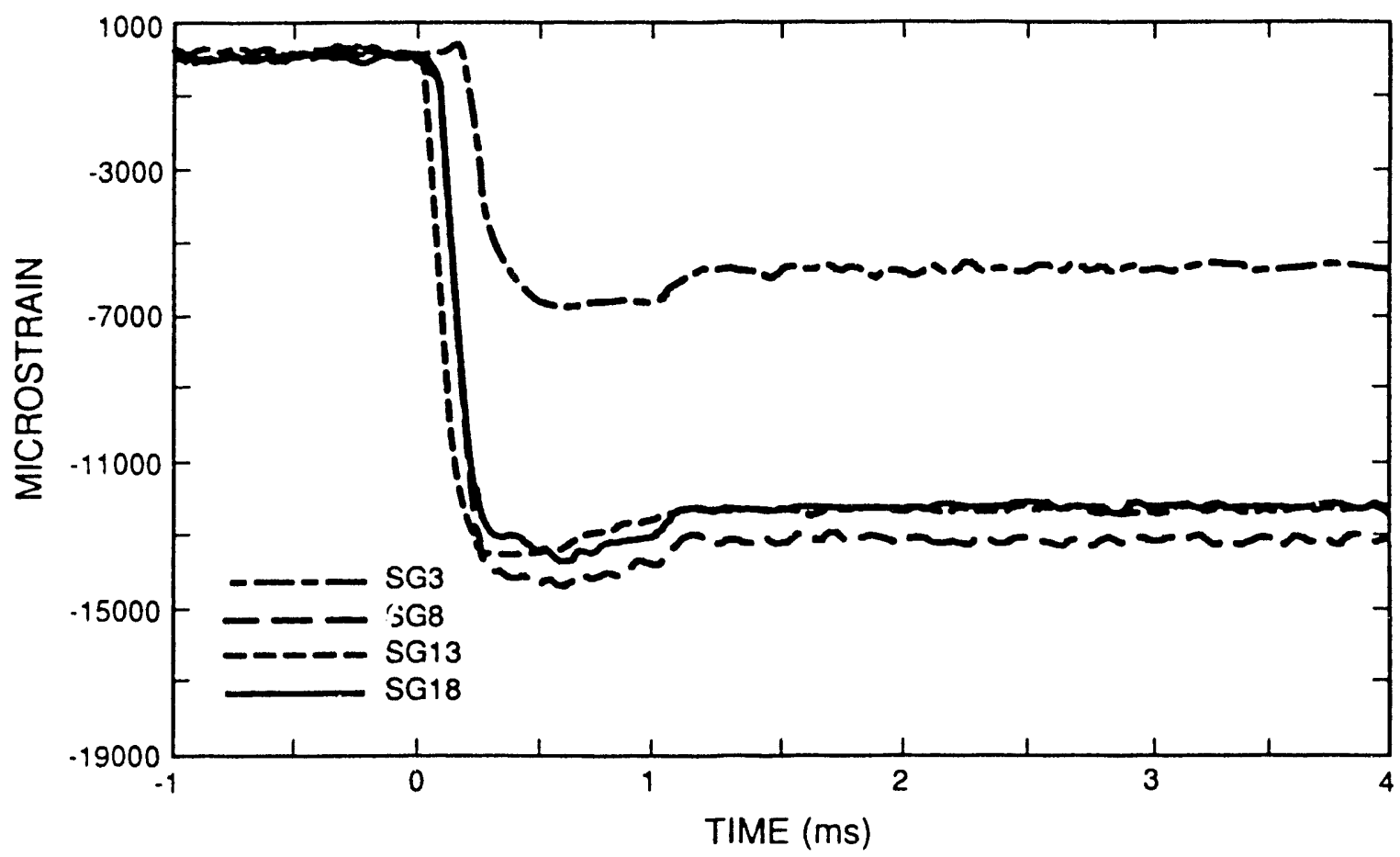

Figure D-23. End-Impact Test 5 Axial Strain at 3 in.

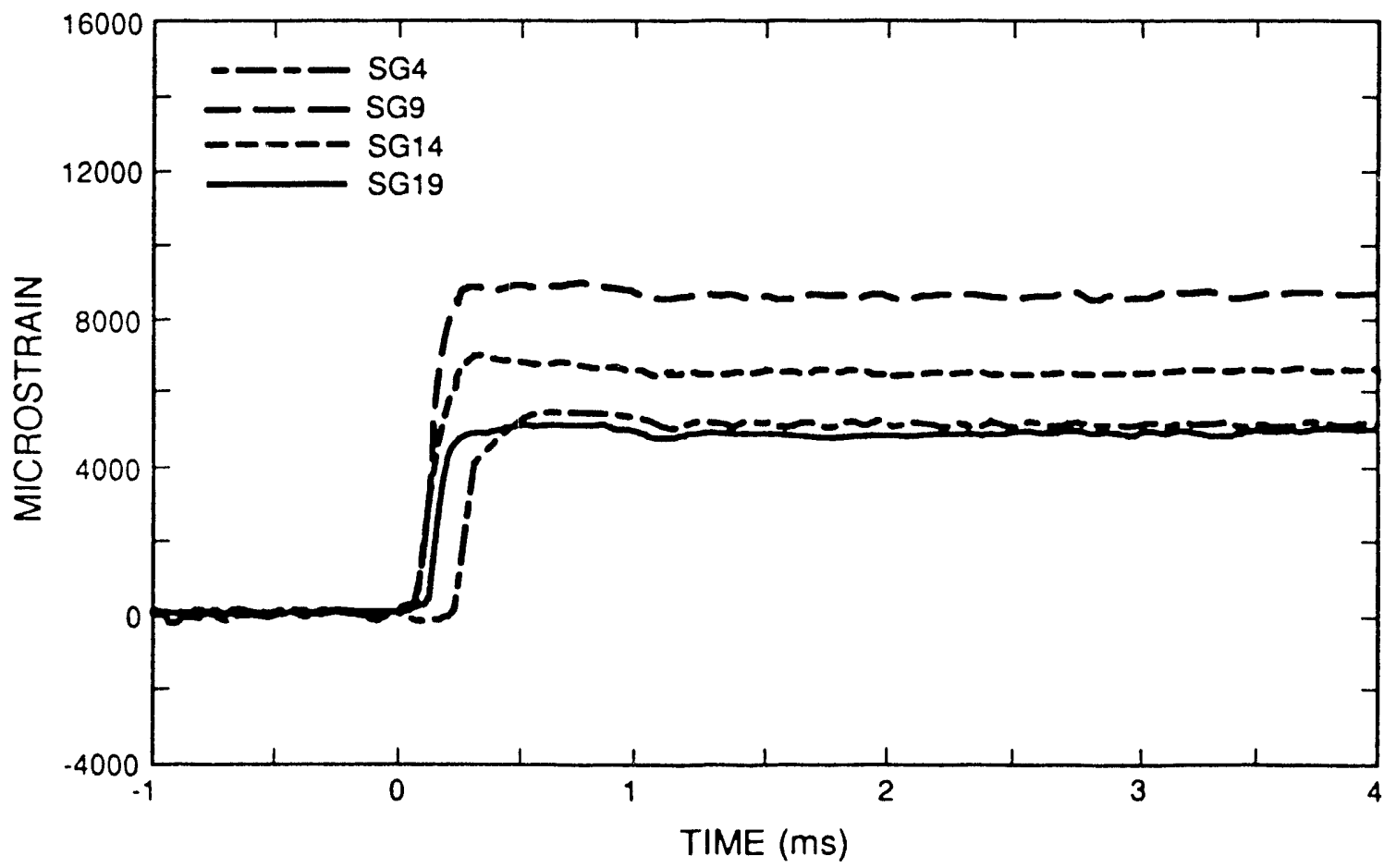

Figure D-24. End-Impact Test 5 Hoop Strain at 3 in. 


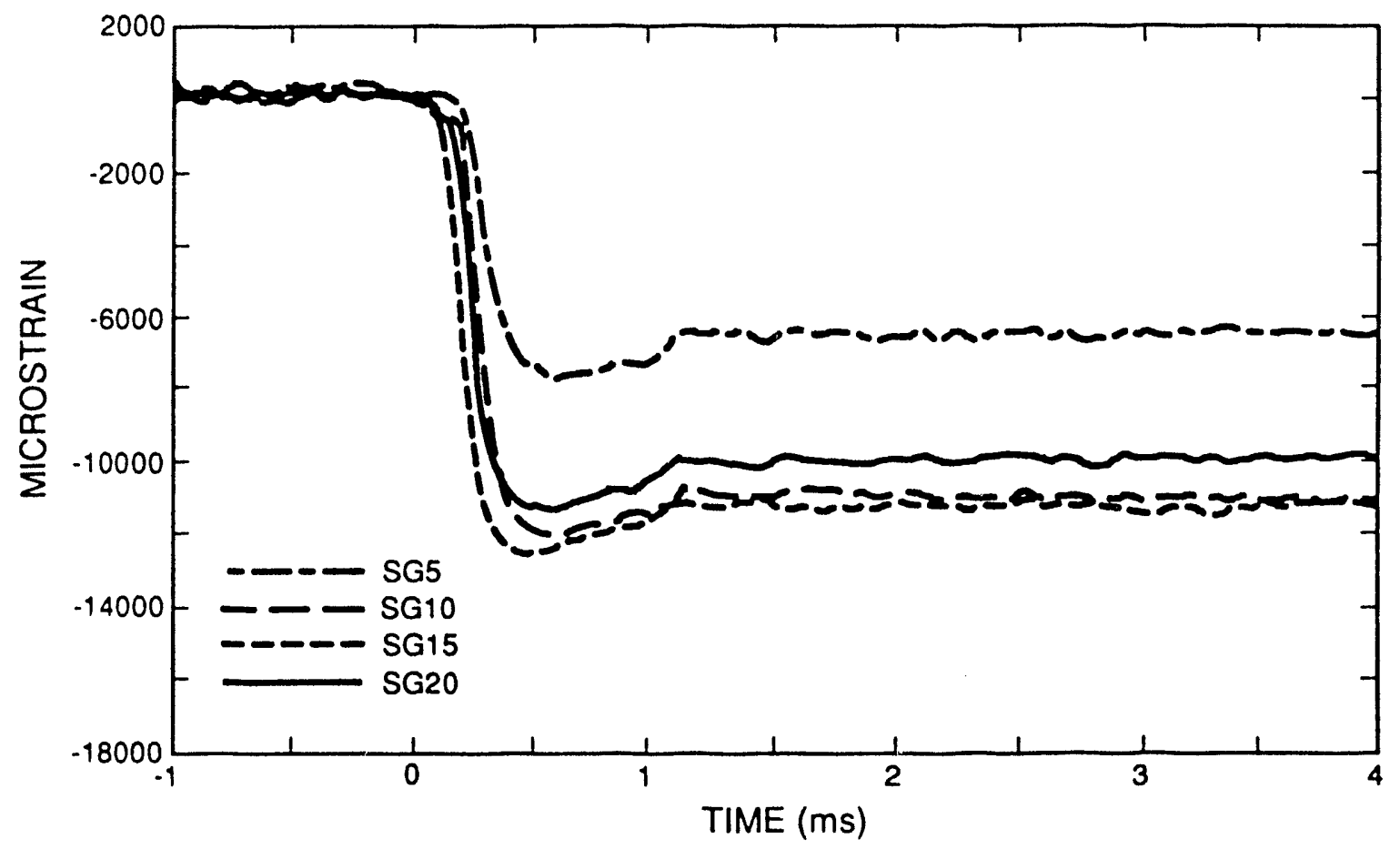

Figure D-25. End-Impact Test 5 Axial Strain at 6 in.

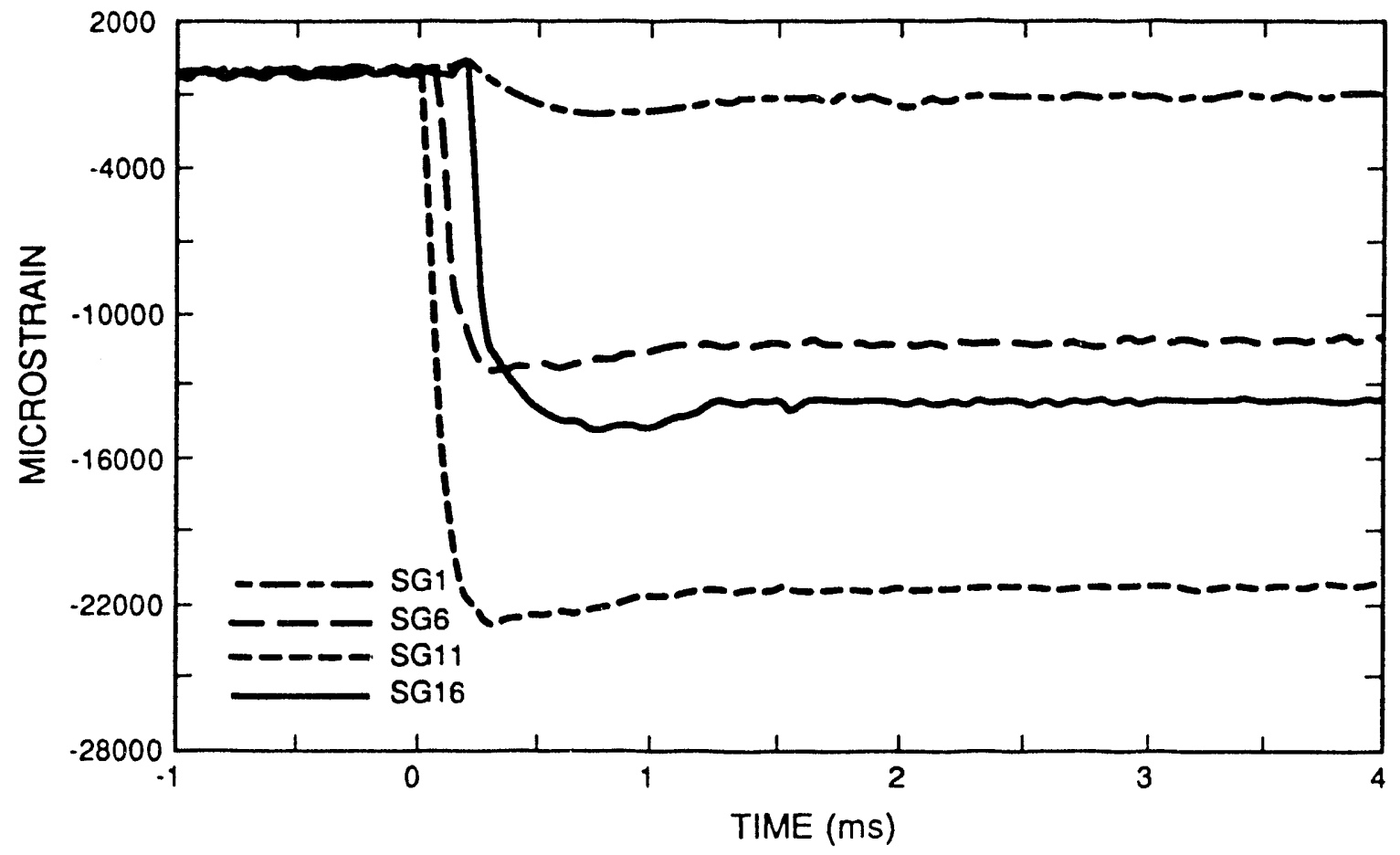

Figure D-26. End-Impact Test 6 Axial Strain at 1 in. 


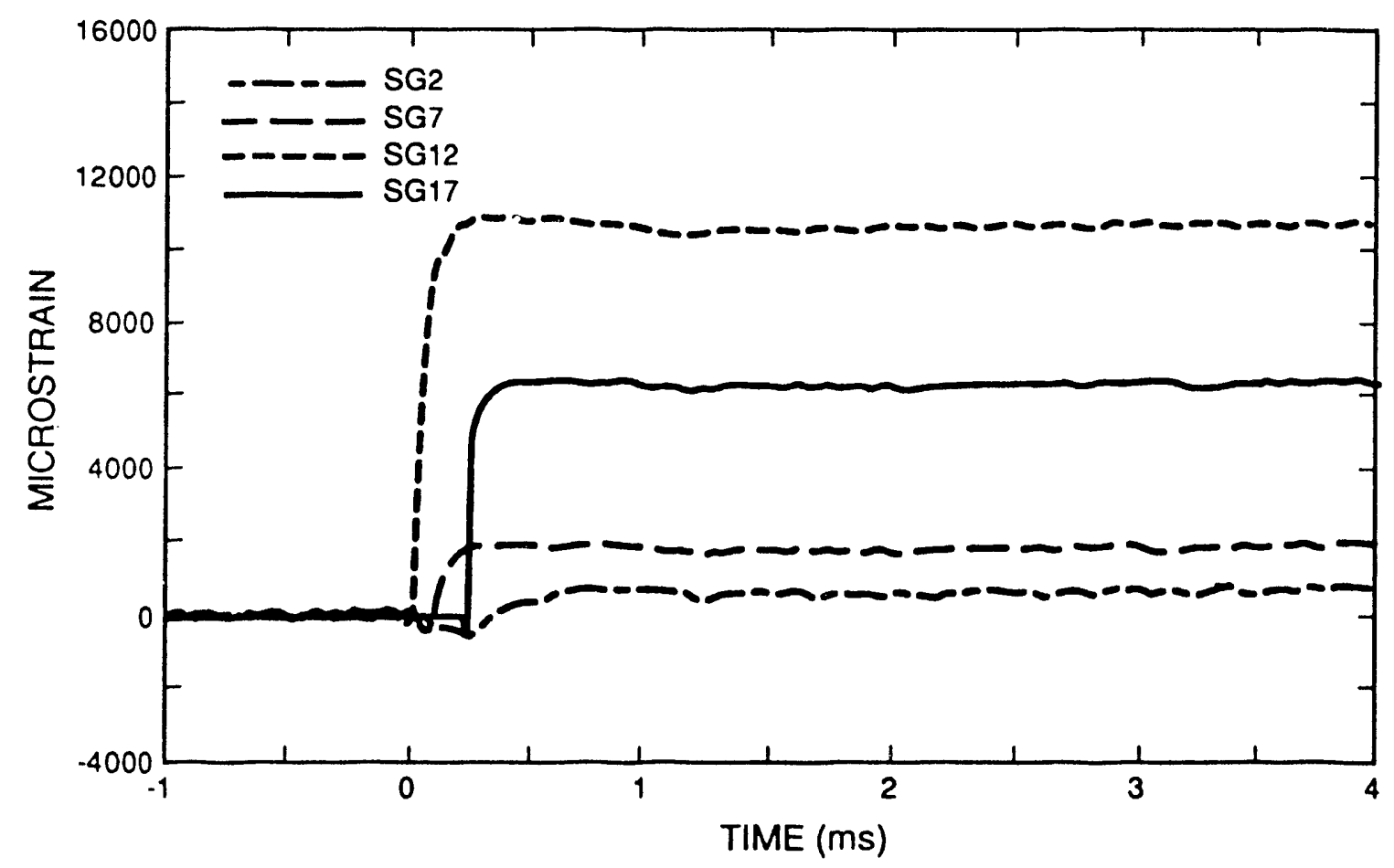

Figure D-27. End-Impact Test 6 Hoop Strain at 1 in.

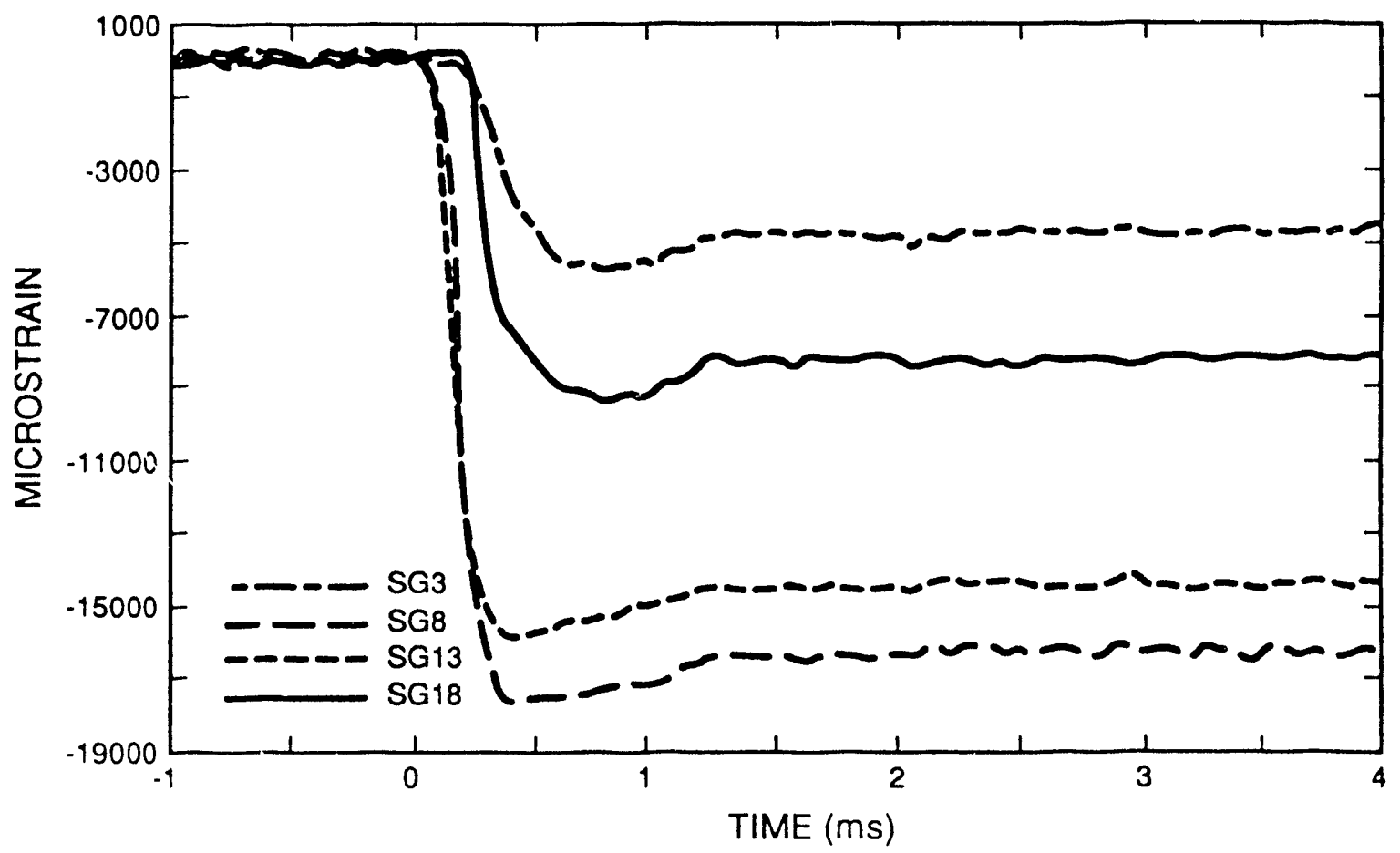

Figure D-28. End-Impact Test 6 Axial Strain at 3 in. 


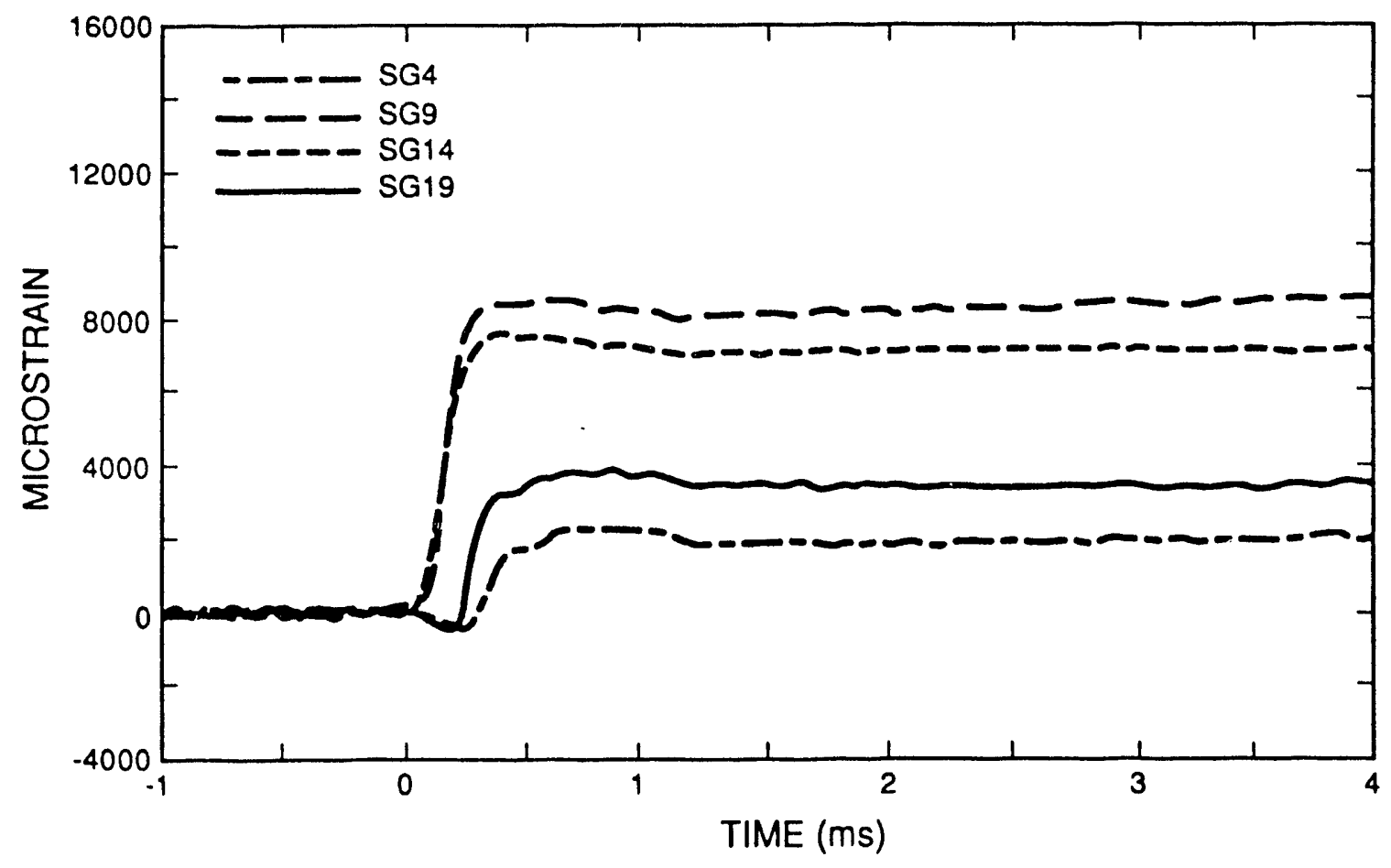

Figure D-29. End-Impact Test 6 Hoop Strain at 3 in.

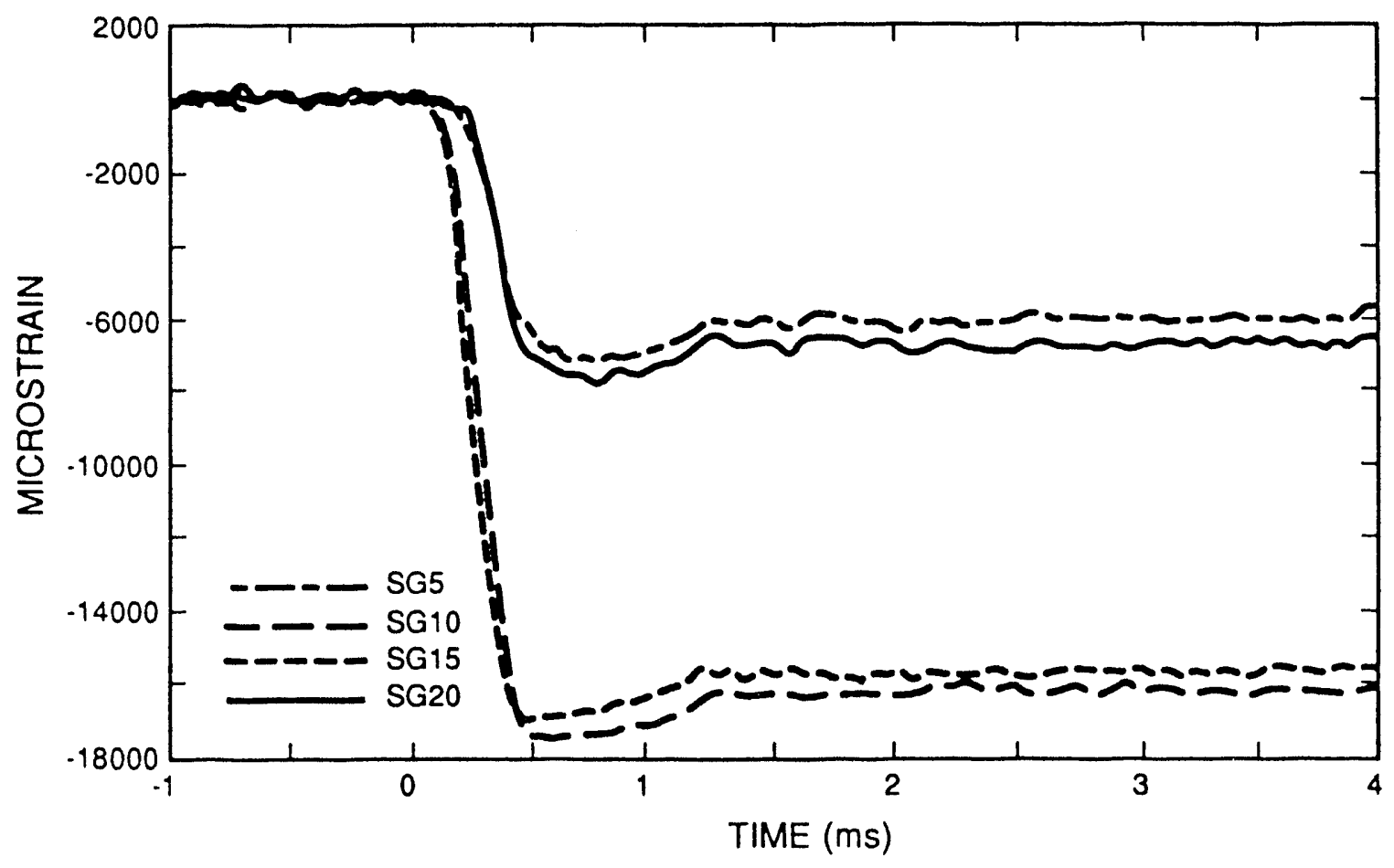

Figure D-30. End-Impact Test 6 Axial Strain at 6 in. 


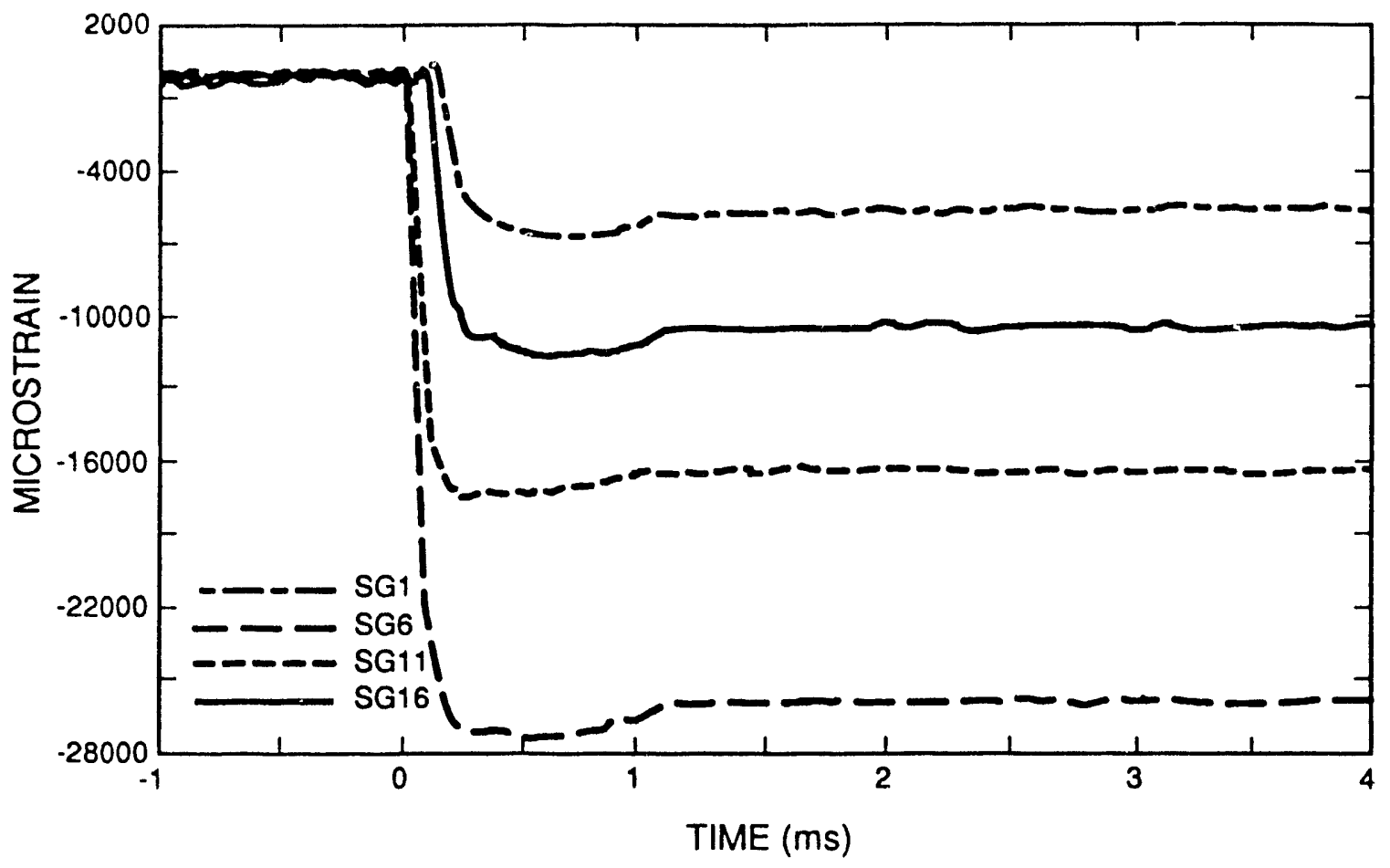

Figure D-31. End-Impact Test 7 Axial Strain at 1 in.

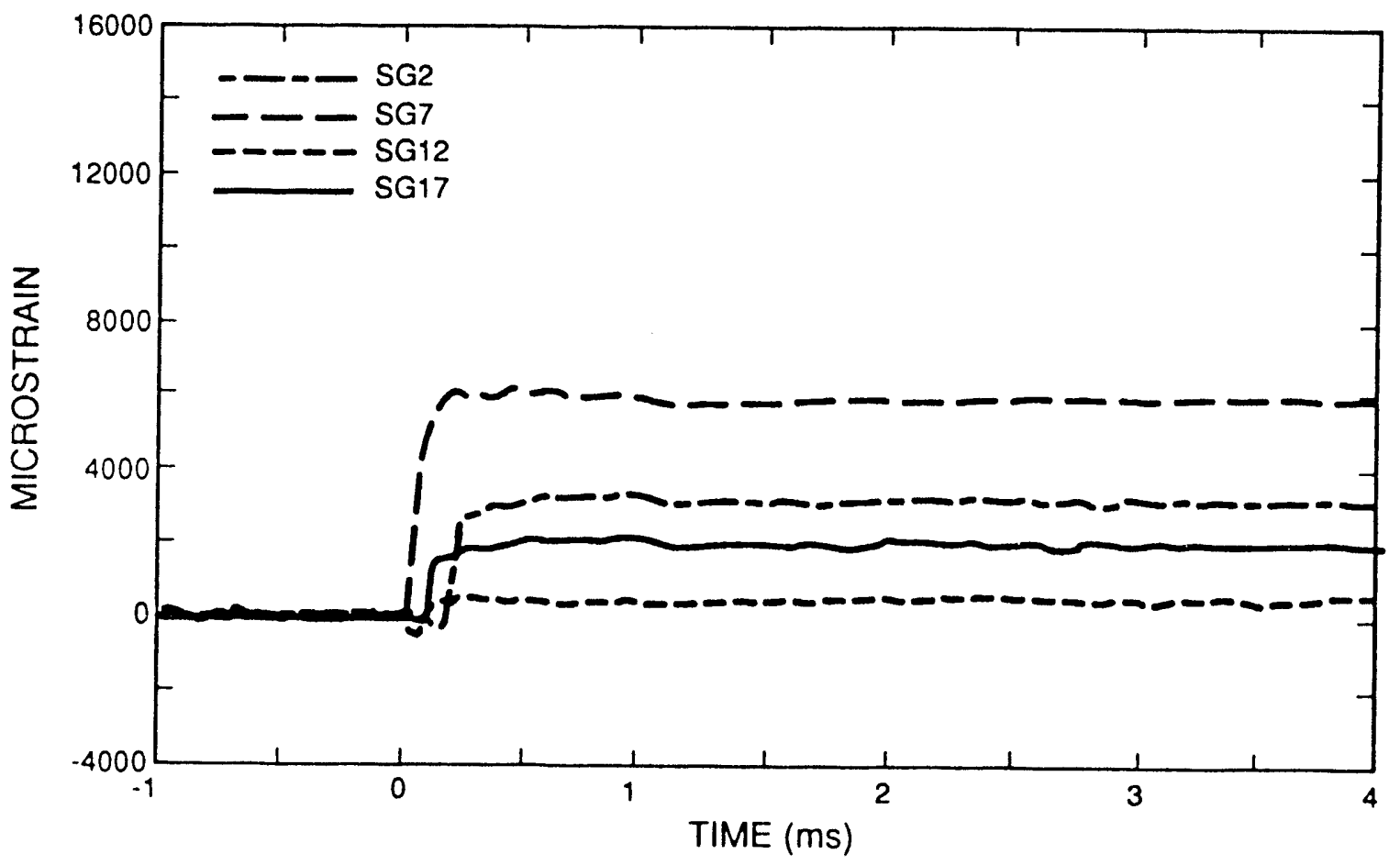

Figure D-32. End-Impact Test 7 Hoop Strain at 1 in. 


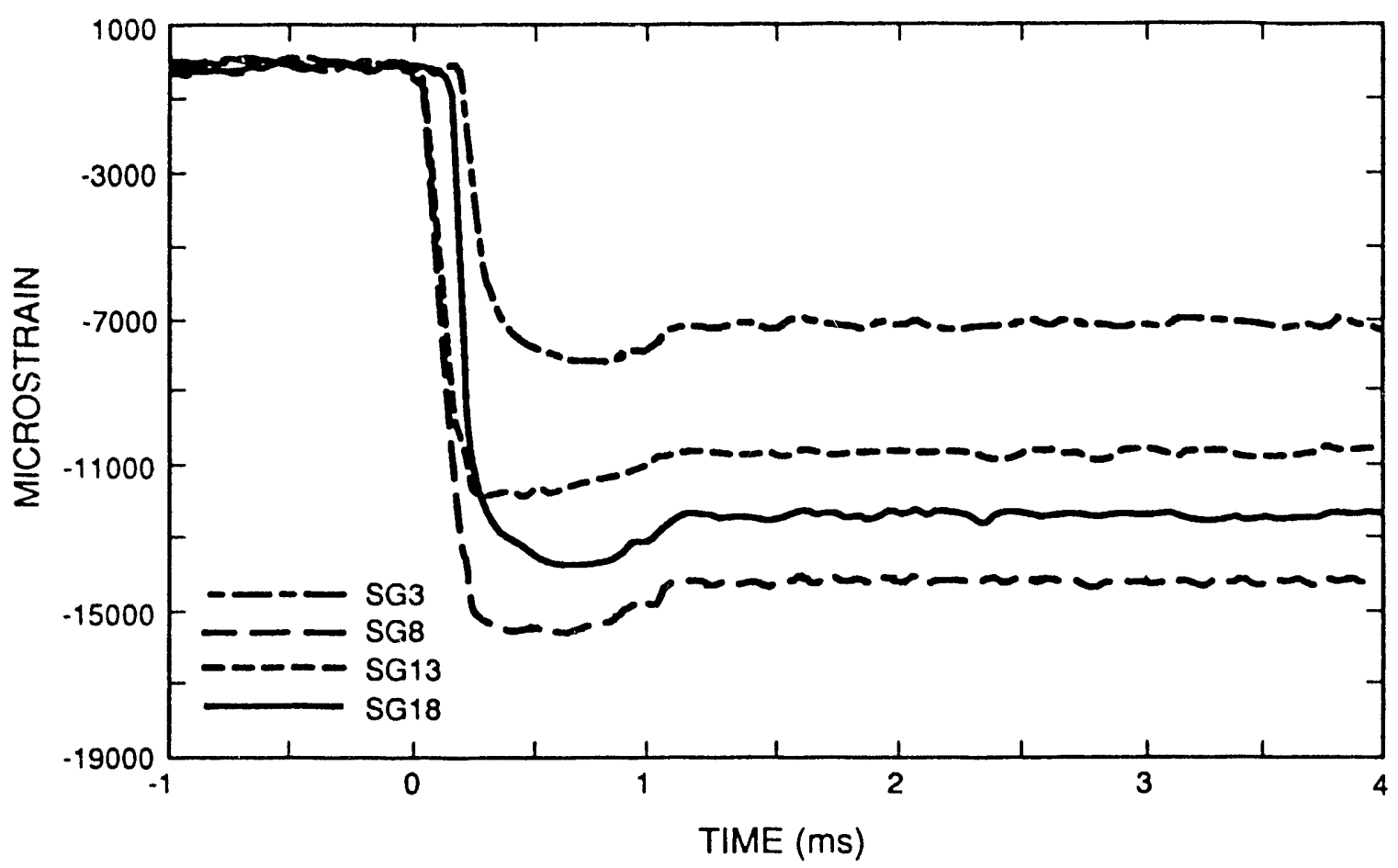

Figure D-33. End-Impact Test 7 Axial Strain at 3 in.

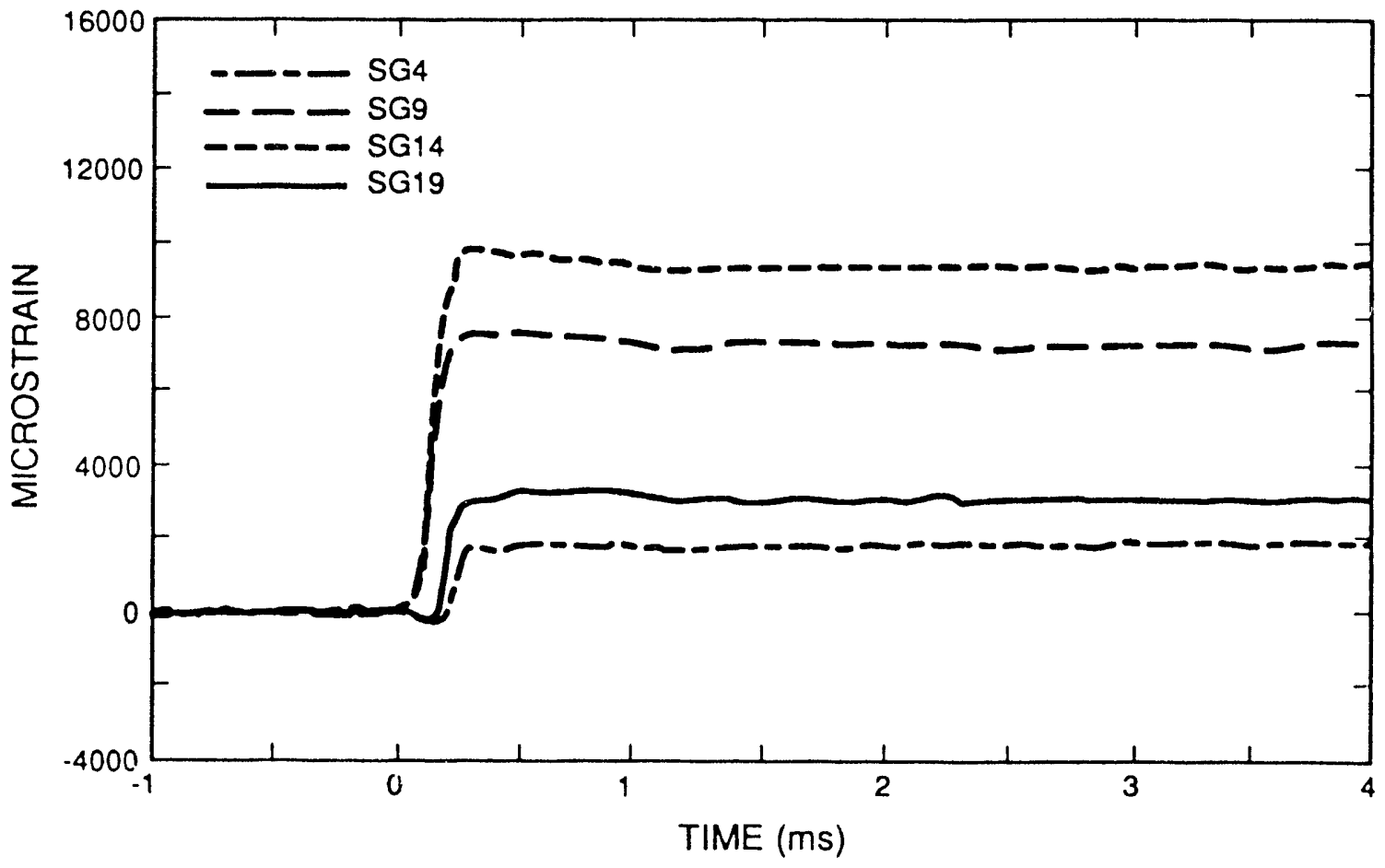

Figure D-34. Lud-Impact Test 7 Hoop Strain at 3 in. 


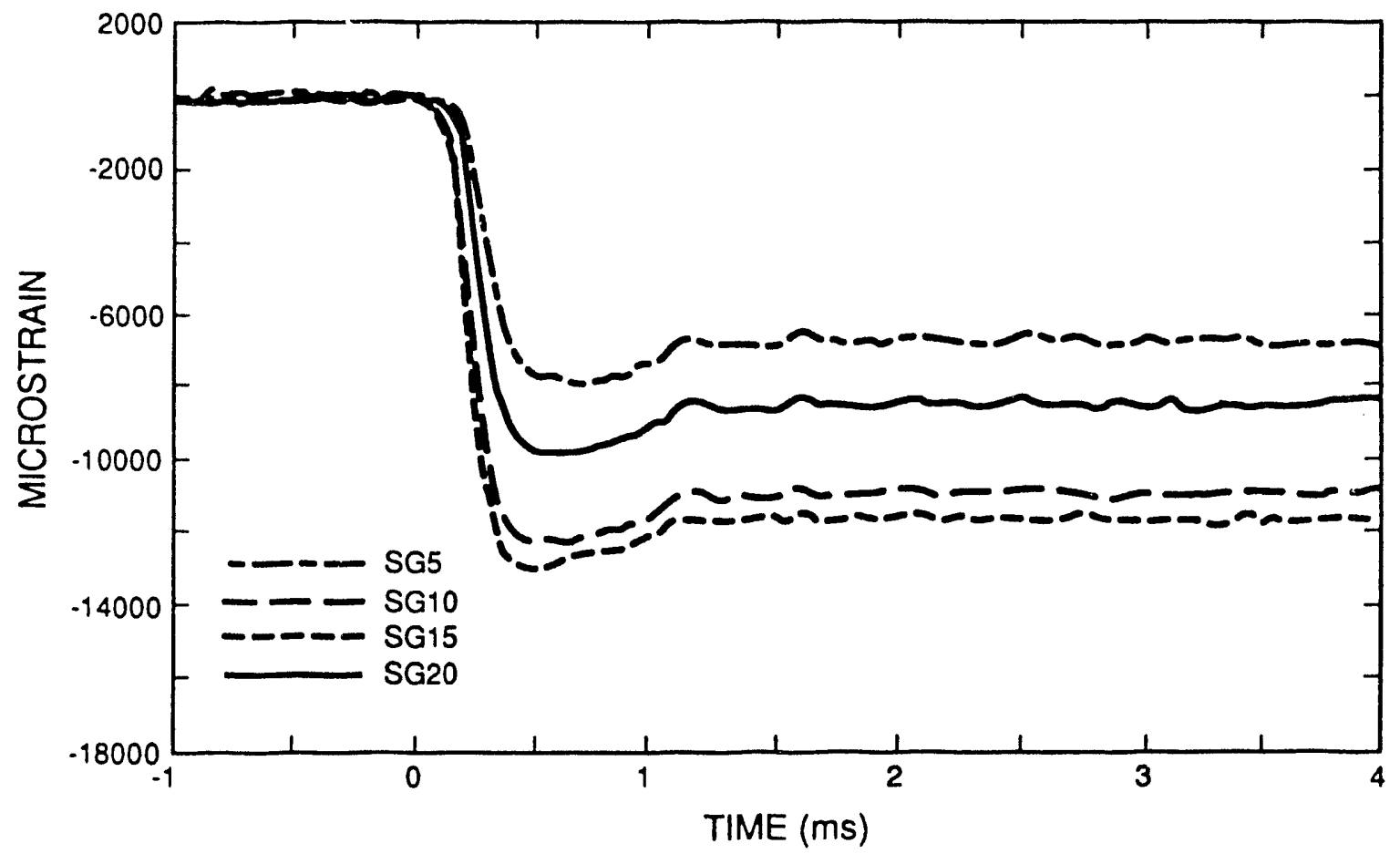

Figure D-35. End-Impact Test 7 Axial Strain at 6 in.

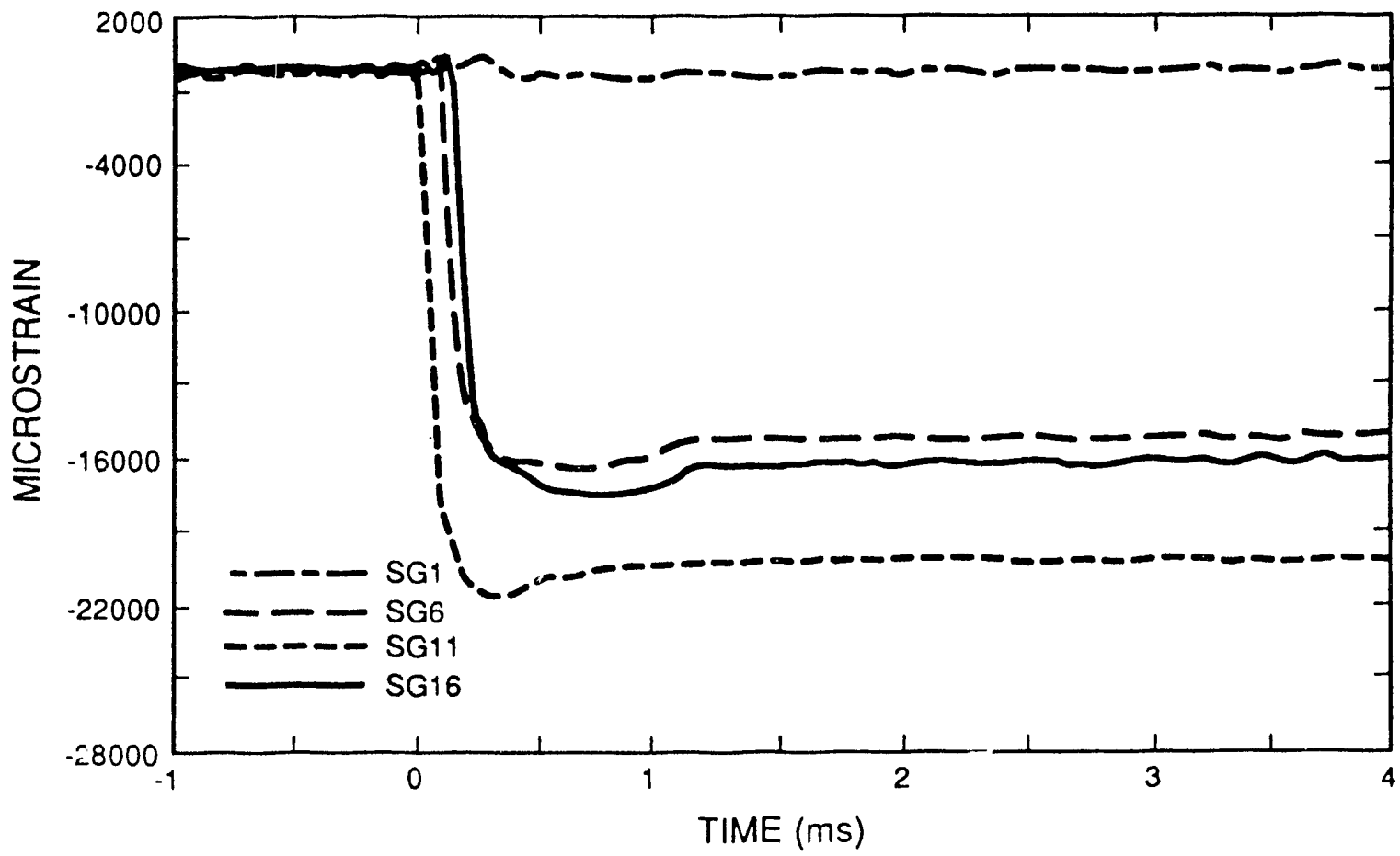

Figure D-36. End-Impact Test 8 Axial Strain at 1 in. 


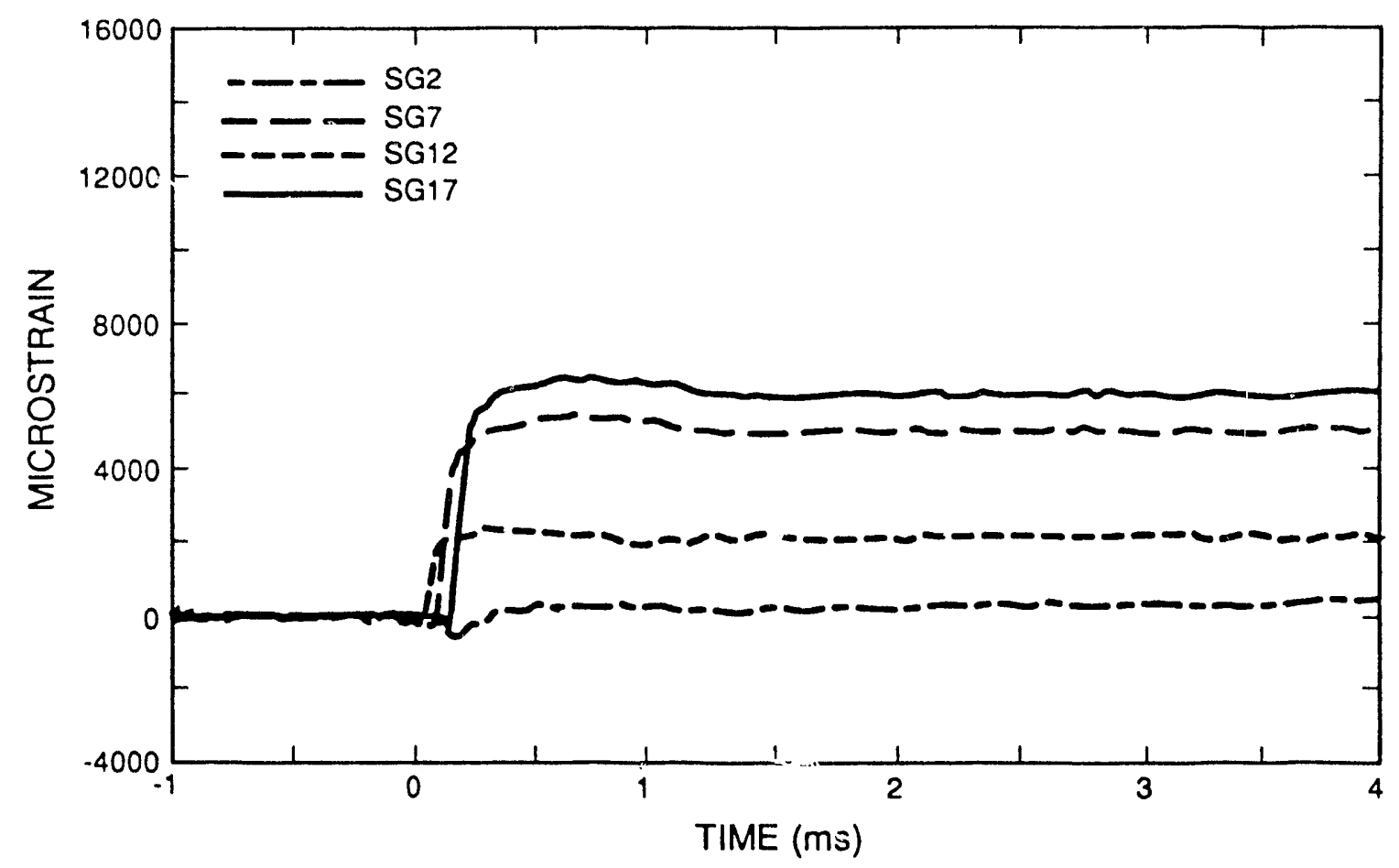

Figure D-37. End-Impact Test 8 Hoop Strain at 1 in.

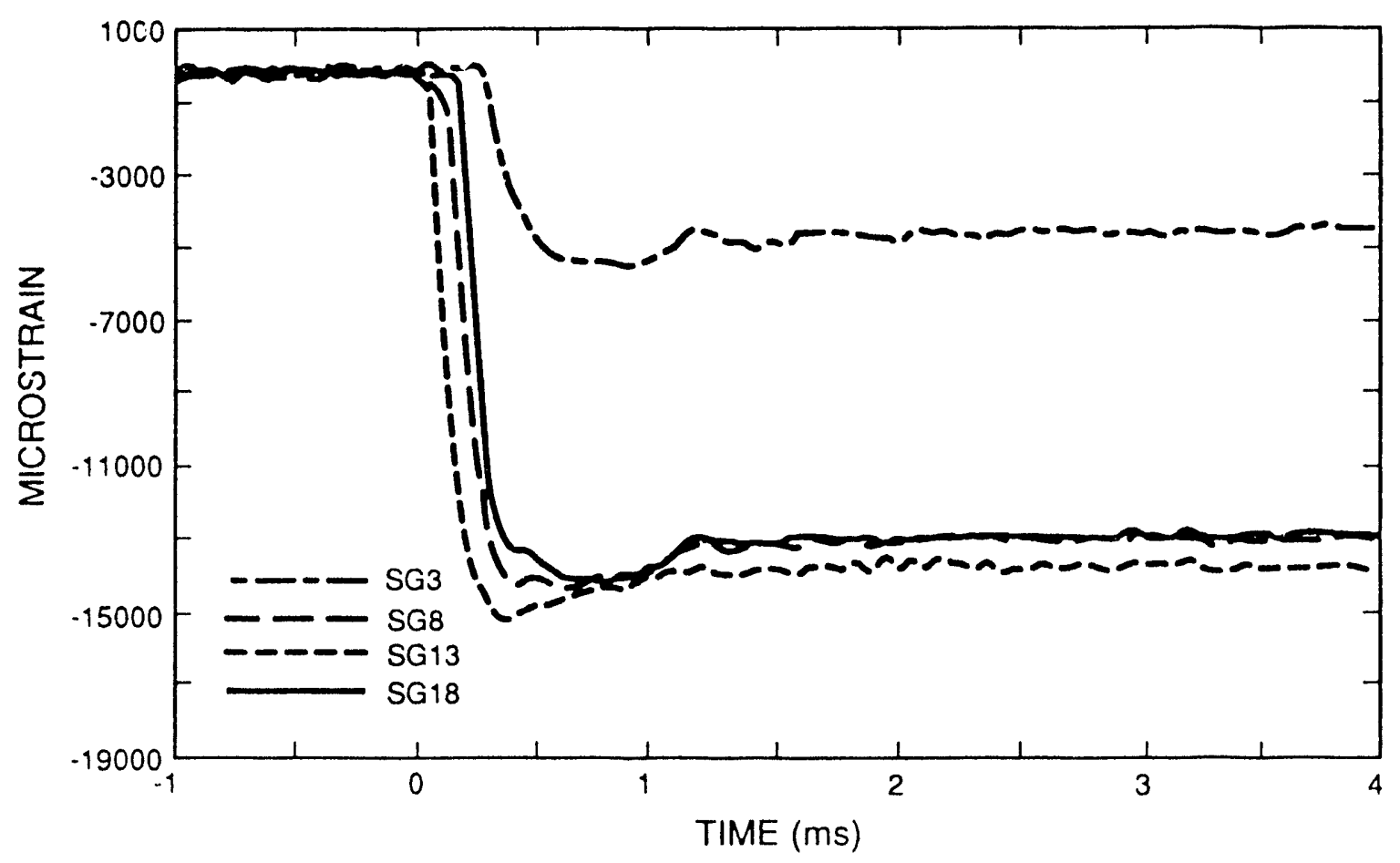

Figure D-38. End-Impact Test 8 Axial Strain at $3 \mathrm{in.}$ 


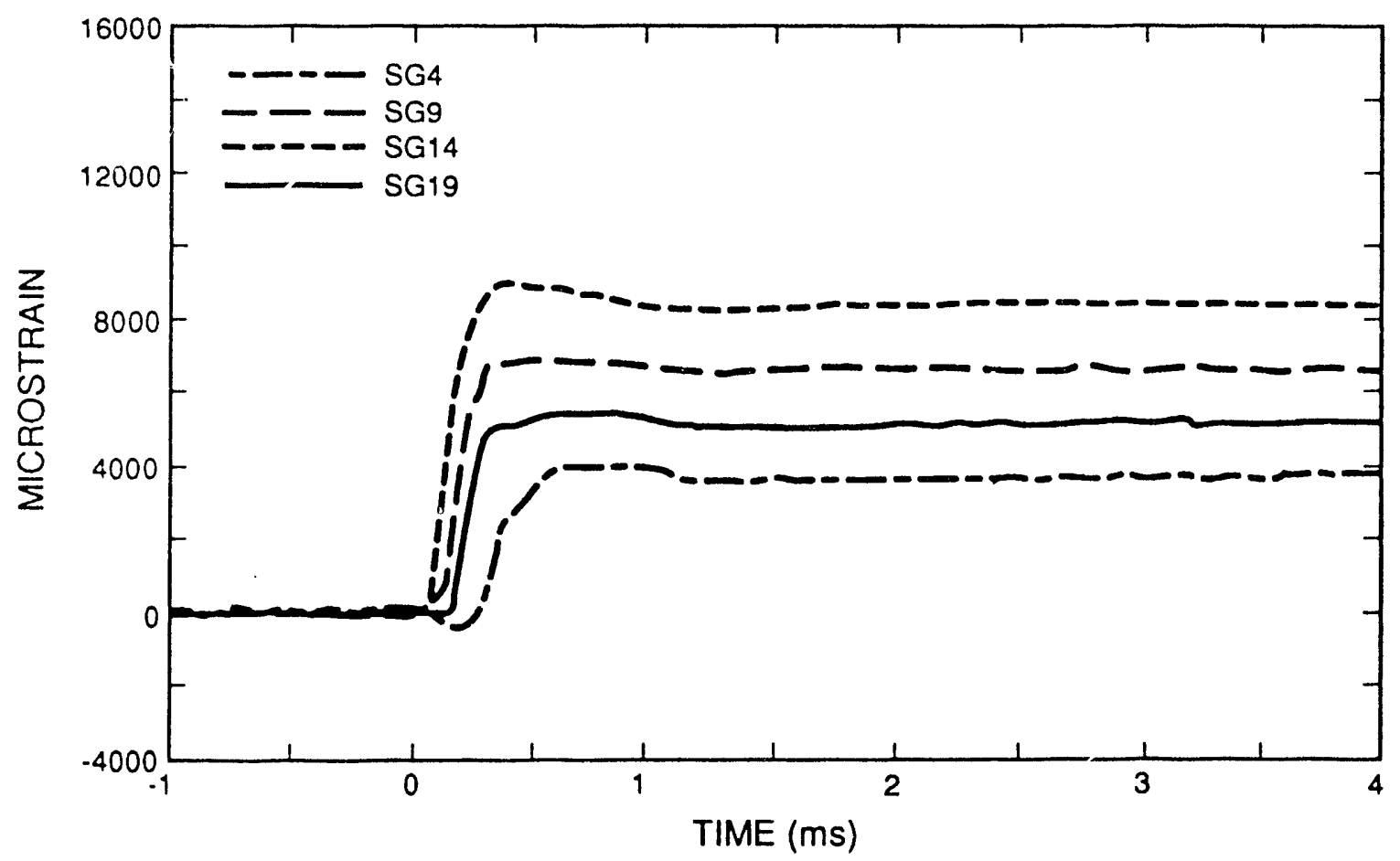

Figure D-39. End-Impact Test 8 Hoop Strain at 3 in.

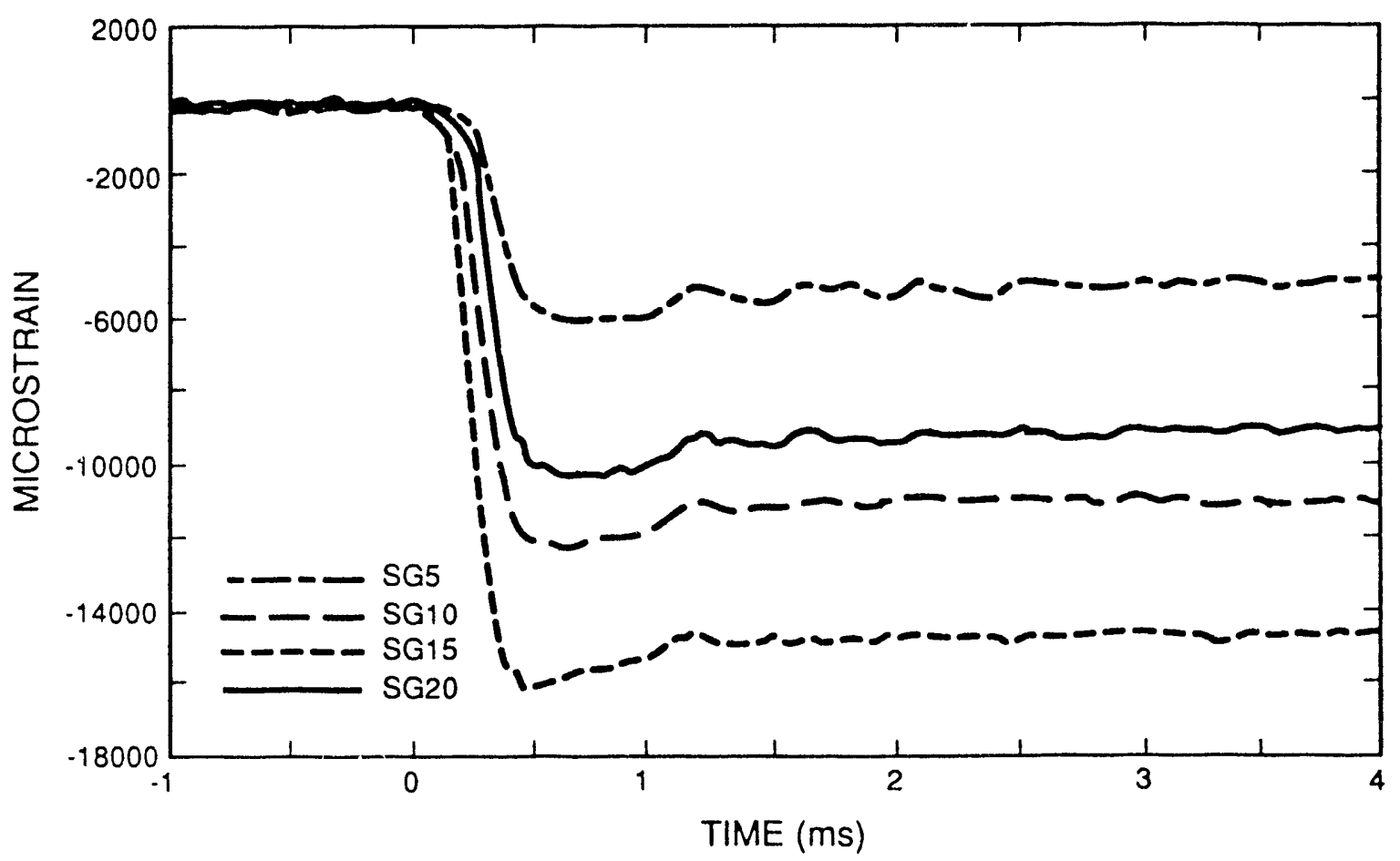

Figure D-40. End-Impact Test 8 Axial Strain at 6 in. 


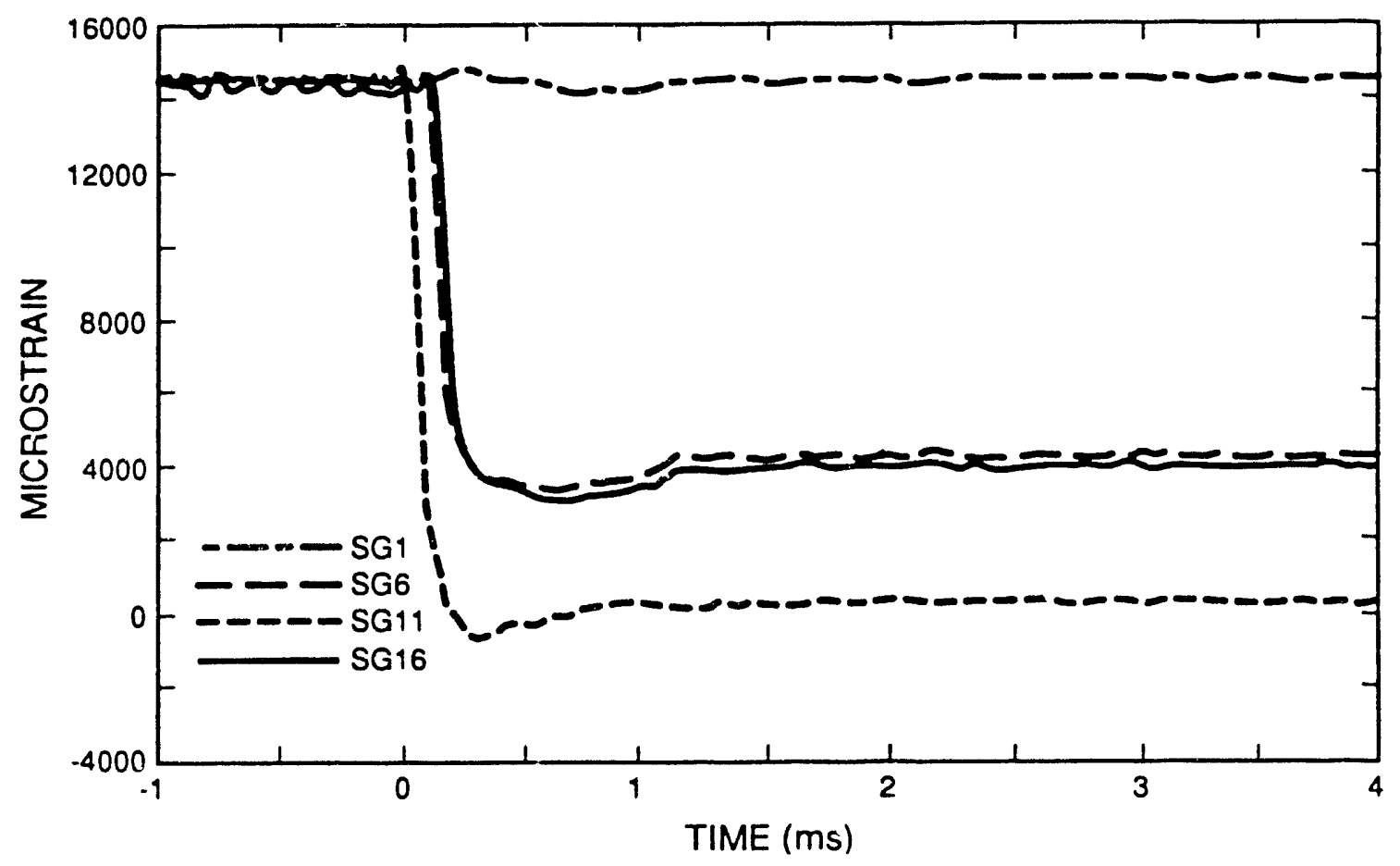

Figure D-41. End-Impact Test 9 Axial Strain at 1 in.

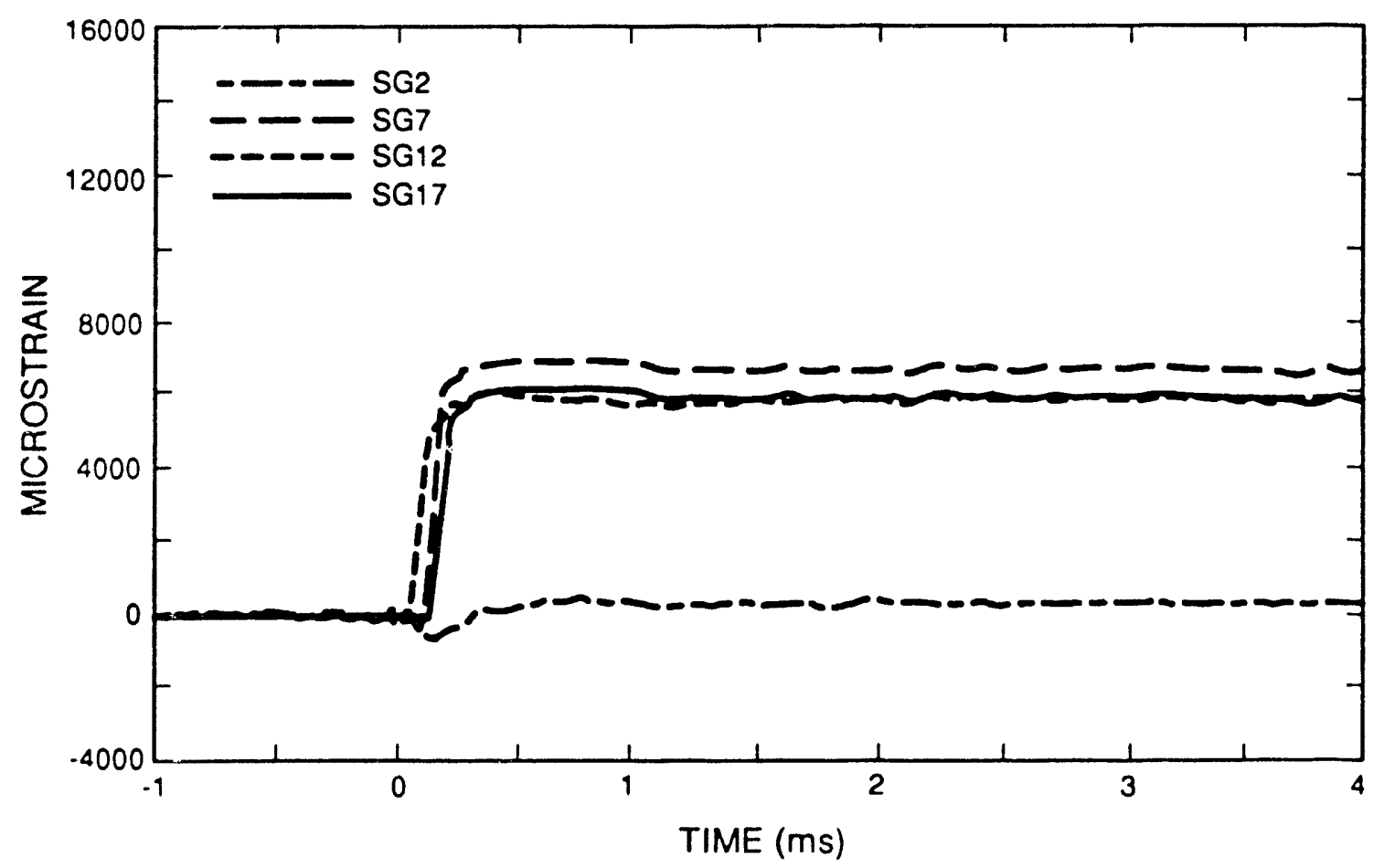

Figure D-42. End-Impact Test 9 Hoop Strain at 1 in. 


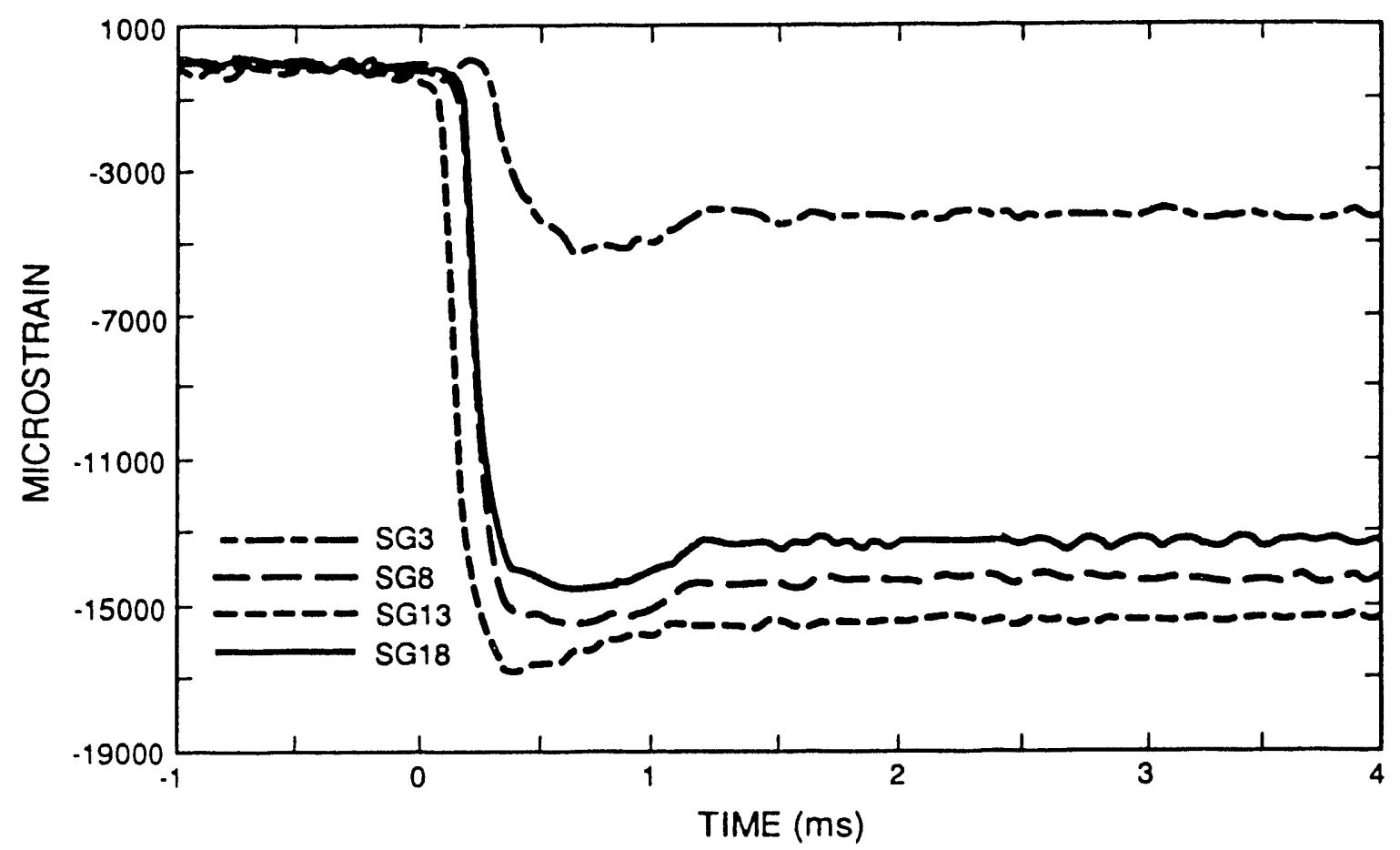

Figure D-43. End-Impact Test 9 Axial Strain at 3 in.

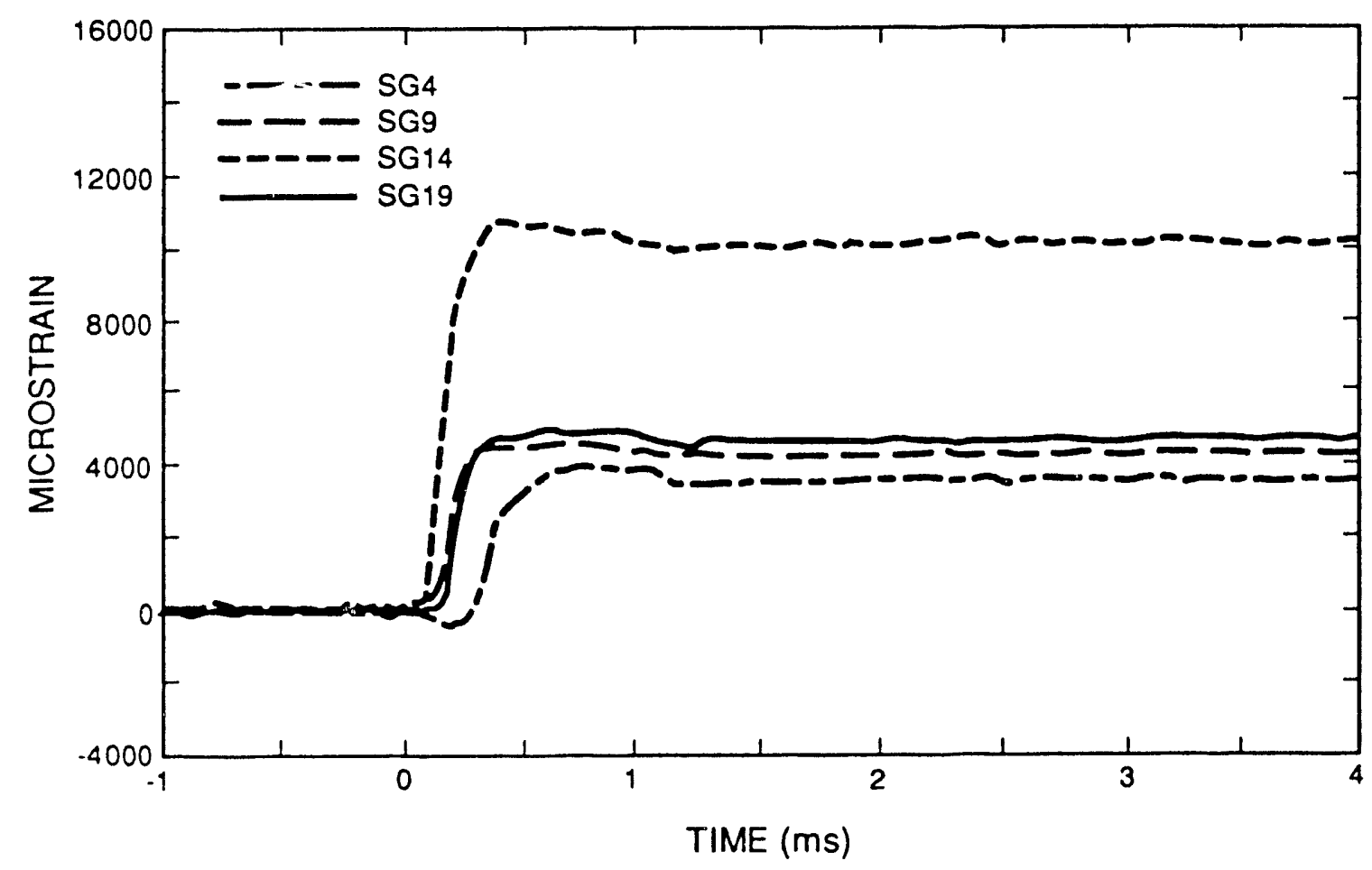

Figure D-44. End-Impact Test 9 Hoop Strain at 3 in. 


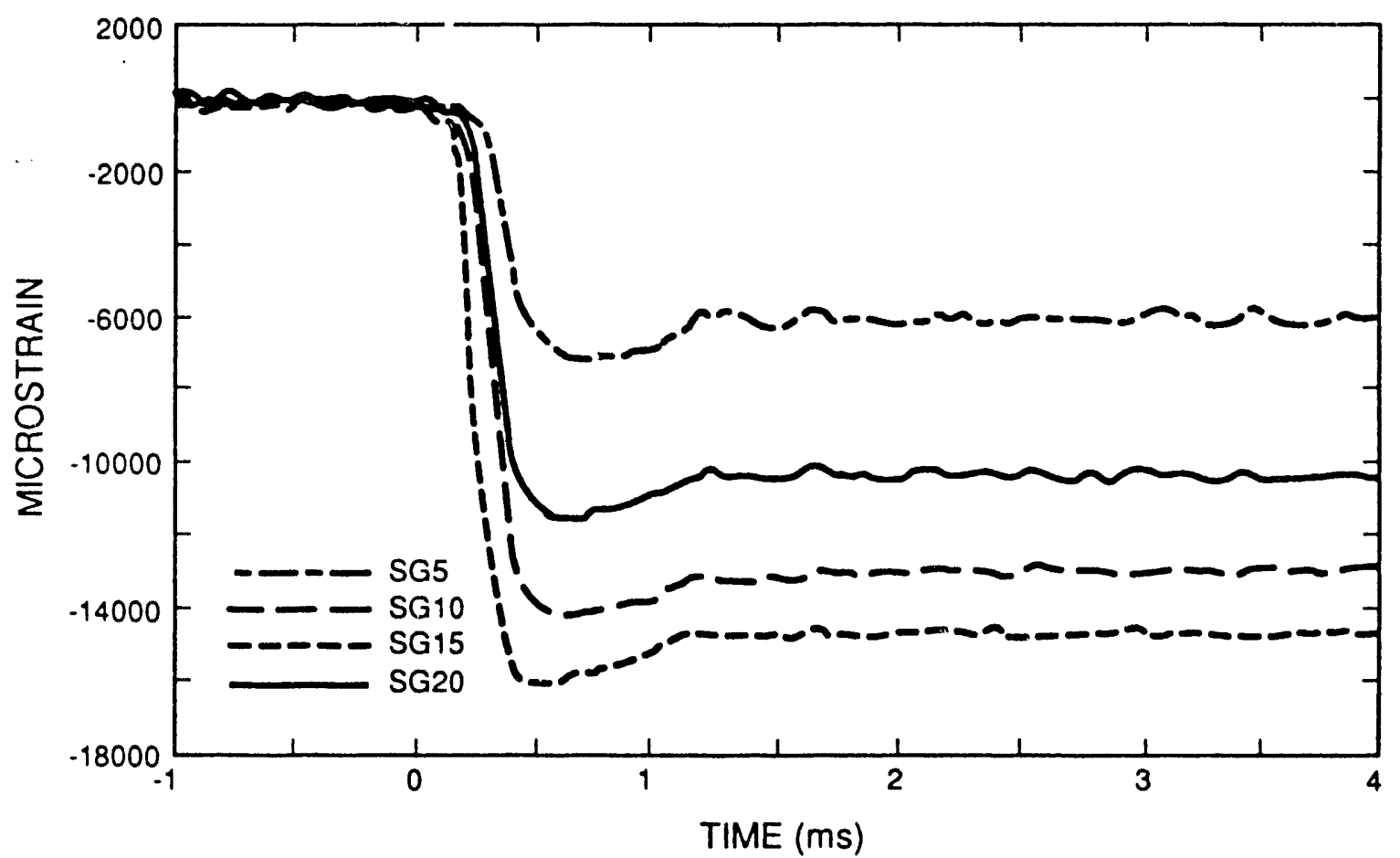

Figure D-45. End-Impact Test 9 Axial Strain at 6 in.

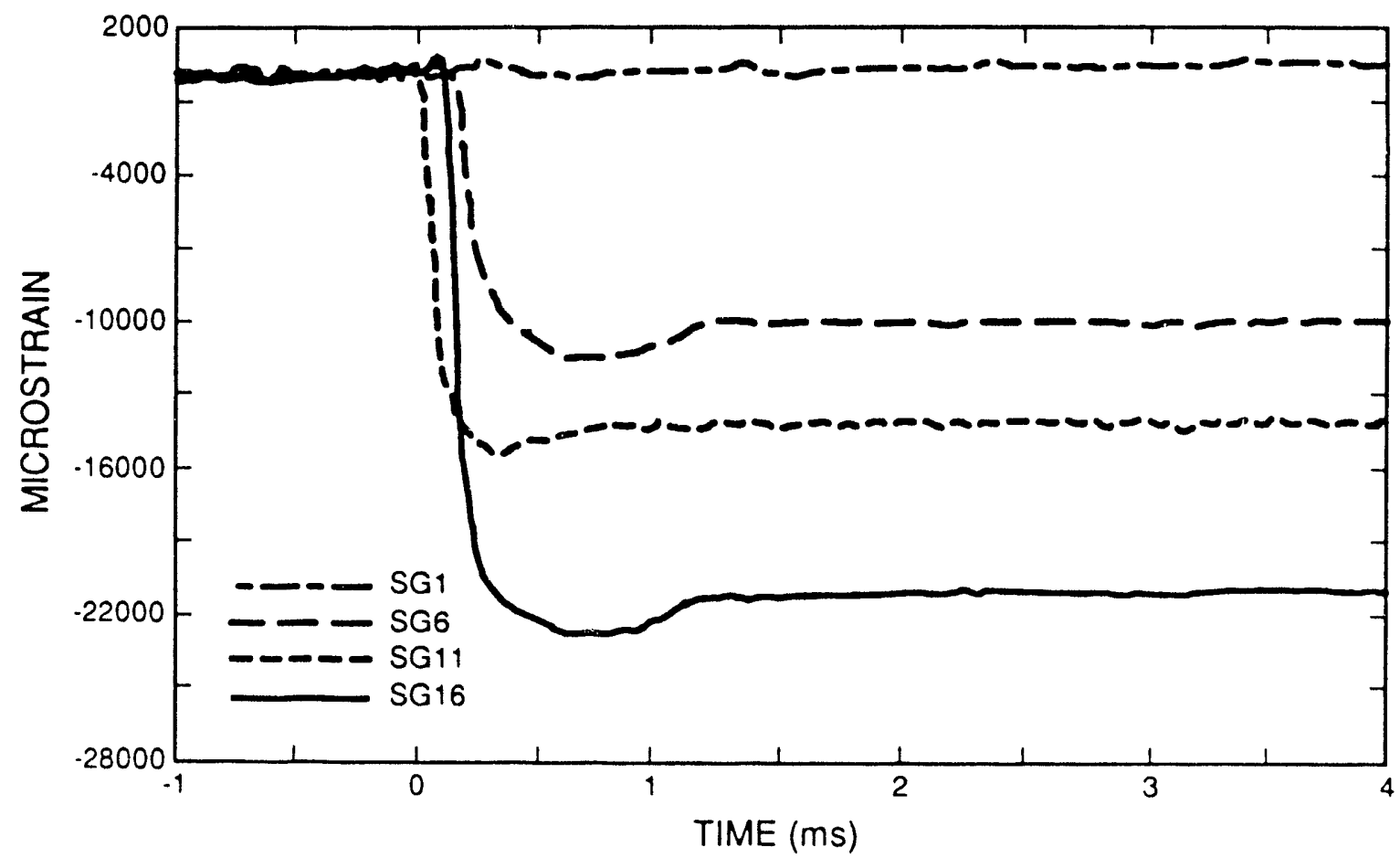

Figure D-46. End-Impact Test 10 Axial Strain at 1 in. 


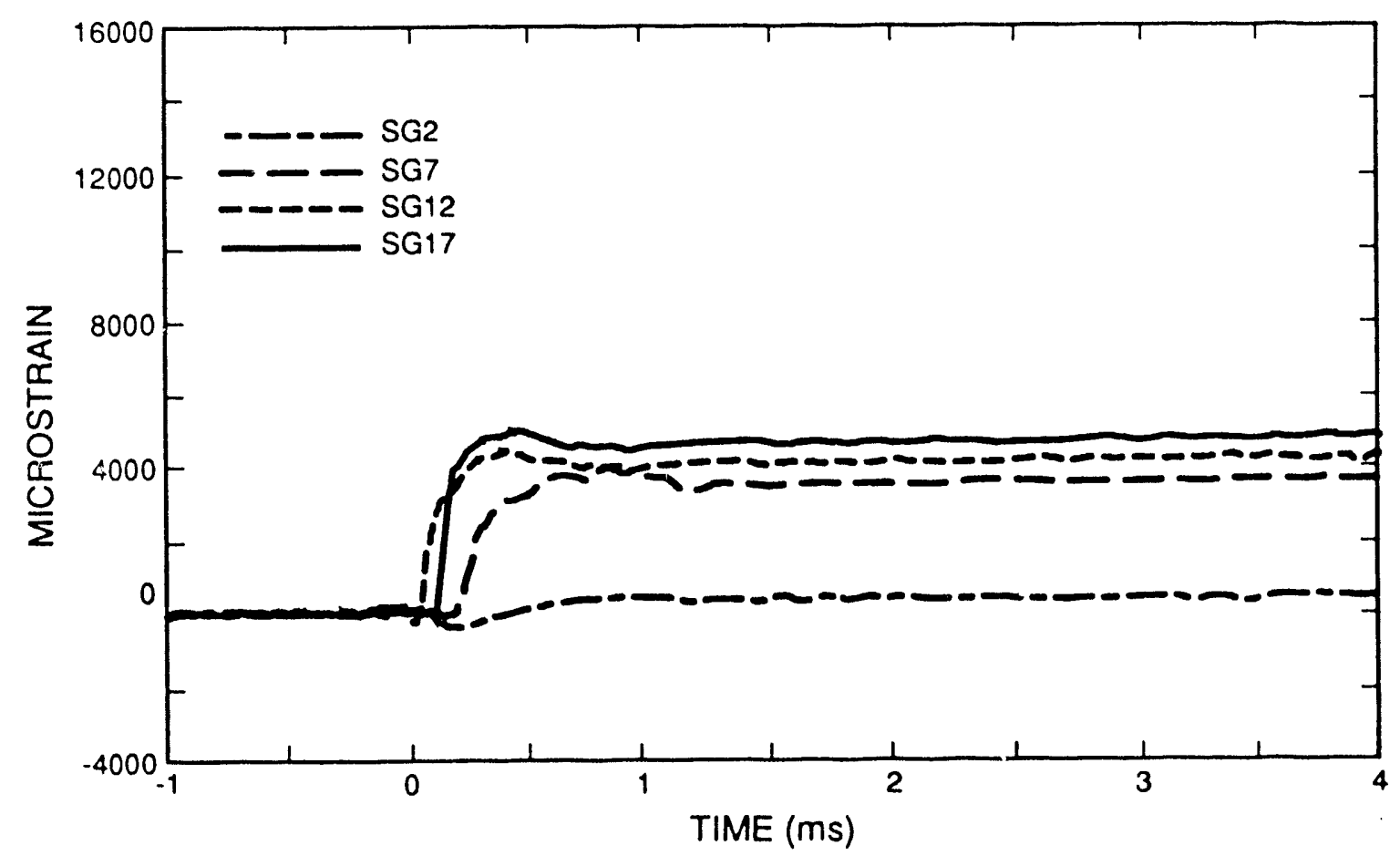

Figure D-47. End-Impact Test 10 Hoop Strain at 1 in.

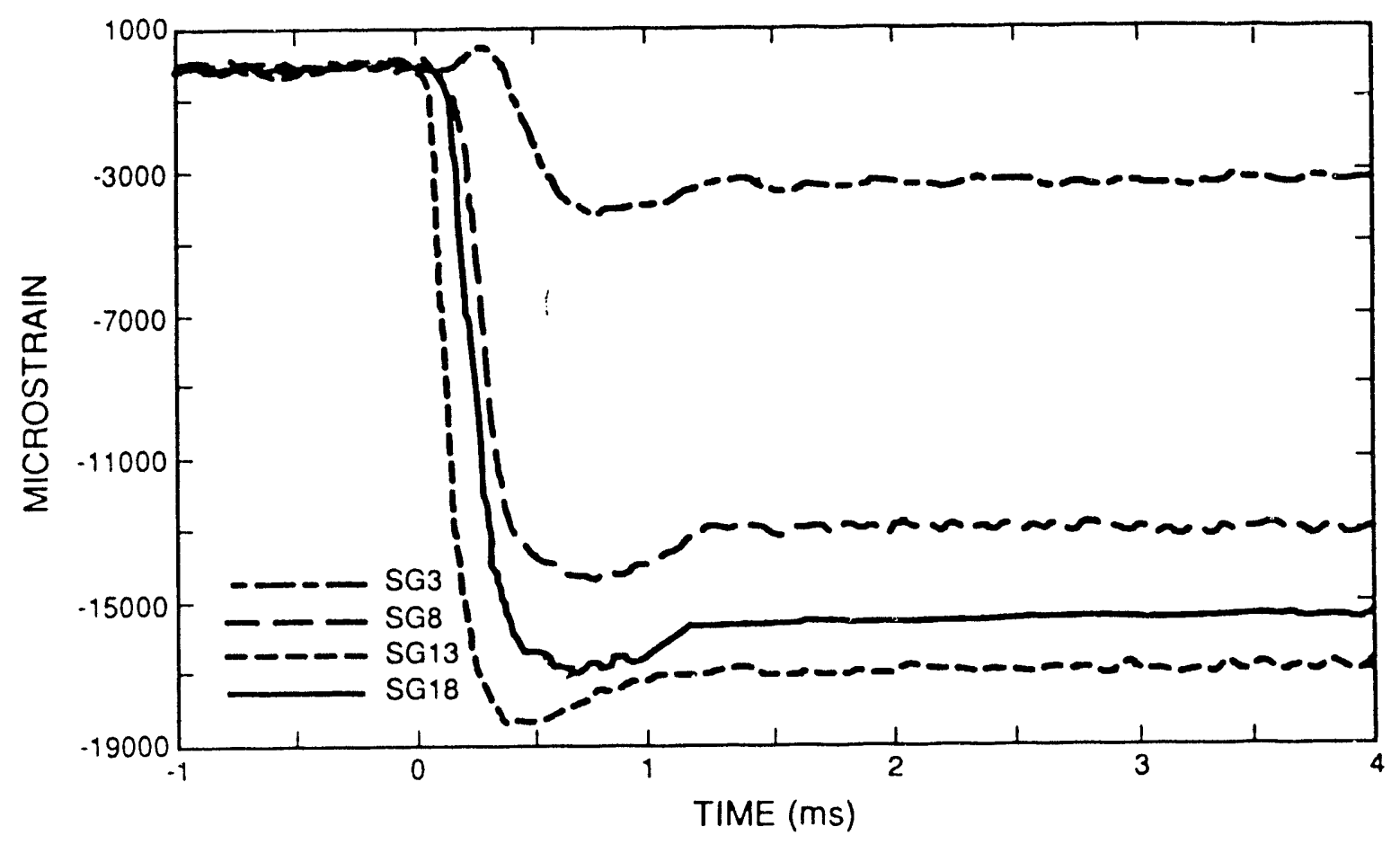

Figure D-48. End-Impact Test 10 Axial Strain at 3 in. 


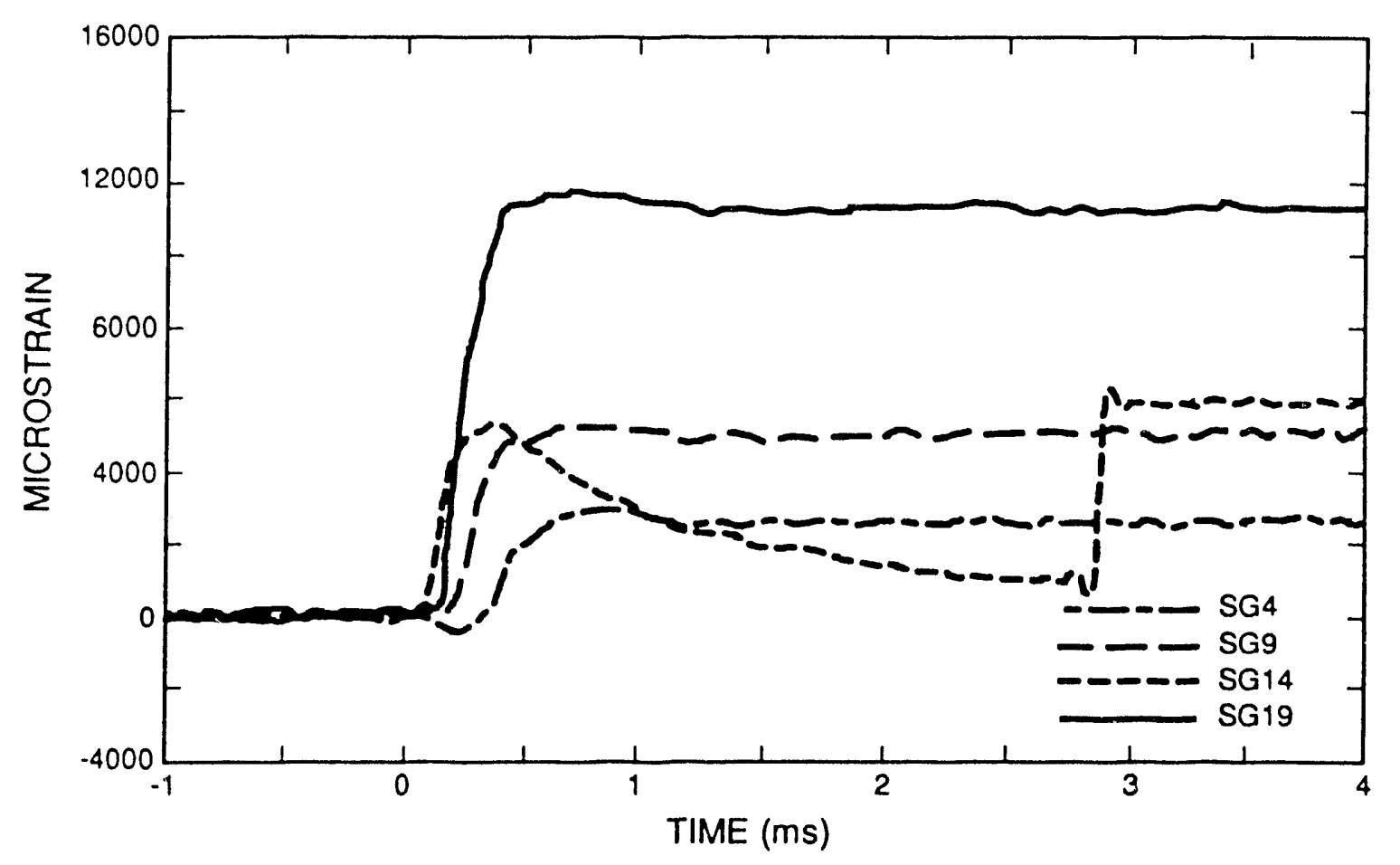

Figure D-49. End-Impact Test 10 Hoop Strain at 3 in.

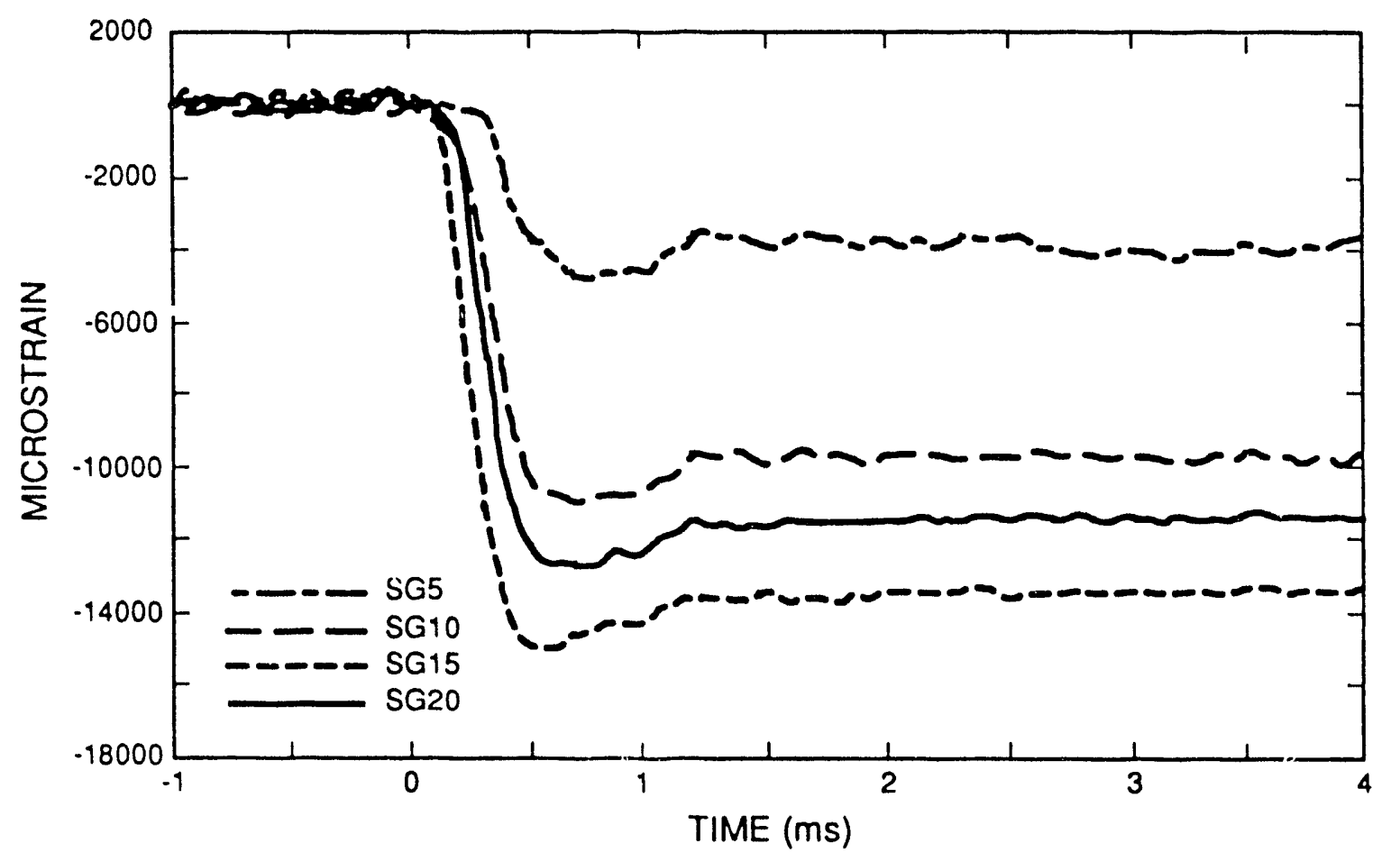

Figure D-50. End-Impact Test 10 Axial Strain at 6 in. 
APPENDIX E

ACCELEROMETER MULTIPLOTS

$E-1$ 


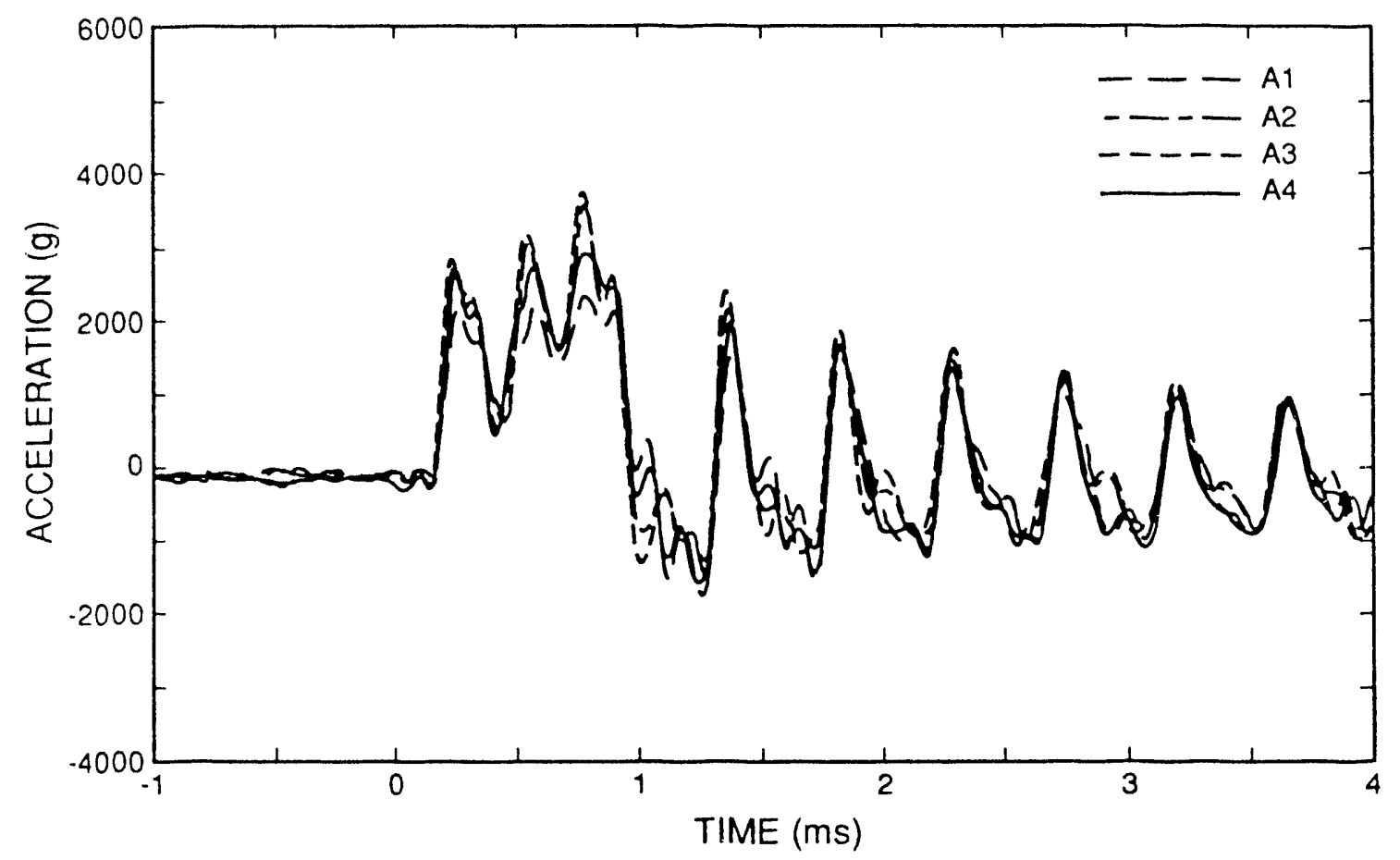

Figure E-1. End-Impact Test 1 Endevco 7270A-20K Accelerations Filtered at $10,000 \mathrm{~Hz}$

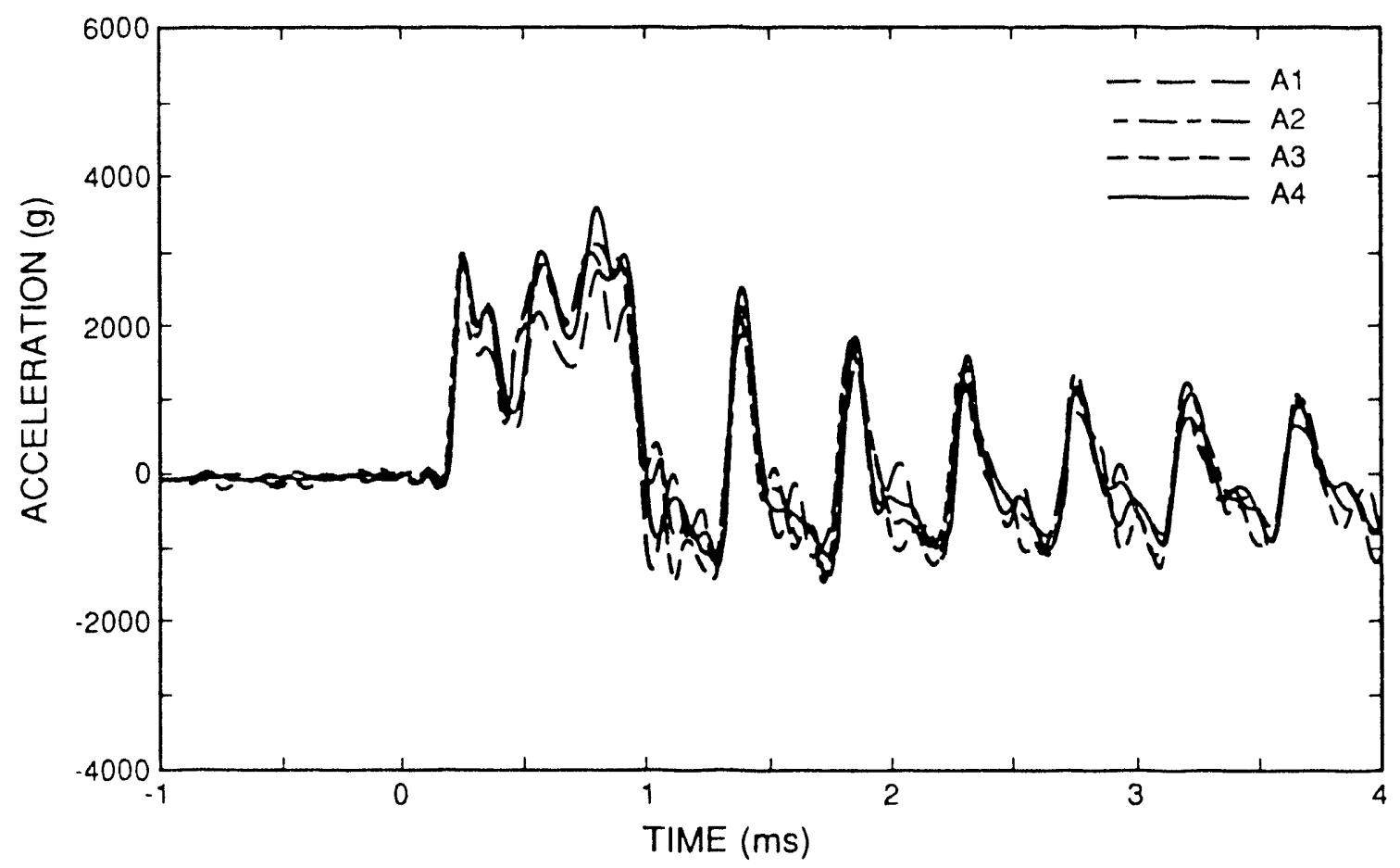

Figure E-2. End-Impact Test 2 Endevco 7270A-20K Accelerations Filtered at $10,000 \mathrm{~Hz}$ 


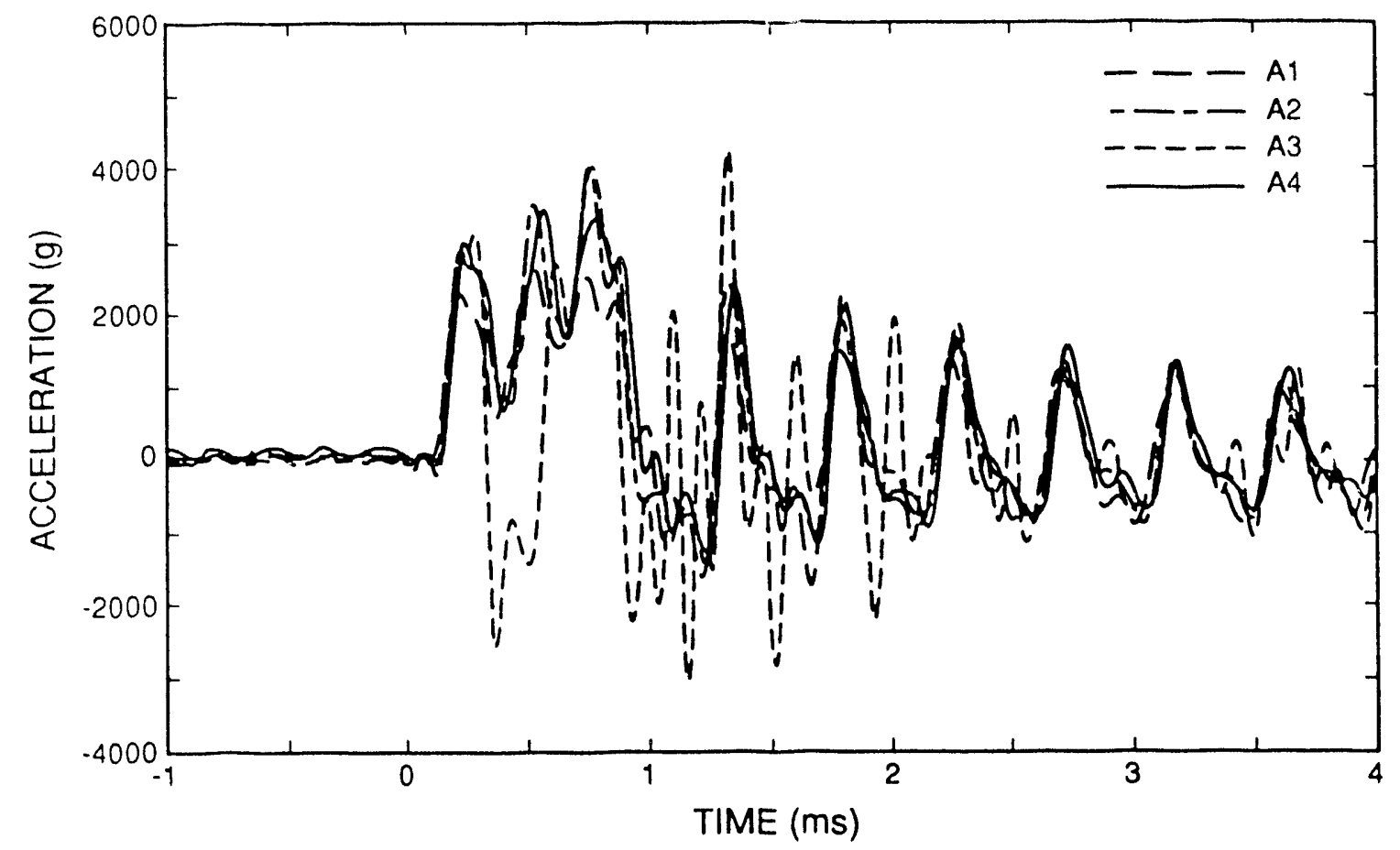

Figure E-3. End-Impact Test 3 Endevco 7270A-20K Accelerations Filtered at $10,000 \mathrm{~Hz}$

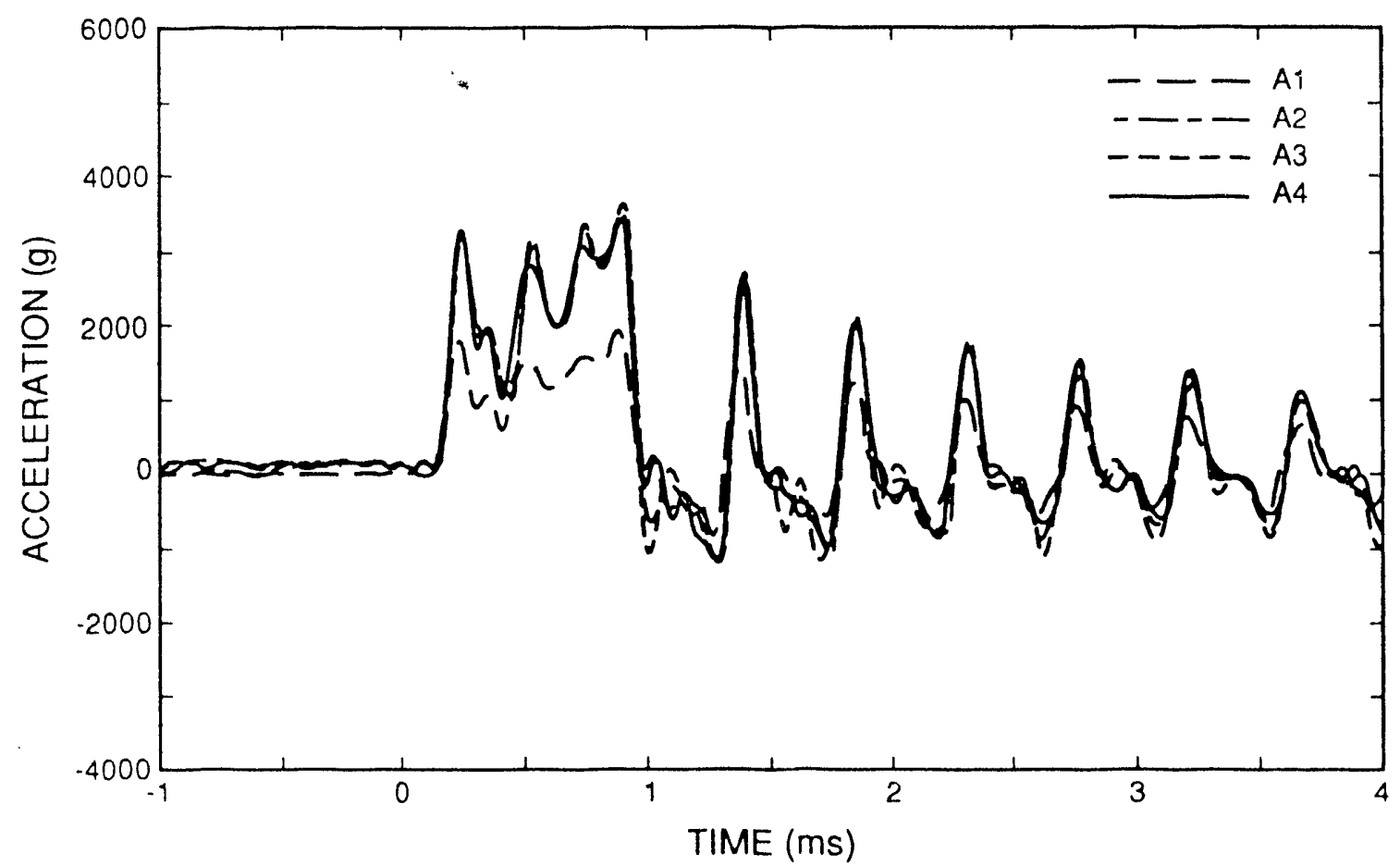

Figure E-4. End-Impact Test 4 Endevco 7270A-20K Accelerations Filtered at $10,000 \mathrm{~Hz}$ 


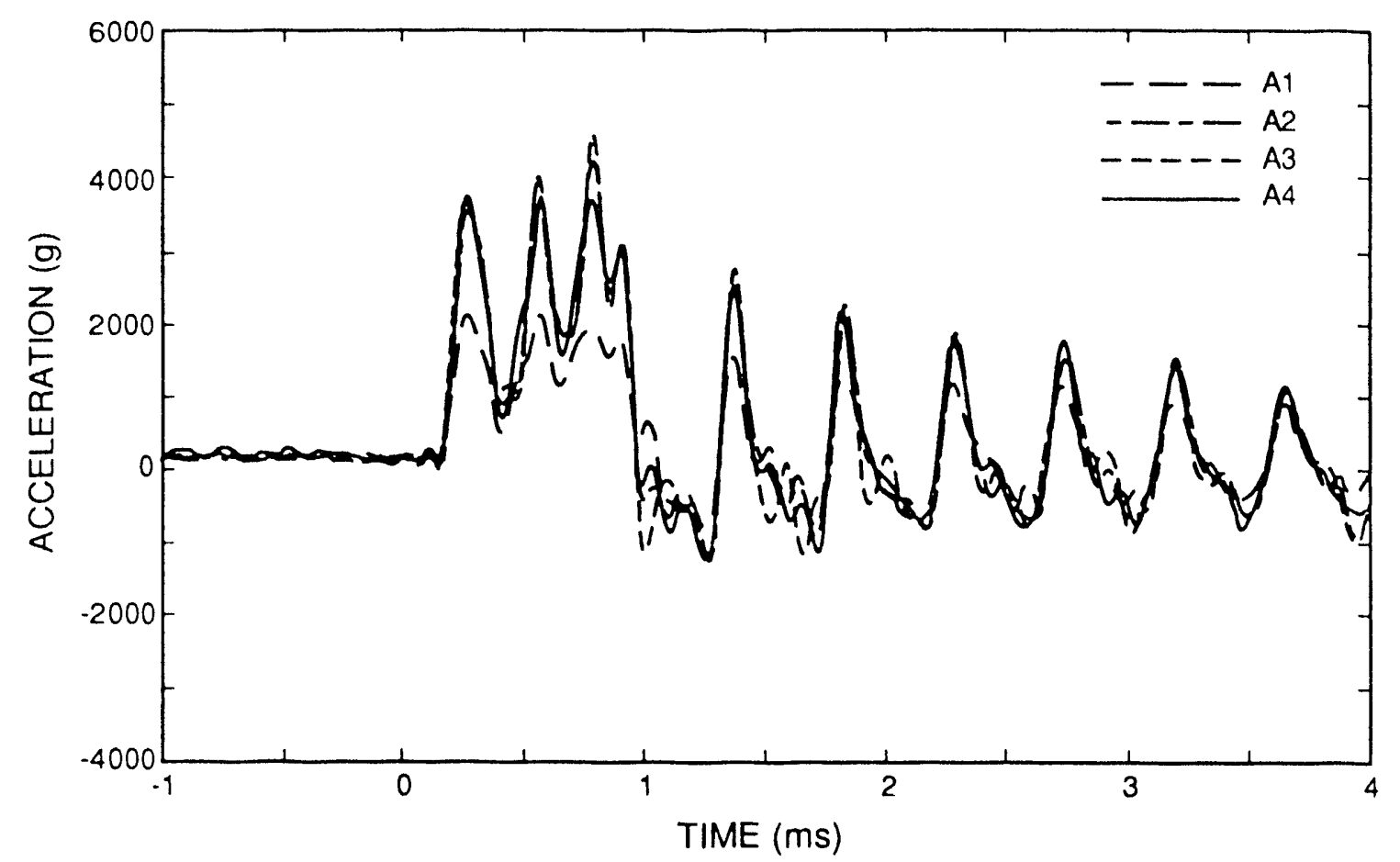

Figure E-5. End-Impact Test 5 Endevco 7270A-20K Accelerations Filtered at $10,000 \mathrm{~Hz}$

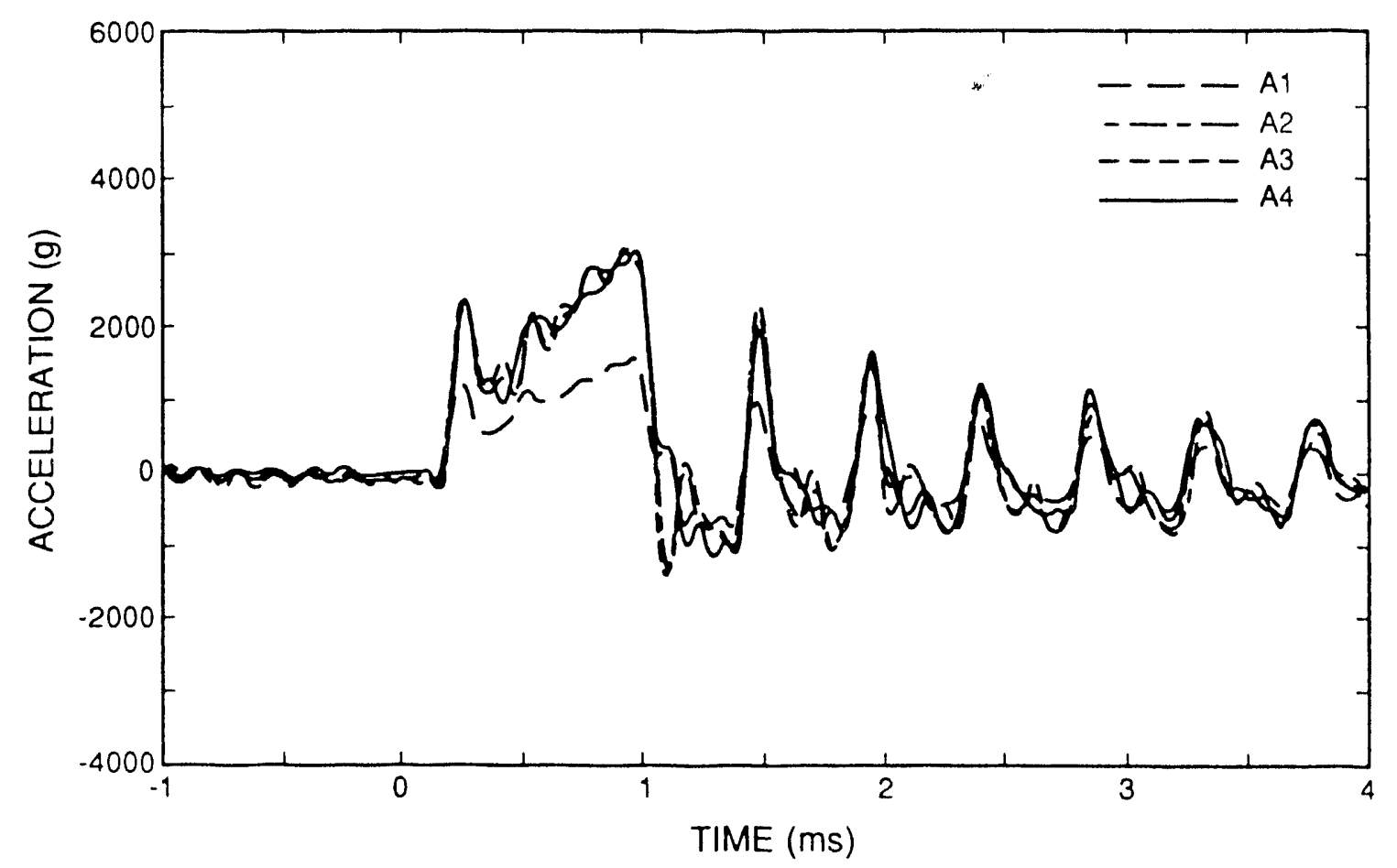

Figure E-6. End-Impact Test 6 Endevco 7270A-20K Accelerations Filtered at $10,000 \mathrm{~Hz}$ 


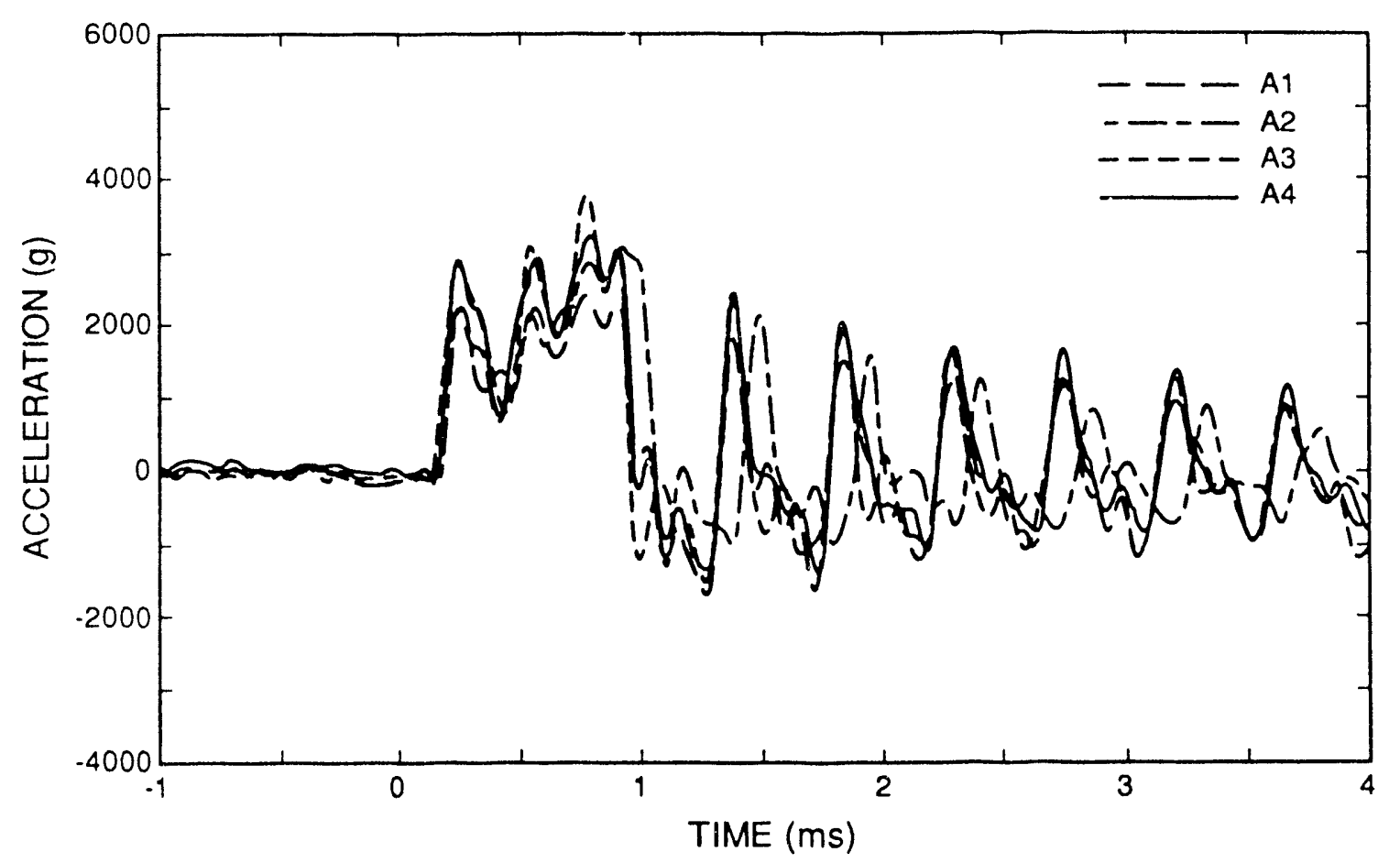

Figure E-7. End-Impact Test 7 Endevco 7270A-20K Accelerations Filtered at $10,000 \mathrm{~Hz}$

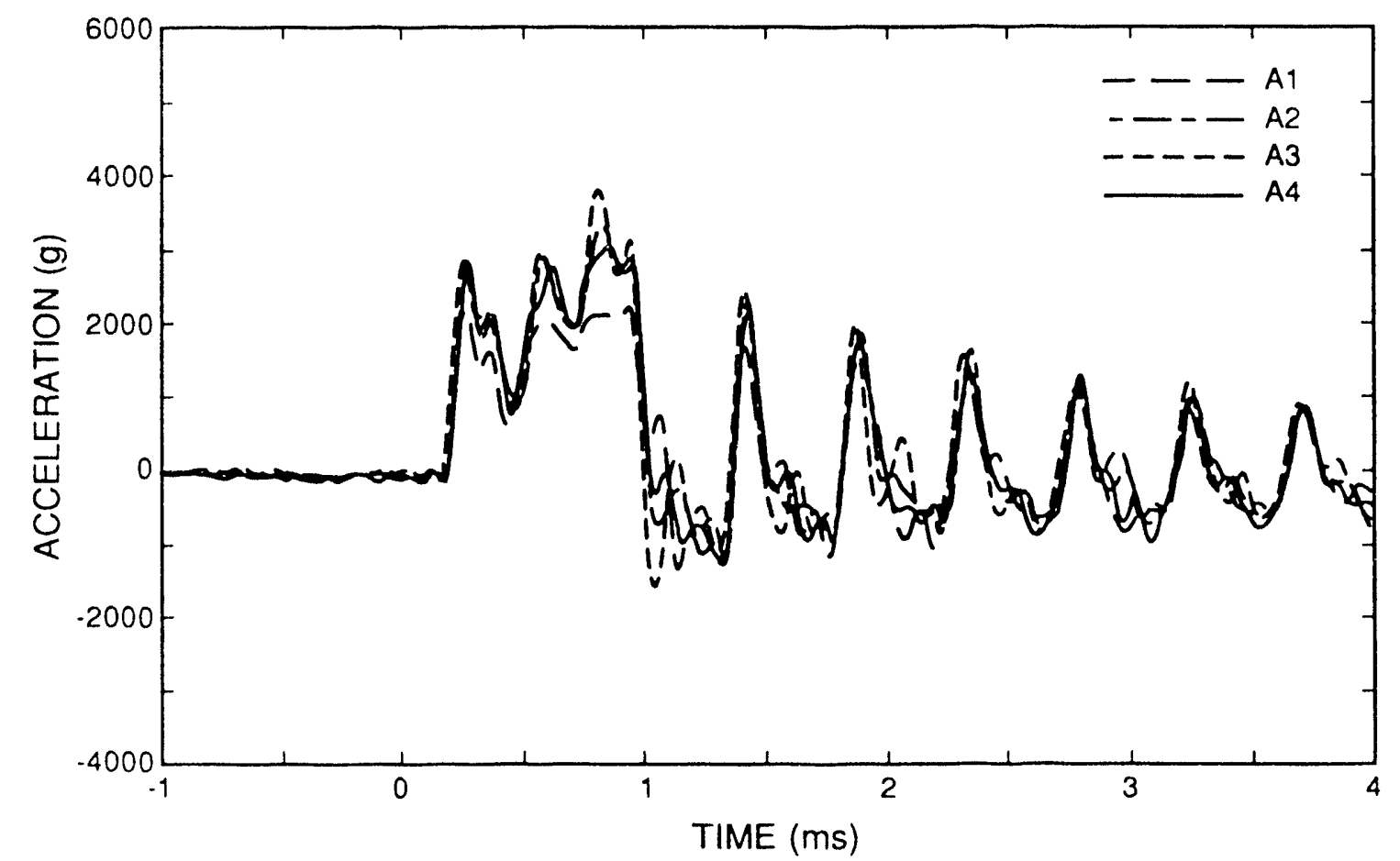

Figure E-8. End-Impact Test 8 Endevco 7270A-20K Accelerations Filtered at $10,000 \mathrm{~Hz}$ 


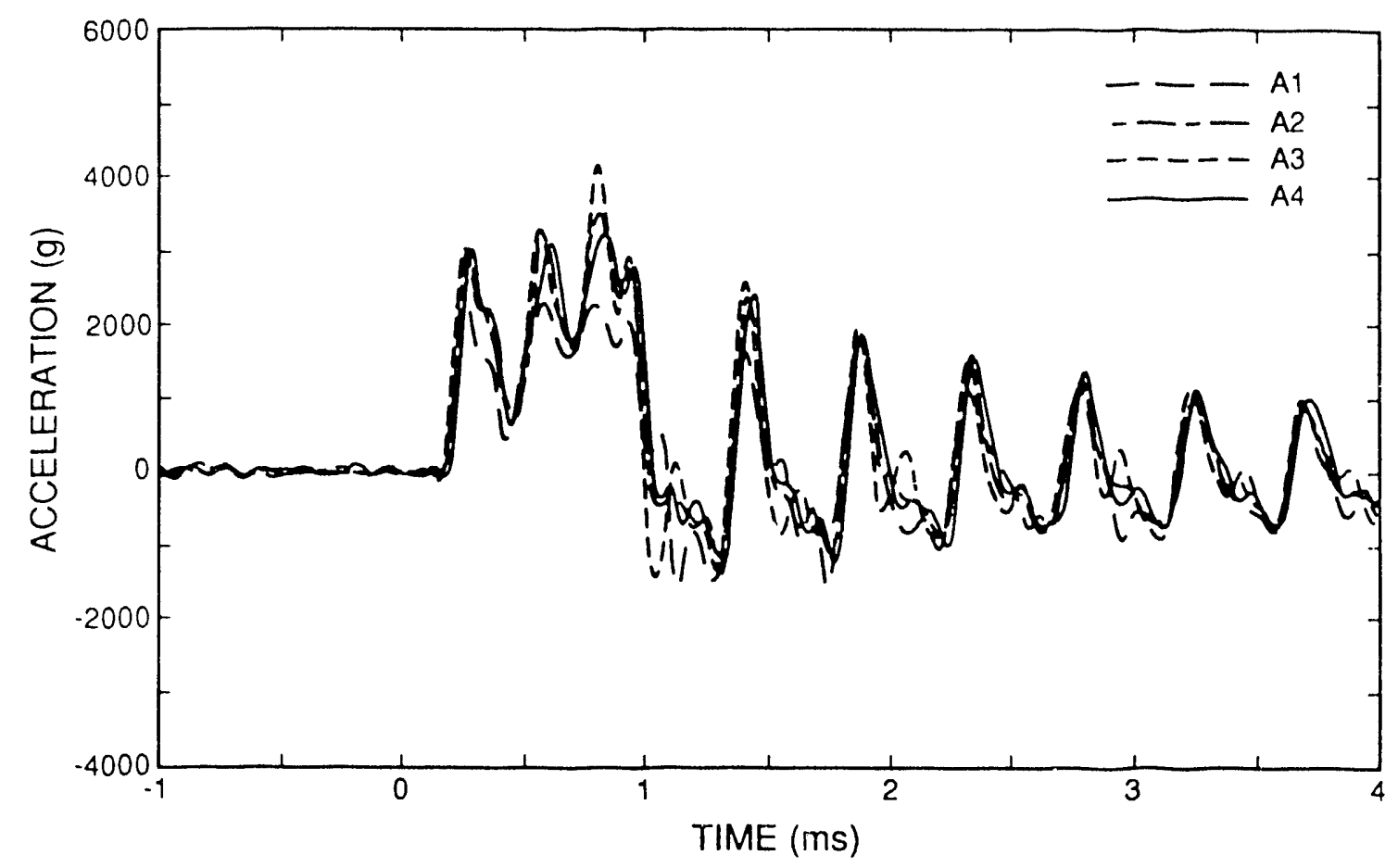

Figure E-9. End-Impact Test 9 Endevco 7270A-20K Accelerations Filtered at $10,000 \mathrm{~Hz}$

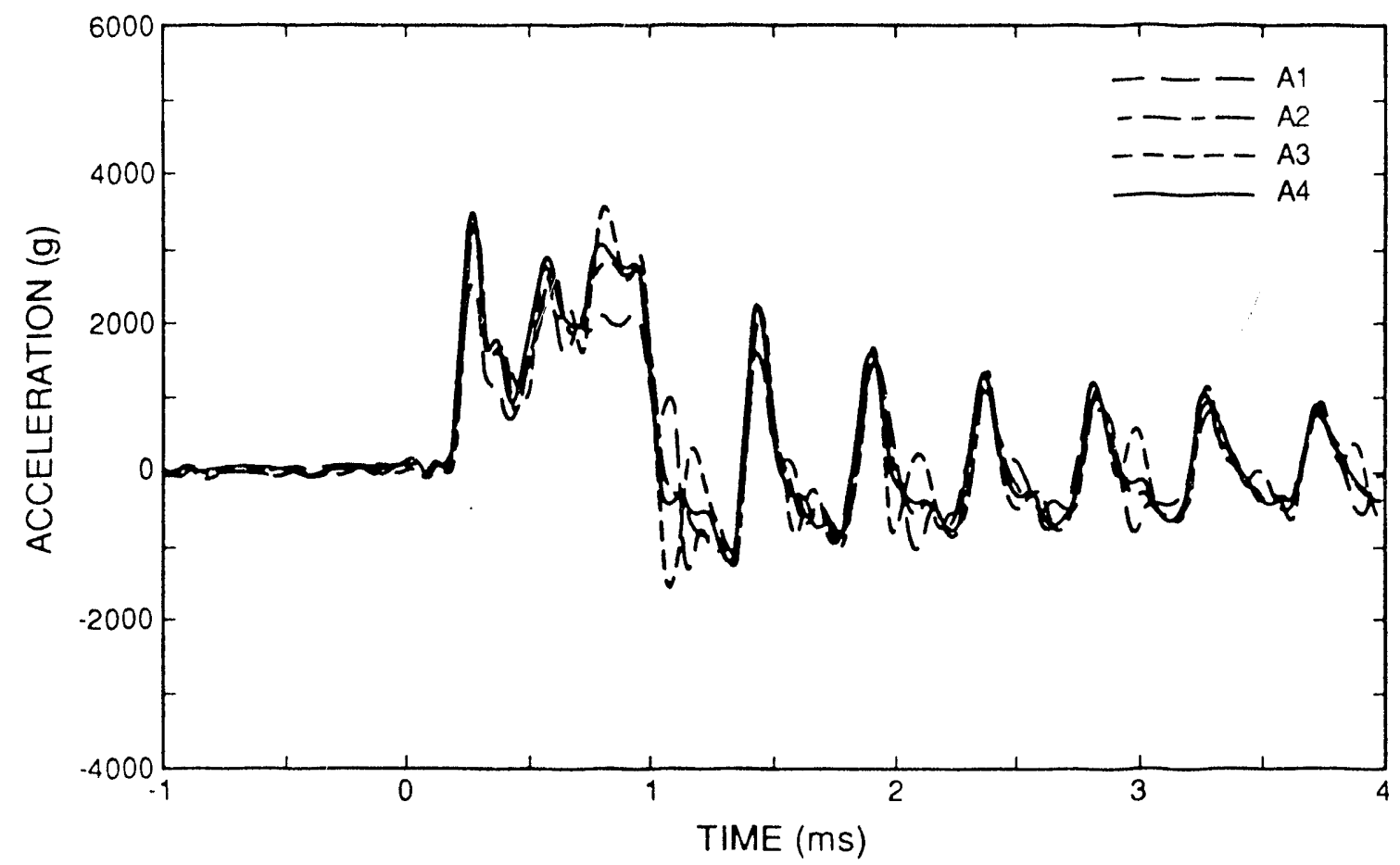

Figure E-10. End-Impact Test 10 Endevco 7270A-20K Accelerations Filtered at $10,000 \mathrm{~Hz}$ 

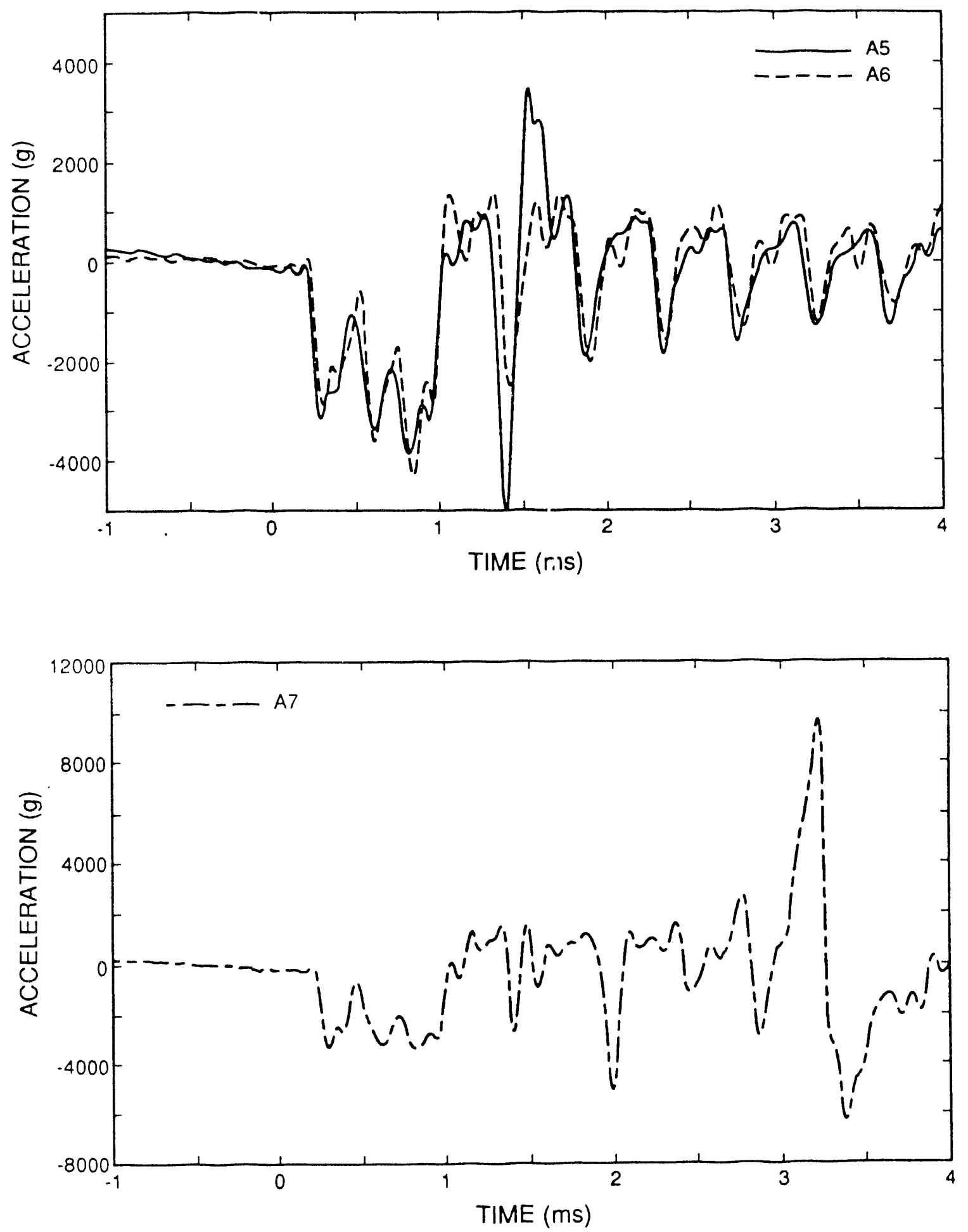

Figure E-11. End-Impact Test 1 B\&K 8309 Accelerations Filtered at $10,000 \mathrm{~Hz}$ 

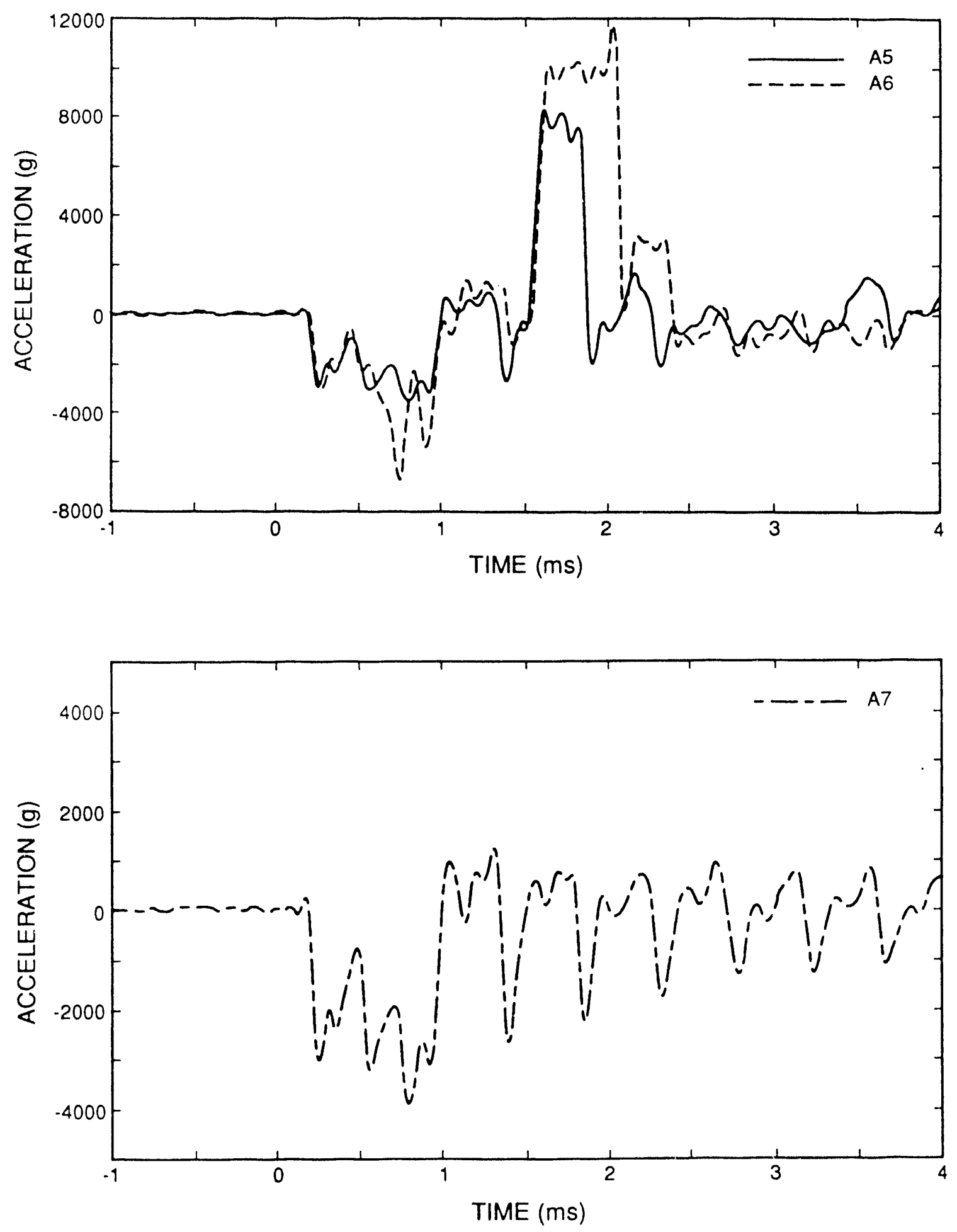

Figure E-12. End-Impact Test 2 B\&K 8309 Accelerations Filtered at $10,000 \mathrm{~Hz}$ 


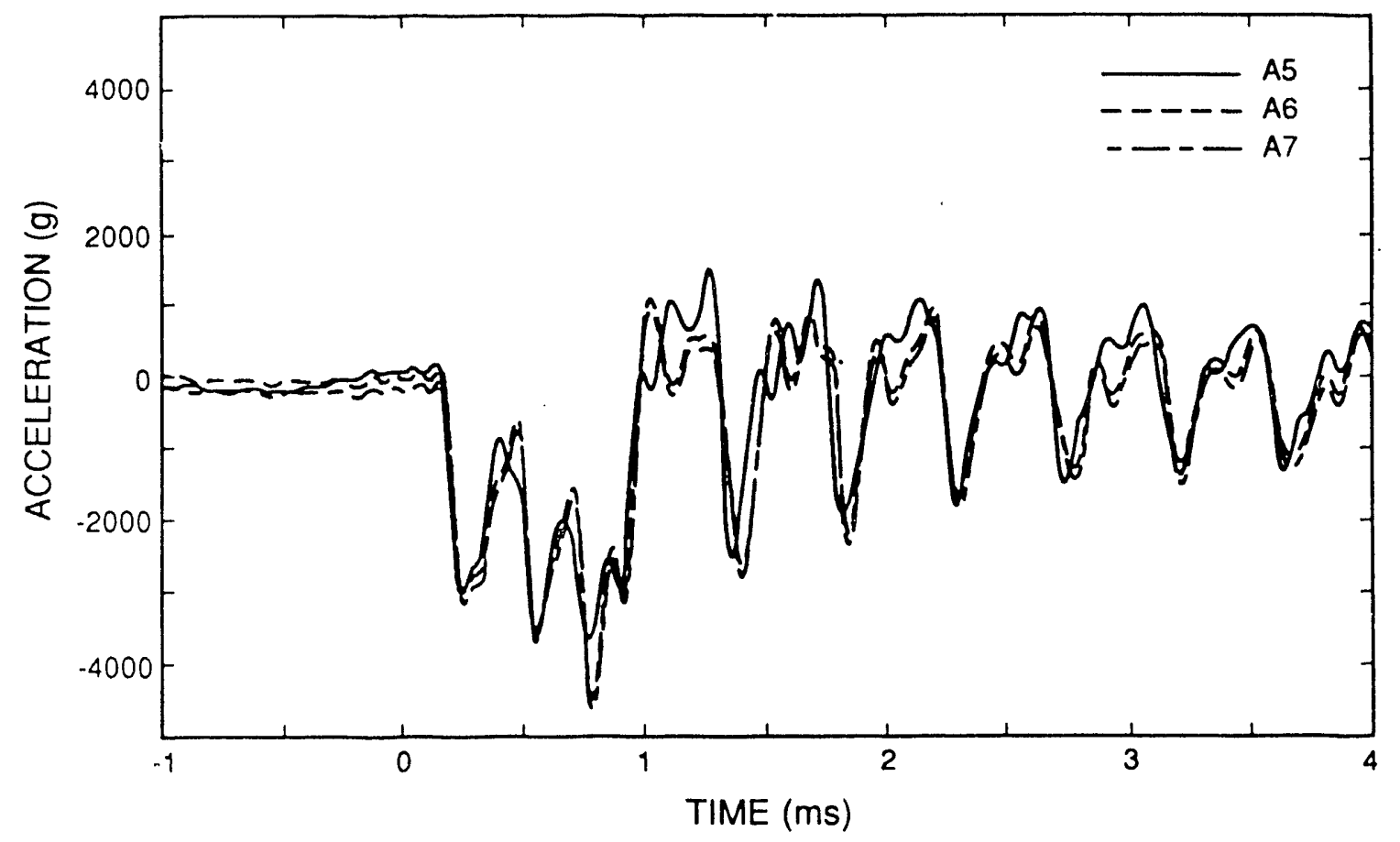

Figure E-13. End-Impact Test 3 B\&K 8309 Accelerations Filtered at $10,000 \mathrm{~Hz}$

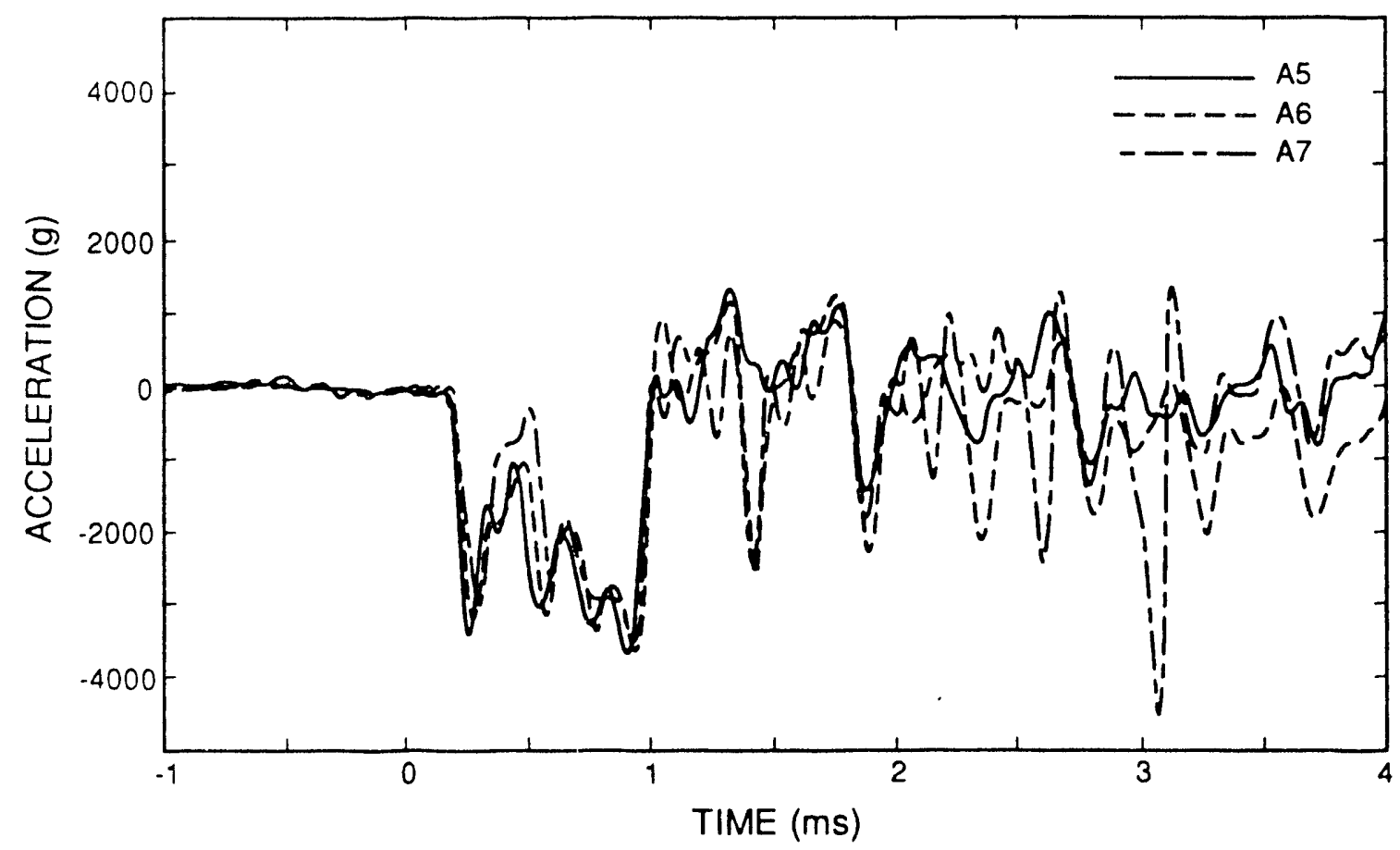

Figure E-14. End-Impact Test 4 B\&K 8309 Accelerations Filtered at $10,000 \mathrm{~Hz}$ 

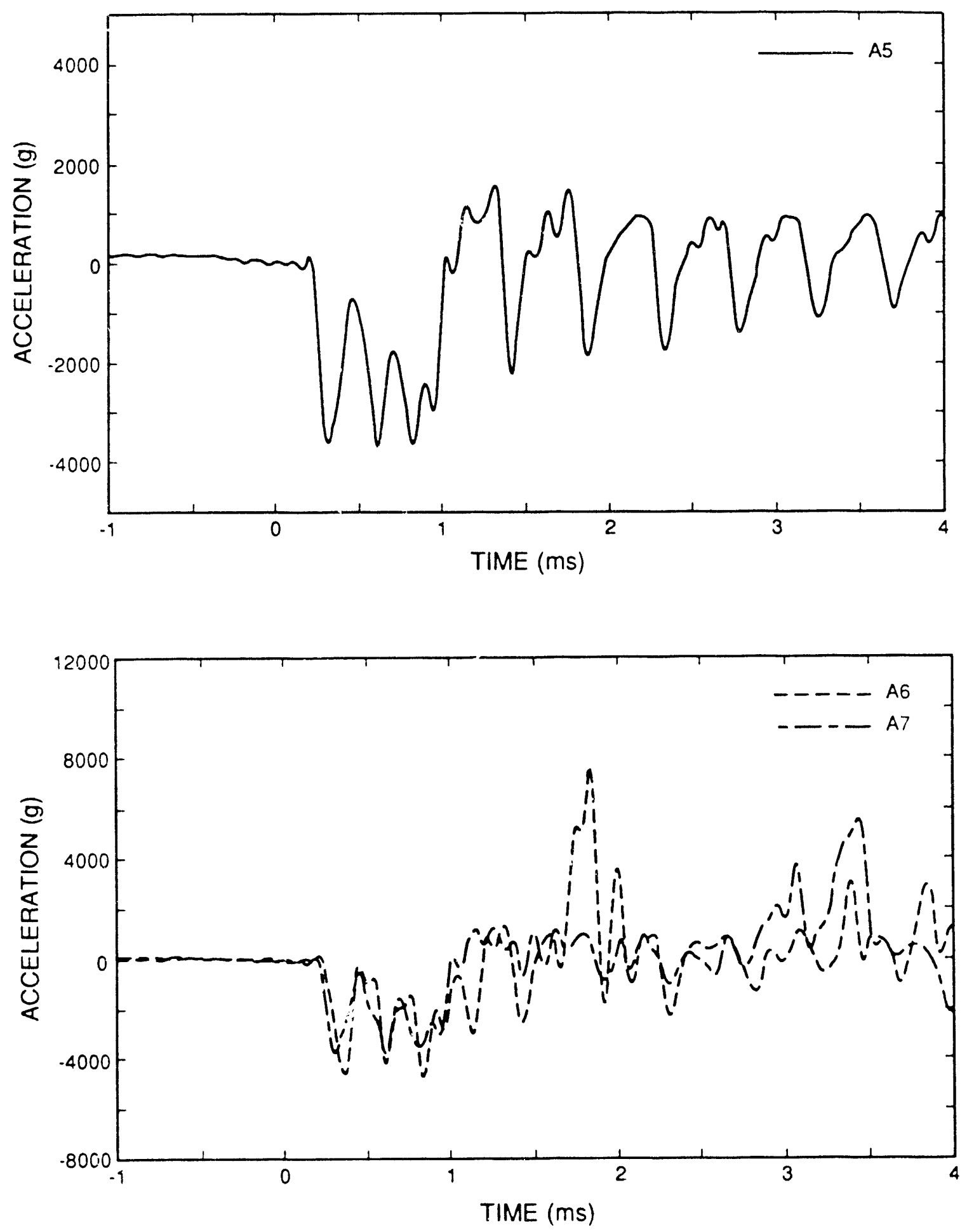

Figure E-15. End-Impact Tét 5 B\&K 8309 Accelerations Filtered at $10,0110 \mathrm{~Hz}$ 


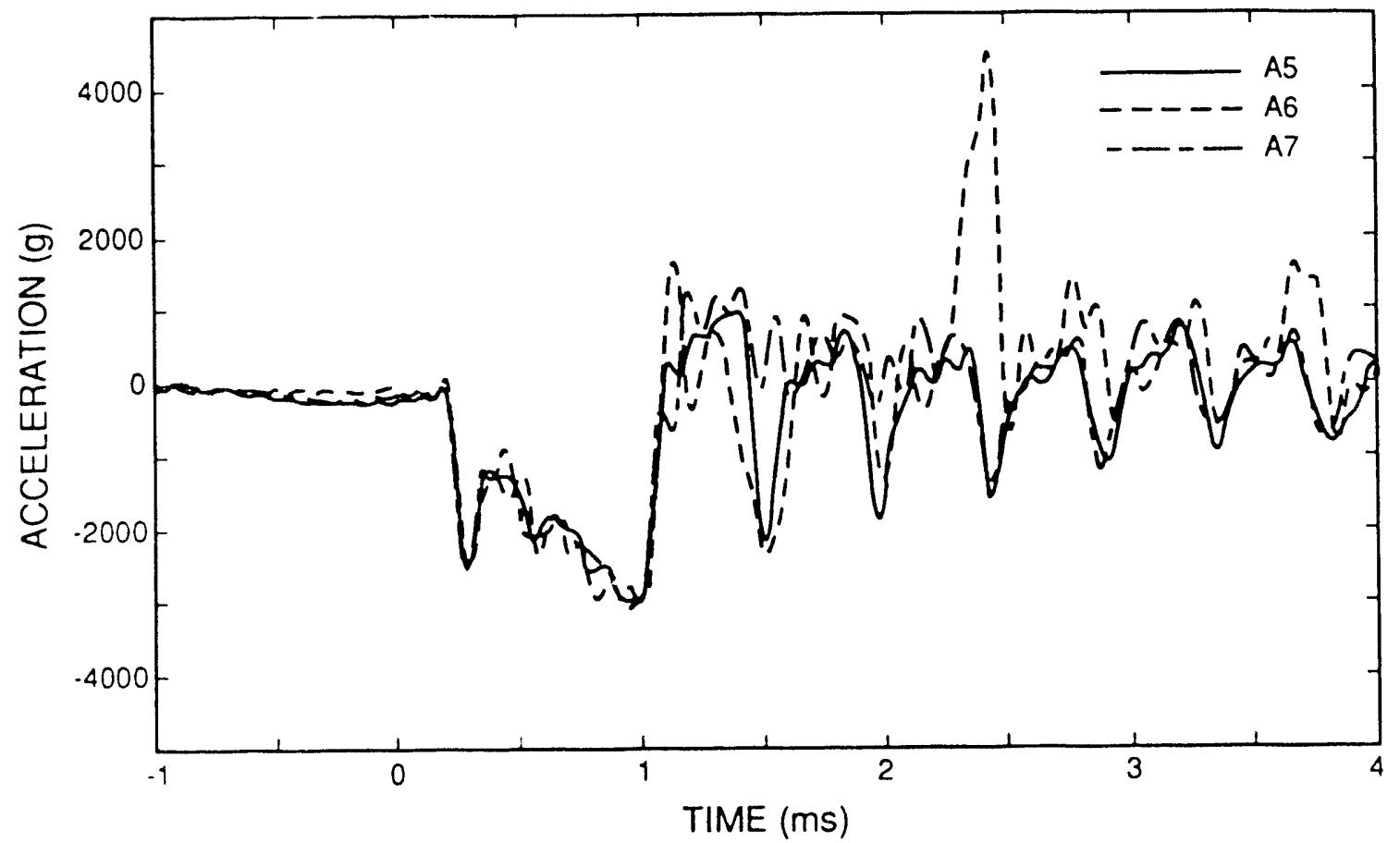

Figure E-16. End-Impact Test 6 B\&K 8309 Accelerations Filtered at $10,000 \mathrm{~Hz}$

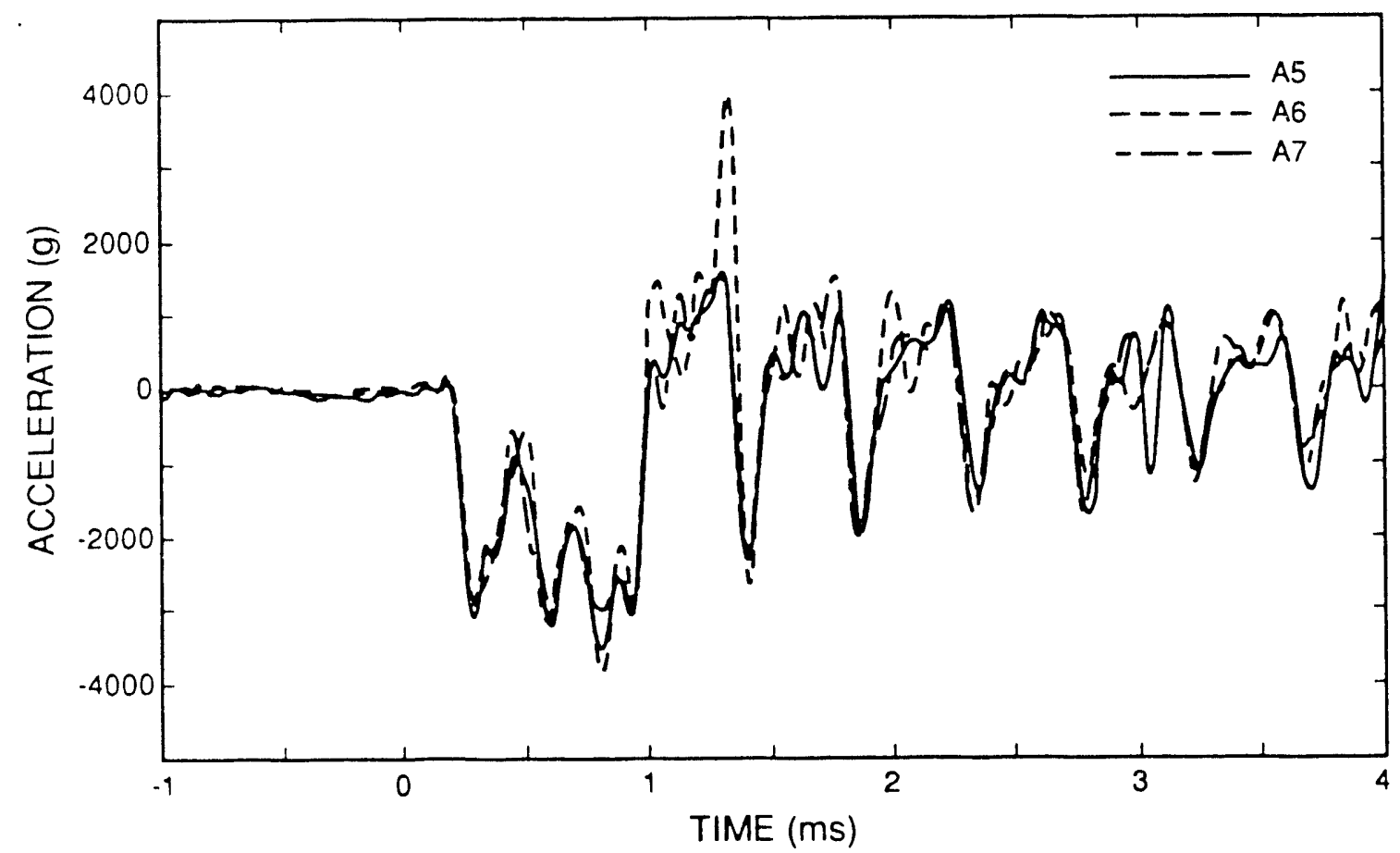

Figure E-17. End-Impact Test 7 B\&K 8309 Accelerations Filtered at $10,000 \mathrm{~Hz}$ 


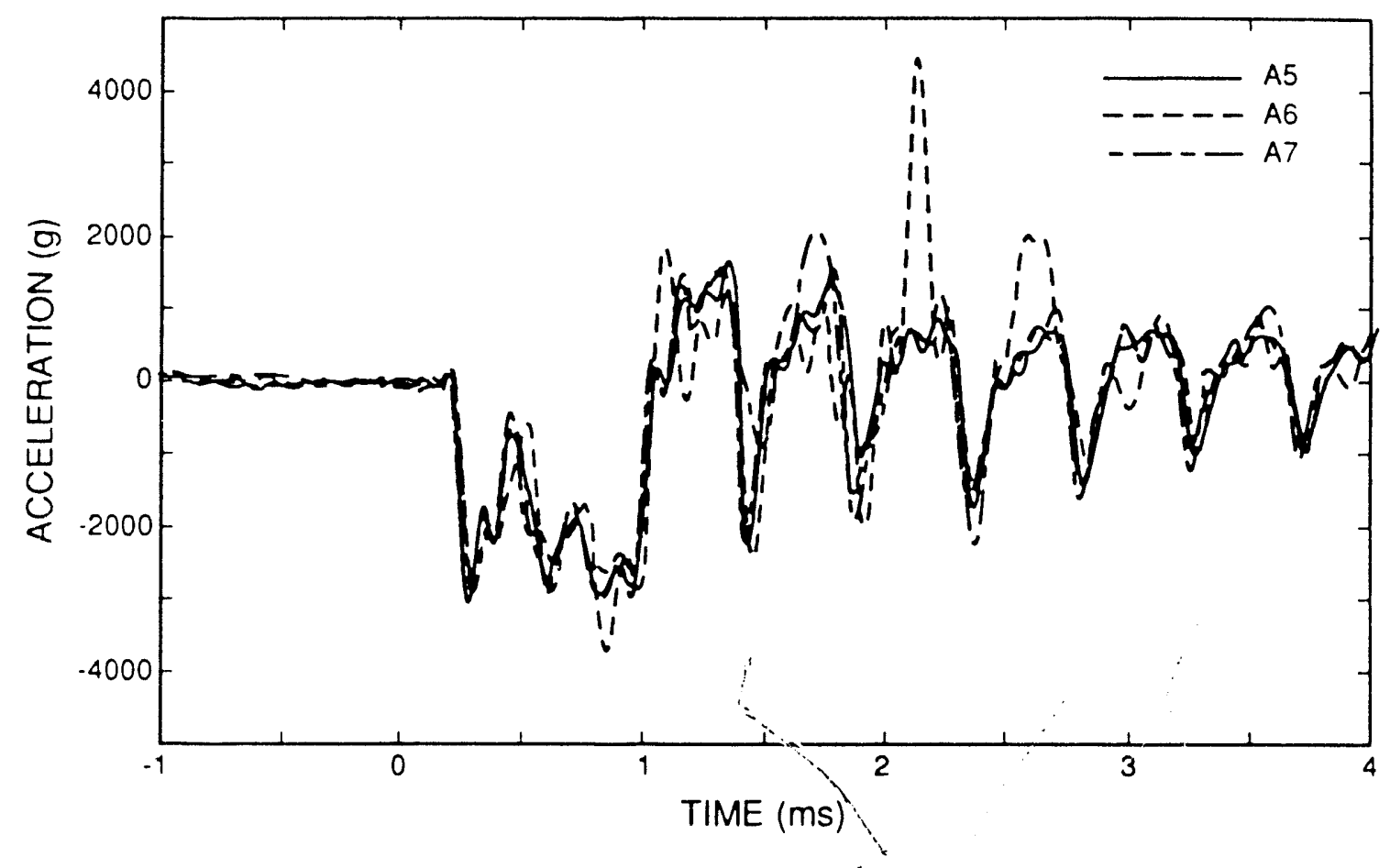

Figure E-18. End-Impact Test 8 B\&K 8309 Accelerations Filtered at $10,000 \mathrm{~Hz}$

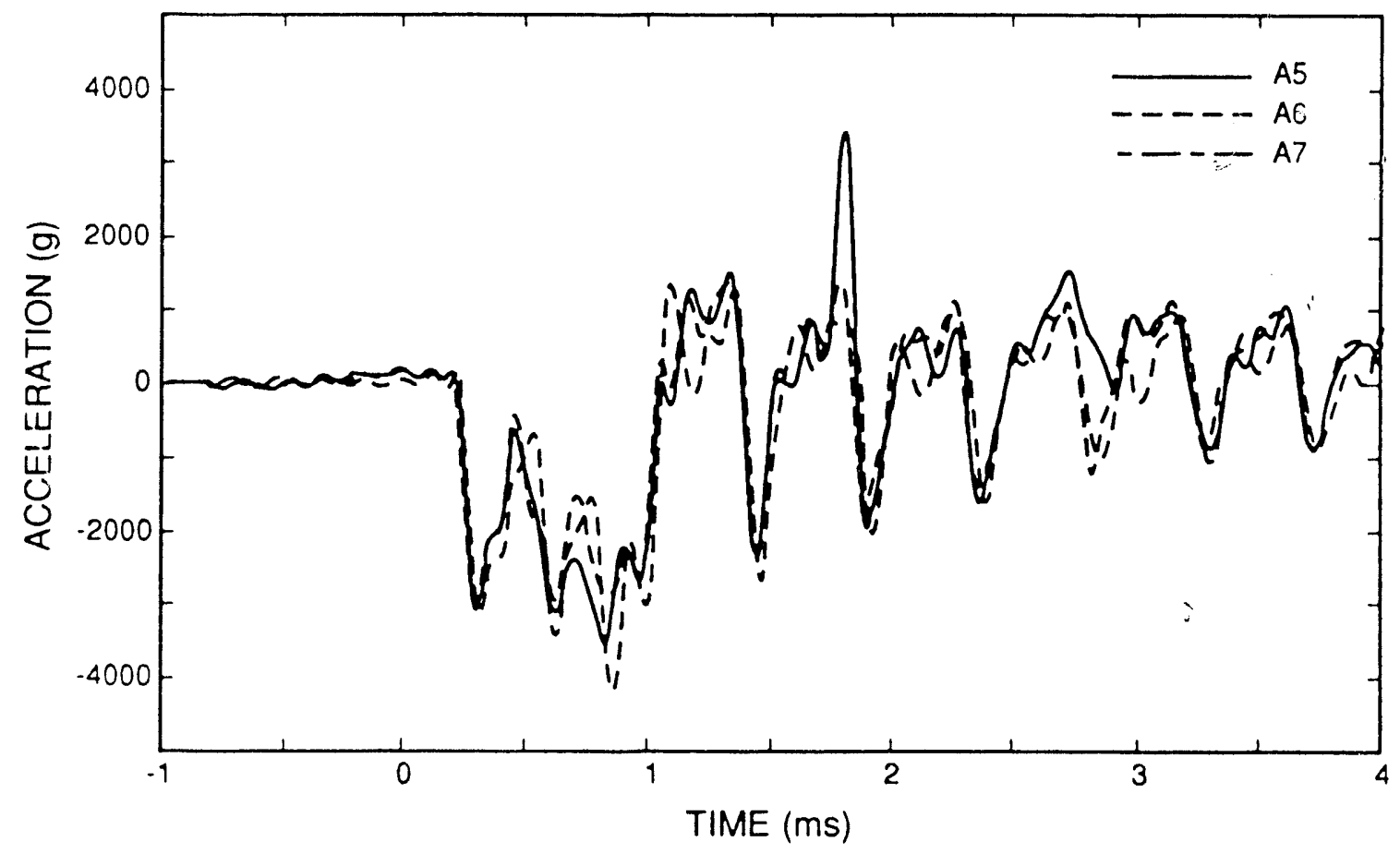

Figure E-19. End-Impact Test 9 B\&K 8309 Accelerations Filtered at $10,000 \mathrm{~Hz}$ 
No. of

Copies

175 U.S. Department of Energy

Office of Scientific and

Technical Info mation

Oak Ridge, TN 37830

Attn: DOE/OSTI-4500-R74 UC-820

7 U.S. Department of Energy

Routing RW-40

1000 Independence SW

Washington, DC 20585

Attn: R. Milner, RW-40

J. Williams, RW-411

J. Carlson, RW-42

C. Kouts, RW-42

W. Lake (3), RW-42

1 U.S. Department of Energy Naval Reactors

Routing NE-60

1000 Independence SW

Washington, DC 20585

Attn: R. Kulbitskas, NE-60

1 U.S. Department of Energy

Northwestern On-Site

Remediation Branch

Mail Stop EM-442

B - 205

19901 Germantown Road

Germantown, MD 20585

Attn: J. C. Lehr, EM-442

1 U.S. Department of Energy

Office of Waste Operations

Mail Stop EM-30

A-214A

19901 Germantown Road

Germantown, MD 20858

Attn: S. P. Cowen, EM-30
No. of

Copies

1 U.S. Department of Energy Office of Environmental

Restoration

Mail Stop EM-40

7A-049

1000 Independence SW

Washington, DC 20585

Attn: R. P. Whitfield, EM-40

1 U.S. Department of Energy

Division of Demonstration

Testing and Evaluation

Ma11 Stop EM-55

7A-049

1000 Independence SW

Washington, DC 20585

Attn: C. Cooley, EM-55

1 U.S. Department of Energy Office of Waste Operations Mail Stop EM-30

7A-049

1000 Independence SW

Washington, DC 20585

Attn: J. Lytle, EM-30

1 U.S. Department of Energy

Division of Waste Management Projects

Mail Stop EM-34

A- 233

19901 Germantown Road

Germantown, MD 20585

Attn: M. Trei, EM-34

1 U.S. Department of Energy

Mail Stop EM-343

19901 Germantown Road

Germantown, MD 20585

Attn: K. Chacey, EM-343 
No. of

Copies

1 U.S. Department of Energy

Office of Environmental

Restoration and Waste

Management

Mail Stop EM-1

7A-049

1000 Independence SW

Washington, DC 20585

Attn: Leo P. Duffy,

Director, EM-1

1 U.S. Department of Energy

Office of Technology

Development

7A-049

1000 Indeperdence SW

Washington, DC 20585

Attn: Clyde Frank, Associate

Director, EM-50

6 U.S. Department of Energy

Routing EM-50.1

Washington, DC 20545

Attn: G. Boyd, EM-50.1

S. Denny, EM-50.1

F. Falci, EM-50.1

R. Garrison, EM-50.1

C. Miller, EM-50.1

R. Yoshimura, EM-50.1

2 U.S. Department of Energy

Routing EM- 53

Washington, DC 20545

Attn: L. Harmon, EM-53

D. Alexander, EM-53

1 U.S. Department of Energy

Nevada Operations office

P.O. Box 14100

Las Vegas, NV 89114-4100

Attn: W. Dixon

3 U.S. Department of Energy

Albuquerque Operations office

Albuquerque Headquarters

P.O. Box 5400

Albuquerque, NM 87115

Attn: J. Bickel

K. G. Golliher

D. Bandy
No. of

Copies

4 U.S. Department of Energy

Chicago Operations office

9800 S. Cass Ave., B1dg. 350

Argonne, IL 60439

Attn: J. Holm

S. Kouba

J. Roberts

R. Rothman

4 U.S. Department of Energy

Idaho Operations office 550 2nd St.

Idaho Falls, ID 83401

Attn: M. Fisher

W. Mings

K. Svinicki (2)

1 U.S. Department of Energy Oak Ridge Operations Office P.O. Box E Oak Ridge, TN 37831

Attn: M. Heiske11

1 U.S. Department of Energy Richland Operations office P.O. Box 550

Richland, WA 99352

Attn: J. Peterson

1 U.S. Department of Energy Office of Security Regulations Defense Programs EM-321 Washington, DC 20545

Attn: F. Punch

1 AEA Winfrith Technology

Reactor Physics Division 205/B71 Winfrith Technology Center Dorchester

Dorset

UNITED KINGDOM DT28DH

Attn: M. Burgess

1 Argonne National Laboratory 9700 South Cass Ave. Argonne, IL 60439

Attn: G. Popper 
No. of

Copies

1 Babcock \& Wilcox

Nuclear Equipment Division

91 Stirling Avenue

Barberton, OH 44203

Attn: T. Stevens

3 Babcock \& Wilcox

P.0. Box 10935

Lynchburg, VA 24506-0935

Attn: G. Vanes

R. Fish

E. McGuinn

1 British Nuclear Fuels, Ltd.

2926 92nd Ave. E.

Puyallup, WA 98371

Attn: D. Snedeker

2 British Nuclear Fuels, Ltd.

Risley Fleming House

Warrington, Cheshire

UNITED KINGDOM WA36AS

Attn: D. Boyer

H. Lewis

2 Central Research Institute of

Electrical Power Industry

1-6-1 Ohtemachi

Chiyodo-Ku, Tokyo

JAPAN 100

Attn: S. Fukuda

T. Saegusa

1 Chem Nuclear Systems, Inc.

220 Stoneridge $\mathrm{Dr}$.

Columbia, SC 29210

Attn: R. Anderson

1 Combustion Engineering

CE Power Systems

P.O. Box 500

Winsdor, CT 06095-0500

Attn: M. Falzarano
No. of

Copies

1 Commissariat a l'Energie Atomique

Department des Etudes

Mecaniques et Thermiques

Service d'Etudes des Systemes

Demt Syst. CEN-Saclay

Gif-sur-Yvette

Cedex

FRANCE 91191

Attn: C. Vallepin

1 Edison Electric Institute

1111 19th Street, NW

Washington, DC 20036

Attn: C. Henke 1

7 EG\&G Idaho, Inc.

P.O. Box 1625, MS 9109

Idaho Falls, ID 83415-9109

Attn: R. Chapman

B. DaBell

$K$. Henry (3)

H. Worle

3 Electric Power Research Institute

P.O. Box 10412

Palo Alto, CA 94303

Attn: R. Lambert

R. Williams (2)

4 General Atomics

P.O. Box 85608

San Diego, CA 92138

Attn: R. Grenier

M. Koploy

R. Meyer

A. Zimmer

2 Gesellschaft fur Nuklear-

Service mbH (GNS)

Goethestr. 88

D-4300 Essen 1

GERMANY

Attn: H. Geiser

W. Weyer 
2 Institut de Protection et de Surete Nucleaire

Departmente d'Analyses de Surete

Commissariat a 1'Energies Atomique

CEN/FAR-BP No. 6

FRANCE F-92260

Attn: D. Devillers

L. Tanguy

1 International Atomic Energy Agency

Division of Publications

Wagramerstrasse 5

P.O. Box 100

Vienna

AUSTRIA A-1400

Attn: R. Kelleher

1 E. R. Johnson Associates, Inc.

10461 White Granite Dr.

Sutie 204

Oakton, VA 22124

Attn: B. McLeod

1 JNT, Inc.

P.0. Box 1510

Los Gatos, CA 95031-1510

Attn: $R$. Jones

1 Lawrence Livermore National Laboratory

University of California

P.0. Box 808

Livermore, CA 94550

Attn: L. Fisher

2 Los Alamos National Laboratory

HAZ PACT Section HSE3

Mail Stop G726

Los Alamos, NM 87845

Attn: $M$. Lewis

R. Sharp

1 Northern States Power Co. 414 Nicollet Mall

Minneapolis, MN 55401

Attn: L. McCarten
2 Nuclear Assurance Corp. 6251 Crooked Creek Rd. Norcross, GA 30092

Attn: P. Aucoin

W. Lee

1 Nuclear Packaging, Inc. 1010 S. 336th St.

Suite 220

Federal Way, WA 98003

Attn: R. Doman

4 Ontario Hydro

Research Division

800 Kipling Avenue

Toronto, Ontario

CANADA M8Z 5S4

Attn: J. Boag

C. Naumenko

R. Zane

R. Sauve

1 Southern States Energy Board 3091 Governors Lakes Dr.

Suite 400

Norcross, GA 30071

Attn: K. Nemeth

1 Southwest Engineering

Associates

3616 Derick

E1 Paso, TX 79925

Attn: M. Huerta

1 Transnuclear, Inc.

2 Skyline Dr.

Hawthorn, NY 10532-2120

Attn: M. Mason

1 U.S. Department of Transportation

Federal Rail Administration RRS - 32

4007 th Street, SW

Washington, DC 20590

Attn: J. Peña 
No. of

Copies

1 U.S. Department of

Transportation

office of Materials

Transportation

400 Seventh Street, SW

Washington, DC 20590

Attn: K. Smith

6 U.S. Nuclear Regulatory

Commission

Office of Nuclear Materials

Safety and Safeguards

Washington, DC 20555

Attn: R. Chappe11

E. Easton

D. Huang

H. Lee

C. MacDonald

L. Wang

1 U.S. Nuclear Regulatory

Commission

Office of Nuclear Regulatory

Research

Washington, DC 20555

Attn: W. Lahs

NL/S - 139

1 Western Interstate Energy

Board

333 Quebec St.

Denver, CO 80207

Attn: L. Friel

1 Westinghouse Electric Corp.

Waste Technology Services

Division

P.0. Box 286

Madison, PA 15663-0286

Attn: B. Nair

2 Westinghouse Electric Corp.

Bettis Atomic Power Laboratory

Mail Stop 36E

Box 79

West Mifflin, PA 15122-0079

Attn: D. Krawiec

M. Schneider 
No. of

Copies

$\begin{array}{rll}1 & 1425 & \text { S. W. Attaway } \\ 1 & 1514 & \text { H. S. Morgan } \\ 1 & 1514 & \text { C. M. Stone } \\ 1 & 1514 & \text { G. W. Wellman } \\ 1 & 1544 & \text { G. D. Sjaardema } \\ 5 & 5222 & \text { M. M. Madsen } \\ 5 & 3141 & \text { S. A. Landenberger } \\ 3 & 3151 & \text { W. L. Garner } \\ 3 & 3151 & \text { W. I. Klein } \\ 8 & 3154-1 & \text { C. K. Dalin for } \\ & & \text { DOE/OSTI } \\ 8 & 3154-1 & \text { C. L. Ward } \\ 1 & 6000 & \text { V. L. Dugan, Actg. } \\ 1 & 6300 & \text { T. O. Hunter, Actg. } \\ 1 & 6320 & \text { R. E. Luna, Actg. } \\ & & \text { Attn. TTC Master File } \\ 25 & 6320 & \text { TTC Library } \\ 1 & 6321 & \text { M. G. Vannoni, Actg. } \\ 1 & 6321 & \text { J. Whitlow } \\ 1 & 6322 & \text { G. F. Hohnstreiter } \\ 1 & 6322 & \text { M. Arviso } \\ 5 & 6322 & \text { D. J. Ammerman } \\ 1 & 6322 & \text { J. G. Bobbe } \\ 1 & 6322 & \text { D. L. Bolton } \\ 1 & 6322 & \text { R. E. Glass } \\ 1 & 6322 & \text { D. C. Harding } \\ 1 & 6322 & \text { D. W. Miles } \\ 1 & 6322 & \text { J. D. Pierce } \\ 1 & 6323 & \text { T. L. Sanders } \\ 3 & 6323 & \text { D. R. Bronowsi } \\ 1 & 6323 & \text { N. N. Brown } \\ 1 & 6323 & \text { K. R. Edwards } \\ 1 & 6323 & \text { P. L. Jones } \\ 1 & 6323 & \text { D. R. Stenberg } \\ 10 & 6323 & \text { W. L. Uncapher } \\ 1 & 7414 & \text { C. N. Giles } \\ 1 & 7414 & \text { W. B. Leisher } \\ 1 & 7485-3 & \text { J. M. Poppinger } \\ 1 & 7485-3 & \text { H. Kovaschetz } \\ 1 & 7535 & \text { D. C. Bicke1 } \\ 1 & 7535 & \text { D. M. Gutierrez } \\ 1 & 7541 & \text { T. J. Baca } \\ 1 & 7542 & \text { S. Meyer } \\ 1 & 7542 & \text { R. A. May } \\ 1 & 7542 & \text { S. L. Toledo } \\ 1 & 7556 & \text { R. A. Hil1 } \\ 1 & 7556 & \text { C. C. Holland } \\ 1 & 8024 & \text { P. W. Dean } \\ 1 & 8524 & \text { J. A. Wacker1y } \\ & & \end{array}$



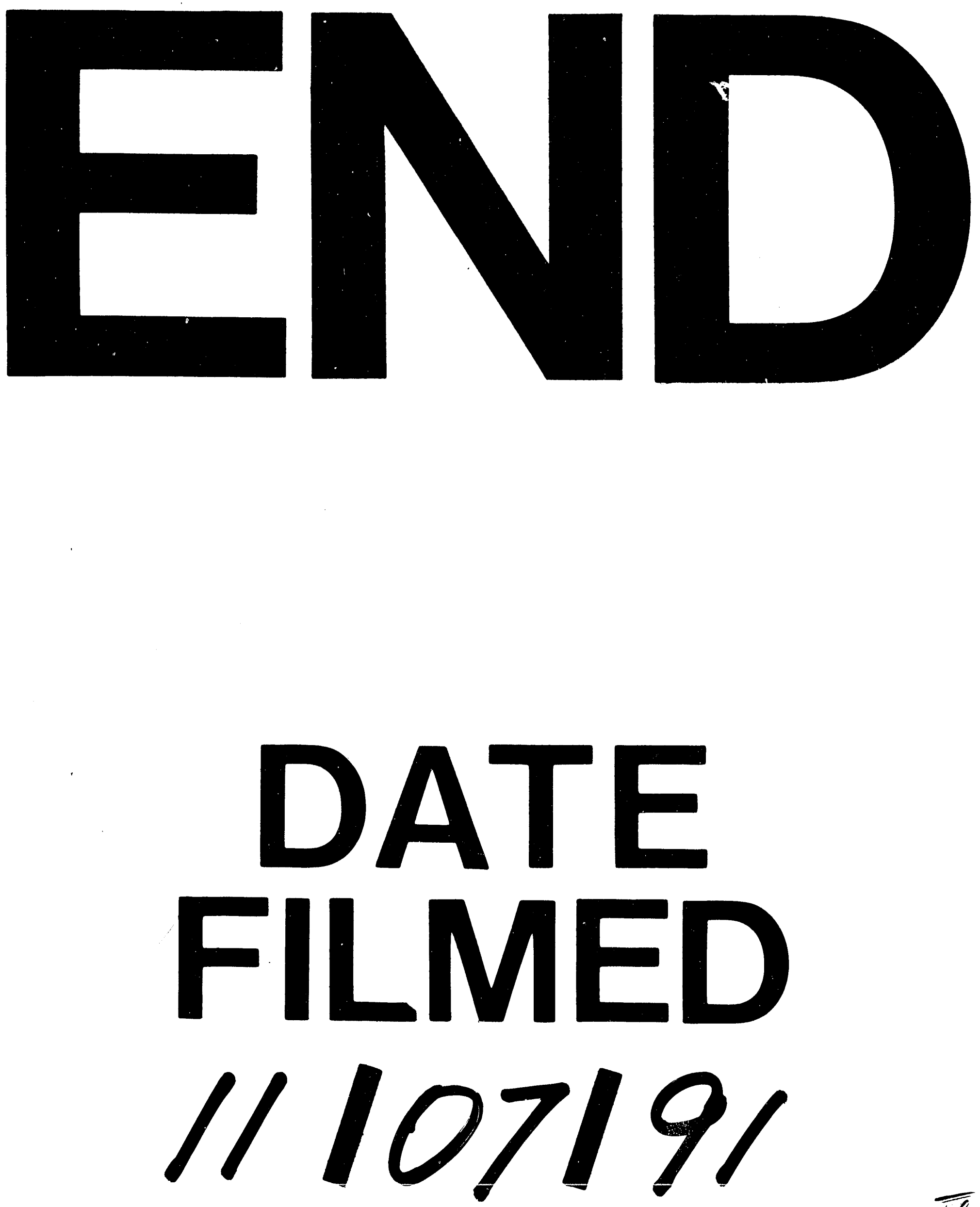

$=$ 


\section{.}

